\title{
Classical Trade Protectionism 1815-1914
}

Classical Trade Protectionism 1815-1914 will bring readers up to date with recent empirical research carried out in the field.

Long-held views on modern trade policies have been challenged by the introduction of recent theoretical developments in international economics and in measurement techniques brought about in the 1960s and 1970s. One question in particular has attracted attention and has contributed to the bringing to light of a number of heretofore ignored measurement and interpretation problems: the assessment of French and British nineteenth-century trade policies.

Classical Trade Protectionism 1815-1914 examines the theoretical and practical problems associated with the assessment and measurement of the direct impact of tariffs, prohibitions and quotas on domestic prices, output structure and competitiveness. The contributors to this volume also examine the direct and long-run consequences of protectionist measures on particular economies, utilising evidence from in-depth investigations of trade statistics as well as 'best practice' statistical techniques such as effective protection, elasticity of demand and revealed comparative advantage.

Jean-Pierre Dormois is Professor of Modern Economic History at the University of Strasbourg, France. Pedro Lains is Senior Research Fellow at the Institute of Social Sciences, University of Lisbon, Portugal. 


\section{Routledge explorations in economic history}

\section{Economic Ideas and Government Policy}

Contributions to contemporary economic history

Sir Alec Cairncross

\section{The Organization of Labour Markets}

Modernity, culture and governance in Germany, Sweden, Britain and Japan

Bo Stråth

\section{Currency Convertibility}

The gold standard and beyond

Edited by Jorge Braga de Macedo, Barry Eichengreen and Jaime Reis

4 Britain's Place in the World

A historical enquiry into import controls 1945-1960

Alan S. Milward and George Brennan

5 France and the International Economy

From Vichy to the Treaty of Rome

Frances M. B. Lynch

6 Monetary Standards and Exchange Rates

M. C. Marcuzzo, L. Officer and A. Rosselli

7 Production Efficiency in Domesday England, 1086

John McDonald

8 Free Trade and its Reception 1815-1960

Freedom and trade: volume I

Edited by Andrew Marrison

\section{Conceiving Companies}

Joint-stock politics in Victorian England Timothy L. Alborn 
10 The British Industrial Decline Reconsidered

Edited by Jean-Pierre Dormois and Michael Dintenfass

11 The Conservatives and Industrial Efficiency, 1951-1964

Thirteen wasted years?

Nick Tiratsoo and Jim Tomlinson

\section{Pacific Centuries}

Pacific and Pacific Rim economic history since the 16th century

Edited by Dennis O. Flynn, Lionel Frost and A. J. H. Latham

\section{The Premodern Chinese Economy}

Structural equilibrium and capitalist sterility

Gang Deng

14 The Role of Banks in Monitoring Firms

The case of the Crédit Mobilier

Elisabeth Paulet

15 Management of the National Debt in the United Kingdom, 1900-1932 Jeremy Wormell

16 An Economic History of Sweden Lars Magnusson

17 Freedom and Growth

The rise of states and markets in Europe, 1300-1750

S. R. Epstein

18 The Mediterranean Response to Globalization Before 1950 Sevket Pamuk and Jeffrey G. Williamson

19 Production and Consumption in English Households 1600-1750

Mark Overton, Jane Whittle, Darron Dean and Andrew Hann

20 Governance, the State, Regulation and Industrial Relations Ian Clark

21 Early Modern Capitalism

Economic and social change in Europe 1400-1800

Edited by Maarten Prak

22 An Economic History of London, 1800-1914

Michael Ball and David Sunderland 
23 The Origins of National Financial Systems Alexander Gerschenkron reconsidered Edited by Douglas J. Forsyth and Daniel Verdier

24 The Russian Revolutionary Economy, 1890-1940 Ideas, debates and alternatives Vincent Barnett

25 Land Rights, Ethno Nationality and Sovereignty in History Edited by Stanley L. Engerman and Jacob Metzer

26 An Economic History of Film

Edited by John Sedgwick and Mike Pokorny

27 The Foreign Exchange Market of London Development since 1900 John Atkin

28 Rethinking Economic Change in India Labour and livelihood Tirthankar Roy

29 The Mechanics of Modernity in Europe and East Asia The institutional origins of social change and stagnation Erik Ringmar

30 International Economic Integration in Historical Perspective Dennis M. P. McCarthy

31 Theories of International Trade Adam Klug Edited by Warren Young and Michael Bordo

32 Classical Trade Protectionism 1815-1914

Edited by Jean-Pierre Dormois and Pedro Lains 


\section{Classical Trade Protectionism 1815-1914}

\section{Edited by Jean-Pierre Dormois and Pedro Lains}


First published 2006 by Routledge

Published 2017 by Routledge

2 Park Square, Milton Park, Abingdon, Oxon OX14 4RN

711 Third Avenue, New York, NY 10017, USA

Routledge is an imprint of the Taylor $\mathcal{E}$ Francis Group, an informa business

Copyright (๑) 2006 selection and editorial matter, Jean-Pierre

Dormois and Pedro Lains; individual chapters, the contributors

Typeset in Baskerville by Wearset Ltd, Boldon, Tyne and Wear

The Open Access version of this book, available at www.tandfebooks.com, has been made available under a Creative Commons Attribution-Non Commercial-No Derivatives 4.0 license.

British Library Cataloguing in Publication Data

A catalogue record for this book is available from the British Library

Library of Congress Cataloging in Publication Data

A catalog record for this book has been requested

ISBN13: 978-0-415-35226-0 (hbk) 


\section{Contents}

Introduction 1

JEAN-PIERRE DORMOIS, JAMES FOREMAN-PECK AND PEDRO LAINS

PART I

Assessing the intensity of nineteenth-century protectionism

1 The myth of free-trade Britain and fortress France: tariffs and trade in the nineteenth century

JOHN VINCENT NYE

2 Free trade and protection in nineteenth-century Britain and France revisited: a comment on Nye

DOUGLAS A. IRWIN

3 Protectionism is "special": reply to Irwin on free trade

JOHN VINCENT NYE

4 Measuring protection: a cautionary tale

KEVIN H. O'ROURKE

5 Measuring protection in the early twentieth century

ANTONI ESTEVADEORDAL

6 Assessing the protectionist intensity of tariffs in nineteenthcentury European trade policy

ANTONIO TENA JUNGUITO 
viii Contents

\section{PART II}

The impact and implications of tariff barriers

7 Tariffs and growth in the late nineteenth century KEVIN H. O'ROURKE

8 Interpreting the tariff-growth correlation of the late nineteenth century

DOUGLAS A. IRWIN

9 The impact of late-nineteenth-century tariffs on the productivity of European industries (1870-1930)

JEAN-PIERRE DORMOIS

10 Protection and Italian economic development: much ado about nothing

GIOVANNI FEDERICO

11 From virtual free-trade to virtual protectionism: or, did protectionism have any part in Germany's rise to commercial power 1850-1913?

BÉATRICE DEDINGER

12 Protectionism and Portuguese industrialisation PEDRO LAINS

13 Spanish protectionism during the Restauración, 1875-1930 ANTONIO TENA JUNGUITO

14 The role of open economy forces in Portugal and the Balkans, 1870-1913

PEDRO LAINS

15 A model of later-nineteenth-century European economic development 


\title{
Introduction
}

\author{
Jean-Pierre Dormois, James Foreman-Peck \\ and Pedro Lains
}

Two-hundred years after Adam Smith's and David Ricardo's (as well as the other classical economists) prescription about the supposedly beneficial effects of free trade, trade policy orientation still constitutes a major bone of contention among economists, as in the public and the media. More than in any other area of human knowledge, the conviction of laymen and experts alike seems difficult to sway, grounded as it is in people's political beliefs. These, in turn, are based on, or at least linked to, a representation and an understanding of past episodes of human history - of economic history in fact. To paraphrase Keynes, "intellectuals are usually the slaves of some defunct economic historian". ${ }^{1}$

So it is with present-day globalisation - attention has been drawn to the immediate precedent: the wave of expanding trade and making of global markets between 1840 and 1914 halted for most of the twentieth century by a dreadful succession of wars, world crises and nationalist economic policies. $^{2}$

In the past fifteen years, new approaches to the role of international trade in economic development have attracted renewed interest both at the theoretical and the empirical level. As a result, the once-standard policy recommendation of the promotion of import substitution, especially in developing countries, has given way to more sophisticated treatments of the available evidence, most of them stressing the complex interactions of tariffs and economic growth: ${ }^{3}$ a vast majority of empirical studies for the recent decades have in fact come to strengthen the case for free trade. ${ }^{4}$

When one takes a longer-time view, however, the received wisdom is still strongly influenced by the work of historians of the heyday of import substitution. As a result, the existence of a "tariff-growth paradox" before 1950 has received wide currency. This view, still regarded as orthodox, was formulated some thirty years ago by Paul Bairoch (1930-99), perhaps the most influential economic historian in this area, whom the editors of the prestigious Cambridge Economic History of Europe entrusted with the chapter on trade. He stands as the leading figure of a school which claims that, far from having been the "handmaiden of growth", the second wave of 


\section{Jean-Pierre Dormois, James Foreman-Peck and Pedro Lains}

European industrialisation as well as the concomitant expansion of international trade were boosted by the very protectionist policies designed to retard and hamper them. From his seminal work, Commerce extérieur et développement économique (1976) onwards, he thus rebuffed those contemporary contemnors of protectionism, most notably Yves Guyot, Eugen von Böhm-Bawerk and Vilfredo Pareto.

Although some of his conclusions seemed, even at the time, highly debatable, they have served as a inescapable reference for economic and other historians ever since. This appears, in retrospect, all the more surprising since Bairoch's indicators were of the crudest sort (unweighted overall tariff rates), that his explanation was based on post hoc propter hoc observations, and that the observed correlations were unconditional. Furthermore, his data are not devoid of miscalculations: for Belgium - the author's native country - he relied on an index where the decimal point had obviously been misplaced, probably by error (15 per cent instead of 1.5 per cent). More importantly, he took tariff rates at their face value and made no mention of the theoretical implications of their use. No discussion was included of the reflections and the instruments already in wide currency in the mid-1960s, especially the work of Balassa, Corden and Johnson.

Bairoch focused on Europe in the crucial period 1860-1914, and assembled trade and growth statistics on a vast array of countries (eighteen). Access to the League of Nations' library in Geneva was instrumental in the compilation of data for a sample of unusually large proportions - trade data which, as practitioners can confirm, are not easy to secure in public libraries for periods prior to the First World War.

Obviously the role of European protectionism needed to be revisited in the light of current developments in theoretical and applied economics. In the present book we have attempted to gather a number of important scholarly work, either published or as yet unpublished in English, which have appeared in the past fifteen years and which shed new light on problems both of the measurement of tariff protection in this period and of the incidence of these tariffs on the economy (some of the alreadypublished material is made available in English for the first time). Accordingly this volume is split into two Parts.

In recent times economic historians have benefited from the influx of a number of innovations in terms of new measurement devices (notably in the work of Anderson and Neary) and have been in a position to test them on old and rejuvenated trade data sets. It is both disheartening and exhilarating at the same time that the voluminous trade data collections of the nineteenth century have not been tapped more systematically. They rank among the oldest statistics collected by European states and they are susceptible to extensive, if sometime painful, processing.

Europe was at its economic zenith in the last quarter of the nineteenth century, for the leviathans of much of the twentieth century, the United 
States and Russia, were largely occupied with expansion across their own continents. A European return to genuine trade protectionism was therefore to influence world, as well as European, development.

Unlike the twentieth century that favoured quotas, the principal instrument of (supposed) protectionism in the period 1870-1914 was a tax. Almost all taxes discriminate in some way because they alter prices. ${ }^{5}$ In so far as prices are otherwise set in competitive markets, without significant un-priced consequences of the trades, then taxes misallocate resources and lower the value of production. But government must be financed, and therefore taxes are a necessary evil. What makes a tax protectionist is discrimination against foreign goods compared with home production. If there were no competing domestic industry, then however high the tax on a foreign product sold at home, there would be no protection. Alternatively, protection could be avoided if the customs duty on imports was matched by an equivalent excise tax on the home-made good - as with Indian cotton textiles and British textiles imported into India from 1886.

The costs of collection are another burden of taxation in addition to the price, and therefore induce distortion. Governments have always favoured taxes on long-distance trade because there have usually been only a few frontier towns or ports through which the trade was able to pass. The trade could easily be controlled and taxed at these points, in marked contrast to widely-spread internal production and commerce. Collection costs for most of history have been of far greater concern than induced price distortions.

Customs duties were therefore a generally favoured fiscal instrument. But the question remained, how far could duties be raised without "killing the goose that lays the golden egg"? By the later nineteenth century, Adam Smith's quotation that "In the arithmetic of the customs two and two, instead of making four, make some times only one ... with regard to ... heavy duties" "had been taken to heart by most European governments.

Adding heavier taxes on imports could subtract from customs revenue by reducing the volume of imports proportionately more than the increase in duties (in part by encouraging smuggling). A drawback of more heavily taxing products where demand would not fall off much in response to higher prices is that these may well be necessities of life (Smith instanced salt, leather, candles and linen) and in equilibrium these would raise the cost of labour, while the process of getting to equilibrium could provoke riots and revolution as well as widespread hardship.

By contrast, taxes on luxuries - among which Smith included tobacco, beer, ale and wine, tea and sugar - had no such effect. So, for paying the expenses of the sovereign, "colonial goods" were "fiscal goods", appropriate targets for taxation. In so far as beer and ale were drunk by the poorer classes and wine by the richer, Smith's equality of sacrifice principle also recommended heavier taxes on wine than on beer. The equivalence of the 


\section{Jean-Pierre Dormois, James Foreman-Peck and Pedro Lains}

British beer excise and wine tariff provides one of the major bones of contention on the issue of the relative restrictiveness of French and British trade in the nineteenth century (see Chapters 1 to 3).

With this in mind, Chapter 6 scrutinises the repercussions of the inclusion or exclusion of fiscal duties (on tropical or "luxury" goods) on assessing the protectionist effect of European tariffs. Fiscal goods indeed bore the greater burden of customs duties in France (72 per cent nominal duty) and Italy (82 per cent), but not so much in Germany (36 per cent) in 1913. Is it likely that $2+2=1$ for French and Italian fiscal goods? For a "small" country, ${ }^{7}$ a partial equilibrium analysis of a tariff on colonial goods, "luxuries" with no domestic substitutes, indicates that the revenuemaximising specific duty as a proportion of the price should equal the reciprocal of (the absolute value of) the price elasticity of demand. ${ }^{8}$ If the elasticity of demand for colonial goods in Italy was -1.25 , then the Italian duties were optimal for revenue purposes $(1 / 1.25=0.8)$. If the elasticity were much greater in absolute value than 1.25 , then for Italy $2+2=1$ as far as revenue was concerned. For Germany, rates were optimal if the elasticity of demand was very much higher $(1 / 0.36=-2.8)$.

While Smith's doctrines were widely accepted in the "long nineteenth century" and therefore may be expected to have influenced practice, economic analysis of taxation has moved on since then and so, in consequence, may our assessment. We may note that the suppliers of fiscal goods lose out from their taxation, and the more so the more elastic is consumer demand. This may provide an optimal tariff argument for a large country where colonial goods were concerned. By taxing sugar, coffee and tea, European buyers could drive down the before-tax price of these products, shifting the terms of trade in favour of Europe and against the tropical exporters.

A tax on "wage goods" may affect the trade-off between work and leisure. "Luxuries" are likely to be complements to leisure, so by taxing them disproportionately the disincentive to work from general commodity taxation is reduced. Conversely Smith's point about necessities could be interpreted as, for example, candles were often complements to work and so a tax on them provided a disincentive to work.

The level of taxation depends upon the amount of tax to be raised, which in turn may be affected by the costs of collection. These costs are influenced by the level of national economic development. In lowproductivity economies agriculture is the principal source of income but is not especially easy to tax. Foreign trade is an easier source of revenue. Without access to an income tax, indirect taxes are bound to be higher and, apart from the accessibility, foreign merchants are likely to have less political influence on taxes than domestic producers - unless these producers use foreign supplies.

Falling collection costs with economic development, differential collection costs between taxes and jumps in the ratio of permanent government 
spending to permanent national income explain the shifts between predominant taxes in US history, according to Gardner and Kimbrough (1992). Tariffs have lower collection costs than excise, the costs of which in turn are lower than income tax, and this is the sequence of US tax revenue evolution as government spending rose. Detached from the Panglossian model of government and inter-temporally optimising representative consumers, the explanation has prima facie plausibility.

It appears broadly to match the British experience. A guide to the relative weight of internal and external indirect tax revenue for the UK is the balance between customs and excise - bearing in mind the $2+2=1$ principle. From the 1830s (before the much-discussed repeal of the Corn Laws), customs revenue exceeded excise revenue, accounting for more than 40 per cent of gross public income. Excise surpassed customs in the 1870s, when customs averaged around 28 per cent of income. ${ }^{10}$ By 1913 , under "free trade", customs revenue was 65 per cent higher than in 1835 but total public revenue was almost four-times greater. Prime Minister Robert Peel defended the reintroduction of income tax, not simply as a means of remedying the budget deficit, but as a "juster principle of taxation" (cited in Howe, 1998: 20, n103). As perhaps the most developed economy of the period, Britain was in a position to begin shifting the tax base before others. Even so, the yield from property and income tax did not exceed the Napoleonic War peak in peacetime, other than temporarily, until the last decade of the nineteenth century.

Hence, low-income countries may have high tariffs for revenue purposes, without necessarily the high tariffs causing the low income. On the other hand, high taxation in general may crowd out productive activity and/or high tariffs discriminating against foreign goods may encourage the expansion of less-productive domestic activity and reduce the gains from trade. More openness to trade does appear to be associated with higher incomes before the First World War, even after the impact of income on trade has been controlled (Irwin and Marko, 2002)

The infant industry argument, based upon learning or economies of scale, is that high tariffs can encourage high-productivity industry, if only they are given the chance and this is one reason why manufacturing tended to acquire protection in the nineteenth century as Friedrich List (1856) argued. In Chapter 7, O'Rourke estimates the correlation between tariffs and economic growth in the late nineteenth century in three types of growth model: unconditional convergence equations, conditional convergence equations and factor accumulation models. For a panel of ten countries between 1875 and 1914, tariffs were positively correlated with growth, a result that would have thrilled List (or Paul Bairoch) but, conversely industrial tariffs seem to have been negatively correlated with relative labour productivity, taking the UK as a European standard (Chapter 9).

Where the competing industries at home and abroad consist only of a few firms, an oligopoly model provides a theoretical structure that could 
support these empirical findings. A tariff in such a model damages domestic consumers as in the standard approach, but in principle they could be compensated from the profit shifted from the foreign oligopolist and the domestic economy could be better off - at the expense of foreigners. The 1879 German soda tariff did indeed help Germany by redistributing profits, but was not fundamental to the rise of the German industry after 1880 and the decline of British industry (as shown by Krause and Puffert, 2000), and this conclusion can safely be extended to the other more successful branches of German industry as Dedinger shows in Chapter 10. Lower German input costs and the adoption of a new process (instead of the Leblanc process) were much more important. The German tariff reduction in 1873 reduced German welfare for the same redistributive reason as the 1879 hike enhanced it.

Yet the positive correlation between growth and tariffs further investigated by Estevadeordal in Chapter 5 is unlikely to reflect a causal relation in general; most industries were not oligopolies. Moreover, for O'Rourke's sample, protectionist or inward-oriented trade strategies were not obviously successful. Several individual country experiences in the late nineteenth century are not consistent with the view that import substitution promoted growth (Chapter 8). First, the two most rapidly expanding high-tariff countries of the period, Argentina and Canada, grew because capital imports helped to stimulate export-led growth in agricultural staples products, not because of protectionist trade policies. Second, most land-abundant countries (such as Argentina and Canada) imposed high tariffs primarily to raise government revenue, and such duties are structured differently from protective tariffs. That two labour-scarce, landabundant countries both grew rapidly and tended to impose high-revenue tariffs renders suspect any inference that tariffs were the cause of their dynamic economic growth in the later nineteenth and early twentieth centuries.

A similar positive (contingent) correlation of tariffs with growth might be expected if the neoclassical model provided some explanation of international growth patterns. Then poor countries would have grown faster than rich, and since poor countries had higher tariffs than rich, on average high tariffs would have been associated with high growth.

If the land-abundant economies are excluded from the sample, and low-income European countries added, a negative simple correlation emerges between income and tariffs. In Figure I.1, the two outliers on the bottom right are the UK in 1890 and 1910. The two on the top left are Russia and Portugal in 1890, and the three points below them are the same countries in 1910 plus Greece (which had raised her tariff rate by proportionately more than her GNP per head since 1890). Even with these seven data points removed, there is still a negative correlation between income and the measure of the tariff rate. The association might simply reflect that for poor countries tariff collection costs are lower than 
those for other taxes, and hence for such economies tariffs are a major source of government revenue. However, the negative association remains, even when the influence of a number of other determinants of income, such as illiteracy, coal production, and commitment of the monetary system to a metallic standard, are controlled. Of particular interest in this respect are the chapters devoted to Portugal (Chapter 12) and the Balkan countries (Chapter 14).

The average tariff of Figure I.1 is measured as the ratio of tariff revenue to import value. As indicated above, a high tariff rate may not indicate a desire to protect, but simply that this is the cheapest way to finance the state. Yet the tax rates may still have been protectionist. More evidence of the desire to protect is "the scientific tariff", intended to allow cheap raw materials in but to exclude foreign manufactures. This then allows the expansion of domestic manufacturing, seen as the key to economic development. List's infant industry argument appeals to learning by doing and economies of scale that would allow protected industries eventually to grow large enough and efficient enough to compete with foreigners. As several country studies gathered here portend to show, this was the case for none of the trade policies adopted, by among others, France, Italy, Germany or Spain. Even relatively free-trade Belgium or Switzerland enforced tariffs which, in their structure, bear some resemblance to those decisively protectionist countries: taxation of agricultural necessities and food, tropical goods and semi-finished textile and metal goods.

As long as domestic firms import raw materials that are untaxed, their "effective protection" is higher than the nominal tariff on the foreign goods with which they compete in the home market. They will raise prices on their value added by proportionately more, the smaller is their value added relative to the total value. This does assume, contrary to the infant industry argument, that prices are always raised by the height of the tariff.

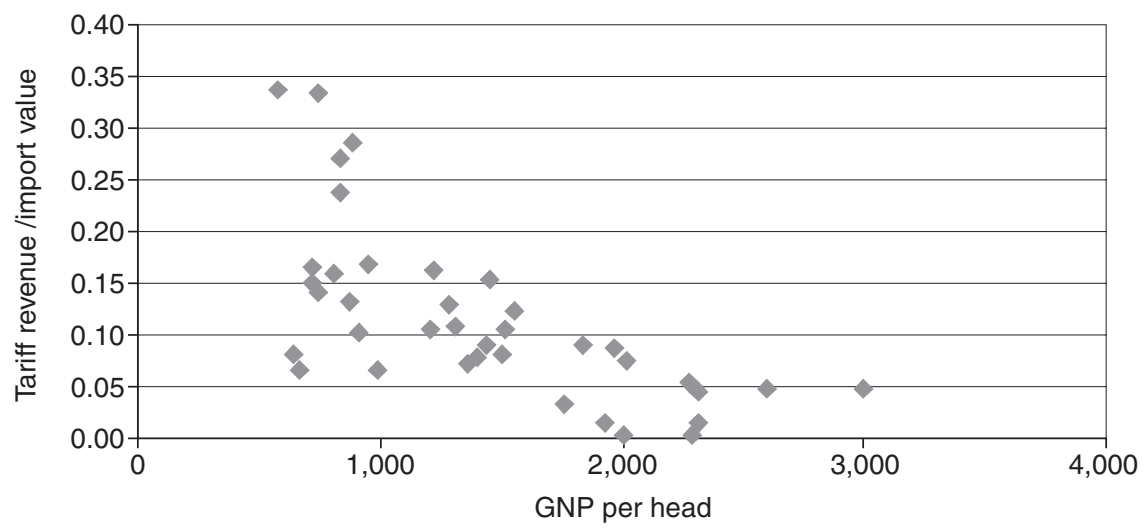

Figure I.1 Average tariff and GNP in Europe, 1890 and 1910. 


\section{Jean-Pierre Dormois, James Foreman-Peck and Pedro Lains}

A competitive domestic industry that learned from experience how to bring down costs would not raise prices above these lower costs, because any firm that attempted to do so would be undercut by competitors. In addition, a monopolistic firm or a firm with market power interested in maximising profits will raise its price by less than the amount of the tariff because it is aware of the custom lost consequently. Effective protection rates therefore depend on market power and also on cost conditions. So long as industries are subject to constant returns to scale and are perfectly competitive, however, these qualifications can be ignored.

Why the shift to protection? Federico examines (in Chapter 10) the various hypotheses laid out by political scientists in the light of the Italian case, and his analysis can safely be extended to most other European countries. With the extension of the franchise, elections and perceived workers' interests became as important for protection as lobbying, if not more so. The British election of 1906 was explicitly fought on the protection issue - though the position of trade unions after the Taff Vale case ${ }^{11}$ was another vital point of concern. In the German election of 1877, as in the Italian election of 1887 and the French election of 1889, protectionism was a major issue; unlike the British, apparently a majority of voters favoured tariffs. Falling grain prices frightened the big farmers' lobbies and under the influence of depression, industrialists in Continental countries formed influential pressure groups which sealed an "alliance of wheat (or rye) and iron”.

Another model by Adam Klug (2001) of the politics of protection assumes voters are motivated by the way in which trade policy would affect their incomes. With workers largely immobile between sectors, all factors employed in a sector see their economic fortunes as tied to that sector. This author attempts to explain voting proportions by district with the employment in various activities in that district and with the previous electoral result. This last variable identifies the effect of tradition, so allowing a test of whether the employment variables account for switches in party allegiance at the election.

Workers in successful export industries tended to favour free trade, and those in industries threatened by foreign competition were more inclined to vote for protection. To explain Britain's continued adherence to free trade and Germany's rejection of it with this model, it is necessary to suppose that the trade performance of the British was more successful than that of the Continental economies, which runs contrary to historiographic tradition. Alternatively an appeal must be made to the more conventional food prices explanation. Britain was more highly urbanised and industrialised than any other European country. Protection in Britain was identified with higher food prices that would harm the majority of workers whereas, in the rest of Europe, the proportion employed in the food supplying sector, agriculture, was much larger. Thus agricultural interests might be irrelevant in his model but it is likely that this stems from the 
level of aggregation; when using constituency-level data, agricultural employment may have seemed less dispersed and more influential. ${ }^{12}$ Behind this lies the enduring attraction of protectionist measures as the ideal vote-catcher, the illusion as Vilfredo Pareto put it, "that everybody could receive something without anyone having to pay" (Pareto, 1984).

\section{Notes}

1 J. M. Keynes, The General Theory of Employment, Interest and Money, chapter 24, V (London, Macmillan, 1973), p. 383.

2 Measures of outward orientation for the world's most important trading partners recovered its pre-1914 level only in 1980, first signalled by Maddison (1982), p. 114.

3 Krueger, 1997.

4 Dollar, 1992; see Irwin in Chapter 8.

5 A fixed tax per person does not alter relative prices but the opprobrium attached to poll taxes suggests not surprisingly that the distributive consequences of taxation matter more in politics than efficient resource allocation. Otherwise, the wider the tax base, the smaller the distortion. So a value added tax at a constant rate on all goods leaves the rate of substitution between these goods unchanged relative to the "no tax" state. However, it does alter the substitution possibilities between work and leisure, unless accompanied by an income tax at the same rate.

6 Adam Smith, The Wealth of Nations, Book V, chapter II, part II, article IV.

7 Here a small country is one that cannot influence the prices of goods imported by varying the volume bought.

8 If $t$ is the tax in, say, money units per quantity unity, $M$ the quantity of imports of colonial goods in perfectly elastic supply and $\mathrm{p}$ the price in the same units, then the objective is to maximise $t \cdot M(t) 0=M+t(\partial M / \partial t), t / p=1 / e$, where $e$ is the absolute value of the price elasticity of demand for imports.

9 Ramsey taxes are proportional to the sum of the reciprocals of the elasticities of demand and supply. The formula takes into account that the deadweight loss increases with the tax rate as well as the $2+2=1$ eventual revenue effect, and asserts that the marginal excess burden of the tax must be the same for all commodities. Commodities with low elasticities of demand or supply have a lower marginal deadweight loss per marginal unit of revenue raised (with independent demands) and so should face higher marginal tax rates.

10 Though this overtaking was helped by revenue for most assessed taxes being transferred from land and assessed taxes to Excise from 1871.

11 A 1901 court decision on a Cardiff railway yard stipulated that trade unions could be sued for the misbehaviour of their members, putting their funds at risk from employers losing money because of a strike.

12 At another level the explanation of the shift to protection is that the committed free trader, Britain, did not sufficiently use its economic bargaining power to offset protectionist pressure in other countries. During the years 1848-71 Britain had maintained an open trading system. Even later she negotiated "most favoured nation" treaties with Portugal (1882), Turkey (1883), and Spain (1886). But, although the Foreign Office put up options for a similar treaty with Germany three times, economic sanctions were allowed to lie dormant after 1878 when German policy moved (see O'Brien, 2002: 20). 

Part I

Assessing the intensity of nineteenth-century

protectionism 



\title{
1 The myth of free-trade Britain and fortress France
}

\section{Tariffs and trade in the nineteenth century $^{1}$}

\author{
John Vincent Nye ${ }^{2}$
}

\begin{abstract}
"Our Parliament is to be prorogued on Tuesday and dissolved the same day," Victoria wrote to her Belgian uncle on June 29. 1852. "Lord Derby himself told us. that he considered Protection as quite gone. It is a pity they did not find this out a little sooner; it would have saved so much annoyance, so much difficulty."3
\end{abstract}

While France [1815-1848] was thus maintaining almost intact her virtually prohibitive tariff, England was making rapid progress toward the adoption of complete free trade, so that the divergence in the tariff policies of the two countries became steadily greater. ${ }^{4}$

One of the great economic advances of the nineteenth century was the spread of liberalism and the expansion of world trade. In the popular fable that makes "history" of this event, Britain was the great nation of free trade, whose liberal commercial policy made possible the achievement of unparalleled peace and prosperity. Britain's abandonment of protection and subsequent rapid success spurred other nations to follow her example, culminating in the general adoption of more liberal trade policies in neighboring European states.

The view that the rise of free trade in Britain initiated the rise of free trade in Europe still frames our historical explanations of the economic expansion of the last century. ${ }^{5}$ The conventional wisdom is that France in contrast to Great Britain - had an outmoded and crippling system of tariffs and prohibitions in the first half of the nineteenth century, and that it was not until the 1860 Anglo-French Treaty of Commerce that the French took steps toward moderate protection.

But how do we know this to be true? From what evidence have we concluded that Britain was the solitary free trader in the early-to-midnineteenth century? What criteria have been used to establish that Britain vigorously liberalized while other nations - especially France - continued to close their doors and raise obstacles to the importation of other nations' products? Paul Bairoch wrote the following on the period in the latest volume of The Cambridge Economic History of Europe: 


\section{John Vincent Nye}

The situation as regards trade policy in the various European states in 1815-20 can be described as that of an ocean of protectionism surrounding a few liberal islands. The three decades between 1815 and 1846 were essentially marked by the movement towards economic liberalism in Great Britain. This remained a very limited form of liberalism until the 1840s. and thus only became effective when this country had nearly a century of industrial development behind it and was some 40-60 years ahead of its neighbors. A few small countries, notably The Netherlands, also showed tendencies towards liberalism. But the rest of Europe developed a system of defensive, protectionist policies, directed especially against British manufactured goods. ${ }^{6}$

Similar stories are told elsewhere in the literature. ${ }^{7}$

But an examination of British and French commercial statistics suggests that the conventional wisdom is simply wrong. There is little evidence that Britain's trade was substantially more open than that of France. Very little of the existing work on British or French trade has taken a comparative perspective, and there has been little economic, as opposed to political, analysis of the commercial interaction between nations. Most of the economic work has focused on the volume of trade in the two nations and has taken the changing tariffs for granted as an interesting stylized fact.

When the comparison is made, the trade figures suggest that France's trade regime was more liberal than that of Great Britain throughout most of the nineteenth century, even in the period from 1840 to 1860 . This is when France was said to have been struggling against her legacy of protection while Britain had already made the decision to move unilaterally to freer trade. Although some have recognized that Napoleon III had begun to liberalize France's trade regime even before the 1860 treaty of commerce, both current and contemporaneous accounts treat the period before the 1860s as a protectionist one in France and a relatively free one in Britain.

A straightforward examination of the raw numbers immediately alerts that something is amiss in the fable. Table 1.1 and Figure 1.1 present the average customs rates of the United Kingdom and France, where the rates are calculated from tariff revenues as percentages of the value of importables. These numbers are taken from Albert Imlah's reworking of British trade statistics and Maurice Lévy-Leboyer and François Bourguignon's recent work on nineteenth-century France. The figures show French tariff rates to be substantially lower than British rates for the period of "high protection" during the first four decades of the century. Average French tariffs in this earlier period were comparable to those of Britain after she had begun her move to free trade with the abolition of the Corn Laws. Judging by the absolute size of the fall in average tariff levels, England seems to have shown a much greater change in tariff levels than France. ${ }^{8}$ But Britain started out from much higher levels - over 50 percent - than 
did France, which never exceeded 25 percent in any single year. Bearing in mind the high point from which British tariff levels fell, one notes that the changes in tariffs seemed to fit the conventional chronology, beginning in the late 1820 s and falling rapidly from the 1840 s onward. ${ }^{9}$ Similarly, French tariffs steadily declined until the early $1850 \mathrm{~s}$ and then plummeted to a low of around 3 percent in 1870 - well below the minimum for Britain at any time in the nineteenth century. French tariff levels remained at quite low levels, until the move back toward protection in the last ten or fifteen years of the century. British average tariff levels did not compare favorably with those of France until the 1880s, and were not substantially lower for much of the time. The view of Britain as the principled free trader is most consistent with the tariff averages from the end of the nineteenth century, indicating Britain's commitment to keeping tariffs low in opposition to rising protectionist sentiment both at home and abroad. Furthermore, her movements toward free trade were magnified by the scale of her involvement in the world economy. In fact, Britain's rapid shift to freer trade was fully matched in timing and extent and even anticipated (in the French discussions of tariff rationalization before 1830) - by the commercial restructuring taking place in France.

Table 1.1 Average customs rates of Great Britain and France: net customs revenue as a percentage of net import values (quinquennial averages of annual rates), 1821-1914

\begin{tabular}{lrr}
\hline Year & Britain & France \\
\hline $1821-5$ & 53.1 & 20.3 \\
$1826-30$ & 47.2 & 22.6 \\
$1831-5$ & 40.5 & 21.5 \\
$1836-40$ & 30.9 & 18.0 \\
$1841-5$ & 32.2 & 17.9 \\
$1846-50$ & 25.3 & 17.2 \\
$1851-5$ & 19.5 & 13.2 \\
$1856-60$ & 15.0 & 10.0 \\
$1861-5$ & 11.5 & 5.9 \\
$1866-70$ & 8.9 & 3.8 \\
$1871-5$ & 6.7 & 5.3 \\
$1876-80$ & 6.1 & 6.6 \\
$1881-5$ & 5.9 & 7.5 \\
$1886-90$ & 6.1 & 8.3 \\
$1891-5$ & 5.5 & 10.6 \\
$1896-1900$ & 5.3 & 10.2 \\
$1901-5$ & 7.0 & 8.8 \\
$1906-10$ & 5.9 & 8.0 \\
$1911-13$ & 5.4 & 8.8 \\
\hline
\end{tabular}

Sources: Imlah, 1958, tables 11 and 19: 121, 160 for Great Britain; Lévy-Leboyer and Bourguignon, 1990, table A-VI: 343-7 for France. 


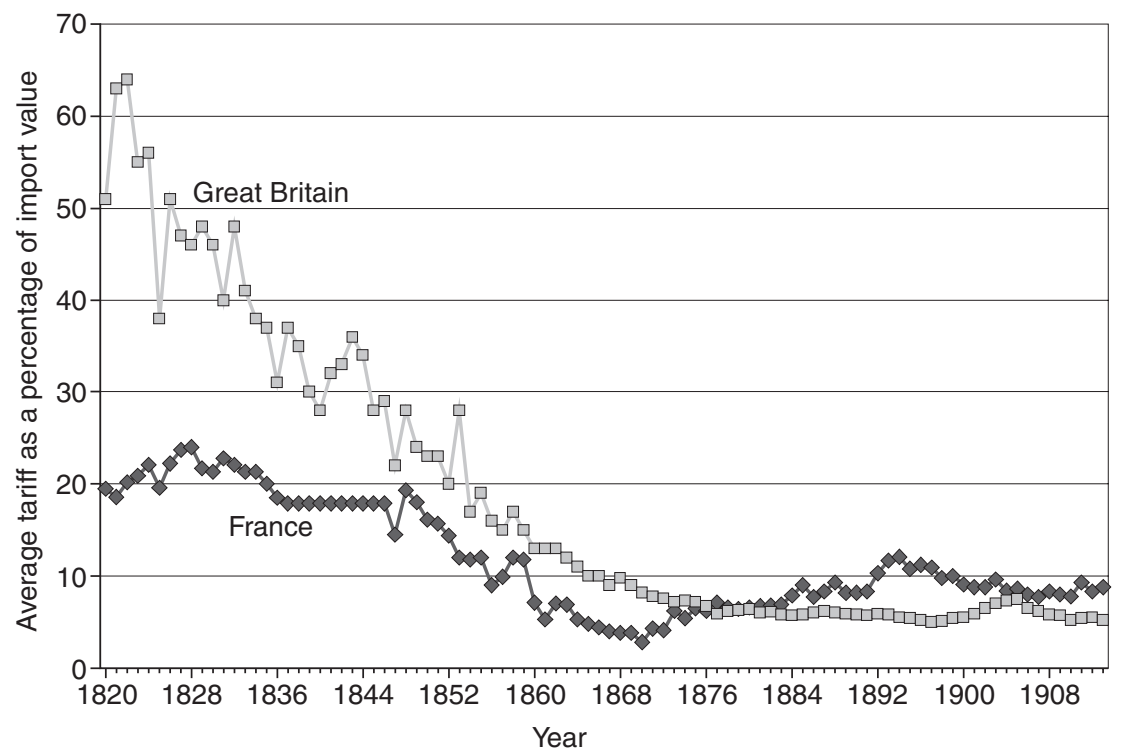

Figure 1.1 Average tariff rates: tariff revenue as a fraction of all imports.

Calculations of average tariff rates based on the ratio of total tariff revenues to total importables require some qualification. For instance, the tariff level may be set so high that certain items that might otherwise be imported in large amounts enter fitfully or not at all. ${ }^{10}$ In the case of outright prohibitions, consumers are implicitly paying a tariff equal to the difference (at most) between the home price of the domestically produced good and its foreign equivalent. Adjustments need to be made to get more comparable British and French tariff statistics.

In short, we have a classic index-number problem, complicated by the lack of a unique and well-accepted index of the degree of openness of a nation's trade. If one nation had had lower tariffs on every single item of trade than the other, it would be easy to state categorically it had the more liberal trading structure. ${ }^{11}$ The inequality is not so simple, of course. Yet we do not need precise average tariff rates to see that British tariffs were not uniformly or even "generally" below those of France for most of the century.

Even without making adjustments, we can see that certain parts of the argument are robust to these re-specifications. First, one would expect the following to be true: if items that were prohibited prior to the policy changes in the late 1850 s and 1860 s were then permitted to enter at some positive tariff, it might well be the case that the average tariff levels after prohibitions were removed would increase, given the new import composition. For instance, most cotton textiles, which were banned prior to the 
1860 treaty, were imported in fairly large quantities after the treaty at a tariff rate (20 to 30 percent) higher than the overall average. But if this meant that average tariff levels prior to the Second Empire would need to be adjusted to take this prohibition into account, the size of the drop in average tariff levels during the period from 1852 to 1870 is underestimated by the unadjusted average tariff rates, because earlier all-commodity averages would be too low. Given the already low tariff levels of the 1860s, full information about the appropriate corrections would only serve to underline the openness of Napoleon Ill's France and the magnitude of the change in tariffs from the early 1840s to the end of the Second Empire.

A substantial share of French imports was duty free and, though prohibitions may have distorted this figure in the first half of the nineteenth century, the proportion of duty-free items did not change much and even grew in the period when prohibitions were replaced with tariffs. ${ }^{12}$ This runs counter to the intuition that the existence of prohibitions masked the true extent of protection by biasing the fraction of duty-free imports upward relative to the years of freer trade. Table 1.2 shows that the proportion of French imports by value that were duty free stood at around 61 percent in 1849 and increased to 65 percent by 1869 . What is remarkable is the stability of the shares of dutiable, and duty-free items in value terms through periods of widely varying tariff levels and trade restrictions. Thus, with only a third of all imports being dutiable even in the period when moderate tariffs replaced all prohibitions, it should come as no surprise that even fairly large adjustments in the composition of earlier imports would not do much to raise the average tariff levels by more than a few percentage points. Certainly these are not enough to eliminate the 8 to 15 percent gap in average tariff rates between Britain and France in the 1830 s and 1840s, nor the larger gap that existed in the 1820s and early 1830s. One way of adjusting the average duties to take some account of the problems mentioned earlier is to apply the tariff rates by commodity class to the import distribution of another period. Using an estimate of the "true" import shares in free trade adjusts for the fact that high tariffs in certain periods may lead to too small a share of imports. In this case, using the import composition of a period characterized by nearly free trade (France in the late 1860 s or Britain in the 1880s) serves as the basis for more reliable index-number comparisons. In addition, I test for the sensitivity of my French figures to the large swings in import composition and tariff rates by applying the rates in every period to the import shares in every other period. As it turns out, these calculations have the advantage of permitting easy comparison with tariff calculations already available in the literature.

In his well-known paper on free trade and British national income, Donald McCloskey examined the sensitivity of changing tariff levels to changing import demand by recalculating British tariff levels for 1841, 1854, and 1881 using the commodity weights of each of the different 
Table 1.2 Percentage of all French imports broken down by tariff classification using current values

\begin{tabular}{llllll}
\hline & 1849 & 1859 & 1869 & $1857-69$ & $1867-9$ \\
\hline Duty-free & 60.7 & 64.4 & 64.8 & 63.2 & 64.9 \\
Dutiable & 39.3 & 35.6 & 35.2 & 36.8 & 35.1 \\
\hline
\end{tabular}

Source: France, Tableau Général du Commerce, 1869.

Table 1.3 Alternative calculations of the British Tariff Rate 1841, 1854 and 1881

\begin{tabular}{llcc}
\hline \multirow{2}{*}{$\begin{array}{l}\text { Using individual tariff } \\
\text { rates from the year }\end{array}$} & \multicolumn{3}{l}{ Weighted by each commodity's share of imports from the year } \\
\cline { 2 - 4 } & $1841(\%)$ & $1854(\%)$ & $1881(\%)$ \\
\hline 1841 & 35 & 30 & 27 \\
1854 & 25 & 18 & 6 \\
1881 & 13 & 10 & 21 \\
Total decline & 22 & 21 & 6 \\
\hline
\end{tabular}

Source: McCloskey, 1980: 309.

years. ${ }^{13}$ I reprint the results of his calculations as Table .3 because it is worth using his numbers as benchmarks. His alternative calculations of the tariff rates alter several of the figures by as much as five to ten percentage points. Nonetheless, the magnitude of the absolute change in tariffs seems fairly constant. The large hypothetical changes produced by using different commodity weights are partly attributable to the coverage of British tariffs throughout most of the century.

The large duty-free component of French goods would make French tariff levels still more insensitive to changes in composition. Table 1.4 shows the results of a similar set of calculations (compare with the Appendix, Tables 1.5 and 1.6) using tariff rates based on decadal averages for France drawn from the official trade statistics. ${ }^{14}$ Each period's tariff rates are then recalculated with weights derived from the import composition of all the other decades. For example, the value of 20.82 on the top line of Table 1.4 represents the counterfactual tariff rate that would have obtained if the tariffs of 1827-36 had applied to the quantities demanded in 1867-76 under the tariff regimes and demand curves of 1867-76.

The numbers I began with were slightly lower than those given by LévyLeboyer and Bourguignon, but the differences cannot be tracked easily because those scholars did not document precisely how they arrived at their figures. ${ }^{15}$ However, some of the difference may be accounted for by adding in the small but rather constant export taxes (usually less than 3 to 4 percent of total import duties) and a number of administrative fees. These figures are left out of my calculations to make the exercise as com- 
Table 1.4 Alternative calculations of French tariff rates using different decadal import weights

\begin{tabular}{llllll}
\hline Decade & \multicolumn{5}{l}{ Percentages, using weights in decade } \\
\cline { 2 - 6 } & $1827-36$ & $1837-46$ & $1847-56$ & $1857-66$ & $1867-76$ \\
\hline $1827-36$ & 20.82 & 19.1 & 19.97 & 21.43 & 19.96 \\
$1837-46$ & 18.73 & 16.86 & 17.55 & 19.05 & 17.67 \\
$1847-56$ & 14.63 & 13.41 & 13.03 & 14.33 & 13.1 \\
$1857-66$ & 8.89 & 7.35 & 7.17 & 6.89 & 5.81 \\
$1867-76$ & 8.74 & 6.76 & 6.4 & 6.02 & 4.93 \\
\hline
\end{tabular}

Source: Calculations based on France, Tableau Décennal du Commerce, 1867-76.

parable as possible to McCloskey's. In any case, the differences are not great enough to affect the discussion. One can treat their figures as a benchmark and use my calculations as a means of testing for the sensitivity of the averages.

Note how robust the French figures are to fairly substantial respecification. In no case do the average tariffs increase by more than two to four percentage points. The numbers used in calculations were selected to bias the results upward. To deal with the problem of prohibitions on textiles, I assumed the effective tariff to be 50 percent. This figure was derived from the comparative prices on cotton yarn for the period from 1825 to 1864 calculated by Patrick O'Brien and Caglar Keyder, using an exchange rate of 25 francs to the pound. ${ }^{16}$ O'Brien and Keyder's figures show cotton yarn in France to be some 30 to 40 percent higher than in Britain during this period, so 50 percent would seem to be a reasonable upper bound. This number is consistent with the writings of even the most fervent French protectionists who argued that a rate of $40+$ percent, consistently applied, would have been sufficient to defend existing producers against foreign competition. ${ }^{17}$ Most of the textiles excluded had fairly elastic demands and therefore faced much smaller effective tariffs. ${ }^{18}$ No easily comparable price series are available for wool, but woolen textile prices did not seem to be systematically higher in France than in Britain. Jean Marczewski's numbers even show a lower average price for raw wool in France than in Britain throughout the century. ${ }^{19}$ At any rate, using the 50 percent markup from cotton yarn for wool is certainly an overestimate. Besides, my using a high tariff rate in these cases, combining the import composition of the 1860 s and 1870 s with the tariff rates for the earlier periods, ignores any changes in income or responses to lowered textile prices that would have increased consumption of such products (so long as they could be imported), thus tending to overstate the weight of textiles, in the recalculations. Any further adjustments made in the direction of more reasonable assumptions would only serve to confirm that French 
tariff levels averaged 10 to 15 percent for the 1840 s and 1850 s and 4 to 8 percent for the 1860 s and 1870 s.

In the light of the high duty-free component of French trade, it should not be surprising that the French tariff averages are robust to changes in the markup assumed for textiles. Furthermore, large increases in many items do not change their representation in dutiable goods, because overall imports rose in most categories. ${ }^{20}$

If French average trade levels were lower than, and at worst comparable to, those of Great Britain for virtually the whole of the nineteenth century, and particularly for the first part of the century and for the late Second Empire, how can such a pattern have been ignored for so long? Many conjectures are possible; I will confine myself to the most obvious. Trade formed a much larger proportion of British production than it did in France for most of the century. This fact, coupled with the much larger absolute level of total British trade, was bound to make British trade policy seem more important to the world at large. ${ }^{21}$ Given the high starting level of British tariffs, the steady and ultimately dramatic drop in the average level of British tariffs would have seemed doubly impressive to outside observers focusing on government action that affected very large volumes of trade. In contrast, much of France's commerce was internal and, to the extent that the economy developed or was retarded, was more seriously affected by domestic economic developments than by trade policy. Tariff reform was a prominent accomplishment of Napoleon III, but it was only one part of a large-scale effort to modernize and stimulate the French economy. Furthermore, and despite discussion that has focused on the exogenous politics of the 1860 treaty, the falling average tariff rates show there were substantial changes in France's overall trading regime even before the treaty came under discussion. Some of those changes were unplanned; others were simply unheralded. Other French reforms in the quarter-century before the 1860 treaty, like those promoted with only limited success by Huskisson in Britain in the 1820 s, did a great deal to improve trading conditions in France through the removal of older prohibitions and a tariff "rationalization" (imposition of more uniform tariff rates), though these improvements may not have received as much attention as did the 1860 treaty.

Certainly a large part of the impressions that have been retained about Britain's shift to free trade was owing to the intensity of the debates over the Corn Laws. Large drops in the tariffs on agricultural items were bound to affect British trade and the ideological nature of the debate stamped commercial discussions in England thenceforth. The spotlight on Corn Law repeal obscured the important, though less publicized, changes occurring in France. The graph of average tariffs in French wheat imports (see Figure 1.2) shows the dramatic drop in rates around the time of the Corn Law repeal. Although the changes moved in parallel, the British talked free trade while the French, even under Napoleon III, always spoke of going no further than moderate protection. 


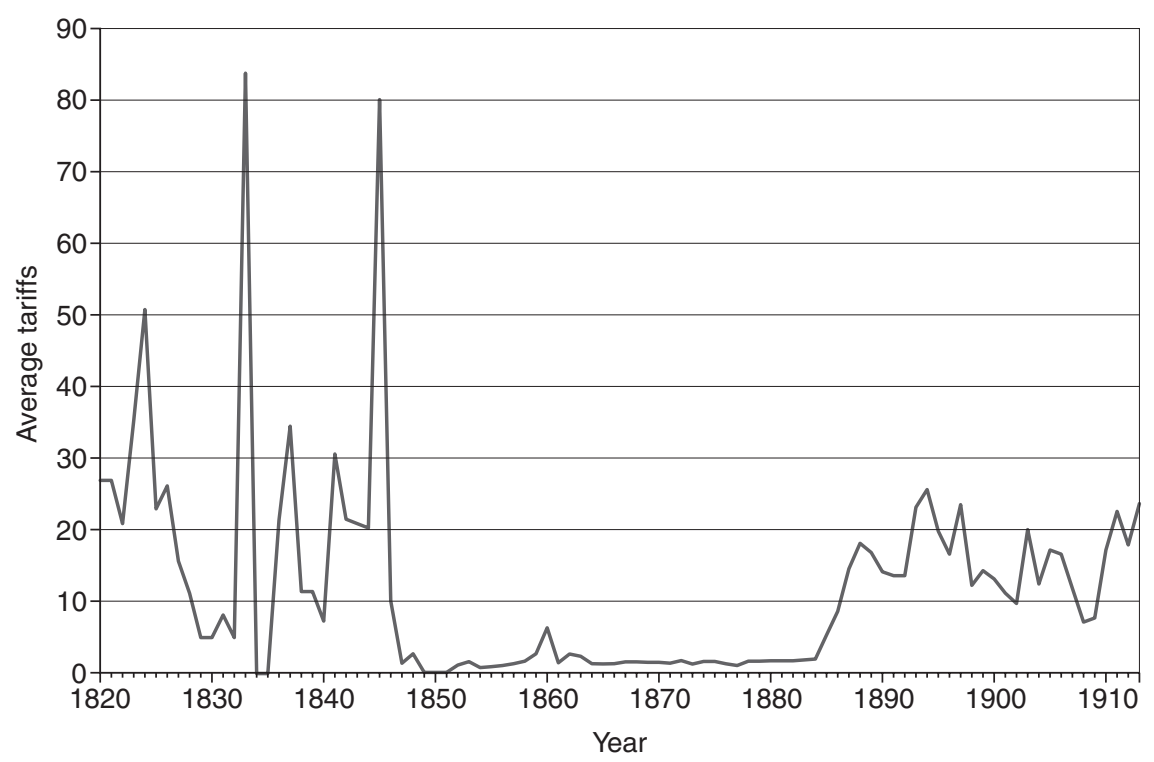

Figure 1.2 Average tariffs on wheat (source: Lévy-Leboyer and Bourguignon, 1990).

Free traders in both England and France were much more concerned with free trade for specific classes of goods they felt were vital to industry than they were with the generalized free trade favored by neoclassical economists.

Lucy Brown wrote in her study of the free-trade movement that the free traders were not averse to tariffs of kinds:

It should be emphasized again that Radical free-traders of this kind expressed no objections to the general principle of deriving a large proportion of the public revenue from import duties. To the regressive character of taxation which lean heavily on duties on tea, coffee, and sugar they were, as has been shown, largely indifferent, perhaps on the grounds that they were not necessities. There is also a final point. None of these duties, except those on timber, which were strongly attacked, and the duty on Swedish iron, were levied on raw materials used in industry, so that they could not be said directly to raise the price of exports. But in criticizing the corn laws a great deal of emphasis was placed on the argument which was itself based on a subsistence theory of wages, that the corn laws raise wages and therefore indirectly the price of exports. This line of argument could equally well be applied to duties on tea, coffee, and sugar, but it was not used. The reason for this distinction was probably the commonsense one that 


\section{John Vincent Nye}

there is a large degree of difference between the effects on the cost of living of the price of bread and the effects of the price of tea. Altogether then, there was nothing in the Board of Trade in 1840 comparable to the late Victorian propaganda for the "free" breakfast table. $^{22}$

The striking thing about the decadal averages of tariff revenues for France is the high proportion of these "consumption" tariffs for all periods from 1827 to 1876 . The large absolute increase in tariffs on wool and cotton products arising from the removal of prohibitions is outweighed by the share of tariff revenues that are accounted for by the main consumption and colonial imports, primarily sugar and coffee. The percentage of total tariff revenues derived from four of the largest consumption items - colonial and foreign sugar, coffee, and olive oil - remained at a fairly constant total of about 55 to 60 percent. If anything, this percentage total is larger for the latter decades, suggesting that tariff levels and their distribution are not substantially biased by the addition (or previous exclusion) of textile products that are no longer prohibited but enter at some tariff level higher than the overall average. In one sense, then, the French prohibitions on cotton and wool textiles and high tariffs on a few other competitive items brand them as protectionist only if one defines protectionism to mean tariffs on a very narrow range of manufactured items. Judged by a broader standard, one that asks how open the nation's trade was, rather than how much it consciously sheltered specific industries, nineteenth-century French trade was quite open indeed.

Whether we make this artificial distinction between consumption and protectionist tariffs or not, the French did seem to perceive that a move to free trade meant a more general move by lowering tariffs across the board for consumption items as well as for industrial goods. Lower tariffs on sugar and coffee were prominent components of the Emperor's stated policy in $1860 .{ }^{23}$ Such intervention was genuinely liberating in light of the protectionist policies advocated by colonial sugar interests. In particular, the gap between tariff rates on foreign and colonial sugar narrows throughout the century to a point at which the average tariff rate on foreign sugar is actually below that of French colonial sugar in the period of 1867 to 1876 (see Table 1.7 in the Appendix).

Finally, a careful study of the Appendix shows that, though coffee and sugar tariffs were high in both nations, they were somewhat lower for Britain than France from the middle of the century. However, the large imports of tea and wine, paying very high tariffs in Britain (usually well over 100 percent), with no dutiable imports of corresponding volume in France, do much to increase the average level of British tariffs. Ultimately, attempts to distinguish too finely between protectionist and revenue tariffs both change the debate and mislead the observer. Revenue tariffs usually mean those that impose a uniform tax on the consumption of an item 
having no domestic substitute. ${ }^{24}$ In contrast, "protective" tariffs penalize foreign products to benefit local industry. But it is troublesome to read protectionism as limited to tariffs on those items also produced in the home country. The problem with this narrow reading is the basic economic fact that there are substitutes for virtually everything. Raise the tariff on wine and people will drink beer; the tariffs on coffee affect the patterns of tea consumption; and the tariffs on sugar affect not only how the tea will be consumed, but also the foods that the tea will be taken with. One can imagine a continuum of substitutes for most imported products, with declining elasticities of substitution. The neat separation of tariffs into those for "revenue" and "protectionist" purposes is useful in explaining both the public revenue and the political economy aspects of tariffs - why revenue tariffs might be more likely to appear than protectionist one. But in evaluating a nation's adherence to the principles of free trade and its importance to the economy, we should take care not to confuse the issues. ${ }^{25}$ Furthermore - the radical free-trader's propaganda aside - most of the remaining British revenue tariffs were strongly protectionist and were recognized as such by British customs officials. The British Parliamentary Papers document both the extent of British tariffs and prohibitions in the earlier half of the century, and the extent to which the so-called revenue tariffs on wine, spirits, tea, sugar, and tobacco survived throughout the period of "free trade" and were used to protect both domestic and colonial industry.

The British Parliamentary report speaks of "the long list of articles which were altogether prohibited to be imported, or could be imported under severe restrictions" lasting virtually unchanged until at least the 1830 s, with a few surviving well into the 1860 s. ${ }^{26}$ In certain cases the prohibitions were said to have been holdovers from British rivalry with the Dutch and to reflect the political influence of the East India Company:

Ever since the year 1660, a positive prohibition had existed and been enforced, against the importation from the Netherlands and Germany, in any ships whatever, of wines, spices, groceries, almonds, currants, dates, ginger, liquorice, pepper, raisins, figs, prunes, sugar, tobacco, potashes, pitch, tar, salt, rosin, thyme. olive oil and numerous other articles. Then silk manufactures of every kind, except silk lace were absolutely prohibited to be imported, as also were embroidery, buttons, band strings, cutwork and fringe made of thread, beef, cattle, ground corn (except wheat meal, wheat flour and oatmeal), mutton, lamb, pork, sheep, swine, malt, foreign fish (with a few exceptions), cards, chocolate, cocoa paste, gloves, thread of copper and brass, manufactured tobacco (except from the plantations of Spain and Portugal, and except snuff), whalebone cut, wines, and woolen cloths. Besides these absolute prohibitions other considerable categories of goods could only be imported by license; others only in a few ports; others only in particular kinds of packages. ${ }^{27}$ 


\section{John Vincent Nye}

It was the commendable accomplishment of the British government to have simplified its tariff structure and eliminated most of these tariffs and prohibitions in the period from the late 1840 s to the 1870 s. But such measures were also being undertaken by the French, who attracted less notice (perhaps because they had less need of drastic reform in the first place). Moreover, the British emphasis on removing tariffs on manufactured goods and not on other "non-essential items" has caused us to ignore the protectionist aspects of those duties augmented "upon purely fiscal considerations." 28

I have already mentioned how wine tariffs must have affected the beer brewers. More significant is the fact that the tariffs on wine and liquor imposed by Britain before the 1860 treaty were levied by volume of wine rather than by alcoholic content or value. This had the effect of favoring Spanish and Portuguese products, in which British merchants had a direct interest, over the products of Bordeaux and Burgundy. ${ }^{29}$ The British Parliamentary report contains this query:

In the present day, when the duty is levied according to alcoholic strength, it strikes the enquirer as curious that until 1831, French wine, which is alcoholically amongst the lightest of wines, should have been saddled with the highest duty of any description [per gallon]. But so it was, until the year mentioned, when the Wine Duties were greatly simplified, a duty of 5 s. 6 d. per gallon being then levied on all foreign wine without discrimination, and 2s. $9 \mathrm{~d}$. on Cape Wine. In 1840 , by the addition of 5 percent to the duties, the two rates became severally 2s. 10 13/20 and 5s. 9 6/20 d. and so remained until $1860 .^{30}$

The French had long complained of the pernicious effects of the British tariff system on the French wine trade. Duties and excises on French alcohol to favor Portugal and Spain were initiated in 1667 and 1685 and had been augmented and refined since then, both to protect British beverage interests and to generate revenue. ${ }^{31}$ A French report to the Minister of Commerce in 1858 remarked that French wines had been the British drink of choice in the seventeenth century, but that the preferential tariff treatment of Portugal and Spain, and the British investment on the Continent that followed, had led to the French wines being displaced. French exports to Britain had barely changed in the last hundred years; they were less in the mid-1840s than they had been in the 1600s; and British per capita wine consumption from all foreign countries had actually declined in the first half of the nineteenth century. Moreover, even after the tariffs on wine by volume were "equalized" in 1831, the French bore the brunt of the tariffs, because the average barrel (la pièce) had a value of 300 or 400 francs, whereas the Portuguese wines of higher alcoholic content were valued at 1,500 or even 2,000 francs. ${ }^{32}$ Other reports complained that the British were in the anomalous position rela- 
tive to other nations (taking into consideration the dominance of French wine in world production and trade) of importing ten to twenty times as much wine from Portugal and Spain as from France and consuming substantially less wine in general than would have been warranted by her growth in income and population. ${ }^{33}$

The degree to which French wines had been kept out of the British market and the degree of substitution of other wines can be seen from the fact that, after the 1860 treaty, when the tariff on all liquor remained high but the gap between French and other wines was partly closed by setting duties according to alcoholic strength, imports of French wines rose fivefold in the first decade. This matched the quantities imported from Portugal and grew from a sixth to a half of Spanish imports in the same period; by 1882 , French wine imports to Britain surpassed those from either Portugal or Spain. ${ }^{34}$ This despite complaints that the British tariffs and excises still biased British consumption toward the more expensive wines and protected British beer and tea, causing growth in total wine consumption from all foreign sources to proceed at a more measured pace..$^{35}$

The section on spirits is equally revealing in that it explicitly discusses the problems of multiple discrimination employed in the British tariff system - with French products at one end, U.K. products at the other, and other foreign and colonial spirits in between. Foreign spirits, and especially French brandies, were either prohibited or taxed at a high rate to favor domestic and colonial spirits. ${ }^{36}$ Although rum from the colonies enjoyed protection vis-à-vis foreign spirits, colonial producers complained of being excluded by tariffs designed to protect local British (U.K.) products such as gin and whiskey. ${ }^{37}$ Protection of domestic and colonial producers extended further in the century than even the wine tariffs, which were substantially revised and lowered after the 1860 treaty; tariffs on spirits were even raised. As France was a major producer of both wine and spirits, all this customs activity would have seemed quite exclusionary, regardless of the fiscal motivation. ${ }^{38}$

One group, however, did notice that there was a British double standard with respect to free trade: the protectionists. In the vigorous battles over the first attempt at major tariff reform in 1856, a number of writers denounced British unwillingness to lower the duties on wine and spirits while vigorously promoting free trade. Le Moniteur Industriel - the leading protectionist newspaper - editorialized as follows on its front page:

The wine-producing nations now know that they are the dupes in this great British market that should enrich them; they know that Great Britain will never sacrifice either their distilleries or their pubs for them. She [Britain] does not go so far in her devotion to the theories of free trade. From competition that she does not fear, she is willingly faithful [to free trade]. But free trade that touches her domestic production is another matter: she will hear none of it. 
We have recently heard a story concerning these British tendencies, whose authenticity we guarantee. In Spain, as in France, the diplomats of liberalism have shamed the Spanish for their backward ideas regarding the protectionist system and have generously proposed establishing free trade between their two nations. Unfortunately, the Spanish asked if the free introduction of their wines was also included. They responded that that was a separate issue; that it touched too great a number of English interests; that Great Britain drew large revenues from her production of beer and of spirits; that these industries represented vast sums of capital, were the livelihood of masses of workers, and that England could never agree to make such a sacrifice on the altar of her principles. That is how the English understand the regime of free trade! ... Everything to one side and nothing to the other. ${ }^{39}$

These arguments have been forgotten partly because the protectionists used such rhetoric to bolster unsound and discredited theories, but mainly because trade reform eventually triumphed in France with the coming of the 1860 Anglo-French Treaty of Commerce. Still, however misguided their defense of protectionism may have been, their observations regarding the limitations of British tariff policy were not inaccurate and shed light on our story.

Although wine and spirits were the major focus of the Continental faction over British trade policy, protectionist vestiges survived in other high-revenue products such as tobacco. For example, even when reforming the duties on raw tobacco and cigars in 1863 (which involved increased duties), the Chancellor of the Exchequer spoke of "trying to avoid extending a protective duty to the British manufacturer." 40 Yet, on average, there was a "cover" to the British manufacturer (effective protection in making cigars) of eleven pence a pound; said cover was in practice an underestimate, established so that the laborers "who were employed in manufacture, amongst whom were women and children, might be well looked after." 1

Sugar duties were not done away with until 1874. Before then British manufacture and British colonies had been well protected. Imports of raw sugar came almost exclusively from the West Indies before 1844, and refined sugar derived entirely from domestic British production. In 1844 raw sugar imports were opened up, but protection was prolonged as a result of extraneous political concerns having to do with a bill designed to distinguish between free sugar and slave-produced sugar from foreign countries. After 1846 these distinctions were eliminated by Peel, but British refiners were protected until $1874 .^{42}$

In the final analysis, the paradoxical gap between historical perception and commercial reality highlighted in this chapter is explained by the observation that writers who talked about trade policy did not really consider the economy as a whole. For the thousandth time, it seems, scholars have con- 
fused the process of growth and development with industrialization most narrowly defined as a few areas of production: textiles, machinery, iron, and steel. They have confused what was politically important with what was economically significant. When writers from Clapham to Dunham spoke of the benefits of free trade, they often looked to what was happening in the crucial "leading" sectors. Because France had prohibitions on textiles, for example, she was economically backward in relation to England. The fact that France had no comparative advantage in mass-market cotton textiles, consumed large masses of raw cotton and wool for home production, and generally had a comparative advantage in agriculture and expensive silk rather than spun cotton seems to have been overlooked. The importance of certain traded commodities to the political debate has misled scholars into confusing trade and protection in these few areas with overall trade and protection. ${ }^{43}$

Protection from the imports of French silks (in Britain) and English cottons (in France) dominated much of the political discussion of protectionism in the two nations, despite the fact that consumption of both items was always small in relation to total trade. ${ }^{44}$ In contrast, agricultural products were important to both economies, so the British Corn Laws and wine duties did increase the gap in the average tariff between France and Britain before the mid-century. In addition, both France and Britain derived many of their import revenues from coffee and tea, assorted foreign manufactures and construction materials such as wood. These items were always a significant fraction of revenues, and fluctuations in demand for them were more dependent on changing incomes than on changing tariffs. Furthermore, most of these imports came from nations outside the circle of the half-dozen world trading leaders and were likely to have been left out of discussions of policy designed to increase direct trade between France and Britain. In addition, the problems of colonial protection were an important determinant of trade policy.

Several historians have argued that the achievements in economic growth during industrialization had more to do with the overall performance of an economy than with the stellar characteristics of the more visible sectors. ${ }^{45}$ Leading sectors make for interesting metaphors, but swiftly rising values in areas that form only small parts of the economy do not explain overall changes in that economy. In much the same way uncritical analyses of trade policy that place a large and unspecified weight on duties levied on "essential" industrial products ignore the direct effects of high tariffs on other items. While it is possible to create models in which certain sectors of the economy provide important dynamic benefits that outweigh static losses in other sectors, these asymmetries are almost never empirically supported. Deadweight losses to the economy from tariffs on sugar, tea, and wine could outweigh losses from tariffs on cotton textiles, if textiles were a small part of one's trade.

None of this is meant to suggest that the move to free trade and its attendant political climate were unhelpful to growth. Undoubtedly the 
more open attitudes to trade did much to foster a more enlightened view of the role of market forces at home. There was some correlation between the interest in freer trade and the rise of a laissez-faire philosophy. Freer trade did have an impact on French industry, and Napoleon III's reforms did affect the structure of the French economy; improved transportation, better capital markets, and overall economic liberalization played equal if not greater roles. In the final analysis, although the calculations in this chapter might be further refined and judgment vary regarding the historical effects of different trade policies, one thing is certain: the traditional stories of free trade opposing a liberal Britain against a protectionist France, reluctantly dragged into a world of more enlightened commercial policies, must now be seen as false. Economic and political analyses that are motivated by the old stylized facts need to be re-examined accordingly.

\section{Notes}

1 Originally published in the Journal of Economic History, 51, 1 (March 1991). (C) The Economic History Association. All rights reserved.

2 The author wishes to thank Jeremy Atack for assistance in obtaining various documents. Douglass North, Joel Mokyr, Ed Greenberg, Gary Libecap, Donald McCloskey, Larry Neal, and Peter Temin provided helpful comments and suggestions. He also benefitted from the comments of the editors, Paul Hohenberg and Peter Lindert and two referees. He naturally means to retain sole responsibility for all errors. This research was supported by a fellowship from the Olin Foundation and the Bradley Foundation to whom he gratefully acknowledges their assistance.

3 Clapham, 1936: 1.

4 Dunham, 1930: 11.

5 This fable of commercial prosperity and international integration through free trade has seemed so compelling that it has become the fundamental motivation of an entire branch of the political science literature through the theory of hegemonic stability (Gilpin, Political Economy; Keohane, After Hegemony). The hypothesis is, in brief, that international free trade is a public good requiring a powerful leader, or hegemon, to become established. In the absence of a dominant Britain, Prisoner's Dilemma Problems Would Prevent States From Moving Toward Free Trade. Britain's unique and unilateral shift to free trade is therefore a necessary if not quite sufficient condition for the integrated European market that developed late in the nineteenth century. In another publication, I consider the implications of my findings for the literature on commercial policy and international relations (Nye, "Revisionist Tariff History").

6 Bairoch, 1989: 6.

7 The scholar who did most to enlighten us about the details of changing trade policy in the French Second Empire did not himself seem to perceive how open French trade had become even before the 1860 Cobden-Chevalier treaty. Dunham underestimated the efforts of Napoleon III when he wrote in reference to the treaty that, "On the side of England it marked the practical completion of the adoption of free trade which had been begun by Huskisson nearly forty years before, whereas on the side of France it was only the first decisive step in a reduction which was not desired to go beyond the limits of moderate protection" (Dunham, p. 1). A recent text by Rondo Cameron 
reviewed conventional wisdom in its discussion of the rise of trade, first in Britain and then in France. Cameron wrote of the period that:

Napoleon tried in the 1850 s to reduce the strongly protectionist stance of French policy, but because of opposition in the legislature he was unable to carry through a thorough reform of tariff policy.... The thought in Britain at this time, after its move to free trade, was that the advantages of a free trade policy would be so obvious that other countries would adopt it spontaneously. Because of the strength of protectionist interests, however, this was not the case. Accordingly, a treaty negotiated by Cobden and Chevalier late in 1859 was signed in January 1860. The treaty provided that Britain would remove all tariffs on imports of French goods with the exception of wine and brandy. These were considered luxury products for British consumers, so Britain retained a small tariff for revenue only.... France, for its part [with the 1860 treaty] removed its prohibitions on the importations of British textiles and reduced tariffs on a wide range of British goods to a maximum of 30 percent; in fact, the average tariff was about 15 percent ad valorem. The French thus gave up extreme protectionism in favor of a moderate protectionism.

(Cameron, 1989: 276)

8 The use of average tariff levels as a basis from which to denote the size and timing of the move to free trade is standard in the literature. Both Imlah's classic discussion and McCloskey's employ some version of tariff revenues as a percentage of importables to indicate how free British trade was (Imlah, 1958; McCloskey, 1980).

9 The British figures are not entirely reliable before the 1820s (and indeed before the $1840 \mathrm{~s}$ ) due to the inappropriate valuations of the commodities imported and exported. An extensive reworking of the trade statistics was produced by Imlah based on the work of Gayer, Rostow, and Schwartz, and has remained the basis for all further research, though Davis expanded further on the commodity series (Imlah, 1958; Davis, The Industrial Revolution).

10 In Bairoch, a table of comparative tariff levels for Western Europe does not list that of France given the prohibitions on many items (1989: 6, table 3). However, the items primarily affected - manufactures - were never that large a share of imports. As I demonstrate, it is possible to take some crude account of the effects of those prohibitions by examining import shares in the later periods of very low tariffs and no prohibitions.

11 One possible index compares tariff revenues in Britain and France using each other's rates. If Britain were clearly more open than France, French tariff revenues would decline using British rates and British revenues would increase using French tariffs. However, calculations for the period from 1847 to 1856 indicate that both countries' revenues decrease when the other's tariff rates are applied. This is not surprising, given the later discussion in this chapter. Contrary to the precepts of international trade, Britain and France tended to levy duties on items on which they did not have a comparative advantage, which partially explains the results of this index.

12 The other officially protected commodity was colonial sugar. Both colonial and foreign sugar were taxed at high rates, though the latter paid much higher duties than the former. As we will see later, the sugar tariffs did play an important role in the overall tariff levels for both countries.

13 McCloskey, 1980: 309.

14 France, Tableau Décennal du Commerce, 1867-76.

15 Lévy-Leboyer and Bourguignon, 1990: 228. The authors seem to note the low average level of French tariffs but do not push the idea much further except to 
note that the 1860 treaty could not have accounted for large changes in GNP. No comparison with other nations was made or suggested.

16 O'Brien and Keyder, 1978: 46.

17 I have simplified the calculations by focusing on French prohibitions, again with an eye toward refuting the hypothesis that British trade was uniformly freer. A more detailed calculation would make corrections for redundant British tariffs.

18 The more extreme protectionist case is represented by the following example from France, Enquête: Traité de Commerce, vol. 4, p. 59. A rather biased comparison of spinning costs in Oissel and Oldham that appears in testimony before the 1860 inquiry comes to the conclusion that British spinners have a cost advantage of about a third relative to French spinners (and this information was challenged vigorously by the English and numerous Frenchmen). The witnesses presented average total costs per spindle for Oissel and Oldham and found that:

"soit pour la filature

d'Oissel, le prix de chaque broche $\quad 41,16 \mathrm{frs}$ pour celle d'Oldham 26,35 frs

Différence de prix par broche $\quad 14,71 \mathrm{frs}$

Therefore, even accepting that this cost per spindle fully represented differences in the marginal costs in both industries and taking the above as a high upper bound, it seems that a tariff of 50 percent strictly applied would have served to maintain existing rents of the protected industries even if transportation costs were ignored. These figures were subsequently challenged by various officials and some observers maintained that no such different existed at all (see Fohlen, 1956).

19 Marczewski, 1965: xxii.

20 The tariff averages are fairly insensitive to large changes in the tariff rate I substitute for prohibitions of textile manufactures. Calculations performed using a 100 percent tariff on both cotton and wool do not change Table 1.3 significantly. Given the data we have on prices and the range of textiles imported, it is unlikely that the true effect of prohibitions on French prices would even have matched the 50 percent figure I employed in the text.

21 It should be noted that total British trade was greater than that of France throughout the nineteenth century; however, it is interesting that the share of exports in GDP was not very much higher in Britain than in France and did not remain so after the Second Empire. After 1870 the ratios for the two countries were quite similar, and France's export-to-GDP figure was even higher on occasion in the 1890s. (Based on independent calculations using figures in Mitchell, 1992 and Lévy-Leboyer and Bourguignon, 1990).

22 Brown, 1958: 157.

23 Thus, in his letter of January 5, 1860, to the Minister of State, Napoleon III summed up his economic policy goals as the following: (1) suppression of tariffs on cotton and wool, (2) successive reductions on sugar and coffee, (3) vigorously pursued improvements in transportation routes, (4) reduction in the canal tariffs and then general reductions in the costs of transportation, (5) loans to agriculture and industry, (6) large scale public works projects, (7) removal of all prohibitions, and (8) commercial treaties with other nations (France, AN FI2 2484).

24 Alternatively, they mean tariffs imposed uniformly on domestic products as well as imports, which was certainly not the case for the British revenue tariffs.

25 In some ways, the question of consumption or revenue tariffs is about the ratio of government tariff revenues to gains to domestic producers from the higher 
tariff. In the revenue case, this ratio is large (or more accurately, the producer gain is small). However, the long-run elasticity of domestic supply is always greater than the short-run elasticity, ensuring that even a fairly strong "revenue" tariff will become more protectionist in the long run.

26 Great Britain, Customs Tariffs: 38.

27 Ibid.: $38-9$.

28 Ibid.: 40.

29 The system whereby resident British merchants in foreign countries could organize as factories with a measure of independence from the local authorities was well known in Portugal and Spain. These factories were an important special interest in British trade policy, quick to respond to changes in commercial legislation and quick to lobby for change. For example, the large British communities of the Lisbon and Oporto factories only became heavily involved in wine and spirits in the early 1700s, when the tariffs favoring Portugal and Spain over France came into effect. They quickly became important actors in the wine trade and worked to preserve and control the advantages they derived from that preferential treatment (Francis, The Wine Trade, pp. 179-224). This British-controlled wine trade "was a principal factor in stabilizing Anglo-Portuguese relations (ibid.: 179). British and Portuguese wine concerns played a major role in blocking all attempts at liberalizing trade with France at the end of the War of Spanish Succession in 1710 and 1713 and solidified British ties to the Portuguese that would persist for over a century after (ibid.: 129). Given the extent of Britain's merchant interests in wines from Spain and Portugal, one could say that the trade involving the three nations was as much domestic British trade behind barriers as it was international trade.

30 Ibid.: 141.

31 Ibid.: 5 .

32 France, Archives Nationales $F^{12} 2525$.

33 Although the figures here are not precise, British and French observers agreed that French wine production constituted some 40 to 50 percent of the world's total and that France's representation in internationally traded wine was usually greater than this. Portuguese exports were overwhelmingly sent to the British market and were themselves an anomaly of British tariff policy. Thus French wine imports into Britain, at 5 percent of those from Spain and Portugal, were seen as virtually prohibitive by the French and some members of the British Parliament. Even given the tendency of wine to be a preferred source of customs and excise revenues, no other country in the world came close to having such an odd pattern of wine imports ( $\left.\mathrm{AN} \mathrm{F}^{12} 2525\right)$.

34 Great Britain, Customs Tariffs: 156.

35 The French viticulteurs had long considered all drinks together and worried not only about the effects on their trade of the obvious substitutes such as sherry, port, or beer, but also about the growth in consumption of tea and coffee. After all, in the eighteenth century, tea was as much a luxury as wine, though it had become the poor man's drink while wine remained an expensive luxury in the nineteenth century (France, Archives Nationales $\mathrm{F}^{12} 2484$ and $\mathrm{F}^{12}$ 2525). In addition, to the extent that there is a "learned" component of the taste for beer or wine, British tariffs and excises helped form British tastes to the detriment of French wine during the period when rising incomes provided a new consumer base; this required several decades of lower prices to readjust.

36 Great Britain, Customs Tariffs: 166. Throughout the first half of the century, the report notes, "the high duty on brandy tended not only to restrict consumption of that article to a comparatively small quantity, but - which was far more serious - it encouraged smuggling to any extent which all the efforts of the customs authorities, and of the revenue cruisers failed to put down." 
37 Ibid.: 167-8.

38 The tariffs on wine and spirits played an especially important role in commercial history because Britain's unwillingness to risk a revenue shortfall through lowered liquor tariffs caused it to rebuff initial French overtures toward bilateral liberalization in the 1840s (Dunham, 1930).

39 Le Moniteur, p. 1.

40 Great Britain, Customs Tariffs: 87.

41 Ibid.: 186.

42 Ibid.: 211.

43 Entirely typical is the discussion of the coming of the Anglo-French Treaty of Commerce by Leone Levi in his classic work, History of British Commerce. Levi has a fine though brief discussion of the changes in French tariff policy leading up to the 1860 treaty and includes the full text of the treaty. However, to compare tariffs between nations he presents a table of comparative tariffs on textiles: cotton, woolens, and linens (Levi, 1988: 433). He uses this as an indication of the differences in the openness of trade among nations and as a guide to the extent of the changes ushered in by the era of commercial treaties. As France had rather severe prohibitions on most subclasses of these items, French trade around 1854 appears extremely protectionist. In a different context, though Bairoch's recent account of commercial policy, discusses tariff restrictions on all classes of items, he still describes the period of "European free trade $1860-79$ " primarily in terms of trade in manufactures. His central comparative table of tariffs in Europe is based on a comparison of the average level of duties on fourteen manufactured products in 1875 (Bairoch, 1989: 42, table 5).

$44 \mathrm{It}$ is amusing to see how similar protectionist claims were in both countries. The French objected that Britain had such natural advantages and such hardworking laborers that French spinners could offer no serious competition to British cotton and linen. Thus the following from Douai, in 1838:

a Messrs les Président et Membres de la Chambre des Députés: Les maires soussignés au nom des fileurs de lin au rouet, ont l'honneur de vous exposer que ces très nombreux industriels, se trouvent maintenant dans une situation tellement misérable que si le gouvernement n'intervient point en leur faveur, le travail va leur manquer, partant du pain; situation cruelle, intolérable; ayez pitié de leur détresse.... Le gouvernement de nos voisins d'outre manche n'oublie rien pour tuer cette industrie de famille, par cela donc essentiellement nationale; sa manière est vraiment libérale, pour atteindre son but plus sûrement et sans bruit et accorde aux fils de lins mécaniques, une prime ad valorem de 15 pour cent,...

(France, Archives Nationales $\mathrm{F}^{12}$ 2537, my emphasis).

On the other hand, British manufacturers upset by French silks and fine woolens argued as late as 1855 that:

the French produce ... goods which by their intrinsic beauty of texture and dye leave every competitor hopelessly in the rear. The prices ... are such that we have long since abandoned their manufacture; and the Deputation, unable to find out the cause of this undeniable superiority were obliged to ascribe it to the well-known truth that a trade once established in a certain locality cannot be carried on with the same success at another place, though the latter may, to all appearances, possess even superior advantage.

(Clapham, 1936: 18).

45 Mokyr, 1993; McCloskey. "The Industrial Revolution.” 


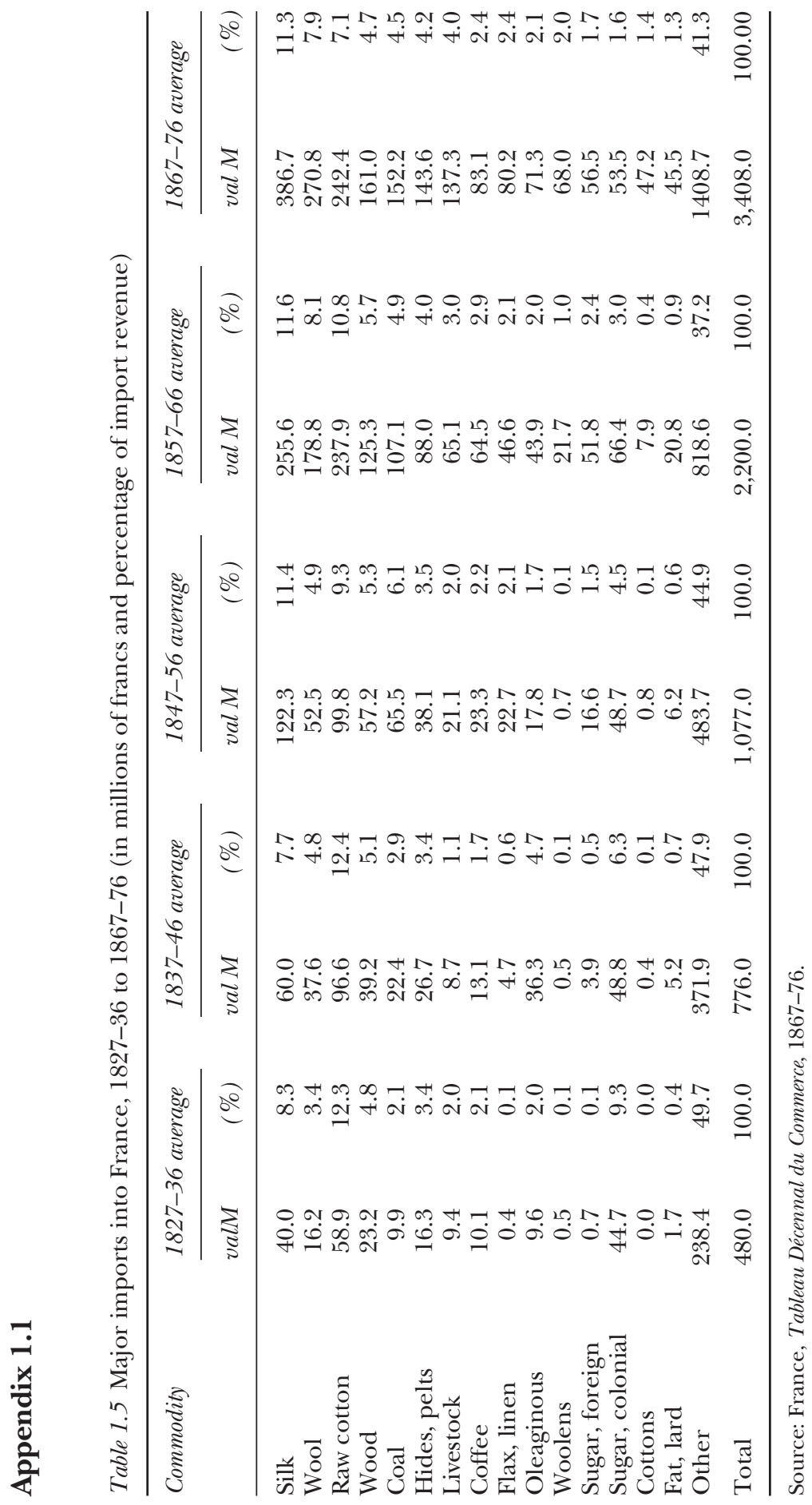




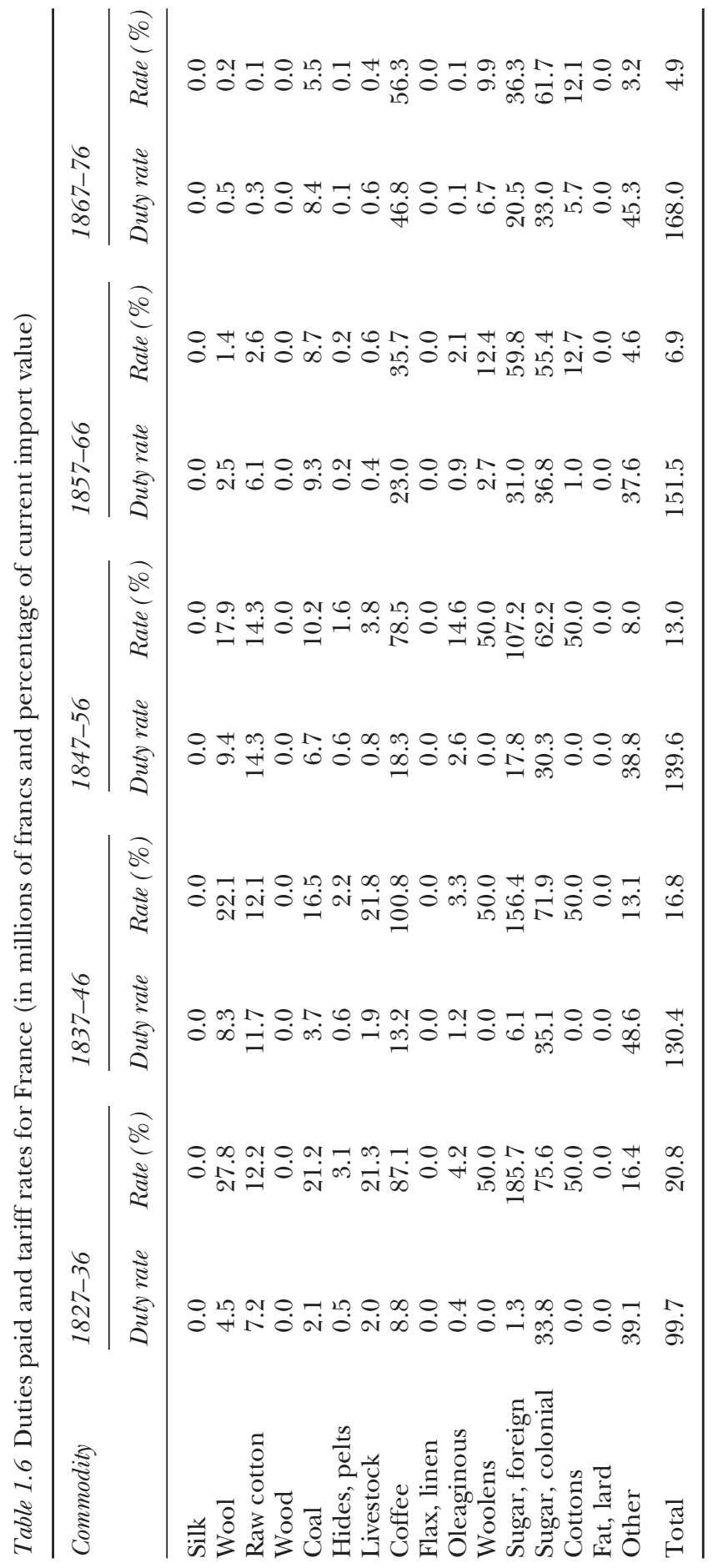




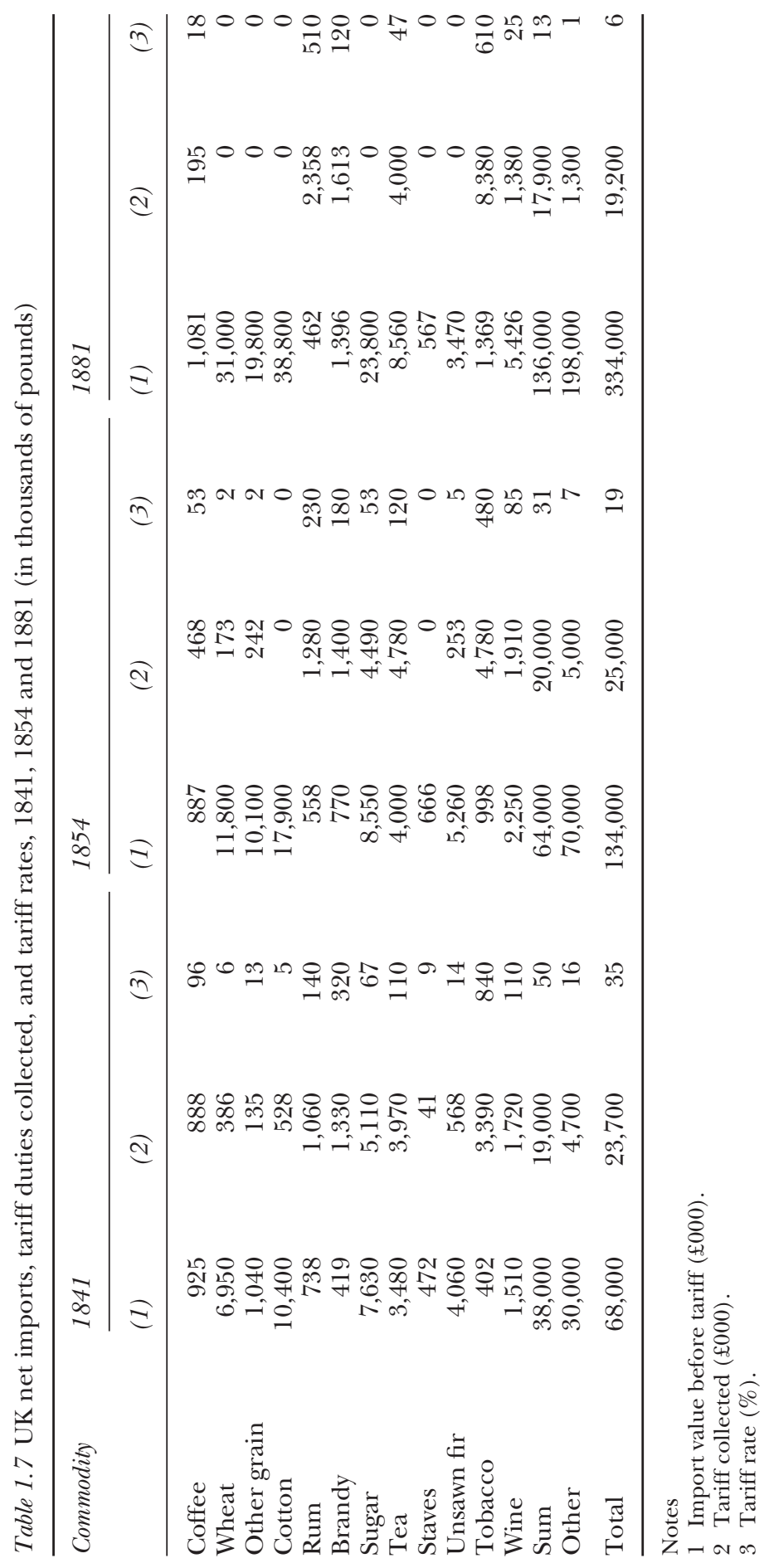




\title{
2 Free trade and protection in nineteenth-century Britain and France revisited
}

\section{A comment on Nye}

\author{
Douglas A. Irwin ${ }^{1}$
}

In Chapter 1, John V. Nye disputed the "conventional wisdom" that Britain was a paragon of free trade and France a practitioner of protection in the nineteenth century. Nye's case is based primarily on figures for tariff revenue as a percentage of the value of imports, calculated using various weights. These figures, as Nye interprets them, "suggest that France's trade regime was more liberal than that of Britain throughout most of the nineteenth century ... British average tariff levels did not compare favorably with those of France until the 1880 s and were not substantially lower for much of the time."

In this chapter I argue that the rate of tariff revenue is an inadequate and potentially misleading indicator of whether a country's commercial policy tends toward free trade or protection. In examining the structure of Britain's tariff in the second half of the nineteenth century, when those problems were particularly acute, I found that the tariff was carefully constructed to avoid protecting domestic producers. A cursory examination of French policy, by contrast, indicates that domestic producers were protected by substantial tariff barriers.

In Figure 1.1, Nye presented evidence on tariff revenue as a percentage of the total value of imports in Britain and France over the course of the nineteenth century. In the first half of the century, the average rate of tariff revenue appears initially to be much higher but to decline more rapidly in Britain than in France, until the rates converge in the two countries at about 5 to 10 percent around the 1860s. In the second halfcentury, the rates remain roughly stable at this level until the end of the century. Taking these tariff revenue measures as a proxy for average tariff levels in the two countries, Nye judged France to have been equally as liberal in its commercial policy as Britain was over the course of the nineteenth century, bringing into question what he believes to be the traditional view on the matter.

Given these figures for the first half of the century, Nye asked, why have economic historians "concluded that Britain was the solitary free trader in the early to mid-nineteenth century?" This questioning of the conventional wisdom is curious, because no scholar of the period has disputed 
the fact that Britain's commercial policy was quite protectionist prior to the 1840s. What is disputable is using the rate of tariff revenue as the sole metric by which to rank-order two countries in terms of the liberality of their commercial policy, as Nye did when he concluded that "there is little evidence that Britain's trade was substantially more open than that of France... France's trade regime was more liberal than that of Great Britain." That rates of tariff revenue were higher in Britain than in France for some decades does not mean a priori that Britain was less open to trade than France: those data alone are not revealing about nominal or effective rates of protection across sectors, and other plausible measures of' "openness" suggest different conclusions (for example, imports as a percentage of GDP averaged 5.1 percent in France and 13.1 percent in Britain over the 1830s). ${ }^{2}$ Focusing on aggregate tariff revenue figures alone can also prompt misleading inferences about a country's trade regime. One might view the sharp decline in the rate of British tariff revenue from the 1820 s to the 1840 s as a sign of trade liberalization. But because many of Britain's tariffs were specific duties, "the burden of duties imposed on trade increased with the post-war deflation of prices." ${ }^{3}$ Thus the decline in the rate of tariff revenue - driven by rapidly growing imports of duty-free raw cotton - came at a time when the protectionist effect of existing duties was greater, perhaps even reducing their ability to raise revenue.

The shortcomings of the tariff revenue measure for judging commercial policy are particularly apparent in the second half of the century. In that period tariff revenue rates were comparable in the two countries, and Nye takes France to have been equally as liberal in trade policy as Britain. In 1846 Britain repealed the Corn Laws that protected agricultural producers and reformed its tariff through the 1850s. With Gladstone's famous budget of 1860, Britain eliminated all remaining protectionist duties and maintained a tariff only to raise fiscal revenue on a few imported consumption items that either were not produced at home or were already subject to domestic excise taxes. ${ }^{4}$ After 1860 , but before 1875 , duties on sugar, timber, paper, and a few minor items were abolished. After 1875 Britain's tariff was applied on the following items: beer, playing cards, chicory, cocoa, coffee, essence of spruce, certain fruits, malt, plate, spirits, tea, tobacco, vinegar, and wine. ${ }^{5}$ From 1875 until at least 1897, this list constituted the entire schedule of foreign goods subject to import duty all other goods were duty free. Just four of these goods - tobacco, tea, spirits, and wine - accounted for over 95 percent of customs revenue in $1880{ }^{6}$

These isolated tariffs were not protectionist duties. A protectionist trade policy impedes international trade in order to shelter (protect) domestic producers in import-competing sectors from foreign competition. These tariffs, in contrast, were carefully imposed for revenue purposes, a distinction that is key to understanding British trade policy during 
this period. When there was domestic production of the imported good, Britain's tariff had no protective effect, because by design it merely offset domestic excise taxes not applied to imports - that is, these tariffs were the natural extension of domestic excise taxes to foreign goods. Almost half of the twenty-six items in the 1860 tariff code were subject to duty "solely for the purpose of countervailing duties of excise on the like articles produced in the United Kingdom." An excise tax levied at the place of sale to consumers, of course, would have made such tariffs unnecessary. But excise taxes were usually assessed on British producers to ensure tax compliance, and consequently tariffs levied at customs ports were required to cover the same imported goods. Without such tariffs, domestic and foreign goods would have competed on unequal terms that favored imports.

This fiscal feat of equal tax treatment for domestic and foreign goods was accomplished in the Anglo-French (Cobden-Chevalier) Commercial Treaty of January 1860, which was passed by Parliament as part of the budget of 1860. According to Article VII of the treaty, Britain agreed

to admit into the United Kingdom merchandize imported from France, at a rate of duty equal to the excise duty which is or shall be imposed upon articles of the same description in the United Kingdom. At the same time the duty chargeable upon the importation of such merchandize may be augmented by such a sum as shall be equivalent for the expenses which the system of excise may entail upon the British producer. ${ }^{8}$

Imports from all sources received this same treatment because Britain automatically extended all provisions of the Anglo-French agreement to other countries. For example, Article VIII of the accord read as follows:

In accordance with the preceding Articles, Her Britannic Majesty undertakes to recommend to Parliament the admission into the United Kingdom of brandies and spirits imported from France, at a duty exactly equal to the excise duty levied upon home-made spirits, with the addition of a surtax of two pence per gallon, which will make the actual duty payable on French brandies and spirits eight shillings and two pence the gallon. ${ }^{9}$

A supplementary convention in February 1860 raised the surtax (with French consent) to 5 pence per gallon. Consequently, after 1860 the excise on domestic brandies and spirits was 10s. per gallon, and the import tariff on all foreign brandies and spirits was 10s. $5 \mathrm{~d}$. per gallon, the difference being "to countervail the charges to which the British manufacturer was subject in consequence of conducting his business under Excise supervision." ${ }^{10}$ 
The principle of equal tax treatment of domestic and foreign goods applied to all other dutiable imports. Imported malt used to produce beer was charged 25s. per quarter after 1860 because there was an excise on domestic malt of $21 \mathrm{~s} .8 \frac{1}{2} \mathrm{~d}$., the differential again owing to administrative costs. When the excise on malt was repealed in 1880, so was the import duty. The malt duty was replaced by a direct excise on domestic beer of $6 \mathrm{~s}$. $3 \mathrm{~d}$. per barrel and an import tariff of 6s. 6d. per barrel. Tariffs on gold and silver plate, playing cards, and vinegar were also levied to match existing excise taxes on British producers of those goods. In determining the duty on tobacco products, exacting calculations were made to equalize the tax treatment of domestic and imported and avoid discrimination in favor of British producers. ${ }^{11}$

Imported commodities that were not produced in Britain - such as tea, coffee, raw tobacco, and fruits - were also burdened with tariffs without having a protective effect. Such tariffs are essentially equivalent to a domestic excise tax and entail a consumption cost, but they do not protect domestic producers from foreign competition - provided there are no significant domestically produced substitutes. Nye maintained that there were domestic substitutes for at least one such good, asserting that the wine tariff' "must have" had a protective effect because wine and Britishproduced beer were likely substitutes in consumption. As beer was already subject to a domestic excise tax and equivalent import tariff, Nye probably intended to show that wine was taxed more heavily than beer, although he presented no evidence to this effect. ${ }^{12}$

All alcoholic beverages were chosen for excise taxation because they were relatively inelastic in demand and hence capable of raising large amounts of revenue. ${ }^{13}$ According to my rough calculations, Britain's tax treatment of domestic beer and French wine was approximately equal. Wine imports from 1862 through to the end of the century were taxed on the basis of alcoholic content; wine under 26 degrees of proof spirit were subject to a 1s. per gallon tax, and wine from 26 to 46 degrees of strength were assessed 2s. 6d. per gallon. Virtually all French wines (98 percent from 1871 to 1879 ) were in the 16-to-20-degree range and subject only to the 1s. tariff, whereas virtually all wines from Spain, Portugal, and 'elsewhere' (92 percent from 1871 to 1879) were above 26 degrees and thus subject to the higher tariff. ${ }^{14}$ After the repeal of the malt tax in 1880, the excise tax on domestically produced beer was 6s. 3d. per barrel; the import duty on foreign beer was 6s. 6d. per barrel. Although the pergallon tax on wine was higher than on beer (1s. on French wine, almost 2 s. on all wine, and 0.2 s. on beer), the ad valorem tax burden was comparable because beer was less expensive: the average retail price of beer inclusive of duty ranged from 0.8 to 2 s. per gallon, whereas the import price of French wine exclusive of duties was roughly 9.5s. per gallon and of all wine on average just over 7s. per gallon. According to these figures, after 1880 domestic beer was taxed at a rate of 9 to 26 percent, imported beer 
at about 14 percent, French wine at 10 to 16 percent, and all wine at about 25 percent. ${ }^{15}$ Although other wines were more heavily taxed than scope of this comment. But the reason beer was consumed more than wine in Britain is probably because it was much cheaper rather than because it was protected by the excise and tariff code, as Nye implies. ${ }^{16}$

In light of all these considerations, there is no contradiction in saying that Britain heavily taxed a very small set of imported consumption items - essentially just tobacco, tea, wine, and spirits - yet was not protectionist. As the ardent free-trader Richard Cobden observed in 1861, "We have many duties - such as that, for example, on tea - which are too heavy, but they are not maintained in the interests of any British producers." 17 France also had tariffs on such consumption items, but they were often set higher than domestic excise taxes. French imports of spirits, for example, faced an import tariff in addition to, not instead of, a domestic excise tax, and even the wine industry received tariff protection. ${ }^{18}$ Moving away from the few consumption items on which both the British and French levied taxes, one finds that French commercial policy throughout the entire nineteenth century discriminated against a wide variety of foreign products through tariff barriers that were entirely absent in Britain. According to the terms of the Anglo-French Commercial Treaty of 1860, France abolished all prohibitions and could not impose specific duties exceeding 30 percent ad valorem, or 25 percent after 1865, though in practice most duties were set at 10 to 15 percent. ${ }^{19}$ Although this was a substantial revision of the French tariff code, it came nowhere near the reforms enacted by Britain, which eliminated all remaining tariffs on manufactured goods in 1860 after having repealed the Corn Laws in 1846. France, by contrast, maintained a tariff code that covered hundreds of items and, as shown in Table 2.1, rivaled Russia in its illiberal tariff treatment of major manufactured goods around 1877. Ashley estimated French tariffs on cotton, linen, and woolen manufactures to have been about 15 percent after 1860 and probably over 20 percent by $1877 .{ }^{20}$

Table 2.1 Tariffs on manufactured goods in 1877 (estimated ad valorem rate, in percentages)

\begin{tabular}{llclllll}
\hline & Britain & France & Germany & Belgium & Holland & Sweden & Russia \\
\hline Cotton goods & Free & n.a.* & $4-11$ & $4-19$ & Free & $8-13$ & $23-38$ \\
Pig and bar iron & Free & $27-50$ & Free & $5-7$ & Free & Free & $17-50$ \\
Chemicals & Free & $15-19$ & $7-22$ & Free & Free & Free & $17-23$ \\
Paper & Free & $6-11$ & 5 & $3-5$ & 5 & $7-19$ & 53 \\
Coal & Free & 10 & Free & Free & Free & Free & Free \\
\hline
\end{tabular}

Source: Board of Trade, "Import duties on British goods (foreign countries)," in House of Commons, Sessional Papers, vol. 76 (London, 1877).

Note

*See note 23 . 
Table 2.2 indicates that French tariffs on British exportables ranked among the highest in Europe and covered a wide range of articles in 1902 - a year not entirely unrepresentative of the last quarter of the nineteenth century, even though the 1892 French tariff entailed somewhat higher duties than the tariff of 1881. These tariffs are important not because of unwarranted focus on "leading sectors," as Nye seems to suggest, but because both Britain and France were major exporters of manufactured goods that were also facing increased import competition from foreign producers of those goods. Their response to this competition speaks to the general tendency of their commercial policy. ${ }^{21}$ Tariff protection was also extended to French agriculture. In response to mid-century complaints by the Société des Agriculteurs that "whereas duties on manufactured goods averaged between twenty-five and thirty per cent, agricultural rates did not exceed fifteen per cent," protection to French agriculture, particularly to livestock and grain producers, racheted up several times in the 1880 s to culminate in the Méline tariff of $1892 .{ }^{22}$

Nye was certainly correct in writing that "the large imports of tea and wine paying very high tariffs in Britain ... with no dutiable imports of corresponding volume in France, do much to increase the average level of British tariffs," as he measured them (p. 22). Indeed, taxes on tea, tobacco, and alcohol accounted for virtually all of Britain's "average tariff" and raised enough revenue to match France's much broader system of import tariffs. Nye also noted that the large proportion of raw materials and intermediate goods in British and French imports, which over time came to receive duty-free treatment in both countries, tended to lower the average rates of tariff revenue and thus account for their similarity in the two countries.

But enormous differences in commercial policy are consistent with comparable average rates of tariff revenue. To assess whether a country's commercial policy tends toward free trade or protection also requires examining the principles underlying the tariff treatment of various goods. The French tariff was broadly based and designed to protect domestic producers by keeping out foreign goods. The British tariff was an extension of the domestic excise system, levied only on a select number of commodities to raise fiscal revenue without discriminating against foreign goods in

Table 2.2 Estimated average equivalent of import duties levied on principal manufactures exported by Britain in 1902

\begin{tabular}{llllllll}
\hline Russia & Austria-Hungary & France & Italy & Germany & Sweden & Belgium & Holland \\
\hline 131 & 35 & 34 & 27 & 25 & 23 & 13 & 3 \\
\hline
\end{tabular}

Source: Board of Trade, "The comparative incidence of foreign and colonial import tariffs on the principal classes of manufactures exported from the United Kingdom," in House of Commons, Sessional Papers, Cd. 1761 (London, 1903). 
favor of domestic goods. Equating British and French commercial policies in the second half of the nineteenth century because their tariffs raised similar rates of revenue misses the essential distinction between free trade and protectionism: whether or not domestic producers are sheltered from foreign competition. By this standard, France flunks and Britain passes the free-trade test.

\section{Notes}

1 Originally published in the Journal of Economic History, 53, 1 (1993), pp. 146-52. The author was then Assistant Professor of Business Economics in the Graduate School of Business, University of Chicago, Chicago, IL 60637. He wished to thank, without implicating, Barry Eichengreen and David Galenson for helpful discussions. Peter Lindert and two referees provided particularly useful comments.

2 Lévy-Leboyer and Bourguignon, 1990: table A-3; Mitchell 1988: 451, 831.

3 Imlah, 1958: 120 (emphasis added).

4 As Gladstone put it, the changes in 1860 marked "a final disappearance of all protective and differential duties; and the merchant, with the consumer, will know that every shilling that he pays, he pays in order that it may go to the revenue, and not to the domestic as against the foreign producer." Hansard's Parliamentary Debates, 3rd series, vol. 156 (1860), p. 868.

5 House of Commons, Sessional Papers, "Customs Tariffs of the United Kingdom from 1800 to 1897," vol. 85 (London, 1898), pp. 890ff.

6 Calculated from data in House of Commons, Sessional Papers, "Annual Statement of Trade of the United Kingdom (1880)," vol. 137 (London, 1881).

7 House of Commons, "Customs Tariffs," p. 40. Nye denied the economic basis for distinguishing revenue from protectionist duties. For a more recent discussion, see Corden, 1971: 11-12.

8 House of Commons, Sessional Papers, "Treaty of Commerce between Her Majesty and the Emperor of the French, January 23, 1860," vol. 118 (1860), pp. 473-4. British policy survived the expiration of the Anglo-French accord because its stance was one of unilateral free trade; the policy was not viewed as a negotiating concession, and it extended the provisions of the accord to all other countries unconditionally.

9 Ibid.: 474.

10 House of Commons, "Customs Tariffs," p. 166.

11 Domestic excise taxes (on beer, plate, playing cards, vinegar, and so on) are listed in the "Annual Report of the Commissioner on Inland Revenue," and import tariffs (on the same) are listed in the "Annual Statement of Trade of the United Kingdom." On malt and beer, see also Stephen Dowell, A History of Taxation and Taxes in England, Vol. 4: Taxes on Articles of Consumption (London 1884), pp. 85ff. For tobacco, see House of Commons, "Customs Tariffs," pp. 185ff.

12 Chapter 1, p. 24. Even if wine had been taxed more heavily than beer, however, beer producers may not have been indirectly protected. One could speculate that if Britain were a "small" part of the European beer market - that is, if beer was imported (exported) under conditions of perfectly elastic foreign supply (demand) - and a tariff on imported wine shifted domestic demand toward beer, the volume of imports would rise (or exports fall) to accommodate the entire increase in demand, and domestic production would not change.

13 As Gladstone noted, "the principle on which the duty on wine is levied is one 
which lies at the very root of half our indirect taxation - the imposition of duties on strong liquors." Hansard's Parliamentary Debates, 3rd series, vol. 156 (1860), p. 1845.

14 See House of Commons, Sessional Papers, "Report from the Select Committee on Wine Duties," vol. 14 (London, 1878-9), p. 318

15 The average import price of French wine (per gallon) was 7.8s. in 1866, 6.1s. in $1870,9.5 \mathrm{~s}$. in $1875,9.4 \mathrm{~s}$. in $1880,9.0 \mathrm{~s}$. in $1885,10.35$. in 1890 ; and $9.5 \mathrm{~s}$. in 1895 (data collected from various years of the "Annual Statement of Trade of the United Kingdom"). Applying the 1s. tariff yields an ad yalorem tariff equivalent ranging from 10 to 16 percent, with an average of about 11 percent at the average $9.4 \mathrm{~s}$. per gallon. Wines from other countries were generally subject to the higher tax: in 1879, for example, the average tax burden on all imported wine was about 25 percent, meaning that the average tax burden on Spanish and Portuguese wine was even greater (House of Commons, "Wine Duties," p. 388). As the average import price of foreign beer (mainly from Holland, Germany, Belgium, and Denmark) ranged from 45s. to 48s. per barrel between 1880 and 1895, foreign beer was subject to an ad valorem equivalent of about 14 percent. (The import tariff and import prices are taken from various years of the "Annual Statement of Trade of the United Kingdom.") The average retail price of domestically produced beer in Britain (inclusive of excise) was stable in the years after 1880, but ranged from 30s. per barrel for table beer to 43s. per barrel for mild ales to $75 \mathrm{~s}$. per barrel for strong ales, meaning that the $a d$ valorem excise tax ranged from 9 to 26 percent. (Retail beer prices are taken from "Report on Wholesale and Retail Prices in the United Kingdom in 1902, with Comparative Statistical Tables for a Series of Years" (London, 1903), pp. 335-6, and table beer prices from Mulhall, 1884: 45.) Which beverage was the beneficiary of better tax treatment is by no means clear from this calculation alone, however. It excludes a $£ 1$ annual license fee on domestic beer producers and other related fees on pubs. The ad valorem rates varied because the aim of revenue officials was to levy taxes not on the basis of price but on the amount of alcohol contained in various beverages. A draft parliamentary report in 1879 found that "the principle of taxing alcoholic drinks on the basis of the alcohol they contain has been shown to apply to the beer and spirits produced in this country, and to apply to them even more rigorously than to the wines imported" (House of Commons, "Wine Duties," p. xix).

16 In designing the new wine tariff in 1860, the Chancellor of the Exchequer expressed great concern that the lower wine tariffs might reduce revenues from the excise taxes on British and foreign spirits. Little mention was made of the wine tariff's effect on the revenues from beer duties, implying that his office viewed wine and spirits as much closer substitutes than wine and beer. See Hansard's Parliamentary Debates, 3rd series, 156 (1860), pp. 1847ff.

17 Quoted in Francis W. Hirst, Gladstone as Financier and Economist (London, 1931), p. 197.

18 On spirits, see House of Commons, "Wine Duties," p. 63; on wine tariffs, see Golob, 1944 and Smith, 1980. On beer tariffs, see House of Commons, Sessional Papers, "System of Taxing Beer or Malt-in Foreign Countries," vol. 102 (London, 1874), p. 211. which puts the French excise duty on beer at 3.75 FF per hectoliter and the French tariff on beer at $5.75 \mathrm{FF}$ per hectoliter.

19 Percy Ashley, Modern Tariff History (3rd edn, London, 1920), pp. 299-300.

20 Ibid.: 300 . British authorities were unable to compile an ad valorem tariff estimate for cotton goods because of the complexity of the French tariff schedule, which included an array of specific tariffs depending on the particular characteristics of the goods.

21 Over 75 percent of Britain's exports and roughly 60 percent of France's 
44 Douglas A. Irwin

exports consisted of manufactures in the second half of the nineteenth century, while the share of manufactures in British imports rose from 7 percent (1853 to 1857 ) to 17 percent (1890 to 1899) and in French imports from 5 percent (1857 to 1866 ) to 17 percent (1897 to 1906). See Schlote, 1952: 68, 71; Lévy-Leboyer and Bourguignon, 1990: 48. Smith has this to say about the French tariff on manufactures in the late nineteenth century: "By providing a favorable environment for this cartelization and organization,... [the tariff] in some cases provided the increment of protection needed to save domestic producers from foreign competition and to allow them to divide the domestic market among themselves (especially in some branches of textiles and metallurgy)" (1980: 238). Britain imposed no tariffs on imported manufactured goods after 1860 .

22 The quotation is from Golob, 1944: 179. As Smith wrote, "by establishing or at least confirming agricultural protection, the Méline tariff saved the peasants from the foreign competition that threatened to destroy them" (1980: 241). 


\title{
3 Protectionism is "special" Reply to Irwin on free trade
}

\author{
John Vincent Nye
}

All free-trade nations are alike; every unfree nation is unfree in its own way.

Though Douglas Irwin's comment (Chapter 2) on my 1991 article (Chapter 1) raises some interesting issues, overall I feel that his criticisms are misplaced. He gives greater emphasis to a different historical period than I chose to discuss; his understanding of the notion of free trade and what it means to be a free trader differs from mine; he has misread and oversimplified my use of the trade statistics; and he is mistaken about British intentions with regard to the tariffs and excises on wine, beer, and other alcoholic beverages. Indeed, Irwin seems unaware of the complicated historical origins of the wine tariffs, of their essentially political and protectionist nature, and of the extent to which fiscal and other policy evolved in Britain in the wake of British trade measures specifically directed against France.

By focusing on the nature and substance of British and French tariff policy at the end of the nineteenth century, despite my explicit emphasis on comparisons at mid-century (particularly the period from 1840 to 1860, before the Anglo-French Treaty of Commerce), Irwin misrepresents the substance of my original article. ${ }^{1}$ He then uses the history of the late nineteenth century to reject my evidence of high average tariffs in Britain as a starting point for a re-examination of Anglo-French trade relationships, and claims to have shown that "France flunks and Britain passes the free-trade test (p. 42)". Because of my focus on the mid-century tariffs, I will not spend much time on Irwin's discussions of French agricultural tariffs or French protectionism in the late nineteenth century. Indeed, I did not and do not dispute the fact that the French were less free-trade oriented at the end of the nineteenth century than the British, nor that British maintenance of free-trade policies at the very end of the century accounts for part of our mistaken view regarding her policies in the period from early to mid-century. ${ }^{2}$ Moreover, even the nominal average tariff measures that Irwin disapproves of reveal as much. ${ }^{3}$ Our disagreements lie elsewhere. 
A tariff is a tax, which by its very nature induces a variety of distortions. In his 1986 textbook on international economics, Giancarlo Gandolfo identified five possible types of distortion induced by tariffs and quotas on the production and consumption patterns of a country. ${ }^{4}$ Irwin would have us focus on only one of them - home production of goods similar to those imports subject to tariffs - simply because it has become common, when one wishes to study either the domestic production effects of a tariff or the political motivation for a given policy, to speak of the narrowly protective effects of a given tariff. This distinction clearly ignores the other distortions induced by tariffs, and in fact provides us with no help in identifying just how far a nation has strayed from free trade. In practice, no tariff goes without protective effects for long. Even when few domestic substitutes exist, prolonged restrictions on trade will result in domestic firms springing up to exploit the tariff (something I will say more about later). Similarly, any tariff imposed for narrowly protectionist purposes will come to generate revenue unless a good is totally prohibited. That is one of the most basic points I wished to illustrate in my original article. Moreover, if a sales tax is desired that limits consumption purely while limiting the various other distortions, that excise must be levied equally on all goods consumed at home, not simply on those one happens to import. ${ }^{5}$

Sometimes revenue versus protection is discussed with respect to how "sensible" a given trade policy is. "Protectionist" tariffs are said to be worse (that is, to lead to lower welfare for the nation) than purely "revenue" tariffs. But for deciding whether or not a nation was a free trader, such a distinction is arbitrary and unhelpful.

There is no unique, widely accepted index of how "free" or "unfree" a nation's trade is. In all probability, it would be impossible to construct one. My use of the average tariffs did not stem from any faith in its definitiveness as a proper index of openness, but from judging it a useful starting point for seriously re-examining the nature and origins of European trade policy. Irwin objects to this because he wants to make narrow protection the opposite of free trade, and because he confuses the issue of how economically efficient or traditionally liberal a given trade policy is with whether or not it constitutes genuine free trade. So he focuses on alternative measures of openness, on the extent to which tariffs on wine and excises on beer were "equalized" after the 1860 treaty, and on the apparent intention of the British to use remaining tariffs for "revenue" purposes.

Let's take the least-important objection first: Irwin argues that average import-to-GDP ratios were a good measure of openness and were lower in France than in Britain. But this is inconclusive. We cannot use those ratios to measure the openness of the two nations, because Britain probably would have had to import more as a share of her GDP than France - given the size of the French economy and the relative variety of its production even if both nations were to have moved to "pure" free trade. An altern- 


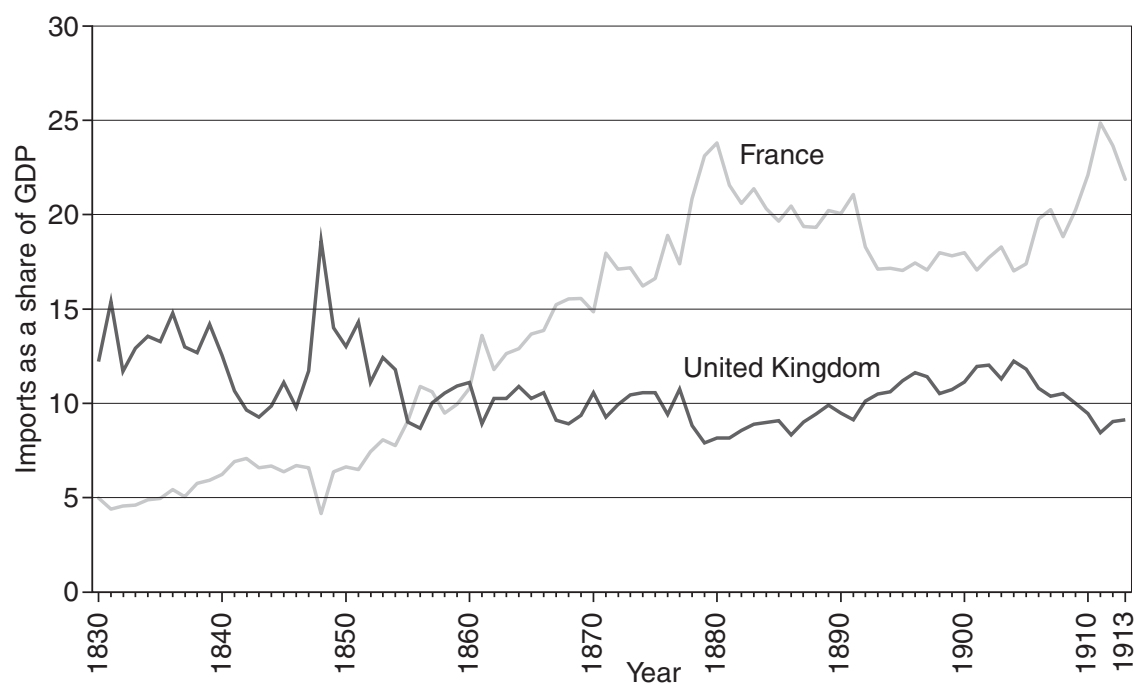

Figure 3.1 Imports as a share of GDP in France and Great Britain, 1820-1913 (sources: Mitchell, 1988; Lévy-Leboyer and Bourguignon, 1990).

ative test would examine changes in the import-to-GDP ratios over time as a useful guide to the changing degree of national openness (see Figure 3.1). I believe that the similarity of the rise in imports to GDP for both nations supports my original emphasis, on the underappreciated parallelism in British and French trade liberalization. Irwin's most serious criticisms concern my claims that the British wine tariff protected domestic beverages; Irwin oversimplifies, and misunderstands the politics and motivations regarding British wine tariffs. ${ }^{6}$

Part of the reason that the 1860 treaty was so important is that the British had resisted reforming their wine schedule for well over a century (attempts to reach a bilateral trade agreement with France in the 1840s had been scuttled by British intransigence on the issue of wine, which impeded similar negotiations with Spain) because tariffs on French wine were the centerpiece of British protectionist measures (in every sense of the term) in the previous two centuries. Wine tariffs were not originally designed as a revenue-generating measure, but rather formed part of a coherent strategy aimed directly at the French. Wine and beer had come to play such a large role in British revenues precisely because of the politics of protection that Britain had pursued.

Britain began to prohibit or seriously tax French wine imports in the late 1600 s, allowing local beverage-makers to earn enormous rents. Moreover, British investments in Portugal formed another interest group that benefitted from protection by switching to wine production. The British had long tried to develop a wine industry in Portugal to serve as a bulwark 
against France (with whom the British had a large trade deficit in the 1600s), but only prohibitions and exorbitantly high tariffs (about fifty-five times the price of vin ordinaire in the early 1700 s) made such investments in Portugal viable. The peace of 1713 led to renewed negotiations to return Britain and France to the status quo ante 1689 trade policies. But the newly strengthened interests of beer, gin, and Anglo-Portuguese wine scuttled those attempts, eventually leading to even higher tariffs on French wine, which was penalized not only relative to British produce but relative to that of Spain and Portugal as well.

The Methuen Treaty locked in this imbalance by promising the Portuguese a tariff no more than two-thirds of that imposed on the French. Moreover, the tariffs were specifically per volume; so they adversely affected the largest class of cheap French wines by favoring beer at the low end and the more alcoholic ports and sherries, as well as the fine bordeaux, at the higher end of the British consumption spectrum. This permitted the government, however, to raise excises on domestic beverages and share in the rents combining alcoholic tariffs and taxes, which undermined trade reform, particularly in the period from 1840 to 1860 (which I stressed in my original article).

The first real trade breakthrough came in 1860. Although the 1860 treaty did not bring ad valorem tariffs, the French were overjoyed because the British lowered the per volume wine duties and assessed lower duties on wine with different alcoholic content, thus redressing some of the imbalance that the old specific duties had instituted vis-à-vis the stronger drink of Spain and Portugal. Nonetheless, average tariff rates continued to be higher on imported wine than on beer, and the gap widened with the abolition of the malt excise. ${ }^{7}$ More importantly, the British tariff continued to protect beer throughout the latter half of the nineteenth century. Because the wine tariffs were specific (by volume) and not ad valorem, they were prohibitive of the cheapest class of French wines, which would have been competitive with beer, but relatively less prohibitive of the highest quality, high-priced wines liable to be consumed by the upper classes.

The duty on French wine (by volume) was about six-times higher than on beer, even after 1860. Irwin concedes this, yet suggests that ad valorem comparisons did not favor beer unduly. But he does not recognize that this would bias the comparisons of ad valorem rates on French wine: he calculated ad valorem rates using all beer produced at home, whereas some classes of wines were simply not imported from France. Using Irwin's figures we can see that the specific excises on domestic beer were 6s. 3d. per 36-gallon barrel in 1880. In contrast the duties on French wine were 1s. per gallon (or 36s. per barrel). The average price of all wines produced in France (as opposed to those exported to Britain) ranged from about 13 francs per hectoliter in the 1840 s and 1850 s to 25 to 35 francs per hectoliter in the 1860s and 1870s (the vin ordinaire price being somewhat 
lower), which comes to no more than $5 \mathrm{~d}$. to $12 \mathrm{~d}$. per gallon or about $15 \mathrm{~s}$. to 36s. per barrel. ${ }^{8}$ Even using markup factors of 100 percent or more (biasing the figure upward) to convert to retail prices, we would arrive at wine prices within the range of $45 \mathrm{~s}$. to $75 \mathrm{~s}$. per barrel, which Irwin identifies as the retail price of beer. ${ }^{9}$ This would mean that the British tariff was equivalent to a rate of 50 to 100 percent of the price of average French wine ad valorem and much higher still for the cheapest wines, even for the liberal years after the 1860 treaty. It should not surprise us, then, that only the better wines tended to enter Britain, as the specific tariffs would have lightly constrained the demand for the best bordeaux and burgundy while greatly distorting the consumption choices of ordinary people's demand for beverages. ${ }^{10}$

Certainly the very desirability of the Anglo-French trade agreement for the French was that the British were willing to shift from a per volume tariff to one based on alcoholic content, which more closely approximated an ad valorem rate than the highly discriminatory rate the French had to suffer for 150 years. The remaining rate was still high enough to keep out the cheapest class of French wines, as it had not been in the early to mid1600s. Indeed, for all the free-trade talk, British trade with France in wine was never again to be as open as it had been in the sixteenth and seventeenth centuries. In contrast, French imports of British textiles were taxed ad valorem, thus tending to minimize the bias that would have kept out the cheaper British products. $^{11}$

Part of my motivation for using average nominal tariffs was to weigh the effects of the various tariffs and prohibitions by calculating how significantly the averages would have changed under different trade conditions. I demonstrated how robust the French numbers were to adjustments in prices or totals by using imputed tariffs of as much as several hundred percent on textiles with constant or increasing volumes of imports. Thus wide swings in the quantities and tariffs on textiles used in calculating the French average would have made little difference to the final outcome. The same cannot be said of British wine tariffs. I made no such corrections in my article, but if one were to take account of any reasonable estimate of how much more wine the British would have imported under conditions of genuine tax parity ad valorem between wine and beer, the British average tariff levels would have risen substantially, suggesting the importance of those restrictions to the overall trade picture. I hope that a more detailed portrait will emerge from my work in progress.

Thus, by intent, Britain was not free trade for the first sixty years of the nineteenth century, and it maintained protections on several items throughout the century. Its overall tariff levels were higher than France's for the first three-quarters of the century. Its so-called revenue tariffs and excises were differentially imposed on items in which it had no comparative advantage and were often used to protect British interests abroad. Its lack of tariffs on manufacturing was unimportant because it had so little 
need for protection in that area. Some of the items (such as wine and brandy) that were so slowly liberalized were precisely the goods that defined Britain's essentially protectionist policies in the last century and that continued to bear a disproportionate burden of the remaining duties. And the one major reform of the Corn Laws was apparently matched just as dramatically, but with less fanfare, by the French. ${ }^{12}$ Moreover, it turns out that many of the pre-1860 French prohibitions were less than binding because the Emperor routinely undercut them with "temporary" import exceptions throughout the 1850s. The French had a larger number of moderate ad valorem tariffs on a variety of items that made up no more than a third of their total imports. The heaviest restrictions were placed on a class of items - textiles - that never played as large a role in French trade as wine and spirits had in Britain's history, and they therefore had a smaller effect on the overall picture of French trade policy. ${ }^{13}$

I did not and do not believe that simple average nominal tariffs are a definitive guide to a nation's trading status. I used those measures because they have been commonplace in the literature on Great Britain and because I wanted to dramatize our lack of understanding of an essential episode of European trade history. ${ }^{14}$ They also afforded an idea of the overall effects of the numerous tariffs and restrictions on trade. Even with appropriate corrections, it is startling how constant the gap between British and French average tariffs was, thus indicating how revealing the nominal average tariff levels were. The latter also suggest that we look beyond comparing the number of items on which duties were levied to evaluate their weight in total trade. Subsequent investigations have led, and will continue to lead, to new insights into trade history that have hitherto been obscured by a simplistic story about British exceptionalism with respect to free trade in the mid-nineteenth century. ${ }^{15}$ The reader who reviews my original article (in Chapter 1) will find my central conclusions unchanged by Irwin's criticism: Britain's trade in the first three-quarters of the nineteenth century was not so free as we have been led to believe, and France's trade policy was more liberal than we had supposed. The myth has been re-examined and found wanting. We must now get on with the task of understanding better what determined the actual course of AngloFrench commercial policy.

\section{Notes}

1 See Chapter 1. In the epigraph at the beginning of this Chapter I state that "French average tariff levels were, surprisingly, consistently below those of Britain throughout most of the nineteenth century, even after the abolition of the Corn Laws and before passage of the 1860 Treaty of Commerce" (emphasis added). I go on to quote Bairoch regarding British free-trade exceptionalism from the 1840 s to 1860. I then say, "When the comparison is made, the trade figures suggest that France's trade regime was more liberal than that of Britain throughout most of the nineteenth century, even in the period from 1840 to $1860 "$ p. 14). 
2 For an elaboration of this point, see my overview of the Anglo-French trade (John Vincent Nye, "Guerre, Commerce, Guerre Commerciale," Annales ESC, 3 (May-June, 1992: 613-32).

3 See Chapter 1, Figure 1.1. The averages are useful to get a sense of how important the different components of the tax code are. Indeed, one of the problems with Irwin's method of simply noting that fin-de-siècle France "maintained a tariff code that covered hundreds of items," is that one is left with the impression of a highly closed economy, when counting tariffs is not in fact a reasonable way of deciding how significant those tariffs were relative to large British tariffs on a small number of items that made up a substantial fraction of total trade. Nominal average tariffs were not meant to settle the issue but rather to serve as a starting point for demonstrating how important weighted measures are in comparing the trade policies of different nations. And it is useful to know that the nominal averages do seem to confirm our suspicions that end-ofthe-century France had more restrictive trade policies than did Britain, which I had already noted.

4 Giancarlo Gandolfo, International Economics, Book 1 (Berlin, 1986).

5 For instance, more than a few commentators have noted that the U.S. luxury tax on automobiles costing over $\$ 30,000$ differentially burdens foreign manufacturers, who dominate that end of the market - and that this is no accident.

6 I address the historical consequences of British policy from 1689 to 1860 with respect to alcoholic beverages at home and abroad on British consumption habits and on French income, as well as the implications for British trade policy in a work in progress tentatively titled, "The unbearable lightness of drink: British wine tariffs and French national income: 1689-1860."

7 In the 1850s the average tariff on all wine imported into Britain ranged from about 45 to 85 percent. This dropped to about 25 to 30 percent in the decades following the treaty, whereas beer excises on all domestic production averaged about 12 to 18 percent ad valorem before the treaty and between 10 and 15 percent afterwards.

8 France, Ministère du Commerce, Annuaire Statistique de la France (Paris, 1884), pp. 340-1.

9 Price quotes from the Journal d'Agriculture Pratique (new period, 1859, tome 2) give market prices for the cheaper wines in 1858 and 1859 trading in France at roughly 13 to 18 francs per hectoliter, which would come to under 20s. per barrel. Even after I added a generous markup, this again suggested a lower price per barrel than beer in Britain, with an effective ad valorem tariff of more than 100 percent.

10 Though we do not know the exact types of wines imported into Britain from France, we do have one useful proxy, the ratio of bottled to barrel wines by volume. Wines imported in bottles were only of the best kind, because they were expensive to transport and liable to breakage. For most countries, the French trade statistics indicate a ratio of one bottle to twenty barrels or more by volume. Britain is unique in having a ratio of one to three, again indicating that the British duties essentially cut out the low end of the wine market (France, Archives Nationales, $\mathrm{F}^{20} 744$ ). Indeed, since the $1700 \mathrm{~s}$ it had been typical for the British market to obtain a disproportionately large share of the high-end Bordeaux output, because those wines would have been less seriously affected by the volume tariffs.

11 This comparison is particularly appropriate because the French specialized in high-quality woollens, silks, and linens. The fear was that low ad valorem rates would mean that much larger quantities of the cheap British cottons would "flood" the French market. The French protectionists were not mistaken: very large amounts of British cottons of all types were imported from 1860 on: the 


\section{John Vincent Nye}

French protectionists were also justified in worrying that the ad valorem rates would not be enforced systematically, as under-reporting was always a serious problem (and one not shared by the British-specific duty on French wine).

12 See Chapter 1, p. 20.

13 For France, the only category that seriously affected overall tariff averages was tariffs on agriculture. Not surprisingly, the overall French average tariff rose or fell depending on major changes in duties on imported grain.

14 See, for example, Imlah, 1958; McCloskey, 1980: 303-20.

15 See Bairoch, 1989: 1-160. 


\title{
4 Measuring protection
}

\section{A cautionary tale ${ }^{1}$}

\author{
Kevin H. O'Rourke ${ }^{2}$
}

\section{Introduction: measuring protection}

What is the relationship between trade policy and growth? Although the issue is fundamental, empirical evidence remains unsatisfactory. The most basic difficulty facing researchers is how to quantify the level of protection in an economy. As is well known, a classic index number problem arises: take the following trade weighted average tariff

$$
t=\Sigma_{i} \frac{M_{i} t_{i}}{M}
$$

where $M_{i}$ is the import of $\operatorname{good} i, t_{i}$ is the tariff levied on $\operatorname{good} i$, and $M$ is total imports.

The problem with this measure is clear: as the tariff on good $i$ is increased, the weight on good $i$ declines. In the extreme case, if a tariff is raised so high that imports are excluded, the weight drops to zero, and the tariff no longer contributes to the index. Other attempts to measure the openness of national economies have been no more satisfactory. For example, some researchers have used the ratio of exports, or imports, to GDP as a measure of openness. This measure is clearly unconvincing. The equilibrium ratio of trade to GDP might be low for a particular economy in free trade. More recently, Leamer and others have developed a measure of trade openness based on a Heckscher-Ohlin empirical trade model. ${ }^{3}$ If trade patterns for a country do not confirm with the predictions of the model, this is taken as evidence of protection. The problem with this index of protection is also obvious: the Heckscher-Ohlin model may not adequately describe late-twentieth-century trade patterns. The problems which the lack of a suitable measure of protection has given rise to may be gauged from two surveys of the literature on trade policy and economic growth that have appeared in recent years: Tariffs and Growth (Capie, 1994), on the 1850-1940 period, and the Edwards (1993) survey article on trade policy in developing countries in IEL. Both pieces are concerned with establishing the relationship, if any, between protection and growth; both are hamstrung by the basic question of how to measure the 
degree to which a country is protectionist. The Capie book devotes extensive space to the relative merits of such indices as the ratio of tariff revenue to imports, the trade to GDP ratio, and the effective rate of protection (for specific industries), none of which give an entirely adequate picture of the overall trade policy stance of an economy. The promise of the book's title is never fulfilled, simply because there have only been one or two, unsatisfactory, cross-country studies of the issue to date; although Capie reaches strong free-trade conclusions, the book provides almost no empirical findings to back this up.

The Edwards survey reveals that more work has been done on the postwar period, but even here the use of discrete classifications of countries ('strongly outwardly oriented', and so on) makes it impossible to estimate the elasticities we are most interested in, and introduces the possibility of bias on the part of the classifier. These classifications have been adopted largely because of the growing importance of non-tariff barriers in overall trade policy. Once again, the absence of a theoretically satisfactory index of protection has hampered research in the area.

This chapter focuses on an index of overall protection recently proposed by Anderson and Neary, the trade restrictiveness index (TRI). The TRI is defined as the uniform tariff which would have the same static welfare effect as the structure of tariffs and quotas actually in place. ${ }^{4}$ Unlike previous ad hoc measures, the TRI makes theoretical sense. However, by definition the TRI can only be measured within the context of a particular general equilibrium model. The question thus arises: how sensitive is the TRI to the specification of that model?

The chapter proceeds as follows. The following section introduces the TRI, as well as the generic CGE model proposed by Anderson and Neary within which to evaluate it. After this, a specific historical debate is presented: was nineteenth-century France really more protectionist than Britain? The answer depends on how you measure average protection. In particular, the qualitative literature has pin-pointed the structure of demand as being crucial to the debate. The next section calculates the TRI for nineteenth-century Britain and France within the context of the generic Anderson-Neary model, but alters the specification of the model's demand side. The TRI is shown to be extremely sensitive to the specification of the CGE model. The final section provides a conclusion.

\section{The trade restrictiveness index and a generic model}

In a series of papers, Anderson and Neary (1992, 1994a, b) have proposed the most promising measure yet of a country's protection, based on solid analytical foundations: the trade restrictiveness index (TRI). To motivate the TRI, consider the standard partial equilibrium analysis of the effects of a tariff in a small open economy (Figure 4.1). The quota equivalent to a tariff $t$ is $A B$; i.e., it is the quota which produces the same static welfare loss 


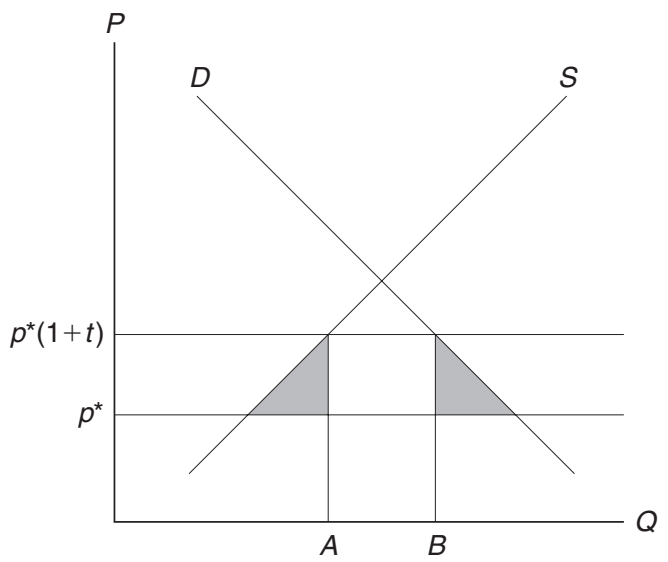

Figure 4.1 Equivalent tariffs and quotas.

(the shaded triangles) as the tariff. It makes sense to similarly define an index of protection for more general cases. A country's TRI is the uniform tariff which would have the same static welfare effect as the structure of tariffs and quotas actually in place. It is a weighted average tariff, but the weights are marginal welfare weights, rather than trade shares.

It follows from the definition of the TRI that its level depends not only on the structure of protection, but also on the structure of the economy in question, which in practice boils down to the structure of the computable general equilibrium (CGE) model used to evaluate it. Ideally, we would like to know what the 'true' model was for each country and time period. Since arriving at the true model is impossible, the danger arises that the value of the index for a particular country might be a consequence of some quirk of the country-specific model. How comparable would such indices be across periods and countries? It seems sensible to use a 'standard' model when calculating the index for different countries.

Moreover, such a cross-country model should be very disaggregated, at least as far as the treatment of imports is concerned.

To operationalise their index in data scarce environments, Anderson and Neary propose a particularly simple and parsimonious CGE model with which to evaluate the TRI (see Figure 4.2, p. 60). The model can treat imports in as disaggregated a manner as is desired; while the supply side of the model is extremely aggregated, facilitating calibration. Anderson and Neary also provide an EXCEL spreadsheet program enabling researchers to easily implement the model. The economy produces two goods, a non-traded good (NT) and an export good (EX).

Production uses two types of inputs: a non-traded input, i.e. domestic factors of production, imported intermediate inputs (II). The production function is CES on the input and CET (constant elasticity of 
transformation) on the output side. Anderson and Neary typically take as benchmark values 0.7 for the elasticity of substitution $(s)$ and 5.0 for the elasticity of transformation $(t)$.

The consumer is endowed with the non-traded input, and receives all tariff revenue. The consumer is also endowed with enough foreign exchange to enable him to run the (exogenous) trade deficit. He consumes the non-traded good, as well as imported final goods (IF). The entire production of the non-traded good is consumed by the consumer; the entire production of the export good is exported. The model thus assumes implicitly that imported goods and exported goods both differ from domestic commodities consumed locally. The utility function is CES with the benchmark elasticity of substitution being taken as 5.0.

The advantage of this specification is that the model can be calibrated with only three numbers (in addition to the import and trade policy data you obviously need): GDP, the value of exports and the trade balance. Calibration proceeds as indicated in Table 4.1. Note that the consumer receives the tariff revenue on both intermediate and final goods, and that the cost to the consumer of final goods includes the tariffs levied thereon. Therefore the consumer's budget constraint is satisfied.

Some complications arise in the presence of quotas. First, the welfare effects of a quota depend on who gets the rents; and thus the TRI also depends on who gets the rents. In the spreadsheet version of their model, Anderson and Neary make the 'convenient assumption' that all rents are dissipated through competitive rent-seeking; but other assumptions could be made.

Second, the presence of quotas leads to data problems. In the case of an ad valorem tariff, we observe domestic prices and quantities, and can infer the world price. Thus, given the slope of the demand and supply

Table 4.1 Calibrating the CGE model (domestic prices)

\section{Production}

Input: non-traded input

Input: imported inputs

Output: exports

Output: non-traded good

\section{Consumption}

Endowment: non-traded input

Endowment: foreign exchange

Demand: non-traded good

Demand: imported final goods
Quantity: GDP

Quantity: INTER + TI

Quantity: EXP

Quantity: GDP + INTER + TI - EXP

Notes

INTER, value at world prices of imported intermediates; TI, tariffs levied on imported intermediates; EXP, value of exports; FINAL, value at world prices of imported consumer goods; TF, tariffs levied on imported consumer goods; TDEF, INTER + FINAL - EXP (i.e. trade deficit at world prices). 
curves, we can calculate the welfare loss associated with the tariff, and consequently the TRI. However, in the case of a quota, while we observe domestic prices and quantities, we only know the world price if we also know the quota premium - which is typically not the case. It is thus impossible to calculate the welfare loss associated with a quota, and by implication, it is impossible to calculate the level of the TRI. However, it is possible to calculate the change in welfare associated with a change in quotas; it is thus possible to calculate changes in the TRI. The spreadsheet program provided by Anderson and Neary does precisely this; it allows you to track how the TRI of an economy is changing over time. (Of course, if one of the periods being compared is a hypothetical free-trade period, and data on world prices of quota-constrained goods are available, then the program can be used to calculate the level of the TRI in a given period.)

At this point, the reader will have two questions. Does it matter whether you use the TRI or not? Is the index trustworthy? In answer to the first question, Anderson and Neary have computed the TRI for a number of cases, and find that indeed its behaviour differs dramatically from that of the trade-weighted average tariff equivalent. Table 4.2, taken from Anderson and Neary (1994a), gives changes in the US protective stance vis-à-vis Hong Kong textiles: the complete lack of correlation between changes in the TRI and changes in the standard index is typical of their findings to date. Clearly, standard measures such as weighted average tariffs could give an extremely misleading impression of what is happening to a country's trade policy.

This chapter focuses on the second question: is the TRI trustworthy? The index itself makes theoretical sense, of course, so the question really is: how sensitive is the index to the specification of the CGE model which is used to calculate it? How sensitive is it to the elasticities of substitution and transformation embedded in the model? If changing these elasticities, or the specification of the model, changed the level of the index significantly, we would still have an index number problem, albeit of a more

Table 4.2 US imports of Hong Kong textiles and apparel: changes in protection (percentage change)

\begin{tabular}{lcc}
\hline Year & Change in TRI & Change in average tariff equivalent \\
\hline 1983 & 1.1 & 84.4 \\
1984 & 11.0 & -8.1 \\
1985 & 1.5 & -39.2 \\
1986 & -3.8 & 42.2 \\
1987 & 1.9 & 12.0 \\
1988 & 3.6 & -53.0 \\
Cumulative & 15.7 & -22.9 \\
\hline
\end{tabular}

Source: Anderson and Neary (1994a, Table 1). 
Table 4.3 Changes in Colombian TRI, 1989-90: sensitivity analysis

\begin{tabular}{llll}
\hline $\begin{array}{l}\text { Elasticity of final } \\
\text { demand }\end{array}$ & $\begin{array}{l}\text { Elasticity of intermediate } \\
\text { demand }\end{array}$ & $\begin{array}{l}\text { Elasticity of } \\
\text { transformation }\end{array}$ & $\begin{array}{l}\text { Change in } \\
\text { TRI(\%) }\end{array}$ \\
\hline 1.5 & 1.0 & 1.5 & -4.9 \\
2.0 & 0.7 & 2.0 & -4.8 \\
2.0 & 0.7 & 5.0 & -4.2 \\
5.0 & 0.5 & 5.0 & -4.4 \\
5.0 & 0.7 & 5.0 & -3.7 \\
\hline
\end{tabular}

Source: Anderson and Neary (1994a, Table 4).

fundamental, 'economic' nature. In such a case the index number problem would reflect the modeller's ignorance about the true structure of a particular economy.

Anderson and Neary recognise that whether the TRI is robust to changes in elasticity values is an important issue. The evidence to date is that the TRI is not sensitive to changes in elasticities: Table 4.3 gives some illustrative calculations for Colombia. They note that the robustness found in the Colombian case has also been found in the other TRI applications that have been carried out to date; but go on to state that 'Because it is only an empirical finding, of course, it needs to be replicated extensively on other data sets before it can be regarded as typical' (Anderson and Neary, 1994a: 166). Is this finding generally true? An historical example suggests otherwise.

\section{France and the UK: nineteenth-century fortresses or free traders?}

In a strongly revisionist 1991 text (reproduced here in Chapter 1), Nye (1991) challenged the conventional view that Britain was the free trader of nineteenth-century Europe, while France was relatively protectionist. Nye based his argument on trade-weighted average tariffs for the two countries, as well as the evidence on individual tariff levels contained in Tables 4.4 and 4.5: he found that British average tariffs were higher than their French counterparts until the late 1870s. Nye concluded that the mistaken impression that Britain was the leading free trader of the period, especially when compared with its nearest neighbour, is due to the fact that historians have tended to have too narrow a focus, obsessing about a small number of 'leading sectors' such as cotton textiles, rather than the economy as a whole. ${ }^{5}$ Nye's article was in many respects deeply shocking, challenging as it did one of economic history's most established stories (or morality tales): Britain's conversion to free trade in 1846, and the huge growth in overseas trade and investment that followed. It was therefore not surprising when Irwin (1993) responded to Nye. Irwin questioned the 
usefulness of trade-weighted average tariffs: after 1846, and especially after the 1860 Gladstone budget, British tariffs were mainly levied for revenue purposes, and had little or no protective effect.

Irwin's argument can be appreciated by examining either Tables 4.6 or 4.7 of Nye's article, ${ }^{6}$ or the summary statistics in Tables 4.4 and 4.5. These tables, based on the information provided by Nye, give trade-weighted average tariffs for three classes of commodities: 'exotic goods', 'wines' and 'other goods'. Exotic goods are imported goods with no domestic substitutes: sugar and coffee in France, sugar, coffee, tea and tobacco in Britain. Wines, consisting of wine, rum and brandy, are a separate category for Britain, for reasons which will become apparent. Tables 4.4 and 4.5 show that, in the 1840s and 1850s, British tariffs on exotic goods were higher than their French counterparts. British tariffs on 'other' goods were higher than in France in 1841, but lower in 1854, and virtually non-existent in 1881. Britain levied high tariffs on wine and spirits throughout the period. The result of high tariffs on exotic goods and wines was British average tariffs which were higher than in France: this is essentially Nye's point. However, Irwin argued that the duties on exotic goods and wines were not protective, as there were no domestic substitutes for these goods. Nye had argued that wine and beer were substitutes; Irwin replied that

Table 4.4 Tariff averages, France, 1837-76 (per cent)

\begin{tabular}{llccc}
\hline Tariff category & $1837-46$ & $1847-56$ & $1857-66$ & $1867-76$ \\
\hline Exotic goods & 82.7 & 74.8 & 49.8 & 51.9 \\
Other goods & 10.8 & 7.5 & 3.0 & 2.1 \\
Average tariff & 16.9 & 13.0 & 6.9 & 4.9 \\
TRI $(30 \%)$ & 17.6 & 11.4 & 4.7 & 5.5 \\
TRI $(50 \%)$ & 17.8 & 11.6 & 4.7 & 5.5 \\
\hline
\end{tabular}

Sources: see text. The import data are taken from Nye (1991: 43). The GDP and export data are from Lévy-Leboyer and Bourguignon (1990, Table A-III). There are minor discrepancies between the import totals in the latter source and Nye's totals; the GDP and export data are thus scaled up or down proportionally, so as to match Nye's import data.

Table 4.5 Tariff averages, UK, 1841-81 (per cent)

\begin{tabular}{lrrr}
\hline Tariff category & 1841 & 1854 & 1881 \\
\hline Exotic goods & 106.5 & 99.3 & 35.7 \\
Wines & 150.8 & 127.6 & 66.2 \\
Other goods & 12.3 & 4.8 & 0.7 \\
Average tariff & 35.0 & 18.5 & 5.8 \\
TRI(1) & 15.2 & 6.9 & 0.6 \\
TRI(2) & 154.1 & 104.7 & 253.9 \\
\hline
\end{tabular}

Sources: see text. The import data are taken from Nye, 1991: 44. GDP at factor cost is taken from Mitchell, 1988: 831-2; domestic exports are taken from Mitchell, 1988: 452-3. 
tariffs on wine were simply the equivalent of excise taxes on domestic beer, and that they therefore had no protective effect.

The Nye-Irwin debate, which was largely qualitative, thus hinged on the specification of demand, and in particular on how exotic goods should be treated. It was these goods which faced the highest tariffs, with the British tariffs on exotic imports, in particular tobacco, being far higher than in France. Moreover, several of these tariffs increased in Britain over the period, in contrast to the general pattern of tariff reductions. It seems natural to try to resolve this debate using the TRI. In particular, it makes sense to calculate the TRI for both countries, using the generic Anderson-Neary COE model. However, given the nature of the Nye-Irwin debate, it will be necessary to see if the TRI is sensitive to the specification of the model's demand side.

\section{The TRI and model specification: sensitivity analysis}

The TRI is a measure of the overall distortion implicit in a country's trade regime. Intuitively, this should imply that a country with a more widely dispersed tariff structure will have a higher TRI, ceteris paribus (since a greater dispersion of tariffs implies greater discrimination between commodities). Anderson (1995) shows that this is not generally the case; the TRI is rather a function of the 'marginal trade-weighted generalised variance' of the tariff schedule. Nonetheless, the intuition persists that the British TRI level will be extremely high indeed, if all imported goods are treated symmetrically. The generic Anderson-Neary model of Figure 4.2 does precisely this. However, it seems unreasonable to assume that the domestic elasticity of substitution between tea and domestic products should be as high as that between, say, American grain and domestic products. What if different categories of imports are treated asymmetrically?
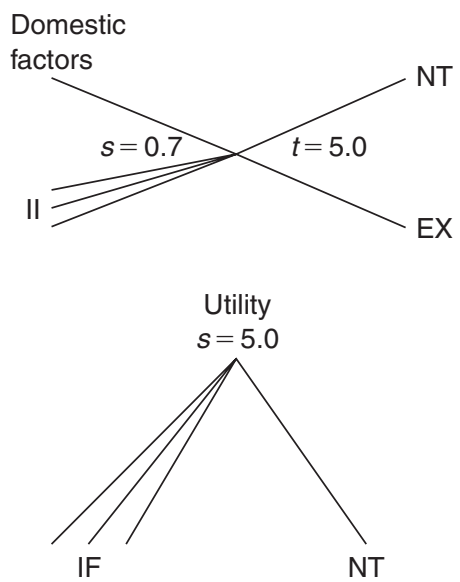

Figure 4.2 Generic Anderson-Neary model. 


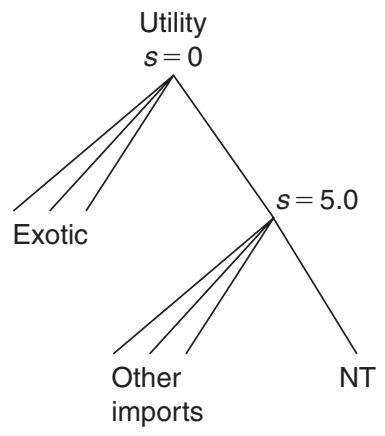

Figure 4.3 British two-level utility function.

For example, Irwin might argue that the model should distinguish between exotic and other goods, letting the latter substitute with domestic goods, but not the former. This structure might be represented by Figure 4.3 , indicating a two-level utility function. At the top level, exotic goods enter in fixed proportions with all other goods (the elasticity of substitution between the two groups is set to zero). At the second level, other imports substitute with the domestic good in the normal fashion.

Table 4.6 gives calculated values for the French TRI, assuming that quota premia on textiles were either 30 per cent or 50 per cent (the range indicated by Nye as being reasonable). ${ }^{7}$ The TRI is calculated using MPSGE/GAMS. First the benchmark equilibrium is reproduced; a counterfactual experiment then abolishes all existing tariffs and quotas, and imposes a uniform, endogenous tariff, whose level is determined by the requirement that welfare be equal to benchmark welfare.

The French model makes one further sensible assumption (Figure 4.4): colonial and foreign sugar are assumed to substitute very closely with each other (the elasticity of substitution is taken to be 10). As can be seen, the assumption made about quota rents matters very little. Based on the data

Table 4.6 Tariff averages, France, 1837-76 (per cent)

\begin{tabular}{llccc}
\hline Tariff category & $1837-46$ & $1847-56$ & $1857-66$ & $1867-76$ \\
\hline Exotic goods & 82.7 & 74.8 & 49.8 & 51.9 \\
Other goods & 10.8 & 7.5 & 3.0 & 2.1 \\
Average tariff & 16.9 & 13.0 & 6.9 & 4.9 \\
TRI (30\%) & 17.6 & 11.4 & 4.7 & 5.5 \\
TRI (50\%) & 17.8 & 11.6 & 4.7 & 5.5 \\
\hline
\end{tabular}

Sources: see text. The import data are taken from Nye (1991: 3). The GDP and export data are from Lévy-Leboyer and Bourguignon (1990, Table A-III). There are minor discrepancies between the import totals in the latter source and Nye's totals; the GDP and export data are thus scaled up or down proportionally, so as to match Nye's import data. 


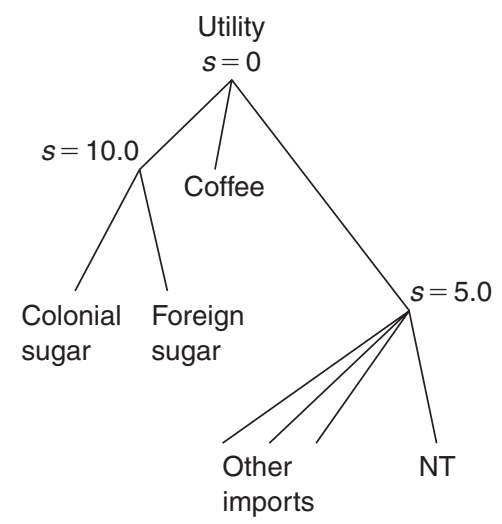

Figure 4.4 French two-level utility function.

given in Nye, it appears that French protection was equivalent to a uniform tariff of 17.7 per cent in $1837-46,11.5$ per cent in $1847-56,4.7$ per cent in 1857-66 and 5.5 per cent in 1867-76.

The TRI is then calculated for the UK, using the same model framework as indicated in Figure 4.3 (colonial and foreign sugar not being distinguished in the tariff statistics for Britain). The obvious problem, which clearly relates to the exchanges between Irwin and Nye, is whether or not to include wine, rum and brandy with the other exotic goods. Table 4.7 indicates, not surprisingly, that it matters hugely whether or not you do. It appears that if wine, rum and brandy are taken to have no domestic substitutes (case 1), Irwin is right: the British TRI is lower than its French counterpart. This is even true for 1841 , the period just prior to Repeal, when, as Tables 4.4 and 4.5 indicate, trade-weighted average tariffs on broad categories of products were all higher in Britain than in France. This illustrates the importance of the classic index number problem, which the TRI was devised to solve.

Table 4.7 Tariff averages, UK, 1841-81 (per cent)

\begin{tabular}{lrrr}
\hline Tariff category & 1841 & 1854 & 1881 \\
\hline Exotic goods & 106.5 & 99.3 & 35.7 \\
Wines & 150.8 & 127.6 & 66.2 \\
Other goods & 12.3 & 4.8 & 0.7 \\
Average tariff & 35.0 & 18.5 & 5.8 \\
TRI(1) & 15.2 & 6.9 & 0.6 \\
TRI(2) & 154.1 & 104.7 & 253.9 \\
\hline
\end{tabular}

Sources: see text. The import data are taken from Nye, 1991: 44. GDP at factor cost is taken from Mitchell, 1988: 831-2; domestic exports are taken from Mitchell, 1988: 452-3. 
However, if wine, rum and brandy are not treated as exotic, but are assumed to be as substitutable with British goods as imported wheat or timber, then Nye is spectacularly right. Indeed, in this case (2) the British TRI reaches absurdly high levels, reflecting for example a tariff of 510 per cent on rum in 1881. The treatment of imported alcoholic beverages thus emerges as crucial when calculating the British TRI. Neither of the extremes considered up to now (they did not substitute at all with British domestic goods; they were like any other import) may seem satisfactory. I therefore tried an intermediate approach next, illustrated in Figure 4.5. This involves three-tier British utility functions. At the top level, exotic goods and everything else enter in a Leontieff fashion.

At the second tier, wines substitute with other goods in a CES fashion. At the third level, other imports substitute with the non-traded good, with an elasticity of 5 .

This formulation focuses on the elasticity of substitution between wines and other goods (domestic and imported). The question of how substitutable wine and beer were can thus be addressed in this framework. Irwin's argument that domestic excise duties on beer meant that the wine tariff was not protective cannot, however, be addressed; to do that, we would need to break out beer from the rest of domestic production, and model indirect taxes on that sector. In the present framework, the distinction between protective and revenue tariffs boils down simply to a question of demand elasticities. Table 4.8 calculates the British TRI for the three years, in each case letting the elasticity of substitution between wines and other goods vary between 0 and 1.5. As expected, the TRI is extremely sensitive to this elasticity, with the 1841 index varying from 15.2 per cent to 38.9 per cent, and the 1881 index varying from 0.6 per cent to 21.2 per cent. In this framework, Britain is the relatively more liberal nation for low elasticities, ${ }^{8}$ and France is the free trader otherwise.

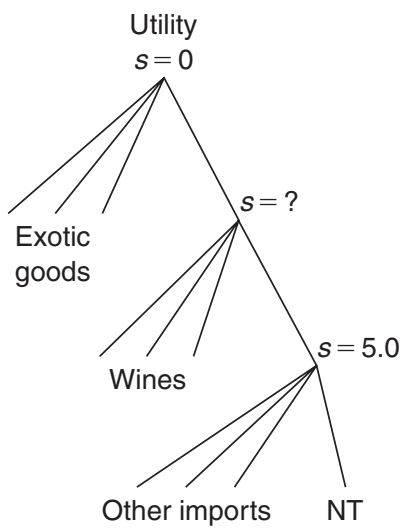

Figure 4.5 British three-level utility function. 
Table 4.8 Trade restriction index, UK 1841-81 (per cent) by elasticity of substitution

\begin{tabular}{lrrr}
\hline Elasticity & 1841 & 1854 & 1881 \\
\hline 0.0 & 15.2 & 6.9 & 0.6 \\
0.1 & 16.4 & 8.2 & 3.3 \\
0.2 & 17.6 & 9.4 & 4.7 \\
0.3 & 18.9 & 10.5 & 6.0 \\
0.4 & 20.2 & 11.6 & 7.1 \\
0.5 & 21.6 & 12.8 & 8.2 \\
0.6 & 23.0 & 13.9 & 9.3 \\
0.7 & 24.5 & 15.0 & 10.4 \\
0.8 & 26.0 & 16.2 & 11.6 \\
0.9 & 27.6 & 17.3 & 12.7 \\
1.0 & 29.3 & 18.5 & 14.0 \\
1.1 & 31.0 & 19.7 & 15.2 \\
1.2 & 32.9 & 21.0 & 16.6 \\
1.3 & 34.8 & 22.3 & 18.0 \\
1.4 & 36.8 & 23.6 & 19.6 \\
1.5 & 38.9 & 25.0 & 21.2 \\
\hline
\end{tabular}

Sources: see text. Data sources as for Table 4.7.

\section{Conclusions}

The Anderson-Neary TRI represents the best option researchers have of correctly measuring protection. Moreover, since it is theoretically based, and since it can only be calculated within the context of particular trade models, the TRI forces users to think more deeply about what really constitutes protection than some other measures currently available. The generic Anderson-Neary CGE model used to calculate the TRI is ingenious, in that it provides a uniform framework within which to evaluate the TRI across countries, is easy to calibrate, and can handle a very disaggregated treatment of imports. The fact that the TRI has proved robust to changes in the elasticities embedded in this model, when applied to modern data, seems reassuring. However, experience with CGE modelling suggests that CGE results are typically far more sensitive to changes in model specification than to changes in elasticities. Changing the supply side of the generic model might in certain cases make theoretical sense, but there are formidable data obstacles to doing so. The demand side of the generic model can, however, be easily re-specified; unfortunately, this chapter has identified one instance where the TRI was absurdly sensitive to changes in both the model specification and demand elasticities. Of course, a historian might not like any of the demand specifications I have used, but that is not the point: rather, the point is that the specification used has a profound impact on the level of the TRI. The initial aim of the exercise was to resolve an essentially qualitative debate by applying new 
technology to old data: this has proved impossible (which, in retrospect, should have been predictable). The TRI is capable of making the terms of this debate more precise, but not of resolving the debate.

The TRI continues to be a sensible index of protection. Nevertheless, there are important methodological lessons arising from this exercise. First, since model specification apparently matters, it seems logical that if a researcher is only interested in calculating the change in protection in one particular country, and has a good CGE model of that economy to hand, incorporating a suitably disaggregated treatment of imports, then that model should be used to calculate the TRI. Second, if cross-country comparisons are being made, and a generic model is needed, the Anderson-Neary model should be used with some caution. In particular, researchers need to think carefully about the structure of demand when calculating the index for a particular country, rather than blindly reaching for any particular off-the-shelf model. Third, it is worthwhile considering why the TRI was so sensitive to model specification in this case. First, the British tariff structure was extremely dispersed: very low or zero tariffs on many commodities, tariffs of several hundred per cent on others. Second, commodities with no obvious domestic substitutes, such as tea, coffee and tobacco, accounted for a significant fraction of British imports. Third, there was a close correspondence between tariff levels, on the one hand, and the nature of the product on the other, with the highly tariffed commodities being those which (arguably) had no good domestic substitutes. If any of these three conditions had not obtained, the British TRI would not have been so sensitive to model specification. If all imports were clearly equally substitutable with domestic goods, Irwin's case would not stand up. If 'exotic' imports, or 'wines', had not faced such high tariffs compared with other imports, Nye would not have a case, and the index would also have been more robust.

It should be stressed that this exercise was carried out in the context of nineteenth-century Europe: the issues it raises may not be as important in the twentieth-century, at least in so far as rich countries are concerned. Exotic commodities with no domestic substitutes, such as tea and coffee, are not as prominent in world trade as they were then; inter-industry trade between countries is more important; and there is considerably less variation in the inter-industry structure of protection than in the British case just described. For small, developing countries, on the other hand, which are highly specialised in production, and which may tax 'luxury' imports heavily, the cautionary tale just presented may be of greater relevance.

\section{Notes}

1 First published in the Journal of Development Economics, 53 (1997), pp. 169-83.

2 Department of Economics, University College Dublin. Belfield, Dublin 4, Ireland. The author is grateful to James Anderson, Peter Neary, John Nye, 


\section{Kevin H. O'Rourke}

Jeffrey Williamson and two anonymous referees for their comments. The usual disclaimer applies.

3 See Leamer (1988) or Edwards (1992) for an application.

4 By contrast, Leamer (1974) discusses the uniform tariff which keeps the total level of imports constant.

5 The tables confirm that, in industries like textiles, the French were more protectionist than the British.

6 Cf. supra pp. 17-18.

7 As indicated in the previous section, making assumptions about the quota premium makes it possible to calculate the level of the TRI, rather than merely the change in the TRI.

8 Below 0.2 in 1841, 0.4 in 1854, and 0.3 in 1881. 


\title{
5 Measuring protection in the early twentieth century ${ }^{1}$
}

\author{
Antoni Estevadeordal ${ }^{2}$
}

\section{Introduction}

Trade policy constitutes one of the most important chapters in any account of the late-nineteenth-century economic development. This was a period when the major players in the world economy gradually shifted to more protectionist policies after thirty years of economic liberalism, between the European revolutions of 1848 and the depression of 1873 . Although much of the tariff increases during the period from 1880 to 1913 can be seen partly as a response to the spectacular fall in transportation costs, commercial policy responses to the process of economic integration of the world commodity, capital and labour markets remains to be studied comprehensively. To assess the impact of these policy responses we need comparative measures of the late-nineteenth-century or early-twentieth-century level of protection. Most of the economic history literature on tariff policy, the single most important commercial policy instrument of this period, has been written at the national level, and the focus has usually been on the domestic political processes behind the tariff legislation. Few international comparative studies are available and they have mostly focused on the analysis of commercial policy through changes in tariff law.

This study does not offer an evaluation of trade policies for the period, but it attempts to introduce a new set of measures of protection covering a sample of eighteen countries for the year 1913 using trade data as circumstantial evidence. The goal is to construct indices of protectionism or, alternatively, indices of 'openness' based on a traditional Heckscher-Ohlin general equilibrium trade model $(\mathrm{H}-\mathrm{O})$. The advantages of these indices are many. First, they are kept objective: no attempt is made to classify a priori the trade regime of a country based on its tariff legislation. Second, they reflect all types of trade interventions, independent of whether they are export promoting or import substituting policies. Third, they are constructed in a continuous manner allowing for different degrees of openness. And, fourth, they are comparable across countries and sectors. To my knowledge, we do not have any quantitative study of 
the degree of protection at a comparative level, based on a sound trade model, for this important period. The rest of the chapter proceeds as follows. The next section reviews the conventional measures of protection used for the late-nineteenth-century and early-twentieth-century period. This is followed by an outline of the theoretical framework on which this study is based. The next section presents the estimation results of a linear version of the $\mathrm{H}-\mathrm{O}$ model for 1913. In the final section, several alternative indices of protection are constructed and compared for 1913. A discussion on sources and methods can be found in the Appendix.

\section{Comparative measures of protection in the early twentieth century}

The most widely used comparative measures of outward orientation in the economic history literature for the early twentieth century are either unadjusted trade intensity ratios or some average of directly measured trade barriers. Given that most foreign trade statistics report data on the value of duty-free and dutiable imports and the amount of import duties collected, the easiest method of measuring protection in time series or cross-country studies has been to express the duties collected as a percentage of dutiable imports or of total imports ${ }^{3}$ (Table 5.1). Duties as a percentage of total imports overcome the serious problem of the conversion of specific duties, the most commonly used tariff during this period, to ad valorem equivalents. Since this was a time when prices of many commodities were falling sharply, ad valorem equivalents are certainly a better measure of protection than simply looking at legislated specific duties. However, even this measure fails to give a correct picture of the level of protection. The first problem is a Laffer effect. The amount of duties collected depends upon the elasticity of import demand with respect to prices after tariffs. Thus, a country or a commodity with a high tariff, but with a low elasticity, can collect the same revenue as a country or a product with a low tariff but higher elasticity. Second, if used as a measure of protection over time, the ratio of tariff revenues to imports not only reflects the changes in the tariff level, but also the change in the commodity's composition induced by the presence of a tariff. The ratio of duties to imports amounts, in statistical terms, to the average of individual rates weighted by the value of each commodity imported. Since such weighted averages can be fallacious, in some cases it is preferable to use unweighted averages. An unweighted average will only be meaningful when it refers to a list of properly selected commodities. Ideally, the averaging method would have to be based on a hypothetical import pattern that would have taken place in a free-trade world.

Tumlir and Till (1971) suggested that, since the importance of a duty is the amount of trade it holds back, each rate should ideally be weighted by the difference between the actual and the hypothetical imports. 


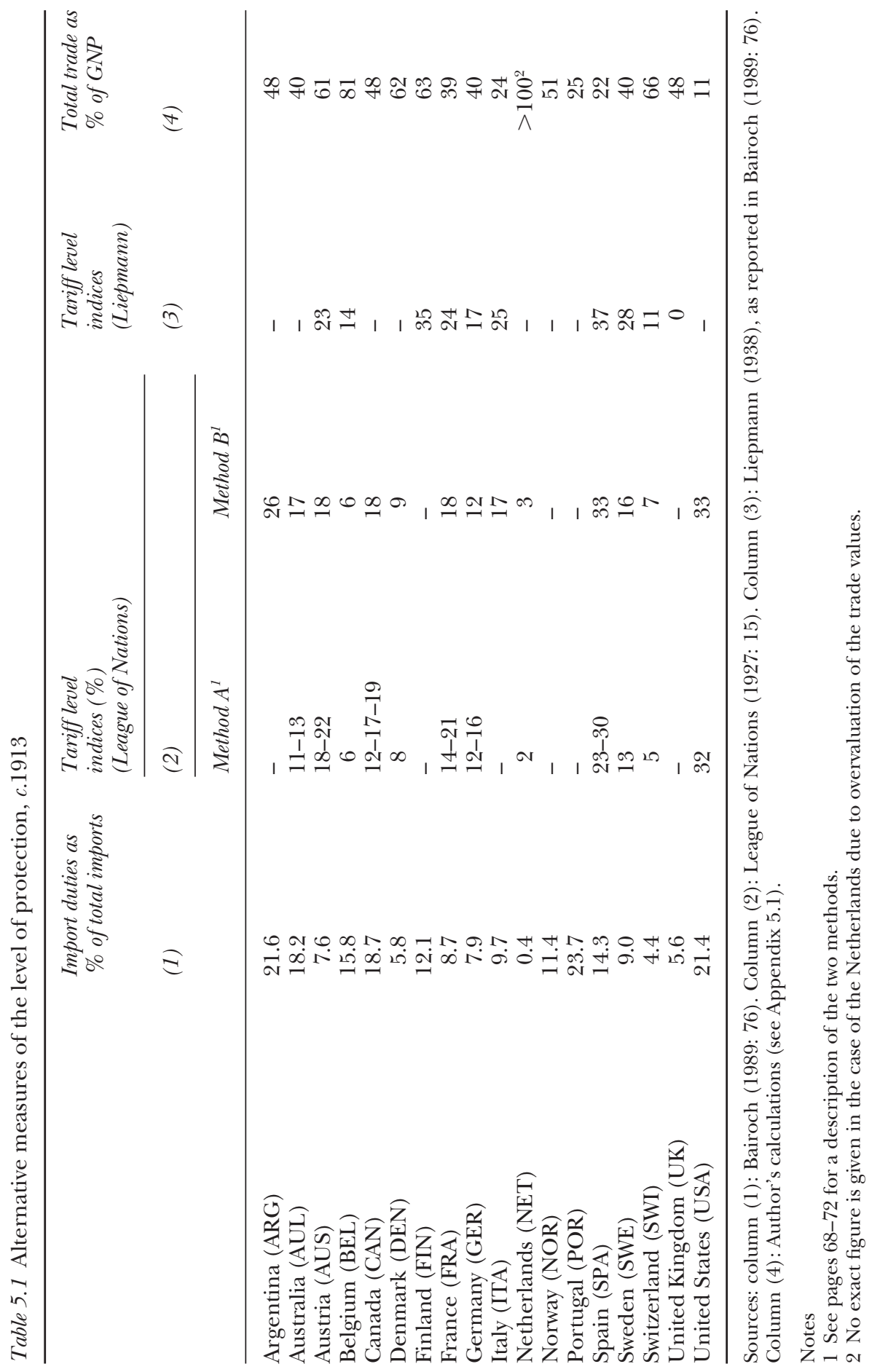


For the early twentieth century, only two measures of protection based on different methods of averaging tariff rates are available. The first was requested by the Preparatory Committee of the World International Conference of 1927 to the Economic Secretariat of the League of Nations. The study was prepared under the supervision of A. Loveday, Director of the Economic Department of the League of Nations, and published in 1927 under the title Tariff Level Indices (League of Nations, 1927). The study suggested a standard method for computing indices of tariff protection for fifteen European and five overseas countries in 1913 and 1925. The comparison was limited to a list of commodities that played an important role in the foreign trade of the countries in question, and did not include non-competitive articles with revenue duties for excise purposes only. First, the ad valorem equivalent of specific duties was computed in each country. Two methods were used for calculating the tariff rate and the results are reported in Table 5.1. In method A, the duty of each article was expressed as a percentage of the import value of the article before duty. In method B, the prices prevailing in the exporting country were taken as basis for comparison. Finally, the index of tariff level was calculated as the unweighted means of these rates.

A more disaggregated analysis was conducted a decade later by H. Liepmann (1938) in his book Tariff Levels and the Economic Unity of Europe. He measured what he called 'Potential Tariff Levels' for fifteen European countries in 1913, 1927 and 1938. ${ }^{4}$ The measure is based on arithmetic means of ad valorem duty rates computed for 144 products widely distributed among all classes of goods. Although the degree of cross-country comparability increases for each commodity group, the method leaves open the question of how to combine the group indices into an overall tariff level index. Table 5.1 includes an overall average from Liepmann's figures computed by Bairoch (1989). When the Liepmann method is carried to its extreme we end up comparing particular duty rates for identical goods. This was, indeed, the method followed by J. Grunzel (1916) in his important book, Economic Protectionism. He computed the duties on eight identical commodities in 1912-13 in twenty-one countries. Grunzel's study is reproduced in Table 5.2. No other systematic study exists on protection at a comparative level. ${ }^{5}$

With the availability of GDP estimates for the nineteenth century, economic historians have used some form of trade intensity ratios to measure the degree of openness over time. However, measures of openness that use trade ratios without any adjustments are also open to criticism, since one can conclude that countries with unusual supplies of resources are the most open, merely because these countries have the highest levels of trade in the absence of any barriers (Grassman (1980)) at all. used a trade income ratio defined as the ratio of exports plus imports to GNP, measured at current prices, to show that over the last one-hundred years there was no clear-cut tendency for economies to become more open. He also 


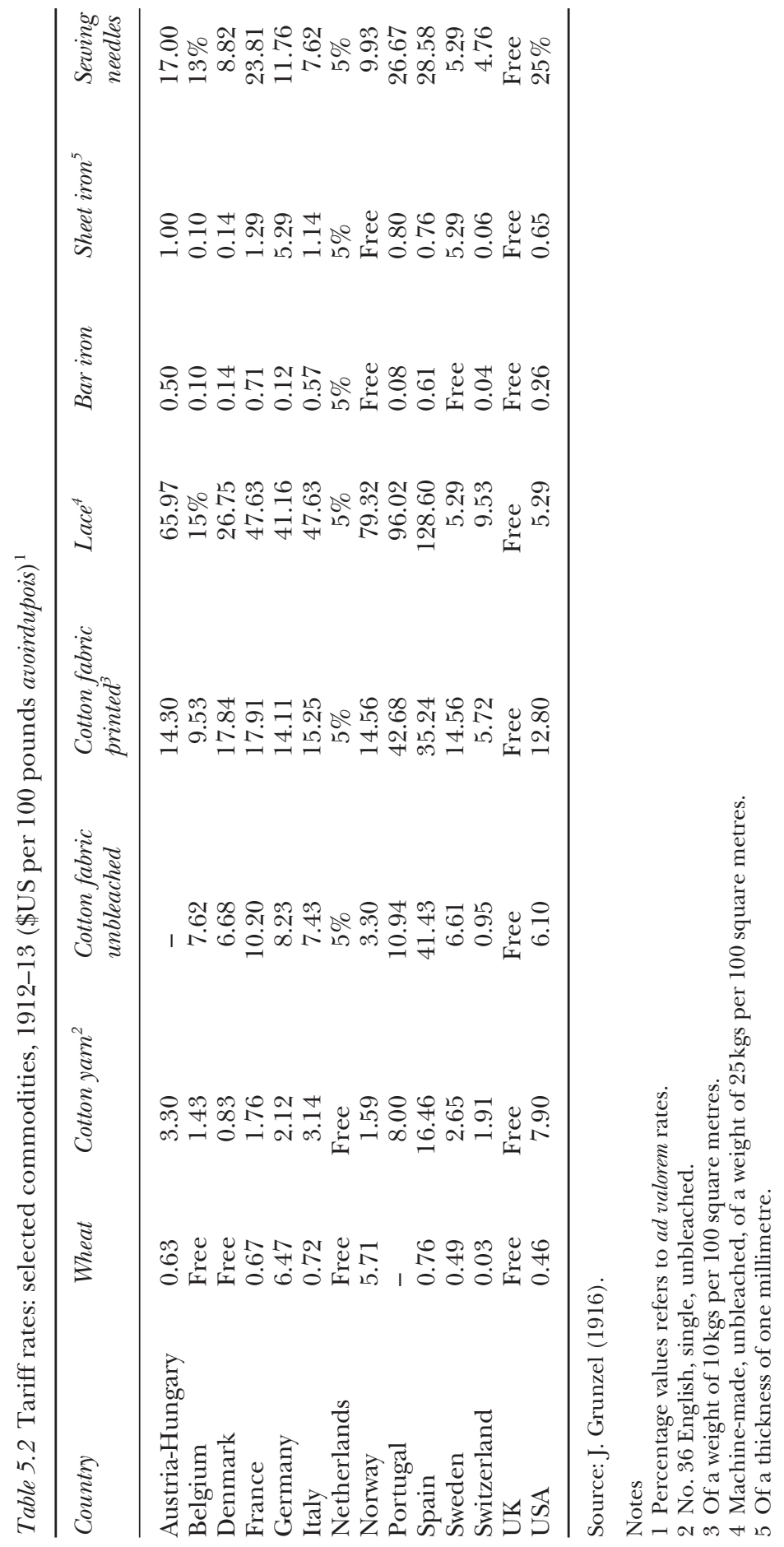


pointed out that Great Britain was more open in the 1870 s than it was a hundred years later, while the US economy has only recently reached the degree of openness it achieved before the First World War. Beenstock and Warburton (1983) argued that these results can be reversed when constant price data is used.

\section{The model}

The goal of this chapter is to compare the levels of trade barriers for eighteen countries for the period just prior to the First World War, using trade data as circumstantial evidence. The methodology used here was introduced by Leamer (1988) who constructed a set of openness and intervention indices for 1982 for a larger sample of countries. The method uses a traditional Heckscher-Ohlin general equilibrium model as a theoretical framework. The purpose is to construct an index of 'openness' based on the difference between the predicted and the actual trade intensity ratios. Drawing on Leamer's (1988) work, this section outlines the theoretical framework needed both to determine the conditions under which trade intensity ratios can serve as indicators of trade barriers and also to determine the nature of adjustments to the trade intensity ratios that are needed to account for determinants of trade other than barriers. The model invokes the conventional assumptions of identical homothetic tastes, constant returns to scale, equal number of goods and factors, and with sufficiently similar factor endowments so that all countries are in the same cone of diversification.

The production side of the model can be summarised by the following equations:

$$
\begin{aligned}
& Q=A^{-1} V \\
& w=A^{\prime-1} p \\
& A=A(w, t)
\end{aligned}
$$

where $Q$ is the vector of outputs, $V$ is the vector of factor supplies, $A$ is the input-output matrix with fixed elements equal to the amount of a factor used to produce a unit of a good, $p$ is the vector of (internal) commodity prices, and $w$ is the vector of factor returns. Equation (5.1), which translates factor supplies $V$ into outputs $Q$, is the inverted form of the factor market equilibrium condition equating the supply of factors $\mathrm{V}$ to the demand for factors $A Q$. Equation (5.2), which translates product prices into factor prices, is the inverted form of the zero-profit condition equating product prices $p$ to production costs $A^{\prime} w$. Equation (5.3) expresses the dependence of input intensities on factor prices $w$ and on the state of technology $t, A_{(w, t)}$ being the cost-minimising choice of input intensities at time $t$. 
In the absence of trade barriers, all individuals face the same commodity prices, and if they have identical homothetic tastes, then they consume in the same proportions:

$$
C=s C_{w}=s A^{-1} V_{w}
$$

where $C$ is the country's consumption vector, $C_{w}$ is the world consumption vector, $V_{w}$ is the vector of world resource supplies, and $s$ is the country's consumption share. Thus trade in a $\mathrm{H}-\mathrm{O}$ model can be expressed as:

$$
T=Q-\mathrm{C}=A^{-1} V-s A^{-1} V_{w}=A^{-1}\left(V-s V_{w}\right)
$$

The trade balance condition $\pi T=0$, with $\pi$ the vector of prices, implies that the country's consumption share is the ratio of the country's GNP to world GNP:

$$
s=\pi^{\prime} A^{-1} V / \pi^{\prime} A^{-1} V_{w}=\mathrm{GNP} / \mathrm{GNP}_{w}
$$

Using this value for the consumption share and dividing equation (5.5) by GNP, we obtain:

$$
T / \mathrm{GNP}=A^{-1}\left([V / \mathrm{GNP}]-\left[V_{w} / \mathrm{GNP}_{w}\right]\right) .
$$

Finally, premultiplying by $\Pi$, a diagonal matrix with prices down the diagonal, and using $W$, a diagonal matrix with wages down the diagonal, we find the trade vector in value terms:

$$
\begin{aligned}
\Pi T / \mathrm{GNP} & =\Pi A^{-1} W^{-1}\left([W V / \mathrm{GNP}]-\left[W V_{w} / \mathrm{GNP}_{w}\right]\right) \\
& =\Theta\left([W V / \mathrm{GNP}]-\left[W V_{w} / \mathrm{GNP}_{w}\right]\right) \\
& =\Theta\left(\lambda-\lambda_{w}\right)
\end{aligned}
$$

where $\Theta$ is the inverse of the matrix of input shares, and $\lambda=W V /$ GNP is the vector of factor incomes.

The trade intensity ratio (TIR) thus becomes a measure of the difference between the factor incomes of the world and the country:

$$
\mathrm{TIR}=|\Pi T / \mathrm{GNP}|=\left|\Theta\left(A-A_{w}\right)\right|,
$$

Where $|T|$ indicates the sum of absolute values of the elements of $T$, and $\Pi$ is a diagonal matrix with prices on the diagonal. Thus with no differences in technologies or tastes, and no trade barriers, the trade intensity ratio in this model is a measure of resource endowment distinctiveness. Leamer has shown that, when trade barriers are introduced in the model using standard assumptions, they are a major determinant of trade intensity ratios. The precise effects are however very complex. In 
Leamer (1988) the following model for econometric testing is suggested:

$$
N_{i j}=\beta_{j}^{\prime} V_{i}+\epsilon_{i j}
$$

where $N_{i j}$ is the value of net exports of commodity $j$ in country $i, V_{i}$ is the country's $i$ vector of resource supplies, $\beta$ is a vector of parameters depending on tastes, technologies, and prices and, finally, $\epsilon_{i j}$ is an error term attributable to the trade barriers and represents the effect of the difference between this country's tariff structure and the typical or average tariff structure.

The measure of protection suggested by the model will be constructed as follows. Let $N_{i j}$ be the value of net exports and $N^{*}{ }_{i j}=\beta_{j}{ }^{\prime} V_{j}$ be the corresponding net exports value 'predicted' by the model. The difference between the actual net trade and the predicted net trade is indicated by $E_{i j}=N_{i j}-N_{i j}^{*}$, which according to the model outlined reflects the impact of trade barriers on trade. The measure of protection to be constructed will be the difference between the actual trade intensity ratio and the trade intensity ratio predicted by the model. A country is said to be 'open' or with low protection if its trade is unusually great compared with the predictions of the model. Two measures of protection are suggested. The first is the adjusted trade intensity ratio:

$$
\operatorname{TIR}_{i}^{A}=\left(\Sigma_{j}|N i j|-\Sigma_{j}\left|N_{i j}^{*}\right|\right) / \text { GNP. }
$$

This adjusted trade intensity ratio is the actual trade intensity ratio minus the trade intensity ratio predicted by the model. The country-size effect is eliminated here by dividing by GNP.

An alternative measure of openness is the ratio of actual trade to predicted trade:

$$
\text { OPE }=\Sigma_{j}|N i j| / \Sigma_{j}\left|N_{i j}^{*}\right| .
$$

The choice between these two measures will depend on the analysis of protection we are interested in. The ratio of actual to adjusted trade is analogous to a tariff average that suggests how much trade is suppressed by barriers. The adjusted trade intensity ratio is equivalent to a measure of welfare loss indicating the percentage of GNP loss as a result of trade barriers.

\section{Estimating an inter-industry trade model in 1913}

This section is devoted to carrying out an econometric test of the $\mathrm{H}-\mathrm{O}$ paradigm introduced in the previous section using a newly constructed data set described in the Appendix. The results of this section will confirm the findings obtained in Estevadeordal (1993) when a more aggregated 
commodity categorisation was used, that is, the $\mathrm{H}-\mathrm{O}$ framework is a perfectly valid model explaining the trade pattern just prior to the First World War.

The Heckscher-Ohlin equation (5.5) expresses trade in terms of excess endowments $\left(V-s V_{w}\right)$. It can be interpreted as a set of relations between factor intensities, trade flows and resource endowments. Most empirical studies of the $\mathrm{H}-\mathrm{O}$ model use measures of two of these variables to infer the third. Thus, three different approaches can be found in the empirical literature. Factor content studies, the most famous of which was performed by Leontieff (1953), ${ }^{6}$ take measures of trade $(T)$ and factor intensities $(A)$ for a given country, and from them infer the so-called factor abundance vector $\left(V-s V_{w}\right)$, where $(V)$ is the vector of the country's factor resources and $\left(V_{w}\right)$ is the vector of world's factor resources. Given a set of factor input requirement coefficients for each industry, the implicit exchange of factor services through trade is computed as the weighted average of these input requirements where the weights correspond to the share of each industry's exports (imports) in total exports (imports). Cross-commodity studies regress net exports on the commodity's factor input intensities for a given country. The estimated coefficients are interpreted as the country's relative abundance of each factor of production involved. Finally, cross-country studies use measures of trade $(T)$ and direct measures of endowments $(V)$ and implicitly infer the inverse of the matrix of intensities $(A)$. As noted in Leamer (1984) this type of study, though conceptually appropriate, cannot be said to be a complete measurement of the accuracy of the theory because it uses no data on factor intensities. The approach can be said to be measuring the accuracy of a weaker version of the theory that does not depend on factor intensities, namely, 'There exists a matrix $A$ such that $A T=V-s V_{w}$ ' (Leamer, 1984: 59). This is the framework used in this study.

Equation (5.5) expresses trade in terms of excess endowments $\left(V-s V_{w}\right)$. For empirical purposes, alternatively, we can regress trade on endowment supplies alone. As shown in Leamer (1984: 159), this alternative formulation of the model is preferred for econometric reasons. ${ }^{7}$ Therefore the following equation is estimated for each trade aggregate:

$$
N X_{i j}=a_{0 J}+a_{1 J} C A P_{j}+a_{2 j} S K I_{j}+a_{3 J} U N S K_{j}+a_{4 j} A G R_{j}+a_{5 J} M I N_{j}+a_{6 j} D I S_{j}
$$

where: $N X_{i j}$ : Net Exports for commodity group $i$, country $j$

$C A P_{j}$ : Measure of total capital stock, country $j$

$S K I_{j}$ : Skilled labour force, country $j$

$U N S K_{j}$ : Unskilled labour force, country $j$

$A G R_{j}$ : Agricultural land, country $j$

$M I N_{j}$ : Mineral resources, country $j$

$D I S_{j}$ : Distance to markets, country $j$ 
Thus, equation $\left(5.8^{\prime}\right)$ will be estimated with data taken from eighteen countries and for each of the 46 sectors listed in Table 5.11. The five factor endowments used in this estimation include a measure of capital stock $(C A P)$, labour grouped by skill using an educational attainment variable (SKI and UNSK), agricultural land $(A G R)$ and mineral resources $(M I N)$. Except for the land and labour force variables, the rest of these explanatory variables have been constructed from primary sources. The discussion of sources and methods used can be found in the Appendix.

Since we do not have comparable measures of capital stock $(C A P)$ for this large sample of countries, energy consumption of solid fuels in 1913 is used as a proxy. ${ }^{8}$ The data on energy consumption refers to apparent consumption of primary sources, including net imports of secondary as well as primary energy forms. Because of data availability only solid fuels have been considered (hard coal, brown coal, lignite and coke). In order to permit aggregation and comparison, data are expressed in thousands of hard-coal equivalents. ${ }^{9}$ Solid fuels consumption was, by and large, the most important source of energy before the First World War. Even for countries in the European periphery poor in coal and where the use of wood fuel (especially the Scandinavian countries) or hydroelectric power (in particular Italy and Switzerland) was an important source of energy, the correlation between coal consumption and levels of industrialisation is very high. ${ }^{10}$ The labour endowment is divided into unskilled labour, UNSK (labour force times the illiteracy rate), and skilled labour, SKI (labour force minus unskilled labour). Data is in thousands of workers. The illiteracy rate is defined as the percentage of population ten years old and over who cannot read and write. In this chapter, literacy is used as an objective measure of educational attainment. An alternative measure is provided by elementary schooling (more advanced types of education are a less reliable measure for international comparisons). However, years of schooling is a less precise estimator of elementary educational attainment than literacy levels, mainly for two reasons. First, teaching effectiveness may vary across countries. Second, at the early stages of development, many people achieve literacy outside of the formal educational institutions. Finally, instead of measuring the education industry's performance by its inputs, literacy rates permit us to judge it by its output. Because of data availability, no attempt has been made to adjust these variables by female illiteracy rates and their participation in the labour force.

Land endowment is agricultural land $(A G R)$ and is expressed in thousands of hectares. Alternative measures of land were also used in the estimation of equation $\left(5.8^{\prime}\right)$ with similar results. Total area divided in climatic zones, as in Leamer (1984), was also consistent with the model.

Finally, the mineral endowment $(M I N)$ variable is a proxy for natural resources and is measured by domestic oil and ore production, the latter of a composite of minerals: bauxite, copper, iron ore, lead, manganese, 
nickel, phosphate, potash, pyrites, sulphur, tin and zinc. Prices in international markets were used for aggregation. ${ }^{11}$ Since in this model we are interested in the size of the residuals as an indicator of trade barriers, distance is introduced as an additional independent variable. It should be interpreted as a proxy for natural barriers to trade and is computed as the GNP-weighted average direct line distance between capitals. It is expected to be negatively related to the absolute value of net exports. ${ }^{12}$

The results of estimating equation $\left(5.8^{\prime}\right)$ are given in Tables 5.3 and 5.4. Based on the reported F-statistics, thirty-seven out of the forty-six net trade regressions are significant. Moreover, most of the $R^{2} \mathrm{~s}$ are very high. For individual factor endowments, out of forty-six estimated equations, capital has significant coefficients (at the 10 per cent confidence level), in

Table 5.3 The Heckscher-Ohlin-Vanek model in 1913 (Equation (5.8'), OLS estimates)

\begin{tabular}{|c|c|c|c|c|c|c|c|}
\hline & $R^{2}$ & $\operatorname{Adj} R^{2}$ & $F(6 / 11)$ & & $R^{2}$ & $\operatorname{Adj} R^{2}$ & $F(6 / 11)$ \\
\hline 1 Coal & & & & PROAGR [42] & 0.80 & 0.69 & $7.35^{* *}$ \\
\hline COAL [32] & 0.89 & 0.83 & $15.04 * *$ & PROAGR [43] & 0.74 & 0.60 & $5.40^{* *}$ \\
\hline \multicolumn{4}{|l|}{2 Raw materials } & \multicolumn{4}{|c|}{6 Beverages and tobacco } \\
\hline RAWMAT [24] & 0.72 & 0.57 & $4.83^{* *}$ & BEVTOB [11] & 0.54 & 0.54 & $4.41 * *$ \\
\hline RAWMAT [27] & 0.22 & 0.10 & 0.53 & BEVTOB [12] & 0.78 & 0.66 & $6.70^{* *}$ \\
\hline RAWMAT [28] & 0.84 & 0.76 & $10.66^{* *}$ & \multicolumn{4}{|c|}{7 Labour-intensive manufactures } \\
\hline RAWMAT [33] & 0.86 & 0.78 & $11.42 * *$ & LABINT [61] & 0.82 & 0.73 & $8.71 * *$ \\
\hline RAWMAT [68] & 0.77 & 0.65 & $6.35^{* *}$ & LABINT [62] & 0.80 & 0.69 & $7.35^{* *}$ \\
\hline \multicolumn{4}{|c|}{2 Cereals and textile fibres } & LABINT [63] & 0.77 & 0.64 & $6.14 * *$ \\
\hline CERTEX [04] & 0.90 & 0.85 & $17.53^{* *}$ & LABINT [64] & 0.70 & 0.54 & $4.42 * *$ \\
\hline CERTEX [08] & 0.70 & 0.54 & & LABINT [66] & 0.69 & 0.52 & $4.12^{* *}$ \\
\hline CERTEX [26] & 0.79 & 0.68 & $*$ & LABINT [84] & 0.80 & 0.69 & $7.39 * *$ \\
\hline \multicolumn{4}{|c|}{3 Raw agricultural products } & \multicolumn{4}{|c|}{8 Capital-intensive manufactures } \\
\hline RAWAGR [00] & 0.66 & 0.48 & 2.52 & CAPINT [65] & 0.86 & 0.79 & $12.22 * *$ \\
\hline RAWAGR [03] & 0.39 & 0.06 & 1.17 & CAPINT [67] & 0.83 & 0.74 & $9.15^{* *}$ \\
\hline RAWAGR [05] & 0.68 & 0.50 & $3.90 * *$ & CAPINT [69] & 0.84 & 0.76 & $10.23 * *$ \\
\hline RAWAGR [07] & 0.98 & 0.97 & $137.11 * *$ & CAPINT [81] & 0.88 & 0.82 & $14.65^{* *}$ \\
\hline RAWAGR [21] & 0.96 & 0.94 & $46.34 * *$ & CAPINT [82] & 0.59 & 0.38 & 2.72 \\
\hline RAWAGR [22] & 0.74 & 0.61 & $5.48 * *$ & CAPINT [89] & 0.34 & 0.01 & 0.99 \\
\hline RAWAGR [29] & 0.62 & 0.41 & 3.04 & 9 Machinery & & & \\
\hline RAWAGR [41] & 0.70 & 0.53 & $4.31 * *$ & MACH [71] & 0.94 & 0.91 & $29.85 * *$ \\
\hline \multicolumn{4}{|c|}{4 Processed agricultural products } & MACH [72] & 0.87 & 0.80 & $12.49 * *$ \\
\hline PROAGR [01] & 0.79 & 0.69 & $7.30 * *$ & MACH [73] & 0.94 & 0.91 & $31.32 * *$ \\
\hline PROAGR [02] & 0.75 & 0.62 & $5.62 * *$ & MACH [86] & 0.49 & 0.22 & 1.82 \\
\hline PROAGR [06] & 0.58 & 0.35 & 2.55 & MACH [95] & 0.83 & 0.73 & $8.96 * *$ \\
\hline PROAGR [09] & 0.73 & 0.59 & $5.08 * *$ & 10 Chemicals & & & \\
\hline PROAGR [23] & 0.96 & 0.94 & $49.54 * *$ & CHEM [51] & 0.74 & 0.59 & $5.23 * *$ \\
\hline PROAGR [25] & 0.58 & 0.35 & 2.55 & CHEM [52] & 0.66 & 0.47 & $3.58 * *$ \\
\hline
\end{tabular}

Notes

See Table 5.11 for definitions of sectoral categories and pages 76-7 for aggregation methods. Statistics reported $F$-test: $F(6,11), 5$ per cent significance level $=3.09$; significance at this level is indicated by an asterisk. 
Table 5.4 The Heckscher-Ohlin model in 1913 (number of significant regressors in equation $\left(5.8^{\prime}\right)$ by sectors)

\begin{tabular}{|c|c|c|c|c|c|c|c|c|c|c|}
\hline \multirow[t]{2}{*}{$\begin{array}{l}\text { Number of equations } \\
\text { estimated by sector }\end{array}$} & \multicolumn{2}{|c|}{ Capital } & \multicolumn{2}{|c|}{$\begin{array}{l}\text { Skilled } \\
\text { labour }\end{array}$} & \multicolumn{2}{|c|}{$\begin{array}{l}\text { Unskilled } \\
\text { labour }\end{array}$} & \multicolumn{2}{|c|}{ Land } & \multicolumn{2}{|c|}{$\begin{array}{l}\text { Mineral } \\
\text { resources }\end{array}$} \\
\hline & + & - & + & - & + & - & + & - & + & - \\
\hline (1) Coal & 1 & - & - & 1 & 1 & - & - & 1 & - & - \\
\hline (5) Raw materials & - & 1 & - & 3 & - & - & 4 & - & - & 1 \\
\hline (3) Cereals and fibres & - & 1 & - & 2 & - & 1 & 3 & - & - & 1 \\
\hline (8) Raw agr. products & 1 & 1 & - & 2 & - & - & 5 & - & 2 & 3 \\
\hline (8) Processed food & - & 8 & 1 & - & - & 1 & 2 & - & 7 & - \\
\hline (2) Beverages, tobacco & - & 1 & - & 1 & 1 & - & - & - & 1 & - \\
\hline (6) Labour int. mfr. & - & 4 & 3 & - & - & 2 & - & 4 & 5 & - \\
\hline (6) Capital int. mfr. & 4 & - & - & - & - & - & - & 5 & 3 & 1 \\
\hline (5) Machinery & 4 & - & 1 & - & - & 1 & - & 3 & 1 & 1 \\
\hline (2) Chemicals & - & - & - & - & - & - & - & 2 & 1 & - \\
\hline
\end{tabular}

Notes

Numbers in parentheses at the left of sectoral grouping rows indicate the number of equations in each sectoral grouping. Equations were estimated by OLS, without the White (1980) procedure for heteroskedasticity adjustment. Critical values (two-tail test) at the 10 per cent level were obtained from Student's $t$ Distribution for 11 D.F.

twenty-six cases, skilled labour has fourteen, unskilled labour only seven, land has twenty-nine, and mineral resources has twenty-seven. The distance variable, not reported, captures consistently the importance of natural barriers in most cases. A better way to summarise those results and to assess the impact of each factor endowment on the sectoral trade is to compute Beta coefficients for each of the independent variables. Those Beta coefficients are directly proportional to the contribution that each variable makes to a prediction of net trade, indicating the amount of change in standard deviation units of the net trade variable induced by a change of one standard deviation in the factor endowment.

The Beta values are reproduced in Table 5.5. In general, capital and skilled labour are sources of comparative disadvantage in the inter-industry trade in primary products. Capital is a source of comparative advantage in the most capital-intensive manufactures and a source of disadvantage in the labour-intensive group, where skilled labour contributes to its comparative advantage. Agricultural land is consistently a source of advantage for primary products and creates comparative disadvantage in manufacturing. Interestingly, mineral resources are a source of comparative advantage in the processed agricultural products group and in almost all manufactures. Using the conventional 0.5 level $^{13}$ to define a significant Beta value, then capital is significant in thirty-six out of forty-six net trade equations. Skilled labour is significant twenty-four times, unskilled labour only four times, agricultural land thirty-eight times, and mineral resources thirty-six times. 
Table 5.5 The Heckscher-Ohlin model in 1913 (Beta coefficients)

\begin{tabular}{|c|c|c|c|c|c|}
\hline & $\begin{array}{l}\text { Beta1 } \\
(C A P)\end{array}$ & $\begin{array}{l}\text { Beta2 } \\
(\text { SKI })\end{array}$ & $\begin{array}{l}\text { Beta3 } \\
\text { (UNSK) }\end{array}$ & $\begin{array}{l}\text { Beta4 } \\
(A G R)\end{array}$ & $\begin{array}{l}\text { Beta5 } \\
(M I N)\end{array}$ \\
\hline COAL [32] & 3.37 & -1.08 & 0.45 & -1.56 & -0.53 \\
\hline RAWMAT [24] & 0.23 & -1.19 & -0.15 & 2.38 & -1.22 \\
\hline RAWMAT [27] & 0 & -1.01 & 0.34 & 0.3 & 0.18 \\
\hline RAWMAT [28] & -1.56 & -0.08 & -0.21 & 1.75 & -0.41 \\
\hline RAWMAT [33] & 0.57 & -1.12 & 0.11 & 1.03 & 0.2 \\
\hline RAWMAT [68] & -0.6 & -1.27 & 0.08 & 1.33 & 0.66 \\
\hline CERTEX [04] & -1.19 & -0.68 & -0.18 & 1.87 & 0.28 \\
\hline CERTEX [08] & 0 & 0.09 & 0.01 & 1.82 & -1.09 \\
\hline CERTEX [26] & -0.84 & -0.86 & -0.04 & 1.3 & 0.66 \\
\hline RAWAGR [00] & 0.46 & -0.41 & -0.03 & 2.14 & -2.41 \\
\hline RAWAGR [03] & 1.04 & -0.95 & -0.2 & 1.21 & -1.57 \\
\hline RAWAGR [05] & -0.79 & -0.11 & 0.22 & 0.83 & -0.57 \\
\hline RAWAGR [07] & -0.86 & -0.53 & 0.06 & 0.09 & 0.28 \\
\hline RAWAGR [21] & 0.62 & -0.1 & -0.02 & 0.96 & -1.03 \\
\hline RAWAGR [22] & 0.47 & -1.68 & 0.19 & 1.63 & -0.82 \\
\hline RAWAGR [29] & -0.11 & -1.04 & 0.23 & 1.32 & -0.51 \\
\hline RAWAGR [41] & -0.28 & -0.33 & -0.19 & 2.26 & -1.57 \\
\hline PROAGR [01] & -2.26 & 0.08 & -0.24 & 1.13 & 1.38 \\
\hline PROAGR [02] & -2.29 & 0.03 & -0.25 & 1.4 & 0.67 \\
\hline PROAGR [06] & -2.25 & 0.31 & -0.2 & -0.36 & 2.39 \\
\hline PROAGR [09] & -2.72 & 0.4 & -0.3 & 0.55 & 1.76 \\
\hline PROAGR [23] & -2.32 & 0.46 & -0.16 & 0.11 & 0.95 \\
\hline PROAGR [25] & -2.31 & 0.32 & -0.56 & 0.82 & 1.31 \\
\hline PROAGR [42] & -3.02 & 0.89 & -0.1 & -0.59 & 2.74 \\
\hline PROAGR [43] & -2.35 & 0.19 & -0.23 & 0.55 & 1.18 \\
\hline BEVTOB [11] & 0.7 & -1.15 & 1.03 & -0.98 & 0.68 \\
\hline BEVTOB [12] & -1.13 & -0.65 & -0.04 & 0.46 & 1.71 \\
\hline LABINT [61] & -2.81 & 1.34 & -0.46 & -0.47 & 2.52 \\
\hline LABINT [62] & -1.09 & 1.53 & -0.15 & -1.22 & 1.38 \\
\hline LABINT [63] & -3.04 & 0.6 & -0.35 & 0.27 & 2.09 \\
\hline LABINT [64] & -1.62 & 0.67 & -0.24 & -1.06 & 2.45 \\
\hline LABINT [66] & -0.52 & 0.5 & -0.52 & -1.34 & 1.29 \\
\hline LABINT [84] & -0.18 & 1.54 & 0.05 & -1.85 & 0.68 \\
\hline CAPINT [65] & 1.73 & 0.65 & 0.17 & -1.01 & -1.43 \\
\hline CAPINT [67] & 1.36 & 0.12 & 0.33 & -2.16 & 1.04 \\
\hline CAPINT [69] & 0.58 & 0.26 & 0.1 & -1.91 & 1.59 \\
\hline CAPINT [81] & 1.2 & -0.07 & 0.18 & -1.54 & 0.99 \\
\hline CAPINT [82] & 1.26 & -0.2 & 0.45 & -1.11 & 0 \\
\hline CAPINT [89] & -0.87 & 0.81 & -0.23 & -0.92 & 0.77 \\
\hline MACH [71] & 1.75 & -0.48 & 0.16 & -1.1 & 0.53 \\
\hline MACH [72] & 0.56 & 0.17 & 0.04 & -1.87 & 1.7 \\
\hline MACH [73] & 1.1 & 0.82 & -0.01 & -0.78 & -0.42 \\
\hline MACH [86] & -2.09 & 0.82 & -0.62 & 0.49 & 1.26 \\
\hline MACH [95] & 1.93 & 0.31 & 0.12 & -0.51 & -1.46 \\
\hline CHEM [51] & 0.43 & 0.71 & -0.03 & -2.06 & 0.49 \\
\hline CHAM [52] & 0.55 & -0.06 & 0.11 & -1.54 & 1.38 \\
\hline
\end{tabular}

Notes

See text for definition and interpretation of the Beta coefficients. Detailed description of sectoral categories can be found in Appendix 5/1. 


\section{Measuring protection in the early twentieth century}

This section deals with the construction and comparison of alternative measures of protection using the results presented in the previous section. First, a set of traditional indicators of trade intensity will be constructed for each of our eighteen countries. The Trade Intensity Ratio is a measure that uses the net export data at some level of disaggregation:

Trade Intensity Ratio $(\mathrm{TIR})=\Sigma_{j} \mid X_{j}-M_{j} \mathrm{l}$ GNP.

A more traditional indicator, usually used in the economic history literature because of data availability, does not subtract exports from imports:

Trade Intensity Ratio* $\left(\operatorname{TIR}^{*}\right)=\Sigma_{j}\left(\left|X_{j}\right|+\left|M_{j}\right|\right) /$ GNP.

Obviously, these two measures would be identical if the disaggregation level were fine enough that commodities were either exported or imported but not both. Thus, one can use the difference between the two ratios as a measure of the intra-industry trade or 'two-way' trade taking place at this level of disaggregation:

Intra-Industry Trade $(\mathrm{IIT})=\left(\mathrm{TIR}^{*} / \mathrm{TIR}\right)-1$.

A value of zero would indicate that there was no intra-industry trade at the level reported.

Alternatively, the two measures proposed in this study are based on the model described in Equation (5.8') estimated in the previous section:

$$
N_{i j}=\beta^{\prime}{ }_{j} V_{j}+\epsilon_{i j}
$$

These measures were introduced on pages 72-4 and are defined here again for convenience. The first is an adjusted Trade Intensity Ratio:

Adjusted Trade Intensity Ratio ${ }_{i}^{A}\left(\operatorname{TIR}_{i}^{A}\right)=\left(\sum_{j}\left|N_{i j}\right|-\left|N^{*}{ }_{i j}\right|\right) / \mathrm{GNP}_{i}$

where $N^{*}$ is the predicted trade by the above model. This measure is analogous to a measure of welfare loss indicating the percentage of GNP lost as a result of trade barriers. Alternatively, we can compute the following ratio:

$$
\text { Openness }\left(O P E_{i}\right)=\Sigma_{j}\left|N_{i j}\right| / \Sigma_{j}\left|N^{*}{ }_{i j}\right|
$$

which could be viewed as a measure of how much trade is deterred by trade barriers. Table 5.6 reports the TIR, TIR ${ }^{A}$ and OPE measures computed for three aggregates: primary products (resource commodities and 
Table 5.6 Measuring overall protection in 1913

\begin{tabular}{|c|c|c|c|c|c|}
\hline \multicolumn{2}{|c|}{ Primary products } & \multicolumn{2}{|c|}{ Manufactures } & \multicolumn{2}{|c|}{ Overall } \\
\hline \multicolumn{6}{|c|}{ Trade intensity ratios (TIR) } \\
\hline USA & 4.41 & USA & 1.94 & USA & 6.35 \\
\hline ITA & 7.16 & SPA & 3.44 & ITA & 11.55 \\
\hline SPA & 10.12 & ITA & 4.38 & SPA & 13.56 \\
\hline POR & 12.57 & POR & 5.94 & POR & 18.51 \\
\hline FRA & 12.83 & FRA & 6.00 & FRA & 18.83 \\
\hline GER & 14.50 & AUS & 6.57 & GER & 23.27 \\
\hline SWE & 17.59 & DEN & 8.55 & AUS & 24.89 \\
\hline AUS & 18.32 & GER & 8.78 & SWE & 28.38 \\
\hline NOR & 20.35 & UK & 10.74 & NOR & 35.33 \\
\hline CAN & 20.98 & SWE & 10.79 & SWI & 36.42 \\
\hline SWI & 22.68 & BEL & 10.81 & CAN & 36.97 \\
\hline AUL & 26.03 & FIN & 12.11 & BEL & 37.65 \\
\hline BEL & 26.84 & SWI & 13.73 & UK & 38.17 \\
\hline UK & 27.43 & ARG & 13.99 & AUL & 40.94 \\
\hline NET & 35.44 & AUL & 14.91 & ARG & 50.22 \\
\hline ARG & 36.23 & NOR & 14.98 & FIN & 54.85 \\
\hline FIN & 42.75 & CAN & 15.99 & DEN & 57.51 \\
\hline DAN & 48.96 & NET & 33.76 & NET & 69.20 \\
\hline \multicolumn{6}{|c|}{ Adjusted trade intensity ratios $\left(T I R^{A}\right)$} \\
\hline POR & -8.42 & SPA & -6.94 & SPA & -13.52 \\
\hline ITA & -7.05 & FIN & -3.86 & POR & -9.15 \\
\hline SPA & -6.58 & DEN & -1.73 & ITA & -8.66 \\
\hline AUL & -4.98 & ITA & -1.61 & USA & -4.62 \\
\hline NOR & -4.25 & POR & -0.73 & FRA & -4.33 \\
\hline USA & -4.13 & USA & -0.49 & AUL & -4.11 \\
\hline FRA & -3.99 & FRA & -0.34 & FIN & -3.41 \\
\hline SWI & -3.10 & BEL & 0.37 & NOR & -2.47 \\
\hline BEL & -0.58 & AUL & 0.87 & BEL & -0.21 \\
\hline GER & -0.38 & ARG & 0.96 & SWI & 1.32 \\
\hline CAN & 0.08 & NOR & 1.78 & GER & 3.19 \\
\hline FIN & 0.45 & AUS & 3.39 & SWE & 4.87 \\
\hline SWE & 1.26 & GER & 3.57 & CAN & 6.51 \\
\hline AUS & 7.09 & SWE & 3.62 & ARG & 9.98 \\
\hline ARG & 9.01 & UK & 3.97 & AUS & 10.47 \\
\hline UK & 10.65 & SWI & 4.42 & UK & 14.62 \\
\hline NET & 14.54 & CAN & 6.42 & DEN & 18.73 \\
\hline DEN & 20.47 & NET & 26.92 & NET & 41.46 \\
\hline \multicolumn{6}{|c|}{ Openness measures (OPE) } \\
\hline ITA & 5.04 & SPA & 3.32 & SPA & 5.01 \\
\hline USA & 5.16 & ITA & 7.31 & ITA & 5.71 \\
\hline POR & 5.99 & FIN & 7.58 & USA & 5.79 \\
\hline SPA & 6.06 & USA & 7.99 & POR & 6.69 \\
\hline FRA & 7.63 & DEN & 8.31 & FRA & 8.13 \\
\hline NOR & 8.27 & POR & 8.91 & AUL & 9.09 \\
\hline AUL & 8.40 & FRA & 9.46 & NOR & 9.35 \\
\hline SWI & 8.80 & BEL & 10.36 & FIN & 9.42 \\
\hline GER & 9.75 & AUL & 10.62 & BEL & 9.95 \\
\hline BEL & 9.79 & ARG & 10.74 & SWI & 10.38 \\
\hline
\end{tabular}


Table 5.6 continued

\begin{tabular}{llcrll}
\hline Primary products & \multicolumn{3}{c}{ Manufactures } & \multicolumn{2}{c}{ Overall } \\
\hline CAN & 10.04 & NOR & 11.35 & GER & 11.59 \\
FIN & 10.11 & SWI & 14.75 & SWE & 12.07 \\
SWE & 10.77 & SWE & 15.04 & CAN & 12.14 \\
ARG & 13.31 & UK & 15.88 & ARG & 12.48 \\
AUS & 16.31 & CAN & 16.72 & DEN & 14.83 \\
UK & 16.34 & GER & 16.85 & UK & 16.21 \\
NET & 16.96 & AUS & 20.63 & AUS & 17.27 \\
DEN & 17.18 & NET & 49.37 & NET & 24.95 \\
\hline
\end{tabular}

Notes

See page 80 for definitions.

Column (1): Primary products: groups 00, 01, 02, 03, 04, 05, 06, 07, 08, 09, 11, 12, 21, 22, 23, 24, 25, 27, 28, 29, 32, 33, 41, 42, 43, 68 .

Column (2): Manufactures: groups 51, 52, 61, 62, 63, 64, 65, 66, 67, 69, 71, 72, 73, 81, 82, 84, 86, 89, 95 (Statistical Appendix, available on demand).

agricultural products) and manufactures; as well as an overall measure. Countries in these tables are ranked from highly closed to highly open economies. A main feature of this approach in measuring protection is that those indices can be computed for any commodity aggregate of interest. A major contribution of this study is to produce a set of protection levels at the sectoral level, which can be used to explore commercial policies of this period across countries.

Table 5.7 offers the openness measure for eight commodity aggregates. ${ }^{14}$

To assess the ability of these indicators to measure protection, Table 5.8 compares the overall Adjusted Trade Intensity Ratio $\left(\mathrm{TIR}^{A}\right)$ and the Overall Openness Measure (OPE) with other three alternative overall indices traditionally used in the economic history literature: (a) Import duties as a percentage of total imports (IDR); (b) Two measures of the average level of tariffs (the $T L I_{1}$ taken from the League of Nations (1927) and the $T L I_{2}$ from Liepmann (1938) as reported in Bairoch (1989)); and (c) Trade intensity ratio (TIR*) or exports plus imports as a percentage of GNP. The remarkable rank correlation observed among those indices reinforces some of the properties attributed to the measures constructed using the methodology of this study and, at the same time, the validity of the $\mathrm{H}-\mathrm{O}$ model to explain trade patterns during this period. That is, first, the indices presented are objective in the sense of being the result of a trade model. Second, those indicators not only reflect the impact of tariff barriers but also other trade deterring policies. Third, they are continuous indices, allowing for different degrees of openness. The average level of protection has been normalised to zero for the $\operatorname{TIR}^{A}$ and to ten for the OPE. Thus, the negative $\operatorname{TIR}^{A}$ values or the OPE index below ten indicates that the country had a higher level of protection than the world average. 
Table 5.7 Measuring sectoral protection in 1913 (openness indices)

\begin{tabular}{|c|c|c|c|c|c|c|c|}
\hline \multicolumn{2}{|c|}{ Raw materials } & \multicolumn{2}{|c|}{ Cereals and fibres } & \multicolumn{2}{|c|}{ Raw agricultural goods } & \multicolumn{2}{|c|}{ Processed foods } \\
\hline SPA & 1.94 & SPA & 1.52 & POR & 1.14 & SPA & 0.53 \\
\hline NOR & 3.62 & POR & 1.61 & NOR & 1.77 & POR & 1.06 \\
\hline POR & 4.00 & SWI & 2.54 & SPA & 2.81 & NOR & 1.65 \\
\hline ITA & 4.83 & NOR & 2.77 & FIN & 3.06 & BEL & 3.42 \\
\hline BEL & 6.07 & FIN & 3.01 & CAN & 3.22 & ITA & 4.06 \\
\hline DEN & 7.44 & SWE & 4.12 & SWE & 3.95 & CAN & 5.19 \\
\hline SWI & 7.53 & ITA & 4.17 & SWI & 4.23 & ARG & 7.22 \\
\hline AUL & 8.37 & DEN & 4.71 & BEL & 4.37 & SWE & 7.36 \\
\hline CAN & 8.78 & BEL & 6.27 & AUL & 4.92 & FRA & 8.09 \\
\hline SWE & 8.89 & NET & 6.62 & ITA & 6.28 & AUL & 8.11 \\
\hline NET & 8.91 & CAN & 6.91 & USA & 9.89 & FIN & 8.71 \\
\hline FRA & 10.85 & ARG & 8.59 & FRA & 10.43 & USA & 10.11 \\
\hline UK & 11.02 & AUL & 9.16 & GER & 11.26 & SWI & 11.52 \\
\hline ARG & 11.63 & UK & 11.42 & UK & 11.39 & UK & 11.83 \\
\hline USA & 12.44 & FRA & 11.48 & NET & 11.95 & GER & 13.85 \\
\hline GER & 12.75 & USA & 12.41 & ARG & 16.09 & AUS & 20.32 \\
\hline FIN & 14.96 & GER & 13.50 & AUS & 19.59 & NET & 26.93 \\
\hline AUS & 15.68 & AUS & 38.06 & DEN & 21.59 & DEN & 58.17 \\
\hline \multicolumn{2}{|c|}{ Labour-intensive mfr. } & \multicolumn{2}{|c|}{ Capital-intensive $\mathrm{mfr}$. } & \multicolumn{2}{|c|}{ Machinery } & \multicolumn{2}{|c|}{ Chemicals } \\
\hline SPA & 0.73 & SPA & 0.75 & POR & 3.73 & FIN & 3.75 \\
\hline POR & 1.80 & FIN & 1.86 & FIN & 4.51 & SPA & 4.09 \\
\hline NOR & 3.27 & NOR & 2.31 & DEN & 4.58 & POR & 4.15 \\
\hline ARG & 4.20 & POR & 3.96 & SPA & 6.36 & SWI & 5.54 \\
\hline DEN & 4.64 & BEL & 4.68 & CAN & 6.67 & $\mathrm{ARG}$ & 5.81 \\
\hline SWI & 5.28 & SWE & 4.76 & NOR & 7.08 & CAN & 8.42 \\
\hline BEL & 7.16 & ITA & 4.94 & SWE & 7.11 & USA & 10.17 \\
\hline FIN & 9.61 & DEN & 5.81 & ARG & 7.65 & FRA & 10.31 \\
\hline ITA & 10.28 & SWI & 6.67 & ITA & 8.27 & AUS & 11.87 \\
\hline USA & 10.73 & ARG & 7.19 & BEL & 8.27 & UK & 12.38 \\
\hline FRA & 10.77 & AUS & 7.58 & USA & 9.65 & DEN & 12.74 \\
\hline CAN & 11.56 & CAN & 9.64 & UK & 10.57 & NOR & 13.11 \\
\hline UK & 11.74 & USA & 10.31 & GER & 11.12 & GER & 14.36 \\
\hline SWE & 11.78 & AUL & 10.89 & AUL & 11.96 & AUL & 14.85 \\
\hline GER & 12.61 & FRA & 10.94 & FRA & 13.16 & ITA & 22.30 \\
\hline AUL & 15.31 & UK & 11.11 & AUS & 24.17 & SWE & 23.37 \\
\hline NET & 18.26 & GER & 11.74 & NET & 26.53 & NET & 52.09 \\
\hline AUS & 21.84 & NET & 31.44 & SWI & 29.72 & BEL & 96.67 \\
\hline
\end{tabular}

Notes

This table uses the openness indicators introduced on page 80. See Appendix for a detailed description of the sectoral categories.

Finally, and most important, those indices are comparable across countries and sectors.

To examine further these residual measures we can construct measures of peculiarity of trade of country $i$ or commodity $j .{ }^{15}$ The quality of the 


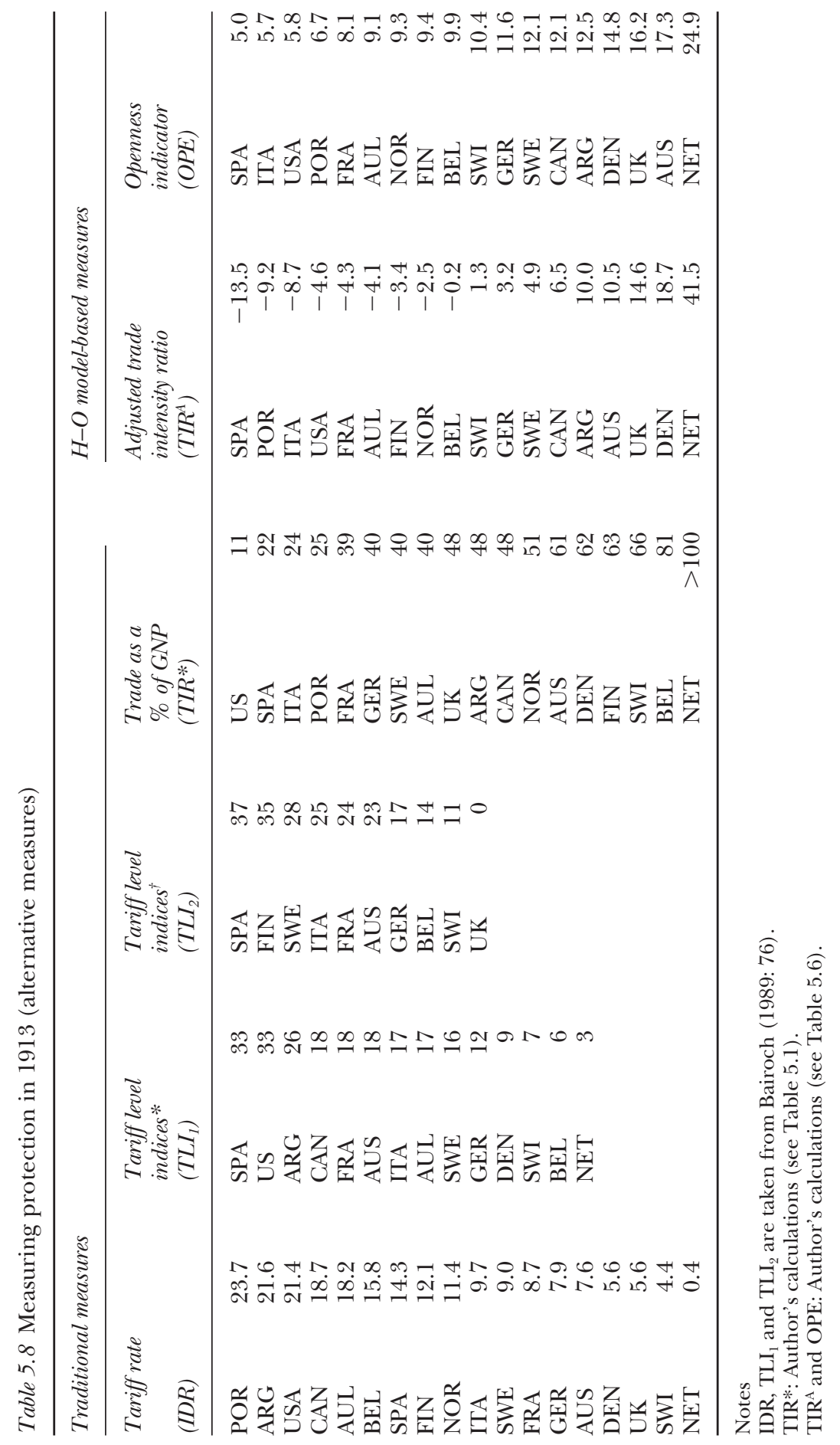


model in explaining the variability of the data is measured traditionally by the $R^{2}$. Following the model introduced on pages 72-4, a country $R^{2}$ can be defined as:

$$
R_{i}^{2}=1-\left[\Sigma_{j} \mathrm{E}_{i j}{ }^{2}\right] /\left[\Sigma_{j}\left(N_{i j}-N_{i}\right)^{2}\right]
$$

where $N_{i}=\Sigma_{j} N_{i j} / J$ is the average trade of country $i, N_{i j}$ is the value of net exports of commodity $j$ in country $i$, and $E_{i j}$ is the difference between the actual net trade and the predicted net trade by the model, that is, $E_{i j}=N_{i j} N_{i j}{ }^{*}$. If trade were balanced, then the mean would be zero and the country $R^{2}$ would measure the size of the squared residuals relative to the size of squared net trade. However, this $R^{2}$ need not to be a positive number, since the model is estimated across countries for each commodity aggregate. Countries with negative $R^{2}$ indicate that net trade is poorly explained for each commodity.

Table 5.9 reports the overall $R^{2}$ for each of our eighteen countries.

Overall, the scaled model does pretty well in explaining the net trade data. The exceptions are the three Latin economies and the United States. This chapter attributes the presence of outlier behaviour to policy intervention. However, the presence of non-linearities associated with the failure of some assumptions on which the model is based, like incomplete specialisation or constant returns to scale should be further explored. Alternatively, omitted resources or measurement errors are other possible candidates to account for this behaviour.

Table 5.9 Overall fit of the model by country $\mathrm{R}^{2}$

\begin{tabular}{lr}
\hline Argentina & 0.63 \\
Australia & 0.78 \\
Austria-Hungary & 0.63 \\
Belgium & 0.75 \\
Canada & 0.59 \\
Denmark & 0.43 \\
Finland & 0.78 \\
France & 0.20 \\
Germany & 0.51 \\
Italy & -0.67 \\
Netherlands & 0.31 \\
Norway & 0.88 \\
Portugal & -0.95 \\
Spain & -0.77 \\
Sweden & 0.20 \\
Switzerland & 0.07 \\
United Kingdom & 0.58 \\
United States & -4.97 \\
\hline
\end{tabular}

Notes

See pages $80-7$. 
Additionally, a measure of the peculiarity of commodity $i$ in country $j$ can be defined as its contribution to the total lack of fit for that country:

$$
P_{i j}=E_{i j} / \Sigma_{j}\left|E_{i j}\right|
$$

Table $5.10^{16}$ reports the set of extreme commodities as defined by the above peculiarity measure. Consider, for example, the case of Spain, which has one of the lowest overall $R^{2}$ s. Twenty per cent of its sum of absolute residuals is due to overpredicting cereals net exports, 9 per cent from underpredicting textile products net exports, and so forth. Therefore, this factor-endowment-adjusted model suggests that Spain's cereals sector was relatively unprotected and that the textile sector was relatively protected or subsidised, compared with other countries. These numbers are subject to numerous caveats and are provided here in order to stimulate criticism and to open directions for future research in a topic that has been understudied from a comparative and sectoral perspective.

The trade-model-based measures shown in Table 5.8 consistently identify the Latin economies (Spain, Italy and Portugal) as the most protectionist. This finding, although consistent with the various national economic history accounts for these three countries, gives a contrasting picture in comparison to other overall measures. When average duties or trade intensity ratios are used, Spain always ranks first in level of protection. If an import duties ratio is used, Portugal seems to be the most closed economy, while Spain and Italy are rather average countries. The cases of other continental economies are also interesting. France belonged clearly among the most protectionist countries, well above the levels of Germany, although both had similar trade dependency ratios (around 40 per cent). Austria, according to the resource adjusted measures, was a relatively open economy, even though her tariffs were above average. The Swedish level of protection differs greatly when measured by the League of Nations or by Liepmann, and it is relatively open when the $\mathrm{TIR}^{A}$ or $O P E$ measures are used. Although its trade ratio to total GNP was only 40 per cent, given its resources it should have been less tradedependent. Norway and Finland, which were much more trade-dependent, are identified as relatively closed economies by our measures, suggesting that they should have depended even more on trade. This finding agrees with the only direct measure of tariff averages for one of these countries. Liepmann's index ranked Finland one of the most protectionist countries, only after Spain. Belgium and Switzerland were only moderately protectionist.

The long-standing debate on the role of tariff protection in the longterm development of regions of recent settlement like Argentina, Australia and Canada can also be approached with this new set of measures. In Table 5.8, all three countries appear to be highly protected economies according to either the import duties ratio or average tariff measures, 
except Australia which the League of Nations index identifies as an average country. When trade ratios adjusted by factor endowments are used, the picture that emerges is quite different. In the cases of Argentina and Canada, our resource-adjusted measure suggests that they should have been less trade-dependent. Australia, however, was clearly a relatively protected country, after controlling for her resources and natural barriers. However, a more sectoral approach will be needed to assess the impact of the tariff policies for the long-run economic development of these three regions.

\section{Concluding remarks}

In this chapter I have constructed what appears to be the first set of measures of protection or, alternatively, trade openness for 1913 following Leamer's methodology based on the Heckscher-Ohlin general equilibrium trade model. This chapter is based on a new trade set for net exports in 1913 computed for eighteen countries and fifty-five sectors according to the SITC system. The measures suggested are, first, objective in the sense of not attempting to classify a priori the trade regime of some country based only on its tariff legislation. Second, they reflect all types of trade interventions. Third, they are constructed as a continuous measure. Finally, and most importantly, they are comparable across countries and sectors. When the overall measures proposed are compared with other alternative measures that have been extensively used in the economic history literature, the degree of rank conformity is remarkable; thereby increasing the credibility of these measures when computed for more disaggregated commodity groups for which other measures are not available. Further research, building on some of these new protection measures, will contribute to a better understanding of the economic development during this period from a comparative perspective.

\section{Appendix 5.1}

This study uses a data set assembled by the author in the context of a larger project to study the determinants of late-nineteenth-century comparative advantage from a comparative perspective. This Appendix is devoted to discuss the statistical sources and methods to construct this database. The first section provides an overview of trade data available to economic historians and introduces a new data set on net exports for 1913. The second section discuss some aggregation methods of the trade data used in this study. The statistical sources on trade and factor endowments are discussed in the third section. 


\section{A note on historical trade data}

In this section I compare the main feature of this newly constructed data set on net exports with other alternative sources available. The project involved the laborious task of codifying (and translating) the original trade statistics for 1913 for a sample of eighteen countries: Argentina, Australia, Austria, Belgium, Canada, Denmark, Finland, France, Germany, Italy, the Netherlands, Norway, Portugal, Spain, Sweden, Switzerland, United Kingdom and United States. Due to differences among the various national trade classification systems, it was not possible to use the summary reports that most countries include, and it became necessary to work with the detailed trade returns and regroup the different items according to some standardised classification system. The Standard International Trade Classification System, SITC Revised (United Nations, 1961) was adopted. This involved the reclassification of the individual commodities using the fifty-nine commodity groups reported in Table 5.11. For each country, exports and imports were computed for each commodity group, although this study uses only net export data.

The main reason why a data set like this has never been assembled before is that traditionally every nation had its own national system of commodity classification. The first attempt to secure conformity to an international code was drawn up by a committee of experts in Brussels in 1912 and subsequently named the 'Brussels Classification'. This classification divided commodities into five major groups: (a) live animals; (b) foodstuffs; (c) raw materials and semi-manufactures; (d) manufactures; and (e) gold and silver bullion and coin. A second list was a revision prepared by the League of Nations and entitled the 'Minimum List', but since this was promulgated shortly before the Second World War it was never widely adopted. Third came the system operating today, namely the Standard International Trade Classification (SITC) accepted by the Economic and Social Council of the United Nations in 1950 and adopted by the majority of countries ever since.

Most previous studies analysing trade data for the pre-First World War period have been concerned with the compositional changes of trade patterns through time. The analysis, with few exceptions, has been carried out at a highly aggregative level, for a particular group of commodities or considering only a few countries or 'trading areas'. The pioneering work in this analysis was undertaken by F. Hilgerdt (1945), Industrialization and Foreign Trade (Geneva: League of Nations), who, using the Brussels system, divided world trade into very broad categories of manufactures and primary products with no commodity subdivisions, and presented the data according to this classification by country from 1871 to 1938 . Hilgerdt did not disclose which commodities furnished official figures and which had to be covered by estimates, nor did he say anything about general or special trade, about imports recorded f.o.b, or about the error in official 
Table 5.11 Standard International Trade Classification (SITC) trade aggregates

\author{
Group 0: FOOD AND LIVE ANIMALS \\ 00 Live animals \\ 01 Meat and meat preparations \\ 02 Dairy products and eggs \\ 03 Fish and fish preparations \\ 04 Cereals and cereal preparations \\ 05 Fruit and vegetables \\ 06 Sugar, sugar preparations and honey \\ 07 Coffee, tea, cocoa, spices and $\mathrm{mfr}$. \\ thereof \\ 08 Feeding stuff for animals \\ 09 Miscellaneous food preparations \\ Group 1: BEVERAGES AND TOBACCO \\ 11 Beverages \\ 12 Tobacco and manufactures \\ Group 2: CRUDE MATERIALS EXC. FUELS \\ 21 Hides, skins and furskins, undressed \\ 22 Oil-seeds, oil nuts and kernels \\ 23 Crude rubber \\ 24 Wood, lumber and cork \\ 25 Pulp and waste paper \\ 26 Textile fibres \\ 27 Crude fertilisers and minerals \\ 28 Metalliferrous ores and metal scrap \\ 29 Crude animal and vegetable \\ materials, n.e.s.
}

Group 3: MINERAL FUELS, LUBRICANTS* 31 Coal, coke and briquettes

32 Petroleum and products

Group 4: NON-MINERAL OILS AND FAT

41 Animal oils and fats

42 Fixed vegetable oils and fats

43 Processed oil and fat; wax

Group 5: CHEMICALS

51 Chemical elements and compounds

52 Mineral tar and crude chemicals from petroleum and natural gas

53 Dyeing, tanning and colouring materials
54 Medicinal and pharmaceutical materials

55 Essential oils and perfume; toilet, polishing and cleansing preparations

56 Manufactured fertilisers

57 Explosives and pyrotechnic products

58 Plastic materials, regenerated cellulose and artificial resins

59 Chemical materials and products, n.e.s.

Group 6: MANUFACTURED GOODS

61 Leather, manufactures and dressed furskins

62 Rubber manufactures

63 Wood and cork manufactures (excl. furniture)

64 Paper, paperboard and manufactures

65 Textile yarn, fabrics, made-up articles

66 Non-metallic mineral manufactures n.e.s.

67 Iron and steel

68 Non-ferrous metals

69 Manufactures of metal n.e.s.

Group 7: MACHINERY AND TRANSPORT EQUIPMENT

71 Machinery, other than electric

72 Electric machinery, apparatus and appliances

73 Transport equipment

Group 8: MISC. MANUFACTURED GOODS

81 Sanitary, plumbing, heating and lighting fixtures and fittings

82 Furniture

83 Travel goods, handbags and similar articles

84 Clothing

85 Footwear

86 Professional, scientific and controlling instruments

89 Miscellaneous manufactured articles

Group 9: NOT CLASSIFIED

95 Firearms of war and ammunition

Notes

Sectoral classification from United Nations (1961).

*SITC Groups 34 (Gas, natural and manufactured) and 35 (Electric current) were excluded. Only Group 95 in Group 9 is included.

values. Two important studies followed the work of Hilgerdt, at a more disaggregated level, but less comprehensive in scope. The first was conducted by H. Tyszynski (1951), 'World Trade in Manufactured Commodities, 1899-1950', Manchester School, 19, pp. 272-304, who studied the 
composition of exports of manufactured goods from 1899 until 1950. Using original trade returns, he reported export data for eleven countries (United States, United Kingdom, France, Germany, Belgium, Italy, Sweden, Switzerland, Canada, Japan and India) and for five benchmark years: 1899, 1913, 1929, 1937 and 1950. He defined 'manufactured commodities' as those goods included in Class III of the British export list used until 1950 ('Articles Wholly or Mainly Manufactured'). He constructed his own classification system based on 17 groups (iron and steel; nonferrous metals; chemicals; non-metalliferrous materials; miscellaneous materials; industrial equipment; electrical goods; agricultural equipment; railways, ships, etc.; motor-cars, aircraft, etc.; spirits and tobacco; textiles; apparel; metal manufactures, n.e.s.; books, films and cameras; not classified). I. Svennilson (1954), Growth and Stagnation in the European Economy (Geneva: United Nations), gives export figures for eight countries (United Kingdom, France, Germany, Belgium, Italy, Sweden and Switzerland), in 1913, 1928, 1938 and 1950. Data is disaggregated into nine commodity groups (food, drink and tobacco; raw materials; metals; machinery; vehicles; chemicals; textiles; miscellaneous; unspecified). Cairncross (1955), 'World Trade in Manufactures Since 1900', Economia Internazionale, 8, pp. 715-41, compared the data reported in Hilgerdt, Tyszynski and Svennilson, and suggested a method to link them with modern data reported by the United Nations under SITC headings since 1950. Later on, R. E. Baldwin (1971), 'The Commodity Composition of Trade: Selected Industrial Countries, 1900-1954', extended Svennilson's data, adding export figures for Canada and Japan and carrying all figures back to 1900 and forward to 1952 and 1954. He also collected data on imports for the whole sample according to the same classification and for the same years. Finally, very influential and ambitious studies were carried out by P. L. Yates (1959), Forty Years of Foreign Trade (London: George Allen \& Unwin) and A. Maizels (1963), Industrial Growth and World Trade (Cambridge: Cambridge University Press). Yates' goal was to ascertain for the year 1913, the value of world exports and imports by individual commodities to be compared with the United Nations Trade Census of 1953. Although very rich in statistics, the book failed in a very important aspect for our purposes. There was a big gap between the data actually collected and the data reported. He claimed that the 1913 data was collected from national trade statistics for fifty-six countries and disaggregated at the level of fifty-seven commodity groups. However, the underlying data has never been published. Information on world total exports and imports is given by commodity groups. By country, only total exports and imports is reported (with the exception of a few primary commodities, where data for the most important countries is given). In addition, commodities grouped into seven broad categories (food; agricultural materials; minerals; metals; machinery; textiles; and other manufactures) was reported for eight 'trading areas' (United States and Canada; United Kingdom and Ireland; 
North-West Europe; Other Europe; Oceania; Latin America; Africa; and Asia). Even if he had published the basic data set, his exercise needed to be completed. He was mostly interested in primary product trade, rather than manufactures. Therefore, forty-seven out of his fifty-seven groups were primary products. Finally, the leading book on manufacturing trade with data for the pre-World War period was published four years later, in 1963, by Maizels. Maizels constructed a set of trade network tables for manufactures based only on export statistics for twelve countries (Belgium, France, Germany, Italy, Netherlands, Sweden, Switzerland, United Kingdom, Canada, United States, India and Japan). With this method, the import figures reported differed from true imports. In the first place, 'imports' came only from the twelve exporting countries included in his analysis. Second, since 'imports' of one country were arrived at from the export returns of other countries, the valuation is on a f.o.b. basis, whereas imports are normally valued at c.i.f. Third, there is always some time-lag between the export of a commodity and its recording as an import in the receiving country. The network tables were constructed for 1899, 1913, 1929, 1937, 1950, 1955, 1957 and 1959. His definition of manufactures was Groups 5 to 8 from the United Nations, SITC (metals; metal goods; machinery; transport equipment, divided into passenger road vehicles and other transport equipment; chemicals, divided into intermediates and finished; textiles, divided into yarns, fabrics and made-up goods; other manufactures, divided into intermediates and finished). In this chapter I offer a new trade data set on net exports in 1913 for eighteen countries and for fifty-five sectors according to the Standard International Trade Classification System (United Nations, 1961), which should encourage economic historians to devote more effort to extending this data set over longer periods of time.

\section{Aggregation methods of net trade in 1913}

The focus of the aforementioned studies is the compositional changes of trade patterns through time, from the late nineteenth century until the post-Second World War years. In contrast, the analysis carried out in this chapter applies to a cross-section of net trade flows at a point in time, 1913, the year that marked the end of the nineteenth century. Although I have used the commodity classification provided by the SITC (Revised version, 1961) as a basis for assembling a homogeneous trade data set for the eighteen country sample, no attempt has been made to use this a priori classification for the econometric analysis on pages 74-8. Instead, different clustering algorithms were used trying to produce broad groups of commodity aggregates. Given the nature of the model introduced on pages 72-4 and the estimation problems that it implies, some level of aggregation is necessary in order to compute sensible measures of protection, as defined in the same section. Since those are aggregated measures 
of residuals, the model had to be estimated at a very disaggregated level, and the indices of protection will only be meaningful at some higher degree of aggregation. The easiest way to proceed was to use the same classes of the SITC system of Table 5.11. However, those are arbitrary, as in any classification system of this nature. In this section, two different methods of aggregation of the basic data will be explored. The first uses a clustering procedure with the purpose of dividing our initial fifty-five net trade data groups (Table 5.11) into a smaller set of disjoint clusters. Commodity groups in a given cluster tend to be similar to each other in some sense, and groups in different clusters tend to be dissimilar. The underlying hypothesis is that a high correlation between two commodity groups indicates that these commodities behave similarly in international trade in the sense that if a country has large positive net exports of one, then it also has large net exports of the other. When such a correlation is found, these classes are combined into one, since the forces that determine trade in a component are likely to be the same as those that determine trade in the corresponding aggregate.

The cluster algorithm begins with a $55 \times 55$ matrix of cross-country correlations of the net export data using trade data from the eighteen country sample. The procedure is based on an iterative reassignment of variables in a sequence of clusters, trying to maximise the sum across clusters of the variance of the original variables that is explained by the cluster components. ${ }^{17}$ The results of this procedure were compared with a set of cross-section regressions of the net export data on a set of factor endowments as reported in Tables 5.3-5.5. Commodities with similar coefficients are said to belong to the same groups.

The final classification is a compromise between the two methods. However, both methods are surprisingly consistent between themselves and with the SITC system initially used. Table 5.11 reports the final groups and sub-groups that will be used to compute the measures of protection in the section on pages $80-7$. The number on the columns to the right show the cluster assignment during the third, seventh and last iteration performed by the procedure and should be compared with the sign of the regression coefficients reported in Tables 5.3-5.5. Few comments need to be made. Before the clustering procedure was applied, and due to some well-known estimation problems when the dependent variable has a high proportion of zero observations, a few groups with this problem were initially grouped. Thus, Group 81 in Table 5.11 includes SITC codes 81,83 and 85 (from Table 5.11); Group 51 includes SITC 51, 52, 53, 55, 59 (from Table 5.11) and Group 52 was formed adding up SITC 54, 56, 57 and 58 categories (from Table 5.11). The division of the 'chemical' group follows closely Maizels' subdivision into 'intermediates' and 'finished' goods, and reveals the difficulties of classification of these commodities from the original trade returns. After this initial adjustment was made, the final ten groups have been partly the result of a certain amount of 'fid- 
dling' designed to produce a plausible set of aggregates using the clustering results and the cross-section regressions. For instance, Group 62 was included in Group 7 although the cluster procedure assigned it consistently to Group 8; however, the sign-coefficients from the regression results placed it among the 'labour-intensive manufactures' group. Similar reallocation criteria apply to Group 89 ('Miscellaneous manufactures') and Group 95 ('Firearms and ammunition'). Thus, the analysis uses the following ten commodity aggregates: Group 1: coal (COAL); Group 2: raw materials (RAWMAT); Group 3: cereals and textile fibres (CERTEX); Group 4: raw agricultural products (RAWGR); Group 5: processed agricultural products (PROAGR); Group 6: beverages and tobacco (BEVTOB); Group 7: labour intensive manufactures (LABINT); Group 8: capital intensive manufactures (CAPINT); Group 9: machinery (MACH); and Group 10: chemicals products (CHEM).

\section{Methods and sources}

The data assembled for this study includes eighteen countries (Argentina, Australia, Austria, Belgium, Canada, Denmark, Finland, France, Germany, Italy, the Netherlands, Norway, Portugal, Spain, Sweden, Switzerland, United Kingdom and the United States) and data on net exports and factor endowments.

(a) Capital Stock Measure (CAP). Energy consumption has been used as a proxy for capital stock. It refers to apparent consumption (production plus net imports) of solid fuels (hard coal, brown coal, lignite and coke). In order to permit aggregation and comparison across countries, data are expressed in thousands of hard-coal equivalents (a metric ton of hard coal contains approximately 28 million Btu - British Thermal unit - defined as the heat needed to raise one pound of water by one degree Fahrenheit, at or near the temperature of maximum density). The conversion factors used in this computation are from J. Darmstadter (1971), Energy in the World Economy (Baltimore: Johns Hopkins Press, p. 828). The primary source was B. R. Mitchell (1980), European Historical Statistics 1750-1975, 2nd edn (London: Macmillan) and (1983), International Historical Statistics: the Americas and Australasia (London: Macmillan). His data was carefully checked against and complemented with R. P. Rothwell (ed.), The Mineral Industry, its Statistics, Technology and Trade (Several issues. New York: Scientific Publishing Company). Whenever a discrepancy existed, the latter source was used.

(b) Skilled Labour (SKI). Skilled Labour was computed as Labour Force times Literacy rate. Data are in thousands of workers.

(c) Unskilled Labour (UNSK). Unskilled Labour was obtained as Labour Force minus Skilled Labour. Data are in thousands of workers.

(d) Labour Force. Data for all countries except Argentina, Spain and Portugal is total labour force (in thousands) estimated at mid-year and is taken from A. Maddison (1982), Phases of Capitalist Development (Oxford, 
UK: Oxford University Press). Data for Argentina, Portugal and Spain refers to the economically active population as reported in B. R. Mitchell (1980), European Historical Statistics, 1750-1975, 2nd edn (London: Macmillan) and (1983), International Historical Statistics: the Americas and Australasia (London: Macmillan). Linear interpolation between census years was used when needed.

(e) Literacy Rate. Illiteracy rate is defined, whenever possible, as the percentage of population ten years old and over who cannot read and write. Data was taken from J. E. Abel and N. J. Bond (1929), Literacy in Several Countries of the World (United States Bureau of Education), I. Adelman and C. T. Morris (1984), Comparative Patterns of Economic Development 1850-1914 (Baltimore: Johns Hopkins University Press), C. M. Cipolla (1969), Literacy and Development in the West (Statistical Appendix. London: Penguin Books), Dominion Bureau of Statistics (1926), Illiteracy and School Attendance in Canada, chapter 3 (Ottawa); A. M. Lindergren (1945), Literacy and Illiteracy in Various Countries of the World, Education For Victory, 3; P. Sothi (1966), Trends of World Illiteracy since 1900 and its Relationships with Some Selected Educational, Social and Economic Factors (PhD thesis, Ann Arbor: University of Michigan), L. C. Stedman and C. F. Kaestle (1987), Literacy and Reading Performance in the United States: from 1880 to Present, Reading Research Quarterly 22; and UNESCO (1953), Progress of Literacy in Various Countries (Paris) and (1957), World Literacy at Mid-Century (Paris).

(f) Agricultural Land (AGR). Agricultural land in thousands of hectares for all countries (except Portugal) are available in League of Nations (1927), Population and Natural Resources (Geneva). For Portugal, data on agricultural land are taken from P. Lains (1989), Foreign Trade and Economic Growth in the European Periphery. Portugal, 1850-1913 (Florence: European University Institute, mimeo).

(g) Mineral Resources $(M I N)$. This natural resource variable is computed as the value in thousands of dollars of petroleum production plus ore production of a composite of twelve minerals: bauxite, copper, iron ore, lead, manganese, nickel, phosphate, potash, pyrites, brimestone, tin and zinc. Value is in thousands of dollars. The primary sources for production in all countries are B. R. Mitchell (1989, 1983, ibid.), and R. P. Rothwell (ed.) (ibid.). Secondary sources for specific countries were used in the following cases (several issues).

Argentina: Estadística Minera de la República.

Australia: Australian Mineral Industry: Production and Trade: 1842-1964.

Belgium: Statistique des Industries Extractives et Métallurgiques.

Canada: Annual Report of the Mineral Production of Canada.

France: Statistique de l'Industrie Minérale en France.

Germany: Statistiches Jahrbuch für das Deutsche Reich and Annual Summary of Metal Statistics by the Metallgesellschaft (Frankfurt-amMain). 
Italy: Rivista del Servizio Minerario.

Spain: Estadistica Minera de Espana.

United Kingdom: Annual Report of the Secretary for Mines.

United States: Mineral Resources of the United States. Prices were taken from N. Potter and F. T. Christy, Jr. (1962), Trends in Natural Resource Commodities (Baltimore: Johns Hopkins Press), and R. P. Rothwell (ed.) (ibid.).

(h) National Product. All figures are expressed in \$US millions at current prices converted at market exchange rates.

Argentina: GDP, from IEERAL (Instituto de Estudios Económicos sobre la Realidad Argentina y Latinoamericana) (1986), Estadisticas de la Evolución Economica Argentina 1913-1984. Estudios, 9 July/September, Table 12, pp. 103-84.

Australia: GDP, from Mitchell (1983, ibid., Table K1).

Austria: GNP, from Mitchell (1980, ibid., Table Jl).

Belgium: NNP, from Mitchell (1980, ibid., Table Jl).

Canada: GNP (1910), from Mitchell (1983, ibid., Table Kl).

Denmark: GNP, from Mitchell (1980, ibid., Table Jl).

Finland: GDP, from R. Herppe and E. Pihkala (1977), 'The Gross Domestic Product of Finland in 1860-1913: a preliminary estimate', Economy and History, 20, 2, pp. 59-68.

France: GDP, from M. Lévy-Leboyer and F. Bourguignon (1985), L'Economie Française au XIXè siecle, Table A III (Paris: Economica).

Germany: NNP, from Mitchell (1980, ibid., Table Jl).

Italy: GNP, from Mitchell (1980, ibid., Table JI).

Netherlands: NNP, from Mitchell (1980, ibid., Table J1).

Norway: GDP, from Mitchell (1980, ibid., Table Jl).

Portugal: GNP, from Justino, D. (1987), 'A Evolucão do Producto Nacional Bruto em Portugal, 1850-1910, Algunas estimativas provisorias', Analise Social, 23, 97, pp. 451-61.

Spain: NNP, from Mitchell (1980, ibid., Table Jl).

Sweden: GDP, from Mitchell (1980, ibid., Table JI).

Switzerland: NNP, from Mitchell (1980, ibid., Table Jl).

United Kingdom: GNP, from Mitchell (1980, ibid., Table Jl).

United States: GNP, from Mitchell (1983, ibid., Table Kl).

Note: GDP: Gross Domestic Product; GNP: Gross National Product; NNP: Net National Income.

(i) Exchange Rates. The exchange rates used to convert national currencies into US\$ were taken from: Board of Governors of the Federal Reserve System (1943), Banking and Monetary Statistics 1914-1941 (September, Washington, DC), except for the following countries: Argentina: IIERAL (1986 ibid.). Australia: G. A. Rousch (ed.), The Mineral Industry, its 
Statistics, Technology and Trade (Several Issues. New York: Scientific Publishing Company). Finland: League of Nations (1927). Norway: G. A. Rousch (ibid.). Portugal: G. A. Rousch (ed.) (ibid., 1914). Spain: A. Carreras (ed.) (1989), Estadistícas históricas de España. Siglo XIX-XX (Madrid: Fundación Banco Exterior, Table 99).

(j) Net Export Trade Data. Net export data were aggregated in fifty-five commodity groups. Commodities were classified according to the Standard International Trade Classification (Revised, 1961) at the two-digit level. The original trade records were used for all countries, after being translated into English whenever was necessary, except for Spain where trade statistics were complemented from data kindly provided by A. Tena in private correspondence. All data is for 1913 except for a few countries for which the closest year to 1913 was used. Data are in thousands of dollars at market exchange rates.

Argentina: Dirección General de Estadística (1913), Anuario de la Dirección General de Estadística Correspondiente al año 1912 (Buenos Aires).

Australia: Commonwealth Bureau of Census and Statistics (1914), Trade and Customs and Excise Revenue of the Commonwealth of Australia for the year 1913 (Melbourne).

Austria-Hungary: K. K. Handelsministeriums (1914), Statistik des Auswärtigen Handels im Jahre 1913 (I Band - Spezialhandel, Vienna).

Belgium: Ministre des Finances (1914), Tableau Général du Commerce de la Belgique avec les Pays Etrangers pendant l'année 1913 (Brussels).

Canada: Minister of Trade and Commerce (1915), Canada Yearbook (Ottawa).

Denmark: Statens Statistiske Bureau (1910), Statistisk Aarbog (Copenhague).

Finland: Statistiska Centralbyran (1915), Statistisk Arsbok For Finland 1913 (Helsinki).

France: Direction Générale des Douanes (1914), Tableau Général du Commerce et de la Navigation (Paris).

Germany: Statistik des Deutschen Reichs (1914), Auswärtiger Handel 1913 (SpeziaIhandel \& Gesamteigenhandel, Berlin).

Italy: Ministero delle Finanze (1914), Movimiento Commerciale del Regno d'ltalia nell'anno 1913 (Rome).

Netherlands: Departement van Financieën (1908), Statistiek van den in-, uit- en doorvoer over het jaar 1908.

Norway: Statistiske Centralbyran (1914), Norges Officielle Statistik. Norges Handel 1913 (Kristiana).

Portugal: Ministerio das Financas (1914), Comércio e Navegacão 1912 (Lisbon).

Spain: Dirección General de Aduanas (1914), Estadística General del Comercio Exterior de España en 1913 (Madrid) and Tena, A. (1993), Clasificación de las Estadísticas Españolas de Exportación y Importación de acuerdo a la CUCI Revisión 2 en 1913 (private communication).

Sweden: Statistika Centralbyran (1914), Statistisk Årsbok för Sverige (Stockholm).

Switzerland: Département Fédéral des Douanes (1909), Statistique du Commerce de la Suisse avec l'Etranger en 1908 (Bumpliz).

United Kingdom: Board of Trade (1915), Statistical Abstract for the United Kingdom from 1900 to 1914 (London).

United States: Department of Commerce (1914), The Foreign Commerce and Navigation of the United States (Washington). 


\section{Notes}

1 First published in the European Economic History Review, 1 (1997), pp. 89-125.

2 Trade and Hemispheric Issues Division, Inter-American Development Bank, 1300 New York Avenue, N. W. Stop W0608, Washington, D.C. 20577, USA. The author wishes to thank Jeffrey G. Williamson for his guidance and support. I have also received useful comments at different stages of this project from Bradford DeLong, Richard N. Cooper, Claudia Goldin, Tim Hatton, Leandro Prados, Carles Sudrill, Antonio Tena and participants at the Harvard Economic History Workshop.

3 Excellent economic history accounts on measuring protection from a comparative perspective can be found in, for example, Bairoch (1989), Capie (1983), Pollard (1981), Nye (1991) and Irwin (1993).

4 Due to frontier changes, only thirteen countries are studied in 1913: Germany, France, Italy, Belgium, Switzerland, Austria-Hungary, Sweden, Finland, Russia, Romania, Serbia, Bulgaria and Spain.

5 Important exceptions, however, were the Board of Trade (1904) and the Committee on Industry and Trade (1925) studies which measured the mean ad valorem equivalent of the import duties imposed by each country on the main classes of manufactures which were exported from the United Kingdom. Although useful from a British point of view, those studies have a limited use for comparative purposes.

6 Leontieff obtained his classic 'paradox' when he found that the ratio of capital to labour embodied in US exports was smaller than that embodied in import substitutes. The debate following Leontieff's results has been surveyed in Deardorff (1984).

7 The Heckscher-Ohlin-Vanek model of trade, as presented on pages 72-4, can express trade in terms of endowment supplies or in terms of excess endowment supplies. In a $2 \times 2$ version, the equations of the model are:

$$
\begin{aligned}
& T_{1}=\beta_{I L}\left(L-Y L_{w} / Y_{w}\right)+\beta_{I K}\left(K-Y K_{w} / Y_{w}\right) . \\
& T_{2}=\beta_{2 L}\left(L-Y L_{w} / Y_{w}\right)+\beta_{2 K}\left(K C K-Y K_{w} / Y_{w}\right) . \\
& Y=w_{L} L+W_{K} K .
\end{aligned}
$$

where $T_{1}$ and $T_{2}$ are net exports of the two commodities, $Y$ is GNP, $L$ is labour, $K$ is capital, $W L$ and $W K$ are factor returns, the $w$ subscripts refer to the world, and the $\beta$ is the Rybczynski coefficients. This form of the model expresses net trade as a linear function of excess supplies of factors. However, because each of the excess factor endowments is a linear function of all factor supplies (i.e., $\left.L-Y L_{w} / Y_{w}=L-\left(w_{L} L+w_{K} K\right) L_{w} / Y_{w}\right)$ for almost all distributions of $K$ and $L$, these excess supplies are correlated, and a regression of trade on a subset of the excess supplies will yield biased and inconsistent estimates. This problem will be compounded if there are measurement errors. Because of this problem, a reduced form of the model is preferred in empirical studies. This reduced form is found by inserting the GNP equation into the net exports equations:

$$
\begin{aligned}
& T_{1}=\theta_{I L} L+\theta_{I K} K \\
& T_{2}=\theta_{2 L} L+\theta_{2 K} K \\
& Y=w_{L} L+w_{K} K
\end{aligned}
$$

8 Estimates of non-residential fixed capital stock in 1913 are only available for a few countries: France, Germany, Italy, Japan, UK and US (see Maddison, 1982). An alternative measure considered was effective horse-power (fixed, railways and steamboat). Some rough estimates exists for 1895 (see Mulhall, 1896, 1899; Woytinsky, 1926) these are available, though, for only thirteen countries 
(Australia, Austria, Belgium, Canada, Denmark, France, Germany, Italy, the Netherlands, Spain, Switzerland, UK and US).

9 See Appendix 5.1 for a description of this measure.

10 The most immediate problem is using a flow variable as a proxy for a stock. No attempt has been made in this chapter to deal with this approximation. However, the use of energy consumption has been widely used as a proxy for capital. As an example, Frank (1959), writes:

The coefficient of correlation between energy consumption and such calculations as have been made of industrial capital stock is astonishingly high - for the United States from 1880 to 1948, 0.9995; for the United Kingdom from 1865 to $1914,0.96$ or 0.99 , depending on the series employed. Indeed, one is almost tempted to ask whether direct, composite measurement of capital formation is worth the effort.

For the most peripheral economies, in a recent study, Fraile (1992) reports correlations higher than 0.95 between industrial production indices and coal consumption, from 1880-1913, for Austria, Italy, Russia, Sweden and Spain. In addition, with data for 1958, the correlation between energy consumption (including solid fuels, liquid fuels, natural gas and hydroelectric power) and capital stock measured as the accumulated and discounted gross investment flows since 1948, assuming an average life of fifteen years, as computed in Leamer (1984), is very high: 0.98 .

11 See Appendix 5.1 for sources and methods.

12 The distance variable $D I S j$ is weighted as: $D I S_{j}=\Sigma\left(Y_{i} / D I S_{j i}\right) / \Sigma Y_{i}$ where $D I S_{j i}$ is the direct-line distance from country $i$ 's capital to $j$ 's capital, taken from Fitzpatrick and Modlin (1986) and $Y_{i}$ is the GNP of country $i$.

13 In highly disaggregated studies, 0.5 is usually used as a threshold for a Beta value to be considered significant (see Leamer, 1984, Saxonhouse, 1986).

14 As explained in detail in Appendix 5.1, these residual-based protection measures are only significant when computed for some aggregated sectoral trade. Pages 91-3 of the Appendix discuss the aggregation method to produce these ten categories. Table 5.7 excludes the categories of COAL and BEVERAGES and TOBACCO in computing the OPE measures. The Adjusted Trade Intensity ratio offers a very similar ranking of countries.

15 See the discussion on this measure and other alternative peculiarity measures in Leamer (1988: 64-7).

16 Omitted for reason of space. Available in the original version, pp. 110-12.

17 I have used, specifically, the VARCLUS procedure from the SAS/STAT software. This algorithm attempts to divide a set of variables into non-overlapping clusters. 


\title{
6 Assessing the protectionist intensity of tariffs in nineteenth- century European trade policy ${ }^{1}$
}

\author{
Antonio Tena Junguito ${ }^{2}$
}

The relation between trade policy and growth is a fundamental question that requires an answer based on empirical evidence. Measuring the level of protection in an economy through time and across countries is the main problem with which researchers have been struggling when trying to answer this question. Economic historians and development economists still depend on the traditional and theoretically poorly based measures of protection as the best available instruments to study empirically the relation between trade and growth in the long run. ${ }^{3}$ The trade-weighted average tariff is the most widely known measure to isolate the effect of tariff policies from that of other policies and provides a very convenient index of protection across time because it is easily calculated as the ratio of tariff revenues over import values. ${ }^{4}$

The motivation of the present work is the abundant recent empirical research using ad valorem tariffs rates as a single measure to establish a correlation between growth and trade policy in the long run (Clemens and Williamson, 2001; Irwin, 2002; Vamvakidis, 2002; Dejong-Ripoll, 2005; O'Rourke, this volume, Chapter 7)..$^{5}$ Positive cross-country correlations found between tariffs average and growth during the years of 'the return to protection' (1880-1913) strengthened the traditional good reputation between protection and growth. ${ }^{6}$ This chapter discusses some faults that make the use of average tariff to establish a causal relationship between tariff and growth especially vulnerable, as well as the implications for nineteenth-century European commercial policy.

First, there are a number of luxury consumer products which has represented a substantial share of total trade since the sixteenth century, most of them traded from tropical countries and heavily taxed, especially in Europe, for fiscal reasons and mainly because their low elasticity of demand allowed for increases in tariffs and more revenue. ${ }^{7}$ The inclusion of this kind of product in protection measures for the nineteenth century hinges on the specification of demand and, in particular, on how these 'exotic' products should be treated. The revenue tariff impacts mainly on consumer income and government revenue, and its economic effect is similar to that of a 'sales tax' over certain luxury products such as tobacco 
or gasoline. The prevalence of the so-called fiscal products and their changing weight over time makes this point important in the analysis of the comparative evolution of international trade policies, especially in Europe.

Second, the well-known 'index number problem' of the tariff import weighted average usually biases downwards the weight of the most protected importables. The extent of the bias depends on the height of the current tariff rate and on the elasticity of imports of the most heavily taxed goods. ${ }^{8}$ From the first it follows that a country, which imposed prohibitive tariffs on all goods but one (imported free) would appear less protectionist than another, which raised a uniform 5 per cent duty. The generally more elastic demand for manufactures implies a systematic downward bias, in tariffs averaging, for industrial goods vis-à-vis agricultural and fiscal commodities. This bias is especially conspicuous for those periods and countries in which revenue products reduced or increased their share in total imports at the expense of manufactures. For instance, a tariff increase on manufactured goods introduces a downward bias in the Spanish average index of protection, and an increase in revenue tariffs biases the Italian tariff average index upwards so much as to radically change the respective trade policy as well as tariff growth correlations for both countries.

This chapter puts the various criticisms of the use of tariff average to the test with regard to the tariff growth debate or the qualification of European commercial policies in the nineteenth century. The first section discusses Nye's provocative statement of French commercial policy being more free trade than the UK's prior to 1880, and points out the implications of some assumptions on the influence of exotic products in computing the tariff average for both countries. The second section estimates the level and changing share of fiscal products in other European countries, and their relevance for a comparative evaluation of commercial policy in the last quarter of the nineteenth century. The third section tackles the index number problem in the averaging operations of conventional tariffs and attempts to measure the import contraction effect of the Spanish and Italian tariffs and its influence during the years of the 'Return to protection'. Concluding remarks emphasise the importance of taking account of the changing weight of the so-called fiscal products for an evaluation of trade policy, of scrutinising the index number problem for periods and countries with both high levels of protection and a sizeable share of manufactured imports. All the evidence at hand advises caution in the use of the conventional average tariffs and suggests the estimation of alternative manufacture, agrarian and fiscal tariff rates by countries as a necessary contribution for a better understanding of the tariff growth debate. 


\section{A 'cautionary tale': fiscal Britain versus protectionist France}

A revenue tariff mainly affects consumer income and government revenue, while its general economic effect is more similar to a 'sales tax' over certain 'luxury' goods. In theory, there are no pure fiscal tariffs, neither are there pure protective ones. However, those which have a small elasticity of demand (so-called fiscal goods) have a much more limited impact on welfare and import substitution than those with high elasticity. ${ }^{9}$ Generally, fiscal commodities are those with no direct domestic substitutes. ${ }^{10}$ The assumption is that a low elasticity of demand is a consequence of the absence of clear domestic substitutes (elasticity of substitution close to zero), even if this also depends on the size of the home market and its stage of development (see Krueger, 1997; O'Rourke, 1997; Irwin, 1998). In the absence of specification on demand elasticity, we will make the assumption that fiscal products are the commodities that yield the highest revenue and have no obvious domestic substitutes.

The share of revenue products in the nominal protection average index is part of a recent debate about the comparative trade policy experience in France and the United Kingdom during the nineteenth century (see the debate between Irwin and Nye above, Chapters 1-3). Nye's main proposition is that the comparative examination of the average nominal protection index of both countries supports the argument of a freer trade policy in France relative to the UK, especially between 1840 and 1880. This observation is reinforced when applying the tariff rates by commodity class to the import distribution of another period close to free trade as a way to test the average tariff index. After examining some other qualifications on the robustness of tariff rates for Britain and France, Nye refuses to accept that there is an economic argument in distinguishing between the protectionist effect of fiscal tariffs in the United Kingdom and that of tariffs on manufactures which accounted for most of French protectionism. In either case, in Britain as in France, the tariff was designed so as to offset imports in which both countries suffered a comparative disadvantage. Irwin argues that the large share of revenue tariffs during this period is responsible for an upward bias in the British tariff rate. In the United Kingdom, fiscal tariffs bore proportionately more on exotic products not produced at home: customs duties constituted 'an extension of the domestic excise system, levied only on a select number of commodities to raise fiscal revenue without discriminating against foreign goods in favor of domestic goods' ${ }^{11}$ This would apply to brandies or even beer, for which a dutiable excise was designed to offset wine duties. Nevertheless, we ignore by how much the difference between the French and British average tariff is due to the presence of revenue products. In his reply, Irwin puts forward convincing qualitative arguments but no consistent quantitative evidence. As a result, the share of the revenue tariffs in the average index emerges as the main point of contention resolving the Nye-Irwin debate. 
Figures 6.1 and 6.2 visualise the quantitative evidence at hand to cast some light on the relative weight of fiscal duties in British and French protectionism. Nye argues that exotic foodstuffs and alcoholic beverages in the British tariff were used as an important source of revenue, but the tariffs levied on these commodities necessarily induced some form of protection for direct and indirect substitutes. Fiscal tariffs must have distorted domestic production and consumer welfare in Britain, as the protection of textiles manufactures did in France. On the basis of this observation, Nye insists that Figure 6.1 represents acceptable quantitative evidence of the relative protectionist stance of both countries and supports the provocative argument that France enjoyed freer trade than Britain between the repeal of the Corn Laws in the 1840s and the turn to protection in France in the $1880 \mathrm{~s}$.

Figure 6.2 , by contrast, illustrates the conventional and widely accepted argument put forward recently by Irwin that British protection from the 1840 s onwards was mainly of a fiscal character. When leaving aside the main fiscal products in dispute (tea, tobacco, sugar, coffee, wine and spirits), there is no question that Britain emerges as the country enjoying comparatively freer trade - as the traditional view would have it. Irwin insists that British tariffs on wine and spirits were 'carefully constructed to avoid protecting domestic producers'. ${ }^{12}$ Tariffs on wine and foreign spirits were required to allow British domestic producers of beer and spirits, who were taxed with an excise, to compete, on equal terms, with these imported foreign beverages. As a result, tariffs on brandies and even on wines did not have a protective effect on domestically produced beverages and should be treated as fiscal products like colonial imports such as tea, sugar, tobacco and coffee.

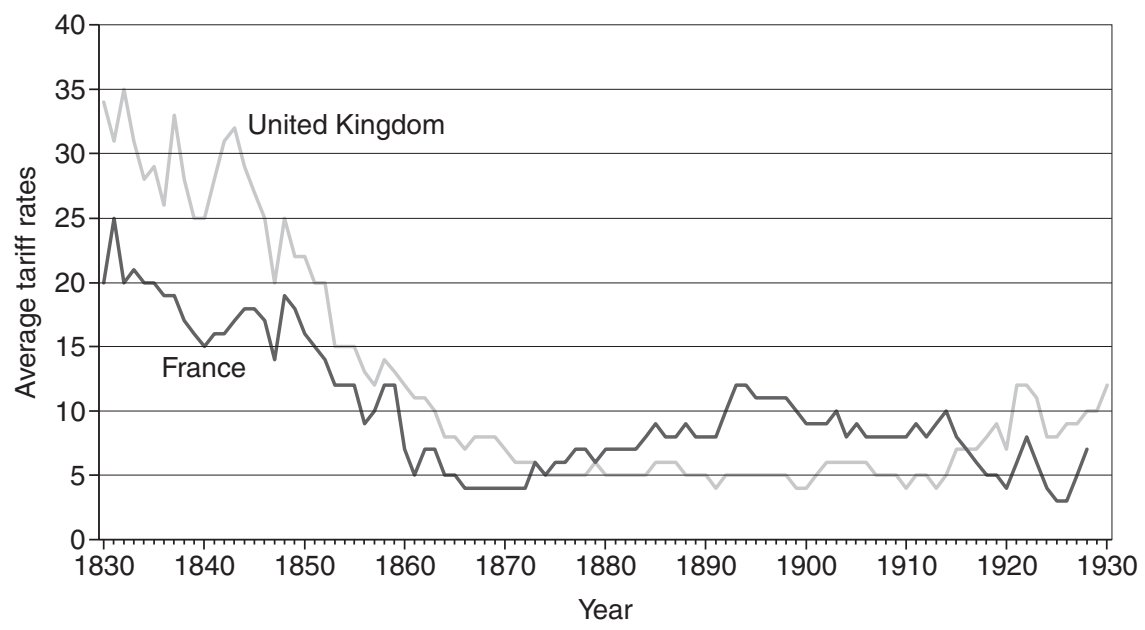

Figure 6.1 Average tariff rates in Britain and France, 1830-1930. 


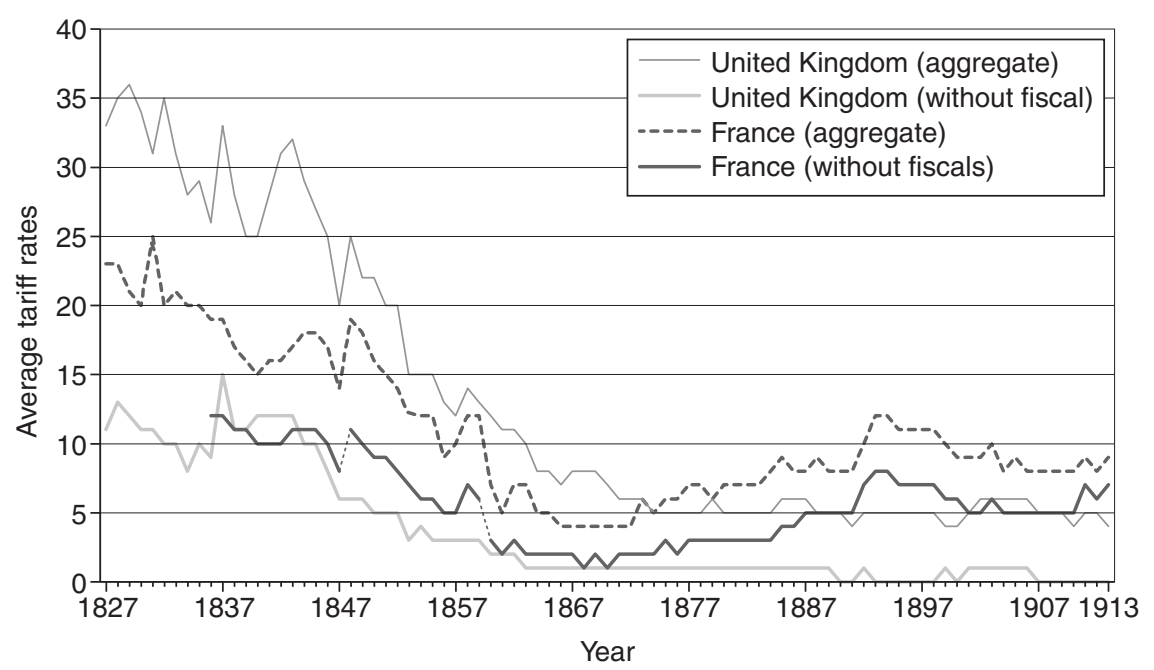

Figure 6.2 Average tariff rates in France and the United Kingdom (aggregate and without main fiscal duties).

Neither Irwin nor Nye pay much attention to the growing share of fiscal products in French tariff revenues during the period in question. The share of colonial imports such as cocoa, coffee and sugar represented in France over 40 per cent of the average tariff rate index in the second half of the 1840s and surged to 60 and 70 per cent in the 1860s and 1870s. France's trend of nominal protection was therefore strongly influenced by fiscal tariffs as well. To be meaningful, a comparison requires taking account of the incidence of revenue products in the averaging operation of French tariffs.

Figure 6.3 charts this compromise in which spirits are excluded on account of the excise tax offsetting protection of domestic brandies production (as suggested by Irwin), but wine is included and considered a protected good, because the excise beer did not fully compensate for the wine duty (as Nye insists). With this new British rate of protection, we repair to familiar ground: Britain appears to have been more protectionist than France before the 1840s but this decade represents a complete turnaround in the country's commercial history - reducing protection by half in the space of a mere six years, when her main partner, France, was holding the line. This shows that, while earlier moves towards freer trade had been conditioned by an insistence on reciprocity, from the 1840 s onwards British trade policy tended to be unilaterally determined. The 1846 repeal of the Corn Laws appears to have been instrumental in the fall of the index, even if tariff reductions were introduced in the early 1840s. French tariff reductions gathered momentum only at the turn of 


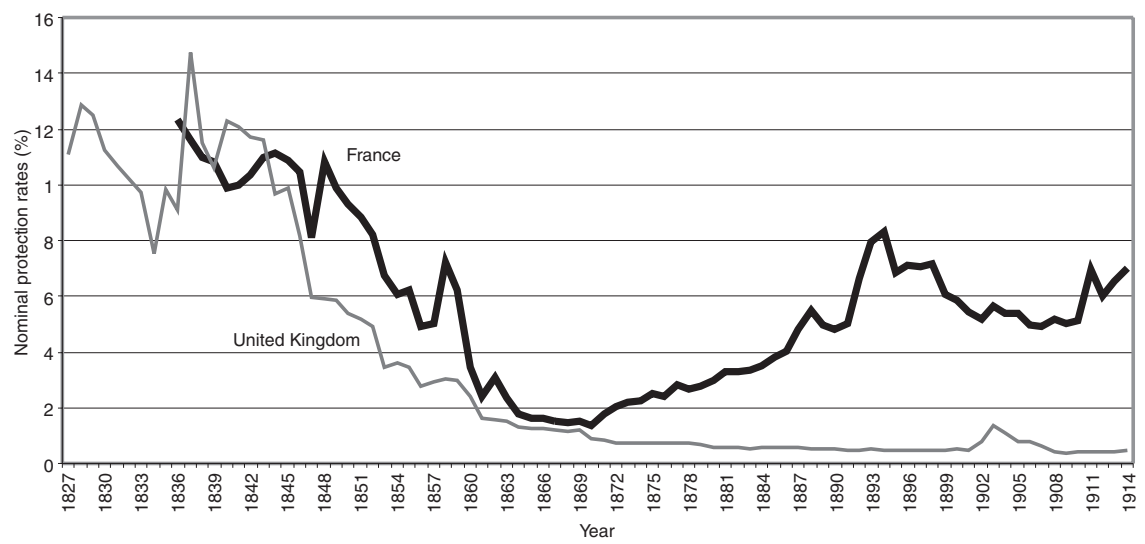

Figure 6.3 A compromise aggregate tariff rate for Britain and France excluding fiscal goods, 1827-1913.

the decade, and were less dramatic than in Britain. During the 1850s, the average French tariff level was almost double the British one, and converged only significantly after the $1860 \mathrm{~s}$, a trend which persisted to the 1870s. The French backlash against liberalisation built up in the 1870s and culminated in the early 1890s with the passing of the Méline tariff.

One can hope to disentangle the fiscal from the protective impact of tariffs, first, by excluding the respective four main revenue products in each country and, second, by removing spirits and wine, the two controversial British excisable goods. The outcome of the first operation exhibits a similarity in both levels and trend between the two countries since the 1840s. France appears to have been more liberal than Britain before the abolition of the Corn Laws. The much-praised British liberalising measures resulted in an average tariff rate slightly lower than that of French, its rival by the 1860s; by the early 1880s, however, both countries exhibited almost identical levels of protection. Following the Cobden-Chevalier Treaty, France's liberalising efforts resulted in an even lower rate of protection than that observed across the Channel.

Excluding wine and spirits duties takes us back to the conventional wisdom defended by Irwin. Here, the controversial wine and spirits and their adjacent duties are removed from the computation of the average tariff rate. Prime Minister Peel's reforms of the 1840s caused a steep reduction in the British tariff rate, both in absolute terms and in relation to the French rate. France followed in the footsteps of Britain during the 1850s, and the Cobden-Chevalier 1860s triggered faster liberalisation in France; meanwhile the UK remained ahead in the free-trade league for the rest of the nineteenth century. 


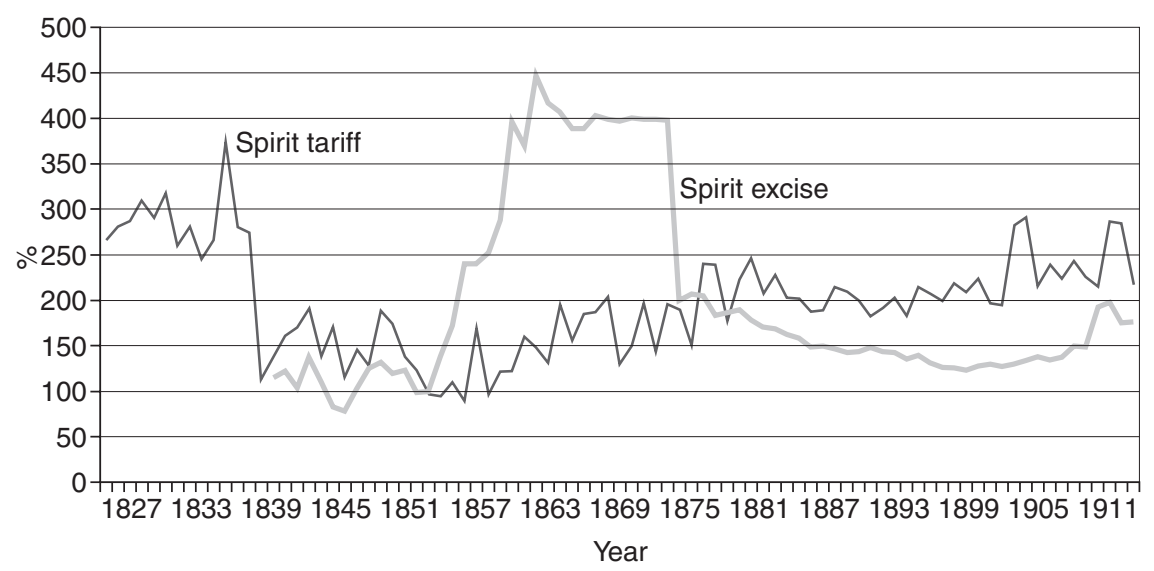

Figure 6.4 (a) Rate of excise and ad valorem tariff on spirits 1827-1913.

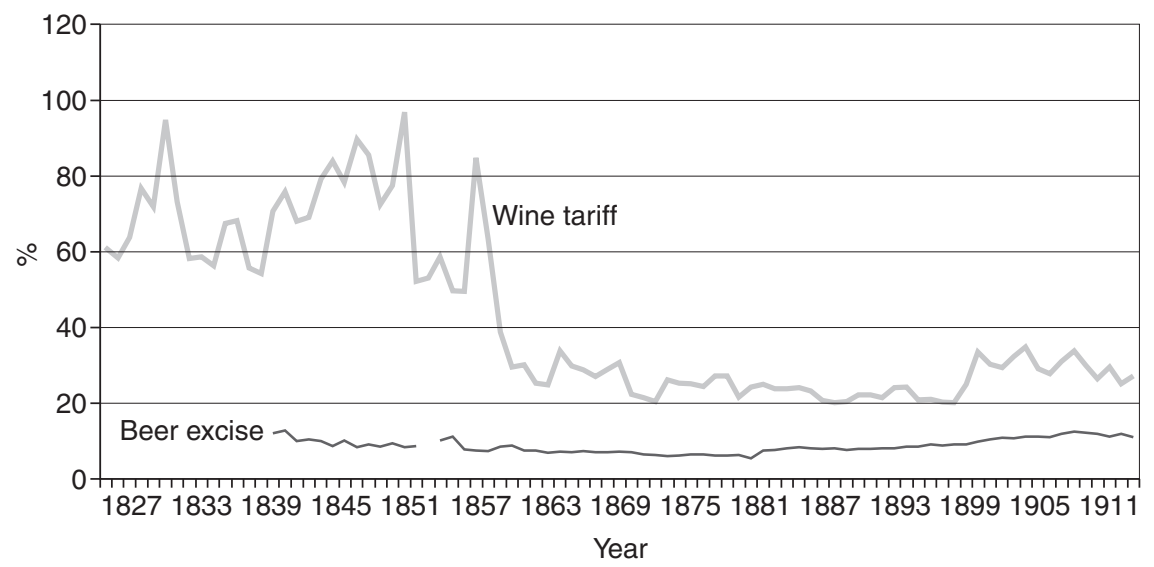

Figure 6.4 (b) Rate of excise on beer ad valorem tariff on wine 1827-1913.

As a result, the wine, rum and brandy tariffs, and the excise on their domestic substitutes, beer and spirits, appear crucial in this debate. Figure 6.4a provides some additional evidence charting the ad valorem spirit duty and its respective ad valorem rate of excise over the period 1840 to 1913 . The spirit tariff fell by half from the 1830s to the 1840s, and hovered during the 1840s a cut above the excise ratio. Only in the second half of the 1850 s did this trend undergo an upturn, resulting in the rate of excise being at least twice as high as the tariff rate during the next two decades.

Figure $6.4 \mathrm{~b}$ offers a graphic representation of the relation between the wine tariff and the beer excise ratios over time. Before 1850, the wine duty stood more than four-times higher than the rate of excise on beer (its main substitute produced in the United Kingdom). 
In the second half of the $1850 \mathrm{~s}$, the excise was reduced steeply in accordance with the Cobden-Chevalier negotiations. From the 1860s the wine duty always appears close to double the beer excise. As a result, the evidence assembled here encourages the adoption of a reasonable compromise between Nye's and Irwin's positions. The wine duty seems to have been independent of beer excise and may have influenced domestic beer production, and could therefore be regarded as protective; by contrast, the spirit excise seems to have consistently offset its tariff duty on imported spirits and could be regarded as purely fiscal.

With the use of a CGE model, O'Rourke reached a similar conclusion on the Nye-Irving debate: 'If wine, rum and brandy are not treated as exotic, but are assumed to be as substitutable with British goods as imported wheat or timber, then Nye is spectacularly right' (see O'Rourke in Chapter 4, p. 63). O'Rourke, however, did not consider the special case of excisable exotic goods. With evidence on fiscal duties and rates of excise, we should retain Nye's contention of the protectionist effect of the British wine duty but push its significance on overall protection back in time (before the 1840s); on the whole, this scenario is reconcilable with the mainstream view of British trade policy. ${ }^{13}$ Furthermore, his provocative claim should encourage the use of caution when dealing with overall tariff rates and calls for more attention to be paid to the fiscal products when evaluating average protection rates on the basis of customs revenues.

\section{The role of revenue and protective tariffs in nineteenth- century trade policy}

The previous section discussed the absence of a clear economic criterion to isolate purely fiscal tariffs from protective and discriminatory ones, but suggests that tariff rates excluding exotic products would probably provide a better indicator of trade restrictiveness than the commitments negotiated at the multilateral and bilateral level among Europe's main trading partners. In this section we offer additional evidence on how exotic products without obvious substitutes, such as sugar, cocoa, tea or coffee, represented a significant fraction of European imports and try to assess the relevance of this distinction for evaluating nineteenth-century trade policies.

\section{A general impression}

Figure 6.5 documents the changing impact of fiscal products on the overall tariff rate in some core European countries during the nineteenth century. ${ }^{14}$ For the United Kingdom, fiscal revenues in a context of falling protection accounted for between 40 to 80 per cent of the total, the trend exhibiting a growing cyclical pattern from the 1820s to the First World War. 


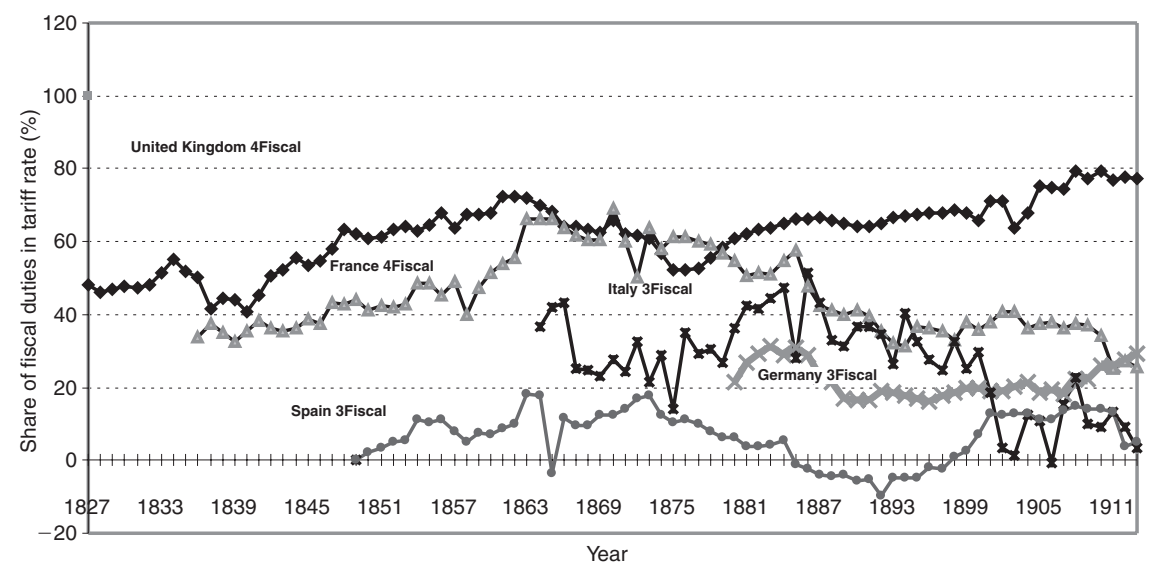

Figure 6.5 Share of fiscal in total tariff revenue for main European countries, 1827-1913.

In the case of France, this share increased from 35 per cent in the 1830 s to 70 per cent at the end of the 1870 s, before falling again to about 40 per cent at the turn of the twentieth century, when general protection spread across the trade classification. Germany, by contrast, exhibits a more moderate and constant influence of exotic products in its tariff rate with a cyclical pattern undulating in the 20-30 per cent range. The share of exotic goods in the overall tariff rates of Spain and Italy experienced a trend reversal around 1870. Fiscal products became more prevalent in Italy's tariff revenue while Spain experienced the reverse during the years of return to protection between 1875-1900 (they ranged from -5 (below average) to 20 per cent for the former, to 20-60 per cent for the latter).

\section{Was Germany first?}

On the basis of these observations we are led to amend our perception of the comparative history of European protectionism. As Figure 6.6 illustrates, Germany's overall tariff rate over the period 1880-1914 does not seem to match the received account of German trade policy, as presented by Bairoch (1989), especially with respect to France's own during the same period.

On the basis of the tariff rate charted in Figure 6.6, it seems indisputable that Germany was not the forerunner in the return to protection in Continental Europe as the early adoption of the July 1879 Bismarck tariff would have us believe. The French backlash against globalisation materialised at least as early and more dramatically than the 


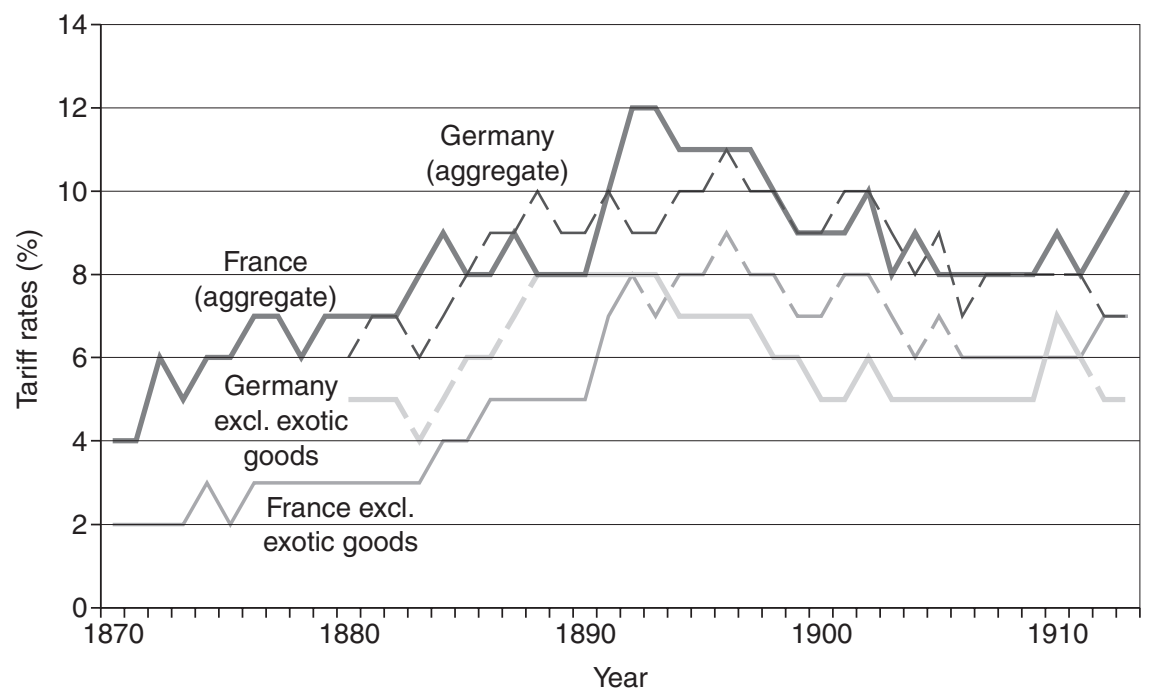

Figure 6.6 French and German average tariff rates with and without fiscal goods, 1870-1913 (sources: own database).

German one, reaching a significantly higher level during the first half of the 1890s. Afterwards, both countries exhibited a similar decreasing protection level until the First World War, reflecting the incidence of the general price increase on ad valorem equivalents of unchanged (specific) duties.

Once exotic products are excluded from the average tariff, however, an alternative history appears, as Figure 6.6 illustrates. Here, Germany's precocity in introducing protection in the $1880 \mathrm{~s}$ is clearly identifiable, showing levels almost twice as high as the French equivalents at the end of decade. Only for a short time span of two years after the passing of the Méline tariff in 1892 and apparently more steadily after the tariff revision of March 1910, was the French average tariff above the German. Between the two dates, the German average was steadily above its French counterpart, a scenario more in tune with the standard narrative of the Return to protection.

\section{Spanish versus Italian protectionism}

The last cautionary tale about the influence of fiscal products on tariff rates is illustrated by the commercial history of two peripheral countries: Spain and Italy. Italy during the twenty years after its unification remained a virtually free-trade country; meanwhile, in Spain, a shorter and more 
doubtful free-trade period started in the mid-1860s to be cut short by the adoption of the July 1877 tariff which displayed for the first time the double tariff (general and conventional) that was to be adopted by many other European countries in the following years. Subsequently, the Italian tariff, passed in 1878, while still relatively moderate, preceded the 1879 German tariff. Most scholars concur that it was not before the 1887 tariff that Italy adopted a decisively protectionist policy and, for Spain, not before the Canovas Law of 1892. The Italian 1887 tariff brought into force a new duty on wheat and some manufactured goods that caused an open trade war with France, then Italy's main trading partner. The 1887 tariff lasted officially more than three decades, although it underwent some minor amendments. From the mid-1890s, the country's overall level of protection fell as price inflation reduced the incidence of specific duties on the tariff rate. Spain's 1892 protectionist tariff also caused a tariff war with France and Germany. In addition, the loss of her remaining colonies (Cuba, the Philippines and Puerto Rico) in 1898 amputated her export markets and induced, in both government and the public, a pessimism which, in turn, led to calls for increased protectionism that materialised in the new 1906 tariff. $^{15}$

On the basis of this qualitative evidence, historians have assumed that both countries conducted broadly similar trade policies. A look at the respective tariff rates partially confirms this conventional wisdom, at least for the years of the return of protection. Protection appears to have been on the ascendant in Italy from the late 1870s onwards, but it is not until the late 1880s that its overall tariff rate caught up and overtook the Spanish level which was itself on an upward slope. Likewise, the downturn in both Italy and Spain occurred in the mid-1890s while the overall rate hovered around the 12 per cent mark during the first decade of the twentieth century. As a result, the Spanish protection index does not seem to fit with the idea of a temporary return to protection as the Italian one does; it appears to be more of a structural feature of the Spanish economy from the second half of the 1870 s onwards. However, from the mid-1880s to the early 1900s, Italy exhibited a superior average tariff level than Spain.

During the years of the 'return of protection', three consumer goods (sugar, coffee and oil) yielded around half of total customs revenue in Italy, while in Spain the three main revenue earners (cod, coffee and oil) accounted for only one-fifth of the total (and all colonial goods for a quarter). As Figure 6.7 illustrates, the combined weight of the three main exotic products in the average tariff was much heavier in Italy than in Spain, while the trend of this change was practically the reverse in either country.

Figure 6.7 shows that, in excluding three main exotic products, the Italian free-trade period can easily be extended until the 1887 tariff (its tariff rate culminating at 6 per cent). The upward trend in protection is much less impressive than when fiscal products are included, with peaks 


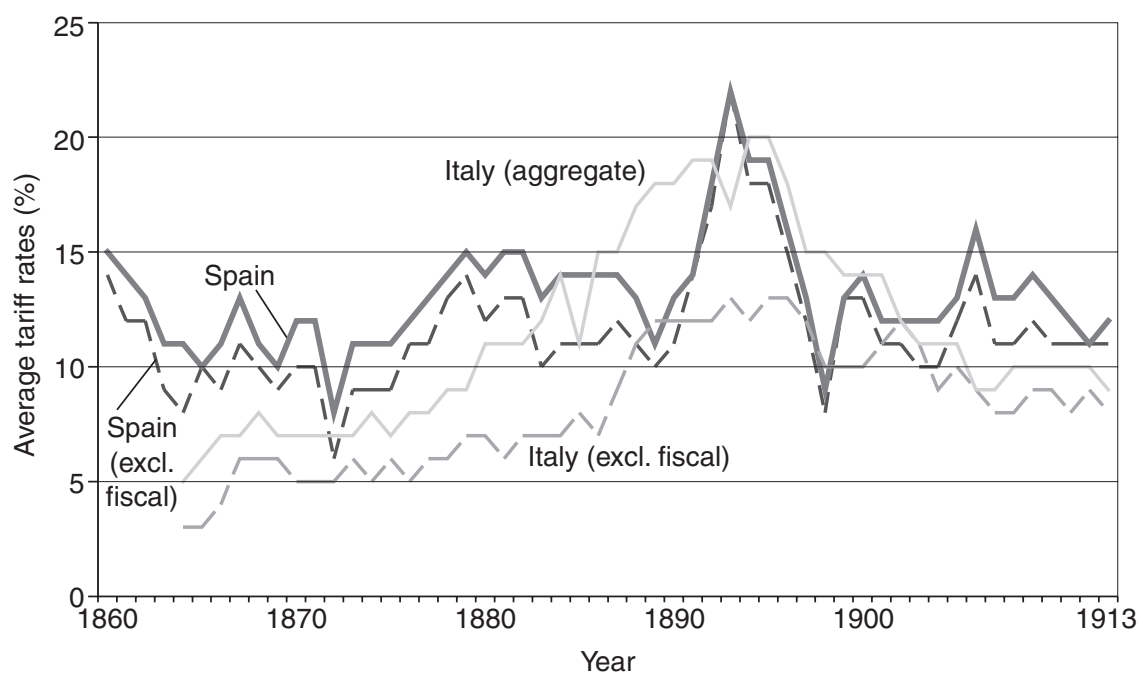

Figure 6.7 Spanish and Italian average tariff rates with and without fiscal goods, 1870-1913 (sources: own database).

over 10 per cent during the 1890s. The direct implication is that one cannot understand the structure of Italian duties without taking into account the fiscal side of the issue. The increased importance of Italian fiscal duties is noticeable from the late 1870 s onwards, and buoyed custom revenues significantly in the following years without affecting imports substantially. Fiscal protection accounted for about three-quarters of the rise in total protection from 1877 to 1897 (Federico and Tena, 1998, Table 1). In Spain, the main fiscal duties were imposed after the 1898 Cuban war, following the fiscal reforms of Fernandez Villaverde in 1899, when taxation of colonial goods increased substantially. Nevertheless, while enhanced fiscal tariffs affected the domestic price of these goods, they did not alter significantly the trend and level of Spanish overall protectionism, because of their small share in total imports. Comparing both countries' nominal protection rates for the crucial 1890s reveals an increase in aggregate protection of comparable magnitude. But the increment in Italian protection was mainly due to the taxation of fiscal products, and the Spanish increase was mainly due to the introduction of a higher tariff on manufactured goods (Federico and Tena, 1998; 1999).

\section{Industrial, fiscal tariffs and the classic index problem}

A well-known index number problem plagues the computation of an accurate trade-weighted average tariff, which is usually biased downwards by the most protected goods. The extent of the bias depends on the 
current tariff level and on the elasticity of demand for the major imports. ${ }^{16}$ While the Italian turn to protection is exaggerated by the prevalence of fiscal tariffs, there is a tendency to downplay Spanish protectionism on account of index number problems in measuring the incidence of any increase in the taxation of manufactured goods. The use of alternative indices suggests a much higher level for overall protection in Spain relative to Italy which has implications for the trade-growth relationship in the two economies.

The tariff average index

$$
N T t=\sum_{i=1}^{n}\left(Q_{i t} * T_{i t}\right) / \sum_{i=1}^{n}\left(Q_{i t}{ }^{*} P_{i t}\right)
$$

is a Paasche index that weights the duty on individual products by their respective share in total imports for any given year. A classic index number problem arises because when $T_{i}$ increases $M_{i}$ falls: a relatively small rise in duty collection can generate a relatively large fall in the quantity imported causing a downward bias (or index number problem) in NT overtime. The more elastic the demand for manufactured goods, the larger the downward bias for this class of goods vis-à-vis primary or exotic products in the computation of a tariff average. Off-setting this bias is especially necessary for those periods and countries in which exotic products reduced or increased their share in total imports in relation with manufactured goods.

In Table 6.1 we offer a comparative test on the robustness of the conventionally weighted (NT) and unweighted (UNT) tariff rates. We should expect the ratios (columns 5 and 6 ) to be below 1, the wider distance from 1 implying a bigger index number problem for the accuracy of the $N t$ conventional tariff rates. The evidence presented here reveals that, on the one hand, the Spanish NT/UNT ratio is, for each single year, and for both manufactured goods and total imports, always below 1 and systematically larger than in Italy; on the other hand, the downward bias

Table 6.1 Weighted (NT) and unweighted (UNT) tariff average for Spain and Italy 1877-1926

\begin{tabular}{lllrlrll}
\hline & & $\begin{array}{l}\text { NT } \\
\text { Spain }\end{array}$ & $\begin{array}{l}\text { NT } \\
\text { Italy }\end{array}$ & $\begin{array}{l}\text { UNT } \\
\text { Spain }\end{array}$ & $\begin{array}{l}\text { UNT } \\
\text { Italy }\end{array}$ & $\begin{array}{l}\text { NT/UNT } \\
\text { (Spain) }\end{array}$ & $\begin{array}{l}\text { NT/UNT } \\
\text { (Italy) }\end{array}$ \\
\hline \multirow{2}{*}{1877} & Total & 12.7 & 7.3 & 17.7 & 6.8 & 0.72 & 1.07 \\
& Industry & 17.6 & 6.5 & 22.4 & 5.4 & 0.78 & 1.20 \\
\multirow{2}{*}{1889} & Total & 11.0 & 17.6 & 16.7 & 16.9 & 0.66 & 1.04 \\
& Industry & 13.8 & 16.9 & 17.6 & 15.6 & 0.78 & 1.08 \\
\multirow{2}{*}{1897} & Total & 14.6 & 18.5 & 26.3 & 16.1 & 0.55 & 1.15 \\
& Industry & 18.4 & 13.2 & 32.4 & 15.2 & 0.56 & 0.87 \\
\multirow{2}{*}{1926} & Total & 14.9 & 9.6 & 25.2 & 12.7 & 0.59 & 0.75 \\
& Industry & 15.5 & 9.3 & 23.6 & 11.9 & 0.66 & 0.78 \\
& Total & 15.5 & 11.9 & 26.6 & 13.7 & 0.58 & 0.87 \\
\hline
\end{tabular}

Sources: Spain: Tena (1999); Italy: Federico and Tena (1998). 


\section{Antonio Tena Junguito}

of the Spanish index looms larger for the years that follow the main tariff reforms (1897, 1913 and 1926); finally, the year with the largest divergence is 1897 , which cannot be taken as a simple matter of chance since this year comes after the introduction of the 1892 tariff which stood for the adoption of decisively protectionist policies. Meanwhile, one notices no significant contraction of the ratios in the case of Italy (only for the final year 1913 did it fall below 0.8). Two factors account for the much smaller bias observed in this case relative to Spain during the period 1889-97; first, import substitution played a much bigger role for the most protected products - whether manufactured or primary - after the adoption of the Spanish 1892 tariff compared to the Italian 1887 tariff; second, the larger share of revenue products in the Italian tariff and hysteresis - the lower initial level of Italy's industrial tariffs - are probably responsible for a limited import substitution effect for both manufactured and overall imports.

In an attempt to evaluate the respective import substitution effect, we decompose the changes in tariff rates (NTt) to measure the demand elasticity of imports as the ratio of quantity decline in relation to tariff and price changes.

Table 6.2 documents the breakdown in the change of the weighted average tariff rate $(N T t)$ based on the available information for the periods following the adoption of protectionist tariffs in 1887 and 1891 . Italy's 'turn to protection', carried out from a situation of virtual free trade, appears more spectacular.

Besides, the comparative breakdown of the NT change with regard to tariffs, price and quantity imports reveals the order of magnitude of the index number problem for the overall and industrial tariff rates. Despite the steep increase in protection between 1877 and 1889, the Italian elasticity of import demand (0.26) was less than half that of Spain (0.53). This

Table 6.2 Decomposition of changes $[\mathrm{NTt}-\mathrm{NTt}-1]$ in overall tariff rate during the turn to protectionism

\begin{tabular}{|c|c|c|c|c|c|}
\hline $\begin{array}{l}\text { Spain } 1897 \\
\text { relative to } 1889\end{array}$ & $\begin{array}{l}\text { Tariff } \\
\text { (1) }\end{array}$ & $\begin{array}{l}\text { Price } \\
\text { (2) }\end{array}$ & $\begin{array}{l}\text { Quantity } \\
\text { (3) }\end{array}$ & $\begin{array}{l}\text { Import elasticity } \\
(4)=(3) /[(1)+(2)]\end{array}$ & $N T_{t}-N T_{t-1}$ \\
\hline Total & 6.8 & 0.9 & -4.1 & -0.53 & 3.6 \\
\hline Industrial goods & 8.5 & -0.5 & -5.8 & -0.72 & 2.1 \\
\hline Primary goods & 5.6 & 1.8 & -2.3 & -0.31 & 5.1 \\
\hline $\begin{array}{l}\text { Italy } 1889 \\
\text { relative to } 1877\end{array}$ & $\begin{array}{l}\text { Tariff } \\
\text { (1) }\end{array}$ & $\begin{array}{l}\text { Price } \\
\text { (2) }\end{array}$ & $\underset{\text { (3) }}{\text { Quantity }}$ & Import elasticity & $N T_{t}-N T_{t-1}$ \\
\hline Total & 13.1 & 0.9 & -3.7 & -0.264 & 10.3 \\
\hline Industrial goods & 15.1 & -4.4 & -1.3 & -0.121 & 9.4 \\
\hline Primary goods & 11.8 & 6.6 & -7.8 & -0.438 & 10.6 \\
\hline
\end{tabular}

Sources: Own database, see Federico and Tena (1998) and Tena (1999). 
means that the Spanish return of protection as measured by $N T_{t}-N T_{t-1}$ is effectively minimised by substantial import contraction (almost half) while, in the case of Italy, the contraction effect was much more limited (0.264), close a quarter, most of the lever provided by primary products. In Spain, the demand behaviour of manufactured imports was even more elastic $(0.72)$, around six times that of Italy $(0.12)$. In this country, by contrast, the demand elasticity of primary products exhibits coefficients only slightly superior to those of Spain. Most of the evidence assembled in Table 6.2 supports the contention that the increase in trade discrimination between 1889 and 1897 is minimised by the use of the crude tariff rate. During this period in Spain, protectionist tariffs were raised from an already high level of protection, and data suggest an especially high elasticity of import substitution for most manufactured goods. As the unweighted tariff average (UNT) displayed in Table 6.1 illustrate, Spanish industrial protection almost doubled between 1889 and 1897, pointing to the apparent moderation of the Spanish industrial tariff having damped substantial import contraction. As could be expected, the elasticity for Spanish manufactured imports was more than double that of primary goods, while in the Italian case it was the reverse. Import contraction also depends on the base year chosen to compute the tariff level. As it happens, the Spanish 1889 tariff was already quite high, higher in any case than that for primary products, exactly the reverse situation as that observed in Italy in 1877.

Table 6.3 documents the contribution of each major class of imports, as well as prominent products to the tariff hike after Spain's and Italy's 'return to protection'. The contribution of every sector is assessed on the basis of the difference between the overall protection (measured by the arithmetic average of $N T, U N T$ and $R N T$ ) and the estimated counterfactual rate on the assumption of the stability of tariffs and demand in the sector before and after the introduction of the new tariffs in Spain in 1897 and Italy in 1889. The main contributor to Italy's 'return of protection' was the increase in the taxation of primary products, especially that bearing on a handful of fiscal products. Keeping Italian tariffs on and demand for, sugar, petroleum and coffee at the same levels in 1889 as in 1877 reveals that fiscal products were responsible for more than half of the total protection increment in this period. Conversely, the manufacturing sector emerges as the main beneficiary of Spain's return to protection between 1889 and 1897, as duties on textiles contributed to almost half of the incremental tariff revenue, followed by wheat with less than a quarter of the total. Among protected goods, consumer goods and its largest component, cotton textiles, enjoyed the highest degree of protection, although the steel industry 'got a piece of the pie' (Federico and Tena, 1999). In Italy, by contrast, industrial protection was more moderate; the advantage went to heavy industries such as steel and chemicals, which improved their ranking in the tariff schedule (Federico and Tena, 1998). Protection of agricultural produce in Spain exhibits greater stability than 


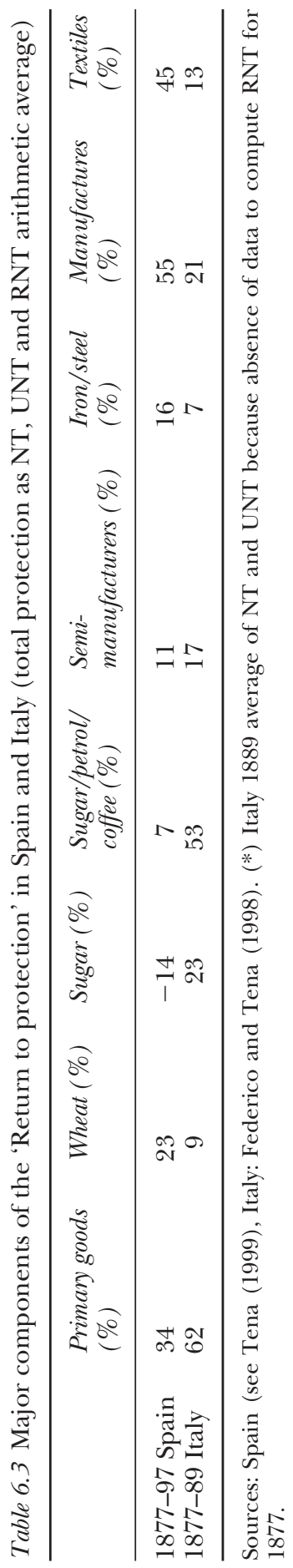


that displayed by manufactured goods. It is generally admitted that when the overall protection index is moderate, agriculture improves its position vis-à-vis industry, and the reverse is true when protection is on the rise. Spanish fiscal tariffs jacked up at the turn of the century, but this did not affect this general shape of trade policy (Federico and Tena, 1999).

Evidence provided in this section confirms that, because manufactures tend to have higher demand elasticity and fiscal products the lower, this introduces a downward bias in estimating a tariff's protectionist impact. This defect is especially damaging for periods during which the share of revenue items in total imports was large in relation to manufactured goods. The prominence of this phenomenon stands out when comparing changes in the Spanish and Italian cases. The significant increase in Spanish protection on manufactures cannot be detected by using the overall weighted tariff rate, while the steep increase in fiscal tariffs is reflected completely by the Italian index. Thus the industrial tariff hike tended to bias the Spanish index of protection downwards, while revenue tariffs biased the Italian tariff index upwards to the extent that it could radically change the assessment of the reality of each country's trade policy.

\section{Conclusion}

This study recommends caution in the use of average tariff rates for the study of comparative European commercial history. We acknowledge that it is, in theory, not possible to exclude exotic products from average tariff rates because there is no such thing as a purely fiscal nor a purely protective tariff. This chapter takes up the challenge while examining the differences induced by the inclusion or exclusion of exotic tariffs on welfare impact. Fiscal products with a low elasticity of demand typically have much less impact on welfare than those with high elasticity. Thus the Nye-Irwin debate on nineteenth-century Britain and France brings forth the implications of not taking into account the changing share of topical products in the evaluation of average tariff barrier for the analysis of nineteenthcentury European trade policy. We offer some evidence on how the separate treatment of fiscal tariffs can enlighten our understanding of nineteenth-century trade policy.

Furthermore, it has been shown how standard measures of the average tariff rate may entail a significant bias in assessing the degree of tariff protection because of the multi-faceted nature of a classic index number problem. Since manufactures usually have the most elastic demand, primary products and foodstuff the least, a systematic downward bias is introduced for those periods of the rapidly changing share of revenue products in total imports relative to manufactures. Evidence suggests the need to use cross-country comparisons to assess trade protection for industrial, primary and fiscal goods more accurately and as a prerequisite for clarifying the tariff growth debate. 
In a contribution mentioned earlier, O'Rourke recognised that 'the average tariff measure which [he was] using is extremely crude, and [could] in some cases be misleading.... The construction of a superior index of protection, on an uniform basis, for as many countries as possible during the late 19th century should be a major research priority' (O'Rourke, this volume: 146). This chapter has been stimulated by O'Rourke's observation and it is hoped it will contribute to clarify the main variables that influence the accuracy of the tariff measures and the different implications this has for investigating the mechanism between trade policies and economic growth.

\section{Appendix}

\section{Sources and methods on tariff revenues and fiscal products}

United Kingdom: data on import value and customs revenue

Total import value and total custom revenue from 1827 to 1913: Imlah (1958).

Fiscal products import value and customs revenue for: coffee, tea, sugar, tobacco, spirits and wine:

- Quantities and revenues from: House of Commons (1898), 'Customs tariffs of the United Kingdom from 1800-1897', 85, London; Board of Trade, British Parliamentary Papers 1890-1913, yearly.

- Prices for coffee, tea, sugar, tobacco, spirits and wine before 1854, using declared values from the official trade statistics of 1854 and the Sauerbeck's price index (1886) 'import price index omitting cotton and wool'.

- Quantities, prices and revenues 1890-1913: Board of Trade (various years) and Annual Statement of Trade of the United Kingdom, British Parliamentary Papers (various years).

UK Fiscal data on Excise revenue and Production, 1841-1913 for Spirits and Beer \& Ale from House of Commons (1898).

Prices: spirits and beer export prices from Board of Trade (various years).

France: data on import value and customs revenue

Total import value and total customs revenue from 1827 to 1913, from Levy-Leboyer and Bourguignon (1990). Imported values and tariff revenues for cocoa, sugar, coffee, petroleum (1827-95), Tableau Général du Commerce de la France (1896-1913), Tableau Général du Commerce de la France et de la Navigation (Commerce Special). 
Germany: data on import value and customs revenue

Total import value and total customs revenue from 1880 to 1913 , from Mitchell (1981).

Data on customs revenue of coffee, tobacco (Fiscal 2) from Statistisches Jahrbuch für das Deutche Reich (1880-1913).

Data on import values of coffee and tobacco from Der auswärtige Handel Deutchlands in den Jahren ... (various years).

Italy: data on import value and customs revenue

Italy total revenue from 1864-72: Ragioneria Generale dello Stato 1969 table 12 (Riscossioni complessive delle dogane, 1873-1913: R. Repaci (1962), pp. 84-5 and 208.

Total import value and tariff revenue from sugar and coffee from Movimento Commerciale dall'Italia (yearly).

Spain: data on import value and customs revenue

Total import value between 1850-1913: new series by Prados de la Escosura (1986). Total revenue from Estadisticas del Comercio Exterior (yearly). The revenue of a tax imposed on foreign sugar and paid at the border between 1882-98 is also included. Import value and tariff revenue between 1850-1913 of sugar, coffee, cacao and brandies from Estadisticas del Comercio Exterior. Sugar revenue 1882-98, Martín (1982), Cuadro c.3, p. 349 .

\section{Decomposition of changes in Total Nominal Protection}

$[\mathbf{N T t}-\mathbf{N T t}-1]^{17}$

$$
\begin{aligned}
& N T t=\sum_{i=1}^{n}\left(Q_{i t}^{*} T_{i t}\right) / \sum_{i=1}^{n}\left(Q_{i t} * P_{i t}\right) \\
& R N T t=\sum_{i=1}^{n}\left(Q i_{t-1} * T i_{t}\right) / \sum_{i=1}^{n}\left(Q i_{t-1} * P i_{t-1}\right) \\
& R N P t=\sum_{i=1}^{n}\left(Q i_{t-1} * T i_{t}\right) / \sum_{i=1}^{n}\left(Q i_{t-1} * P i_{t}\right) \\
& {[N T t-N T t-1]=[N T t-R N P t]+[R N P t-R N T t]+[R N T t-N T t-1]} \\
& {[N T t-N T t-1]=\text { Quantity Eff. + Price Eff. + Tariff Eff. }}
\end{aligned}
$$

Each component on the right-hand side of the fourth equation measures how much the aggregate protection (NT) would have changed ceteris paribus. The first term, or quantity effect, estimates the variation that 
would be caused by changes in the composition of imports if duties and prices remained constant. The second term, or price effect, computes the change that would be caused by changes in prices ceteris paribus when duties and demand structure are constant. The third one, the tariff effect, estimates the variation that would be caused by a change in tariffs with unchanged world prices and composition of imports - i.e. the effects of trade policy. ${ }^{16}$

$$
\text { Quantity Eff. }=\left[\sum_{i=1}^{n}\left(Q_{i t} * T_{i t}\right) / \sum_{i=1}^{n}\left(Q_{i t} * P_{i t}\right)\right]-\left[\sum_{i=1}^{n}\left(Q i_{t-1} * T i_{t}\right) / \sum_{i=1}^{n}\left(Q i_{t-1} * P i_{t}\right)\right]
$$

Price Eff.

$$
=\left[\sum_{i=1}^{n}\left(Q i_{t-1} * T i_{t}\right) / \sum_{i=1}^{n}\left(Q i_{t-1} * P i_{t}\right)\right]-\left[=\sum_{i=1}^{n}\left(Q i_{t-1} * T i_{t}\right) / \sum_{i=1}^{n}\left(Q i_{t-1} * P i_{t-1}\right]\right.
$$

Tariff Eff.

$$
=\left[\sum_{i=1}^{n}\left(Q i_{t-1} * T i_{t}\right) / \sum_{i=1}^{n}\left(Q i_{t-1} * P i_{t-1}\right)\right]-\left[\sum_{i=1}^{n}\left(Q_{i t-1} * T_{i t-1}\right) / \sum_{i=1}^{n}\left(Q_{i t-1} * P_{i t-1}\right)\right]
$$

\section{Notes}

1 The author would like to thank Regina Grafe, Stefan Houpt and Elena Ruiz Martín for their special help. He also thanks, for comments and a helpful discussion, Giovanni Federico, Knick Harley, Tim Hatton, Esteban Nicolini, Kevin O'Rourke, Jeffrey Williamson and participants in the EHES Fourth Conference in Oxford, Universidad Carlos III workshop and EHES Montpellier Summer School. This research has been made possible by a five-month research sabbatical at Harvard University financed by the Spanish Minister of Education; additional support was provided by MEC Project PB98-0141 and SEJ200405894/ECON

2 Departamento de Historia Económica e Instituciones, Universidad Carlos III de Madrid, Calle Madrid 126. 28903 Getafe (Spain).

3 Most of the theoretically founded indices of protection developed recently are impracticable when using time series. Leamer's and other indices of protection based on a Heckscher-Ohlin empirical model or the CGE (Computable General Equilibrium) models require knowledge of the basic production structure; unfortunately when the input-output data is available, it is feasible only for some isolated years. Even the most simplified GCE model, as that used by Anderson's TRI (Trade Restrictiveness Index), which does not require the exact knowledge of the production structure, is based on import and tariff data disaggregated enough to make the index only empirically feasible for benchmark comparisons. For the theoretic of the TRI model, see Anderson and Neary (1996), and Anderson (1998) for a comparative study in 1989-90.

4 Edwards (1993) uses import-export to GDP ratios to obtain a classification of the openness of countries for the second half of the twentieth century. The equilibrium ratio of this measure relies on the size and changes in the trade structure and demand-elasticities that make this measure endogenous and unconvincing over the long run. For a review of the empirical studies of the relation between trade policy and economic growth during the post-war years, see Rodriguez and Rodrik (1999).

5 There are many reasons that justify the use of the tariff average as a protection 
index in the long run. Edwards (1998) runs a regression of total productivity growth on nine alternative indicators of openness, but only three results are statistically significant, the trade tax ratio being the only one not being a complex arbitrary variable constructed by an institution.

6 'Although import substitution policies have gradually lost their shine over the postwar period, their reputation has remained intact for the late nineteenth century' (Irwin, 2002: 1). Most notably Bairoch (1976a, 1989, 1996) extols protectionism as instrumental in the development of late-nineteenth-century Continental Europe.

7 This is only a general statement, as protective tariffs can also boost tariff revenue. Irwin (1998) measures the import elasticity in the USA at the end of the nineteenth century and shows how higher tariffs in protected products raised additional customs collections. Strictly speaking, it depends on the import demand elasticity and whether the previous level of the tariff was below the revenue-maximising tariff.

8 For an extension of the index number problems in tariff averaging see Tumlir and Till (1971) and Federico and Tena (1998).

9 O'Rourke (1997) puts forward this argument in the context of the discussion of the applicability of the Anderson TRI CGE model to resolve the Nye-Irwin debate. He concludes that when there is a high proportion of products with a low elasticity of demand of any given country, the specification of the import demand elasticity is crucial to the determination of the impact of the import tariff structure on aggregate welfare.

10 Nineteenth-century United States protectionism constitutes a paradigmatic case of government revenue being heavily dependent on tariff revenue. Most US tariffs were levied on commodities, which were also domestically produced. Perhaps it was bound to be so given the spatial extension of the country and its climatic variety, which made them a producer of almost every 'exotic' consumer good (the only exception being cane sugar, only produced in small quantities in Louisiana). Irwin (1998) documents the different behaviour of the general index depending on the inclusion or exclusion of sugar in the general index. Variations were less significant in Europe, as is shown below.

11 See Irwin (1993: 147).

12 Irwin (1993: 146). This argument reflects the mainstream view on the history of British taxation. For a very recent account, see Martin Daunton (2001). In a summary of its main conclusion, Daunton insists that:

excise duties were 'voluntary', falling on goods such as tobacco or spirits which the tax payers could do without - they might even be morally suspect narcotics. Import duties were limited to commodities which could not be produced at home (such as sugar or tea), so that they did not offer any protection to domestic producers, with the danger of distorting the allocation of resources in the economy.

(Daunton, 2001: 10)

13 Surprisingly Nye does not tackle this point in his last article on this topic (Dankhilas and Nye 2004).

14 This is the difference between the total tariff average including fiscal duties and that excluding them expressed as a percentage of the latter. It represents the weight of fiscal items in the (conventional) nominal tariff across time and between countries. If the total tariff average including fiscal duties is lower than that excluding them, then the result is negative. This means that the tariff average would be higher if we eliminate fiscal duties.

15 See Tena (2001). 
120 Antonio Tena Junguito

16 For an extension of index number problems in tariff averaging, see Tumlir and Till (1971) and Federico and Tena (1998)

17 The problem has been dealt with recently by Crucini (1994). However, his approach is less accurate in so far as it takes into account the duty and price effects only. 


\section{Part II}

The impact and implications of tariff barriers 



\title{
7 Tariffs and growth in the late nineteenth century ${ }^{1}$
}

\author{
Kevin H. O'Rourke
}

Economic theory is ambiguous as regards the relationship between trade policy and growth. The growth literature of the past decade has produced an impressive array of models in which protection can either increase or reduce long-run growth rates (Grossman and Helpman, 1991; Rivera-Batiz and Romer, 1991; Stokey, 1991; Young, 1991). Such theoretical ambiguity invites empirical research.

While new growth theory is ambiguous on the subject, the new empirical growth literature has produced a consensus that free trade is positively associated with growth, based on evidence from the late twentieth century (but see Rodriguez and Rodrik (1999) for a sceptical review of the literature). The clear message that emerges from cross-country studies such as Harrison (1996), Lee (1993) and Sachs and Warner (1995) is that protection has slowed growth in the late twentieth century; a conclusion bolstered by more detailed studies of countries, or entire regions, such as Latin America, which have experimented with import-substitution policies (e.g. Taylor, 1998).

However, what is true of the late twentieth century is not necessarily true of earlier periods. Theory identifies off-setting effects of protection on the growth rate, which leaves open the possibility that different effects may predominate in different epochs. In a recent paper, Vamvakidis (1997) has introduced a note of historical caution into the literature, finding that correlations between trade and growth do indeed differ between periods. In particular, while he confirms that a positive correlation between openness and growth characterised the twenty years between 1970 and 1990, there was no such correlation in the 1950s and 1960s. Moreover, the correlation between tariffs and growth was positive in the 1930s. Vamvakidis argues that individual countries could have benefited from protection in a decade when unemployment was high, and other countries were already adopting protection. The late nineteenth century is a period to which proponents of protection have often pointed as offering evidence in support of their position. In particular, the United States and Germany both adopted protectionist policies, and experienced strong growth, arguably linked to the development of infant industries behind 
high-tariff barriers. Surprisingly, however, there have been relatively few quantitative cross-country studies of the effects of protection on growth in this period; while those which do exist have typically relied upon fairly crude correlation analysis.

This chapter goes further, by estimating the correlation between tariffs and growth in the late nineteenth century in the context of three types of growth equation: unconditional convergence equations; conditional convergence equations, associated with Mankiw et al. (1992); and factor accumulation models of the type estimated by Taylor (1996). The analysis uses data for ten developed countries between 1875 and 1913: Australia, Canada, Denmark, France, Germany, Italy, Norway, Sweden, the United Kingdom and the United States. While there are inevitably problems with some of these data, hopefully the method represents an advance on earlier work in this area. The findings are quite robust, and may come as a surprise to some.

The first section recalls the main features of late-nineteenth-century tariff policy in the ten countries considered here. The next section reviews the literature on late-nineteenth-century tariffs and growth, while the section that follows presents empirical evidence on the link between the two. The following section tries to interpret this evidence in the light of the existing historical literature. The chapter then concludes with some qualifications and suggestions for future research.

\section{Late-nineteenth-century tariff policies}

The evolution of European trade policies between 1860 and 1913 is wellknown. ${ }^{2}$ The Franco-British trade agreement of 1860 initiated a wave of commercial treaties involving all the main European powers. The inclusion of the most-favoured-nation clause into these treaties ensured that concessions were rapidly generalised, and Europe moved swiftly towards free trade. The turning point came in the late 1870s and 1880s, when cheap New World and Russian grain flooded Europe (Kindleberger, 1951; O'Rourke, 1997). Not surprisingly, this undermined agricultural support for free trade, although in several countries (e.g. Sweden) cleavages emerged between smaller, grain-using farmers specialising in animal husbandry, and larger, grain-producing farmers. Moreover, agricultural protection often triggered a reversion towards industrial protection. Thus, in Germany, where rye-producing Junkers were powerful, Bismark's 1879 'alliance of iron and rye' afforded protection to both agriculture and industry. In France, the protectionist breakthrough is typically taken to be the Méline tariff of 1892; Italy introduced moderate tariffs in 1878, and rather more severe tariffs in 1887 (Federico and Tena, 1998); Sweden adopted agricultural protection in 1888, much earlier than Norway, where farm sizes tended to be smaller, and export interests (shipping, timber and fishing) were politically powerful. 
Of the major Western European powers, only Britain adhered to freetrade principles, which may reflect the diminished role and political clout of agriculture in the first industrial nation. Denmark, as is well-known, also adhered to free trade in agriculture throughout the grain invasion, engaging in a radical structural adjustment in the process. Whether this Danish response was due to the size distribution of farms, a high degree of social cohesion, the German defeat of 1864, or other factors, remains a topic of considerable interest (Kindleberger, 1951).

In Europe, therefore, protection was in the first instance agricultural, although industrial protection followed in several countries, and the net impact on the allocation of resources between town and country remains to be determined. In the New World, no such ambiguity as to protection's overall sectoral impact exists: the regions of recent settlement were agricultural exporters. Thus, their tariffs were designed to provide 'infant' industries with protection from European competition. In the United States, the Civil War brought about a large increase in tariffs, as part of the attempt to finance the war effort. After the war, tariffs remained high, a result not only of Republican domination of Congress, but also of the combination of specific duties and falling import prices between the $1870 \mathrm{~s}$ and 1890s (Irwin, 1998). Canada also chose to protect its manufacturing industries; especially after 1878, when the Conservatives were elected on a 'National Policy' platform aiming 'to select for higher rates of duty those [goods] that are manufactured or can be manufactured in the country'. In Australia, finally, some colonies opted for protection (e.g. Victoria), while others (e.g. New South Wales) opted for free trade. By 1893, after a succession of tariff increases, the maximum Victoria tariff rates stood at 45 per cent (Siriwardana, 1991: 47). The first federal tariff of 1902 was a compromise between protectionist and free-trading colonies, but federal protection was greatly strengthened in 1906 and 1908.

\section{Late-nineteenth-century tariffs and growth: sources and methods}

Over the last twenty years, a greater range of national accounts data has become available to economic historians seeking to explore the correlation between tariffs and growth. This chapter exploits those data, as summarised in Angus Maddison's most recent book on the subject (Maddison, 1995). In conjunction with national sources, Maddison's data make it possible to estimate conventional growth equations using PPP-adjusted GDP data that are consistent across countries and across time.

Previous authors had to make do with country-specific national accounts data that have, in some cases, been superseded by more recent estimates. The best-known investigation of the link between tariffs and growth in the late nineteenth century probably remains Bairoch (1972), updated and expanded as Bairoch (1976a), and summarised in Bairoch 
(1996). His strategy was to compare aggregate growth rates in free trade and protectionist periods, for the major European countries. For example, using the work of Marczewski, Toutain, Lévy-Leboyer and Crouzet, he examined the growth rates of French agricultural, industrial and total output in the free trade era of 1860-91, as compared with the protectionist periods 1824-59 and 1892-1913. Sectoral and aggregate growth rates were lower during the free-trade period, and especially the growth rate of agricultural output. Moreover, innovation was, if anything, slower during the free-trade period: Bairoch's conclusion was that free trade was bad for French growth.

Broadly speaking, the same picture emerged when Bairoch examined other Continental countries, although there were important exceptions (most notably, German industrial and aggregate output grew more rapidly during the liberal period, defined for that country as 1862-79). On the other hand, the leading European economy, Britain, did relatively well during the 1860s and 1870s: for Bairoch, liberalism was associated with divergence, not convergence.

Bairoch's pioneering work can be criticised on several grounds. First, the method relies on a post hoc ergo propter hoc logic: differences in growth rates between periods are ascribed to differences in trade regimes, when other factors might have been important. Second, the method requires deciding what constituted the 'free trade' and 'protectionist' eras in different European countries. This is not always obvious; for example, Bairoch takes the Méline tariff of 1892 as marking the end of the 'liberal interlude' in France, although wheat duties were raised significantly in 1885 and 1887. Different starting and end points for the liberal period, which inevitably reflect an element of judgement, would produce different growth rates.

The second comparative, quantitative study of which I am aware is Capie (1983), whose results are summarised in a later survey (Capie, 1994). Capie argues that there is no evidence that tariffs boosted growth in late-nineteenth-century Europe. First, average tariffs (i.e. the ratio of customs duties to total imports) were fairly low in all countries bar Russia, and there was not much variation in tariffs across countries. 'Protection does not appear to have been sufficiently high to make any significant impact on performance' (Capie, 1983: 9). Second, simple country-bycountry regressions of growth rates on tariffs, using annual data from Germany, Italy, the United Kingdom and Russia, found no relationship between tariffs and growth.

Vamvakidis (1997) finds little or no relationship between tariffs and growth between 1870 and 1910, in a simple bivariate framework. However, he does find that the Spearman rank correlation coefficient (which eliminates the influence of extreme observations) between average tariffs and growth, using decade averages for eleven countries, is positive: 0.345 , with a $t$-statistic of 2.438. Finally, Foreman-Peck (Chapter 15, this volume) uses 
decadal data for an unbalanced panel of up to eighteen European countries between 1860 and 1910 to estimate an 'eclectic' model of the level (rather than the growth rate) of output per capita, expressed as a system of equations. His reduced form estimates indicate that average tariffs were negatively related to output per capita; structural equations suggest that the result is due to the fact that output per capita was negatively related to agriculture's share of employment, and that the latter variable was positively related to tariffs. Foreman-Peek's interpretation is that tariffs were biased towards (low-productivity) agriculture, of which more later; an alternative interpretation is that the grain invasion provoked higher tariffs in more agricultural economies (O’Rourke, 1997).

This chapter aims to improve on previous studies, in three ways. First, unlike Bairoch and Capie, I use Maddison's (1995) PPP-adjusted GDP data. ${ }^{4}$ Second, unlike Bairoch, Capie and Vamvakidis, I control for the other forces that theory says should affect growth when estimating the impact of protection. ${ }^{5}$ Third, the growth equations estimated here are more directly comparable with the late-twentieth-century literature cited in the introduction, than are Foreman-Peck's output level equations.

\section{Tariffs and growth: some cross-country evidence}

My data set covers ten countries, three in the New World (Australia, Canada and the United States) and seven in Europe (Denmark, France, Germany, Italy, Norway, Sweden and the United Kingdom). For each country, I have data on real GDP, the GDP deflator, population, agricultural land endowments, the share of agricultural output in GDP, school enrolments, investment rates, imports as a share of GDP, tariff rates and coal consumption. The data cover the period 1875-1914, and are expressed as five-yearly averages. Working with late-nineteenth-century data naturally necessitates compromises. Theory suggests that I should be examining the behaviour of GDP per worker, not per head of population, but labour force data are not available for all countries on an annual basis. School enrolment rates are simply the total number of pupils in primary and secondary schools, divided by the total population: cohort-specific enrolment rates would clearly be preferable. When I run factor accumulation models, in which the growth of GDP per head is related to the growth in endowments per head, I am forced to use coal consumption as a proxy for the capital stock, since the latter are unavailable (following Collins et $a l ., 1997$ and Vamvakidis, 1997). This short-cut does at least have a venerable pedigree: see Landes (1969: 293). As in previous studies, average tariffs are simply defined as the ratio of customs duties to total imports, of which more below. When estimating land endowments and enrolment rates, I am occasionally forced to rely on interpolation where data are missing. Appendix 7.1 provides the details.

Table 7.1 gives the raw data on tariffs, while Table 7.2 reports 


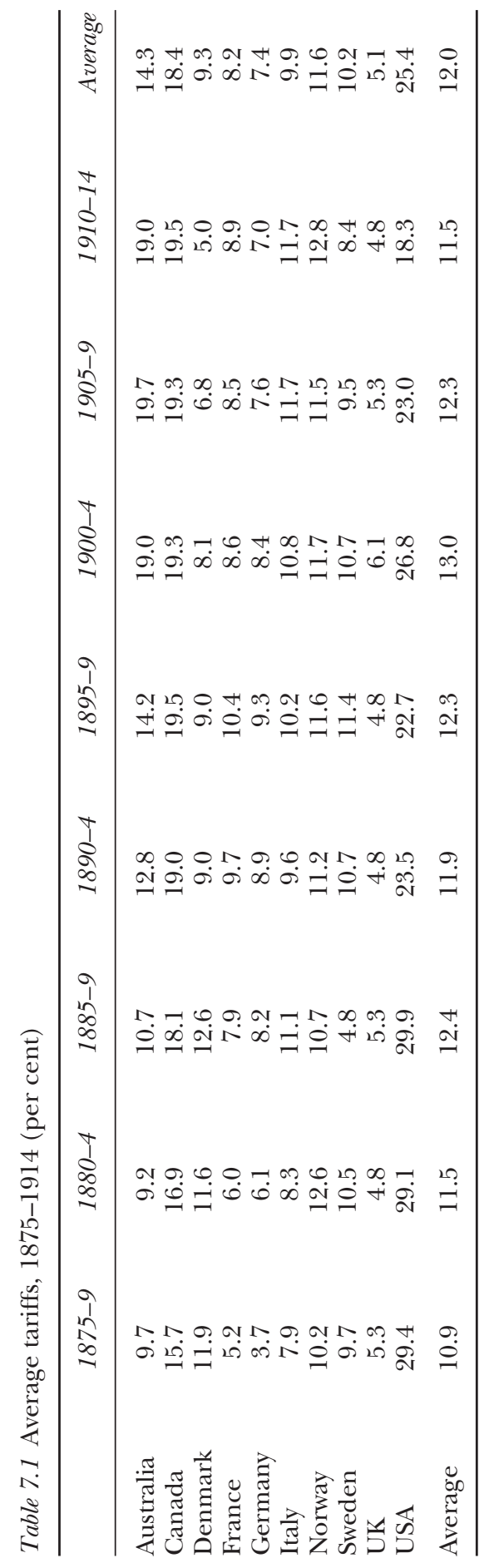


Table 7.2 Tariff levels across countries and time (dependent variable is average tariff)

\begin{tabular}{lrr}
\hline Variable & Coefficient & $t$-statistic \\
\hline$C$ & 0.120 & 44.776 \\
$D 1877$ & -0.011 & -1.558 \\
$D 1882$ & -0.005 & -0.652 \\
$D 1887$ & 0.004 & 0.550 \\
$D 1892$ & -0.000 & -0.046 \\
$D 1897$ & 0.003 & 0.485 \\
$D 1902$ & 0.010 & 1.393 \\
$D 1907$ & 0.003 & 0.434 \\
$D 1912$ & -0.004 & \\
$D A U S$ & 0.023 & 2.889 \\
$D C$ & 0.065 & 8.047 \\
$D D K$ & -0.027 & -3.379 \\
$D F$ & -0.038 & -4.749 \\
$D G$ & -0.046 & -5.686 \\
$D I$ & -0.021 & -2.587 \\
$D N$ & -0.004 & -0.487 \\
$D S$ & -0.018 & -2.214 \\
$D U K$ & -0.068 & -8.510 \\
$D U S$ & 0.134 & \\
No. of observations & & 80 \\
$R$-squared & & 0.879 \\
Adjusted $R$-squared & & 0.848 \\
S.E. of regression & & 0.024 \\
-statistic & & 28.570 \\
Prob (F-statistic) & & 0.000 \\
Mean of dependent variable & & 0.120 \\
S.D. of dependent variable & & 0.061 \\
Sum of squared residuals & & 0.036 \\
Durbin-Watson statistic & & 0.767 \\
\hline & &
\end{tabular}

Note

Coefficients on $D 1912$ constrained to be equal to minus the sum of the coefficients on $D 1877$ to $D 1907$ inclusive. Coefficients on DUS constrained to be equal to minus the sum of the coefficients on DAUS to DUK inclusive. Estimation: OLS. For variable definitions, see Table 5.

regressions of tariffs on country and time dummies. As expected, the tables show that tariffs were highest in the United States, and lowest in the United Kingdom, with tariffs also being high in Australia (I use the Victoria tariffs) and Canada. Continental European countries all have average tariff rates somewhere in between these two extremes, with Scandinavian (and, in particular, Danish) tariffs being surprisingly high, and German tariffs being surprisingly low. The general increase in tariff levels in the $1880 \mathrm{~s}$ is also apparent from the tables.

There are several problems associated with this average tariff measure. First, there is a well-known index number problem: as protection on a particular commodity increases, the weight of that commodity in the 
overall tariff index declines. In the extreme case of a prohibitive tariff, the weight would drop to zero. Second, and perhaps more importantly during this period, many tariffs were raised for revenue purposes, and were not necessarily directly protective: British duties on tobacco, for example. If these revenue duties were not included, British and Danish average tariffs would be much lower (Irwin, Chapter 2, this volume). On the other hand, even revenue tariffs will have a general equilibrium impact of some sort in an open economy.

Despite the impact of revenue tariffs on average customs duties, many features of Table 7.1 correspond with what we know about the tariff history of the period, in particular the high United States and low United Kingdom tariffs (although the British index for 1875-9 is slightly higher than that for France, mirroring the debate between Nye and Irwin. ${ }^{6}$ Even features of Table 7.1 that seem surprising are often compatible with other evidence on relative protection levels in the late nineteenth century. Table 7.3, taken from O'Rourke and Williamson (1997), summarises various measures of protection in 1875 and 1913. First, there are Bairoch's (1989) estimates of tariffs on wheat. Second, there are several average tariffs, computed using a variety of weights, for both manufacturing and the economy as a whole. These were computed by the League of Nations in 1927, by $\mathrm{H}$. Liepmann in his classic, Tariff Levels and the Economic Unity of Europe (1938), and by Bairoch himself. Third, I report the estimates of sectoral and overall protection calculated by Estevadeordal (Chapter 5, this volume). Estevadeordal estimated a model predicting trade flows for eighteen countries in $1913 .^{7}$ He then constructed two measures of 'openness' based on the difference between countries' predicted and actual trade-intensity ratios. Table 7.3 indicates where individual countries ranked among Estevadeordal's eighteen nations in terms of their openness (the most open being ranked 1, and the most protected being ranked 18). These scholars also found, for example, that protection for manufacturing (although not overall protection) was higher in Denmark than in Germany: Denmark's free-trade reputation is due to its refusal to protect agriculture. Contrary to popular opinion, Germany was not particularly protectionist within the context of Continental Europe, and indeed neither was Italy (see Federico, Chapter 10, this volume). The data in Table 7.1 are therefore not wildly out of line with what other sources suggest. However, there remains the possibility that revenue tariffs were more important in some countries than in others. It will therefore be important to check that econometric results are robust to the inclusion of country-specific fixed effects.

Table 7.4 gives average annual per capita growth rates between successive five-year periods. Canada, Denmark and the United States experienced relatively rapid growth, while British growth was somewhat below par, and Australia performed poorly. Since I am using five-year averages, and there are eight five-year periods between 1875 and 1914, there are seven periods of growth to be explained. I thus have seventy observations. 
Table 7.3 European tariffs, 1875-1913

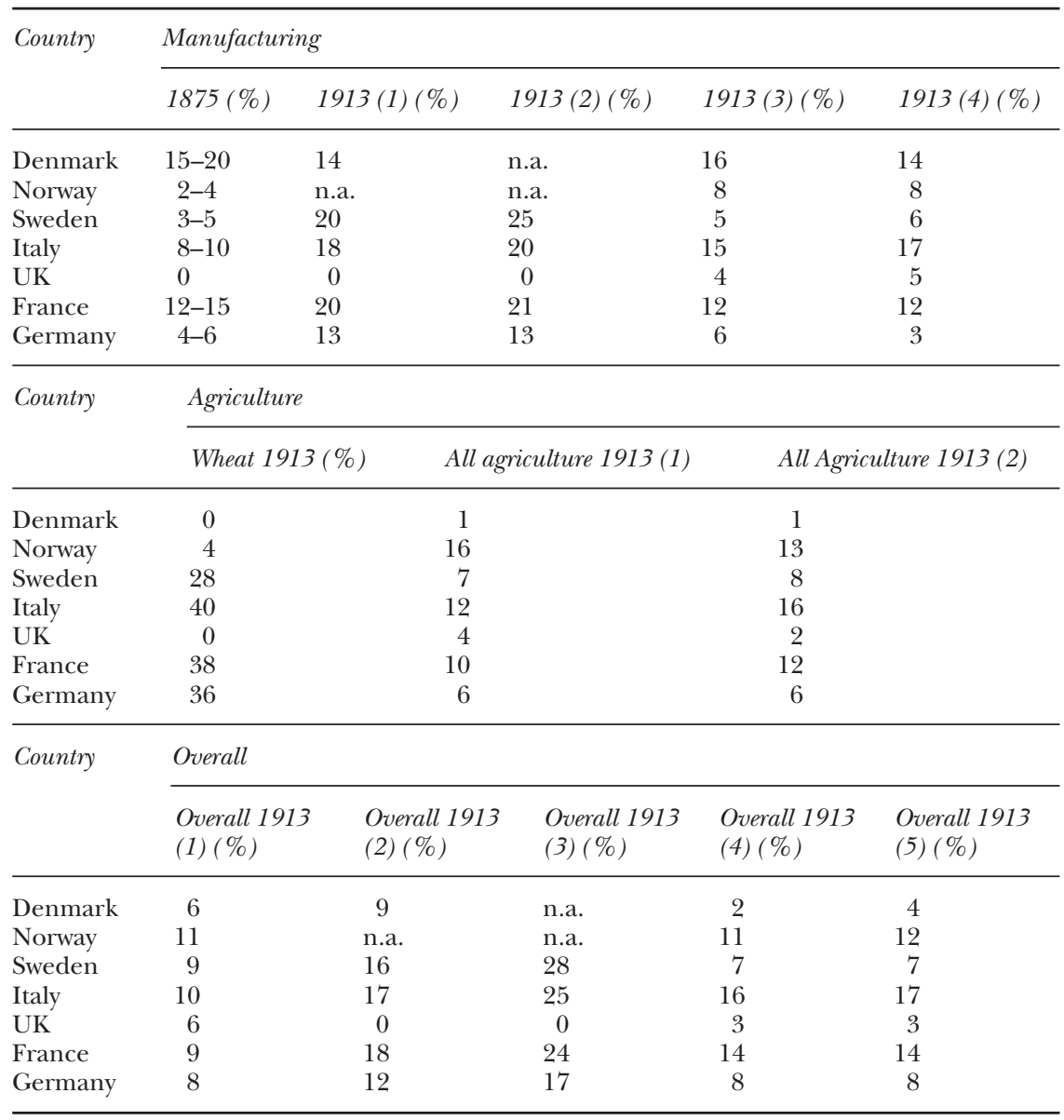

Notes

Manufacturing 1875: average levels of duties on manufactured products in 1875, from Bairoch (1989: 42).

Manufacturing 1913 (1): League of Nations estimate, as reported in Bairoch (1989, Table 9: 76).

Manufacturing 1913 (2): Liepmann (1938) estimate, as reported in Bairoch (1989, Table 9: 76).

Manufacturing 1913 (3): rank among eighteen countries ( $1=$ least protectionist, $18=$ most protectionist), based on the adjusted trade intensity ratios in Estevadeordal (1997, Table 6: 104).

Manufacturing 1913 (4): rank among eighteen countries ( $1=$ least protectionist, $18=$ most protectionist $)$, based on the openness measures in Estevadeordal (1997, Table 6: 105).

Wheat 1913: levels of duties on wheat, calculated by Bairoch (1989, Table 9: 76).

Agriculture 1913 (1): rank among eighteen countries ( $1=$ least protectionist, $18=$ most protectionist), based on the adjusted trade intensity ratios in Estevadeordal (1997, Table 6: 104).

Agriculture 1913 (2): rank among eighteen countries ( $1=$ least protectionist, $18=$ most protectionist), based on the openness measures in Estevadeordal (1997, Table 6: 105).

Overall 1913 (1): import duties as percentage of special total imports (1909-13), calculated by Bairoch (1989: 76).

Overall 1913 (2): League of Nations estimate, as reported in Bairoch (1989, Table 9: 76). Overall 1913 (3): Liepmann (1938) estimate, as reported in Bairoch (1989), Table 9, p. 76 . Overall 1913 (4): rank among eighteen countries $(1=$ least protectionist, $18=$ most protectionist $)$, based on the adjusted trade intensity ratios in Estevadeordal (1997, Table 8: 107).

Overall 1913 (5): rank among eighteen countries $(1=$ least protectionist, $18=$ most protectionist $)$, based on the openness measures in Estevadeordal (1997, Table 8: 107). 


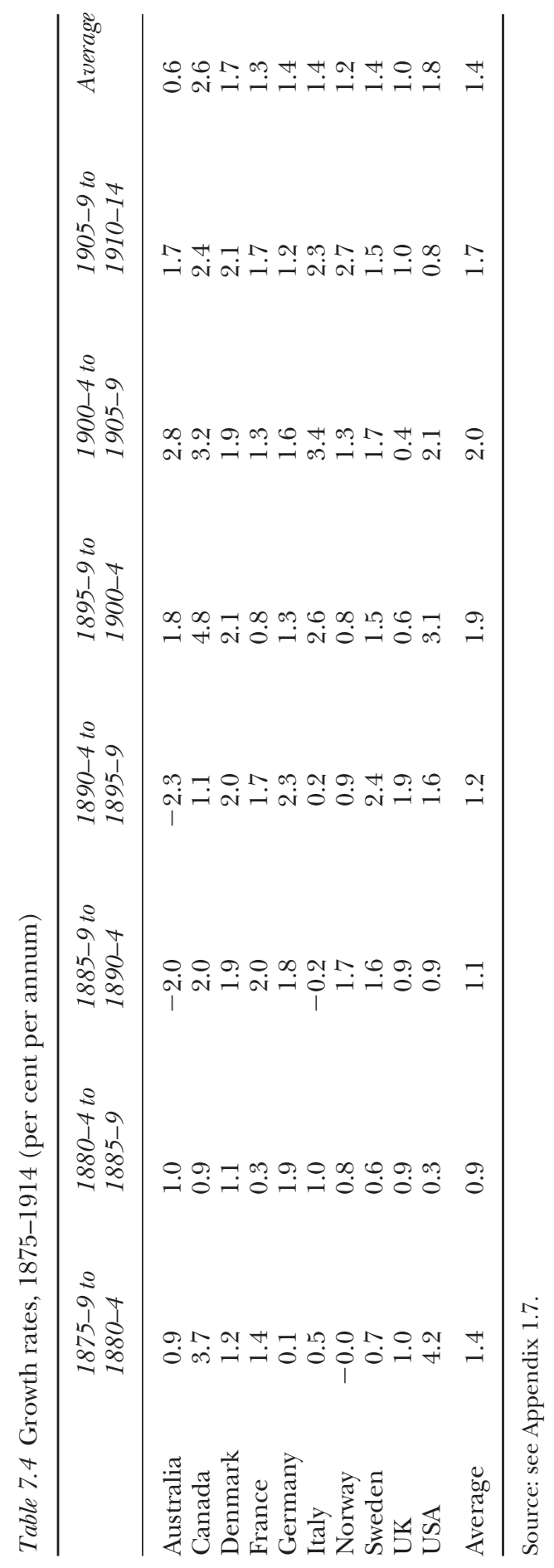


Table 7.5 List of variables used in regressions

\begin{tabular}{ll}
\hline Variable & Description \\
\hline$C$ & Constant \\
$D 1877$ & Dummy variable: 1 if period is $1875-9,0$ otherwise \\
$D 1882$ & Dummy variable: 1 if period is $1880-4,0$ otherwise \\
$D 1887$ & Dummy variable: 1 if period is $1885-9,0$ otherwise \\
$D 1892$ & Dummy variable: 1 if period is $1890-4,0$ otherwise \\
$D 1897$ & Dummy variable: 1 if period is $1895-9,0$ otherwise \\
$D 1902$ & Dummy variable: 1 if period is $1900-4,0$ otherwise \\
$D 1907$ & Dummy variable: 1 if period is $1905-9,0$ otherwise \\
$D 1912$ & Dummy variable: 1 if period is $1910-14,0$ otherwise \\
$D A U S$ & Dummy variable: 1 if country is Australia, 0 otherwise \\
$D C$ & Dummy variable: 1 if country is Canada, 0 otherwise \\
$D D K$ & Dummy variable: 1 if country is Denmark, 0 otherwise \\
$D F$ & Dummy variable: 1 if country is France, 0 otherwise \\
$D G$ & Dummy variable: 1 if country is Germany, 0 otherwise \\
$D I$ & Dummy variable: 1 if country is Italy, 0 otherwise \\
$D N$ & Dummy variable: 1 if country is Norway, 0 otherwise \\
$D S$ & Dummy variable: 1 if country is Sweden, 0 otherwise \\
$D U K$ & Dummy variable: 1 if country is UK, 0 otherwise \\
$D U S$ & Dummy variable: 1 if country is US, 0 otherwise \\
$L Y$ & Log of initial income \\
$L T A R$ & Log of average tariff (first period) \\
$S K$ & Log of the savings rate \\
$S H$ & Log of school enrolment rate \\
$N G D$ & Log of population growth rate plus 0.05 \\
$D K L$ & Rate of change of capital-labour ratio \\
$D R L$ & Rate of change of land-labour ratio \\
$C Y C$ & Deviation of output from trend output (based on regressions of \\
$S P E C T A R$ & output on time and time-squared) \\
$L T A R(+1)$ & Log of average tariff times implicit GDP deflator \\
$L T A R 12$ & Log of the second period average tariff \\
$G D P$ & Log of the average of tariffs in first and second periods \\
$P O P$ & Real GDP \\
$D O L D$ & Population \\
$D N E W$ & Dummy variable: 1 if country is European, 0 otherwise \\
\hline & Dummy variable: 1 if country is New World, 0 otherwise \\
\hline &
\end{tabular}

(For a good justification of using panel data in this context, see Harrison (1996).) Unless otherwise stated, the dependent variable is the average annual growth rate of output per capita. Table 7.6 explores the impact of tariffs on growth in the context of an unconditional convergence model, with per-capita growth being related to the initial income per capita. (Table 7.5 provides a list of variable names used in subsequent tables.) There is little evidence of unconditional beta-convergence for this tencountry sample: the coefficient on initial income in (1) is very small, albeit negative, and insignificant at conventional levels. ${ }^{8}$

Adding the log of the (initial) average tariff improves the fit of the equation somewhat; the coefficient on the tariff variable in (2) is positive, 


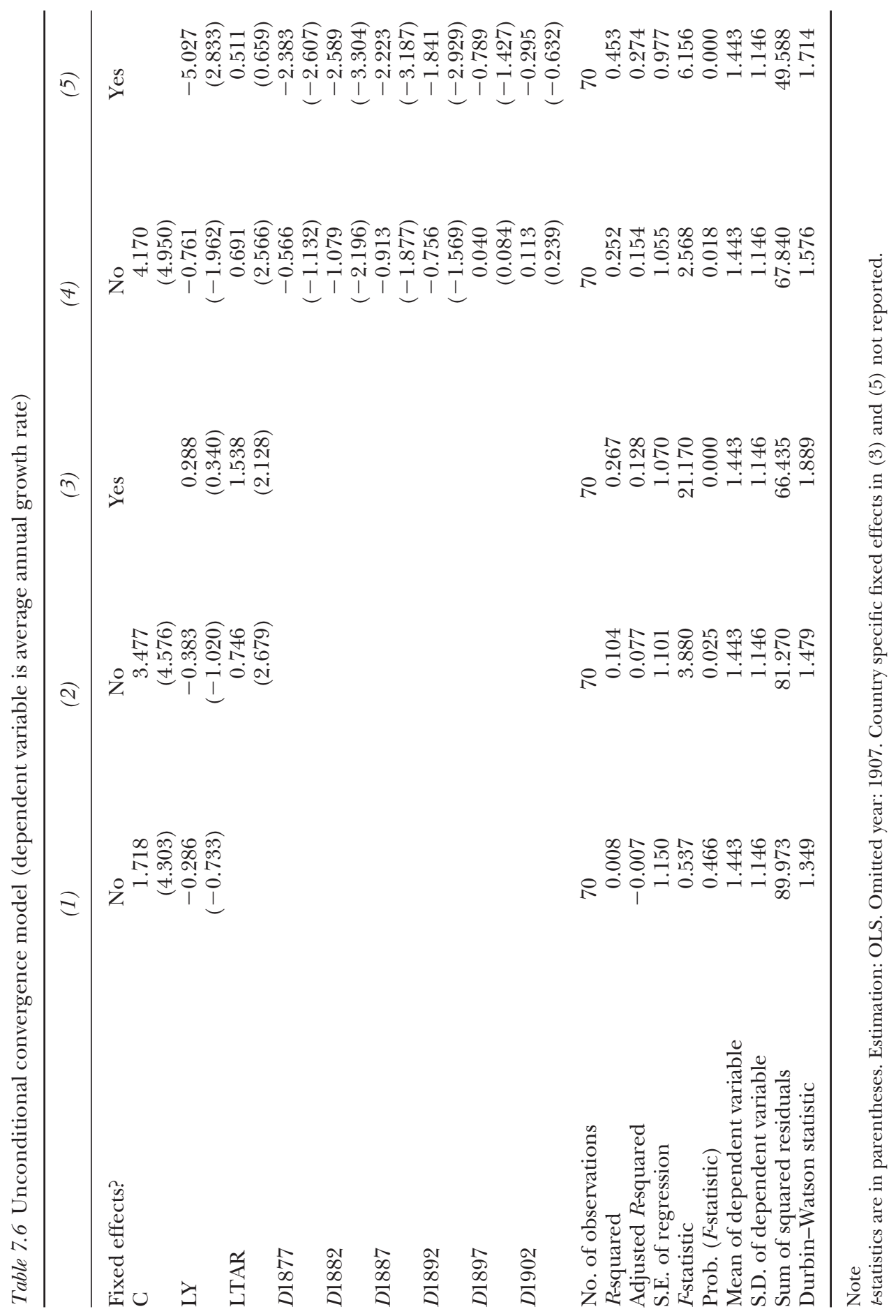


at 0.746 , and significant at conventional levels. The coefficient implies that a 10 per cent increase in the tariff rate is associated with an increase in annual growth rates of 0.075 per cent per annum, or 5.2 per cent $(100 \times 0.075 / 1.443)$; a one standard deviation increase in the tariff rate $(0.481249)$ would increase average annual growth rates by 0.359 per cent p.a., or by 24.9 per cent $(100 \times 0.359 / 1.443)$. These are quite large effects. When country-specific fixed effects are introduced, the coefficient on the tariff variable increases to 1.538; a one standard deviation increase in tariffs is now associated with an increase of 0.74 per cent p.a. in the average annual growth rate, or 51.3 per cent. The coefficient is marginally smaller at 0.691 when time dummies are introduced. When both time and country dummies are introduced, the coefficient declines to 0.511 , and is no longer significant at standard confidence levels. However, this is hardly surprising, given that a regression of tariffs on time and country dummies produces an $R^{2}$ of 0.879 (Table 7.2$) .^{9}$

These results were sufficiently surprising to me that I ran equations relating tariffs and growth using many different specifications, in an attempt to see how robust this correlation was. I first explored the link between tariffs and growth in the context of an augmented Solow model, of the sort associated with Mankiw et al. (1992): consistent with the findings of Taylor (1996), this model performs extremely poorly in the late nineteenth century. ${ }^{10}$ Most notably, the savings rate and population growth coefficients have the wrong signs, while the coefficient on initial income has the wrong sign in several specifications. Once again, the tariff coefficient is large, positive and statistically significant, unless both time and county dummies are included.

In Table 7.7, I run factor accumulation models, of the sort favoured by Taylor (1996): growth in output per worker is related to growth in the land-labour and capital-labour ratios (recall that capital stocks are proxied by coal consumption). This specification reflects the important role that expanding frontiers played in the late-nineteenth-century Atlantic economy, as well as the greater role of agriculture in that period. In (4) and (5) a catch-up term is added to the specification. Since both specification tests (not shown) and common sense suggest that country fixed effects should be included, all regressions in this and subsequent tables incorporate them. The model performs much better than the augmented Solow model, and the positive relationship between tariffs and growth survives (but note that the coefficient on initial income is positive in (4). The tariff coefficient ranges from 0.57 to 1.853 . Again, adding country fixed effects alone to the specification increases the size of the tariff coefficient, while adding time dummies as well as country dummies lowers both the size of the coefficient and the significance level (to below conventional levels). ${ }^{11}$

Finally, it should be noted that controlling for import shares strengthens the correlation between tariffs and growth. For example, when the 


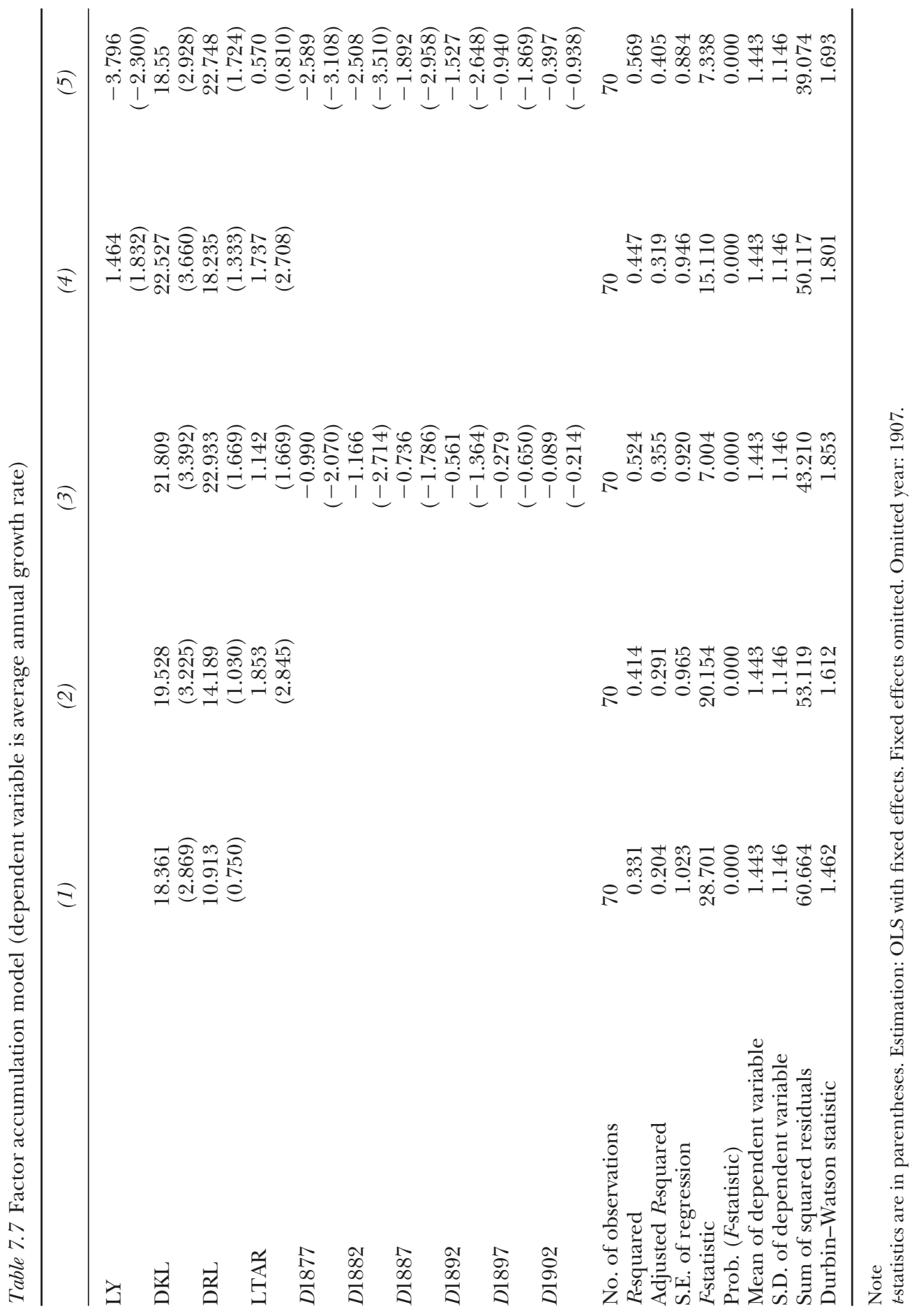


simple factor accumulation model with country dummies is re-estimated, the coefficient on tariffs increases to 2.374, up from 1.853 (equation (2) in Table 7.7). The import share is positively and significantly related to growth, consistent with findings for the late twentieth century.

Clearly my prior hypothesis, which was that tariffs should be negatively correlated with growth, is not supported by the data. The data are far more comfortable with the hypothesis that tariffs boosted late-nineteenthcentury growth. What could be driving the results?

One possibility is that the results are driven by one or two countries: the United States, for example, was both a high-growth and a high-tariff economy. On the other hand, Australia was a low-growth country; using high Victoria tariffs, as I do, rather than tariffs reflecting the free-trading New South Wales, should have reduced the correlation between growth and tariffs. The fact that my results are robust to the inclusion of country dummies indicates that something more than country fixed effects is going on. Indeed, in all cases, the tariff coefficient increases in size when country dummies are introduced.

In Table 7.8, I let the tariff variable interact with country and time dummies, in the context of a simple factor accumulation specification. With country dummies already included, I am using up many scarce degrees of freedom; the hope is that such an exercise will yield some insight into what is driving the overall result. For the sake of comparison, the coefficient on tariffs was 1.853 in equation (2) of Table 7.7.

F-tests clearly reject the null hypothesis that tariff coefficients are equal across countries, while there seems to be a tendency for the tariff coefficient to fall over time. The tariff coefficient was 'larger than average' (i.e. greater than 1.853) for Australia, Canada, Germany, Italy and Norway. ${ }^{12}$ Reassuringly, the tariff coefficient was (insignificantly) negative for the two free traders in the sample, Denmark and the United Kingdom, as well as for the United States. The fact that no positive correlation emerges for Denmark and Britain, countries whose histories contain no suggestion that tariffs boosted growth, suggests that the overall correlation is more than a spurious by-product of the way these data are generated.

At this point, a sceptic might well ask whether the causation could be going the other way round, from growth to tariffs. One could argue as follows: in depressions, tariff rates increase. This could be because duty rates are raised (which is what the endogenous tariff literature emphasises), or it could be because specific duties translate into higher rates of protection in periods of low prices (Crucini, 1994; see also Thornton and Molyneux, 1997). In either event, tariffs are higher when output is low, and thus about to grow more rapidly than average. There is some evidence that the latter effect may have been at work during recessions. Let CYC be a business cycle variable, defined as the deviation of actual output from predicted output, where predicted output is derived from a regression of annual output on time and time squared. Table 7.9 gives the 
Table 7.8 Tariffs and growth in different countries and periods (dependent variable is annual average growth rate)

\begin{tabular}{|c|c|c|}
\hline & (1) & (2) \\
\hline$D K L$ & $23.761(4.091)$ & $22.992(3.633)$ \\
\hline$D R L$ & $22.766(1.728)$ & $25.238(1.802)$ \\
\hline$D A U S \times L T A R$ & $2.836(2.390)$ & \\
\hline$D C \times L T A R$ & $4.297(0.955)$ & \\
\hline$D D K \times L T A R$ & $-1.600(-0.985)$ & \\
\hline$D F \times L T A R$ & $1.096(0.760)$ & \\
\hline$D G \times L T A R$ & $2.317(2.049)$ & \\
\hline$D I \times L T A R$ & $10.664(3.987)$ & \\
\hline$D N \times L T A R$ & $3.633(0.643)$ & \\
\hline$D S \times L T A R$ & $0.789(0.138)$ & \\
\hline$D U K \times L T A R$ & $-3.110(-0.743)$ & \\
\hline$D U S \times L T A R$ & $-1.07(-0.359)$ & \\
\hline$D 1877 \times L T A R$ & & $1.258(1.867)$ \\
\hline$D 1882 \times L T A R$ & & $1.212(1.719)$ \\
\hline$D 1887 \times L T A R$ & & $1.057(1.423)$ \\
\hline$D 1892 \times L T A R$ & & $0.975(1.312)$ \\
\hline$D 1897 \times L T A R$ & & $0.911(1.211)$ \\
\hline$D 1902 \times L T A R$ & & $0.816(1.072)$ \\
\hline$D 1907 \times L T A R$ & & $0.743(1.004)$ \\
\hline No. of observations & 70 & 70 \\
\hline$R$-squared & 0.581 & 0.511 \\
\hline Adjusted $R$-squared & 0.397 & 0.339 \\
\hline S.E. of regression & 0.890 & 0.932 \\
\hline$F$-statistic & 6.041 & 6.668 \\
\hline Prob. (F-statistic) & 0.000 & 0.000 \\
\hline Mean of dependent variable & 1.443 & 1.443 \\
\hline S.D. of dependent variable & 1.146 & 1.146 \\
\hline Sum of squared residuals & 38.031 & 44.322 \\
\hline Durbin-Watson stat. & 2.169 & 1.834 \\
\hline Restrictions & $p=0.042$ & $p=0.139$ \\
\hline
\end{tabular}

correlation between $C Y C$, the GDP price deflator, the log of the average tariff $L T A R$, and growth over the subsequent period. As can be seen, during booms (CYC is positive), prices are higher, tariffs are lower and subsequent growth is lower; during troughs (CYC is negative) prices are lower, tariffs are higher and subsequent growth is higher. When the log of the tariff is regressed on country dummies and $C Y C$, the coefficient on CYC is strongly negative, as predicted by the political science literature (e.g. Gallarotti; 1985; Cassing et al., 1986), although maybe not for the reasons suggested here. ${ }^{13}$

One simple and extremely crude way to check whether it is this dependence of tariffs on the business cycle that is driving the results is to regress the growth rate between five-year periods on tariffs in the second period, rather than the first period. Say the economy was in recession in the first 
Table 7.9 Prices, tariffs and the business cycle (correlations)

\begin{tabular}{lcclll}
\hline & CYC & Prices & LTAR & SPECTAR & Growth \\
\hline CYC & 1 & & & & \\
Prices & 0.335 & 1 & & & \\
LTAR & -0.224 & -0.412 & 1 & 1 & \\
SPECTAR & -0.160 & -0.194 & 0.974 & 1 \\
Growth & -0.382 & -0.187 & 0.300 & 0.277 & 1 \\
\hline
\end{tabular}

Note

Prices are the implicit GDP deflator. CYC is as defined in the text. LTAR is the log of the average tariff. SPECTAR is the $\log$ of (average tariff $\mathrm{X}$ prices). All data sources given in Appendix 7.1.

Table 7.10 Factor accumulation model, second period tariffs (dependent variable is average annual growth rate)

\begin{tabular}{lcc}
\hline Variable & $(1)$ & $(2)$ \\
\hline$D K L$ & 16.979 & 17.925 \\
& $(2.688)$ & $(2.923)$ \\
$D R L$ & 13.741 & 14.595 \\
& $(0.959)$ & $(1.042)$ \\
$L T A R(+1)$ & 1.352 & \\
& $(1.838)$ & 1.851 \\
LTAR12 & & $(2.493)$ \\
& & 70 \\
No. of observations & 70 & 0.397 \\
$R$-squared & 0.368 & 0.270 \\
Adjusted $R$-squared & 0.235 & 0.980 \\
S.E. of regression & 1.002 & 18.748 \\
-statistic & 16.627 & 0.000 \\
Prob. (F-statistic) & 0.000 & 1.443 \\
Mean of dependent variable & 1.443 & 1.146 \\
S.D. of dependent variable & 1.146 & 54.700 \\
Sum of squared residuals & 57.271 & 1.570 \\
Durbin-Watson stat. & 1.532 & \\
\hline
\end{tabular}

Note

$t$-statistics are in parentheses. Estimation: OIS with fixed effects. Fixed effects omitted.

period: first-period tariffs might be higher than usual, but second-period tariffs would reflect the better economic conditions that followed. Table 7.10 presents the results when growth is regressed on second-period tariffs, and the average of first- and second-period tariffs, in the context of the factor accumulation model. Using second-period tariffs lowers the tariff coefficient somewhat, to 1.352, down from 1.853, while using average tariffs leaves the coefficient unchanged.

An alternative is to construct a specific tariff variable, SPECTAR, 
defined as the log of the average tariff times the GDP price deflator. Table 7.9 shows that SPECTAR is not as strongly correlated with the business cycle as is the average tariff, while a regression of SPECTAR on CYC and country dummies reveals no statistically significant relationship between specific tariffs and the business cycle. ${ }^{14}$ Table 7.11 shows that when the average tariff is replaced by SPECTAR in a simple factor accumulation model, the coefficient on tariffs is still large and positive, if somewhat smaller than in equation (2) of Table 7.7.

From these exercises, it appears that the counter-cyclicality of tariffs can on its own explain my results; moreover, if the positive correlation between tariffs and growth were due to the interaction of changing price levels over one business cycle and specific tariffs, then why does a positive correlation emerge for Britain and Denmark, the two free traders in the sample?

Table 7.11 Growth and 'specific' tariffs (dependent variable is average annual growth rate)

\begin{tabular}{|c|c|c|}
\hline Variable & (1) & (2) \\
\hline$D K L$ & $\begin{array}{l}19.896 \\
(3.177)\end{array}$ & $\begin{array}{c}22.504 \\
(3.451)\end{array}$ \\
\hline$D R L$ & $\begin{array}{l}12.382 \\
(0.875)\end{array}$ & $\begin{array}{l}23.627 \\
(1.697)\end{array}$ \\
\hline SPECTAR & $\begin{array}{c}1.467 \\
(2.097)\end{array}$ & $\begin{array}{c}0.796 \\
(1.154)\end{array}$ \\
\hline$D 1877$ & & $\begin{array}{c}-1.089 \\
(-2.280)\end{array}$ \\
\hline$D 1882$ & & $\begin{array}{c}-1.198 \\
(-2.750)\end{array}$ \\
\hline$D 1887$ & & $\begin{array}{c}-0.669 \\
(-1.589)\end{array}$ \\
\hline$D 1892$ & & $\begin{array}{r}-0.497 \\
(-1.179)\end{array}$ \\
\hline$D 1897$ & & $\begin{array}{c}-0.196 \\
(-0.446)\end{array}$ \\
\hline$D 1902$ & & $\begin{array}{r}-0.036 \\
(0.086)\end{array}$ \\
\hline No. of observations & 70 & 70 \\
\hline$R$-squared & 0.379 & 0.510 \\
\hline Adjusted $R$-squared & 0.248 & 0.337 \\
\hline S.E. of regression & 0.994 & 0.933 \\
\hline$F$-statistic & 17.390 & 6.643 \\
\hline Prob. (F-statistic) & 0.000 & 0.000 \\
\hline Mean of dependent variable & 1.443 & 1.443 \\
\hline S.D. of dependent variable & 1.146 & 1.146 \\
\hline Sum of squared residuals & 56.319 & 44.410 \\
\hline Durbin-Watson stat. & 1.584 & 1.839 \\
\hline
\end{tabular}

Note

$t$-statistics are in parentheses. Estimation: OLS with fixed effects. Fixed effects omitted. 
Another way that business cycles might matter is suggested by Vamvakidis (1997). As mentioned in the introduction, he finds some support for the theoretical suggestion that tariffs might be beneficial during recessions (due, for example, to their employment-creating effects), but not otherwise. Using pooled data from 1920 to 1990, he regresses growth on domestic tariffs, and other variables. In many specifications, the tariff coefficient is positive (if insignificant); but when he controls for unemployment, the tariff coefficient becomes negative and significant. Specifically, when he adds the unemployment rate and an interaction term between tariffs and unemployment to the specification, he finds: a negative and significant unemployment coefficient; a positive and significant coefficient on the interaction between tariffs and unemployment; and a negative and significant coefficient on tariffs.

Might something similar have been at work in the late nineteenth century? Might the overall positive tariff effect my regressions have uncovered be due solely to the positive effects of tariffs during recessions? Equation (1) in Table 7.12 presents the evidence, in the context of the factor

Table 7.12 Growth and tariffs: alternative specifications (dependent variable is average annual growth rate)

\begin{tabular}{lccc}
\hline Variable & $(1)$ & $(2)$ & $(3)$ \\
\hline$D K L$ & 20.230 & 19.654 & 20.039 \\
& $(3.469)$ & $(3.162)$ & $(3.235)$ \\
$D R L$ & 10.060 & 14.254 & 14.086 \\
& $(0.754)$ & $(1.025)$ & $(1.015)$ \\
LTAR & 1.066 & 1.855 & 1.961 \\
& $(1.521)$ & $(2.823)$ & $(2.819)$ \\
CYC & 5.910 & & \\
& $(0.739)$ & & \\
LTAR $\times$ CYC & 5.062 & & \\
& $(1.244)$ & -0.000 & \\
LTAR $\times$ GDP & & $(-0.109)$ & \\
& & & -0.000 \\
LTAR $\times$ POP & & & $70.465)$ \\
& 70 & 70 & 0.416 \\
No. of observations & 0.479 & 0.414 & 0.281 \\
$R$-squared & 0.346 & 0.278 & 0.972 \\
Adjusted $R$-squared & 0.927 & 0.974 & 0.000 \\
S.E. of regression & 12.622 & 13.207 & 1.443 \\
-statistic & 0.000 & 0.000 & 1.146 \\
Prob. $(F$-statistic) & 1.443 & 1.443 & 52.915 \\
Mean of dependent variable & 1.146 & 1.146 & 1.612 \\
S.D. of dependent variable & 47.281 & 53.108 & \\
Sum of squared residuals & 1.642 & 1.613 & \\
Durbin-Watson stat. & & & \\
\hline
\end{tabular}

Note

$t$-statistics are in parentheses. Estimation: OLS with fixed effects. Fixed effects omitted. 
accumulation model. The $C Y C$ variable here is identical to that used earlier; i.e. it is the deviation from trend output. There is no evidence that the growth effects of tariffs are solely due to their impact during recessions. To be sure, the coefficient on tariffs is lower than in the simpler specifications of Table 7.7, down to 1.066 from 1.853 , and has a $p$-value of 0.133 . On the other hand, the coefficient is still positive; moreover, the fact that the coefficient on the tariff-cycle interaction term is positive suggests that tariffs were more effective during expansions, not less. If tariffs helped boost growth, this is not solely due to some recession effect. ${ }^{15}$ The positive correlation between tariffs and growth, which this section has uncovered, seems surprisingly robust, given the contrary evidence emerging from the late-twentieth-century data.

\section{Discussion}

It appears that the Bairoch hypothesis (that tariffs were positively associated with growth in the late nineteenth century) holds up remarkably well, when tested with recently available data, and when controlling for other factors influencing growth. If the result is accepted, these questions naturally arise: what are the economics underlying the result, and why was the late nineteenth century so different from the late twentieth century? Thus far, this chapter has been silent on the mechanisms through which tariffs influenced growth, and it has been silent for a specific reason: partial correlations such as the ones presented above are the basis for today's conventional wisdom, almost universally accepted among economists and policy-makers, that openness is good for growth. Clearly, it makes sense to see what the same methodology implies about the links between tariffs and growth in an earlier period. Nonetheless, a constant theme of O'Rourke and Williamson (1999) is that late-twentieth-century economists should think harder about the mechanisms underlying their partial growth and convergence correlations. While answering the questions posed above is beyond the scope of this chapter, in this section I make a start, by suggesting possible avenues for further research.

Bairoch himself argues that free trade was bad for French growth, as it exposed the agricultural sector to cheap New World and Ukrainian grain. This reduced agricultural incomes, and hence the demand for industrial products. While it might be possible to rationalise the argument in the context of models incorporating transport costs, in which domestic market size matters, theoretical objections to the argument are easier to envisage. If protection boosted growth, a more straightforward explanation would involve appealing either to the impact of protection on the relative price of capital goods, to learning effects, or to the structural impact of protection.

The first hypothesis is suggested by Williamson (1974), who argued that United States Civil War tariffs increased the United States savings and 
investment rates, by lowering the price of capital goods relative to (heavily tariffed) final goods. Williamson's argument is that construction was nontraded, and thus did not benefit from protection, while "with the outstanding exception of railroad rails, finished capital goods were rarely traded in this phase of American development' (Williamson, 1974: 657). Presumably this rise in the savings rate should have boosted growth rates, other things being equal. An appealing feature of the argument is that if capital goods have become increasingly traded over time, as seems plausible, then this could explain the contrast between the late-nineteenth and latetwentieth-century evidence; indeed, there is considerable late-twentiethcentury evidence to suggest that the relative price of capital is inversely related to economic growth (De Long and Summers, 1991: Jones, 1994), and that protection can slow growth by reducing capital goods imports (Taylor, 1994; Lee, 1995).

In a recent paper, Collins and Williamson (1999) provide more systematic evidence that tariffs lowered the relative price of capital goods during this period. They calculate the price of capital goods, relative to consumption goods, between 1870 and 1950 for eleven countries: my ten, minus France, plus Finland and Japan. They then run a series of regressions explaining the relative price of capital goods, where each observation refers to a particular country during one of the periods 1870-85, 1885-1900, 1900-13, 1913-29, 1929-39 and 1939-50. Controlling for GDP per capita and GDP, and including time dummies, they find that a ten-percentagepoint increase in the tariff rate was associated with a 7.6 per cent decline in the relative price of capital goods (and a 25.6 per cent decline in the relative price of equipment). Moreover, they find that the investment rate was negatively and significantly related to the relative price of capital. In my sample, a bivariate regression of the savings (i.e. investment) rate on the tariff (both variables measured in logs) produces a coefficient of 0.38 , with a $t$-statistic of 6.45 , consistent with Collins and Williamson. However, the relationship is sensitive to the inclusion of country fixed effects, which are not included by Collins and Williamson (incorporating them into the regression reverses the sign of the coefficient, which becomes -0.15 , with a $t$-statistic of -1.24). The fact that the investment share is negatively related to growth when an augmented Solow model is estimated for this data set is also a problem for the hypothesis, although the argument clearly provides a promising avenue for future research. ${ }^{16}$

The factor-accumulation model, which controls for increases in both the capital-labour and land-labour ratios, suggests that tariffs had a positive impact on total factor productivity. What might explain such a finding? Several authors have addressed the venerable argument that learning-bydoing meant that late-nineteenth-century protection was good for growth on infant industry grounds. (Again, it is possible that infant industry effects might be at work in some periods but not in others, since the infant industry argument for protection requires not only dynamic scale 
economies, but underdeveloped capital markets. The technological characteristics of new industries vary over time, and capital markets have clearly become better developed over the last hundred years.) David (1970) argued that there was evidence for learning-by-doing in the United States ante-bellum cotton textile industry, but that this did not justify protection. The reason for the latter assertion was that learning, according to David, was best modelled as being a function of the cumulative time spent producing the good, rather than a function of cumulative output. In the former case, protection, which boosts output, would not speed learning. By contrast, Head (1994) finds econometric support for the notion that learning depended on cumulative output in the late-nineteenth-century United States steel rail industry: protection had a dramatic effect on that industry, and although consumers were hurt by steel rail duties, net welfare effects were positive (if small).

These studies do not by themselves provide strong support for the notion that protection boosted growth on infant industry grounds. Nor do the data support one possible corollary of the hypothesis: that protection should have been more effective in larger countries. Equations (2) and (3) in Table 7.12 interact tariffs with GDP and population respectively, and find no evidence that tariffs had a bigger impact on growth in larger countries: indeed, the interaction terms, while statistically insignificant, are negative rather than positive.

A third hypothesis is suggested by the work of Broadberry (e.g. Broadberry, 1998), who finds that the shift of resources out of agriculture can account for a significant proportion of productivity growth in countries such as Germany, the United Kingdom and the United States in the late nineteenth century. There is overwhelming evidence that internal labour markets were not well-integrated in the nineteenth century: nominal wage gaps were about 51 per cent for late-nineteenth-century industrialisers (see Clark 1957, cited in Hatton and Williamson, 1991: 382); wage gaps were 52 per cent in 1830s Britain (but only 9-13 per cent in 1890s America), even after accounting for cost of living differences. ${ }^{17}$ At first glance, the argument that protection can boost welfare by shifting labour into higher-productivity sectors appears to involve a purely static effect, but if it takes time for labour to move out of agriculture, then the reallocation of labour could indeed have an impact on measured growth rates in the short to medium run, assuming that initial agricultural employment was sufficiently high. Clearly industrial tariffs helped speed up this process, while agricultural tariffs retarded it: if, on balance, tariffs favoured manufacturing in my sample of countries, then according to this logic they would have been growth-promoting. This argument would also have the desirable effect of helping to account for the difference between the late-nineteenth and late-twentieth-century experiences: growth due to the reallocation of labour between agriculture and industry will, by definition, decline and eventually vanish as agricultural labour supplies dry up. 
Table 7.13 regresses the change in agriculture's share of GDP on the following variables: changes in capital-labour and land-labour ratios; a dummy variable for Europe, reflecting the asymmetric impact of declining transport costs on agriculture in the Old World and the New; time dummies, reflecting changing world relative prices of agricultural goods; and average tariffs. As expected, rising capital-labour ratios and falling land-labour ratios were associated with falling agricultural shares. The

Table 7.13 Structural transformation and tariffs (dependent variable is change in agriculture's share of GDP)

\begin{tabular}{|c|c|c|}
\hline Variable & $(1)$ & $(2)$ \\
\hline$C$ & $\begin{array}{c}-2.787 \\
(-1.583)\end{array}$ & $\begin{array}{c}-4.282 \\
(-1.816)\end{array}$ \\
\hline$D K L$ & $\begin{array}{l}-16.658 \\
(-1.402)\end{array}$ & $\begin{array}{l}-20.308 \\
(-1.626)\end{array}$ \\
\hline$D R L$ & $\begin{array}{c}9.893 \\
(0.436)\end{array}$ & $\begin{array}{c}9.460 \\
(0.416)\end{array}$ \\
\hline$L T A R$ & $\begin{array}{c}-1.173 \\
(-1.442)\end{array}$ & \\
\hline$L T A R \times D O L D$ & & $\begin{array}{c}-0.545 \\
(-0.520)\end{array}$ \\
\hline$L T A R \times N E W$ & & $\begin{array}{c}-2.170 \\
(-1.639)\end{array}$ \\
\hline$D O L D$ & $\begin{array}{c}-1.047 \\
(-1.304)\end{array}$ & $\begin{array}{c}2.121 \\
(0.621)\end{array}$ \\
\hline$D 1877$ & $\begin{array}{c}-0.506 \\
(-0.510)\end{array}$ & $\begin{array}{c}-0.394 \\
(-0.394)\end{array}$ \\
\hline$D 1882$ & $\begin{array}{c}-0.762 \\
(-0.826)\end{array}$ & $\begin{array}{c}-0.762 \\
(-0.826)\end{array}$ \\
\hline$D 1887$ & $\begin{array}{c}0.744 \\
(0.827)\end{array}$ & $\begin{array}{c}0.681 \\
(0.755)\end{array}$ \\
\hline$D 1892$ & $\begin{array}{c}-0.471 \\
(-0.524)\end{array}$ & $\begin{array}{c}0.537 \\
(-0.595)\end{array}$ \\
\hline$D 1897$ & $\begin{array}{c}0.331 \\
(0.358)\end{array}$ & $\begin{array}{c}0.328 \\
(0.354)\end{array}$ \\
\hline$D 1902$ & $\begin{array}{c}0.702 \\
(0.775)\end{array}$ & $\begin{array}{c}0.716 \\
(0.790)\end{array}$ \\
\hline No. of observations & 70 & 70 \\
\hline$R$-squared & 0.152 & 0.165 \\
\hline Adjusted $R$-squared & 0.008 & 0.007 \\
\hline S.E. of regression & 2.011 & 2.012 \\
\hline$F$-statistic & 1.056 & 1.041 \\
\hline Prob. (F-statistic) & 0.410 & 0.424 \\
\hline Mean of dependent variable & -1.621 & -1.621 \\
\hline S.D. of dependent variable & 2.019 & 2.019 \\
\hline Sum of squared residuals & 238.575 & 234.884 \\
\hline Durbin-Watson stat. & 2.348 & 2.340 \\
\hline
\end{tabular}

Note

t-statistics are in parentheses. Estimation: OLS. Omitted year: 1907. 
results also show a moderately strong, negative association between tariffs and the change in agriculture's share of GDP (equation (1)); that is, the decline in agriculture's share of GDP was faster when tariffs were higher.

This suggests that, in this sample of countries, tariff protection was biased in favour of industry. Not surprisingly, the effect was stronger in the food-exporting New World, which used tariffs to stimulate industry, than in food-importing Europe, which protected agriculture as well as industry (equation (2)). (The fact that Foreman-Peck (Chapter 15, this volume) concentrates solely on Europe may help explain the contrast between his results and mine, as may the fact that this chapter studies changes in output, rather than output levels.) Clearly, distinguishing between agricultural and industrial tariffs would be necessary to pursue this line of inquiry further.

\section{Research agenda}

There are several qualifications to the above exercises that need to be made, and which suggest possible avenues for further research.

First, the average tariff measure I am using is extremely crude, and may in some cases be misleading, for reasons highlighted earlier, and stressed in recent work (Anderson and Neary, 1994a; Anderson, 1995). The construction of a superior index of protection, on a uniform basis, for as many countries as possible during the late nineteenth century should be a major research priority. The fact that quotas were not as common during this period as they would become in the inter-war period makes the construction of such an index easier, and also more desirable.

It is not clear how developing a superior index of protection would affect these results. Germany was probably more protectionist than my tariff data suggest, resorting in some cases to quotas and export subsidies, Slow-growing Britain was probably less protectionist than my data suggest, assuming that revenue tariffs were not as distortionary as more conventional tariffs. Making adjustments for these two countries would probably strengthen the positive correlation between tariffs and growth, as would replacing high Victoria tariffs with lower average Australian tariffs; on the other hand, lower levels of protection in rapidly-growing Denmark would weaken the correlation uncovered in this chapter.

Second, there is always a significant sample selection issue that arises when quantitative exercises of this sort are performed with nineteenthcentury data. By and large, those countries for which data are available are countries that were already relatively prosperous. In the late nineteenth century, such countries were either undergoing, or had already undergone, their industrial revolutions. Several of these countries also enjoyed relatively large and prosperous domestic markets, and ample natural, administrative and educational resources. For both of these reasons, infant industry protection was more likely to work in these countries than 
in smaller, peripheral economies with little hope of developing a manufacturing base at that time. Indeed, in the most comprehensive study of the subject to date, Reynolds (1985) has found that the developing world benefited greatly by participating in the relatively open international economy of the years 1850-1914. Lessons from the late-nineteenthcentury core cannot automatically be extended to the late-nineteenthcentury periphery: as always, more research on southern and eastern Europe, as well as the developing world, should be high on the agenda of cliometricians.

Third, as already stressed, we need further research to establish whether the mechanisms identified by theory were in operation during this period: correlation on its own is not enough. For example, it is always possible that average tariffs may be proxying in this period for the willingness of governments to get involved in the economy, something which Gerschenkron (1962) believed might be beneficial in a 'backward' society. Of course, precisely the same point - that correlations are not enough can be made about post-1945 studies which show a positive link between growth and free trade. Thus, it is equally possible that late-twentiethcentury tariffs may be proxying for a range of other policies that are bad for growth. The relationship between trade policies and government intervention more generally needs to be explored; and cross-country regressions need to be supplemented with more individual country and industry studies.

Finally, and related to the previous point, the theoretical papers cited in the introduction typically assume that sectors differ in important ways, and that protection matters for growth by altering the structure of the economy. The previous section ended with the suggestion that tariffs may have mattered in the late nineteenth century by altering the allocation of resources between agriculture and industry, which of course implies that a multi-sector model, with disaggregated tariffs, is appropriate for understanding the relationship between protection and growth. Single-sector models, of the sort suggested by much growth theory, may not be the most appropriate for the issue at hand. Of course, precisely the same comment applies to the many empirical studies finding a positive association between openness and growth in the late twentieth century, on which this chapter is modelled.

\section{Appendix 7.1 Data sources}

Data on population, real GDP, coal consumption and tariffs were taken from the database underlying Collins et al. (1997). Collins et al. discuss their data sources in an appendix; the population and real GDP figures are from Maddison (1995); coal consumption and tariff data are mostly from Mitchell $(1992,1993,1995)$. Italian tariff rates were kindly provided by Giovanni Federico; Australian tariff data prior to 1901 were constructed 
from data in the Victorian Year-Book (various editions). In addition, the following data were required.

\section{Land}

Australia, Denmark, France, Germany, Sweden, UK, US: the data were generously provided by Alan Taylor. In turn, those data were based on the numbers used by O'Rourke et al. (1996), who discuss the underlying (national) sources in some detail. The only changes made by Taylor were to convert land endowments to thousands of acres. (In addition, grazing areas were added to the US land endowment.) For details, see Taylor (1996: 21). Canada: area of land in farm holdings; census years, Statistics Canada (1983), series M23 (with geometric interpolations for non-census years). Italy: for 1861, 1892, 1905, 1909, statistics for total land under cultivation were generously supplied by Giovanni Federico; data for intervening years derived by geometric interpolation. The figure for 1909 was accepted for 1910-13. Norway: based on data in Statistics Norway (1995), Table 14.7. For 1900, 1907 and 1917, statistics exist for total area of fully cultivated land; data for intervening years derived by geometric interpolation. For 1865, 1875, 1890 and 1900, statistics exist for area under grain, dry peas and potatoes. The ratio of this area to the total fully cultivated area which applied in 1900 is assumed to apply in 1865, 1875 and 1890, yielding estimates for total fully cultivated area in those years. Intervening years derived by geometric interpolation.

\section{Enrolment rates}

Enrolment rates are crude ratios of primary plus secondary enrolments divided by total population. European population figures are all taken from Mitchell (1992), Table A5. Australia: population from Mitchell (1995), Table A5; primary plus secondary enrolment from Mitchell (1995), Table 11. Canada: population from Mitchell (1993), Table A5; total school enrolment from Mitchell (1993), Table 11. Denmark: primary and secondary enrolment rates from Mitchell (1992), Table 11; data missing for 1875-9, 1880-4 and 1885-9; data for 1875-9 and 1885-9 are taken from Easterlin (1971), Table 1, p. 426; data for 1880-4 derived by geometric interpolation. France: Mitchell (1992), Table 11. Germany: Mitchell (1992), Table 11 (for 1910); 1875-9 and 1885-9 data from Easterlin (1971), Table 1, p. 426; intervening data derived by geometric interpolation. Italy: Mitchell (1992), Table 11. Norway: Mitchell (1992), Table 11. Sweden: Mitchell (1992), Table 11; only primary school data are available before 1890; total enrolment rates prior to 1890 were derived by assuming that the total enrolment rate was 2 per cent higher than the primary school enrolment rate; the figure for 1880-4 was derived by geometric interpolation. UK: British enrolment rates are used. Enrolment 
data are from Mitchell (1992), Table 11; before 1904 only primary school data are used; total enrolment rates prior to 1890 were derived by assuming that the total enrolment rate was 2 per cent higher than the primary school enrolment rate. USA: population from Mitchell (1993), Table A5; primary plus secondary enrolments from Mitchell (1993), Table 11; data are missing for 1875-9

\section{Imports}

Australia: Mitchell (1995), Table E1. Canada: Mitchell (1993), Table E1. Denmark: Gammelgård (1985), Table 4. France: Lévy-Leboyer and Bourguignon (1990), Table AIII. Germany: Hoffmann (1965), Table 127. Italy: ISTAT (1958), Table 84. Norway: Statistics Norway (1995), Table 18.1. Sweden: Johansson (1967), Table 51. UK: Mitchell (1988), p. 453. USA: US Department of Commerce (1975), Part 2, series U193.

\section{Nominal GDP}

Australia: Vamplew (1987), series ANA 64. Canada (GNP): Urquahart (1986), Table 2.9. Denmark: Johansen (1985), Table 10.1. France: Toutain (1987). Germany: Hoffmann (1965), Table 248, col. 5. Italy: Rossi et al. (1993), Table IB (1890-1914); the ISTAT series for 1870-90, given in ISTAT (1958), Table 111, is spliced on at 1890. Norway: Mitchell (1992), Table J1. Sweden: Krantz and Nilsson (1975), as reported in Mitchell (1992). UK: Feinstein compromise estimates, Mitchell (1988), p. 836. USA (GNP): Romer (1989), Table 2.

\section{Investment}

Australia: Vamplew (1987), series ANA 103 (1870-1900), sum of series ANA 107 (public) and ANA 71 (private) (1901-14). Canada: Urquahart (1986), Table 2.2. Denmark: Johansen (1985), Table 10.3. France: LévyLeboyer and Bourguignon (1990), Table A-III. Germany: Hoffmann (1965), Table 42, Italy: Rossi et al. (1993), Table 2B (1890-1914); ISTAT (1958), Table 118 ('Totale') (1870-89). Norway: Mitchell (1992), Table J1. Sweden: Mitchell (1992), Table Jl. UK; Mitchell (1988), pp. 832-3. USA: Kuznets (1961), Table R-29.

\section{GDP deflator}

These were calculated by comparing the nominal GDP figures with real GDP figures, taken from national sources. These were as follows: Australia: nominal GDP deflated by GDP deflator, Vamplew (1987), series PC 79. Canada: price deflator direct from Urquahart (1993), Table 1.6. Denmark: Johansen (1985), Table 10.2. France: Toutain (1987). 
Germany: Hoffmann (1965), Table 249, columns 5, 7 (spliced at 1880). Italy: Bardini et al. (1995), Appendix Table 1. Norway: Mitchell (1992), Table J1. Sweden: older data from Mitchell (1992), based on Krantz and Nilsson (1975). UK: compromise estimate, Mitchell (1988), Table 5A 11SA: Romer (1989), Table 2.

\section{Share of agriculture in GDP}

European data from Mitchell (1992), Table J2. Australia: Mitchell (1995), Table J2. Canada: Urquhart (1993), Table 1.1. US: nominal GDP as above. Agricultural output: US Department of Commerce (1975). 1870-1900: farm gross product, series K 248; 1910-13: net income of farm operators from farming, series K259; missing years interpolated.

\section{Notes}

1 Originally published in the Economic Journal, 110 (2000), pp. 456-83. The author is particularly grateful to Kevin Denny, Anthony Murphy and Jeff Williamson for many helpful discussions, and to Chris Hanes and Cormac O'Grada for extensive comments on an earlier draft; he also thanks Bill CoIlins. Giovanni Federico, Evanna McGilligan of the Canadian Embassy in Dublin, Ian McLean, Michael Roche of the Australian Embassy in Dublin and Alan Taylor for making data available to him; and Bill Collins, Colin Harmon, Morgan Kelly. Elhanan Helpman, Alan Taylor. Athanasios Vamvakidis, two anonymous referees and seminar participants at Harvard and Yale for helpful comments. The usual disclaimer applies.

2 This section draws on O'Rourke and Williamson (1999: 6) who in turn largely follow Bairoch (1989).

3 Leonard Tilley. the new Finance Minister, speaking in 1979 (cited in McDiarmid, 1946: 161).

4 Foreman-Peck and Vamvakidis used earlier versions of the Maddison data (Maddison, 1991).

5 In common with the late-twentieth-century literature, I simply enter my measure of protection as an additional explanatory variable, and am thus estimating a reduced form relationship between protection and growth. However, this chapter speculates at some length about the possible mechanisms that might have linked tariffs and growth in the late nineteenth century.

6 See Chapters 1-3.

7 Countries in the Estevadeordal sample were: Argentina, Australia, AustriaHungary, Belgium, Canada, Denmark, Finland, France, Germany, Italy, the Netherlands, Norway, Portugal, Spain, Sweden, Switzerland, the United Kingdom and the United States.

8 This fact has previously been commented on by Maddison (1994) and O'Rourke and Williamson (1997). The latter paper finds stronger evidence for convergence, conditional on education, based on fixed country-specific enrolment rates. This finding survives when enrolment rates are allowed to vary over time, as is the case here: when growth rates are regressed on enrolment rates and initial income, the coefficient on education is positive and significant at the 10 per cent level, while the coefficient on initial income increases to -0.734 (with a $p$-value of 0.118 ). 
9 When the dependent variable is the log of the average tariff, rather than the average tariff, the $R^{2}$ is 0.862 (not shown).

10 The results (not shown) are available on request from the author.

11 In response to a referee's suggestion, I tried replacing the log of the average tariff with the average tariff itself. The qualitative results remain unchanged; for example, when the average tariff is used in (3), the tariff coefficient is 10.82 , with a $t$-statistic of 1.860 ; when it is used in (5), the tariff coefficient is 5.41 , with a $t$-statistic of 0.881 .

12 The Italian coefficient seems absurdly high; inspection of Tables 7.1 and 7.4 reveals that Italian tariffs did indeed increase after 1895, at the same time that the economy's growth rate accelerated significantly. There are also severe problems regarding the data on Italian land inputs (see Appendix 7.1). Reassuringly, the positive correlation between tariffs and growth does not depend on these Italian observations. Excluding Italy, a simple factor accumulation model with country dummies produces a tariff coefficient of 1.424 , with a $p$ value of 0.027 . This is lower than the coefficient in equation (2) of Table 7.7, but it is large and positive nonetheless.

13 The coefficient on $C Y C$ in the regression (not shown) is -0.830 , with a $t$-statistic of -2.669 .

14 The coefficient on $C Y C$ in the regression (not shown) is -0.271 , with a $t$-statistic of -0.862 .

15 On a somewhat related note, neither is it the case that current tariffs have a positive effect on output, while lagged tariffs have a negative effect. Adding (one-period) lagged tariffs to equation (2) in Table 7.7 reduces the coefficient on current tariffs somewhat while the coefficient on lagged tariffs is positive but statistically insignificant.

16 Note that the positive link between tariffs and growth survives if VKL is omitted in Table 7.7, as might be appropriate if DKL was a function of LTAR. For example, when $D K L$ is omitted from (2), the tariff coefficient is 1.711 , with a $t$ statistic of 2.442; when $D K L$ is omitted from (3), the coefficient is 1.226 , with a $t$-statistic of 1.635 .

17 For Britain, see Williamson (1990: 193); for the United States, see Hatton and Williamson (1991). 


\title{
8 Interpreting the tariff-growth correlation of the late nineteenth century
}

\author{
Douglas A. Irwin ${ }^{1}$
}

Immediately following World War II, many economists believed that a trade policy based on import substitution would best promote economic development. Subsequent experience instead revealed the costs of protectionism (Krueger, 1997). In the nineteenth century as well, many political economists (such as Friedrich List) advocated import tariffs to promote the growth of domestic manufacturing in countries that were behind the industrial leader, then the United Kingdom. Unlike the recent period, however, the late-nineteenth-century experience is often interpreted as confirming the wisdom of import substitution. ${ }^{2}$

Recent work by Kevin H. O'Rourke (see this volume, Chapter 7) and Michael A. Clemens and Jeffrey G. Williamson (2001) has strengthened this impression by finding a positive correlation between import tariffs and economic growth across countries from 1875 to 1914. Such a correlation does not establish a causal relationship between tariffs and growth, but it is tempting to view the correlation as constituting evidence that protectionist or inward-oriented trade strategies were successful during this period. This chapter argues that such a conclusion is unwarranted and that the tariff-growth correlation should be interpreted with great care. First, several individual country experiences in the late nineteenth century are not consistent with the view that import substitution promoted growth. For example, the two most rapidly expanding high-tariff countries of the period (Argentine and Canada) grew because capital imports helped stimulate export-led growth in agricultural staples products, not because of protectionist trade policies.

Second, most land-abundant countries (such as Argentina and Canada) imposed high tariffs to raise government revenue, and revenue tariffs have a different structure than protective tariffs. The fact that labor-scarce, land-abundant countries had a high potential for growth and also tended to impose high revenue-generating tariffs confounds the inference that high tariffs were responsible for their strong economic performance during this period. 


\section{The tariffs-growth relationship: country evidence}

Figure 8.1 presents the unconditional relationship between the average tariff in 1870 and the average annual growth in real per capita GDP from 1870 to 1913 for seventeen high-income "core" countries. ${ }^{3}$ Average tariffs, calculated by dividing customs revenue by the value of imports, are the most frequently used indicator of trade policy for this period. ${ }^{4}$ For these core countries the correlation between tariffs and growth is 0.68 , but a causal interpretation of this correlation is questionable.

First, the correlation is driven by several key outliers: Argentina, Canada, and the United States stand out as high-tariff, high-growth countries. Without these three countries, the correlation falls to 0.08 . These labor-scarce land-abundant New World economies had the potential for rapid growth that European countries did not possess. For example, it is doubtful that the Netherlands could have achieved growth rates equal to those of the New World economies simply by imposing a higher tariff.

Second, the core sample may be too limited. Figure 8.2 adds eleven low-income periphery countries to the sample. The inclusion of countries such as Portugal and Brazil, which had high tariffs but poor growth performance, reduces the tariff-growth correlation from 0.68 to 0.20 (or from 0.08 to -0.09 if Argentina, Canada, and the United States are excluded).

Third, a descriptive analysis of the high-tariff, high-growth outliers suggests that tariffs did not play a major role in their economic development in the late nineteenth century. For example, Argentina achieved the

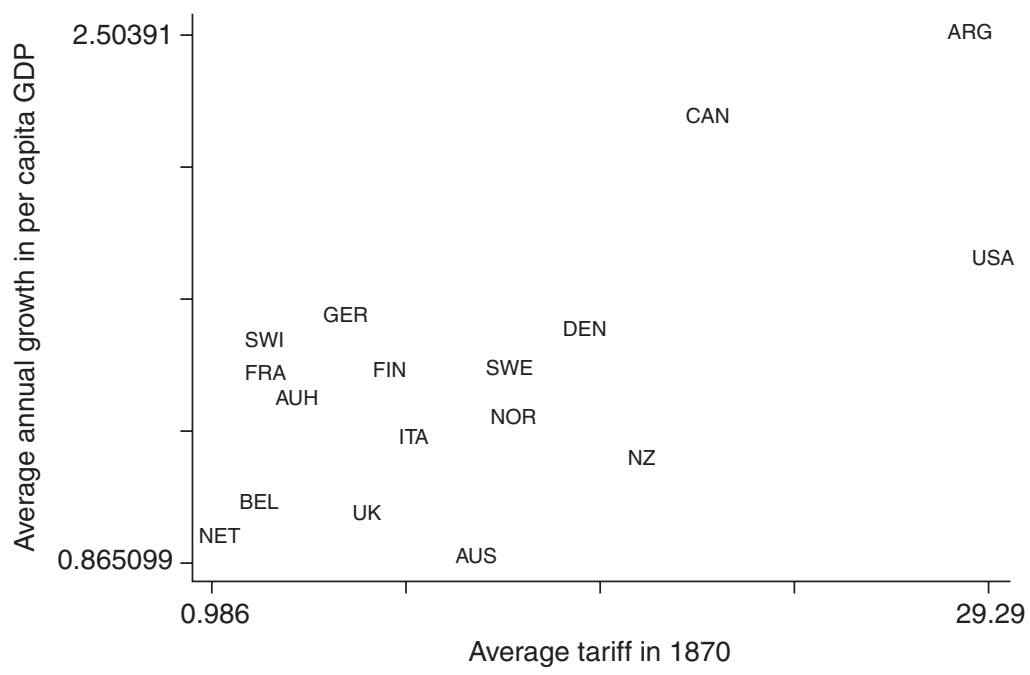

Figure 8.1 Tariffs and growth, 1870-1913: core countries. 


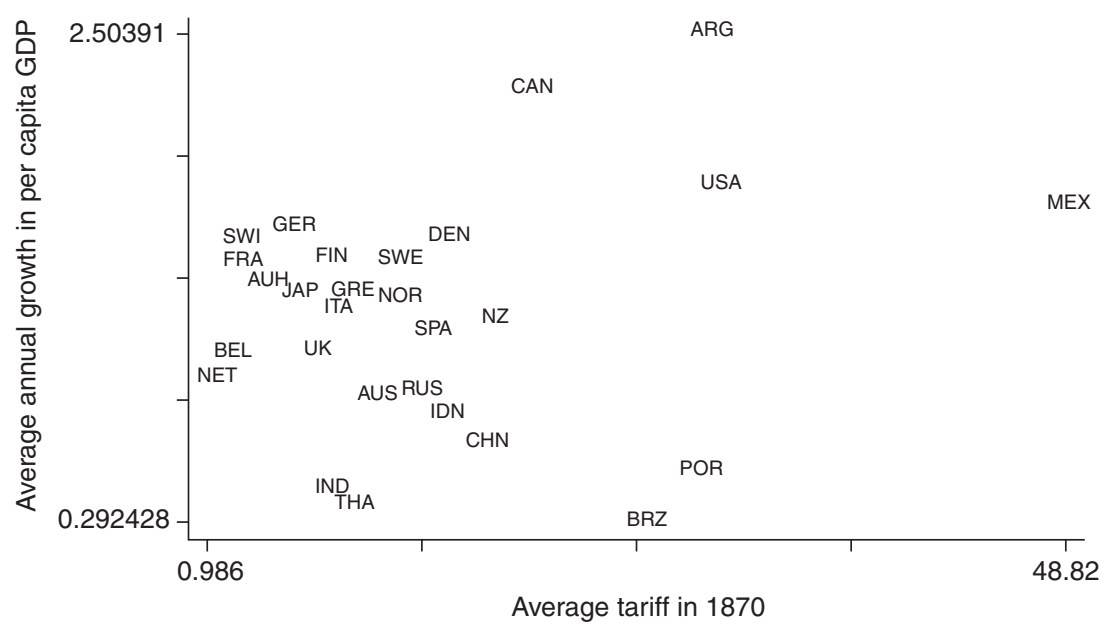

Figure 8.2 Tariffs and growth, 1870-1913: core and periphery countries.

highest recorded rate of growth in per capita income during this period and had very high average tariffs. However, its trade policy was not designed to foster inward-oriented development, and its growth was not based on industrialization achieved through import substitution. Argentina grew rapidly because it experienced an investment boom that led to an export boom in staple products. Argentina received massive foreign investment (particularly from Britain) in the 1880s that resulted in the construction of thousands of kilometers of railroad track and other infrastructure-related public works. This literally paved the way for an enormous expansion in exports, particularly wheat and livestock. As Roberto Cortés Conde (1993: 75) explains, the "growth which changed Argentina was based on the exploitation of staples: agricultural and cattle products which found an outlet in international markets."

Argentina's tariff code was not designed to promote industrialization based on import substitution, and "industrial growth did not stem from protectionist tariffs" (Cortés Conde, 1993: 68). ${ }^{5}$ As a by-product of the expansion of agricultural exports, complementary activities, both in manufacturing (food processing) and in services (transportation and construction), arose and absorbed an increasing share of the labor force. Capital investments were directed toward activities that would develop, facilitate, and service the agricultural exports and were not undertaken to produce goods domestically in replacement of imports. Thus, "manufacturing growth came mainly from export expansion plus growth of the domestic market, with import substitution playing a minor role" (Lloyd Reynolds, 1985: 88). Canada was another high-tariff country that grew rapidly from 1896 to 1913, but this growth was not the result of import substitution or an inward-oriented development strategy. Like Argentina, Canada experi- 
enced "a classic investment boom, a major part of it related directly or indirectly to the settlement of the west ... that the settlement of the west was based on the expectation, in the minds of the settlers, of there being a viable [international] market for wheat is beyond doubt" (Urquhart, 1986: 35-6). Substantial investment in railroads (such as the Canadian Pacific Railroad extending into the prairies) in the 1880 s made possible an export boom in Canadian staple products, particularly wheat and flour. Industrialization was not critical to Canada's growth; indeed, during the period of its most rapid growth, from 1891 to 1911, the share of the labor force in Canadian industry (manufacturing and construction) was unchanged.

Thus, two high-tariff countries did grow rapidly, but export-led growth is a better description of their development process than import substitution. What about the link between tariffs and growth in other countries? In the United States, high tariffs on manufactured goods originally imposed during the Civil War were kept in place after the war, but the United States overtook Britain in terms of per capita income primarily by improving its productivity in the service sector, not in manufacturing (Broadberry, 1998; Irwin, 2001). Figure 8.1 suggests that, in Western Europe, the variation in tariff levels and the differences in growth performance were relatively small, making it difficult to draw firm conclusions.

Australia is an interesting case to consider. At first glance, Australia has characteristics similar to Argentina and Canada, being an agricultural exporter with high tariffs, abundant land, and scarce labor. Unlike the others, however, Australia grew slowly during this period, perhaps due to the fact that its share of employment in agriculture was already low by 1870, and therefore the possibility of growth through structural change was limited. Australia is also intriguing because each of the several colonies there pursued independent trade policies before federation in 1901. The two largest colonies, New South Wales and Victoria, adopted different tariff policies: New South Wales eschewed tariffs and embraced free trade, while Victoria imposed protectionist tariffs to promote manufacturing. The outcome of this experiment suggests that tariffs were not decisive: as measured by the level or the growth of per capita GDP, economic performance in the colonies was not all that different (Haig, 2001).

Some countries did pursue import-substitution policies during this period. In Russia, for example, "this process of import substitution and export promotion was actively fostered by the government through tariff protection, government orders, location of railways and the railway rate structure, and export premiums" and "was particularly dramatic for cotton fibre, copper, steel, cloth and many types of machinery," according to M. R. Dohan (1991: 215). Russia grew rapidly after the 1880s, but doubts remain about the degree to which the tariff protection helped manufacturing overall. ${ }^{6}$ Mexico also imposed high tariffs and brought about 
"substantial import substitution, particularly in textiles, clothing, processed foods and beverages, tobacco, cement, and other building materials" (Reynolds, 1985: 100). Whether restrictive trade policies were responsible for the strong growth is still open to question. Thus, the relationship between trade policy and economic performance is a complicated issue that cannot be inferred from a simple correlation alone. As Cynthia Taft Morris and Irma Adelman (1989: 1420) conclude

success along this inward-oriented growth path varied greatly [in the late nineteenth century] ... in moderately backward, import-substituting countries protection levels varied greatly and did not systematically accelerate economic growth.... In sum, the effects of tariff policies are complex and vary greatly across countries in ways depending strongly on resources, institutions, and government strategies.

\section{What explains the high tariffs?}

Why did export-oriented countries such as Argentina levy high tariffs if they did not employ them as part of an import-substitution trade strategy? In many cases, import duties were primarily designed to raise fiscal revenue for the government. Figure 8.3 illustrates that labor-scarce, landabundant countries often relied on customs duties to generate a large proportion of their government revenue. Figure 8.4 shows that these countries also tended to impose high tariffs.

Land-abundant countries tended to impose high tariffs for public finance and for political economy reasons. In terms of public finance,

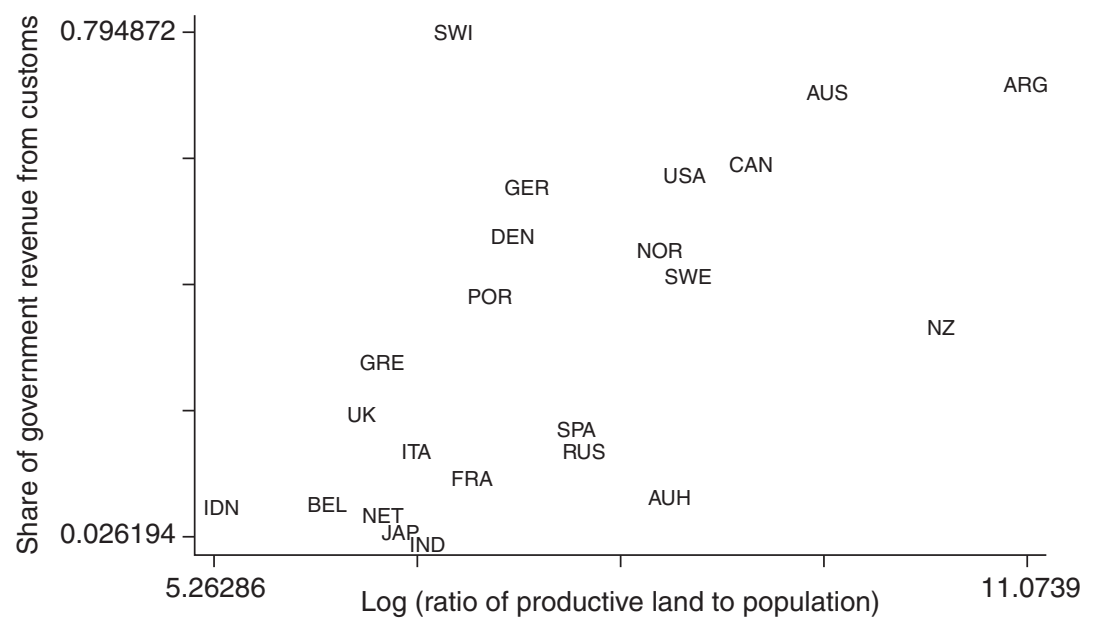

Figure 8.3 The fiscal importance of customs duties in 1890. 


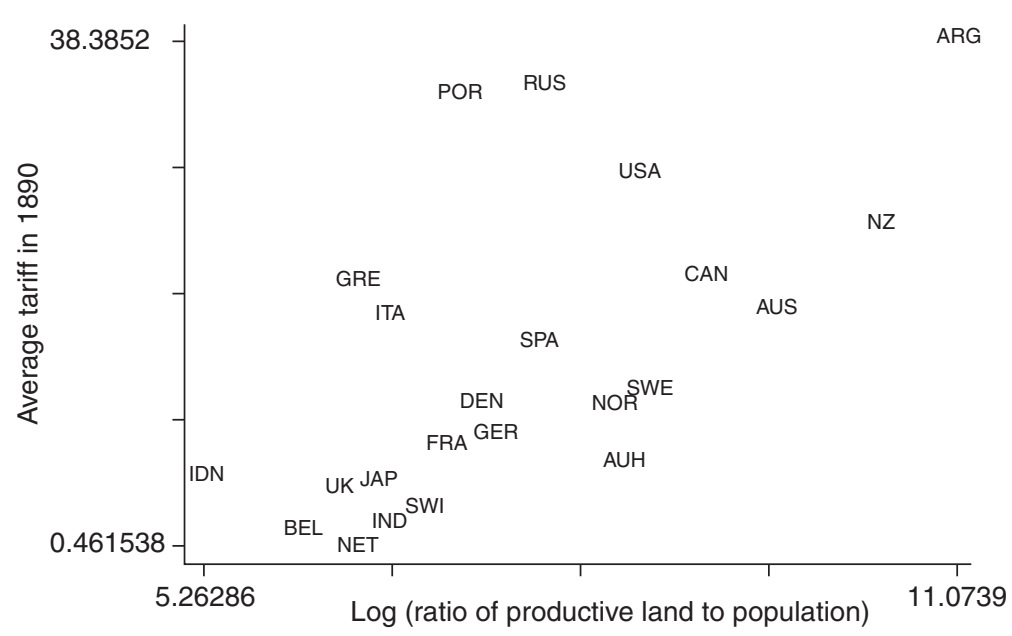

Figure 8.4 Average tariffs and relative land abundance in 1890.

import taxes made sense for countries with low population densities. Other means of raising revenue (excise taxes, land taxes, income taxes, etc.) were not as feasible or as enforceable in countries with a widely dispersed population, particularly in the late nineteenth century. The taxation of foreign goods arriving at the nation's ports reduced the problem of tax compliance. In terms of political economy, if a majority of the population owns land (or if the government is controlled by landowners), they may have an interest in avoiding direct taxes on land in favor of high taxes on imported luxury goods. ${ }^{7}$

Revenue tariffs can be structured quite differently from protective tariffs and were not necessarily designed to protect domestic producers from foreign competition. Revenue tariffs are often levied on just a few key commodities (such as alcoholic beverages, coffee and tea, sugar, and tobacco) but are capable of raising more revenue than broadly based tariffs designed to protect domestic producers. In the case of Argentina, import duties on most capital goods and intermediate products related to the production and exports of staples entered duty-free (such as machinery, iron and steel, chemicals, etc.), whereas imported consumption items (sugar, wine, etc.) were heavily taxed. The United Kingdom pursued a policy of free trade and did not use the tariff to discriminate in favor of domestic producers but still levied import duties on non-competing goods (such as sugar, tea, and coffee) and on other goods (tobacco manufactures) to balance domestic taxes on producers (Irwin, 1993).

Thus, high tariff measures (customs revenue divided by imports) are an imperfect indicator of a country's trade-policy orientation and may not always reflect protectionist policies. Despite high measured tariffs, both Argentina and Canada ranked among the most open economies in the 
world in 1913, according to Antoni Estevadeordal's (1997) factorendowment-based indicators of "openness" to trade.

\section{Conclusions}

This chapter has questioned whether the correlation between tariffs and growth in the late nineteenth century by itself reveals anything about the relationship between trade policy and economic growth. Rapid growth in Argentina and Canada, two high-tariff, high-growth outliers, was based on an export orientation in staple products, not industrialization based on import substitution. Labor-scarce and land-abundant countries such as Argentina and Canada often used import tariffs as a means of raising government revenue. Those attributes (as well as sound political institutions and other economic policies) also gave those countries unusually favorable prospects for economic growth. Rather than higher tariffs causing higher growth, the relationship could be spurious: land-abundant countries relied on customs duties to raise government revenue and also enjoyed favorable growth prospects, with little link between the two.

\section{Notes}

1 Department of Economics, Dartmouth College, Hanover, NH 03755. I thank seminar participants at University College, Dublin, the London School of Economics, and the University of Warwick for helpful comments.

2 Writing in The Cambridge Economic History of Europe, Paul Bairoch (1989: 69) concluded that "protectionism [equaled] economic growth and expansion of trade; liberalism [equaled] stagnation in both" in the late nineteenth century.

3 The core includes most of Western Europe as well a Argentina, Australia, Canada, New Zealand, and the United States. The eleven low-income countries of the periphery are Greece, Spain, Portugal, Russia, Japan, China, India, Indonesia, Thailand, Brazil, and Mexico. GDP data are from Angus Maddison (2001).

4 Other trade-policy instruments, such as import quotas, voluntary export restraints, and anti-dumping duties, were rarely employed during this period. However, this tariff measure is a crude indicator of trade policy because it provides no information on the structure of protection across industries or sectors.

5 Carl E. Solberg (1987: 106) notes that "Although some Argentine industries did enjoy marked tariff protection, no government during the 1880-1930 period attempted a consistent protectionist policy to spur industrial growth through massive import substitution."

6 The tariffs are commonly believed to have given certain manufacturers significant market power, to the possible detriment of other manufacturing industries. Paul R. Gregory (1994: 60-1) states that "there is no evidence of discretionary tariffs to favor specific industries or to encourage foreign industries to locate behind Russian tariff walls. Manufacturing inputs were taxed at the same rates as manufacturers."

7 As D. C. M. Platt (1972: 78) writes, with respect to Argentina and other Latin American countries,

each of the Republics was feeling the pressure for more revenue, and for each, governed as it was by a landed oligarchy with a rooted distaste for 
direct taxation, the only obvious source of increased revenue was taxation on a larger import trade.... A system of federal inland revenue was not developed in Argentina until as late as 1891, and in the mid-1890s the Customs House was accounting for between 70 and 80 percent of federal government revenues.

As Solberg (1987: 106) notes, "the political base for a reorientation of Argentine economic policy toward protected industrialization did not exist [prior to the First World War], for the pampa landed elite agreed with farmers as well as urban consumers that protectionism in an export-oriented economy would raise the cost of rural production and reduce aggregate real incomes." 


\title{
9 The impact of late-nineteenth- century tariffs on the productivity of European industries $(1870-1930)^{1}$
}

\author{
Jean-Pierre Dormois ${ }^{2}$
}

The last quarter of the nineteenth century witnessed a spectacular revival of tariff protectionism in Europe, following decades of continuous expansion of world trade and trade liberalisation, which brought tariff barriers down to historical lows. A first round of tariffs were passed in virtually all the Continental countries ${ }^{3}$ at the juncture of the 1870s and 1880s, primarily to fend off the 'grain invasion' from the 'new worlds' (Kindleberger, 1975; O'Rourke, 1997) and isolate domestic farmers from outside competition: in Italy in 1878, in Germany in 1879, in France in 1881. These proved inadequate, however, and duties had to be raised and extended in the following decades (in 1887 and 1895 in Italy, in 1892 and 1910 in France, in 1902 in Germany) while other countries (those with control on their trade policy ${ }^{4}$ ) followed suit when time came to renew their trade agreements with their main partners. Only a handful held steadfastly to the free-trade stance they had committed themselves to previously (most notably Denmark, Holland and Britain). ${ }^{5}$

While this reversal in trade policy was primarily aimed at sheltering agricultural home production, industrialists who felt threatened were quick to approach governments to obtain protection for their interests and compensation for the higher prices now demanded for foodstuffs and raw materials. Indeed, it was the coalition of agricultural and industrial interests that made the introduction of tariff reform successful (Gerschenkron, 1943; Lebovics, 1988). Since the 1850 s the reduction of import duties had proceeded on the pattern set by France and Britain in 1860: in exchange for the removal of British duties on foodstuffs and some luxury goods, France had agreed to repeal its industrial protection. The adoption of the Most Favoured Nation clause had thereafter spread this pattern across the Continent. Fortunately a string of good harvests combined with dramatic transport-cost reduction enabled governments to remove the moving scale ${ }^{6}$ and other hurdles to free circulation, boosting agricultural production in those countries which had most to fear from the opening of their domestic market.

Accordingly, scholarly attention has tended to focus on agricultural tariffs - in part because of their overwhelming influence on the standard of living of the bread-eating public - which, as Frédéric Bastiat reminded 
his readers, made up the majority of any nation. The effects of industrial tariffs by contrast have been much more difficult to disentangle, prudence enticing economists to pay attention to the Listian argument on 'infant industries'.

Once the legitimacy of tariff protection was reasserted for industrial as well as agricultural producers, candidate industries were successfully included under the principle of 'first seated, first served'. Parliamentary committees in charge of drafting the tariff bills heard representatives of industrial interests keen to secure protection for their products and depended to a large extent on the information they supplied. This process accounts for the growing complexity of industrial tariffs at a time when manufacturing output was itself diversifying ${ }^{7}$ as well as the 'run-for-shelter' pattern observed among industrial producers. This was illustrated later by David Low, the cartoonist who used the metaphor of the arrival of a longawaited bus at rush hour.

The avowed aim of policy-makers and business representatives was to grant tariff protection to all branches of the domestic economy regardless of their status. Thus Méline stated: 'The committee has considered that it was not in a position to include or exclude any kind of work and that, consequently, all were owed equal treatment'. ${ }^{8}$ While the egalitarian proclamation was sure to find immediate appeal among voters, the claim was essentially untruthful: "in order to be efficient protection must be concentrated upon some articles' ${ }^{9}$ Except in one or two special cases, the indirect

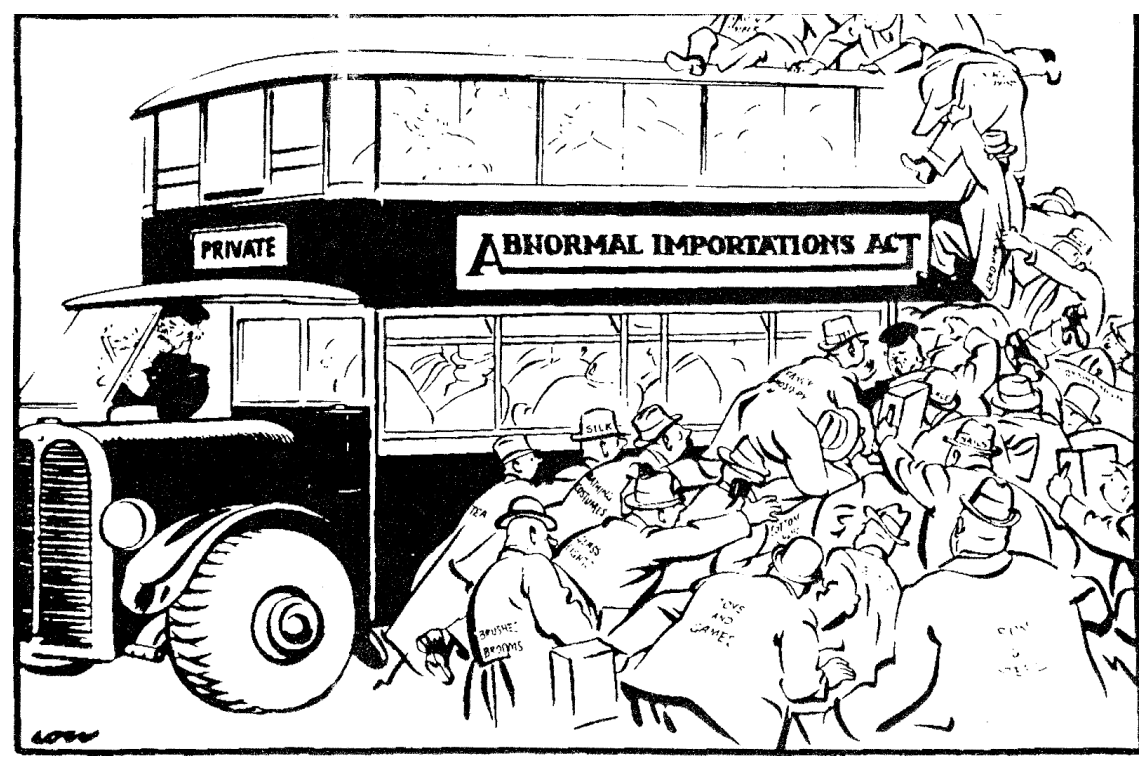

Figure 9.1 The 'Tariff Bus' at rush hour. 
subsidisation of some privileged industries was bound to be supported at the expense of the rest. However, a third - strategic - reason accounts for the protection-feeds-protection pattern observed in all protectionist countries, the fact that 'despoilment becomes less visible as it spreads':

If protection were granted to only one class of producers - iron founders say - despoilment would be so blatant that it could not be maintained. For this reason, all protected (or inspiring to be) industries tend to congregate and even admit new members into their cause; they feel instinctively that despoilment loses itself in a crowd. ${ }^{10}$

The intrinsic complexity of tariffs partly accounts for the difficulty of measuring their overall impact given their often-conflicting effects. Besides, a tariff sets off a chain reaction which takes time to permeate the production system and trickle through the cost structure. As a result, the full effects of a tariff cannot be expected to become manifest instantly.

\section{Identifying the impact of tariff barriers on industrial development}

Despite the delusion nurtured by politicians and business associations that - in Bismarck's words - 'foreigners paid for the tariff', most of its cost was passed on to the final domestic consumer. Furthermore, there is a strong suspicion among economists that protection works against the long-term benefit of protected industries themselves as it relaxes the incentives to innovate and push productivity upwards.

International trade theory usually divides the effects of a tariff on market agents into three types - in addition to the budgetary windfall on public finance: a welfare effect (consumption squeezed as a result of higher prices), a distribution effect (rents allocated to protected industries paid for by unprotected industries) and an effect on the allocation of resources (marginal firms staying in business keep attracting capital and labour despite eroding competitiveness). In Ricardo's classic model these three effects combine to depress overall productive capacity and most economists have since acknowledged that the key to understanding the gains from trade resides in the notion of comparative advantage: unhampered competition enhances the 'discovery process' by which individuals as well as nations can specialise in order to maximise their wealth creation. By contrast, tariff barriers distort the structure of production costs by holding up temporarily the profitability of ailing/marginal firms and industries by retaining resources, thereby thwarting the emergence of new, more innovative activities.

However, the empirical verification of whether, and to what extent, tariffs have a dragging effect on economic development and growth is notoriously difficult to establish. For simplicity's sake a tariff's overall 
detrimental or beneficial impact is estimated on the basis of allencompassing indicators such as the degree of openness or the implicit tariff rate (also referred as the - unweighted - nominal rate of protection). While these indicators are convenient tools to assess crudely the general state of competition, they do not provide adequate instruments for measuring the differential impact of tariffs on industrial performance.

Causality tests as well as pronouncements on the protective intensity of tariffs refer to an implicit counterfactual free-trade situation, which must always remain a figment of the imagination so long as CGE models cannot be reconstructed straightforwardly from the available information.

Traditionally, empirical studies have therefore produced conflicting conclusions on the macroeconomic, short- and medium-term effects of protectionist policies. Giles and Williams (2000) have counted around 150 econometric studies on the relationship between the level of competition in international trade and economic growth performance. The vast majority of these refer to export trade as a measure of openness and focus disproportionately on non-European economies in the second half of the twentieth century. While the vast majority of this research has concluded for the positive role played by foreign trade on economic performance, the long-term European experience has been comparatively left aside by econometricians. In this field the received wisdom has been primarily shaped by the work of historians, despite the recent contributions by economists (Foreman-Peck, 1995b; Foreman-Peck and Lains, 2000). They tend to view in the Listian vision of 'protectionism as a learning process' the alpha and omega of the role of tariffs on economic development, claiming that both Britain and the USA attained industrial power status while pursuing protectionist policies and that their adoption by Continental countries in response to nineteenth-century globalisation was a reaction of self-defence which preserved their growth opportunities. Thus, for both Weiller (1971) and Bairoch (1972, 1976a, 1989), the classical economists' free-trade prescriptions were decidedly misguided and should be regarded as either a delusion or a devious scheme by supporters of the Manchester school. Bairoch claimed that France and Germany lost out during the Free Trade era of the 1860 s and 1870 s in terms of economic and trade performance, while the reintroduction of tariffs in the following decades helped them to either maintain or extend their positions in the face of the 'great depression'. Meanwhile, Britain's continuous adherence to freetrade policies is deemed to have substantially dented her market share and competitiveness.

Bairoch's demonstration was based on the unqualified comparison for a number of European countries of indicators of overall performance (GNP/GDP growth, industrialisation 'level' or 'potential') for ten-year periods qualified as either dominantly 'protectionist' or 'free-trade' on the basis of observed aggregate rates of tariff revenue, an 'inadequate and potentially misleading indicator' as Irwin (1993: 146) rightly observes. 


\section{Jean-Pierre Dormois}

Besides, as emphasised by Capie (1983: 3), such an exercise produced only 'the appearance of a correlation'. One can cast doubts about the meaningfulness of indicators of macroeconomic performance when measured arbitrarily across the business cycle, and not, as is customary, from peak to peak or trough to trough. In addition to the disputable use of tariff revenue as the 'sole metric by which to rank-order ... countries in terms of the liberality of their commercial policy' (Irwin, 1993: 147), there is some illusion in thinking that agents' and firms' response to a change of commercial policy is instantaneous or even that trade policy can alleviate or counterbalance all the other constraints bearing on domestic production. Other powerful determinants necessarily come into line, which are simply ignored in such simplistic models, however large tariff barriers loomed among macroeconomic policy instruments. Finally, one may question the reduction of the problem to a comparison of performance indicators between Britain on the one hand and Germany on the other. The difference in the degree of protection, measured by the aggregate rate of tariff revenue, between Britain, France, Germany or Italy was not so great as to warrant any expectation of spectacular distortions - any at any rate that one could hope to be captured by major differences in the rate of economic growth (Figures 9.1 and 9.2).

The focus should perhaps switch to the contrasts in economic development between, say, the Netherlands or Switzerland on the one hand and Portugal, Greece or Romania (not to mention Russia) on the other. Economies could still grow and prosper while enforcing tariff policies which were detrimental to their medium- or long-term growth potential.

Obviously this type of historical conundrum - the 'tariff growth paradox' - cannot be satisfactorily solved on the basis of either fragmentary evidence or on the observation of coincidences between aggregates. In order to carry conviction on an issue over which scholars rarely switch positions, an explanatory model must lay out the causation chain which links the degree of competitiveness of one industry which can be best approximated through its effective rate of protection with its level of productivity performance. Such an enquiry must therefore be carried out at a relatively high level of disaggregation and break them down into different time periods. Certainly the use of GNP/GDP growth indicators as well as tariff rates has been popular in the investigation on the connection of openness and growth because of its straightforwardness and the wide accessibility of the relevant data (Mitchell, Maddison). Here we use an alternative model borrowed from Hall and Jones (1999), which links rates of effective protection by industry to indices of labour productivity relative to the 'regional' free trader, Britain.

The guiding intuition of this project is that tariffs, by relaxing competitive pressures, have stalled, at least temporarily, the process of improved resource allocation in the domestic economy, and that the loss of potential efficiency gains, at least over the medium term, can be captured in 


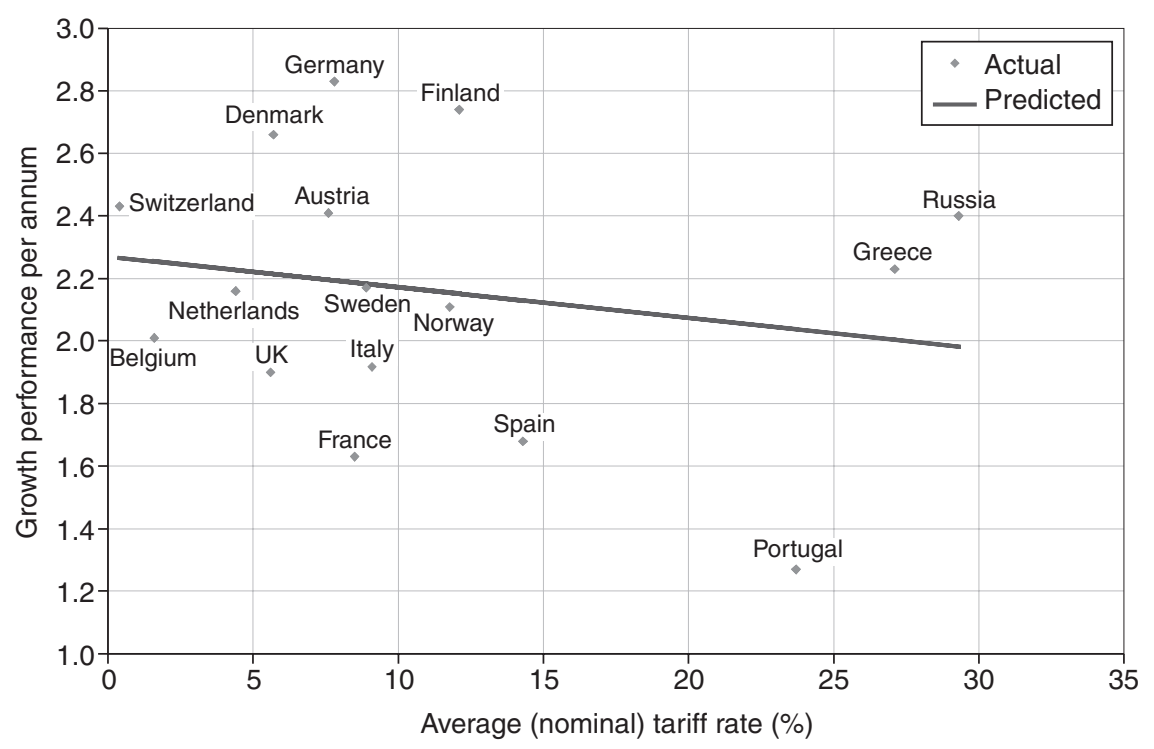

Figure 9.2 (a) Forging ahead or lagging behind: growth performance, 1870-1913 and the tariff rate in 1913 .

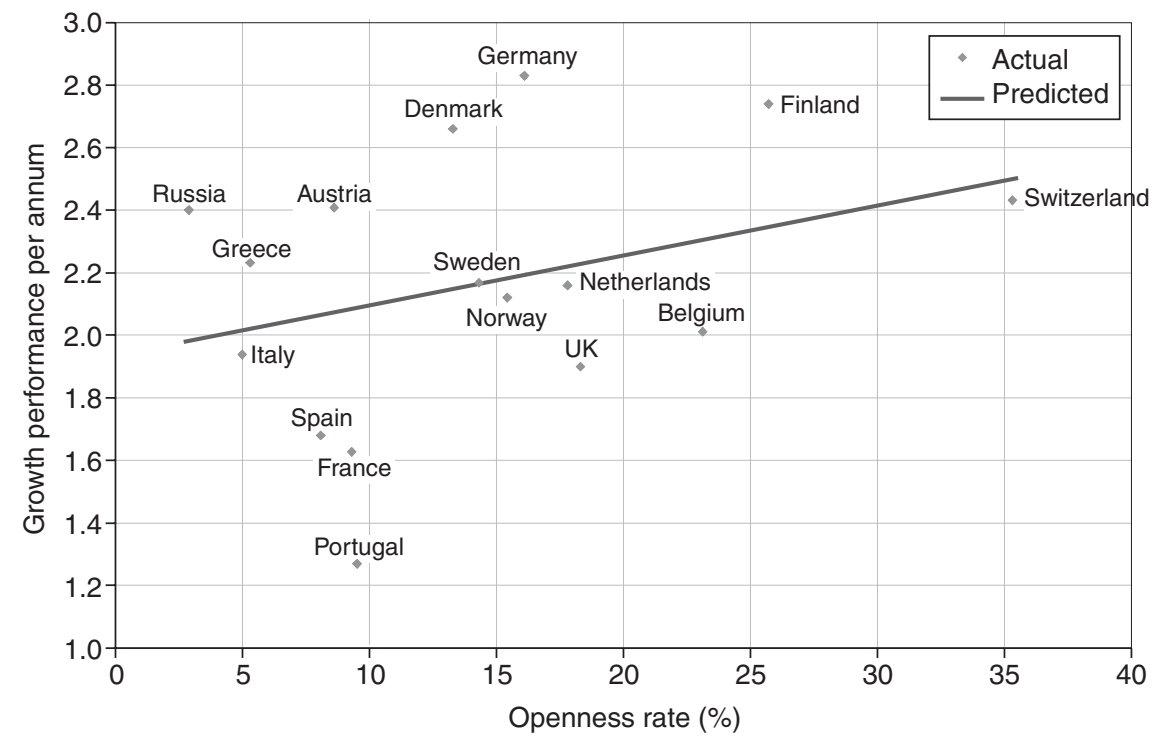

Figure 9.2 (b) Growth performance, 1870-1913 and the openness rate in 1913 (source: Maddison, 2001: 196, 377). 
relative labour productivity indicators, at least over the medium term. The comparative approach is therefore essential to the operation of such a model, as is testing at regular intervals: the statistical documentation allows just that every twenty-odd years, a periodisation which fits the traditional division of the 1870-1914 period: before the 'great depression', in the midst of it and during the prosperity spell of the 'Belle Epoque'.

Relative labour productivity affords a variable less susceptible to conflicting interpretations than output growth, while the breakdown by industry presents the adequate level of analysis of the effects of protection over relatively short time spans. A two variable panel data set stratified by year and country was therefore envisaged as the most straightforward way to test the model suggested by Ricardo that a protective tariff tends, all things being equal, to slow down productivity growth and therefore to depress productivity performance compared to a competitive situation. Two datasets were therefore constructed, both of the same size (four countries $\times$ twelve industries ${ }^{11} \times$ three benchmark years). The first encompassed indicators of labour productivity by industry in Europe's four major industrial economies at three regular intervals between 1870-1914 - thus separating the period of the 'great depression' from the subsequent recovery phase. The second set contains for each corresponding industry and date the observed rates of real effective protection (EPRs) so that we can observe the behaviour of:

$$
\text { Labour productivity }_{i j}{ }^{t}=\mathrm{a}+\mathrm{bEPR}{ }_{i j}{ }^{t}
$$

where $I$ indexes industry, $j$ country relative to UK and $t$ indexes year. ${ }^{12}$

Admittedly this approach constitutes a second best choice for attempting to gauge the impact of a tariff on production. An alternative consists in working out these effects using a GCE model à la Williamson (Federico \& O'Rourke, 2000). However, the accurate reconstruction of a realistic economy-wide or industry-wide counterfactual matrix is, if not entirely impossible, at least very problematic (see Foreman-Peck, in Chapter 15 of this book).

The competitive predicament of British industry offers the counterfactual situation for assessing Britain's European counterparts in so far that it had been for forty years the most closely approaching a free-trade situation. ${ }^{13}$ Indeed, the continuation of free-trade policies after 1875 can be regarded as a credible alternative for the governments of France, Germany or Italy. ${ }^{14}$ Relative productivity indices can be constructed for Continental Europe's industries where British performance is used as the denominator and, in turn, be linked to observed effective protection rates (EPRs).

Obviously such a procedure leaves out a number of factors, which can be regarded as paramount in determining productivity levels, which should ideally be part of a comprehensive model. ${ }^{15}$ Only if these other 
factors are orthogonal with the right-hand-side variable will the regression results be objectively meaningful. But rather than putting trade policy among the traditional 'proximate determinants' of productivity performance (capitalisation, scale of operation, labour force quality), this model hypothesises that trade policy is a key determinant of 'external' competitiveness and, as such, operates directly on the economic environment - on a different plane therefore. It figures at the end of a causation chain of what Hall and Jones labelled 'institutional infrastructures' shaping the environment in which economic activities take place and hence determine levels of efficiency (typically measured by TFP or Total Factor Productivity), of which labour productivity is a vital, as well as more accessible, element (Hall and Jones, 1999: 85). ${ }^{16}$

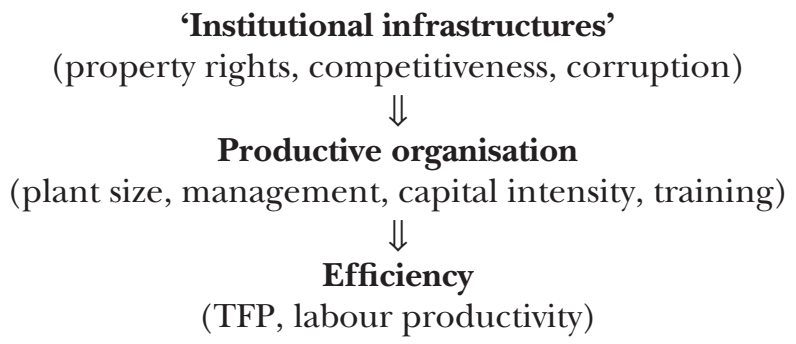

The 'machinery' for this type of operation is more sophisticated than the casual observation of coincidences between aggregates of growth and protection; at the same time it is still more manageable than the construction of a CGE model - especially ex ante (that is, in a hypothetical freetrade situation). This approach also constitutes a departure from traditional practice as far as productivity analysis has usually eschewed the association of performance indicators with not easily quantifiable qualifications about the macroeconomic environment: most of them stop at examining the impact of proximate determinants of productivity specified in a production function framework such as capital intensity or the scale of operations.

Our panel analysis requires the construction of two data-sets for each benchmark year, one yielding real for semi-finished and finished tradables for twelve classes of goods (including one for agriculture) corresponding to standard categories of the industrial classification, the other presenting relative labour productivity indicators for similar categories, expressed in relation to British performance in the same industry. It will proceed in three steps:

1 measuring effective protective intensity of tariffs by industry,

2 evaluating labour productivity by industry and by country, and

3 summing up observed correlations. 


\section{Measuring the protective intensity of European tariffs for industry, 1870-1913}

\section{Apparent or nominal protection}

If one considers nominal protection rates (also referred to as 'rates of tariff revenue'), those of the three major European powers examined here appear as relatively moderate (see Table 9.2): only Italy hovered well over the 10 per cent mark. Over most of the period, rates for Germany approximated a free-trade situation if one considers, as did most contemporaries, that up to a 5 per cent ad valorem rate a situation could be equated with free trade. ${ }^{17}$ Compared to the much higher rates registered in countries such as Russia, Spain or the Balkans,${ }^{18}$ one would not expect seriously distorting effects from such lenient forms of protectionism, especially when they were matched by internal taxes of the same magnitude. However, once rates are disaggregated by main classes of commodities (Table 9.1), a very different picture emerges.

First, industrialists were globally short-changed by their fellow agriculturalists on 'equal protection': nowhere (except in France at the end of the period) do industrial tariffs come to be nearly as high as agricultural ones. This confirms the scope of late-nineteenth-century tariffs as having been essentially geared at sheltering primary producers (and owners of their factors of production) of foodstuffs. Second, the German tariff does not appear to have provided any sort of extensive protection to industrialists throughout the period: the tariff remained decidedly below the 'freetrade ceiling' of 5 per cent ad valorem ${ }^{19}$ although a few selected sectors enjoyed relatively high protection despite the low average.

Given the intricacy of each tariff, the classes retained are not absolutely tight and that of 'raw materials' obviously encompasses goods, which have undergone preliminary transformation or conditioning - most raw materials not produced domestically being usually exempt from duty. ${ }^{20}$ Likewise the class of manufactures comprised a wide variety of goods, some heavily

Table 9.1 Disaggregated tariff rates according to different classes of commodities

\begin{tabular}{|c|c|c|c|c|c|c|c|c|c|}
\hline \multirow[t]{2}{*}{ (in \%) } & \multicolumn{3}{|c|}{1873} & \multicolumn{3}{|l|}{1892} & \multicolumn{3}{|c|}{1913} \\
\hline & $D$ & $F$ & $I$ & $D$ & $F$ & $I$ & $D$ & $F$ & $I$ \\
\hline Foodstuffs* and drink & 7.0 & 6.9 & 15.2 & 17.8 & 12.8 & 37.6 & 10.3 & 11.9 & 20.8 \\
\hline Raw materials & 0.2 & 0.2 & 2.8 & 4.1 & 1.5 & 9.1 & 1.9 & 1.6 & 2.7 \\
\hline Manufactures & 3.1 & 5.9 & 10.6 & 3.7 & 9.4 & 12.1 & 2.9 & 8.4 & 8.9 \\
\hline Overall & 3.1 & 5.4 & 9.4 & 9.3 & 10.3 & 18.7 & 8.2 & 8.8 & 9.4 \\
\hline
\end{tabular}

Notes

*including tropical goods.

D: Germany; F: France; I: Italy. 
protected, others much more lightly. A sizeable share of the trade of the three countries was in fact already mostly intra-industrial, covering therefore semi-finished goods. Rates ad valorem could vary enormously from one 'product' to the next. These differentials are accounted for by the varying degree of influence exercised by interest groups and by asymmetric information between law-makers and business experts; besides, the tariff rate for most products was fixed by trial-and-error and, once a rate was set, interested parties resisted any attempt at a downward revision. Given the wide differences existing in levels of protection, it is still possible that industrial tariffs as they stood could have introduced substantial distortions in the industrial structure of these countries. Early estimates by the Board of Trade and Liepmann suggest that actual protection on finished manufactured goods could have been much higher (at least twice as high) than that suggested by overall nominal rates depending on the weights used (see note 18).

Obviously a variety of situations must have coexisted, depending on the degree of protection enjoyed by some particular industry. Disaggregated real effective protection affords a much more accurate instrument to evaluate the actual protectionist intensity of a tariff.

\section{Lessons from real effective protection}

Table 9.A1 in the Appendix presents the first set of EPRs covering the period 1873-1913. ${ }^{21}$ Our measures of real effective protection tend to magnify - as is customary - the immediate incidence of Continental tariffs in terms of mark-up, and sharpen the divide between sheltered and unsheltered industries. The presence of occasional negative rates highlights the discriminatory effect in this regard. More generally, industries with low nominal protection often ended up with even lower effective protection. However, EPRs remained - save for Italian metallurgy - below the 50 per cent mark, a common minimum threshold for many sectors in Russia, Spain, Portugal or even the USA at the time (Woytinsky, 1955:

Table 9.2 Industrial tariffs, overall nominal rates, 1913

\begin{tabular}{lllll}
\hline & $(1)$ & $(2)$ & $(3)$ & $(4)$ \\
\hline Germany & 8.2 & 7.9 & $13-17$ & 17 \\
France & 8.8 & 8.7 & $21-4$ & 22 \\
Italy & 9.4 & 9.7 & $20-5$ & 18 \\
\hline
\end{tabular}

Source: Bairoch (1989: 76).

Notes

1 Average tariff rate in 1913.

2 Id. 1909-13 (Bairoch).

3 Average tariff on finished goods (Liepmann).

4 Average tariff on British manufactures in 1904. 
277); only fourteen industries (seven of which in Italy) enjoyed momentarily EPRs superior to 15 per cent.

In this regard the path followed by Germany on the one hand and France and Italy on the other diverged markedly; in the first case the aggregate EPR reverted at the end of the period to its initial 1870s level, while in the other two protection crept upwards, continuously diffusing itself through the output structure. As a matter of fact, EPRs produce a picture of actual protection closer to that of tariff level indices à la Liepmann; ${ }^{22}$ for 1913 , indices were 16.0 per cent for France (16.3 for manufactured goods only), 12 per cent for Germany (10 per cent) and 16.5 per cent for Italy (14.6 per cent) (Liepmann, 1938: 413-15).

As the tale of interest groups lobbying for protection would have us guess, identical industries across countries ended up securing the highest protection: metallurgy, food and drink, and textiles - this being verified even for free-trade countries such a Switzerland, Belgium or the Netherlands. Those involved large influential constituencies of well-organised industrialists and workers, which could presumably carry electoral weight (Hilsheimer, 1977). The progress of representative government in this period tended to empower the same socio-economic groups across Europe (Verdier, 1994: 5). In France and Italy, contrary to Germany, the degree of protection granted to these industries shows no sign of falling once the 'great depression' abated.

By contrast, unprotected industries were likewise invariably 'small' industries, geographically dispersed as myriads of small production units. They included sawing and paper mills, tanneries, leather and joiner workshops as well as quarries and brickworks. The interests of the chemical industry proved especially difficult to accommodate given its wide range of inputs, processes and outputs.

As tariff level indices reveal, protection bore disproportionately on semi-finished goods, burdening the costs of consumer good industries, which therefore requested compensatory duties. Those were not always adequate, as the case of Italian engineering makes clear (Toniolo, 1977). As Toniolo has argued, one would think that follower countries such as Italy would have greatly benefited from developing (occasionally with the help of tariff barriers) products for final consumption rather than intermediate staples. 'Instead exactly the opposite was done' (Toniolo, 1978: 234). An import-substitution policy could have been potentially successful, but 'mature' rather than 'infant' industries were selected for preferential treatment and semi-finished staples such as cotton yarn, iron bars, flour and sugar. ${ }^{23}$ Besides, with the unarrested expansion of intra-industry trade during this period, discrimination in favour of intermediate goods was bound to harm consumer good industries.

But perhaps this 'sensible' import substitution policy would have been impossible anyhow. What politicians were after was a 'quick fix', short-term relief for embattled industrialists who perceived their trouble 
as temporary; not an industrial strategy for the future. Besides, duties on common, relatively price-elastic staples were a 'sure bet': easily identifiable and promising to yield ample returns. Customs collections were both a means and an end, the only guide at the disposal of policy-makers to evaluate the success of a tariff and a way to increase customs proceeds to government coffers.

Preferential treatment was preferably granted therefore to established old staples which further reinforced the consensus in favour of the status quo - witness British retardation during the same period. Our expectation would be that protectionist policies should have affected resource allocation and hence relative performance of protected industries over the medium term. Labour productivity provides one tool to chart the course of productivity before and after of the introduction of tariffs.

\section{Levels of production and labour productivity in Europe's industries, 1870-1913}

The second step of this study consists in establishing series of labour productivity indicators by industry, which requires reviewing industrial production data by country for a period in which statistical information is still fragmentary. The drawbacks attendant upon the absence of systematic industrial censuses in this period are here again glaring. The reconstruction of comparable industrial accounts for the four countries at hand has necessitated the exploitation of data on domestic output as well as on industrial employment from national censuses. ${ }^{24}$

Fortunately, recent scholarship on historical national accounts offers a wealth of information, as well as checks to guide this reconstruction. For the UK and Italy we have relied extensively on the work of Charles Feinstein and Stefano Fenoaltea and Carlo Bardini respectively; their series demanded only minor reprocessing operations. For France, by contrast, despite the existence of two competitive series of industrial output for the nineteenth century ${ }^{25}$ we have worked out our own production and productivity indicators from original data while, for Germany, we have endeavoured to revise Hoffmann's widely quoted (and criticised) figures to align them with recent revisions of German NNP by Ritschl and Spoerer (1997) and Burhop and Wolf (2005).

In spite of the 'great depression', industrial production remained robust in Europe through the forty-four years leading up to the First World War. According to extant production indices, output in volume was multiplied by a factor of five in Germany, by four in Italy and 2.3-2.4 in France and the UK. Except in the latter two countries, between 1882-90, growth was evenly spread out during the whole period. 


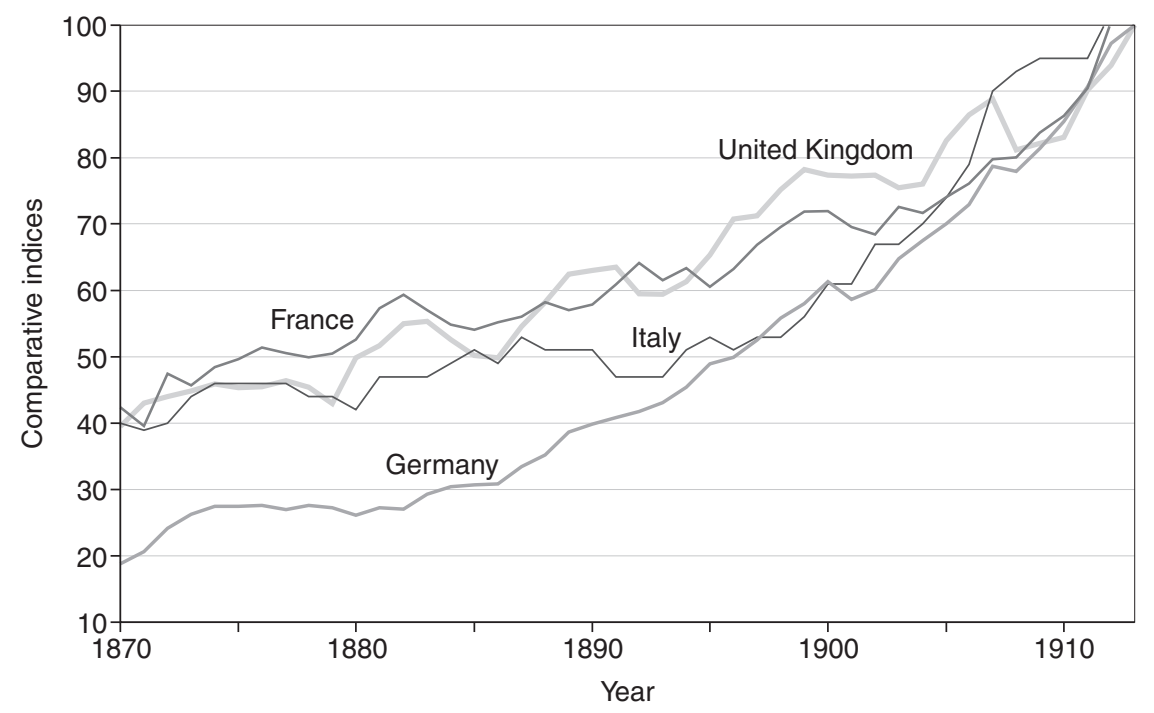

Figure 9.3 Comparative indices of industrial production, 1870-1913 $(1913=100)$.

\section{France}

France's two rival series of GNP - both constructed from the output side ${ }^{26}$ - make an informed guess difficult since the gap between the two can be substantial (close to 50 per cent by 1913). To avoid this dilemma, industrial accounts have been reconstructed for three benchmark years from the income side - a procedure not hitherto attempted. The reconstruction is based on first-hand data such as the number and distribution of the industrial population, observed wage rates and capital-output ratios. The 1896 and 1911 benchmark years, marking the end of the 'great depression' and the 'Belle époque' respectively, are documented mostly by the censuses of industrial employment taken in those two years; 1873 was selected because it represents the first 'normal' year after the FrancoPrussian war of 1870-1. Industrial classifications had to be standardised from one benchmark year to the next.

The salient features of France's active population, which reverberated on its production capacity, is the relative stability of industrial employment after 1900: this being the combined effect of stagnant demography, slowing migrations to urban centres and 'Malthusian' entrepreneurship. On this point, Méline's ambition of a 'return to the land' achieved his avowed objective of promoting a 'more balanced economy'. ${ }^{27}$

Taken globally, our own reconstructed estimates of value added in industry (including mining) ${ }^{28}$ appear remarkably close to Lévy-Leboyer's figures, despite his being worked out from the output side. By contrast, 
Table 9.3 Estimates of industrial output in France (market prices), 1873-1911

\begin{tabular}{lrcr}
\hline (in Fm) & Dormois & Léry-Leboyer & Toutain \\
\hline 1873 & 6,798 & 6,902 & 9,753 \\
1896 & 9,366 & 8,428 & 10,960 \\
1906 & 10,840 & 10,887 & 13,716 \\
1911 & 13,451 & 13,665 & 17,084 \\
\hline
\end{tabular}

Sources: see notes 24 and 25.

Toutain's reconstruction and ours are wide apart due to the original estimate for the base year (Markovitch) being unrealistic (Table 9.5).

\section{Germany}

Ever since Hoffmann's publication of his 'magnum opus' ${ }^{29}$ there has been no 'successful attempt' (Fremdling, 1995) to produce a global revision of German economic growth in the nineteenth century. ${ }^{30}$ As time wears on, a number of cracks have appeared in the master's towering edifice, based on the reconstruction of national accounts for one single year (1913) and a 'pyramid of indices' (Tipton, 1999), the components for which are particularly difficult to disentangle. Hoffmann's figures suggest a relatively backward economy by the mid-nineteenth century, a backwardness which is supposed to have lingered until the outbreak of the First World War, implying markedly inferior living standards and labour productivity performance compared to its immediate competitors, France and Britain. Such an implicit characterisation runs contrary to a vast body of evidence, starting with contemporary testimonies who acclaimed or deprecated pre1914 German technical and industrial prowess. ${ }^{31}$ Eminent witnesses of Germany's 'rise to industrial power' include such luminaries as Thorstein Veblen and John Maynard Keynes. ${ }^{32}$ Most historians writing after the publication of Das Wachstum have either ignored or waved aside the implications of his figures for their 'meta-narrative'. ${ }^{33}$ There is a strong suspicion therefore that Hoffmann's widely used figures may underestimate German industry's actual performance.

Sectoral indicators of performance as well as anecdotal evidence and testimonies suggest that the most dynamic German industries had caught up, in terms of labour productivity, with their British counterparts as early as 1870 (Broadberry, 1997:153). Given the exceptional gains recorded by Germany in the following period, it is to be expected that its performance results should be much closer to Britain's than Hoffmann's figures suggest. ${ }^{34}$ Broadberry and Fremdling have shown that, by the end of the nineteenth century, German industry had in fact overtaken Britain's in terms of labour productivity (Broadberry and Fremdling, 1990).

In order to offset a possible bias in any forthcoming comparison and 


\section{Jean-Pierre Dormois}

bridge the gap between Hoffmann's series of NNP and GNP estimates, it has been deemed necessary to reconstruct at least part of German industrial accounts for the immediate pre-1914 period (1911 has been selected as a preferred benchmark because of availability of information and matchability with other countries). This operation is limited to the industrial sector (manufacturing, mining and construction).

This reconstruction has been conducted on two fronts, the second approach serving the purpose of controlling for the soundness of the results. On the one hand, industrial value added has been reconstructed for the main branches of the sector from the income side by adding up the wage bill and capital income calculated separately. ${ }^{35}$ With regard to labour income, the wage rate obtained by reverting to contemporary compilations diverges only marginally from Hoffmann's original calculation (in fact based on previous investigations by $\mathrm{Hirsch}^{36}$ ). Meanwhile, the employment totals retained by Hoffmann for 1913 are obviously underestimated, as a recent compilation makes clear (Hohls and Kaelble, 1989). Hoffmann's figures are based on the results of the 1907 occupational census. Data from the population census of 1 December 1910 suggests continued growth of industrial employment after 1907, logically calling for an adjustment for 1911 .

Hoffmann's method for estimating capital compensation has attracted the sharpest criticisms (Holtfrerich, 1983: 126; Fremdling, 1988: 35-6; Tipton, 1999: 12). Hoffmann's complicated method for estimating profits is based on the use of pre-war tax returns for the Land of Baden and the sectoral distribution of equity observed in 1936. Given the vicinity and closeness in industrial structure, it has been assumed instead that the capital-output ratios observed in Austria at the time, as derived from the 1910 industrial census (Fellner, 1916), could supply the missing information on capital returns for German industry.

The aggregation procedure of value added estimates by branch yields a gross total of 22bn Marks, up 11 per cent from Hoffmann's own (19.6bn), a difference that can be accounted in great part by the missing capital depreciation in Hoffmann's estimates (which opted for a net definition of value added while our comparison requires gross estimates), as well as the difference between factor cost and market price evaluation. In order to extrapolate forwards (to 1913) and backwards (to 1870), Wagenführ's 1933 industrial index has been used with the help of moving weights (Hoffmann used fixed weights).

\section{Italy and Britain}

For the two remaining countries in the sample, the establishment of data on output and employment has been limited to the manipulation of existing series and their adaptation to the standard classification adopted for the other countries. 
For Italy we have relied extensively on Fenoaltea's reworking of the Istat output data for 1891 and 1911 (Fenoaltea, 1992; Fenoaltea and Bardini, 2000). The figures for 1911 have been extrapolated to 1913 using Vitali's production index. In order to obtain estimates for the starting year, 1871, we have applied Fenoaltea's correction for 1891 to this former date. The recent revisions of the data by Fenoaltea has substantially modified the descriptions of Italy's industrial profile during this period. In particular they suggest a path of industrialisation as expressed by the industrial index somewhat different from the one implied by Giorgio Fuà's earlier calculations on the basis of the Istat series. Incidentally, the 'compromise index' which has been retained here, is remarkably close to the one defended by Gerschenkron (1962: 75-6).

For Britain, the scholar treads on safer ground: British sources since the end of the nineteenth century have been both more numerous and more thoroughly searched. Feinstein's magisterial reconstruction of British national accounts for the 1855-1965 period (Feinstein, 1972) remains unchallenged.

For the end-of-period comparison, we have reverted to the data supplied by the second census of production of 1912 - belatedly published after the First World War, which presents the advantage of matching output with employment indicators. The occasional gaps in statistical information can be bridged with the results taken from its immediate predecessor, the first census of 1907 which are relatively close. Furthermore, the quasi-stability of industrial prices between 1912 and 1913 allows for a direct extrapolation of 1912 estimates to 1913 using the production index. This index, originally compiled by Paul Rousseaux (1938), serves to extrapolate backwards industrial output to 1871, 1875, 1891 and 1896, yielding output and productivity indicators expressed in 1913 prices. Reflation being extremely hazardous given the paucity of industrial prices, a comparison will necessitate the conversion of the industrial output figures for France and Italy at constant 1913 prices.

While Italy's record has suggested a roller coaster of a trajectory for industrial production in the period - 'the Kuznets cycle' (Fenoaltea, 1988, 2005) - Britain's has impressed upon most analysts the idea of a stability verging on stagnation which has fuelled a lengthy debate about the existence of a 'climacteric' (Dormois and Dintenfass, 1998).

Table 9.4 Conflicting estimates of industrial value added for Italy, 1871-1913

\begin{tabular}{lllll}
\hline Lit. million & 1871 & 1891 & 1911 & 1913 \\
\hline ISTAT & 1,623 & 1,960 & 4,335 & 4,745 \\
Fenoaltea & n.a. & 2,268 & 4,946 & n.a. \\
Here & 1,811 & 2,268 & 4,945 & 5,416 \\
\hline
\end{tabular}




\section{Jean-Pierre Dormois}

\section{Comparing labour productivity in Europe 1870-1913}

Estimating indicators of output per worker for three or more benchmark years serves a double purpose. First, when examined in a purely national framework, it helps to document the internal development of different industries. Second, it allows for transnational comparisons for identical industries. With the construction of productivity indices, it can chart the changing paths of industrialisation in different countries. In these calculations, British industries have been taken as the standard since one may regard British tariff protection on manufactured goods relative to Continental countries as nil.

Labour productivity indicators are expressed as the ratio of output (or gross value added) to labour force, taken from the contemporary occupational censuses. The benchmark years have been selected so as to have census dates match years for which the reconstruction of industrial value added was feasible.

However, concessions have had to be made to take into account the idiosyncrasies of national censuses; for instance, adjacent years were also considered as valid (O’Brien, 1995).

Thus, for the 1870s, performance as recorded in France and Germany in 1873 is supposed to be directly comparable to indicators recorded in Britain in 1871. Likewise for the 1890s, the comparison was split between 1891 (for a comparison between Britain and Italy) and 1896 (for a comparison with France and Germany). The detailed examination of the panel of productivity indicators is reserved for a later occasion. Suffice it to say that they present a great homogeneity which is interpreted here as being a guarantee for their soundness. However, in order to compare term-to-term, and for each industry in the sample, indicators need to be converted into a single currency. The pound sterling, the most internationally traded currency, has been chosen as the most expedient for this multi-bilateral comparison. There remains the choice of the 'converter' or exchange rate to be used.

Table 9.5 Census dates with corresponding dates for estimating value added

\begin{tabular}{lllll}
\hline & France & Germany & Italy & UK \\
\hline Census years & 1872,1876 & 1875 & 1871 & 1871 \\
Value added estimated for & 1873 & 1873 & 1871 & 1871 \\
Census years & 1896 & 1895 & 1891 & 1891,1901 \\
Value added estimated for & 1896 & 1895 & 1891 & 1891,1896 \\
Census years & 1911 & 1907,1910 & 1911 & 1911 \\
Value added estimated for & 1911 & 1911 & 1911 & 1912 \\
\hline
\end{tabular}




\section{Why use the official exchange rate?}

In international comparisons of output and productivity, standard procedure normally rules out the use of official (also called 'commercial') rates of exchange because of the interference of international capital transactions in the setting of the exchange rate between currencies at any given time. Correct procedure requires the use of purchasing power parity (PPP) exchange rates which can be computed at various degree of aggregation using price ratios.

Unfortunately for the period under examination, the available price information is very sparse for industrial commodities or of dubious quality for such an operation as calculating factory-gate price ratios. Wholesale prices are generally accessible for a limited range of commodities but these incur transaction costs and sales margins. Factory-gate prices, by contrast, are usually provided by production censuses and these were relatively underdeveloped in the pre-1914 era. Only in the 1920s did statistical agencies start to collect price information of this type. From 1926 onwards the Economic and Financial Department of the League of Nations (then headed by Alexander Loveday) started to publish crude 'real' exchange rates. By coupling these effective exchange rates with the appropriate price indices, we can hope to verify how close official exchange rates came to approaching purchasing power parity in the pre-1914 period.

For any European country, $E$, and for 1929, one currency unit, $N$, was equivalent to $X 1929$ US dollars:

$$
N_{E}=X_{\mathrm{US}} \cdot R_{\mathrm{PPP}}
$$

where $R_{\mathrm{PPP}}$ represents the exchange rate at PPP.

One can assume that the movement of prices for internationally traded commodities was similar across countries over the period 1913-29. For year $t$, the value of $N_{E}$ can be expressed relative to 1929 via the price index PI.

Thus,

$$
N_{E}(1913)=N_{E}(1929) \cdot P I_{E}(1913) \text { and } X_{\mathrm{US}}(1913)=X_{\mathrm{US}}(1929) \cdot P I_{\mathrm{US}}(1913)
$$

Hence,

$$
R_{\mathrm{PPP}}(1913)=\frac{N_{E}(1929)}{X_{\mathrm{US}}(1929)} \cdot \frac{P I_{E}(1913)}{P I_{\mathrm{US}}(1913)}=\frac{1}{R_{\mathrm{PPP}}} \cdot \frac{P I_{E}(1913)}{P I_{\mathrm{US}}(1913)}
$$

This operation may seem hazardous given the volatility of exchange rates in the post First World War period. However, this procedure offers better guarantees than the use of more recent alternatives: Maddison's 1991 international dollars or Milton and Kravis's PPP exchange rates for 1950.

Price indices for tradables indexed on 1913, as computed by the 
Table 9.6 Dollar equivalents at PPP of major European currencies, 1913

\begin{tabular}{|c|c|c|c|c|}
\hline & 1929 & 1913 & PPP rate & Official rate \\
\hline & \multicolumn{2}{|l|}{ in $1929 \$$} & \multicolumn{2}{|l|}{ in $1913 \$$} \\
\hline Mark & 0.2382 & 0.324 & 0.2454 & 0.2405 \\
\hline Franc & 0.0392 & 0.2433 & 0.1843 & 0.1907 \\
\hline Lira & 0.053 & 0.252 & 0.1909 & 0.1906 \\
\hline Pound & 4.8763 & 6.4855 & 4.9132 & 4.8685 \\
\hline
\end{tabular}

Economic Department of the League of Nations for 1929, were 136 for Germany, 621 for France, 476 for Italy, 133 for the UK and 132 for the US (League of Nations, Annual Statistical Abstract, 1935: 26). PPP equivalents were likewise computed for 1929 (League of Nations, Annual Statistical Abstract, 1930: 101) and can therefore be retropolated using equation (9.6). They yield PPP equivalents for 1913, which end up remarkably close to the official exchange rates.

Thus, the use of official exchange rates does not seem to introduce major distortions for the purpose of pre-1914 cross-country comparisons. These figures vindicate Maddison's and Prados de la Escosura's argument that the use of official exchange rates for pre-1914 countries with relatively stable currencies is preferable to the construction of PPPs based on dubious price information.

Furthermore, this observation has the backing of those monetary historians in whose eye it is at this date (1913) 'unlikely that variations between official and PPP exchange rates were substantial' (McCloskey and Zecher, 1985: 66). In a fixed exchange rate regime, the possibilities of arbitrage worked in such a way as to foster a peg close to the real exchange rate. Trade competition even on an admittedly limited range of actually traded commodities contributed to this process by enhancing price convergence the world over (Williamson and Bordo, 2002). This alignment mechanism could operate even in the absence of direct competition, which remained therefore to some extent 'virtual'. On this basis, McCloskey and Zecher (1984: 124) conclude that 'before 1914 ... prices as well as interest rates can be regarded as world rather than national phenomena'.

\section{The record of achievement}

In the following section, indicators of labour productivity were converted in a common currency, the pound sterling, using the exchange rates and then indexed on British performance in identical industries. At the disaggregated level (Table 9.A3), the relatively large number of indices superior to 100 suggests that British pre-eminence was far from being 
Table 9.7 Aggregate indices of labour productivity in industry, 1910-13 $(\mathrm{UK}=100)$

\begin{tabular}{lllllll}
\hline & Here & Burger & $\begin{array}{l}\text { Dormois and } \\
\text { Bardini }\end{array}$ & Maddison & Crafts & Bairoch \\
\cline { 2 - 7 } & $1911-12$ & 1910 & 1910 & 1913 & 1910 & 1913 \\
\hline Germany & 101 & 79 & 82 & 81 & 87 & 93 \\
France & 81 & 67 & 79 & 90 & 80 & 83 \\
Italy & 50 & 60 & 46 & 57 & 46 & 49 \\
Sweden & n.a. & n.a. & 75 & 80 & 87 & 101 \\
\hline
\end{tabular}

systematic. This observation is reinforced by the fact that British labour productivity indicators for 1912 ignore firms with five employees or less and tend therefore to be biased upwards.

At the aggregate level, and for the end period, the present results fall within a narrow band of obtainable data by other authors (Table 9.7).

The only notable difference between this and other series of indices regards, of course, the German index, for which other authors have used Hoffmann's estimates. The present figures confirm that, in terms of efficiency, German industry performed on the whole on a par with Britain's (Broadberry, 1997: 153). Meanwhile some German industries out-performed their British counterparts in a number of productions, including the heavy 'Montanindustrie' as well as clothing and paper manufacture, this superiority apparently going back to the beginning of the period. By contrast, most French and Italian industries trailed behind and even seem to have lost ground vis-à-vis their two other competitors between 1870 and 1914. Could this be in any way related to the introduction of steep industrial tariffs in these two countries?

\section{The correlation between levels of protection and of labour productivity}

The relationship between protection and labour productivity is necessarily an indirect one. First, trade protection is only one among many factors affecting the institutional environment and, hence, the behaviour of agents - although, as Clemens and Williamson (2001) observe, 'historically liberalism comes as a package'. Second, due consideration must be lent to the time dimension. Given that the calculation of value added is made at market prices (and not factor costs) and that this difference cannot be eliminated by the use of PPP exchange rates, the short-run immediate effect of a tariff is to inflate the turnover of a protected industry and hence its value added (Verdoorn law). From one year to the next, labour productivity with unchanged manpower is likely to be higher than it would have been in the absence of a tariff. This implies that a tariff's 
impact in the sense predicted by international trade theory may become apparent only over the medium or even long term, as buyers adjust to higher prices or producers become less efficient. It is to be expected that low or moderate duties will take longer to generate adverse effects on an industry's productive capacity.

In order to verify these intuitions, panel analysis has been conducted in three sequences. The first examines the concomitant behaviour of the two variables for all industries (twelve branches) for each of the three benchmark years. In the second the relationship has been investigated in more detail for the Italian case in 1911, for which indices of performance are available for a broader range of products (sixty-eight branches). Likewise, an Anglo-French comparison in 1930 affords the possibility of verifying the correlation at a more disaggregated level. In the third sequence, we have sought to illuminate the mechanism by which a tariff affects structural change and hence slows down productivity gains over-time. In so far as tariff barriers were intended to maintain employment in marginal firms or uncompetitive industries, their impact on relative labour productivity performance was two-fold: on the one hand, they propped up value added (the numerator) in the short run but, as new opportunities arose for redeploying resources and upgrading output, they forewent growth opportunities, depressing the industry's overall performance. On the other hand, by maintaining existing employment levels (the denominator) protection acts as a brake on productivity growth to the point when production methods become obsolete while preventing the transfer of resources to new emerging industries. The relative stability in terms of productive structure can directly be linked to the relative level of protection.

We have attempted to capture this tendency to obsolescence by observing the change in the distribution of industrial employment among various industries and linking them to observed levels of protection. The French and German cases lend themselves to this experiment because of the greater level of detail of their occupational censuses at 10-12 years' interval (1896-1906 for France and 1895-1907 for Germany).

Given the imprecision of the data inherent to any empirical investigation of this type, results appear as remarkably meaningful. One has to take into account that tests of significance requirements for cross-sections are less stringent than for time series. Correlation coefficients appear quite satisfactory in the first case and highly satisfactory in the second and third cases. The French and German cases illustrate that it was mainly through the maintenance of existing production structures that protection contributed to depress the productivity performance of existing industries.

\section{A global approach at twenty-year intervals}

A first batch of regressions to ascertain the degree of correlation between labour productivity performance and protection levels embraced all three 
Continental countries relative to Britain for three selected benchmark years. Thus EPRs for 1871 were paired with observed productivity indices for Italy in 1871, France in 1873 and Germany in 1875 using two thirty-sixentry panels constructed earlier in the chapter.

These simple linear regressions produced results much more significant than any other obtained by comparable means (Cameron et al., 1999). Given the weakness of the $R^{2}$ for the $1870 \mathrm{~s}$ - a period of virtual free trade in manufactured commodities - the first regression can probably be disposed of. For the other two periods coefficients appear much more significant than those obtained by the Bank of England survey linking labour productivity gains to openness rates over the period 1970-97 $\left(R^{2}=0.029\right)$. Here, not only are coefficients of the right sign (i.e. negative) but the coefficients are also much more satisfactory.

At first sight, these results seem to vindicate, for the period 1870-1913, the contention by Cameron et al. that 'the more open were industries to trade, the higher their gains in terms of productivity', here illustrated by the observation that the more protected industries fared worse in the productivity performance league.

\section{The French and Italian cases under scrutiny}

Higher nominal tariffs on manufactured goods in France and Italy after 1890 (see Table 9.1) provide a hint that industrial protectionism in these two countries could have had more profound repercussions than in Germany, where industrial duties remained, on the whole, lower and much less pervasive. Besides, from the first regressions emerged the suspicion that the end-of-the-century tariffs imposed on their 'beneficiaries' the kind of penalty suggested by international trade theory. In order to carry conviction, the investigation must be carried at a greater level of disaggregation. Unfortunately, the nineteenth century's limited nomenclature does not allow such a detailed analysis. Only for Italy in 1911 and for France in 1930 can the systematic comparison of industrial branches' performance be carried out.

In the first case, labour productivity indicators could be computed for sixty-eight branches and aligned on their British equivalents for 1912 (the

Table 9.8 Regression results for three benchmark years

\begin{tabular}{lccc}
\hline Decades & $1870 s$ & $1890 s$ & $1910 s$ \\
\hline Correlation coefficients & -0.2172 & -0.3325 & -0.3331 \\
$t$-statistic & 1.6829 & 4.2256 & 4.2434 \\
Coefficient of the tariff variable & 0.2033 & 0.4757 & 0.4712 \\
Standard error & 3.39 & 3.29 & 2.82 \\
Degree of freedom & 35 & 35 & 35 \\
\hline
\end{tabular}


British Census of that year displaying returns for a total of 108 branches ${ }^{37}$ ). The labour productivity indices were then matched by EPRs as reported for 1900 . At first, the correlation coefficient turned out somewhat disappointing $(-0.1354)$, inferior therefore to those obtained previously. But three outliers were identified and eliminated from the sample, either on the ground of an abnormal rate of duty (sugar and spirits) or an abnormal level of productivity performance (fish curing). With such restrictions, the correlation coefficient leaps to -0.5623 , by far the most satisfactory index obtained so far. The equation took the following form (standard errors in parentheses):

$$
\text { Labour productivity }_{i j}=85.8-0.156 E P R_{i j}
$$

In the second case we have relied on the numbers drawn from a comparison of productivity performance in French and British industry in 1930 (Dormois, 2004). Comparative labour productivity indicators for eighty-eight branches were arranged so as to match the two-digit product classification of the trade data (fifty-four tradables, of which forty-one were manufactures). While the same test for 1911/12 (twenty-seven products) produces only disappointing results $\left(R^{2}=0.005\right)$, the regression results for 1930 appear much more satisfactory (despite the fact that the handful of British duties introduced during the First World War couldn't be factored in).

$$
\text { Labour productivity }_{i j}=99.6-0.1435 E P R_{i j} \text {. }
$$

$$
\text { (3.40) (0.212) }
$$

\section{Linking the dynamic composition of the labour force to tariff protection}

Concentration on the labour force distribution under a protectionist tariff regime (the denominator of labour productivity indicators) shifts the

Table 9.9 Regression results for German, Italian and French manufacturing

\begin{tabular}{llllll}
\hline & \multicolumn{3}{l}{ Relative to UK } & & \\
\cline { 2 - 5 } Year of comparison & Germany & Italy & \multicolumn{2}{l}{ France } & \\
\cline { 2 - 6 } & 1907 & 1911 & 1911 & 1930 \\
\hline Correlation coefficient & -0.69 & -0.562 & -0.024 & -0.735 \\
$t$-statistic & 11.2 & 14.02 & 4.076 & 29.38 \\
Coefficient of the tariff variable & 73.02 & 85.5 & 1.425 & 45.74 \\
Standard error & 6.517 & 45.89 & 0.35 & 10.79 \\
Degree of freedom & 26 & 68 & 104 & 40 \\
\hline
\end{tabular}




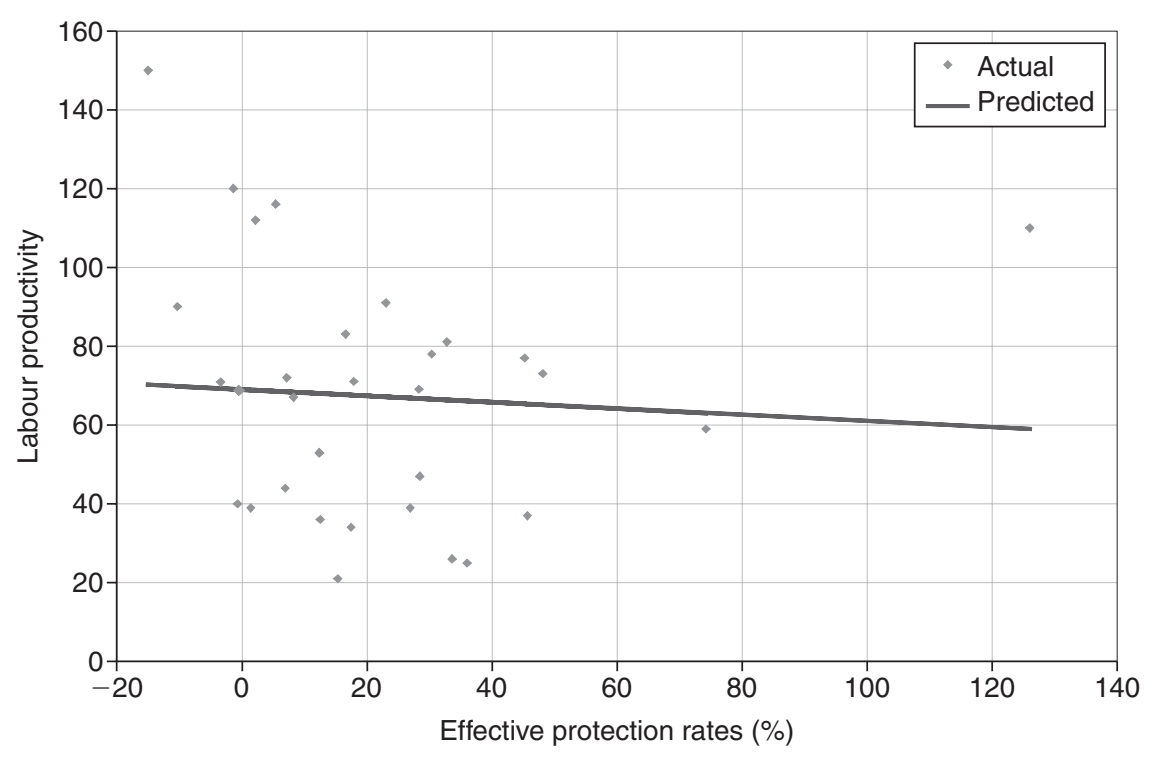

Figure 9.4 Italian labour productivity related to tariff protection.

attention to the effect of a tariff in slowing down the redeployment of labour from less to more productive forms of activity. It also serves to verify whether late-nineteenth-century tariffs fulfilled the promise of their promoters: the 'defence of domestic jobs' - the maintenance of the existing employment levels and structure. In carrying out this investigation, it has been assumed, first, that technological, productivity-enhancing innovations concentrated in progressive industries which can be distinguished from traditional, technologically stagnant industries, and that either progressive or, alternatively, declining industries clustered in particular branches of the industrial sector. Second, we supposed that, in a period of intense technological change such as the post-depression years of the turn of the twentieth century, protected industries experienced over the medium term, all other things equal, a greater relative stability of their workforce than unprotected industries, which had to deal with more rapid expansion or contraction of their workforce. The range of new industries emerging in the last decade of the nineteenth century is well known; this was also a period when first-generation firms in the staple industries such as basic metallurgy and textile manufacture (especially spinning mills) faced their first serious crisis.

To carry out this investigation, we have relied on the survey of employment change between 1896 and 1906 in France and 1895 and 1907 in Germany included in the occupational censuses. Each survey covers seventy standardised branches in manufacturing between the two dates and changes were indexed on the base year. Here again the regression of 
these indices on protection rates yielded interesting results: correlation coefficients were -0.31 in the French case, where protection rates for 1900 (a high-duty period) were taken into account and -0.438 for Germany, where reference was made to the 1892 tariff returns.

The respective equations took the following form (standard error in parentheses):

$$
\begin{aligned}
y= & 1.306-0.011 x \text { for France over the period } 1896-1906 \\
& (0.05) \quad(0.003) \\
y= & 1.668-0.038 x \text { for Germany over the period } 1895-1907 \\
& (0.056)(0.006)
\end{aligned}
$$

In each case $y$ denotes the magnitude of structural change in employment for each industry and $x$ the effective rate of protection. Despite a weaker correlation coefficient, the French case appears to be stronger, as Figure 9.5 shows.

In the German case, the anomalous behaviour of iron and steel manufacture - one of the few substantially protected industries - casts doubts on the meaningfulness of the relation. German low average protection

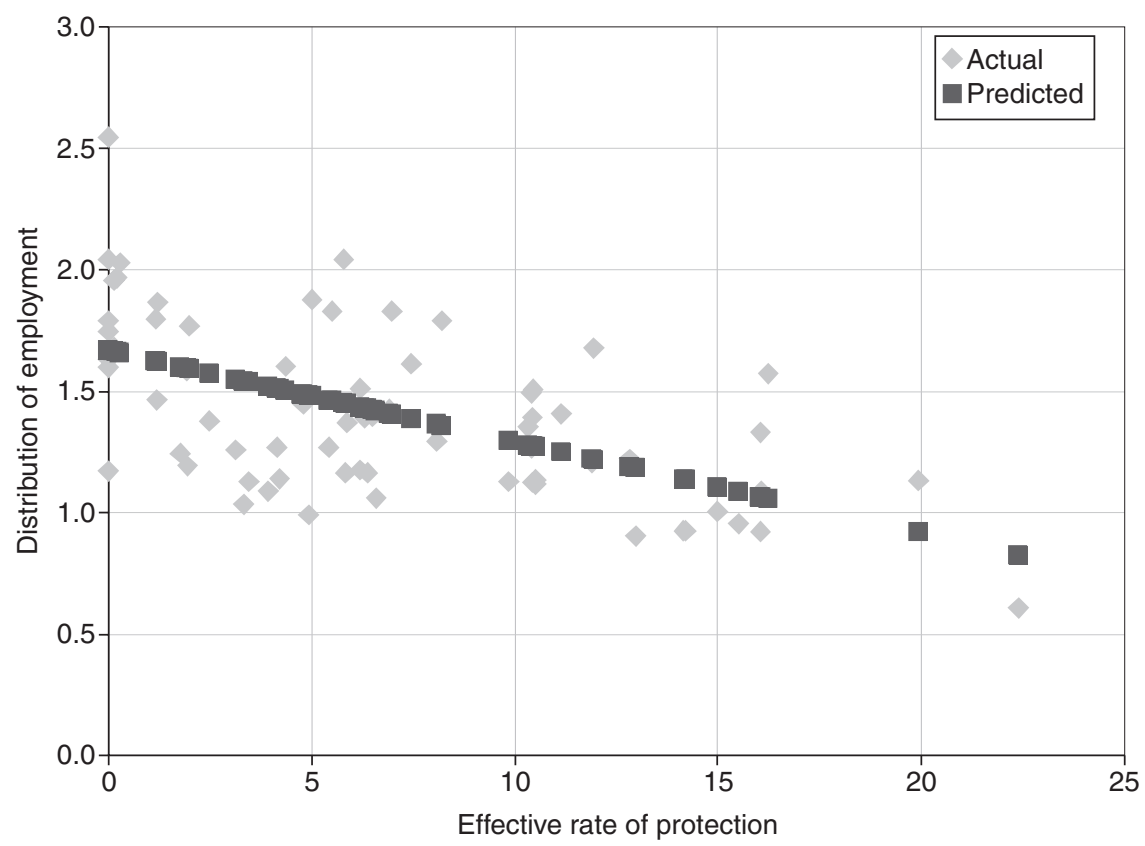

Figure 9.5 The influence of protection on France's structural distribution of employment, 1896-1906. 
Table 9.10 Regression results for the influence of tariffs on the dynamic labour force composition

\begin{tabular}{lcc}
\hline Period & $\begin{array}{c}\text { Germany } \\
\text { 1895-1907 }\end{array}$ & $\begin{array}{c}\text { France } \\
1896-1906\end{array}$ \\
\hline Correlation coefficient & 0.583 & -0.309 \\
$t$-statistic & 2.973 & 2.613 \\
Coefficient of the tariff variable & 1.668 & 1.306 \\
Standard error & 0.29 & 0.252 \\
Degree of freedom & 69 & 69 \\
\hline
\end{tabular}

on manufactured goods, as well as concentration on a few items, is bound to make the traceability of the structural effects of the tariff difficult.

However inconclusive with regard to the extent to which protectionism slowed down growth opportunities, this exercise has added one more piece of evidence for the prosecution: the directly observable effects of a tariff need time to deploy themselves and influence the structure of employment, as its repercussions on the product mix cannot be expected to materialise on short notice.

International trade is one area where economic 'laws' seem particularly difficult to verify empirically - witness the 150-odd recent empirical studies on the relationship between trade and growth, and there is perhaps a certain naivety in believing that any insight by a great economist can be submitted to a simple verification using such undiscriminate variables as GDP growth and overall tariff rates. Besides, no sensible freetrader ever claimed that a free-trade policy constituted a cure-all, shortcut recipe for growth and development. Labour productivity indices should provide a more sensitive tool to help resolve the riddle that mounting tariff protection had disastrous effects in Europe in the 1930s, while it supposedly sustained economic growth before 1914. But disentangling the short-run from the longer-run effects of trade barriers cannot be expected to be a straightforward affair, all the more so that diminishing returns are bound to set in - just like in any system of protection.

At the time of the 1887 Italian tariff debate (and the subsequent Franco-Italian trade war) Vilfredo Pareto railed almost weekly in the Giornale degli economisti against the 'protectionist sophistry' voiced by politicians and his economist colleagues. Using only plain logical deduction he reached more or less the same conclusions that the present study has tried to demonstrate - only by more economical and elegant means. It is therefore fitting to use one of his pronouncements as an epitaph to the present story: 
186 Jean-Pierre Dormois

Protection does not create wealth; quite the opposite: it destroys it. What it gives to some has to be taken away from others and it is absurd to hold on to the belief that everyone can be better off without anyone having to pay for it. ${ }^{38}$ 


\section{Appendix 9.1}

Table 9.A1 Real effective protection rates by industry (in \%)

\begin{tabular}{|c|c|c|c|}
\hline France & 1873 & 1892 & 1913 \\
\hline Mining and quarrying & 5.56 & 10.06 & 10.23 \\
\hline Iron and steel & 1.14 & 2.04 & 16.7 \\
\hline Engineering & 4.59 & 8.24 & 12.25 \\
\hline Non-ferrous metals & 4.16 & 7.96 & 11.56 \\
\hline Chemicals & 4.14 & 18.09 & 11.61 \\
\hline Textiles & 16.4 & 22.09 & 17.21 \\
\hline Clothing and apparel & 5.15 & 5.85 & 14.94 \\
\hline Leather & -0.73 & -1.52 & 2.44 \\
\hline Paper and print & 1.17 & 4.95 & 12.86 \\
\hline Food and drink & 1.21 & 8.02 & 8.73 \\
\hline Wood and furniture & -0.52 & 8.18 & 10.88 \\
\hline Building materials & 3.52 & 5.16 & 3.06 \\
\hline Luxury and other goods & 0 & 0 & 8.6 \\
\hline Average (weighted) & 4.67 & 9.13 & 12.23 \\
\hline Germany & 1874 & 1892 & 1913 \\
\hline Mining and quarrying & -1.12 & 3.54 & 2.97 \\
\hline Iron and steel & 7.08 & 10.48 & 14.05 \\
\hline Engineering & 4.97 & 3.36 & 6.9 \\
\hline Non-ferrous metals & 5.89 & 17.33 & 9.56 \\
\hline Chemicals & 6.3 & 6.61 & 11.37 \\
\hline Textiles & 1.17 & 10.75 & 7.82 \\
\hline Clothing and apparel & 7.88 & 4.84 & 8.07 \\
\hline Leather & 6.8 & 4.7 & -3.28 \\
\hline Paper and print & 2.77 & 2.43 & -1.26 \\
\hline Food and drink & 9.23 & 11.31 & 16.45 \\
\hline Wood and furniture & 0.67 & 3.04 & 5.34 \\
\hline Building materials & 7.31 & 12.06 & 8.04 \\
\hline Luxury and other goods & 0 & 0 & 0 \\
\hline Average (weighted) & 4.95 & 6.26 & 4.09 \\
\hline Italy & 1873 & 1892 & 1913 \\
\hline Mining and quarrying & -1.95 & -2.04 & 1.78 \\
\hline Iron and steel & 9.64 & 49.51 & 46.51 \\
\hline Engineering & -1.02 & -11.06 & -5.55 \\
\hline Non-ferrous metals & 5.03 & 24.3 & 17.53 \\
\hline Chemicals & 19.5 & 25.53 & 40.89 \\
\hline Textiles & 8.55 & 14.6 & 26.9 \\
\hline Clothing and apparel & 9.05 & 20.27 & 20.51 \\
\hline Leather & 3.72 & 17.01 & 15.24 \\
\hline Paper and print & 4.79 & 4.99 & 5.34 \\
\hline Food and drink & 33.53 & 34.55 & 35.04 \\
\hline Wood and furniture & 8.13 & 0.11 & 7.05 \\
\hline Building materials & -0.07 & 9.87 & 16.84 \\
\hline Luxury and other goods & 1.74 & -5.24 & -4.6 \\
\hline Average (weighted) & 11.68 & 12.36 & 14.26 \\
\hline
\end{tabular}


Table 9.A2 Labour productivity indices by industry $(\mathrm{UK}=100)$

\begin{tabular}{|c|c|c|c|c|}
\hline Germany & $1871 / 5$ & $1895 / 6$ & 1907 & $1911 / 12$ \\
\hline Mining and quarrying & 89.3 & 126.3 & 114.0 & 138.6 \\
\hline Basic metallurgy & 102.8 & 125.3 & 122.5 & 113.8 \\
\hline Engineering & 92.1 & 136.4 & 139.5 & 137.4 \\
\hline Chemicals & 97.7 & 106.0 & 77.8 & 95.8 \\
\hline Textile & 49.3 & 88.4 & 81.0 & 87.4 \\
\hline Clothing and apparel & 92.1 & 133.1 & 126.8 & 126.2 \\
\hline Leather & 46.3 & 99.8 & 87.0 & 82.8 \\
\hline Paper and printing & 113.6 & 103.3 & 108.7 & 88.0 \\
\hline Food and drink & 76.4 & 97.1 & 53.8 & 58.3 \\
\hline Wood and furniture & 103.6 & 91.4 & 68.2 & 66.2 \\
\hline Building materials & 97.7 & 71.4 & 86.9 & 90.5 \\
\hline Construction & 166.6 & 170.4 & 94.4 & 95.1 \\
\hline Utilities & 50.5 & 46.3 & 83.0 & 48.2 \\
\hline Manufacturing & 93.7 & 103.6 & 104.2 & 101.2 \\
\hline France & $1871 / 3$ & 1896 & $1906 / 7$ & $1911 / 12$ \\
\hline Mining and quarrying & 69.7 & 80.8 & 73.1 & 72.5 \\
\hline Basic metallurgy & 80.0 & 82.8 & 87.2 & 79.3 \\
\hline Engineering & 74.4 & 66.0 & 91.8 & 94.3 \\
\hline Chemicals & 132.9 & 137.3 & 88.2 & 83.9 \\
\hline Textile & 66.7 & 71.5 & 78.9 & 90.9 \\
\hline Clothing and apparel & 138.8 & 137.1 & 121.5 & 137.1 \\
\hline Leather & 98.2 & 75.3 & 69.5 & 65.1 \\
\hline Paper and printing & 103.4 & 94.0 & 93.9 & 90.9 \\
\hline Food and drink & 133.5 & 120.3 & 66.3 & 70.0 \\
\hline Wood and furniture & 113.9 & 112.8 & 82.7 & 75.6 \\
\hline Building materials & 92.2 & 67.0 & 86.7 & 89.2 \\
\hline Construction & 125.4 & 123.4 & 87.5 & 102.6 \\
\hline Utilities & 95.2 & 74.1 & 50.6 & 50.9 \\
\hline Manufacturing & 89.6 & 79.9 & 74.1 & 81.1 \\
\hline Italy & 1871 & 1891 & $1911 / 12$ & \\
\hline Mining and quarrying & 83.1 & 85.5 & 45.9 & \\
\hline Basic metallurgy & 39.3 & 88.1 & 71.3 & \\
\hline Engineering & 56.6 & 78.4 & 56.9 & \\
\hline Chemicals & 27.7 & 47.0 & 66.8 & \\
\hline Textile & 58.3 & 32.3 & 33.6 & \\
\hline Clothing and apparel & 28.4 & 15.9 & 18.2 & \\
\hline Leather & 43.2 & 38.8 & 27.1 & \\
\hline Paper and printing & 136.5 & 119.2 & 94.9 & \\
\hline Food and drink & 47.6 & 67.9 & 52.4 & \\
\hline Wood and furniture & 46.6 & 30.3 & 38.2 & \\
\hline Building materials & 88.3 & 42.0 & 53.1 & \\
\hline Construction & 55.3 & 68.8 & 51.0 & \\
\hline Utilities & 86.9 & 82.9 & 84.9 & \\
\hline Manufacturing & 50.8 & 42.9 & 42.3 & \\
\hline
\end{tabular}


Table 9.A3 Nominal and effective protection rates for France, 1930

\begin{tabular}{|c|c|c|}
\hline & Nominal & Effective \\
\hline Raw inputs & 12.6 & 14.4 \\
\hline Raw hides & 14.68 & 14.68 \\
\hline Animal products & 6.52 & 6.52 \\
\hline Fish bones, fat and whale oil & 8.54 & 8.54 \\
\hline Stone and fuels & 25.65 & 44.99 \\
\hline Iron ore & 0 & 0 \\
\hline Quarrying products & 0.1 & 0.1 \\
\hline Fruit and seeds & 7.14 & 7.14 \\
\hline Spices and medicinal plants & 1.2 & 2.51 \\
\hline Common lumber & 6.2 & 18.8 \\
\hline Tropical timber & 0.15 & 0.46 \\
\hline Fibres & 0.09 & 0.1 \\
\hline Drugs & 0.33 & 0.33 \\
\hline Dyestuffs & 0.35 & 0.35 \\
\hline Scrap and waste & 7.11 & 7.11 \\
\hline Semi-manufactured goods & 17.59 & 25.44 \\
\hline Corn and flour & 39.67 & 44.08 \\
\hline Tropical produce & 6.05 & 6.05 \\
\hline Vegetable oil & 2.46 & 2.46 \\
\hline Drinks & 7.8 & 17.34 \\
\hline Sugar & 7.49 & 41.6 \\
\hline Metals & 8.2 & 18.21 \\
\hline Precious metals & 4.85 & 10.32 \\
\hline Other non-ferrous metals & 9.78 & 21.72 \\
\hline Manufactured goods & 11.76 & \\
\hline Metal goods & 11.91 & 25.33 \\
\hline Jewellery, gold and silver plate. clock-making & 10.7 & 22.77 \\
\hline Machinery and appliances & 11.2 & 21.55 \\
\hline Tools and instruments & 14.59 & 29.18 \\
\hline Firearms and ammunition & 18.45 & 32.36 \\
\hline Vehicles & 18.51 & 35.6 \\
\hline Scientific instruments & 13.0 & 23.7 \\
\hline Chemicals & 5.14 & 14.70 \\
\hline Artificial dyes & 16.18 & 38.53 \\
\hline Colours & 13.61 & 32.41 \\
\hline Soap, perfume, wax, starch, glue, paraffin & 20.87 & 90.76 \\
\hline Rubber & 14.61 & 45.65 \\
\hline Match and lighters & 6.1 & 13.5 \\
\hline Yarn & 2.95 & 11.34 \\
\hline Woven cloth & 16.86 & 76.62 \\
\hline Lace & 9.99 & 23.78 \\
\hline Garments and underwear & 15.4 & 41.63 \\
\hline Felt and artificial flowers & 14.7 & 50.5 \\
\hline Umbrellas & 20.5 & 78.6 \\
\hline Manufactured paper & 15.96 & 44.34 \\
\hline Prints and photography & 11.1 & 19.48 \\
\hline Leather goods & 6.3 & 21.71 \\
\hline Asbestos and mica & 17.94 & 37.38 \\
\hline Miscellaneous house appliances & 17.51 & 50.02 \\
\hline Fancy goods & 23.4 & 52.0 \\
\hline Cork & 56.9 & 132.2 \\
\hline Furniture & 12.46 & 25.42 \\
\hline Musical instruments & 22.63 & 51.43 \\
\hline Basket ware & 4.56 & 10.61 \\
\hline Brush and & 18.2 & 40.5 \\
\hline Pottery and glass & 15.91 & 28.92 \\
\hline Coral, meerschaum, insulating material & 28.6 & 45.3 \\
\hline
\end{tabular}


Table 9.A4 Labour productivity indices, nominal and effective protection rates, Italy 1911

\begin{tabular}{|c|c|c|c|c|}
\hline & LP index & nominal & effective & share of VA \\
\hline Coal mining & 39 & 2.5 & 1.4 & 0.09 \\
\hline Basic metallurgy & 59 & 28.1 & 74.2 & 8.16 \\
\hline Iron and steel & 90 & 0.1 & -10.3 & 1.28 \\
\hline Non-ferrous metals & 53 & 10.4 & 12.4 & 6.88 \\
\hline Metal goods & 69 & 11.2 & 28.3 & 14.52 \\
\hline Rails and rolling stock & 72 & 9.7 & 7.2 & 0.21 \\
\hline Engineering & 67 & 11.9 & 8.2 & 4.98 \\
\hline Shipbuilding & 69 & 0.3 & -0.13 & 8.75 \\
\hline Watch-making, instruments & 70 & 1.5 & -3.4 & 0.58 \\
\hline Chemicals & 71 & 11.0 & 17.9 & 1.48 \\
\hline Rubber & 77 & 4.7 & 45.2 & 0.13 \\
\hline Textiles & 39 & 12.9 & 26.9 & 18.58 \\
\hline Silk & 34 & 8.36 & 17.45 & 7.54 \\
\hline Cotton & 47 & 13.62 & 28.4 & 5.52 \\
\hline Wool & 91 & 11.02 & 23.0 & 1.48 \\
\hline Flax, hemp, jute & 25 & 17.25 & 36.0 & 1.98 \\
\hline Other fibres & 112 & 1.04 & 2.17 & 2.06 \\
\hline Clothing & 21 & 13.2 & 15.3 & 21.02 \\
\hline Leather & 40 & 5.2 & -0.7 & 11.05 \\
\hline Paper & 116 & 7.7 & 5.4 & 2.74 \\
\hline Printing and publishing & 120 & 1.8 & -1.4 & 0.11 \\
\hline Food and drink & 78 & 17.8 & 30.3 & 9.42 \\
\hline Grain milling & 73 & 28.25 & 48.09 & 5.19 \\
\hline Bakery & 81 & 19.24 & 32.75 & 0.64 \\
\hline Preserves & 83 & 9.73 & 16.57 & 1.44 \\
\hline Milk products & 150 & 3.4 & -15.0 & 0.78 \\
\hline Sugar refining & 110 & 65.1 & 126.0 & 0.38 \\
\hline Drink & 37 & 26.8 & 45.63 & 0.21 \\
\hline Tobacco & 26 & 16.8 & 33.63 & 0.77 \\
\hline Timber and furniture & 44 & 7.7 & 6.9 & 12.17 \\
\hline Glass and stone & 53 & 10.4 & 12.4 & 6.88 \\
\hline Miscellaneous & 36 & 10.3 & 12.5 & 0.53 \\
\hline
\end{tabular}

\section{Notes}

1 An amended and extended version of 'Protectionnisme et productivité du travail en Europe avant 1914', Revue de l'OFCE, 82 (2002), pp. 11-47.

2 Member of Institut Universitaire de France and director, Institut d'Histoire Contemporaine, Université Marc-Bloch, Palais Universitaire, F - 67084 Strasbourg. Email address: dormois@umb.u-strasbg.fr.

3 Italy in 1878, 1887 and 1895, Germany in 1879, France in 1881 and 1892, Romania in 1885, Spain, Portugal and Greece in 1892, Russia and Serbia in 1893, Bulgaria and Sweden in 1895, Norway in 1897.

4 Some countries such as Japan and Romania had been forced under 'unequal treaties' to adopt free-trade policies.

5 See Bairoch (1989: 78). 
6 A mechanism by which tariff duties on grain imports could be adjusted seasonally depending on the domestic price of the commodity.

7 The 'Méline tariff' of 1892 harbours 1,313 entries, not taking into account variations in size; the revised 1895 Italian tariff of 1877.

8 Méline, Rapport général. ..: 9, cited in Dijol, 1910: 333.

9 Lotz, 1904: 516.

10 Bastiat, 1854: 143. Author's translation.

11 Industries producing non-tradables such as construction and public utilities are excluded.

12 A 'full' panel regression and a fixed-effect model would include dummy variables for country and perhaps year.

13 The last industrial tariffs were repealed in the 1860s, and during his third administration Gladstone trimmed the last remaining protective duties (see Irwin, 1993: 148).

14 On the basis of comparative rates of tariff revenue, German trade policy was in fact more liberal than Britain's through the 1870s.

15 This is the whole problem of 'ceteris paribus'. Reverse causation also needs to be considered: the contention that it was precisely because decision-makers were all too aware of their country's deficiencies that they promoted protectionist legislation. The major hurdle to such a reasoning is the absence of objective measurement instruments at the disposal of the political personnel. Besides, business organisations and their constituents took profits into considerations rather than efficiency as such.

16 As other authors have noted, levels of 'external' are positively correlated to 'internal' competitiveness.

17 The 'unequal treaties' imposed on Japan and the Ottoman empire (and its successor states in the Balkans) generally imposed such caps on import duties.

18 See Pedro Lains in Chapter 14 of this book.

19 See Béatrice Dedinger, this volume, Chapter 11.

20 Although France taxed its coal imports (as did Spain and Russia).

21 The choice of the first benchmark year was dictated by the need to neutralise the fallout effects of the Franco-Prussian War of 1870-1 and the revision of recording procedures by the Centralbureau of the Zollverein.

22 Arithmetic mean of ad valorem rates of duties for seventy-eight items (of which forty-three are manufactured, and eighteen are semi-manufactured).

23 In this context the a posteriori justification that late-nineteenth-century protectionist tariffs were inspired by the Listian argument seem especially misguided.

24 Details are including in Chapters 5-8 of Dormois, 2006.

25 Lévy-Leboyer and Bourguignon, 1990 and Jean-Claude Toutain, 'La croissance française 1789-1990: nouvelles estimations', Economies et société, HEQ Series, 11 (1997).

26 That is, with an end-of-period estimate extrapolated backwards with production and price indices.

27 Jules Méline, Le retour à la terre et la surproduction industrielle (Paris, Hachette, 1905).

28 Mining has traditionally been considered as being part of the 'primary' sector in France.

29 Walter G. Hoffmann et al. (1965).

30 Ritschl and Spoerer (1997) have tackled the problem of converting his NNP estimates into GNP estimates for the twentieth century.

31 For a review of contemporary comments in the German press, see Volker Hentschel, Wirtschaft und Wirtschaftspolitik in wilhelminischen Deutschland. Organisierter Kapitalismus und Interventionsstaat (Stuttgart, Klett-Cotta, 1978).

32 Thorstein Veblen, Imperial Germany and the Industrial Revolution (New York, 


\section{Jean-Pierre Dormois}

Macmillan, 1915); J. M. Keynes, The Economic Consequences of the Peace (London, 1919), Ch. I and IV.

33 See Henderson, 1975; Helmut Böhme, Deutschlands Weg zur Großmacht. Studien zum Verhältnis von Wirtschaft und Staat während der Reichsgründungzeit 1848-1881 (Cologne, Kiepenheuer \& Witsch, 1974).

34 Maddison's comparative figures of GDP, GDP per capita and per employee for Germany bear the stamp of Hoffmann's making.

35 For detailed procedure, see Dormois, 2006: chapter 5.

$36 \mathrm{~J}$. Hirsch, 'Wandlungen im Aufbau der deutschen Industrie', in B. Harms (ed.), Strukturwandlungen der deutschen Wirtschaft, Bd 1, Berlin, pp. 191-226.

37 The difference is accounted for by the inclusion in the British census of mining and quarrying, construction, the utilities, arsenals and other government departments. Otherwise, industrial divisions are very similar across countries.

38 Vilfredo Pareto, 'Curiosités doctrinale et vérités objectives', in Giovanni Busino (ed.), Mythes et idéologies (Geneva, Droz, 1966), pp. (author's translation). 


\title{
10 Protection and Italian economic development
}

\author{
Much ado about nothing ${ }^{1}$
}

\author{
Giovanni Federico ${ }^{2}$
}

\section{Introduction}

Trade policy is arguably the most controversial topic in the entire debate over Italian economic development, et pour cause. It represented the main instrument of state intervention in the allocation of resources, at least until the 1930s. Trade policy was utilised both to defend sectors that were threatened by foreign competition, and also to promote the development of others, the presence of which was considered desirable for any reason. The political implications, therefore, were considerable, both because of the reaction of the interested parties involved, and also because of their possible influence on the long-run pattern of Italian development. Trade policy was thus highly controversial at that time, and historians have picked up much of this debate, albeit with a wider range of opinions than that of the simple contrast between free-traders and protectionists. Opinions vary from a very strong criticism to a more or less critical acceptance.

It is not surprising that nineteenth-century economists, with both their modest analytical and computational tools, and their interest in day-to-day politics, could not progress very far in the empirical assessment of the effect of protection. However, the empirical analysis has also remained underdeveloped in recent years. To fill this gap in our knowledge, the author has undertaken a wide-ranging project of research in collaboration with A. Tena (University Carlos III, Madrid) and Kevin O'Rourke (Trinity College, Dublin). This chapter outlines the main results of these works, which have already been published in three articles. ${ }^{3}$ The first two sections summarise the main lines of Italian customs policy from the Restoration to the Great Depression, and the state of the literature. The subsequent four sections deal with the main issues - the level of protection and the effects on welfare), the effects on the economic structure and on the allocation of resources, the effects on the distribution of income factor capital, land and labour, and the causes of customs policy. 


\section{Italian trade policy, 1820-1940: a brief summary}

Italian trade policy did not, at least not in general terms, differ much from that of the other large countries on the European continent, such as France and Germany, even if Italy's economy was decidedly more backward than them. ${ }^{4}$

During the short-lived experiment of the Continental Block, most of the Italian peninsula had belonged to an area of European free trade, but after the collapse of the Napoleonic Empire, all the states on the peninsula returned to their traditional protectionist policy of mercantilist inspiration. Duties remained relatively low only in Tuscany. ${ }^{5} \ln$ the following decades, almost all the states reduced their tariffs, following a pan-European trend. Of particular importance was the liberalisation of trade in Piedmont. It started in 1834-5, and culminated in the late $1840 \mathrm{~s}$ with some autonomous cuts in duties and a series of trade treaties with all major European states. On the eve of Unification (1861), imports of cereals were free, but several other products was still subject to duties, and the average tariff was about 7 per cent. After the Unification, the Piemontese tariff was extended to the entire peninsula, and duties were further reduced in the 1863 treaty with France. ${ }^{6}$ This treaty probably marked the acme of free trade in the history of modern Italy up until the Second World War and beyond. For about fifteen years, the policy remained formally faithful to Cavourian laissez-faire, and the industrialists' cries for protection were scornfully rejected. ${ }^{7}$ In practice, however, the parlous state of public finances inspired a whole series of increases in duties, including the introduction of a 'trade balance fee' on all goods, and a modest 'fiscal' duty on wheat in 1866.

The free-trade policy was formally abandoned at the end of the 1870s, with the stipulation of a new commercial treaty with France (July 1877) and the approval of a new customs tariff (April 1878), which incorporated the necessary changes. Thus, Italy anticipated the similar shift in AustriaHungary and Germany by one year, and thus it can be considered to be the forerunner of the pan-European return to protection in the $1880 \mathrm{~s}$. However, duties were initially low, and limited to only some products most notably cotton and other textiles. Furthermore, duties were reduced in trade treaties, notably that with France in $1881 .{ }^{8}$ Industrialists called for more protection, and, in 1883, Parliament appointed a committee, chaired by V. Ellena, to draw up a new comprehensive tariff. His final report suggested a modest rise in duties on almost all industrial products, but no protection on agricultural goods. The proposal was discussed in Parliament during the height of the agricultural crisis. The landowners sitting in the House (or at least the majority of them) demanded a duty on wheat, and, in exchange, accepted an increase in duties well beyond the level proposed by the Ellena Committee. In 1887, Parliament eventually approved both the duty on wheat and the new tariff on manufactures, 
with high duties on textiles and, above all, on iron and steel goods. This tariff was to remain in force for more than thirty years, while the duty on wheat was increased in 1888 and again, twice, in 1894. The new tariff was inconsistent with the existing (1881) treaty with France - and indeed many high duties were justified as tokens of exchange in the negotiations. But negotiations broke down in March of the following year, setting off a trade war between the two countries with the reciprocal imposing of retaliation tariffs. Thus, the years 1887-8 marked the real turning point in Italian trade policy, in the direction of high protection.

The tide turned quite early. The trade war with France turned out to be a disaster, and extra-duties were abolished in December 1890 (France waited until 1892). New treaties with Austria-Hungary, Germany and Switzerland (1891-2) stipulated reductions in duties on manufactures, in exchange for reductions in foreign duties on wines and other Italian agricultural goods. Duties were further reduced during a second round of treaties with the same countries in 1904-6. Thus, nominal duties were decreasing from the mid-1890s onwards until the First World War. This downward trend was to culminate with the suspension of the tariff on wheat upon the outbreak of war. In the meantime, in 1913, a committee had been set up to revise the tariffs in anticipation of the renewal of the 1904-6 treaty, which was due in 1916-17. The committee recommended almost at the dictation of the industrialists - high duties for all manufactures, including those not yet protected, such as engineering and chemical products. The war and the post-war confusion caused a delay in the approval of the new tariff until 1921. The approved tariff was much less radical than the original proposal, and in the following years many duties on industrial products were further reduced by a series of customs treaties (there were nineteen of these between 1922 and 1926). Trade policy during the first years of the Fascist regime followed the pre-war liberal path - still without the duty on wheat. However, the orientation changed quite suddenly in 1925, with the restoration of the duty on wheat and an increase in that on sugar - which were officially motivated by difficulties in the balance of payments. These measures were followed in the following year, 1926, by increases in duties on manufactures and then by a decided return to protectionism. Protection would greatly increase with the Great Depression and the autarchic policy.

\section{Italian trade policy 1820-1940: interpretations and controversies}

A comprehensive analysis of trade policy should answer four main questions:

1 How much did customs policy affect the welfare of the country?

2 How much did it affect the allocation of factors by sector? 
3 How much did it change the distribution of income among factorowners (capitalists, workers, land owners)?

4 Why was this policy adopted?

This last question is placed at the end of the list and not, as is possible, at the beginning, simply because of the principle of cui prodest: he who can derive benefit from a given provision is always the first to be suspect.

Italian economic historians have concentrated almost exclusively on the second question, in a particular version: how much did customs policy influence, positively or negatively, the long-term growth of the Italian economy? They deem the effects on welfare or on the distribution of income to be negligible when compared with the overarching imperative of accelerating economic growth. They also pay little attention to the political economy of protection, probably because they deem the causes of the policies to be self-evident (as we will discuss below). Their attention has concentrated on three issues:

a Did protectionism favour or slow down industrialisation?

b Would it have been better to protect other industrial sectors?

c How much did the tariff on wheat damage industrial growth?

The first subject was at the centre of the nineteenth-century debate. All the major Italian economists (a very high-level group) opposed protectionism. Italy should have maintained faithful with post-Unification freetrade policy, thus exploiting its comparative advantages in agriculture and in 'natural' industries. ${ }^{9}$ Thus, free trade did not rule out industrialisation if it were spontaneously determined by the accumulation of capital, by growth in the size of the market, and by the increase in technical competencies. ${ }^{10}$ On the contrary, the attempt to accelerate this process with 'artificial' protectionism caused serious distortions in the economy, and also nurtured nationalism and imperialistic aggressiveness with negative political consequences. This 'free-trade proto-model' - to use Cafagna's definition - is not widely accepted among historians. ${ }^{11}$ Very few of them endorse the basic assumption that industrialisation could be achieved without any protection. Instead, the discussion deals with the concrete choice of the sectors to be protected.

Some historians, such as V. Zamagni, Sapelli and Pescosolido, view trade policy, on the whole, positively. In spite of all its defects, protection made the development of key sectors, such as the iron and steel industry, possible. ${ }^{12}$ This is a minority view: most scholars criticise the trade policy, although for different reasons. On the one hand, Are argues that all industries should have received the same level of (effective) protection, clearly to the detriment of agriculture ${ }^{13}$ On the other, Gerschenkron sustains that it would have been much better to protect engineering, a highly (skilled) labour-intensive sector, or the technologically more advanced 
chemical industry, rather than the textile industry (an 'ancient [ sic] industry scarcely touched by modern technological progress') and the iron and steel industry (unsuitable for a country without coal). ${ }^{14}$ Taking reasoning to an extreme, Fenoaltea affirms that, without the duty on steel, engineering could have experienced an export-led boom sixty years before the 'economic miracle'. ${ }^{15}$ The duty on wheat appears to be more difficult to defend. Wheat-growing was certainly ill-suited to a country with a very low land/labour ratio, and it harmed industrialisation. In fact, it increased the price of bread and thus lowered real wages - or increased nominal wages for any given level of real wages. ${ }^{16}$ Fenoaltea maintains that real wages were determined by the world market, and that higher nominal wages reduced industrial employment below the minimum required to absorb the natural increase in population. ${ }^{17}$ The rest had to emigrate: in brief, he argues, the duty on wheat was the ultimate cause of Italian emigration. In the face of these criticisms, the duty could be defended as a temporary measure to adjust to the sudden fall in the world prices of grain, avoiding the fact that the sudden increase in wheat imports jeopardised the crisis of the Italian balance of payments and caused social disaster in the countryside. ${ }^{18}$

An important and somewhat surprising feature of the literature is the contrast between the wealth of hypotheses and the scarcity of empirical testing. Of the authors mentioned, only Fenoaltea puts forward some, admittedly tentative, estimates of the potential effects of the duty on wheat. Historians simply assume that protection was necessary without further discussion, recalling, at most, the example of industrially more advanced countries, such as the USA or Germany. The main evidence for the positive effect of protection is the fall in imports, and the increase in domestic production. ${ }^{19}$ This sort of reasoning can be useful as a very first approximation, but it is clearly insufficient. In fact, it does not take into consideration the opportunity cost of protection, and, if taken at its face value, would lead to the extolment of Stalin's five-year plans as a highly successful industrialisation strategy. Up until now, the main empirical contribution remains a pioneer analysis by Toniolo on the effects of the abolition of the duties on iron and steel industrial products, and their replacement with an equivalent subsidy. ${ }^{20}$ This counterfactual policy would have considerably increased engineering production, but it 'would not have significantly altered the course of Italian growth'. ${ }^{21}$ Toniolo deals with the effects on the domestic market, without examining Fenoaltea's hypothesis of a growth in exports. He believes that Italian industry was not very competitive on the world market, because of its 'backwardness on a technical and organisational level', and because of the duties on materials.

\section{How high was protection?}

Almost all historians deem the 1880s the key moment of transformation of Italy from a relatively free-trade country into a protectionist fortress. 
However, this conventional wisdom is not borne out by the simpler measurement of the level of nominal protection (NT), the ratio of total customs revenues to total exports. As can be seen (in Figure 10.1), the average protection increased at the end of the 1870s and then, after a pause, from the end of 1872 up to an absolute maximum in 1896 (19.8 per cent). From then on, it dropped: in 1913, the average tariff had returned to the levels of 1880 and, in 1919, it registered an absolute historic minimum of 3.5 per cent. Subsequently, it rose again, but, still on the eve of the Great Depression, it was only a little higher than its pre-war level.

The average duty may be a biased measure of protection, because the amount of imports depends on protection itself. The higher the duty, the lower imports of protected goods are, and thus the higher the share of the total imports of products not subject to duties or subject to low duties. A country which subjects its imports of manufactured goods to prohibitive duties, leaving those of raw materials free, would appear to be less protectionist than a country which imposes a uniform duty of 10 per cent on all goods. ${ }^{22}$ The higher the duties and the more price-elastic the demand for imports, the more biased the average duty as a measure of protection. Unfortunately, imports consisted of hundred of goods, and estimating the elasticity of the demand for all of them is very difficult, if not impossible.

Various alternative indications of the level of protection have been proposed, such as the simple average of the tariffs on all the products (UNT) or the average of the tariffs according to product, weighted with the composition of the imports during the period preceding the tariff (RNT), or

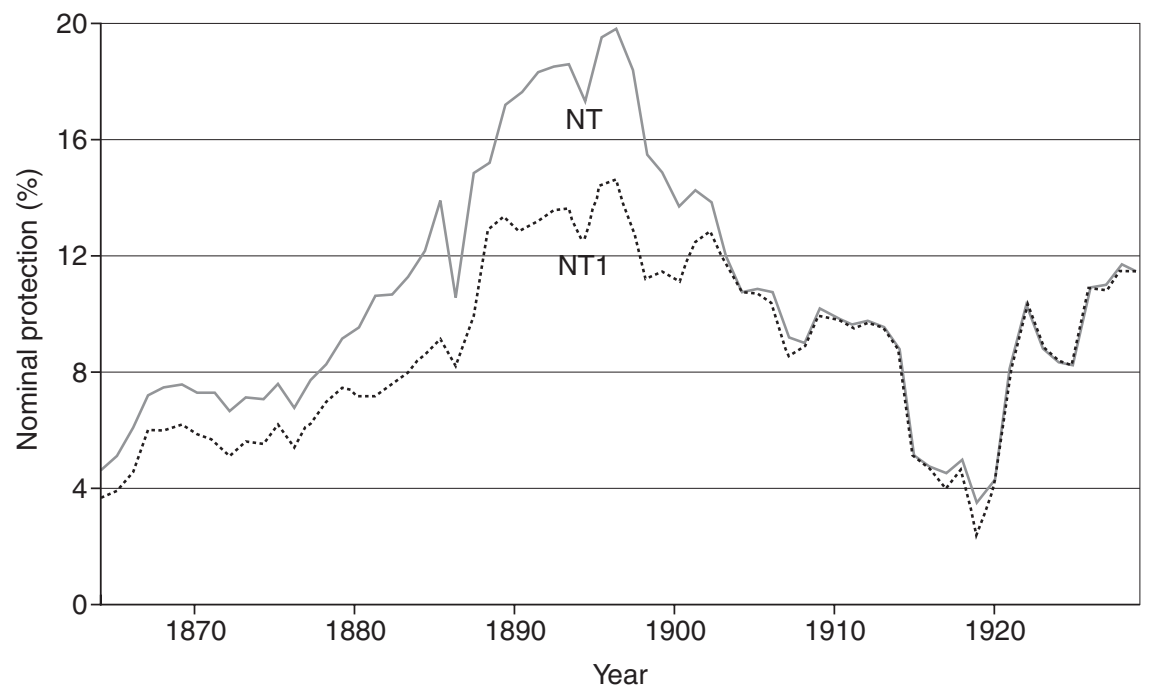

Figure 10.1 Nominal protection in Italy, 1860-1930. 
Table 10.1 Rates of nominal protection in Italy

\begin{tabular}{lrlrl}
\hline & $N T$ & $R N T$ & $U N T$ & $N T W$ \\
\hline 1877 & 7.3 & n.a. & 6.8 & n.a. \\
1889 & 17.6 & 20.4 & 16.9 & 14.3 \\
1897 & 18.5 & 20.7 & 16.1 & 17.0 \\
1913 & 9.6 & 11.7 & 12.7 & 11.8 \\
1926 & 11.9 & 15.1 & 13.7 & n.a. \\
\hline
\end{tabular}

Source: Federico and Tena, 1998, Table A1.

with the composition of domestic output of tradable goods (NTw). Table 10.1 shows the calculation of these measures in five benchmark years. ${ }^{23}$

As can be seen, the differences between NT and the other indicators, while not completely negligible, are rather small, and not such as to change the overall assessment about the level of protection. The latter is also confirmed by another measure, logically different and methodologically much more sophisticated, the so-called Trade Restrictiveness Index (TRI).$^{24}$ Protection increased from 1877 to 1889 and decreased from 1897 to 1913. Between 1889-97 and 1913-26, variations were modest, and their sign depends on the assumptions about the elasticity of imports.

Overall, therefore, the variations in the average tariff (NT) seem to be a reliable proxy for trends in the level of aggregate protection. Its over-time changes can be decomposed into:

i changes in nominal duties, then expressed in lire per unit of weight (duty effect);

ii changes in the ratio of nominal duties to prices (price effect);

iii changes in the composition of imports (quantity effect).

Table 10.2 shows the results of this decomposition for the various periods - in terms of unit percentage points of change in NT.

As can be seen, the price effect was quite important between the two last periods. The increase in prices between 1897 and 1913 (the tariffs being equal) contributed considerably to the drop in protection during

Table 10.2 Decomposition of the variations in nominal protection

\begin{tabular}{lccc}
\hline & Duty effect & Price effect & Quantity effect \\
\hline $1877-89$ & 13.1 & 0.9 & -3.7 \\
$1889-97$ & 3.1 & 0.0 & -2.2 \\
$1897-1913$ & -6.8 & -4.3 & 2.2 \\
$1913-26$ & 5.5 & -3.5 & 0.3 \\
\hline
\end{tabular}

Source: Federico and Tena, 1998, Table A2. 
the Giolitti era, while the price growth between 1913 and 1926 dampened the rise in nominal duties. The change in the structure of imports (quantity effect) reduced aggregate protection in the $1880 \mathrm{~s}$ and $1890 \mathrm{~s}$, and increased it between 1897 and 1913. However, most of the changes in aggregate protection were determined by changes in nominal duties (duty effect) - i.e., to trade policy. If the prices and composition of imports had remained unchanged, the average tariff would have increased by 16.2 per cent from 1877 to 1897, instead of by 11.1 per cent, as actually occurred. These results seem to confirm the conventional wisdom about the huge impact of the 1878 and 1887 tariffs and of the duty on wheat. Instead, almost the whole increase in protection was, in reality, caused by the increases in 'fiscal' (non-protective) duties on sugar, petroleum and coffee. These changes accounted for 8.5 points of the total increase in NT from 1877 to 1889 , leaving only 4.4 to the increase in protection for wheat-growing and manufacturing. The duty on sugar was particularly important. In fact, the average level of net protection of sugar (i.e. deducting sugar from both custom revenues and imports) was decidedly lower in the period of high protection of the $1890 \mathrm{~s}$.

Protection has rather complex effects on the economy. Initially, a duty increases the relative prices of products and thus causes its production to increase, attracting factors from the rest of the economy. This movement tends to equalise the returns to mobile factors, such as unskilled labour or capital. However, some factors, such as skilled labour, are sector-specific and cannot move easily from one sector to another. Protection would increase the returns to them, as well as returns to mobile factors most intensively utilised in those industries (e.g. capital for the iron and steel industries) while reducing the returns to other factors, most notably to those specific to the production of exportables. Changes in the relative prices of the products and in factor returns affect consumption, starting a new adjustment in production and so on and so forth, until the economy finds a new equilibrium. The overall changes in both the production structure and in consumption depend on the sensitivity of the economy to variations in prices, which is expressed by the elasticities of substitution and transformation. ${ }^{25}$

It is possible to take all the possible effects into account by using the socalled CGE (Computable General Equilibrium) models. The starting point is the so-called Social Account Matrix (or SAM) - an input-output table augmented with an estimate of the value added by sector and of its distribution among factors. The SAM for Italy refers to 1911, the earliest year for which information is relatively abundant and sufficiently reliable. ${ }^{26}$ The economy is divided into nine sectors: protected arable agriculture (the production of sugar and wheat growing), other arable produce (corn, potatoes, industrial crops, etc.), Mediterranean agriculture (wine, oil, fruit), livestock breeding, the 'military-industrial complex' (iron and steel, shipbuilding, etc.), other capital-intensive industries (engineering, 
the chemical sector), textiles, other light industries (food processing, wood, etc.), and services (lumping together all non-tradables). There are five production factors: capital, non-skilled labour, skilled labour, arable land, and 'Mediterranean' land (i.e. growing vines, olive trees and fruit trees).$^{27}$ ln the basic hypothesis, it is assumed that capital and non-skilled work were mobile throughout the economy, that the 'land' was mobile within agriculture (i.e. that it could be used for planting wheat, potatoes or as fodder for animals). It is assumed that 'Mediterranean land' and skilled labour were sector-specific factors. The former could be used only for Mediterranean agriculture, while each industrial sector (and service) had its own pool of 'skilled workers' who could not be employed elsewhere. Last, but not least, in the basic case, it is assumed that the elasticity of substitution was 1 in consumption and in production among agricultural goods, and 0.5 in the production among manufactures and services. The elasticity of substitution between imports and domestic production is assumed to be very high (10) but not infinite - i.e. they were very similar but not identical (the so-called Armington hypothesis).$^{28}$ All these assumptions are just that: assumptions with no hard evidence regarding the actual mobility of factors, nor estimates of the relevant elasticities. Thus, the conclusions are provisional, and they could be modified should new information be made available, which is unlikely.

In theory, the CGE model could be used to test any set of counterfactual duties that comes to mind. We have considered six of them, which encompass all the main hypotheses put forward in the literature - a uniform tariff on all products, no duty on wheat or on the products of the 'military-industrial complex;' a duty of only 30 per cent on the products of the 'other capital-intensive industries' (the most promising new industries, according to Gerschenkron), and two variants of the free-trade policy advocated by nineteenth-century economists, no duties at all or duties only on 'tropical products'. It would take too long to discuss all the results here. We shall therefore concentrate only on the most extreme hypothesis, pure free trade. Clearly, the first question is whether and to what extent protectionism reduced the welfare of the Italian population. Without duties, GDP would have been 2.4 per cent higher in 1911, and 3.5 per cent higher in 1938 in the so-called 'dynamic' version, which projects the effects in time by taking into account the increase in the factor endowment. ${ }^{29}$ It could be objected that welfare losses appear small only because protection in 1911 was very low. However, it is possible to estimate, although less precisely, the welfare losses from the (higher) 1897 duties. They would have reduced the GDP by 3.1 per cent. In both cases, the losses from protection were small and well within the limits of the statistical error (as is common in CGE models). In other words, protection did not impoverish Italians very much. 


\section{2}

\section{Trade policy and structural change}

The effect of protection on the structure of the economy is not necessarily proportional to the aggregate level of protection, or to the extent of welfare losses. Even a modest aggregate protection can deeply affect the allocation of factors, if it conceals huge differences in duties by sector. It has often been argued that a really effective industrialisation strategy should protect promising industries for a short period of time during the early stage of their development ('infant industry argument'). But even a uniform protection can have substantial structural effects, if demand or supply are very elastic. Did nineteenth-century Italy correspond to one of these cases? Table 10.3, column (a), reports the percentage change in value added by sector (the standard proxy for structural change) if protection had been abolished.

As can be seen, the differences are not huge, except for the case of 'protected arable' (i.e. wheat growing). Without the duty on wheat, its production would have been cut in half. Imports would have more than filled the deficit, and, indeed, the domestic consumption of wheat and sugar would have increased by about one-quarter, improving the welfare of Italians (whose consumption of sugar was the lowest in Europe). Labour and land released from the 'protected arable' sector would have poured into the livestock and 'other arable' farming, thereby increasing their production. Mediterranean agriculture, in contrast, could not have grown, as its land is assumed specific (i.e. the stock of land is assumed fixed). As predicted, the 'military-industrial complex' would have contracted, without disappearing, while textiles would have greatly expanded. Duties might have helped the initial growth in textiles in the nineteenth century, but, by 1911, they had become an obstacle for future developments. Without them, Italian exports of textile products would have increased by 50 per cent, up to three-fifths of the production (instead of half). Total agricultural value added would have shrunk (by 2 per cent),

Table 10.3 Change in value added by sector under free trade

\begin{tabular}{lrr}
\hline & $(a)$ & $(b)$ \\
\hline Protected arable & -53.2 & -62.0 \\
Other arable & 21.5 & 30.6 \\
Mediterranean agriculture & -0.8 & -0.9 \\
Livestock farming & 9.8 & 17.3 \\
Military-industrial complex & -14.2 & -20.2 \\
Capital-intensive industries & -1.8 & -8.8 \\
Textiles & 27.0 & 37.7 \\
Other light industries & 5.0 & 10.3 \\
Services & -0.3 & 0.0 \\
\hline
\end{tabular}

Source: Federico and O’Rourke, 2000, Table 10.4. 
and the industrial one would have increased (by 6 per cent). Contrary to what was feared, free-trade would have accelerated industrialisation, not retarded it. However, the difference is minimal - and this is not surprising as the service sector, only marginally affected by trade policy, accounted for about 40 per cent of GDP. By definition, other counterfactual policies would have had an even smaller effect. However, a tariff of 30 per cent on capital-intensive industries (the Gerschenkron hypothesis) would have augmented their turnover by one-quarter.

How much are these results sensitive to the assumptions on the mobility of the factors and on elasticity? The simplest way to answer this question is to change the assumptions themselves. Almost all the realistic alternative assumptions, however, produce smaller effects. ${ }^{30}$ In fact, as a general rule, the more flexible the economy, the greater the structural effects of a given level of protection. In the basic model, the Italian economy is assumed to have been quite flexible (only two specific factors, rather high values for elasticity, etc.), and thus the effects could have been greater only if it had been assumed to be even more flexible. For instance, one could assume that factors such as 'Mediterranean land' and skilled labour were fairly mobile among sectors - i.e. that it was easily possible to switch the destination of land from arable farming to tree crops, or to move jobs from a steel plant ('military-industrial complex') to a cotton mill ('textiles'). These hypotheses do not seem very plausible, given the investments and time needed to build up a Mediterranean landscape or to acquire the necessary technical skills. Consequently, higher values of elasticity do not seem to be very plausible.

It can thus be concluded that, at least in a first approximation, the structural effect of protection was rather limited. Why? As shown in the previous section, protection in 1911 was quite low, with a total average of 10.6 per cent. The protection for the nine sectors ranged from a maximum of around 30 per cent for wheat and sugar to a minimum of 3.6 per cent for livestock farming. In fact, as column (b) of Table 10.3 shows, the structural effects of a move to free trade in 1897 would have been substantially greater.

CGE models are powerful analytical instruments, but they are hardly suited to micro-economic analysis. In fact, the sectors have to be quite large, as a model with hundreds of sectors would be difficult to build and even more difficult to describe and interpret. Many questions inevitably remain without an answer. For example, the CGE model suggests that free trade would have increased production in textiles. Which branch of textiles - silk, cotton, wool - would have benefited the most? The literature deals almost exclusively with questions of this type, which can only be tackled with more detailed measures. The simplest micro-economic measure of the level of protection enjoyed by a sector is the so-called rate of effective protection - i.e., the nominal protection rate on the final product net of the protection on its input. It can be used to explore the 
effects of trade policy on the structure of the economy under the plausible (but by no means certain) assumption that the rate of growth of a sector is positively correlated to the level of effective protection that it enjoys. ${ }^{31}$ Furthermore, effective protection could be used to investigate the consistency of trade policy if one could interpret it as a reliable proxy for the desired one. ${ }^{32}$ Table 10.4 reports estimates of effective protection for thirty-five sectors in $1911 .^{33}$

The average rates of effective protection (weighted with value added) were 16.7 per cent on manufactures and 11.3 per cent for primary prod-

Table 10.4 Nominal and effective protection in 1911: thirty-five sectors

\begin{tabular}{|c|c|c|c|}
\hline & Nominal & Effective & $\% V A$ \\
\hline Wheat & 29.1 & 30.7 & 5.9 \\
\hline Other tillage & 4.4 & 4.3 & 6.9 \\
\hline Mediterranean crops & 12.6 & 12.8 & 13.7 \\
\hline Animal products & 7.2 & 6.1 & 12.1 \\
\hline Mining & 2.5 & 1.4 & 1.1 \\
\hline Sugar beet processing & 65.1 & 126.0 & 0.3 \\
\hline Other food processing & 17.8 & 30.3 & 3.8 \\
\hline Tobacco & 10.8 & 22.2 & 0.1 \\
\hline Textiles & 12.9 & 26.9 & 2.1 \\
\hline Clothing & 13.2 & 15.3 & 1.2 \\
\hline Leather and fur & 5.2 & -0.7 & 1.5 \\
\hline Timber and furniture & 7.7 & 6.9 & 1.9 \\
\hline Steel-making & 28.1 & 74.2 & 0.3 \\
\hline Other metals & 11.2 & 28.3 & 0.1 \\
\hline Foundries & 0.1 & -10.3 & 0.1 \\
\hline Shipbuilding & 0.3 & -24.6 & 0.4 \\
\hline Rolling stock & 9.7 & 7.2 & 0.5 \\
\hline Gold processing & 1.5 & -3.4 & 0.2 \\
\hline Engineering & 11.9 & 8.2 & 3.0 \\
\hline Non-ferrous minerals & 10.4 & 12.4 & 1.3 \\
\hline Chemicals & 11.0 & 17.9 & 0.7 \\
\hline Coal and tar & 28.1 & 136.3 & 0.0 \\
\hline Rubber & 4.7 & -45.2 & 0.1 \\
\hline Paper & 7.7 & 5.4 & 0.3 \\
\hline Printing and publishing & 1.8 & -1.4 & 0.9 \\
\hline Other industries & 10.3 & 12.5 & 0.1 \\
\hline Building & 0.0 & -10.3 & 3.4 \\
\hline Gas, water, electricity & 0.0 & -1.4 & 0.9 \\
\hline Trade & 0.0 & -1.2 & 12.8 \\
\hline Transportation & 0.0 & -2.2 & 4.9 \\
\hline Communications & 0.0 & -1.0 & 0.6 \\
\hline Banking and insurance & 0.0 & -0.2 & 1.7 \\
\hline Other services & 0.0 & -0.9 & 5.2 \\
\hline Civil service & 0.0 & -3.0 & 5.5 \\
\hline Rents & 0.0 & -0.1 & 6.3 \\
\hline
\end{tabular}

Source: Federico and Tena, 1999, Table B7. 
ucts. Thus Italian protection was quite low, if compared with the levels attained under the ISI (Import-Substitution-Industrialisation) policies of the 1950s and 1960s in many Third World countries: the average effective protection on manufactures in Pakistan in 1963-4 was 271 per cent. ${ }^{34}$ As late as 1983, when ISI was already out of fashion, a World Bank survey defined as 'low' any rate of effective protection inferior to 40 per cent. ${ }^{35}$

A thirty-five-sector disaggregation for one benchmark year alone is still insufficient for a historical analysis. Effective protection rates can be estimated for some 400 'products' in all the five benchmark years, using, as proxies of the missing coefficients by product, those of the sector to which the products belong (e.g. using the same co-efficient for all textile manufactures). ${ }^{36}$ The results cannot be accurate, and thus they will be reported in relative terms - i.e. as the ratio between the rates of effective protection by product and the aggregate one. The latter is calculated as the average of the rates per product, weighted with the percentage of imports (and is therefore conceptually similar to the NT). This is a simple but telling measure of the degree of preference accorded to each 'product' among tradables. Table 10.5 reports the (relative) effective protection for the products that prominently feature in the debate on protection, wheat, iron and steel products, and sugar (nicknamed the 'drillers' by Giretti, a prominent free-trade polemicist), textiles and the three (alleged) 'losers' - engineering, chemicals and rubber industries. ${ }^{37}$

The table apparently supports the conventional wisdom about protection: after 1887, the three 'drillers' were protected more, sometimes much more, than average. ${ }^{38}$ Also, the cotton and wool industries were treated

Table 10.5 Relative effective protection on selected products

\begin{tabular}{lrrrrr}
\hline & 1877 & 1889 & 1897 & 1913 & 1926 \\
\hline Sugar & 4.1 & 17.5 & 24.4 & 37.0 & 3.0 \\
Sugar (a) & 3.7 & 4.8 & 5.3 & 6.5 & 2.5 \\
Pig iron & n.a. & 3.1 & 1.5 & 3.7 & 5.0 \\
Other steel goods & n.a. & 2.3 & 4.6 & 5.2 & 3.4 \\
Total steel manufactures & 1.6 & 2.0 & 2.8 & 3.9 & 3.5 \\
Grains & 0.5 & 1.6 & 2.5 & 2.6 & 1.5 \\
Cottons & 2.7 & 3.7 & 3.6 & 2.3 & 0.9 \\
Woollens & -1.3 & 2.1 & 2.9 & 1.8 & 2.2 \\
Linens and spun hemp & 0.4 & -0.3 & 0.0 & 0.5 & 0.7 \\
Rubber goods & 0.0 & 0.3 & 0.3 & 0.2 & 1.6 \\
Chemicals & 0.0 & -0.1 & -0.2 & 1.1 & 1.9 \\
Machinery & 0.1 & 0.3 & 0.3 & 0.5 & 1.3 \\
\hline
\end{tabular}

Source: Federico and Tena, 1999, Table 1.

Note

(a) protection net of excise on sugar for internal consumption (the figure for all imports, included those subject to a drawback was 13.2). 
better than average before 1913 - even though cottons, an export industry (after the 1890s) with a competitive domestic market, could benefit less than others. As expected, engineering and chemicals enjoyed little or no protection before the tariffs of 1921.

However, the traditional view poses two problems. First and foremost, the causal link between protection, import substitution and industrial growth was not as simple as historians normally assume. Two examples alone suffice to show that protection was neither necessary nor a sufficient condition for industrial development. For instance, the production of cast iron (heavily protected from 1887) began only in 1902, and the national companies did not succeed in dominating the domestic market even twenty years later. By contrast, the rubber industry (in substance, Pirelli) succeeded in developing and becoming established in foreign markets even with very low protection. Furthermore, the literature focuses on a relatively small set of goods. The products listed in Table 10.5 accounted for about one-fifth of the total output of tradables and for one-quarter of total imports. What was happening to the rest of the economy? Was protection inspired by a consistent strategy? The already-mentioned ISI strategy aimed at shifting resources out of agriculture into manufacturing, and thus effective protection on primary products had to be negative or nil or, at the very least, much lower than that on manufactures (thus implying negative protection on non-tradables). Balassa's classic study considers seven countries at the beginning of the 1960s: in two cases (Pakistan and the Philippines), effective protection on primary products was negative, and, in the other five cases, the ratio between effective protection on manufactures and agricultural products ranged from a minimum of 2.6 to a maximum of 26 (in Mexico). In the case of Italy, the same ratio was found to be greater than 1 ('revealing' a preference for manufactured goods) in 1889 and in 1926, very similar to 1 in 1877 and in 1913, and less than 1 in 1897. The maximum value, 1.72 in 1926, was very far from the 'typical' level under the post-1950 ISI policies. One can similarly assess other possible 'strategies'. For instance it could have been reasonable to protect more sectors, which used the abundant factor more intensively. In fact they were more likely to gain a comparative advantage quickly, and thus to wean themselves from protection, than sectors using scarce factors. There is no doubt that labour was the abundant factor in nineteenth-century Italy. On the basis of this principle, therefore, it would have been rational to protect labour-intensive manufactures such as textiles, more than capital-intensive ones, such as iron and steel. Instead, the ratio between effective protection on the two groups varied randomly. Duties were indeed higher on labour-intensive industrial goods in 1897, but in 1877, 1889 and 1926 they were relatively higher on capital-intensive manufactures (thanks to the high protection on iron and steel goods). Even more 'perverse', in this view, was the choice of protecting land-intensive wheat-growing. One could test other 'strategies' with further comparisons (e.g. between investment products and consumer goods, or between inter- 
mediate and finished goods), but the result would not change. Last but not least, protection varied considerably from one benchmark year to another. The coefficients of correlation between rates of protection (nominal and effective) by product range between 0.45 and 0.75 . The lowest coefficients are, predictably, between 1877 and 1889, but correlation is also low in periods which saw no major changes in trade policy (notably between 1897 and 1913).

On the whole, therefore, Italian protection appears to have been a causal collection of not very high duties (with notable exceptions), which were not inspired by any consistent strategy and were quite variable in time. These features derived directly from the political economy of trade policy, which will be examined below. At this point, it is appropriate to emphasise that such a policy hardly seems suited to foster structural change. In particular, the short-term variability was bound to discourage investment in import-competing goods. Needless to say, this conclusion is very general, and must be interpreted with caution. The causal link between protection and industrial development is very complex, and should be assessed case-by-case.

\section{Trade policy and the distribution of income}

The effect of trade policy on the distribution of income by production factors can be tackled with the CGE model described above. As already mentioned, it takes five factors into account: land, 'Mediterranean land', capital, unskilled labour and (sector-specific) skilled labour. Table 10.6 reports the percentage changes in returns to these factors, according to the baseline hypotheses on their mobility, if all duties were abolished in 1911 - column (a) - or in 1897 - column (b).

Table 10.6 Effects of free trade on income by factor

\begin{tabular}{lrr}
\hline & $(a)$ & $(b)$ \\
\hline Unskilled labour & 3.5 & 5.0 \\
Capital & 3.4 & 3.6 \\
Land & -8.1 & -11.1 \\
Mediterranean & 1.6 & 2.7 \\
Skilled labour $(\alpha)$ & -30.3 & -42.1 \\
Skilled labour $(\beta)$ & -0.8 & -16.1 \\
Skilled labour $(\gamma)$ & 80.4 & 118.7 \\
Skilled labour $(\delta)$ & 17.2 & 33.8 \\
Skilled labour $(\epsilon)$ & 2.4 & 4.3 \\
\hline
\end{tabular}

Source: Federico and O’Rourke, 2000, Table 10.6

Note

Greek letters refer to the following industrial sectors: $\alpha$ : 'Military-industrial complex'; $\beta$ : Capital-intensive industries; $\gamma$ : Textiles; $\delta$ : Other light industries; $\epsilon$ : Services. 
As can easily be predicted, protection was important for better or for worse, above all for the sector-specific factors, such as skilled labour in manufacturing. For instance, the wages for skilled labour in textiles (although initially quite low) would have increased by 80 per cent, as, under free-trade, exports would have grown substantially (Table 10.3). ${ }^{39}$ By contrast, the effects on the return to mobile factors, such as unskilled labour, capital and land, would have been modest. In particular, the income of land would have decreased by only 8 per cent, as land would have been re-allocated from wheat to other crops. On top of this, returns from land accounted for only a part of the income of landowners, which also included the profits on capital invested in agricultural estates. Free trade would have reduced the total income of non-Mediterranean landowners by about 5 per cent (135 million Lire out of 2,780) and the total income of all landowners by 2.5 per cent (106 million out of 4,435). In practice, the abolition of protectionism would have been equivalent to an increase of 40 per cent in government taxes on land. Landlords could have afforded it, as the total burden on property would still have been lower than in the $1870 \mathrm{~s} .{ }^{40}$ Workers and capitalists would have gained: protectionism reduced the total wage bill in industry and in services (including returns to skilled labour) by about 4 per cent - 300 million Lire out of 7,450 . The sole abolition of the duty on wheat increased wages by 2.2 per cent, which was certainly much too little to reduce emigration in a significant manner, as hypothesised by Fenoaltea. ${ }^{41}$

To sum up, the effects of protectionism on the distribution of income in 1911 were relatively modest. This result did not depend exclusively on the (relatively low) level of protection in that year. In fact, the high protection in 1897 (Table 10.6, column (b)) did not affect income distribution enough to alter the basic conclusion. The assumptions on the mobility of factors do not seem decisive, either. With all the plausible alternatives, the differences with respect to the basic hypothesis are modest. Protectionism could have substantially changed the distribution of income only if the factors had been completely immobile - but this hypothesis is absolutely unrealistic. Anyway, in this case, protection, by definition, could not have changed the allocation of resources - i.e. it could not have caused structural change and industrialisation.

\section{Some thoughts on the causes of protection}

The political economy of trade policy is a hot topic among economists, political scientists and sociologists who have provided a wealth of interpretative models. ${ }^{42}$ Their suggestions can be summarised - with a considerable dose of simplification - in four, not mutually exclusive, causes:

a the need for fiscal revenue;

b lobbying by potential beneficiaries of protection; 
c interplay with other sovereign states;

d 'spontaneous' decisions by the government.

The first item in the list does not require much comment. Custom duties have long been a major source of revenue. Their collection did not need a huge bureaucracy and their effect on income is much less evident than those of direct or even indirect taxation. ${ }^{43}$ The expression 'potential beneficiaries' is generic enough to encompass two quite different patterns of political mobilisation of interests (and all the many possible intermediate combinations). They can be organised by sector (the iron and steel industry, wheat growing etc.) or by factor (workers, capitalists). Trade policy can be decided correspondingly via bargaining among sector lobbies in parliament, as in nineteenth- and early-twentieth-century United States, or it can be a major issue in general elections, among major parties representing 'classes' (workers, capitalists, landowners) as in the 1906 election in the United Kingdom. Verdier calls these two patterns 'pressure politics' and 'party politics' respectively, and argues that their prevalence depended on features of the political system, such as the loyalty of parliamentarians to their own party and the interest of voters in the issue of trade policy. ${ }^{44}$ Because of his training as a political scientist, Verdier tends to downplay the importance of the purely economic motivations, which, however, did matter a great deal. In particular, the less mobile a factor is, the greater interest the owner has in the conditions of the sector in which he is placed, and thus the likelihood of a sector lobby. Conversely, sectorally mobile factors would more likely gather in major parties. Many economists also stress the influence of the economic cycle: the claims for protection are more intense, ceteris paribus, during a recession than during an expansion. ${ }^{45}$ The third item on the list is often interpreted quite crudely, assuming that a 'hegemonic' power (if it exists) would force other countries to adopt the trade policy which best fits its interests - i.e. almost always, to open their markets to its own exports. Thus, free trade is more likely when there is a strong 'hegemonic' power (Great Britain during the nineteenth century, the USA in the period since the Second World War), while protectionism is likely to prevail in periods of weak or non-existent hegemony (the interwar). ${ }^{46}$ However, international relations may also determine the level of duties, which were often established by bilateral (the practice up until 1945) or multilateral (in the post-1945 period) international agreements. The last item is clearly residual. It includes all the other possible motivations for trade policymaking, such as the need to improve the conditions of the balance of payments or the desire to develop war-related industries. Verdier groups them under the category of 'executive policies', and argues that they inspired French trade policy. The overall aims of the policy were set with bipartisan consensus, and the bureaucrats worked out the details. In a similar way, in many authoritarian regimes, the policy was dictated by the ruler and then specified and implemented by bureaucrats. 
Which of these causes can account for Italian trade policy? The Italian literature is not very helpful in answering this. In fact, the causes of trade policy have attracted historians' attention much less than its sequences. There are few works on the subject, and these do not go much beyond an accurate chronicle of the events. At most, the authors use a crude version of the 'pressure policy model', assuming that trade policy was determined by the dominant elite according to its own interests. ${ }^{47}$ After Unification, landowners dominated the country, and thus they imposed laissez-faire to open foreign markets to Italian agricultural products, neglecting the protests of the (much weaker) industrial interests. They changed their minds when the collapse of international wheat prices endangered income from wheat growing, and forged a protectionist alliance with the industrialists - an 'agrarian-industrial block', very similar to the 'alliance of grain and iron' in Germany. The principal sponsor of the operation was - unsurprisingly Senator A. Rossi, the owner of a wool mill. As an entrepreneur, he should have opposed the duty on wheat, which increased nominal industrial wages. Instead, he was an enthusiastic supporter of it, having realised the power of the landowners (and his tireless campaign gained him wide attention from historians). Once created, the 'agrarian-industrial block' dominated trade policy until the $1950 \mathrm{~s}$, thwarting every attempt on the part of free-traders to reduce duties. This interpretation, first put forward by Sereni in the 1960s on the basis of parliamentary minutes, still largely inspires the conventional wisdom, although further research has enriched the picture. For example, it has been shown that landowners, especially in the South, were far from compact in their support for the duty on wheat. ${ }^{48}$ Bientinesi shows that duties on manufactures in the 1921 tariff were substantially lower than in the first proposal by the committee because the steel industry was hit by a very severe crisis in 1920, which greatly affected its bargaining power. ${ }^{49}$

Conventional wisdom contains a considerable measure of truth. Many decisions clearly benefited some specific interests: for instance, the adoption of the duty on wheat in 1887 not only increased the incomes of landowners, but also assured them that the price of wheat would not be allowed to fall. Furthermore, liberal Italy, on paper, fitted Verdier's definition of 'pressure politics' perfectly. Duties had to be approved by Parliament, which was elected by a tiny minority - some 2 per cent of total population until the electoral reform of 1881, which extended the right to vote to literate males without any further qualification. The share of voters rose to 7-8 per cent of the population and later it jumped to 24 per cent after the introduction of universal male suffrage in 1911. Consequently, until the turn of the century, landowners and entrepreneurs accounted for a sizeable proportion of the electorate, and many of them were also members of parliament, where they could advocate their interests directly, without the need of lobbyists. On the other hand, the actual decisionmaking process was fairly complex. Corbino, for example, writes with regard to the protectionist turning point of 1887 : 
Then, when the consequences of all this [the break with France] were noted, each one hastened to say that he had not been the one and that he would never have wanted such a thing!... The Hon. Ellena [Chairman of the Investigation Committee] said that he had suggested moderate tariffs; Magliani [Minister of the Treasury] sustained that, for his part, he had confirmed them, but that it was the [parliamentary] Committee that had increased them; the [parliamentary] Committee asserted that it was the Chamber of Deputies, and the deputies affirmed, afterwards, that they had done nothing that was not in agreement with Magliani. ${ }^{50}$

The passage refers to the tariff on manufactures, which Parliament could set autonomously. It had much less power on trade treaties, which, as already said, deeply affected the level of protection. They were negotiated by ad hoc envoys, and the Parliament could only approve a treaty or reject it as a whole (as in the fast-track clause in American Congress). This last act might have had serious consequences in international relations, and the chances that a disappointed lobby could persuade the Parliament to reject a treaty were extremely small. Lobbies should have acted upstream, during the negotiations. Unfortunately, it is difficult to understand from the official reports how much the Italian negotiators, or the government which drafted their instructions, were subject to lobbying and how much they bowed to it. Pegorari, in his detailed work on the treaty with France of 1877 and the tariff of 1878, does not mention external pressures. Luigi Luzzatti, the principal negotiator of the treaty, seems to have been able to act almost undisturbed, with the exception of the purely rhetoretical - criticisms of free-traders. ${ }^{51}$ This may have been an exception, as Luzzatti was a very strong-willed and powerful man, who later became prime minister. Unfortunately, we do not know, as there are no comparable works on the negotiations for other treaties. In theory, the extension of suffrage and, above all, the birth of the first mass party, the Italian Socialist Party (PSI), at the end of the nineteenth century could have changed the process of policy-making - moving it towards the English model of 'party politics'. In fact, the PSI claimed to represent the working class, and thus it should have sided according to their general interests. The free-traders hoped to enrol its support in their campaign, stressing the negative effect of the duty on wheat on real wages, but failed. ${ }^{52}$ This failure should not be so surprising if the losses for skilled workers (the party's main constituency) were as low as was estimated on pages 207-8.

So far, we have considered only one of the possible causes of protection. What about the other three? Without specific literature, we can only put forward some very general hypotheses. It seems improbable that international relations played an important role in determining actual policies, although Italy was surely affected by the general climate. Italy was, at least 


\section{Giovanni Federico}

on paper, one of the great European powers, and, as such, was certainly not disposed to let a 'hegemonic' power impose any specific obligation, as Japan had been forced to do until 1899. Conversely, foreign policy considerations may have suggested an aggressive stance in the negotiations with France in 1888, which caused their failure and the subsequent disastrous trade war between the two countries. Undoubtedly, trade treaties limited Italy's freedom, but it was its own choice. For example, from 1904 to 1906, Italy lowered its duties on chemical products in exchange for German concessions for Italian exports of citrus fruits and other primary products. If the Italian government had wanted to protect its chemical industry, it would have ordered its negotiators to arrive at a different agreement or, if necessary, to break off the negotiations. The government's spontaneous decisions may, instead, have played a non-negligible role. The results above rule out the hypothesis of a consistent industrialisation strategy, but the duties on cast iron and other steel products do, at least, seem to have been inspired mainly by 'political' motivations. In the 1880 s, the industry was very small and backward, and thus was unable to organise an effective lobby, as it would subsequently do in order to defend or increase its initial protection. But a strong domestic iron and steel industry was considered essential for the country's growing imperialistic ambitions. Moreover, one should not neglect the impact of personalities such as Cavour and Mussolini in shaping trade policy in pre-Unification Piedmont and Fascist Italy respectively. The massive biography by Romeo attributes to Cavour a decisive role in the liberalisation of Piemontese trade policy in the 1850s. ${ }^{53}$ However, the monumental work by De Felice on Mussolini rarely mentions trade policy before the $1930 \mathrm{~s} .{ }^{54}$ On the other hand, many scholars regard Fascist trade policy as a reaction to the problems of the Italian balance of payments. ${ }^{55}$ The topic undoubtedly deserves more in-depth study.

Last but not least, it seems difficult to understand the structure of Italian protection without taking the fiscal motive into consideration. The need for revenue was routinely quoted to justify increases in duties - e.g. by Luzzatti in the negotiations with France of 1877. Many of these statements may have been instrumental, but duties were certainly a conspicuous source of revenue, which a country often in difficulty with its budget could not afford to overlook. In fact, they supplied between 5 per cent and 8 per cent of the total revenues until the 1880 s, and about 15 per cent in the $1890 \mathrm{~s}$ and early $1900 \mathrm{~s} .{ }^{56}$ Between half and two-thirds of these revenues were provided by duties on wheat, sugar, coffee and petroleum. The duty on wheat was first imposed to stave off the competition of foreign wheat, but further increases in the 1890s were part of revenueraising tax bills (the so-called 'decreti catenaccio'). ${ }^{57}$ The duty on sugar was imposed in 1877, when the national production of sugar was negligible, and the sugar industry refined imported material. ${ }^{58}$ The duties on petroleum and coffee were unquestionably fiscal ones, as the commodities were not produced in Italy, and had no close local substitute. 


\section{Summary: what have we learned?}

It is possible to sum up the results of our research in seven statements.

1 Considered as a whole, Italian trade policy was confused and lacking a clear strategy.

2 Nominal protection remained fairly low, with few important exceptions (many of which were of a 'fiscal' nature).

3 Welfare losses from protection were not large.

4 Effective protection was not high, with some notable exceptions (notably wheat growing and the iron and steel industry).

5 The effects of protection on the structure of the economy were fairly modest, although it was instrumental in the survival of wheat-growing.

6 The effect of protection on distribution of income was noticeable but still not huge.

7 Trade policy seems to have been determined mainly by lobbying and by the needs for tax revenue.

Several of these results are not unexpected, even if a quantitative confirmation is always welcome. Others may be newer and more debatable. They suggest that trade policy (and therefore, by extension, the state) counted much less, for better or for worse, in Italian economic development than is usually believed. This conclusion, we must stress, is based on a static analysis, which is severely constrained by the available data and analytical tools. A 'protectionist' might maintain that protectionism was essential for the development of industries, which had had very important 'dynamic' long-term effects on Italian industrialisation and technical development (although the tariff on wheat cannot be defended from this point of view). As Amatori puts it, 'the word industrialisation was a synonym for steel'. ${ }^{59}$ Unfortunately, these dynamic effects are difficult to identify and, a fortiori, to estimate with the analytical tools so far available at least as far as the author knows. Without a theoretical breakthrough, the debate on trade policy is not likely to be settled. However, the results of this research have made it advance onto firmer ground. Or at least that is this author's hope.

\section{Notes}

1 This paper was originally published in Italian, with the same title, in L. Cafagna and N. Crepax (eds) Atti di intelligenza. Saggi per il bicentenario della nascita di Carlo Cattaneo, Bologna, Il Mulino, pp. 243-81.

2 Department of History and Civilisation, European University Institute, Florence (Italy).

3 Federico and Tena, 1998, 1999; Federico and O'Rourke, 2000.

4 For a general outline on the trade policy of the main European countries, see Bairoch, 1976a, 1989; Foreman-Peck, 1995a.

5 For an outline of the trade policy in the pre-Unity states, see E. Del Vecchio, $L a$ 


\section{Giovanni Federico}

via italiana al protezionismo, Roma, 1979, Vol. 1; and, for the individual states, M. Di Gianfrancesco, 'La politica commerciale degli stati sardi dal 1814 al 1859', Rassegna storica del Risorgimento, 61/1 (Jan.-Mar. 1974), pp. 3-36; Franco Bonelli, 'Il commercio estero dello Stato Pontificio nel secolo XIX', Archivio Economico dell'Unificazione Italiana, I, 9 (Roma, 1961); G. Parenti, 'Il commercio estero del Granducato di Toscana dal 1851 al 1859', in G. Parenti (eds) Archivio Economico dell'Unificazione Italiana, Serie I, Vol. VI. T.1, fasc. 1 (Roma, 1959); Rupert Pichler, L'economia lombarda e l'Austria. Politica commerciale e sviluppo industriale 1815-1859 (Milan, Franco Angeli, 2001).

6 The literature on trade policy is huge, but the best description of Italian trade policy is (still) E. Corbino, Annali dell'economia italiana, 5 vols. (Citta di Castello, 1931-5), then republished and updated in IPSOA, Annali dell'economia italiana. See also, U. Calderoni, I cento anni della politica doganale italiana (Padoua, CEDAM 1961) and, for the period up to 1888, E. Del Vecchio, La via italiana al protezionismo, op. cit. The essential facts are summarised by A. Pedone, 'La politica del commercia con l'estero', in G. Fua (ed.) Lo sviluppo economico in Italia, vol. 2 (Milan, Franco Angeli, 1969), pp. 241-59.

7 See G. Are, Il problema dello sviluppo industriale nell'età della Destra, Pisa (NistriLisch, 1965).

8 Perhaps it is useful to recall that all the treaties included the most favourednation clause - i.e. trade between the two contracting countries had the right to the most favourable treatment possible. Under this regime, a reduction in duties on, say, French imports was automatically extended to imports from Germany, the United Kingdom and so on.

9 The definition of 'natural industry' is rather vague. It unquestionably included the processing of domestic raw materials (notably silk), but sometimes it was extended to processing of imported ones, such as cotton, provided that processing was labour-intensive.

10 The origin of this model can be traced to Cavour (see L. Cafagna, Dualismo e sviluppo nella storia d'Italia (Padoua, Marsilio, 1898, pp. 223-61). For a detailed account of the theories of economists, see A. Cardini, Stato liberale e protezionismo in Italia (Bologna, Il Mulino, 1981) and, for De Viti De Marco, a leading 'free-trader', A. Cardini, Antonio De Viti De Marco (Bari, Laterza 1985); also, S. Inghirami, La predica inutile dei liberisti (Milano, F. Angeli, 1991).

11 Cafagna, 1898, op. cit., pp. 386-7.

12 G. Sapelli, 'Technical change, micro-economic evolution and growth: an introductory view of Italian economic development', in G. Dosi, R. Giannetti and P. A. Toninelli (eds) Technology and Enterprise in Historical Perspective (Oxford, Oxford University Press, 1991), pp. 291-313; V. Zamagni, Lo stato italiano e l'economia, Florenze (Le Monnier, 1981); Dalla periferia al centro (Bologne, II Mulino, 1993), 2nd edn; F. Amatori and B. Bezza (eds) L'industria chimica in Italia in Montecatini 1886-1966 Capitoli di storia di una grande impresa (Bologne, II Mulino, 1990) and, more recently, G. Pescosolido, Unità nazionale e sviluppo economico (Bari, Laterza, 1998).

13 See G. Are, Alle origini dell'Italia industriale (Naples, Guida, 1974).

14 See A. Gerschenkron, 'Notes on the rate of industrial growth in Italy, 1881-1913', originally published in Journal of Economic History (1958) and then reprinted in Economic Backwardness in Historical Perspective (Harvard, Belknap, 1962). The quotation is on page 80 of the Italian edition.

15 S. Fenoaltea, 'Riflessioni sull'esperienza industriale italiana dal Risorgimento alla Prima Guerra Mondiale', in G. Toniolo (ed.), Lo sviluppo economico italiano 1861-1940 (Bari, Laterza, 1973).

16 See A. Gerschenkron, Economic Backwardness, loc. cit.; P. Sylos-Labini, Problemi dello sviluppo economico (Bari, Laterza, 1973) and J. Cohen, 'Fascism and agricul- 
ture in Italy: policies and consequences', Economic History Review, 32 (1979), pp. $70-97$.

17 S. Fenoaltea, 'Politica doganale, sviluppo industriale, emigrazione: verso una considerazione del dazio suI grano', Rivista di Storia Economica, 10 (1993), pp. 65-7 and S. Fenoaltea, 'Notes on the rate of industrial growth in Italy 1860-1913', Journal of Economic History, 63 (2003), pp. 695-734,

18 V. Zamagni, An Economic History of Italy (Oxford, Oxford University Press, 1993); Federico, 'Commercio dei cereali e dazio suI grano in Italia (1863-1913), Una analisi quantitativa', Nuova Rivista Storica, 68 (1984), pp. 46-108 and A. Pescosolido (Unita nazionale e sviluppo economico, op. cit.), who extends the argument to the entire protectionist turning point of 1887 .

19 For a recent example of this post hoc propter hoc reasoning, see S. FenoaItea, 'Manchester, Manchesteriano ... dekwakoncoz?', in Luciano Cafagna and Nicola Crepax (eds) Atti di intelligenza e sviluppo economico. Saggi per il bicentenario della nascita di Carlo Cattaneo (Bologne, Il Mulino, 2001), pp. 491-511.

20 Toniolo, 1977: 659-73. See also the estimates of level of protection on selected products by G. Tattarra, 'Protezione effettiva e sviluppo di alcuni settori dell'industria manifatturiera italiana dal 1921 al 1930', Studi Economici, 11 (1980), pp. 82-151 and V. Zamagni, 'L'industria chimica in Italia', op. cit., pp. 69-149.

21 G. Toniolo, 1977: 671, 672. He estimates that counterfactual engineering production would have been double the actual one in 1906-8 and 40 per cent higher in 1913, but total GDP would have been only 1.4 per cent and 0.9 per cent higher, respectively. The author deems abolition-cum-subsidy politically just as difficult.

22 See the debate between John V. Nye and Douglas Irwin on protectionism in Great Britain and France (Chapters 1-3 of the present volume).

23 For the purposes of the calculation, Italian imports are collected together in about 400 'products', corresponding approximately to four figures of the SITC classification. The NTw in 1913 is computed from data on value added in 1911 (G. M. Rey (ed.) I conti economici dell'Italia. Vol. 2, Una stima del Valore Aggiunto per il 1911 (Bari, Laterza, 1992)) and those in 1889 and 1897 from the value added in 1891 from Rey, I conti economici dell'Italia. Vol. 3**, Il Valore Aggiunto per gli anni 1891, 1938, 1951 (Bari, Laterza, 2000). Thus, these latter estimates are clearly only tentative.

24 The TRI is defined as the 'level of equal tariffs [for all goods] which, if applied to the new level of tariffs, makes it possible to maintain unvaried the initial level of utility of the representative consumer' (Anderson, 1995: 160). In other words, it measures the percentage change in a hypothetical tariff equal for all goods, which corresponds to the effective change (differentiated according to product), the welfare being equal. It is possible to calculate the TRI comparing the actual tariff structure in two different years (e.g. 1889 and 1896), or comparing the actual tariff structure with any counterfactual one, including, obviously, pure free trade.

25 Elasticity of substitution in consumption measures the change in consumption, given a unitary variation in the relative prices between two products; elasticity of substitution in production measures the change in the use of factors in a given production, given a unitary variation in their relative prices. Elasticity of transformation measures the change in the structure of production, given a change in the relative prices of the factors. A unitary elasticity implies that the change is equal, percentage-wise, to the initial variation (an increase of 1 per cent in the relative price of wheat compared to wine, for example, makes the consumption of wheat drop by 1 per cent and increases that of wine by 1 per cent).

26 See G. Federico and K. O'Rourke, 'A social accounting matrix for Italy in 1911', Rivista di Storia Economica, 16, 1 (2000), pp. 3-35. 
27 The total skill premium is the difference between the actual wage (separately for men, women and children) and the wage of a farm labourer, assumed to be the benchmark for non-skilled labour. For all the details and sources, See G. Federico and O'Rourke, 2000, op. cit.

28 The assumption is plausible as each of the nine sectors included a wide range of commodities. Imports which could not be produced in Italy, such as coffee, are lumped together in a category of 'tropical products'.

29 The model assumes a fixed land endowment. The stock of labour increases as much as population, while capital grows for the accumulation of savings (computed as a share of profits). Every year, the 'dynamic' version recalculates the variation in the GDP with the new stock of factors. The estimate in the text refers to the GDP for 1938, and compares the growth in the two alternative hypotheses of free trade and protectionism (at the 1911 levels) during the entire period from 1911 to 1938 . It is scarcely worth noting that this is not a realistic model, since it totally overlooks technical progress.

30 It would change little even if a perfect international mobility of capital were hypothesised (see S. Fenoaltea, 'International resource flows and construction movements in the Atlantic economy: the Kuznets cycle in Italy', Journal of Economic History, 48 (1988), pp. 605-37), i.e. Italy could attract unlimited quantities of capital, instead of having a stock limited by domestic savings.

31 This hypothesis is plausible, but by no means certain. A very high level of protection may not cause an increase in output if production needs some specific factor. In any case, the increase in production is not necessarily proportional to the level of protection.

32 This interpretation assumes that policy-makers could distinguish between nominal and effective protection. The theoretical concepts were formalised only in the 1950 s, but nineteenth century observers did recognise the difference. Industrial lobbyists always asked that duties on their products exceeded those on raw materials.

33 The formula utilised is $E_{p i}=\left[T_{i}-\sum a_{i j} \cdot T_{j}\right] \div\left[1-\sum a_{i j}\right]$, where $i$ indicates the sector (or product), $j$ the input, $T$ the duty, $a_{i j}$ the technical coefficient of the input-output matrix (i.e. the quantity of input $\mathrm{j}$ necessary for producing product $i$ ). Therefore, protection may be negative if duties on inputs exceed those on the finished product. See G. Federico and K. O'Rourke, 2000, op. cit. This is an extension of the table - originally with twenty-six sectors - prepared by O. Vitali, 1992: 283-337.

34 B. Balassa, The Structure of Protection in Developing Countries (Baltimore, Johns Hopkins University Press, 1971), Table 3.1.

35 R. Agarwala, 'Price distortions and growth in developing countries', World Bank Staff Working Papers No. 57, Washington, DC, World Bank, 1983.

36 The calculation is repeated with three different input-output tables - the already mentioned one for Italy in 1911, the well-known matrix of Mark Thomas (1991), for Great Britain in 1907 (with forty-one sectors), and lastly the table estimated by V. Cao-Pinna, 'La costruzione del bilancio analitico dell'economia italiana per il 1950', L'industria (1952), pp. 527-619, formally referred to 1950 , but in reality built on the basis of the 1937-9 industrial census (with fifty-six sectors). The figures of Table 5.11 are simple average rates estimated with different tables, which do not differ substantially (the coefficients of correlation range from between 0.75 to 0.9 .

37 E. Giretti, I trivellatori della nazione italiana (Roma, Libreria Politica Moderna, 1913).

38 The row 'sugar (a)' is closer to the actual rents to producers - the rest of the rents being appropriated by the state as an excise.

39 Returns to skilled labour accounted for only 22.6 per cent of the wage bill in 
textiles, versus 35.4 per cent in the 'military-industrial complex', 42.4 per cent in other light industries and 29.3 per cent in services (and 19.3 per cent in the 'other capital-intensive industries').

40 The amount of the land tax in 1911 was, in fact, 40 per cent less in real terms than the maximum of 1869-71 (F. Repaci, La finanza Pubblica Italiana nel Secolo 1861-1960 (Bologna, ZanicheIli, 1962), table 13), while gross agricultural output was 40 per cent higher (Ercolani, 'Documentazione Statistica di Base', in G. Fuà (ed.) Lo Sviluppo Economico in Italia (Milano, F. Angeli, 1969), pp. 379-470, Table XII.1.1.A).

41 For the elasticity of migration to wages, see T. J. Hatton and J. G. Williamson, The Age of Mass Migration: an Economic Analysis (New York, Oxford University Press, 1997), Table 6.2.

42 For a general perspective, see R. Riezman and J. D. Wilson, 'Politics and trade policy' in J. Banks and E. Hanuschek (eds.) Modern Political Economy (Cambridge: Cambridge University Press, 1995), pp. 108-44. Unfortunately, the literature, precisely because it comes from different disciplines, is difficult to summarise. The indications in the following notes are purely by way of examples.

43 See, for instance M. Jansen, 'Taxation and the political economy of the tariff', International Organization, 44 (Autumn 1990), pp. 526-49.

44 D. Verdier, 1994

45 The hypothesis was tested in a historic context, with mixed results, by J. Thornton and P. Molyneux, 'Tariff homogeneity: evidence from 19th-century Europe', Economic Letters, 56, 3 (November 1997), pp. 345-50; and by K. O'Rourke, 'Tariffs and growth in the late 19th century', Economic Journal, 110 (2000), pp. 456-83.

46 See, for instance, D. A. Lake, Power, Protection and Free Trade (Ithaca, Cornell University Press, 1988), J. C. Conybeare, 'Tariff protection in developed and developing countries: a cross sectional and longitudinal analysis', International Organization, 37, 3 (1983), pp. 442-6 and P. Marsh, Bargaining on Europe. Britain and the First Common Market, 1860-1892 (New Haven and London), Yale University Press, 1998).

47 See E. Sereni, Capitalismo e mercato nazionale (Rome, Editori Riuniti, 1966) and E. Del Vecchio, La via italiana al protezionismo (Rome, Camera dei Deputati, 1978).

48 L. Musella, Proprietà e politica agraria in Italia (1861-1914) (Napoli, Guida, 1984); S. Lupo, 'I proprietary terrieri nel Mezzogiorno', in P. Bevilacqua (ed.) Storia dell'agricoltura italiana in età contemporanea, vol. 2 Uomini e classi (Venezia, Marsilio, 1990), pp. 105-49. Also, the tenants of the large capitalistic farms of the Po Valley were anything but enthusiastic about the protectionistic solution (M. Malatesta, I signori della terra (Milano, F. Angeli, 1989), pp. 199-207).

49 F. Bientesi, 'La tariffa del 1921 e le associazioni degli industriali italiani: ricerca della protezione, equilibri interni e rapporti con iI mondo politico, 1913-1923', Rivista di storia economica, 15 (1999), pp. 167-205.

50 E. Corbino, 1959, Vol. 3: 218.

51 P. Pegorari, II protezionismo imperfetto (Venezia, Istituto Veneto di Scienze, Lettere ed Arti, 1989), above all pp. 219-36, on the 'domestic repercussions'. The lack of information is significant, given that the author bases his research on the personal archives of L. Luzzatti. However, it cannot be excluded that Luzzatti received some informal suggestions, or that Pegorari did not consider this issue to be worthy of greater attention.

52 S. Inghirami, 1991: 48-58.

53 R. Romeo, Cavour ed il suo tempo, vol. II (Bari. 1984), pp. 463-72.

54 R. De Felice, Mussolini il fascista, 2 volumes (Torino, Einaudi, 1995). 


\section{Giovanni Federico}

55 See G. Toniolo. L'economia dell'Italia fascista (Bari, Laterza, 1980), chapter 6; G. C. Falco, 'La bilancia dei pagamenti italiana fra la prima guerra mondiale ed il 1931', Ricerche per la storia della Banca d'ltalia, vol. 6 (Bari, Laterza, 1995), pp. 3-264; G. Tattara, 1980; S. La Francesca, La politica economica del fascismo (Bari, Laterza. 1973).

56 For the data, see F. Repaci, 1962.

57 G. Marongiu, Storia del fisco in ltalia (Torino, Einaudi, 1995-6), 2 vols; G. Parravicini. La politica fiscale e le entrate effettive del regno d'ltalia 1860-1890 (Torino, ILTE, 1958).

58 M. Elisabetta Tonizzi, L’industria dello zucchero (Milan, Franco Angeli, 2001), p. 193.

$59 \mathrm{~F}$. Amatori, 'Italy, the tormented rise of organisational capabilities between government and families', in A. Chandler, F. Amatori and T. Hikino (eds) Big Business and the Wealth of Nations (Cambridge, Cambridge University Press, 1997), p. 225. 


\title{
11 From virtual free-trade to virtual protectionism
}

\author{
Or, did protectionism have any part \\ in Germany's rise to commercial \\ power $1850-1913^{1}$
}

Béatrice Dedinger ${ }^{2}$

The belief that Bismarck's heavily nationalist and protectionist stance sustained German post-1870 industrialisation and eruption onto world markets has survived the test of time, especially among non-economists and international relations specialists. In so far as Germany became a major player both in international trade relations and on the world stage during the Wilhelminian period, it is a little contradictory to assert that it did so by raising protective trade barriers between herself and the rest of the world. Such contentions, however, are still heard, reinforced as they are by authoritative expert contemporaries and later historians. Thus, Ludwig von Mises railed against the luminaries of the German historical school of his early years:

Most professors [while deprecating] the 'errors and abstractions of the Classical school' [...] propagated in their writings and in their courses the policies of the imperial government: conservatism, Sozialpolitik, protectionism, huge armaments and aggressive nationalism.

(Mises, 1956: 58)

Among the latter, the most prominent, Paul Bairoch, asserts that 'Germany was the first nation to draw the lessons from the failure of free trade policies. In 1879 she adopted a well-balanced tariff which fostered industrialisation without hurting agriculture' (Bairoch, 1996: 416). This statement constituted one of the facets of its oft-repeated conviction that tariff protection promoted and free-trade policies harmed economic growth in general, and industrial development in particular. Bairoch worked out his demonstration from the study of the French latenineteenth-century experience (Bairoch, 1970), later extending it to Germany and the rest of Europe at a time when import substitution policies for the Third World, advocated by development economists, was all the rage. Surprisingly his demonstration, however superficial or even 
simplistic, has remained unchallenged and is still regarded as definitive by most scholars outside the field of economic history. It has avoided facing the kind of criticisms and attacks heaped on the 1970s advocates of import substitution. Besides the weakness of the correlations, ${ }^{3}$ which Bairoch retained nevertheless as conclusive proof of the beneficial effects of latenineteenth-century tariffs, his demonstration excludes the observation that heavily protectionist countries such as Spain, Russia and Portugal failed to grow markedly and certainly to catch up on western industrial countries; by contrast, Sweden, Japan or even Romania, whose policies were much closer to free trade (due to unequal treaties in the latter cases), experienced more favourable economic fortunes. Furthermore, leaning heavily as he does on the Listian argument about infant industries, he forgets that late-nineteenth-century tariffs were essentially geared at protecting agriculture, a policy that List strongly repudiated. ${ }^{4}$

However, as a 'handmaiden' of industrial growth, late-nineteenthcentury German protectionism could reveal itself as a red herring or another instance of the gap between reality and rhetoric - to paraphrase Peter Bauer. Historians like Bairoch have been keen to back their arguments by relying on the profuse protectionist literature produced at the time, and this may have influenced their overall impression on the impact of tariffs. With regard to the problems of measuring the impact of protection, Bairoch's use of global rates of tariff revenue and their association to indicators of industrial levels and development/growth has attracted scant - but convincing - criticisms (Capie, 1983; Messerlin, 1985b). His contention of Imperial Germany as the archetypal success story of protectionist policies has only been dealt with on the basis of sectoral, however conclusive, evidence (Webb, 1978). Two key questions seem to need further elucidation:

1 Did German tariffs foster infant industries - especially those which made up the backbone of Germany's storm conquest of world markets?

2 Do protected industries account for Germany's spectacular commercial expansion prior to 1914 ?

This chapter will deal more specifically with the absence of a correlation - implied by the protectionist argument between tariff protection and Germany's comparative advantage in the kind of goods which sustained its trade penetration of world markets before 1914. The absence of any meaningful association between the two highlights the fact that the assertion of a positive link between tariffs and trade growth is unfounded. ${ }^{5}$ Instead, we contend that the Reich's industrial tariffs remained marginal in the aggregate throughout the period and, furthermore, did not grant anticompetitive advantage to the most innovative and expansionary branches of German industry. Instead, the tariff was designed to uphold 
and preserve traditional activities - which, to some extent, it did. All that can be said in its favour is that it did not scuttle the surge of 'Made in Germany' goods. The first section of this chapter surveys the striking features of the emergence of Germany as a global trader in the last quarter of the nineteenth century. The second focuses on the impact of German trade policy on its trade pattern.

\section{The rise of German trading power}

\section{The growing awareness of German commercial supremacy}

The swiftness with which German trade took over foreign markets in the aftermath of the Franco-Prussian War of 1870-1 surprised many observers. Outdistanced by France on world markets until the mid-1860s, the share of German exports in world trade rose steadily, leaving first France (in the 1870s), then shadowing the USA in their ascent, and almost bypassing on Britain on the eve of the First World War (Figure 11.1).

This upturn represented a startling new feature. Whatever the indicator used, the ratio of German to world trade exhibits no significant change for the first three quarters of the century, hovering as it does rather below than above the 10 per cent mark (Table 11.1). Starting in the 1880s, it began to move sharply upwards. This is especially striking when considering manufactured exports (Section 3 of Table 11.1): Germany gained six full percentage points in thirty years (from 1883 and 1913) while the share of the leading commercial powers, France and Britain, crumbled, losing a third of their overall market share over the same period.

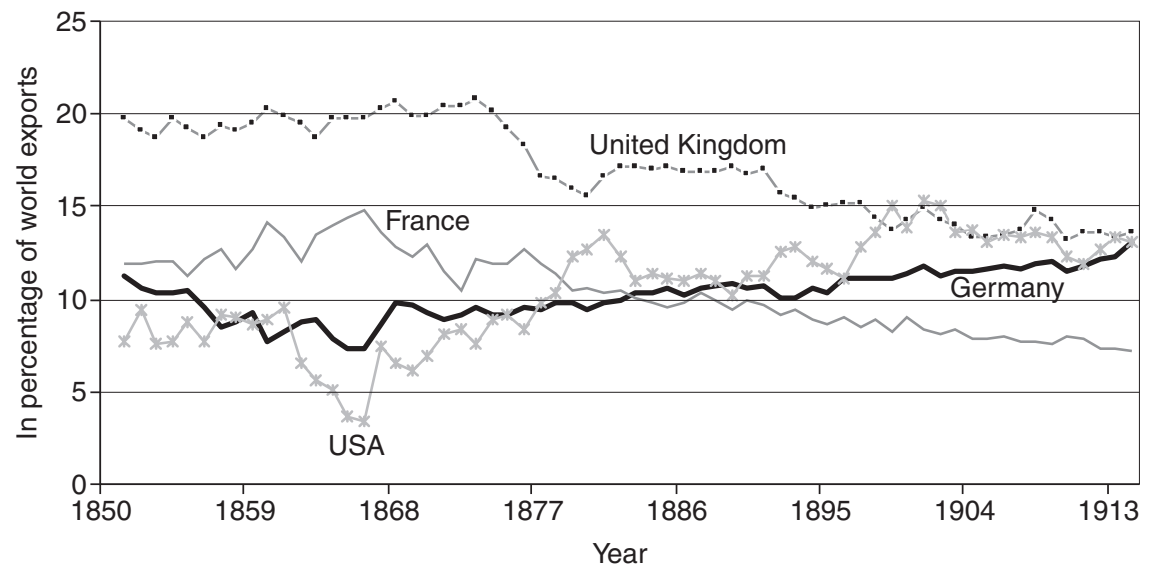

Figure 11.1 The changing share of world trade among four major traders, 1850-1913 (source: Lewis, 1981: 38-59). 
Table 11.1 Germany's relative share in world trade, 1830-1913

1 Share of world trade

\begin{tabular}{llccc}
\hline$\%)$ & Britain & France & Germany & USA \\
\hline 1830 & 27.3 & 11.5 & 10.2 & 7.8 \\
1850 & 23.2 & 10.3 & 14.4 & 8.8 \\
1870 & 24.5 & 12.1 & 11.3 & 9.1 \\
1880 & 19.9 & 11.7 & 9.8 & 11.2 \\
1890 & 18.5 & 9.7 & 10.9 & 10.7 \\
1900 & 18.1 & 8.4 & 12.2 & 11.4 \\
1913 & 14.9 & 7.9 & 12.6 & 11.2 \\
\hline
\end{tabular}

2 Share of world exports

\begin{tabular}{lrrrr}
\hline 1850 & 19.8 & 11.9 & 11.2 & 7.7 \\
1870 & 20.4 & 11.5 & 8.9 & 8.1 \\
1880 & 16.7 & 10.4 & 9.8 & 13.5 \\
1890 & 17.0 & 9.7 & 10.7 & 11.2 \\
1900 & 14.9 & 8.4 & 11.8 & 15.3 \\
1913 & 13.7 & 13.2 & 13.1 \\
\hline \multirow{2}{*}{3 Share of world manufactured exports } & & \\
\hline \multirow{2}{*}{1883} & 37.1 & 14.6 & 17.2 & 3.4 \\
1890 & 35.8 & 14.5 & 17.2 & 3.9 \\
1900 & 28.4 & 12.6 & 19.5 & 9.8 \\
1913 & 25.4 & 10.6 & 23.0 & 11.0 \\
\hline
\end{tabular}

Sources: Lewis (1957: 579); Maddison (1962: 179-84); Lewis (1981: 38-59).

Note

Figures for the 1830-70 time span - during which estimates of world trade are based on that of fifteen countries - are not strictly comparable with those relating the 1880-1913 period. See Sombart (1903: 633).

The rush of the USA onto world markets was also spectacular - especially when considered from the trough of the Civil War years, but while the overall share of America's exports increased in step with Germany's, the former's export trade of manufactured goods remained much smaller than the latter's. Apparently no country could either match German performance or arrest its success. As a result, Germany's growing presence as well as competitiveness on third markets started to alarm its neighbours - a fact often associated with its government's new-found military strength and political assertiveness on the world stage. ${ }^{6}$ Fellow Europeans swapped their vision of a people of romantic poets and abstruse philosophers, such as Mme De Stael described in $1810 .^{7}$ What aroused their curiosity and fears now were the enterprising captains of industry and cunning salesmen. Reactions were especially strong in Britain, where E. E. Williams' rabble-rousing Made in Germany ${ }^{8}$ warned his compatriots that 
The industrial glory of England is departing and England does not know it [...] It is time to disturb the fatal torpor [...] A gigantic commercial state is arising to menace our prosperity, and contend with us for the trade of the world.

(Williams, 1897: 1-2, 10) ${ }^{9}$

The swiftness of German commercial successes on world markets, and its synchrony with the Weltpolitik initiated by Wilhelm II after Bismarck's forced departure (1890), have led in the minds of many historians to an assimilation between formal (political) and informal (economic) imperialism. The jingoism of the time perceived Germany as intent on conquering the world, taking control of foreign territories either by virtue of its (military) strength or (commercial) stealth. Henceforward in the eyes of many journalists and experts the unfairness, pushiness or even deviousness of German marketing methods became a shibboleth.

\section{The stages of the ascent of German trade}

Strictly speaking, there is no such thing as 'German' trade before 1 January 1834, which marks the beginning of the Zollverein. ${ }^{10}$ Henceforward all members of a customs union extending to the German Bund

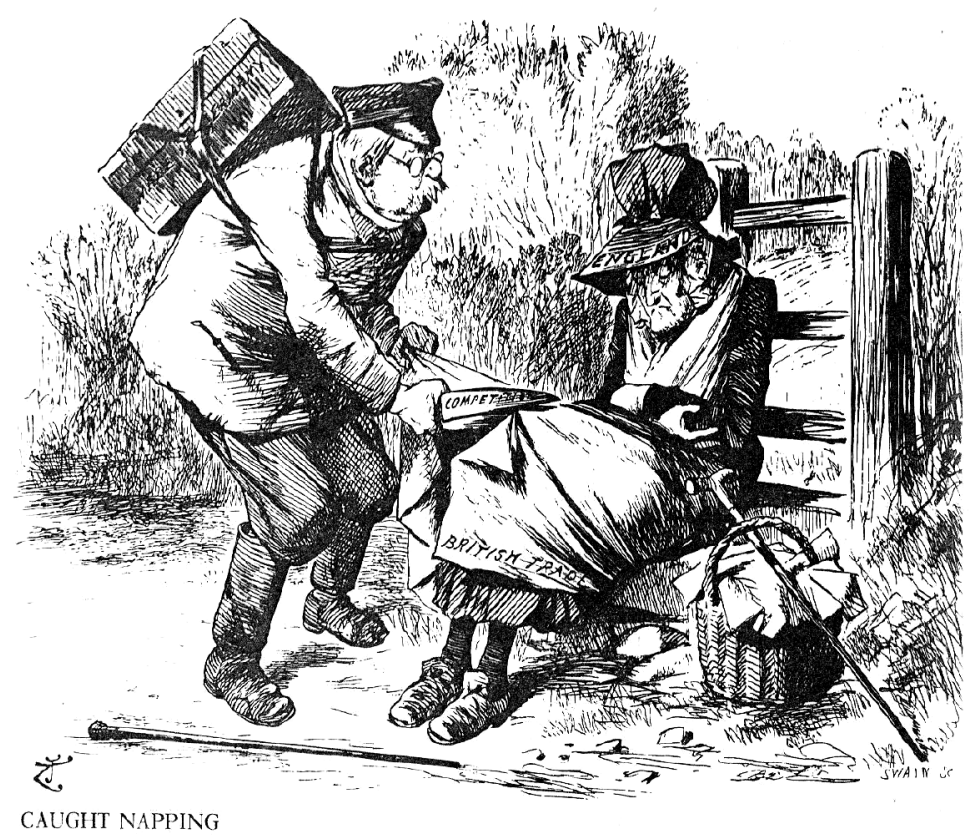

Figure 11.2 Germany cutting into British markets, as seen by Punch. The stages of German commercial ascent. 
(all of them, from tiny Waldeck to mighty Prussia) transferred their sovereignty in trade policy to the executive Centralbureau of the Zollverein.

For the first time in its long history, the German nation was united by the will embodied in a contract to defend their common economic interests; the Zollverein constitutes the first concrete attempt at German unification.

(Benaerts, 1933: 15)

Unfortunately for later historians and statisticians, administrative unification and centralisation did not proceed as efficiently. Some have gone as far as saying that 'German trade statistics are a booby trap' (Lewis, 1978: 43). One of the main hurdles in the collection of nationwide trade statistics is the exclusion from the Zollverein until 1888 of Hamburg and Bremen, the two major ports of entry into the German markets. Trade between the two Hanseatic cities and the rest of Germany qualified as foreign and was treated on a par with that of other foreign states. Furthermore, until 1870 the Centralbureau recorded only volume indicators of trade flows passing the external border - made more difficult to handle because the changing number of member states. ${ }^{11}$ Several attempts have been made at matching trade quantities with current values, most notably by Bondi (1958), von Borries (1970) and Sir William Lewis (1978). From 1872 onwards the (newly set-up) Statistisches Reichsamt published volume and value series of foreign trade in its annual abstracts which improved gradually in coverage, especially after 1880 (Dedinger, 1992: 38-40). This is the material that has served as a basis for Hoffmann, who has produced an evaluation of imports and exports at 1913 prices over the period 1836-1913 - later corrected by Lewis for the 1836-78 sequence (Figure 11.3).

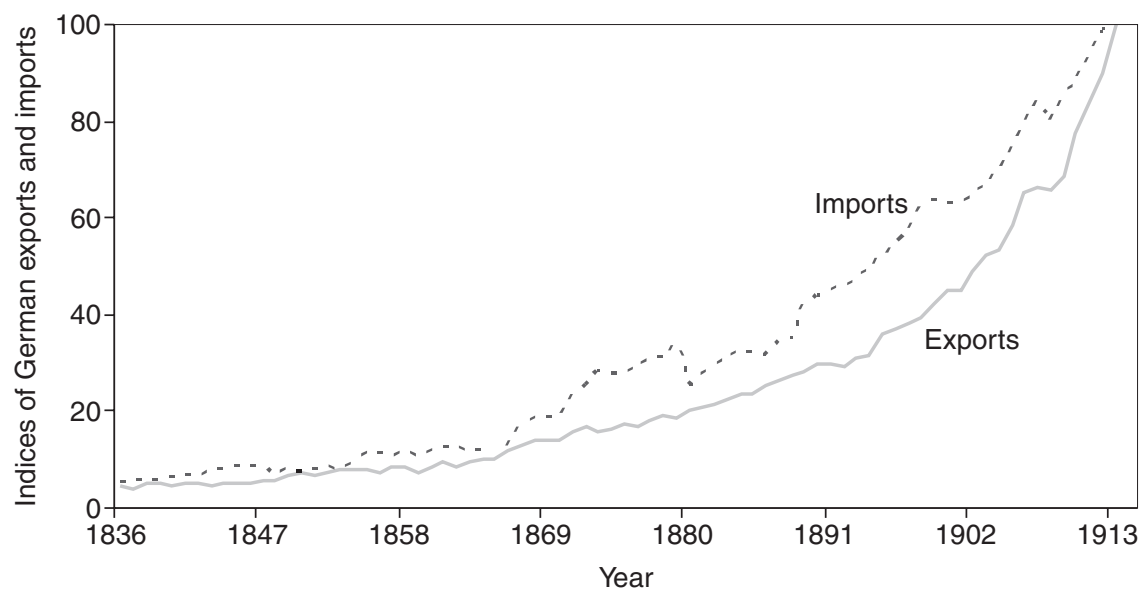

Figure 11.3 Indices of German exports and imports 1836-1913 $(1913=100)$. (sources: Hoffmann, 1965: 537-9; Lewis, 1981: 29-30). 
Clearly, the development of nineteenth-century German trade can be split in two forty-year-odd stages before and after 1870. Stage 1 mirrors the industrial take-off of the German economy, while stage 2 corresponds to its world power ascent. ${ }^{12}$ With emphasis on foreign trade, stage 1 can be split into two phases. During the first, covering the first two decades of the Zollverein's existence (i.e. to 1853), foreign trade remained relatively stagnant. This corresponds to the formation stage of the customs union, during which internal barriers between the different states were dismantled and the domestic transport system built up (Benaerts, 1933: 17). Stimulants of external trade came primarily from the gradual inclusion into legal trade of heretofore smuggled goods, but the development of domestic transactions also contributed to boost foreign transactions as well (Bondi, 1958: 77). In this regard the impetus came first and foremost from the jump-start of the textile and metal industries requiring a growing volume of imported raw materials. From the mid-1850s, a gap opened between the import and export trade, which lagged behind because the new industries still limited production capacity and the competitive edge of British manufactures on third markets (Bondi, 1958: 78-9). As can be seen in Figure 11.2 the trend veers up from the 1850s onwards: Bondi placed the turning point in 1854, the year Hanover and Oldenburg joined the Zollverein which alone could account for inflated trade intensity after this date. However, Lewis's revision of the export series, calculated on the basis of a constant territory, confirms an acceleration of export trade in the 1850s. This change can be clearly associated with that of the country's industrialisation, technological transfers and essential macroeconomic reforms.

Illustrating the recurrent puzzle of German trade statistics, Dumke compares Bondi's estimates with Hoffmann's for the four main product categories (Dumke, 1994, part 2: pp. 16-21, 50). Structurally, German exports remained dualistic in nature: foodstuffs and raw materials on the one hand, finished textile manufactures on the other - the share of the latter diminishing after 1869; among imports, raw materials and semifinished textile goods bulked very large. Imports of iron and steel goods (raw, semi-finished and finished) appear to have been negligible in this period; trade in chemicals picked up in the $1860 \mathrm{~s}$, as did the share of cereals among food imports (Bondi, 1958: 138).

During stage 2 (1871-1913), after the Reichsgründung, the newly founded Reich's foreign trade took off. Germany became " the leading industrial state on the Continent and challenge[d] Britain's supremacy in the markets of the world' (Henderson, 1975: 173). For some industries, foreign trade came to play a leading role in their development. Outward trade started to become paramount in the expansion of some branches of the economy. The most pervasive changes in the structure of Germany's trade occurred during this period. This will be the focus of changing comparative advantage below, but it is perhaps worthwhile to point out its 
Table 11.2 Structure of German (Prussian in 1828) export and import trade, 1828-69 (in \%)

\begin{tabular}{|c|c|c|c|c|c|c|}
\hline \multirow[t]{2}{*}{ Product } & \multicolumn{3}{|c|}{ Exports } & \multicolumn{3}{|c|}{ Imports } \\
\hline & 1828 & 1850 & 1869 & 1828 & 1850 & 1869 \\
\hline Foodstuffs & 9.7 & 19.6 & 19.5 & 8.0 & 7.2 & 15.0 \\
\hline Grains & 8.1 & 15.2 & 8.3 & 1.4 & 0.9 & 6.7 \\
\hline Tropical produce & 1.0 & 3.4 & 2.8 & 19.1 & 16.6 & 8.3 \\
\hline Raw materials and semi-finished goods & 31.3 & 29.6 & 32.9 & 49.7 & 65.0 & 62.5 \\
\hline Wool & 8.0 & 4.0 & 5.4 & 3.3 & 8.4 & 13.6 \\
\hline Cotton & - & - & - & 10.1 & 15.7 & 8.0 \\
\hline Finished goods & 56.9 & 47.0 & 44.1 & 21.0 & 9.5 & 13.2 \\
\hline Textiles & 49.9 & 30.5 & 22.5 & 13.7 & 6.8 & 6.9 \\
\hline Woolens & 12.3 & 9.6 & 9.9 & - & - & - \\
\hline Cottons & 4.3 & 5.6 & 3.2 & - & - & - \\
\hline
\end{tabular}

Source: Bondi (1958: 146); Dumke (1994: 16-21, 50).

salient features now. When considering its broad categories, Germany's merchandise trade was still quite diversified: the country exported a sizeable share of finished products but also of raw materials, foodstuffs and semi-finished as well. The notable change at this stage was the shift from a net exporter to a net importer of foodstuffs. On the import side, raw materials tended to bulk larger and larger. The changing structure of Germany's export trade deserves closer scrutiny. While they remained important in absolute terms, the share of textile goods (silk, wool and cotton fabrics as well as garments and underwear) in total exports was halved between 1880 and 1913 (from 20 per cent to 10 per cent). Meanwhile iron and steel semifinished goods (iron bars, tinplate and wire, rails, boilerwork and castings), already representing the second largest class of export products, rose from 6 per cent to 7.5 per cent of the total in 1913 .

The development of basic metallurgic exports pales in comparison, however, with that of mechanical and electrical engineering from 1890 onwards. The share of mechanical equipment shot up from 1.7 per cent in 1880 to 2.5 per cent in 1893 and 6.7 per cent twenty years later; likewise, electrical equipment, absent from trade statistics in 1880 cut a 2.8 per cent share of total exports in 1913 (1.1 per cent in 1900). Another successful range of products consisted in aniline and other artificial dyes over which the German chemical industry enjoyed a quasi-monopoly which alone made up 1.4 per cent of all exports in 1913. Thus, German export trade gradually veered away from the competitive markets of traditional textile goods and focused increasingly on the products of its 'Montanindustry': coal by-products, basic metals and engineering, leaving its former competitors, France and Britain, far behind.

Did Germany's growing export trade in manufactures drive German 
Table 11.3 The growth rates of Germany's foreign trade (1836-1913) (annual averages, in \%)

\begin{tabular}{lll}
\hline & Exports & Imports \\
\hline $1836-1913$ & 4.1 & 3.9 \\
$1836-65$ & 2.8 & 3.1 \\
$1866-79$ & 4.5 & 7.7 \\
$1880-95$ & 4.3 & 2.6 \\
$1896-1913$ & 5.9 & 3.7 \\
\hline
\end{tabular}

Source: after Lewis, 1981; Hoffmann, 1965.

industrial growth or was it merely a 'vent for surplus' of an essentially selfcentred development process? A close inspection of the successive phases may be instructive in this regard.

From 1866 to 1879 - that is, after the Zollverein accessed to MFN (Most Favored Nation) status with its major partners and before the adoption of the first German tariff, during the free-trade period - the growth of imports accelerated notably at a pace far quicker than the growth of exports. After the turn to protectionism between 1880 and 1895, import growth slowed down markedly, while exports maintained its rate of increase. Export growth speeded up remarkably during the last phase, while imports resumed a more normal course, but still at a slower pace compared to Germany's 'opening' phase.

On cursory inspection, the obvious conclusion seems to be that F. List was right: the 1879 tariff warded off unwanted imports, gave a boost to domestic prices and the substitution of importables whose production was thereby expanded, domestically generating surpluses which fed, in return, export trade. Once this 'virtuous circle' was set in motion, the growth of exports naturally allowed import flows to grow again.

This is the type of deduction that needs to be put to the test: in its simplicity it obviously ignores much more complex processes. Obviously the figures quoted above remain opaque so long as the structure of foreign trade during the protectionist period are not scrutinised. Which kinds of products drove export and import after 1879? Did protected industries supply the bulk of products that fed the export drive? This is the test which should establish the link, supposed or real, between increased protection and increased specialisation at the heart of the success of 'Made in Germany' goods on world markets.

\section{Germany's revealed comparative advantage, 1880-1914}

The use of RCA indices constitutes the best tool at our disposal for estimating changes in the specialisation of any economy over time. Since Balassa's 1965 pioneering method, there has been a number of alternatives put 


\section{8}

forward by other scholars but, as he himself anticipated, these alternative formulas tend to estimate competitive rather than comparative advantage. ${ }^{13}$ Our preference has gone to a third kind of index which alleviates the, in our view, secondary problem of ranking countries for one given product but allows for an international ranking of 'products' (in the SITC sense - i.e. for ranges of kindred products) for any given country. This view corresponds more closely to the Ricardian definition of comparative advantage: a country tends to export goods for which it enjoys comparative advantage. Besides, this approach serves the purpose of studying the relationship between the observed dynamism of one 'product' and the level of tariff protection it enjoys.

Thus, for any product $I$, the revealed comparative advantage index of industry producing $i$ will be:

$$
A C R_{i}=\left[\frac{X_{i}-M_{i}}{X_{i}+M_{i}}-\frac{\Sigma\left(X_{i}-M_{i}\right)}{\Sigma\left(X_{i}+M_{i}\right)}\right] * 100
$$

Where $X_{i}$ and $M_{i}$ report exports and imports of product $i$ And $\Sigma X$ and $\Sigma M$ total exports and imports.

The left-hand section of Table 11.4 below presents the results for four benchmark sequences - the right-hand section gives the relative share of each category in total export and import trade. The frequency of indices of a particularly high grade is indicative of the pervasiveness of German intra-industry trade at the turn of the century.

What are the striking characteristics of the changes undergone by German trade during this period? Considering the most simple classification first, the most notable changes seem to have affected foodstuffs and semi-finished goods whose indices either declined sharply (foodstuffs) or switched from positive to negative signs (indices for both raw materials and finished goods come out only marginally reinforced).

Dis-aggregation by product yields further information. Grains and sugar do not appear to have been responsible for the apparent deterioration of foodstuffs' RCA index. While the index for two staples, wheat and oats, representing on average 6 per cent of German imports, surrender some ground, the other two, rye and sugar, experienced a complete turnaround of their position; the former switching sign and becoming an export product (1.4 per cent of total exports in 1910-13), the latter strengthening its comparative advantage and becoming Germany's third major export (4.7 per cent of total exports on average between 1880 and 1913).

Here Germany's comparative advantage was obviously manipulated by the favoured treatment extended by the government via direct subsidies (to beet growers and sugar refiners) or tariffs (to the rye-growing estates of Prussian Junkers) which distorted market mechanisms at the expense of the German tax-payer and consumer (Gerschenkron, 1943). The dete- 


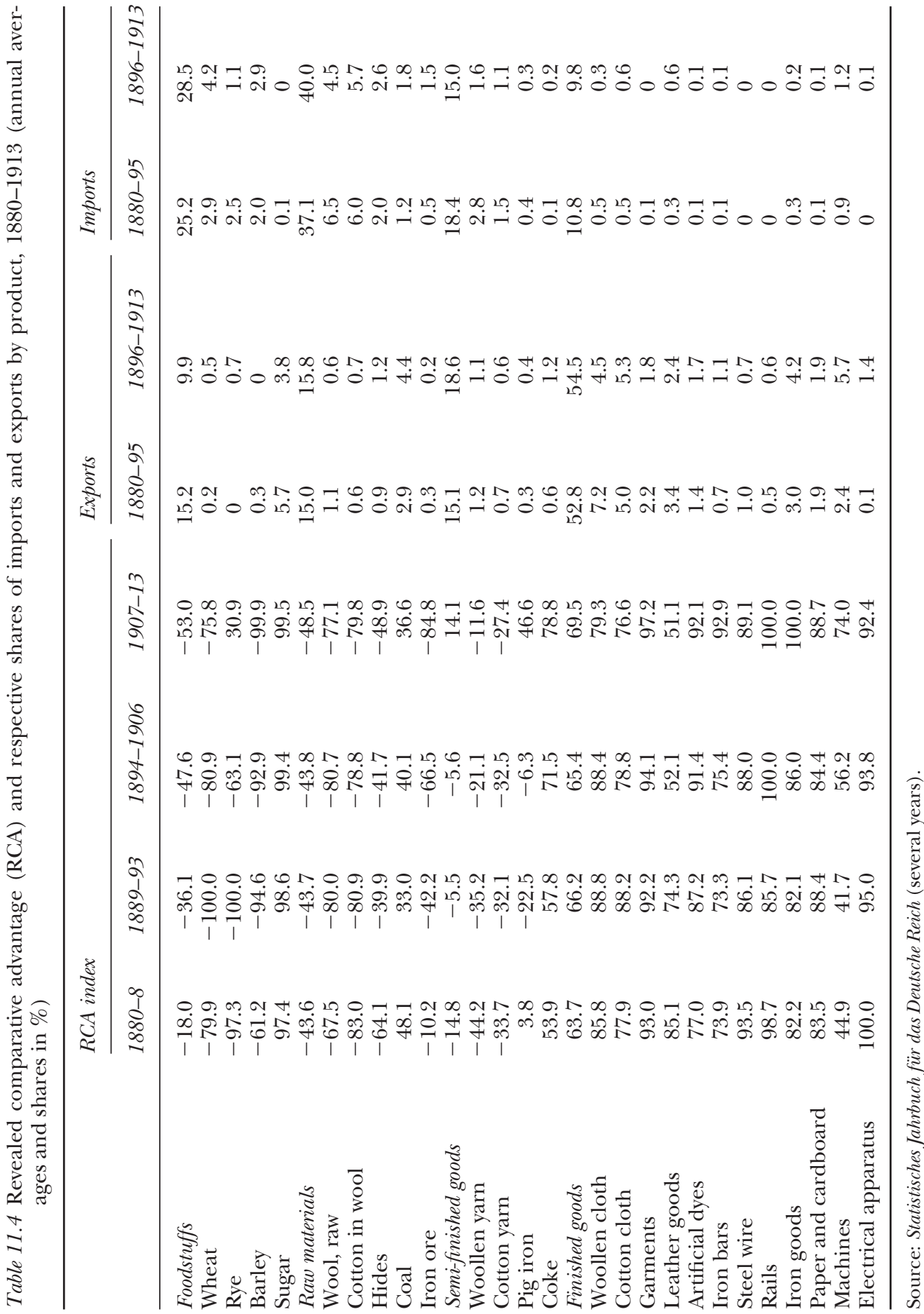


rioration of Germany's trade balance in food products as well as growing dependence on foreign imports stems, in fact, from its growing disadvantage suffered in livestock and dairy products as well as fruits and vegetables.

Among raw materials, there is little change to report except the deterioration of the comparative advantage of iron ore. With coal, the country's sixth major export product, Germany remained through 1880-1913 an exporter of major staple fuel. Among semi-finished commodities, Germany reinforced its advantage in pig iron whose index became strongly positive after 1908 as well as in spun wool whose disadvantage was notably reduced. In the finished goods category all products appear to have enjoyed a strong comparative advantage; this is especially true for paper products, which represented 4 per cent of total German exports. RCA indices for the new industries, such as artificial dyes, machines and parts as well as electrical equipment, exhibit high marks and a tendency to rise. Can these developments be attributed in any way to the outlay of the German 1879 tariff?

\section{The impact of German tariff policy}

\section{Assessing the protective intensity of the German tariff before and after 1879}

The sheer mass of books dedicated to Bismarck's trade policy and that of its successors is daunting. Most offer a narrative of the sequence of events that lead to the reversal of the Zollverein's original policy orientation towards free trade. Furthermore, the German tariff is supposed to have had world wide implications in so far as the German government's precocious conversion to protectionist policies signalled the ralliement of most of Continental Europe: in putting forward the 1879 tariff, 'Bismarck defeated Cobden and set an example for the rest of the world to follow' (Baumont, 1952: 179). ${ }^{14}$ This decision stunned many contemporaries in that it seemed to put an end to the wave of political and economic liberalisation - initiated in the 'Spring of 1848' - which had inflamed the minds of a whole generation over the issue of free trade (Gide and Rist, 1944: 409) and which bound in one ideal the progress of democracy, of universal peace and fraternity. Many observers had seen in the gradual move towards unilateral free trade between 1850 and 1870 the realisation of Montesquieu's and Smith's prediction according to which 'trading nations are naturally inclined to peace', a conviction often voiced by the Cobdenites themselves.

Then, common wisdom held protectionist policies as good as dead and buried (Baumont, 1952: 26). As a result, when Bismarck resuscitated a protectionist tariff in a country and, what's more, had benefited enormously from trade opening, observers stood in awe - all the more so that 
Germany was displaying avowed expansionary tendencies. Some historians (especially French) have gone as far as describing the 1879 tariff as a 'war machine'; in any case as 'excessive' (Robinet de Cléry, 1935: 62).

However, it is symptomatic that most accounts of the tariff's impact are made on the basis of partial examination. This reaction has tended to undermine the achievements of the period of liberalisation of German trade between 1850 and 1879, and to exaggerate the protectionist intensity of the 1879 tariff. Thus, Paul Krugman (1995: 338): '[Before the First World War] the US like Germany were frankly protectionist.'

It would seem appropriate therefore to first take a global view of the actual impact of post-1879 German trade protection. Figure 11.4 charts the parallel evolution of the nominal rate of protection (also referred to as rate of tariff revenue) across the nineteenth century in a comparative framework. Measured by the ratio of tariff revenue to the value of imports, the German nominal protection rate appears to have moved inside a relatively narrow band, falling from around 12-14 per cent in the 1840s to under 5 per cent in the 1870 s, and changing course thereafter without reaching the pre-1855 levels. The US rate, by contrast, escalated to unprecedented heights in the aftermath of the Civil War before subsiding somewhat at the 30 per cent level until the Sherman tariff of 1890. After 1880, Germany's global rate of nominal protection, at around 8 per cent, was inferior to France's and Italy's, and barely superior to that of freetrading nations such as Denmark and Britain. There is no evidence at this stage that Germany was therefore particularly protectionist in the four decades to 1914, especially if the USA is brought into the picture.

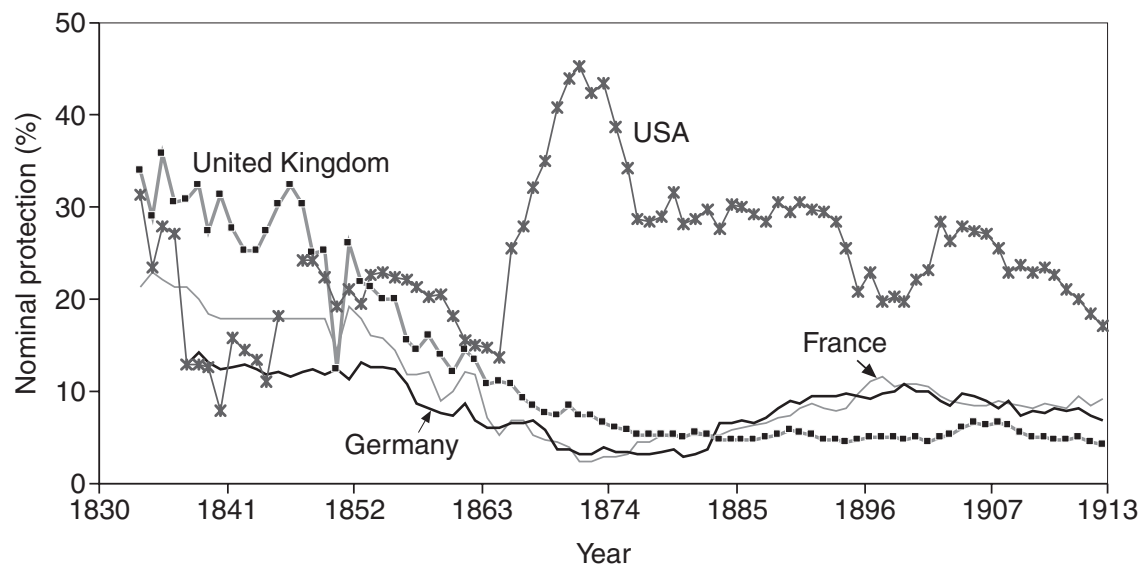

Figure 11.4 Nominal protection of the four major powers 1830-1913 (sources: Bondi, 1958: 145; Levy-Leboyer and Bourguignon, 1990: 343-7; Mitchell, 2003; Statistisches Jahrbuch für das Deutsche Reich (several years). 
Table 11.5 Average nominal rate of protection in Germany, 1834-1913 (annual averages in \%)

\begin{tabular}{lc}
\hline Time period & Average protection \\
\hline $1834-1913$ & 8.4 \\
$1834-65$ & 10.4 \\
$1866-79$ & 3.4 \\
$1880-1913$ & 8.6 \\
\hline
\end{tabular}

Sources: Statistisches Jahrbuch für das Deutsche Reich; Bondi (1958: 145).

Table 11.5 corroborates the impression gathered from Figure 11.4 and shows that average protection, while lower than during the pre-free-trade era, was roughly equal to the secular trend ( 8.6 versus 8.4 per cent). Thus, Dawson was at least partly right:

Protective laws in the interest of industry and agriculture have been the tradition of the states which form the present Empire. Freedom of trade has been the exception, and when it has occurred it has been a temporary lapse from continuity and custom. This is not a proposition to be argued, but an affirmation of facts.

(Dawson, 1904: 1)

While the first part of the quotation may be regarded as accurate, the observation of trends across the nineteenth century can mitigate the notion that free trade was totally alien to German commercial history.

\section{Political forces determining German trade policy}

The Prussian government's drive towards the domination of the German Bund provided the driving force behind the creation of the Zollverein from its inception. After the War of Liberation against Napoleon, Prussia undertook a batch of reforms geared at simplifying and liberalising its legal framework and institutions, especially with regard to commercial transactions and taxation (Dawson, 1904: 1-16; Benaerts, 1933: 215-23). Internally, the law of 16 May 1818 'on the customs and excise duties on foreign goods and on trade between the provinces of the state' unified the Prussian territories into one single market by dismantling internal barriers to trade. Externally, the act provided for a moderate external tariff geared at providing the Prussian state with adequate revenue while, at the same time, fostering cross-border transactions. Clapham claims that this step was 'immeasurably the wisest and most scientific tariff then existing among the great powers' (Clapham, 1936: 97). The Prussian tariff of 1818 provided the basis for the constitution of the Zollverein in 1834. After 1834, Prussian trade policy remained oriented towards free trade for 
reasons of doctrine, national interest (secure entry for German grain onto the British market) and foreign policy (attract free-trading partners from Northern Germany such as the Hanseatic cities of Breme, Hamburg, Lübeck and Rostock into the ambit of the Zollverein). However, the Prussian government did not stop the Zollverein commissioners from raising duties on metal and textile goods in the 1840s, a step that carried the union momentarily away from its original pro-free-trade stance. Average protection remained, in any case, very moderate.

From 1850 onwards, the Zollverein more decisively resumed its move towards trade liberalisation. This was not the outcome of any major shift in either the ideological climate or the balance of political power. It was essentially foreign-policy considerations that induced the Prussian government to sign the free-trade treaty with France in 1862. Politically, this bid carried with it the twin advantage of excluding Austria from the nowunified North German Bund and to anchor the still-dithering Southern states to the Zollverein. This bid proved a success as the Union's compact was renewed in October 1864 and treaties ratified by all member states in 1865 (Hahn, 1984: 151-80). From 1865 to 1877, the remaining barriers were dismantled so that, by 1 January 1877, 'Germany had virtually become a free trade country' (Bairoch, 1989: 41) with an average rate of duty of 3 per cent.

Great emphasis is generally laid upon the 1879 reversal of German tariff policy: 'This fateful turning point [was] one of the most important in the history of modern Germany' (Kindleberger, 1975: 478). In 1876, protectionist interests had set up a cross-sector umbrella organisation, 'zum Schutz der nationalen Arbeit' ('for the safeguard of national labour') whose demands were endorsed by Bismarck's National Liberals and heralded the 'alliance of rye and iron' (Gerschenkron, 1943: 48). But, on the whole, protection remained moderate and failed to even achieve the overall rate of protection of the 1834-65 period. This moderation can be assigned to a number of factors. First, the industries with a stake in an open border policy were relatively numerous and influential; second, outside Prussia, large swathes of domestic producers (especially in small states) favoured a free-trade policy. Finally, the imperial government's aim was not to attain self-sufficiency or foster autarchy (unlike the Nazi government). Besides, Bismarck was concerned to maintain the standard of living of consumers and Caprivi, his successor, even softened the most drastic edges of the tariff by signing, in the 1890s, trade agreements with a number of partner countries. The new tariff adopted on Christmas Day 1902, and due to come in force in May 1906, aimed at reinforcing the protection on domestic rye and sugar, but failed to increase the average protection rate significantly. Quite the opposite, due to inflationary pressures, the average rate actually fell in the early 1900s. It is therefore more accurate to say that the Imperial government 'toyed' with protectionism, rather than decidedly embraced it: protectionism remained 'virtual'. 


\section{Béatrice Dedinger}

However, the average rate of protection, while it provides a crude measure of potential aggregate welfare losses, does not specify the structural effects induced by the tariff. For such a task, a detailed sectoral analysis is required.

\section{Protection levels by sectors}

Germany's protectionist reputation during the Second Reich rests in fact on a generalisation of observed levels of protection in three areas: agriculture, textiles and metallurgy, the latter admittedly the leading sectors of the initial phase of industrialisation. This can be verified in Table 11.6: four product ranges corresponding to four major industries stand out in terms of protection:

Table 11.6 Nominal protection (or rate of tariff revenue) by product, 1880-1913 (annual averages, in \%)

\begin{tabular}{lcccc}
\hline Product & $1880-8$ & $1889-93$ & $1894-1906$ & $1907-13$ \\
\hline Foodstuffs & - & 20.3 & 22.6 & 23.2 \\
Hogs & - & 5.1 & 5.9 & 9.0 \\
Grains & 12.4 & 25.0 & 24.1 & 25.6 \\
Rice & 17.5 & 20.1 & 23.4 & 20.2 \\
Tropical fruit & 25.0 & 19.2 & 20.9 & 19.3 \\
Coffee & 32.4 & 23.0 & 39.9 & 47.2 \\
Tea & 46.3 & 55.5 & 56.8 & 36.4 \\
Spices & 31.8 & 41.0 & 36.1 & 35.5 \\
Wine & 37.6 & 39.8 & 38.3 & 46.7 \\
Raw materials & - & 9.4 & 7.9 & 21.2 \\
Coal & 0 & 0 & 0 & 0 \\
Petroleum & 43.0 & 63.1 & 79.6 & 67.4 \\
Iron ore & 0 & 0 & 0 & 0 \\
Semi-finished goods & & & & \\
Lumber, timber & 5.9 & 8.7 & 7.9 & 6.4 \\
Cotton yarn & 9.3 & 9.4 & 9.0 & 6.4 \\
Woollen yarn & - & 1.8 & 1.4 & 1.3 \\
Pig iron & 21.2 & 20.1 & 17.7 & 13.3 \\
Finished goods & - & 12.9 & 16.0 & 16.7 \\
Cotton fabric & 10.9 & 17.2 & 15.9 & 17.1 \\
Woollen fabric & - & 18.1 & 19.0 & 14.2 \\
Leather goods & 5.9 & 4.8 & 4.1 & 3.3 \\
Artificial dyes & 0 & 0 & 0 & 0 \\
Iron goods & - & 11.3 & 12.1 & 12.8 \\
Machines and vehicles & 3.5 & 5.5 & 5.0 & 5.6 \\
Electrical apparatus & 0 & 0 & 0 & 0 \\
Total & - & 17.2 & 18.7 & 18.9 \\
\hline So & & & & \\
\hline
\end{tabular}

Source: Statistisches Jahrbuch für das Deutsche Reich (several years). 
- imports without domestic substitutes heavily taxed (so-called fiscal duties);

- importables competing with domestic products and taxed with heavy duties, such as cereals, semi-finished textiles and metals;

- $\quad$ raw materials, fuels and some semi-finished inputs entering duty free;

- exportables in which Germany enjoyed a strong comparative advantage and which were left unprotected.

Historians' attention has focused almost exclusively on the second category of goods which brings together the subscribers of the pact between Bismarck on the one hand and the Junkers and ironmasters on the other (Gerschenkron, 1943: 42-8; Böhme, 1967). Although they held a minority share of domestic value added, these two groups managed to enrol government trade policy in the service of their interests. This was a major change of attitude for the Junker aristocracy who had been hitherto 'fanatical free traders' (Gerschenkron, 1943: 42) until they started to face fierce competition after 1873, from Russian and North American wheat and rye growers. In their puppet organisation, the Bund der Landwirte (founded 1893) they agitated continuously for enhanced protection and obtained significant duty increases in 1885, 1887 and 1902. Iron founders, on the other hand, suffered falling prices and increased competition after 1870 from British and Belgian firms, but managed to keep their outlets by dumping practices (Lambi, 1963: 76-9). ${ }^{15}$ In 1876, the iron and steel association merged with cotton manufacturers to create a powerful pressure group, the CDI, which sought to attract the rank and file of entrepreneurs in sugar, leather, glass, paper and chemicals. However, the interests of these assorted industrialists were far from uniform or congruent. In iron and steel, demands for high protection came from large, vertically-integrated firms producing semi-finished or finished goods such as rails and all-purpose castings. Small engineering firms, by contrast, those manufacturing tinplate, wire and various castings, were naturally opposed to any increase of their intermediate costs (Lambi, 1963: 200). Among textile-mill owners, those with the strongest protectionist incentive were the cotton spinners of Southern Germany who stood at a disadvantage compared to comparable British or Belgian firms, and who additionally had to face, after 1871, competition from the newly integrated Alsatian mills. Leaning on the Listian argument, their representatives claimed to be defending an 'infant industry', although most firms went back to the early 1800s. Weaving mills as well as wool spinning were, by contrast, highly competitive and exported a large share of their output; they were inclined to fear the appreciation of domestic duties on their inputs as well as retaliation by foreign consumer countries. Later on, their organisation demanded protection to offset the increased duty on cotton yarn (Lambi, 1963: 234; Webb, 1977: 343-7; Webb, 1978: 57-100). As a result, specific duties - so as to accommodate diverse situations - were generally imposed 
on yarn, fabrics, pig iron and other iron and steel staple products (Dedinger, 1992: 103).

Textile manufacture and basic metallurgy each provide an illustration of the cascading effect of tariff protection, partly hidden by the specific duty but captured by the differentiated effective protection, discounting its negative effect (due to the appreciation of inputs) from its positive effects (on finished goods). Effective protection rates computed by Webb (1977, 1978) show that those industries best protected by the tariff were indeed those identified by nominal protection, but their implicit mark-ups were in general much higher. They covered grains, iron and steel and, until the 1902 tariff, cotton yarn. Meanwhile, other metal goods or textiles had to bear with low or even negative protection (Table 1.7).

Regarding the other branches of German manufacturing such as machinery and electrical engineering as well as chemicals, the literature is mostly silent about their plight; more geographically disseminated and less organised, they were absent from the debates. Engineering firms were divided between free traders and protectionists depending on the origin of their inputs and of their customers; by contrast, chemical and electrical equipment firms were usually inclined towards free trade; On the whole, these lines of products were little or not protected at all (Webb, 1978: 56, 104-5). Obviously the 1879 tariff's objective was not the infant industries of the second industrial revolution.

Table 11.7 Effective protection in different sectors of German industry, 1883-1913 (annual averages, in \%)

\begin{tabular}{lrrrrr}
\hline Sector & $1883-5$ & $1894-6$ & $1900-2$ & $1906-8$ & $1911-13$ \\
\hline Agriculture & & & & & \\
Hogs & -1 & -3 & 26 & 32 & 27 \\
Rye, Wheat & 9 & 41 & 33 & 39 & 42 \\
Textile industry & & & & & \\
Cotton spinning & 31 & 15 & 20 & 15 & 14 \\
Cotton factory weaving & 93 & 97 & 17 & 19 & -7 \\
Cotton non-factory weaving & 0 & 0 & 0 & 0 & 0 \\
Wool yarn & 12 & 7 & 10 & 6 & 5 \\
Wool cloth & -3 & -4 & -2 & -1 & -2 \\
Iron and steel industry & & & & & \\
Vertically integrated firms: & 18 & 48 & 70 & 67 & 52 \\
$\quad$ Pig iron & 26 & 17 & 47 & 12 & 14 \\
$\quad$ Heavy-rolled steel goods & 2 & 4 & 38 & 8 & 5 \\
$\quad$ Light-rolled steel goods & & & & & \\
Vertically non-integrated firms: & -9 & -10 & -10 & -9 & -5 \\
$\quad$ Cast iron & 0 & 0 & -1 & 0 & 0 \\
$\quad$ Kleineisenindustrie products & 0 & & & & \\
\hline
\end{tabular}

Sources: Webb (1977: 62, 68; 1980: 317). 


\section{Level of protection and index of comparative advantage}

The disaggregation of tariff protection by sectors affords the possibility of reverting to the RCA analysis of earlier on. Setting aside the questions regarding welfare losses or the supposedly growth-boosting effect induced by the tariff, we ought to concentrate on the deployment of German comparative advantage during the so-called protectionist period. How did changing protection patterns react upon the RCA indices exhibited in Table 11.4? Our analysis starts in 1880, the very year the new tariff came into force after a good many years of a situation approaching free-trade conditions ${ }^{16}$ and of steadily falling transport costs. We can assume therefore that the structure of German external trade was at this date close to that implied in the Ricardian model. After its introduction, a tariff can influence the structure of a country's RCAs in different ways. First, the increased taxation of some products will tend to quell their importation depending on the price elasticity of demand, and the RCA for these products - previously negative - will tend towards zero. Second, the upwards push provided by tariff duties to the prices of domestic substitutes of imports allows for the entry into the market of hitherto marginal firms with production costs above competitive levels (this phase is precisely the one deemed necessary by supporters of the 'infant industry' argument in order to build up an industry from scratch). In an imperfect competition situation, rising domestic prices in an industry will tend to boost the profits of the leading firms of the sector. Regardless of the competitive status of firms, however, rising prices bring about a contraction of domestic demand and of foreign imports. The question is how can the contraction feed into inflated export flows? ${ }^{17}$

In a microeconomic framework, under competitive conditions, downward pressures on domestic prices can entice firms to invest and upgrade the scale of operation with a view to compress unit production costs - the ceiling being the minimum scale efficiency. In theory there is, therefore, a possibility that a tariff can boost the competitiveness of firms that did not have access to world markets previously: ${ }^{18}$ under conditions of imperfect competition, excess profits generated by the tariff can be channelled into productive investment, new technology, economies of scale which contribute to bringing down production costs, and hence promoting these products to the level of world competitiveness.

This is the hypothetical scenario by which tariff protection can overturn originally negative RCA indices into highly positive indices. However, protection can affect the trade structure in another direction: exporting firms may have to support a general rise of the domestic price level and face retaliatory measures from their foreign partners, both of which tend to undermine their comparative advantage.

From what we know of economic history of the period, and as can be observed in Table 11.4, this is the story behind the changing RCAs of rye, 
woollen yarn, pig iron and, to a lesser extent, of cotton yarn. Iron and steel, semi-finished as well as machinery - whose moderately positive index in the mid-1880s doubled by 1913 - also need to be considered. The path followed by artificial dyes could also lend itself to that kind of interpretation, but this is disproved by the fact that they entered the German market duty-free. With regard to machinery, one must take into account the great diversity of its output as well as market structure, as evidenced by Webb (see Table 11.7). Those manufacturers of machinery with the highest stake in a protective tariff were the large firms facing some import competition. Although the 1902 tariff granted satisfaction to their demands for certain classes of machinery, on the whole protection remained very weak to generate the kind of virtuous circle described above (Webb, 1978: 55).

The case of textiles offers an illustration of the differentiated impact of the tariff: intermediate goods were relatively less protected than finished goods. Protection limited cotton yarn imports to some extent, but woollen yarn were much less protected and this was a commodity for which intraindustry trade was important; the reduction of Germany's disadvantage could be assigned to the expanding high-quality exports concomitant with shrinking run-of-the-mill imports. For woollens and garments, 'the infantry of Germany's exports' (Webb, 1978: 70), protection was deemed superfluous and was indeed sometimes negative.

Finally, regarding cotton weaving, protection probably fostered the mechanisation and the introduction of scale economies between 1870 and 1900, but the already-high RCA index in 1880 suggests that protection does not lie at the heart of the industry's competitiveness (Lambi, 1963: 234; Webb, 1978: 14).

Turning now to the 'infamous Alliance', there is little doubt that protection accounts in great part for its members' spectacular, if artificial, gains in comparative advantage. The path followed by rye is the most stupendous - the staple grain grown in the estates of the Prussian Junkerdom - but wheat, better suited to Middle Germany and the South, enjoyed relatively high protection compared to other grains. As an immediate consequence of the exorbitant favour lavished on these producers, they effected a massive transfer of resources to rye and wheat growing at the expense of pasture and cattle rearing (Gerschenkron, 1943: 71; Webb, 1978: 77). The rise in the output of iron and steel, the other major partner in the 'Alliance' is credited to its preferred treatment extended by the tariff. A distinction must be introduced as to the line of products and the degree of competitiveness in each line. By 1870 pig iron manufacture already developed in many areas and countries, supplying as it did the staple input for casting and refining operations leading to the smelting of more and more sophisticated types of steels, was in need of extensive rationalisation: only firms with a large processing capacity (i.e. plentiful investment and vertical integration) could face outward competition 
undaunted. From the 1870 s, the first cartels emerged in this sector even if their influence remained marginal on prices, given the high level of pig iron imports. From 1879 onwards, pig iron manufacture enjoyed high nominal and effective protection. The tariff certainly contributed to the reduction of imports after this date, but another factor decisively altered the situation of this industry at about the same time: the introduction of the Thomas-Gilchrist process which made it possible to convert phosphorous iron made with Lorraine ores into steel. Domestic output of pig iron and steel rocketed in its aftermath, bringing down production costs. Tariff protection in this context provided manufacturers with the opportunity of managing the ensuing reduction of prices and organising interest groups to lobby for its continuation (Lambi, 1963: 232). Their interest was purely domestic at first, and their aim was never to secure foreign outlets for their production. When surpluses arose at the turn of the century, dumping was used in order to clear unwanted inventories, thus putting domestic consumers of German pig iron clearly at a disadvantage vis-à-vis their foreign competitors.

The rail industry presents yet another instance of a typically oligopolistic market. Manufactured in large-scale units, rolling mills enjoyed substantial protection behind tariff barriers as the establishment of the rail cartel in the 1870s shows. Paradoxically - and unlike pig iron - German firms' initial comparative advantage appears to have been quite strong in 1880. Here demand for higher protection in the 1879 tariff debate aimed at maintaining high domestic prices and preventing any risk of foreign competition. Over the long run, the tariff allowed for stronger profits channelled into investment in new technologies, which gave German rail manufacturers a competitive edge over their British competitors. When domestic prices stood above world prices, German rails were dumped on third markets at average cost price. The domestic market for finished iron and steel products ('light goods' such as tinplate, wire, tools, bolts and nails) was much more competitive owing to the multiplicity of firms and their consequent incapacity to set up effective cartels. Such a market typically enjoyed low levels of protection and could even register negative protection in certain branches given the duty level bearing on their inputs. However, they maintained a very strong comparative advantage throughout the period.

\section{Conclusion}

The particular brand of German protectionism at the end of the nineteenth century decidedly influenced the course of only a handful of industries during this period: rye and wheat growing, cotton spinning, pig iron smelting and also perhaps rail making, representing together 2-3 per cent of all exports and around 7 per cent of all imports (i.e. a tiny fraction of the country's value added). For this limited range of products, the tariff 
reduced Germany's comparative disadvantage and brought forward or maintained a comparative advantage. Apart from rye which was one of the bones of contention in the trade war with Russia, none of these products figure among the goods that made the reputation of 'made in Germany' goods, and so frightened Germany's competitors. It is therefore unlikely that protection played any part in the country's successful seizure of lucrative and innovative markets at the time. Such a conclusion should not surprise us: two observers (Lotz, 1904; Dawson, 1904) reached a similar verdict as early as 1904 . This fact serves only to prove the enduring power of attraction of protectionist solutions.

Conversely, if they failed to boost Germany's commercial expansion abroad, they could very well have held it up by burdening it with heavier production costs. Credit must be given to Reichstag law-makers for steering away from this path - barring the claim that, without the tariff, German success would have been even greater.

On the whole, the 1879 tariff provided only marginal protection to the vast majority of agricultural and industrial producers, which accounts for the absence of any discernible correlation between the level of protection and the changing pattern of comparative advantages. The tariff's tour de force resided in the granting of preferential treatment to a tiny constituency of large landowners and iron masters while resisting the avalanche of claims by other sectors.

If protection proves to have been an unlikely suspect for explaining Germany's commercial prowess, what then could explain it? This is an altogether different story, for which Williams provides the premises in his chapter entitled, 'Why Germany beats us' (Williams, 1897: 130-63).

\section{Notes}

1 French original, translated by Jean-Pierre Dormois.

2 Department of Economics, chair of international finance, Institut d'Etudes Politiques de Paris.

3 'The illusion of a correlation' to paraphrase Capie (1983: 12).

4 List's vision of tariffs was akin to the lesser of two evils. He stresses that the introduction of industrial tariffs must be gradual and that they must likewise be dismantled as soon as domestic industries are established (under the eye of a watchful government) on a safe footing. Furthermore, he recognises the positive check played by foreign competition on the development of domestic industries.

5 For a more elaborate discussion, see Dedinger, 1992.

6 German public opinion itself became only gradually aware of this growing assertiveness; see Halle, 1907: 493-4.

7 Germaine de Stael, De l'Allemagne (1813).

8 An act passed by the British parliament made the mark of the country of origin compulsory. Williams' book, published originally in 1896, had ten reprints up to the First World War.

9 For this author, German successes were the direct outcome of German tariff policy, just as Britain's 'declining' trade was due to its sticking to free-trade policies. 
10 The 1834 Zollverein was the outcome of a process started after the Napoleonic wars. Prussia organised a customs union for all its territories in 1818. In 1828 the 'Mitteldeutscher Handelsverein' was concluded between Hannover, Oldenburg, Nassau, Hesse, Sachsen and the Thuringian states, as was a customs union between Bavaria and Württemberg.

11 Nassau joined in 1836, Baden and Waldeck in 1838, Lippe in 1842, Hannover and Oldenburg in 1854, Schleswig, Holstein and the two Mecklemburgs in 1867.

12 According to the periodisation adopted by Hau, 1994.

13 K. Laursen (1998) offers the varying characteristics of the different versions of competitive/comparative advantage indices.

14 A sentence paraphrased in Bairoch, 1989: 52.

15 Dumping, first scrutinised by Jacob Viner (1902), became common practice for sugar refiners and rye growers in the early 1900s.

16 Duties on iron and steel products were only repealed in 1877 , however.

17 The Economist magazine addressed this problem as early as 1879 . The author of the article argued that protection, by raising profits, fostered the transfer of resources to protected industries, thereby upgrading competition among domestic producers which, in return, will tend to depress internal prices. However, "this internal competition which is quite certain and inevitable, makes protected manufacturers eager for higher and higher tariffs till nothing but exclusion will ultimately satisfy them' (The Economist, 4 January 1879: 3). Dawson had doubts about the possibility for a tariff to boost exports: 'It is clear that neither Germany nor any other country can extend her exports by imposing duties on incoming goods' (Dawson, 1904: 162).

18 This is the theoretical basis for the infant industry argument. 


\title{
12 Protectionism and Portuguese industrialisation $^{1}$
}

\author{
Pedro Lains ${ }^{2}$
}

\section{Introduction}

Portuguese customs policy in the period between 1842 and 1913 is generally divided in our historical studies into three distinct periods, falling between the statutes of 1852 and 1892. The first of these regulations, issued under the signature of Fontes Pereira de Melo, altered the commercial policy that began in 1837, during the government of Passos Manuel. The second, promulgated in the midst of the financial crisis of 1891, is blamed for the return to the protectionist system. ${ }^{3}$ As we will attempt to show in this chapter, this interpretation of successive modifications to Portuguese customs policy, in the period we propose to study here, is not exact. The origins of this uncertainty lie in the fact that the analysis of the Portuguese customs system has largely been based on public opinion, derived from government and opposition political debate.

In this study, we will focus on the development of duties levied by the customs, taking into account their relative value to imports. This approach is, in our opinion, the most reliable, as the regulations established specific duties in relation to weight or volume, rather than ad valorem, i.e. in relation to price. In order to define the customs regime, one must establish the part of the internal price of the imported product owed to the customs service and not the absolute value of the tariff applied. With the specific duties system that was introduced in 1837, the free-trade debate highlighted by our political historians might have been associated with a customs policy of the opposing theory. For this, it would suffice that reductions of the regulatory specific duties would not be sufficient to compensate for the decrease in the international prices of imports.

The changes introduced by the regulations of 1852 and 1892 were the most prominent, as they sparked a greater public debate. However, they did not have the impact they have been credited with, as they came into force amid an international price panorama that dampened their desired effects, a fact to which their creators were certainly sensitive. International prices fell considerably between 1837 and 1852. ${ }^{4}$ This led to the duties that had been introduced in those years (and, in some cases, reinforced in 
1841) to become too severe at the time of the publication of the regulation, which was meant to mark the beginning of Portugal's free-trade policy. Thus, it was feasible to reduce the regulatory tariffs without changing the overall national customs policy. Forty years later, the exact opposite situation could be found, as the abandoning of the gold standard, together with the changes that had taken place internationally, led to rising prices of Portuguese imports. ${ }^{5}$ Now, the duties established in the regulations could be reinforced without a resulting increase in protectionism. The 1892 law certainly did not represent a return to protectionism, but it was only an economic (and also largely a political) measure aimed at maintaining the status quo of the national customs system. In 1837, duties remained, on average, 15 per cent above the total value of imports. From then on, Portugal 'embraced' protectionism, maintaining it until at least the eve of the First World War.

Our conclusions on Portuguese customs policy lead us to refute the thesis of it being a measure for the reinforcement - or even the main cause - of the economic specialisation in the export of agricultural products in the period between 1852 and 1892, then followed by industrial expansion, a consequence of the alleged introduction of the protectionist regime in the latter year. Without denying the evidence for productive specialisation, which was quite blatant in the pattern of Portugal's international exchanges, our interpretation of the customs tariff policy has to be substantially different, as we advocate that the implementation of the protectionist regime began under the tariff reforms of $1835-7 .{ }^{6}$ The protectionist regime followed in Portugal in that period gave, in our opinion, a certain shape to the productive structure of the national economy, which would have been responsible for a certain limitation in sustained long-term growth of national products. After seven decades of protectionism, Portuguese industry at the beginning of the twentieth century had such a structure that allowed it to compete directly with the well-equipped and established industries of the more-developed countries.

The reasons behind the distorting effects of Portugal's custom policy were related to the way it was built - namely, as a response to the financial requirements of the state and the pressure of certain interest groups. These aspects will be dealt with on pages 248-55. Before that, we will show the development of the ad valorem duties between 1842 and 1913, while in the section on pages 255-60 we will study the effects of protectionism on the growth and structure of the Portuguese economy.

\section{The evolution of protectionism}

Our study of Portuguese customs regulations is based, as we have previously mentioned, on an analysis of the development of average ad valorem duties, i.e. of the ratio between the value of the duties and the value of imports, obtained from foreign trade statistics. In Figure 12.1, three major 


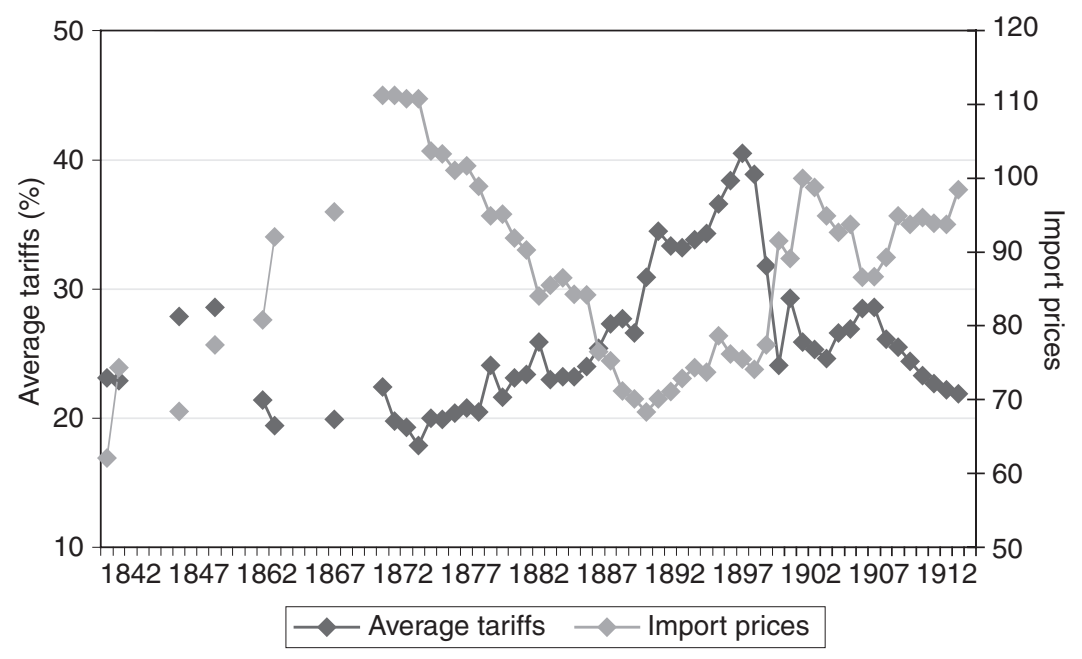

Figure 12.1 Average tariffs and import prices, 1842-1913 (source: Lains (1992)).

phases in the development of those duties between 1842 (the first year we have information for) and the eve of the First World War (1914-18) can be seen. The first phase lasts from 1842 to 1868, and has a marked variable trend, being followed by a period of considerable increase in average duties. Finally, between 1895 and 1913, another phase takes place in which these plummet. The change in average duties, as seen in the figure, can be mainly explained as being due to the variation in the composition of imports and the fluctuation in their international prices.

Indeed, between 1852 and 1856, the free entry of large amounts of cereal altered the composition of imports, increasing the proportion of lower taxed items, which decreased the average index of the tariffs charged by the customs. In the same way, part of the decrease seen in the mean duties from 1895 was due to a substantial increase in the import of raw materials, which were charged substantially below average duties. In order to correct the negative influence of variations in the composition of imports in our indicator of the average protection level, we need to calculate the ad valorem duties on a fixed basis in a certain year. As the period in question is quite long, we calculated an index of average duties based on different years ${ }^{7}$ to take into account changes in the structure of imports (see Table 12.1). What may seem surprising in the light of the argument defending the existence of free trade in Portugal between 1852 and 1892 is that average customs duties in the years in Table 12.1 are always the same, or above those of 1843, a time when the regulation of 1841 was still in force, and which had a level of protectionism similar to that of $1837 .{ }^{8}$ The year 1837 is considered to be the time of the first modern attempt to 
Table 12.1 Weighted index of median added value duties (\%)

\begin{tabular}{|c|c|c|c|c|c|c|c|}
\hline \multirow[t]{2}{*}{ Year } & \multicolumn{7}{|c|}{ Base year } \\
\hline & Current & 1851 & 1865 & 1873 & 1886 & 1897 & 1913 \\
\hline \multicolumn{8}{|c|}{ A Total duties } \\
\hline 1843 & 24.1 & 23.5 & 25.8 & 22.7 & 19.3 & 16.9 & 15.8 \\
\hline 1851 & 29.4 & 29.4 & 30.4 & 26.9 & 23.2 & 21.0 & 19.7 \\
\hline 1856 & 20.3 & 23.6 & 24.9 & 21.5 & 17.3 & 14.7 & 13.4 \\
\hline 1865 & 30.4 & 24.8 & 30.4 & 25.7 & 22.3 & 18.9 & 18.5 \\
\hline 1873 & 27.2 & 26.5 & 32.6 & 27.2 & 22.1 & 18.8 & 17.2 \\
\hline 1886 & 35.4 & 39.1 & 52.4 & -43.3 & 35.4 & 31.6 & 27.0 \\
\hline 1890 & 33.3 & 42.9 & 43.1 & 38.7 & 35.0 & 34.2 & 30.3 \\
\hline 1897 & 31.9 & 45.1 & 43.9 & 40.0 & 34.2 & 31.9 & 27.8 \\
\hline 1905 & 28.6 & 41.3 & 40.8 & 37.0 & 32.6 & 31.1 & 26.9 \\
\hline 1913 & 22.1 & 34.2 & 34.0 & 31.2 & 27.1 & 25.8 & 22.1 \\
\hline \multicolumn{8}{|c|}{ B Excluding cereals, tobacco and sugar } \\
\hline 1843 & 21.6 & 20.7 & 19.9 & 18.4 & 16.7 & 15.0 & 14.1 \\
\hline 1851 & 25.4 & 25.4 & 24.0 & 22.0 & 20.4 & 18.6 & 17.8 \\
\hline 1856 & 18.8 & 20.4 & 18.6 & 16.8 & 14.8 & 12.9 & 11.9 \\
\hline 1865 & 19.9 & 20.2 & 19.9 & 18.2 & 17.5 & 15.3 & 15.6 \\
\hline 1873 & 17.8 & 20.7 & 19.6 & 17.8 & 16.1 & 14.4 & 13.5 \\
\hline 1886 & 20.7 & 27.0 & 25.1 & 24.3 & 20.7 & 19.6 & 16.6 \\
\hline 1890 & 25.7 & 32.6 & 31.2 & 29.6 & 26.6 & 25.1 & 22.9 \\
\hline 1897 & 25.2 & 35.0 & 33.4 & 31.8 & 28.0 & 25.2 & 22.4 \\
\hline 1905 & 21.6 & 31.8 & 30.2 & 28.9 & 25.2 & 22.8 & 20.1 \\
\hline 1913 & 17.2 & 26.9 & 25.9 & 25.1 & 21.8 & 19.9 & 17.2 \\
\hline
\end{tabular}

Sources: Estatísticas do Comércio Externo and Table 12.5.

Note

Index-weighted by the relative value of those imports listed in Table 12.5 for each base year indicated.

install tariff protectionism in Portugal. In Table 12.1 we can also see that, contrary to commonly held belief, average duties did not increase in 1892.

We have to conclude that, according to these results, it is not correct to label Portuguese trade policy as free trade for the period between 1852 and 1892, and that the period following the latter legislation showed no difference in its levels of protectionism. Bearing in mind that duties in Portugal were specific, which means they were established according to the weight of the imported goods, variation in the international prices of these goods considerably determined the amount of customs duties, as we have defined it here. In a period of falling prices, a supposedly free-trade tariff policy might correspond to a de facto protectionist policy, with only insufficient reductions in the customs duties to counteract the negative fluctuation of prices. For example, it was thus possible to increase average tariffs duties between 1867 and 1887 (from 25.7 per cent to 40.7 per 
cent), in spite of the decrease of the current duties arising from the commercial treaty signed with France in 1866, which was renewed in 1882. If we return to Figure 12.1, we can confirm the contradiction between the practice of the duties and the traditional interpretations of Portuguese customs policy.

Between 1856 and 1888, a period usually considered to have marked the premeditated instatement of free trade, average duties rose constantly; from 1895, after a period of indefinite trend and issuing of the 1892 regulation, a new phase began with a reduction of fiscal levies on imports.

Comparison of changes in the average duties with those in import prices (see Figure 12.1) allows us to observe the extent these determined Portugal's customs regime. Bearing this in mind, one may question the validity of the index chosen to define the customs system, as it would not be representative since it depended in extremis on import prices. Would it not be more advisable to establish an indicator independently of prices? The answer to this question is clearly negative: what we need to know in order to characterise customs rules is the size (and change) of the differential between prices of each imported product before and after being dispatched by the national customs. In fact, this seems to have been the reasoning of those in charge of customs policy at the time. Following the publication of the 1852 regulation, Fontes Pereira de Melo wrote:

Due to a deplorable mishap, the exaggerated calculation of the prices on which our regulations are based and the excessive increase in our customs duties have almost excluded us from the benefits arising from the generalised decrease in prices that other nations enjoy. ${ }^{9}$

In the light of evidence, when we say it is not correct to conclude that Portuguese customs policy in the second half of the nineteenth century did not follow free-trade precepts, we do not deny that conditions for national production worsened in relation to foreign competition. Indeed, between 1865 and 1886 the price index of Portuguese imports (with the respective added duties) decreased from 145.1 to $94.8(1900=100) .{ }^{10}$ However, in order to counteract this trend, the duties would have had to have risen in a ridiculous way: for example, the maintenance of the price of imports in 1886 to the level they had been twenty years before would imply an average level of duties of 107 per cent, which might represent the rounding up of the protection rates to 200 per cent or 300 per cent. Although the Portuguese economy was more exposed to external competition in the period 1865-86, this does not gainsay the fact that customs protectionism remained the same. The protectionism on the part of the customs must be defined in relation to international prices and not according to a specific national price of the imports. Indeed, this is the perspective that makes more sense, as the drop in international prices, was general, not only focusing on the final products, but also the raw materials 
used by the industries. On the other hand, to admit that Portugal found it necessary to maintain the level of the import prices (accrued from duties) at 1860s' levels would be to admit the creation of an enterprise incompatible with the small scale of the Portuguese economy.

Some comparisons with what was occurring in other countries confirm the protectionist character of the Portuguese customs system. For example, duties on cotton thread and cotton and wool manufactured items imports in 1875 and 1895 were only exceeded in Europe by duties on cotton manufactured items in Spain and Russia in $1895 .{ }^{11}$ On the other hand, a British commission charged with studying the level of protectionism carried out in markets that were clients of the United Kingdom published a list of the various protectionism levels for 1902 (a year when the Portuguese average duties were at a relatively low level), in which Portugal is shown as one of the most protectionist countries, distancing itself from Russia and the USA, and being level with the backward but larger Spanish economy (see Table 12.2).

The results of these comparisons are quite significant, since it is recognised that the smaller a country's economic size, the less its chances are of implementing a successful protectionist customs system. This is due to a quicker drainage of the absorption capacity of the protected (national) market, as an inevitable greater necessity to import, because of the smaller diversification of the domestic resource base. Even the pioneer of the protectionist theories in modern Europe, Friedrich List, was fully aware of this fact when he proposed his 'national system of political economy' for an expanded Germany and not for the various existing states at the date of the publication of his seminal work (1841). ${ }^{12}$

Table 12.2 Average duty on the export of United Kingdom Industrial products (1902)

\begin{tabular}{lrlr}
\hline Russia & $131 \%$ & Greece & $19 \%$ \\
USA & $73 \%$ & Denmark. & $18 \%$ \\
Spain & $56 \%$ & Canada & $17 \%$ \\
Portugal & $56 \%$ & Romania & $14 \%$ \\
Austria-Hungary & $35 \%$ & Belgium & $13 \%$ \\
France & $34 \%$ & Norway & $12 \%$ \\
Argentina & $28 \%$ & Turkey & $8 \%$ \\
Italy & $27 \%$ & Switzerland & $7 \%$ \\
Germany & $25 \%$ & Australia & $6 \%$ \\
Sweden & $23 \%$ & Netherlands & $3 \%$ \\
\hline
\end{tabular}

Source: BPP (1905: 354).

Note

The figures for Spain and Portugal have been adjusted to take account of the fact that the calculations in the source document were made on the basis of the official parity exchange rate, and not the actual commercial exchange rate. 


\section{The background to protectionism: public finance and pressure groups}

In Portugal, as in the great majority of European countries, revenues from custom levies constituted the main revenues in the state's budget (see Table 12.3). As it was an economic activity centred in specific parts of the country, foreign trade was easy to tax and control. As earnings of citizens and companies were widely dispersed, their taxing necessitated fiscal organisation that could only be carried out by politically, socially and economically developed states. Thus, it can be seen that, at the beginning of the twentieth century, only five countries had tax collection systems similar to present-day ones. ${ }^{13}$

As custom levies were so vital to the Portuguese state's finances, we cannot help but consider their fiscal dimension. To do this, we will have to try to distinguish between the main duties levied on imports to those that were aimed at providing revenue for the state. As can be easily demonstrated, the total level of revenue will be greater when the capacity on the part of the economic agents to import alternative goods is reduced. ${ }^{14}$ Therefore, the greater the requirements of the budget, the higher the charges on products that have inelastic internal demand and supply. Table 12.4 shows import products that might be very difficult to substitute and that could not be supplied via domestic production. ${ }^{15}$ The measurement of the budgetary character of the Portuguese customs system can be made considering that about half the levies charged have a budgetary intent and not a protectionist one. This proportion would be even greater if we added some manufactured products that had a practically non-existent home-grown production, and carried on in spite of the successive increases in the so-called protective duties.

Table 12.3 Breakdown of Portuguese budget receipts (percentage of effective receipts)

\begin{tabular}{lllll}
\hline Years & Fiscal receipts & Indirect taxation & Import duties & Tobacco receipts \\
\hline $1851 / 2-1855 / 6$ & 88.2 & 58.8 & 35.7 & 12.6 \\
$1856 / 7-1860 / 1$ & 82.0 & 53.3 & 33.6 & 10.2 \\
$1861 / 2-1865 / 6$ & 92.1 & 61.3 & 36.3 & 12.3 \\
$1866 / 7-1870 / 1$ & 92.3 & 54.2 & 29.1 & 12.6 \\
$1871 / 2-1875 / 6$ & 88.4 & 53.5 & 28.5 & 10.0 \\
$1876 / 7-1880 / 1$ & 88.3 & 54.9 & 29.8 & 10.7 \\
$1881 / 2-1885 / 6$ & 88.8 & 54.8 & 28.3 & 10.6 \\
$1886 / 7-1890 / 1$ & 88.4 & 57.5 & 33.4 & 10.0 \\
$1891 / 2-1895 / 6$ & 89.7 & 52.7 & 31.1 & 10.4 \\
$1896 / 7-1900 / 1$ & 88.7 & 49.6 & 27.7 & 9.2 \\
$1901 / 2-1905 / 6$ & 87.5 & 48.9 & 28.4 & 8.4 \\
$1906 / 7-1910 / 1$ & 78.6 & 44.7 & 24.1 & 9.7 \\
$1911 / 2-1913 / 4$ & 78.9 & 35.3 & 24.8 & 9.4 \\
\hline
\end{tabular}

Source: Mata (1993). 
Table 12.4 Duty on main imported consumer goods (\% of total duty)

\begin{tabular}{lrllllll}
\hline Year & Cod & Sugar & $\begin{array}{l}\text { Tea and } \\
\text { coffee }\end{array}$ & Lampoil & Tobacco & Cereals & Total \\
\hline 1843 & 6.6 & 10.9 & 3.8 & 0.0 & 6.0 & 0.1 & 27.4 \\
1851 & 11.5 & 18.6 & 4.5 & 0.0 & 3.5 & 0.6 & 38.7 \\
1856 & 10.9 & 21.6 & 3.2 & 0.0 & 4.9 & 1.5 & 42.1 \\
1865 & 5.4 & 16.0 & 2.0 & 0.2 & 29.6 & 2.4 & 55.6 \\
1873 & 6.3 & 16.0 & 2.8 & 1.8 & 26.6 & 1.0 & 56.5 \\
1886 & 5.7 & 16.5 & 2.9 & 3.6 & 26.4 & 10.1 & 65.2 \\
1890 & 5.5 & 20.9 & 3.1 & 5.1 & 1.5 & 11.6 & 47.7 \\
1897 & 6.6 & 23.6 & 3.8 & 7.4 & 1.7 & 12.1 & 55.2 \\
1905 & 4.7 & 20.1 & 3.7 & 5.1 & 1.5 & 15.8 & 50.9 \\
1913 & 5.7 & 17.8 & 3.1 & 5.1 & 1.9 & 16.1 & 49.7 \\
\hline
\end{tabular}

Source: Estatísticas do Comércio Externo.

Now we will analyse the development of the customs duties that were aimed at protecting domestic production. In Table 12.5 we can see the most important customs duties for a series of years, chosen according to the most significant tariff changes. ${ }^{16}$ We grouped the information in this table according to the type of consumption the imports were destined for: foodstuffs, raw materials, intermediate materials for industrial use and manufactured products for final use.

In a consistent protectionist system, the degree of tariffs is dictated by the type of use the imported goods will be subject to. Thus, raw materials pay low levies, as they don't place such a heavy burden on the industries that use them, while manufactured products pay higher tariffs, in order to defend the prices practised by national industry. In general terms this taxation scale of imports seems to have been practised in the Portuguese customs system, as can be seen in Table 12.5.

But when we observe more closely the structure of the Portuguese regulations, the protectionist policy seems somewhat confusing and undefined. For example, in half of the years in the table in question, cotton thread was taxed at a higher rate than when it was used as a raw material, i.e., for weaving. Among many other examples of these inconsistencies, we have chosen that given by an anonymous writer commenting on the 1871 regulation:

If it were not so insignificant [the import of cotton], we would make an effort to try and find out why raw cotton pays 0.5 réis and as much as 200 réis in bales. And we equally question why an intermediate levy was not created for dyed raw cotton, as it was for wool and silk in that state. The levy for simple white threaded cotton is 200 réis per kilo, about $25 \%$ of its value - which seems too much to us, as it serves, in any of its states as raw material for our national factories. ${ }^{17}$ 


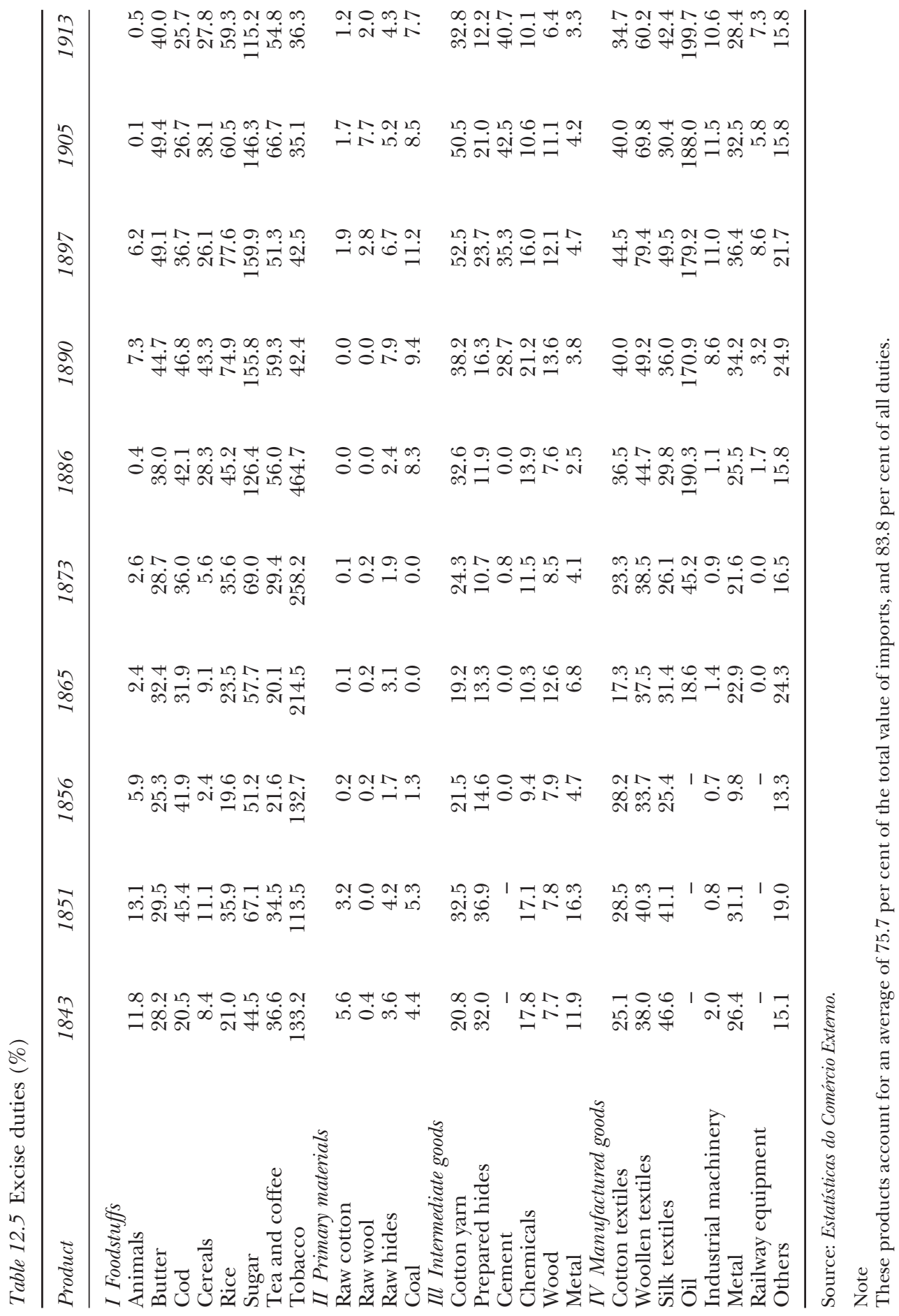




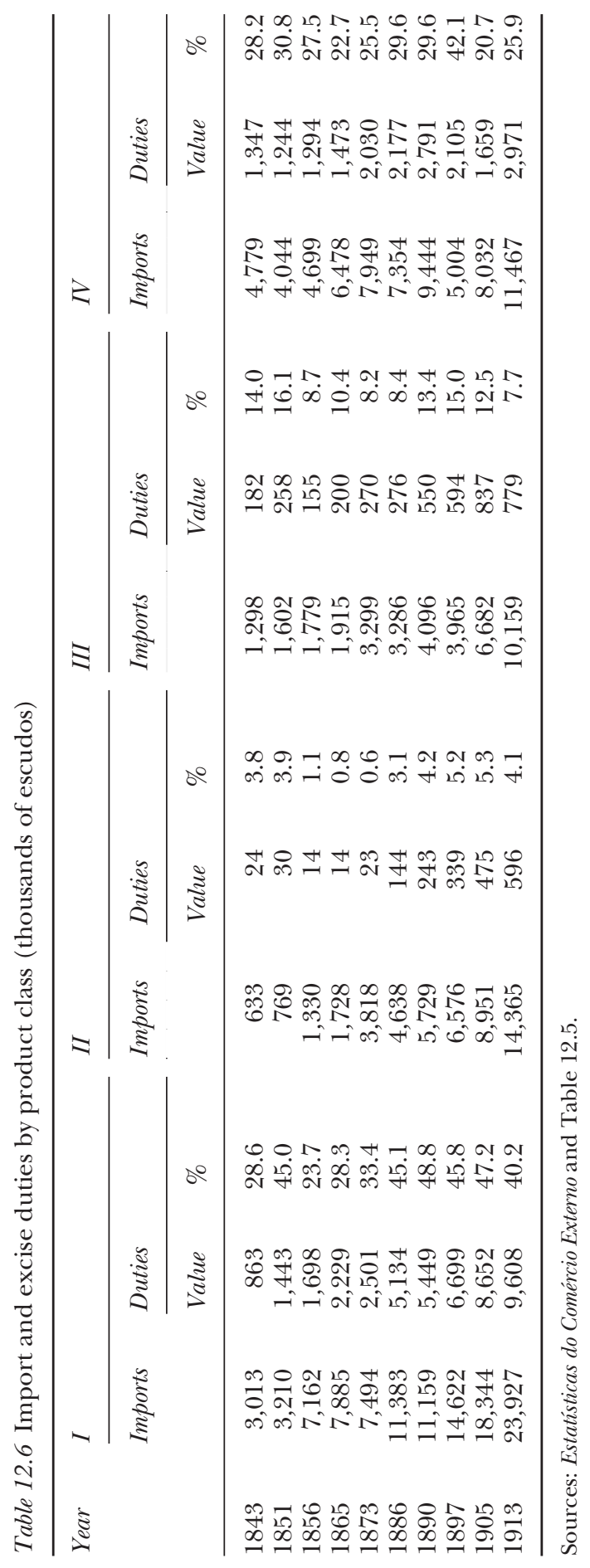


The same author continues in this vein, expressing surprise at the fact that raw threaded cotton pays tariffs of 135 reis per kilo, i.e. 27 per cent of its price, while the corresponding tax for threaded silk was, according to him, 0.3 per cent. This difference in treatment seems strange to the writer, especially as 'silk is for luxury objects, while cotton is a primary and necessity product'. He goes on to add that, in Portugal, the production of silk fabrics was lower than production of cotton fabrics.

The level of protectionism in a certain industry depended not only on levies paid by the imported goods that competed with their final product, but also with duties charged for the acquisition of foreign raw materials and intermediate products, and the difference between these and the value of the final product (i.e. the added value). Taking all of these factors into account, we consider this situation not to be normal, nominal protection, but the concept known as effective protection. To give an example of how the use of this concept may change our analysis, we can see in Table 12.7 the case of the cotton manufactures: here it can be seen that, in 1897 and 1905, woven cloth was the object of relatively small-scale effective protection, in spite of consumers having to pay a price about 40 per cent higher than for similar products that were dispatched through Portuguese customs. This result was due to the fact that the ad valorem duties on the thread were substantially higher to those charged on fabrics. We can also note in the same table that the effective protection granted to the thread industry was always greater to that of the woven cloth, creating substantial differences. ${ }^{18}$

In order to determine the development of protectionism given to national production, we have to consider the development of duties in the different stages of the production process. A careful observation of Table 12.5 allows us to see that protection for the various branches of industry may not have varied a lot with the changes in the ad valorem duties that resulted from changes in the tariffs of the prices. Indeed, the reductions of customs duties (between 1851 and 1873 and between 1897 and 1913) encompassed both final and intermediate products, and even some raw materials. Conversely, in the periods when the duties were bolstered (1843-51 and 1873-90), the effective protection may not have substantially increased, as the added protection granted to the final product was counteracted, at least in part, by the increase in duties on imports. In the light of the concept of effective protection, requests for higher duties by a greater number of industrialists would become more understandable. However, one must distinguish between a free-trade system and a badly devised protectionist regime, as the latter causes added economic costs that do not correspondingly translate into greater support to national manufacturing production.

The absence of a consistent protectionist customs policy leads us to believe the regulations were devised according to fairly antagonistic interests, without compromise being reached between them. It is true that the 
Table 12.7 Effective Protection Index: cotton spinning and weaving

\begin{tabular}{lrrrrr}
\hline & 1886 & 1890 & 1897 & 1905 & 1913 \\
\hline Nominal index (\%) & & & & & \\
Cotton cloth (Tt) & 36.5 & 40.0 & 44.5 & 40.0 & 34.7 \\
Cotton thread (Tf) & 32.6 & 38.2 & 52.5 & 50.5 & 32.8 \\
Raw cotton (Tr) & 0.0 & 0.0 & 1.9 & 1.7 & 1.2 \\
Input-output coefficients & & & & & \\
Cloth/thread (At) & 0.74 & 0.74 & 0.74 & 0.74 & 0.74 \\
Thread/raw (Af) & 0.54 & 0.54 & 0.54 & 0.54 & 0.54 \\
Effective Protection Index (\%) & & & & & \\
Weaving (Et) & 47.6 & 45.1 & 21.7 & 10.1 & 40.1 \\
Spinning (Ef) & 70.9 & 83.0 & 111.9 & 107.8 & 69.9 \\
\hline
\end{tabular}

Sources: Table 12.5 and Reis (1986: 911).

Note

$\mathrm{Et}=(\mathrm{Tt}-\mathrm{At} \times \mathrm{Tf}) /(1-\mathrm{At})$.

$\mathrm{Ef}=(\mathrm{Tf}-\mathrm{Af} \times \mathrm{Tr}) /(1-\mathrm{Af})$.

Note - For information on the problems inherent to the calculation of the Effective Protection Indices, see Balassa (1971). One of the problems that should be noted is that the use of input-output coefficients in protectionist, rather than a free market, situations will lead to an over-estimation of the value of the Effective Protection Index (Balassa, 1971: 300).

creation of protectionist systems is always the result of pressures from various sectors interested in defending their businesses. In the historic period this study encompasses, the state tended only to mediate, solely concerned with raising funds to govern the precarious public treasury. In this scenario, where many pressure groups interact, the customs protection gained varied proportionally according to the strength of the groups involved, which in turn depended on their ability to strive towards certain goals. The more dispersed the consumers of a certain product, the more difficult it would be to make their voices heard before the central authorities, as the costs of organisation and coordinating their actions tended to be greater. ${ }^{19}$ Thus, the consumers of final products were usually in a less advantageous position to influence customs tariff policies than consumers of intermediate goods, i.e. industrialists. ${ }^{20}$ The degree of cohesion of the latter group was certainly greater, not only because they were fewer in number and thus easier to communicate among, but also because they had greater economic capability to debate with the authorities. Among many other authors, Anselmo de Andrade supports the thesis that the Portuguese customs system was largely shaped by the capability for intervention of the parties involved:

Aside from the usual resources, and others that were underused or timidly exploited, taxable items became scarce and therefore unaffected by greater tariffs. Statesmen had only at their disposal (as they did not want to govern via other ways) taxes on consumption, which 


\section{Pedro Lains}

were fiscally preferred as they were varied and were more accepted by the taxpayers. $^{21}$

Our knowledge of the type of relationships between political and economic groups is not sufficient to give us greater precision in the above analysis. However, if we establish a means to measure the strength of certain pressure groups, it would seem legitimate to us to relate it to the corresponding level of protection. The access to those responsible for customs policies is proportionately easier the greater the economic resources and mobility of the industrialists in question. Such characteristics are associated with industries with greater economic power, which in the Portuguese case were those with a greater level of concentration, which could be measured by the average amount of workers operating in the bigger units of the sector. Therefore, this level of concentration operates as an indicator of the pressure capacity of each industrial branch.

In Table 12.8 we can see the existence of a direct relationship between our measure of pressure power and the average level of the tariffs relating to the most important industrial sectors at the close of the nineteenth century. This relationship would be even more obvious if we increased the level of separation: for example, in the cotton industry, the greater protection granted to threads (when it was correctly evaluated via the effective protection tax) was related to the fact that thread was a more concentrated industry than woven cloth.

In conclusion, Portuguese customs policy in the period between 1842 and the First World War must be seen, in our opinion, as resulting from the accord between the groups with greater capacity to press for favours

Table 12.8 Protection and pressure

\begin{tabular}{llll}
\hline Industrial sector & $\begin{array}{l}\text { Average number of factory } \\
\text { employees (1891) }\end{array}$ & $\begin{array}{l}\text { Added value duties } \\
(1894-7)(\%)\end{array}$ \\
\cline { 2 - 3 } & Five largest & Ten largest & \\
\hline Cotton & 669 & 445 & 48.4 \\
Wool & 457 & 336 & 81.5 \\
Metals & 227 & 152 & 38.8 \\
Paper & 156 & 84 & 29.7 \\
Ceramics & 119 & 81 & 37.8 \\
Glass & 118 & $?$ & 43.8 \\
Chemicals & 56 & $?$ & 24.6 \\
Animal skins & 27 & 20 & 24.3 \\
\hline
\end{tabular}

Sources: Inquérito Industrial de 1890; Estatísticas do Comércio Externo.

Note

Approximately 15 per cent of the working population were employed in the ten largest factories. 
and their own interests, and a government that derived its main source of revenue from customs.

\section{The effects of protectionism on the structure of the Portuguese economy}

The only agricultural products with significant national production that were considered as part of the customs policy (with a lack of continuity between 1865 and 1889) were cereals or, to be more precise, wheat. Actual cereal protection was not carried out via the customs, as it depended on the establishment of minimum domestic prices. These were associated with the obligation on millers to acquire it as a condition to be allowed to import wheat. Within the protection provisions for national cereal products, which were introduced in 1889 and reinforced ten years later after Elvino de Brito's well-known 'Hunger Law', customs levies served mainly to furnish the state's tax receipts. ${ }^{22}$ In spite of cereal protection policy having little to do with customs policy in the Portuguese case, we would like to offer a little extra on the matter, as it will help, in our opinion, to support some of the conclusions we have already drafted in the previous section.

As we can see in Table 12.9, growth in cereal production was more intense in the period when it benefited from protection (from about 1885) than in the free-trade period immediately before. However, one should note that the production of cereal did not grow faster than wine or animal products (that together formed the bulk of gross Portuguese agricultural production) in the years between 1846 and 1912. Additionally, the greater growth in cereal production was not accompanied by a larger total farming production growth, due to contractions registered in growth rates of the other two sectors, which can be associated with the expansion of cereals.

Table 12.9 Growth index of agricultural output (annual averages: \%)

\begin{tabular}{lrrlr}
\hline Period & Cereals & Wines & Animal products & Total \\
\hline $1846-52$ & 0.9 & 3.1 & 0.2 & 1.4 \\
$1852-70$ & 0.1 & -1.3 & 0.5 & 0.3 \\
$1870-85$ & -0.4 & 3.1 & 1.4 & 1.4 \\
$1885-1903$ & 2.0 & 1.4 & 1.0 & 1.4 \\
$1903-12$ & -0.5 & -1.9 & 0.2 & 0.8 \\
$1846-85$ & 0.1 & 1.0 & 0.8 & 0.6 \\
$1885-1912$ & 1.2 & 0.3 & 0.7 & 0.7 \\
$1846-1912$ & 0.5 & 0.7 & 0.7 & 0.7 \\
\hline
\end{tabular}

Source: Lains (1990).

Note

The years refer to the middle of the tri-annual averages. 
The protection of wheat production, which was obtained mainly by the southern latifundiario (absentee-landlord farmers), does not seem to have been a consequence of a serious crisis in agriculture in the Alentejo region or a special aptitude of the area to produce the cereal. It seems that the 'Alentejo lobby' was the one with greater chances of attaining success with the economic authorities, as this met the government's pressing budget needs. ${ }^{23}$ Thus, the other products of the Alentejo seem to have been set aside by the use of criteria that were alien to the farming economy of the region. Such an interpretation leads us to conclude that, once again, the interests of the pressure groups, together with the government's fiscal needs, took control of the events. It was not by chance that the branch of Portuguese agriculture receiving the greatest attention from central authorities was characterised by a considerable geographical concentration - not being a dispersed sector, such as the wine, fruit and livestock sectors were. ${ }^{24}$ Equally, among imported goods, cereals were widely consumed and demand could not be met entirely by national production and therefore became a good target for the exchequer, a fact that can be proved by commerce statistics.

Cereal protection, therefore, led to the channelling of some of national agriculture's scarce resources to an area they were not particularly suited for. This opinion is very common among authors who have dealt with the famous 'cereal question' that was raised by protectionism, though they are a long way from consensus on the matter. For example, for Oliveira Salazar, following in the wake of Oliveira Martins and Ezequiel de Campos, Portugal lived 'attached to the misery of cereal cultivation', instead of aiming to exploit other resources. ${ }^{25}$ In a study on the region of Vidigueira, the cultivation of cereals is also considered to be an inadequate way to expand the Alentejo's farming production, as the land that was still available was not suitable. The increase of wheat production in the region led to the reduction of periods of fallow, to the diminishing of pastures and an increase in the number of wage workers. Such changes were adverse to proper livestock management, a fundamental productive factor in the farming economy of the nineteenth century. Working bulls were regularly substituted with mules, an example of a way of farming that is 'hurried and exhaustive'. ${ }^{26}$ The lack of animal manure and the extending of farming to poorer lands led the Alentejo farmers to start using chemical fertilisers, something that would not have changed the productivity of the soil in average terms, as the 'benefits of the technological advances ... were eclipsed by the consequences of the enlargement of the cultivated area under unfavourable natural conditions' ${ }^{27}$

As in the aforementioned case, the protection policy for industry will have been largely influenced by pressure groups connected to the sector. It can also be said that the agreement between industrialists and the government was easier the greater the difficulties in substituting manufactured imports were, so the higher duties did not significantly reduce 
foreign imports and the exchequer did not lose an important source of its revenue. Taking into account the way custom barriers were created in Portugal in the period in question, the absence of positive effects in national production does not strike us as strange, particularly in the most protected sector, i.e. industry. The relationship between the growth of Portuguese industrial production and the fluctuation in customs protection levels seems paradoxical: in spite of the ad valorem duties having risen gradually between 1855 and 1897, industrial production's growth rate was considerably lower to that of the following period (1897-1913), as can be seen in Table 12.10.

As we have previously stated, the effects of duty variations on the economy have been studied with the concept of effective protection. This is the only way to take into account additional costs on industries compelled to buy foreign intermediate products, the inherent reason for the increase in the duty, which may or may not be superior to the benefits obtained from the greater protection granted to the final product. The same logic applies where the trend is to reduce the burden of duties. As occurred in the agriculture sector, industrial protectionism did not promote the expansion of the national manufacturing sector and it also seems to have been responsible for the creation of an industrial structure that was disconnected from the potential of the Portuguese secondary sector. Industrial protectionism had a distorting character when it focused on sectors in which Portugal had fewer advantages in competing with other countries, a phenomenon that arose from the need to levy imported manufactured goods that would be substituted with difficulty by national production. If we compare the advantages of national production in relation to levels of protection enjoyed by foreign competition, we will be able to see to what extent customs policy interfered in a negative way with the structure of our economy in the second half of the century.

As it depends on other complementary production factors (such as capital, technology, raw materials or a productive organisation), the added value per worker may be taken as being representative of industrial productivity. ${ }^{28}$ That is why we have chosen the ratio between the added value per industrial worker in Portugal and the United Kingdom to indicate the comparative advantages of our national industry. In order to

Table 12.10 Growth index of industrial output (annual average, \%)

\begin{tabular}{ll}
\hline $1855-73$ & $2.2-3.0$ \\
$1873-97$ & $2.0-2.4$ \\
$1897-1912$ & $2.8-3.3$ \\
$1855-1912$ & $2.3-2.8$
\end{tabular}

Sources: Reis (1986) and Lains (1990).

Note

The years refer to the middle of the tri-annual averages. 
validate this comparison, we must take these values in a free-trade regime, as is the case for our main supplier of foreign manufactures, as there were no duties for the sectors that we take into consideration here. As far as Portugal is concerned, we have adjusted the values derived by Jaime Reis ${ }^{29}$ in order to calculate the duties charged, both to intermediate and to final products.

As we can see in Table 12.11, the industrial sectors with greater nominal protection ${ }^{30}$ were not those where comparative advantages were greater. The case of timber and cotton products, which had very significant protection, in spite of the average Portuguese worker producing the equivalent of 15 per cent to 25 per cent of her British counterpart, is a good example.

In order for the protectionist system to contribute to sustained growth of the industrial sector, it is essential that it focuses on industries where national production has fewer problems in competing with imports in the short term. As industrial growth in a protectionist regime is obviously limited by the extension of the national market, such a rule in small countries, such as Portugal, is quite relevant.

Indeed, once the domestic capacity to exhaust production is over, the expansion of sales of industrial products will depend on the ability to place them at competitive prices in foreign markets. The protectionism that lasted during the period under study led to the channelling of resources to areas of industrial production in which the national economy did not have any clear advantages over the main foreign competitors. Thus, once the domestic market had been drained for normal cotton fabrics at the end of the nineteenth century, ${ }^{31}$ this industry entered a

Table 12.11 Protectionism and comparative advantages (\%)

\begin{tabular}{lll}
\hline Industrial sector & VAE (Portugal): VAE (UK) (c. 1900) & Added value duties (1894-7) \\
\hline Wool & 15 & 81.5 \\
Paper & 18 & 29.7 \\
Cotton & 25 & 48.4 \\
Animal skins & 32 & 24.3 \\
Glass & 33 & 43.8 \\
Metals & 49 & 38.8 \\
Ceramics & 50 & 37.8 \\
Chemicals & 57 & 14.6 \\
\hline
\end{tabular}

Sources: Reis (1986: 81) and Estatísticas do Comércio Externo. To translate values for a protectionist regime into those for a free market, we have assumed that, in Portugal, there was an average 25 per cent input duty for cotton manufacture, and a 10 per cent input duty for all other goods (see Table 12.5). No adjustments were necessary for the United Kingdom figures (see text).

Note

VAE $=$ Value added per employee in Portugal and the United Kingdom in a free-market situation. 
period of crisis due to a lack of fresh channels for its products. Still, in this sector we can notice a lack of coherence in the fact that thread had an effective protection greater than woven cloth, in spite of being an activity in which bigger countries had far greater advantages. And it is equally curious to notice that, when the industrialists connected to woven cloth managed to temporarily obtain the desired protectionism in 1892, it served to replace some manual labour with machines, without preventing the crisis of the following decade, and at the same time reducing employment and possibly increasing consumer prices. ${ }^{32}$ A more in-depth study of national industry (something this chapter does not claim to be) would certainly show other examples of protected industries that had no viability, as they lacked the capability to compete with overseas ones. But since we lack such accessible references, we can reach similar conclusions by comparing the industrial specialisation in Portugal with that of the smaller nations of north-western Europe.

Some authors have considered the development of specific industries that filled niches left by mass production industries and/or the coal and iron industries that existed in the great economic powers, such as the United Kingdom and Germany, ${ }^{33}$ as a major factor of the industrial success attained by Scandinavian countries, as well as Holland and Switzerland. Instead of trying to compete with the industrial sectors where the large countries had advantages, due to resource availability and their huge internal markets, these small economies opted to focus their efforts on industrial sectors in which the large nations were less competitive. For example, the Belgian and Swiss textile industries specialised in the production of some semi-manufactured articles (such as linen and silk thread and carded wool), which favourably competed with the powerful British and French industries that produced fabrics using mechanical massproduction methods. In Holland and Denmark, the niche industries that prospered were connected to the processing of national or imported foodstuffs, as well as steel and textile threads from imported raw materials. ${ }^{34}$ In these cases, it was essential to compete with areas of industry with a need to use skilled labour in order to fight against the advantages of mass and mechanised production. The most progressive industries of these small north-western European countries were also closely related to the type of available resources: in Sweden, one of the most important industries that contributed the most for its industrial growth was timber, which was obviously based on this country's vast forestry resources.

In Portugal, industrial specialisation was substantially different, thanks to the protectionist system that we have been studying here, which led to an excessive concentration of resources in industries that were about to become suffocated by competition from foreign industries. These were based on advantages the Portuguese economy could not provide: vast markets, an abundance of correctly channelled capital, technical and scientific knowledge, etc. It is obvious that we cannot over-compare the 
Portuguese case with the other small European economies that managed to achieve success in the last quarter of the nineteenth century, as they had clear advantages to a country on the periphery of Europe and that had quite different conditions in the areas of environment, culture, exchange of ideas, experiences, goods and capital.

We will conclude this section with some thoughts on the probable causes for the general immobility that characterised the Portuguese customs system during the period under study here. The concession of a fiscal benefit (for example, a custom tariff) to a certain economic activity worked as a revenue, from the point of view that it allowed profits over the average made in the economy at that time to be gained. If that privilege lasts for a considerable period of time, so as to allow other industries to establish themselves within the protected sector, this revenue will start being capitalised, in the sense that it is considered in decisions relating to new investments within the protected activity. Thus, a certain influx of capital to the protected sector occurs, so that profits tend to decrease. If the entry of capital is limited, for example due to legal reasons, it will be likely that investors are willing to pay additional costs in order to enter the sector in question, as they will compensated by an above-average profit that will then be effectively reduced. In conclusion, in the medium term (i.e. a sufficient period of time to have new investments), the protected sectors will tend to have profits similar to those of the non-protected sectors. Therefore it makes no sense to maintain a protectionist system over a long period of time, as it will cease to have practical effects after a certain period.

However, the fiscal reform of a protectionist system - that existed in Portugal from 1837, with only a short break in the first few years of the 1850 s - is not desired by the economic agents involved in the protected sectors. This tends to happen not because the benefiting industrialists or farmers would receive higher real profits, but because the ending of privileges would imply transition costs corresponding to the loss of the extra capital initially invested to cushion the protected sector. Only a strong central power can impose reform of a system based on the concession of privileges. Otherwise, it is difficult to compensate the sectors that have to pay transition costs. In Portugal, the political authorities did not appear to have the ability to adopt such a stance, even if it were in their interest.

\section{Conclusion}

In 1837, with the publication of the new customs code, the government of Passos Manuel concluded customs revisions that had been started by the chartists two years before. Since then, the national customs had never ceased to charge high tariffs for principal imported goods, whether foodstuffs or manufactured articles. The change in average duties was not regular throughout subsequent years up to the First World War, with 
rising and falling periods proportionate to the value of the goods being imported. As we have seen from the index based upon the theoretical value of the duties, these never deviated from levels practised during the extremely protectionist period immediately after 1837 .

According to political historians, the regeneration of 1852 introduced a free-trade debate at a governmental level, which would only be explicitly contested forty years later in the aftermath of one of the most serious economic crises of our recent history. With the exception of rare cases, Portuguese customs policy has always been predominantly based on this kind of discourse (which a detailed analysis has proven to be in theory only), leading to one of the great misunderstandings of Portugal's economic history in the second half of the nineteenth century, namely the existence of a free-trade regime between 1852 and 1892, a year considered to be one of change towards a protectionist regime. We hope this chapter can contribute in some way towards the revision of such an approach and its subsequent implications.

One such implication, which is well known, is that Portuguese industrialisation would have been hampered by the inexistence of protection towards non-national competition. In our opinion, such a conclusion must be revised, as the case was certainly not one of an absence of protection, but a protection that was poorly targeted towards some industries with great problems in imposing themselves at international level, which is quite a different thing. Thus, the industrialisation of the Portuguese economy was carried out against its corporate advantages, which had, as a result, the inevitable successive increases in the levels of protection and a reduction in industry's growth capacity due to the smallness of the domestic market.

The only thing that remains to be explained is why the proper internal conditions for a complementary (to use Paul Bairoch's terminology in another sense) industrialisation were not created. The influence of social and political factors must be taken into account. Possibly the action of pressure groups combined with the financial necessities of the state were among the most pressing factors.

\section{Appendix 12.1 A note on the main Portuguese tariff laws}

$1837-$

Reorganised the levying of duties being generally applied by national customs. It substituted the ad valorem duties with specific duties, significantly increasing (by 100 per cent on average) their incidence. Number of specific articles: 1,499.

1841 (20 March) - $\quad$ Little difference from the previous rules.

1852 (31 December) - Presented considerable changes, namely in the reduction of the number of customs categories (from twenty-five to nineteen) and the specific articles (947). 
1856 (22 December) - Practically the same regime as the previous one, reducing further the number of articles to 927.

1860 (23 August) - $\quad$ Comprised changes decreed up to the date of its publication.

1861 (18 December) - Made changes to make its consultation easier.

1871 (25 January) - Addressed changes carried out since the previous law and included the conventional regulations of commercial treaties signed with France and Italy. After many simplifications the number of customs articles is now 801. It was reissued in 1875 .

1882 (6 July) - $\quad$ Includes a conventional regulation that resulted from the treaty signed with France in 1881 and which was widened to the most important commercial partners, to which Portugal grants the status of 'favoured nation'. It presents advantages concerning ease of consultation and its preliminary instructions 'are like the codification of all the customs laws'.

1882 (14 December) - Differed little from the previous one.

1885 (17 September) - Differed little from the previous one.

1887 (22 September) - Differed little from the previous one.

1892 (10 May) - $\quad$ Introduced considerable changes to tariffs. It was reissued on 17 June of the same year with its own preliminary instructions, and subsequently in 1907.

Source: Correia (1913: 78-80)

\section{Notes}

1 Translation of ' $O$ proteccionismo em Portugal 1836-1913: Um caso mal sucedido de industrialização concorrencial', Analise Social, 22 (1986), pp. 381-419.

2 Instituto de Ciências Sociais, University of Lisbon.

3 The principal studies on the Portuguese customs and excise system are still those of Halpern Pereira (1983) and Sandro Sideri (1978). These works are responsible for the spread of this viewpoint in recent times. For a different interpretation, see Jaime Reis (1984: 12-13) and David Justino (1988-9, vol. 2: 204 and following). In relation to customs policy in the middle of the last century, see also Fátima Bonifacio (1984: 467-88).

4 See, in relation to the cases of British and Spanish foreign trade, Imlah (1958: 95-6) and Prados (1982: 160).

5 See Figure 12.2 above.

6 For a similar perspective, consult the aforementioned work by David Justino and Jaime Reis.

7 The years in Tables 12.1, 12.4 and 12.7 were selected taking account of the main changes to the tariffs (see Appendix 12.1).

8 The comparison of the incidence of the duties of these two regulations, together with the regulation of 1837 , in relation to the previous situation, is 
one of the objects of Fátima Bonifácio's research, which she is presently undertaking and to whom I am indebted for this information.

9 Cited in Work Report (1879: 125).

10 For the index of the prices of the imports, see Lains (1986).

11 Bairoch (1976a: 48 and 53).

12 See excerpts from this author's writings published by Scheidl and Roque (1985: 128-35).

13 That is, Sweden (with laws dating from 1861), Italy (1890), Holland (1892) and the Austro-Hungarian Empire (1896). In France, income tax was introduced between 1914 and 1917 and in Portugal between 1922 and 1929.

14 See, for example, Greenaway (1982: 122-4).

15 The duties on cereals had a predominantly fiscal aim, as shall be shown later. As far as tobacco and sugar are concerned, their substitution by home-grown production was forbidden by legal mechanisms in order to not endanger fiscal revenue. During the tobacco-free trading period, its revenue was charged at customs (1865-88) and its cultivation was forbidden (with the exception of certain areas in the Douro region from 1866 on an experimental basis). In order to guarantee revenue from sugar, the state prohibited the building of factories for production of beet sugar nationwide. See Ezequiel de Campos (1913: 410-25) and Esteves dos Santos (1974: 199-203) in relation to these two cases. In order to evaluate the economic effects of the customs regime, one must bear in mind the influence of those laws that could have slowed the spread of tobacco and sugar beet crops, which Portugal was particularly suited to (a fact proved by present above-average European production levels). As occurred in other European countries, these crops might have brought considerable benefits to the national farming sector, as they have a high degree of profitability and guaranteed markets, sugar beet being a soil fertiliser.

16 See Appendix 12.1.

17 Anonymous (1879: 22).

18 For a different approach to this problem, see Halpern Perreira (1978: 16-17).

19 According to Baack and Ray (1983: 77, 83 and 86), the level of industrial protection in America was determined by the position of the products in the market (consumer goods versus raw materials, for example) and by the dynamics of industrial growth, factors that, according to them, are associated with the capacity of pressurising the authorities.

20 As far as workers were concerned, management found it easier to obtain favourable responses from governments. Filomena Mónica (1986: 210), referring to the negotiations for the 1892 regulations, drew the following conclusion: 'The [industrial] workers ... told the state many times they did not understand the reason it gave them for not being able to intervene in the case of the regulations on the introduction of machinery or apprentice numbers, and yet, it did so with ease when similar anti-liberal requests [e.g. regulation policy] were made by their bosses.'

21 Anselmo de Andrade (1902: 486) (our italics).

22 See Jaime Reis (1979: 747-8).

23 Jaime Reis (1979: 769-71).

24 The problems raised by the dispersion of these sectors were only solved with the cooperative movement of the 1940s and 1950s. In relation to the political power of the Alentejo producers, see Jaime Reis (1979: 762-3).

25 Martins Casaca (1987: 351).

26 Vaz Pinto (1938: 12-16).

27 Jaime Reis (1978: 785).

28 O'Brien and Keyder (1978: 84).

29 Jaime Reis (1986). 


\section{Pedro Lains}

30 For a more rigorous analysis one would have to consider the rates of effective protection in different sectors. However, the conclusions we reach depend not on the level of these rates, but on the position of each of the industries in relation to the protection they benefited from. This relative position tends to be independent from the concept of protection that was used.

31 Including the saturation of the colonial markets that took place at the same time.

32 As far this topic is concerned, see Filomena Mónica (1986, chapter 4).

33 See, Saul (1982).

34 Saul (1982). 


\title{
13 Spanish protectionism during the Restauración, 1875-1930 ${ }^{1}$
}

\author{
Antonio Tena Junguito
}

\section{Introduction}

Although few Spanish economic historians make it explicit, most of them seem to take for granted the importance of protectionism for Spain's economic growth in the last quarter of the nineteenth century and the first third of the twentieth century. Broadly speaking, it can be argued that most of the literature favours a positive assessment of the incidence of protectionism on economic growth, although this is expressed with several nuances. On the one hand, and coinciding with Flores de Lemus, most are critical of excessive protectionist measures that the rhetoric proposition of 'integral protection' would imply. But, on the other hand, they suggest that a more free-trade alternative was too risky. In their opinion, the lack of development of the Spanish economy implied serious difficulties for initiating specialisation processes, and, consequently, both factors and resources could disappear if they were forced to face international competition (instead of moving to other productive sectors with comparative advantage)..$^{2}$

That is, most authors hide behind the inevitability of the protectionist option, either for political reasons, ${ }^{3}$ or instead for economic ones. ${ }^{4}$ In other words: the belief that an alternative and milder form of protectionism would have been politically unfeasible and negative as a whole in economic terms. ${ }^{5}$ Only during these last few years have some authors emphasised the possibility that, in the absence of such a high level of protection, the Spanish economy may have reacted similarly to other countries in that period, thus precipitating some of the transformations that were eventually undertaken in the second half of the twentieth century. ${ }^{6}$

Protectionism achieved a central role in the political debate of the second half of the nineteenth century and, in consequence, in the recent historiographic debate. The study of the protectionist law-making process, the instruments used and the objectives followed has concentrated a great deal of research efforts in recent years. ${ }^{7}$ Despite the fact that these studies have provided an in-depth analysis and have enriched the vision of this period, they have left aside some of the essential questions on the role 
played by commercial policy in Spanish economic growth in the last quarter of the nineteenth century and the first quarter of the twentieth. Thus, it seems necessary to refocus on a few simple but essential questions:

1 Did Spain have a high or a low protection in the last quarter of the nineteenth century and first third of the twentieth? That is, was the evolution of protection in Spain fundamentally different to other countries with similar welfare levels?

2 What were the main causes that explain the Spanish protection on some sectors at the expense of others?

3 Did these differing levels of protection have important consequences for Spanish economic growth, and, if so, were they positive or negative?

This study is part of a broader research project whose ambition is to give an answer to these questions, albeit that it may be a provisional one, by simultaneously studying the Spanish and Italian cases. ${ }^{8}$ It represents an attempt to face the issue of measuring Spanish protectionism in the long term, with the purpose of providing a more rigorous answer to the first question raised above. Difficulties in measuring protection have extended the traditional methodology for studying tariff laws, the protectionist debate and its results. This study, although necessary, is not enough, since it may introduce an incorrect vision of the protection that was really implemented: changes in tariff laws raising specific tariffs can, paradoxically, represent a reduction in the nominal protection, given certain conditions in other variables. The first necessary step in the study and analysis of protectionism is inevitably measuring nominal ad valorem protection, for particular products as well as at the aggregate level, with the objective of portraying a comparative perspective of the Spanish experience, as well as the study of its effects over the economy. ${ }^{9}$

The main technical discussion of this chapter is dedicated to the analysis of a new series of indicators to measure Spanish protectionism in the period between 1870 and 1930. These indicators do not, by themselves, comprehend the broad topic of protectionism and economic growth, but establish a solid base to deepen our knowledge on the level, the changes and the nature of the Spanish protectionist profile.

These indicators are presented in the first section, along with other qualitative assessments that appear in the literature. The intention here is to openly discuss the contradictions of our current knowledge of the evolution of protectionism in Spain. Recent conventional methods for measuring protection in Spain offer a relatively moderate vision of the Spanish protection levels from the beginning of the Restauración, displaying a relatively flat profile during the following years. Agricultural interests would have led the years of return to protection in the 1890s and industry would have been eventually satisfied only with the 1906 tariff law, some years 
before the First World War. A new change in the level would come only with the Cambó Tariff in the 1920s. ${ }^{10}$

The second and third are, respectively, dedicated to putting forward alternative and more adequate indicators for measuring protection, as well as looking at the technical problems and the reliability of the tariff average measures for the Spanish case. The fourth section looks over the results of all these tests and confirms that the levels of protection in Spain were already relatively high at the beginning of the Restauracion, either compared with subsequent levels or with other countries. What is observed at a later stage is not a flat profile but, instead, one with an upward tendency, albeit cyclical in its evolution. The conclusions of this chapter discuss previous results and suggest a return to the traditional view on the causes of the new industrial protectionist turn of 1891 .

\section{What do we know about the evolution of protectionism in Spain?}

The economic indicator that is generally accepted as a good indicator of the long-term evolution of the protection level of a given economy is the tariff average. This index calculates the percentage of tariff revenue in relation to the value of imports (from now on, NT). Another option, more dubious but also very extensive because of the simplicity of its computation, involves estimating the evolution of imports as a percentage of the gross national product (GNP), assuming that increases and decreases in demand equally affect the numerator and the denominator of this indicator (from now on, OM). ${ }^{11}$ In general terms, both indicators should evolve with an inverse trend, that is, when the protection represented by NT increases, a contraction in imports greater than that of the GNP can be expected, which in turn implies a decrease in OM. Bearing in mind the fragility of this relationship, it is interesting to follow the evolution of trade policy changes through a systematic comparison of both indicators.

Figure 13.1 offers a stylised comparison of both indicators in logarithmic terms, confirming, to a large extent, the expected negative evolution.

The most outstanding feature of the 1849 tariff was the reduction in the list of prohibited imports and the replacement of ad valorem rights for specific ones, which, in the context of a moderate price increase tendency, seems to have helped to obtain a more moderate protection level in Spanish trade policy in the following years. ${ }^{12}$ In the decade of 1850 and the first half of the following decade, both indicators coincide in portraying a period of significant liberalisation in tariff protection. The second half of the 1860s and the first half of the $1870 \mathrm{~s}$ is a period of unstable maintenance of the previous achievements, despite the fact that the NT indicator decreases until 1872.

The beginning of the Restauracion, with the suspension of the Base Quinta $^{13}$ of July 1875, is depicted by both indicators, respectively, as an 


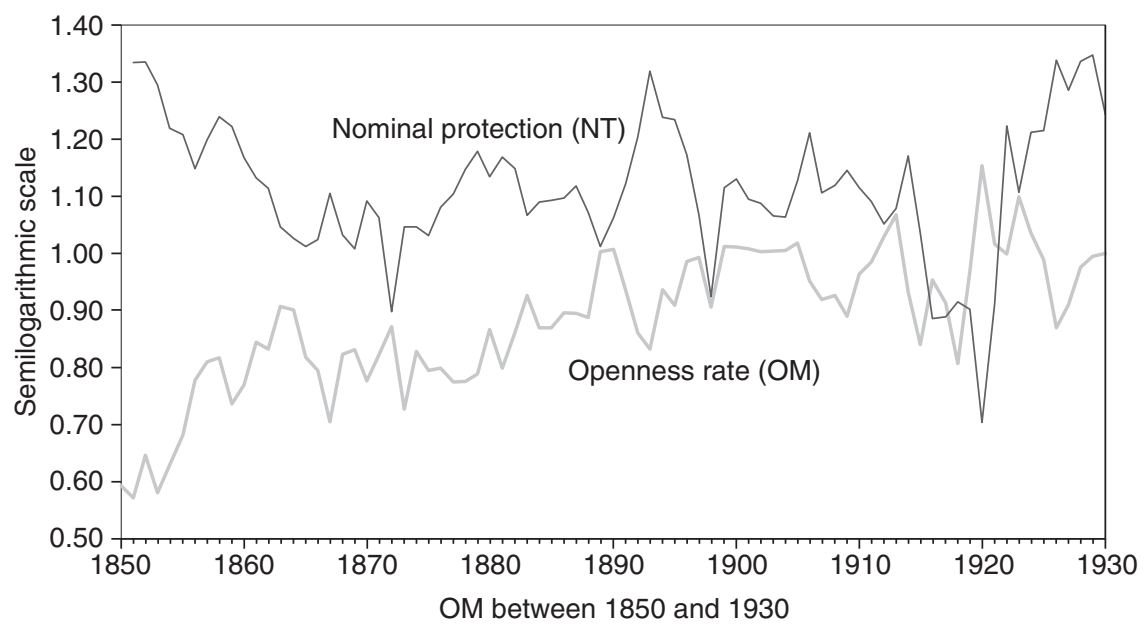

Figure 13.1 Changes in the nominal protection (NT) and the degree of openness of Spanish imports (sources: Tariff revenue, from Volúmenes Anuales Estadísticas del Comercio Exterior; Imports, from Tena, 1989; GNP from Prados, 1995).

increase in the level of protection through portraying a contraction in imports and an increase in NT. This tendency changes again at the beginning of the 1880s, with a smoothening of NT and a greater openness in imports. The impact of the 1891 tariff is clearly detected by the inverse behaviour of both indicators, although over a very brief period of time. Broadly speaking, one can observe less coherence in the expected behaviour of both indicators during the turn of the century, as well as a certain difficulty in evaluating the relative importance of the tariff laws of 1891 and 1906. The effect of the Cánovas Tariff of 1891 is significant, although it only lasts three years, whilst that of the Salvador Tariff of 1906 seems less relevant. Between 1923 and 1926, the indexes show an increase in the nominal protection accompanied by a significant contraction of imports. The impact of the Cambó Tariff of 1922 on both indexes lasts a little longer but is quite similar to that of the Cánova's Tariff of 1891.

A further necessary step to avoid blind alleys is to highlight the differences encountered in the series of tariff revenue and 'special trade' most commonly used in the historiography.

In Table 13.1, the common denominator of all series, excluding that of Tirado (1996), refers to import series constructed by Prados de la Escosura and Tena, and presented in Tena (1989). Thus, discrepancies in the results of the NT indicator have their origin in the different sources used to obtain the tariff revenue of the numerator. In the cases in which (state) budgetary sources have been used, such as in Comín (1993) or in Mitchell (1992), the results obtained show higher levels than in the cases in which 
Table 13.1 Commonly used indexes of nominal protection (NT) (tariff revenue/value of imports)

\begin{tabular}{llllll}
\hline & $\begin{array}{l}\text { NT }(a) \\
(\text { Comin })(\%)\end{array}$ & $\begin{array}{l}\text { NT }(b) \\
(\text { Mitchel })(\%)\end{array}$ & $\begin{array}{l}\text { NT }(c) \\
(\text { Tirado) }(\%)\end{array}$ & $\begin{array}{l}\text { NT }(d) \\
(\text { Esta. Comer })(\%)\end{array}$ & $\begin{array}{l}\text { NT }(e) \\
(\text { Tena })(\%)\end{array}$ \\
\hline 1877 & 16.5 & 16.3 & 14.0 & 12.7 & 12.7 \\
1889 & 14.9 & 14.7 & 11.3 & 10.3 & 11.0 \\
1897 & 10.6 & 10.2 & 11.0 & 11.7 & 14.6 \\
1913 & 16.3 & 15.9 & 13.4 & 12.0 & 14.9 \\
1926 & 26.3 & 25.4 & n.a. & 23.8 & 20.1 \\
\hline
\end{tabular}

Notes

(a) Comín (1985); (b) Mitchell (1992); (c) Tirado (1996); DAOMEPON series; (d) Estadísticas del Comercio Exterior; (e) Tena (2001): Tariff revenue data obtained from the database of this study, Apendix 13.1.

it was chosen to use tariff revenue data derived from Spanish trade statistics (Tirado's (c) estimation and (d) and (e), author's calculation). ${ }^{14}$ Within each group (budget-based sources or sources based on trade statistics), the levels and evolution are reasonably similar. However, in comparing both groups, the perception of the level and the evolution can be very different. The first two indicators in Table 13.1 show, generally, higher levels than the last two. This happens for every year except for 1897. This implies that, in the first two cases, the return to protectionism appears represented in the year 1877 (the year with the highest protection until 1926), whilst in the last two, it seems rather an incremental process beginning at the end of the 1880s.

In any case, whatever NT indicator we use to measure protection in Spain, the most relevant characteristic of this indicator is that it shows a much higher level and a different profile when compared with the arithmetic average of a large sample of European countries for which information is available.

As can be seen from Figure 13.2, the Spanish NT displays, in the first place, a much higher level, and, additionally, a profile which is more or less a concave curve, whose inflexion and lowest level are in the centre. This contrasts with the European NT, which is closer to a convex profile and whose climax is in the central years of the chosen period.

May it be said that the evolution of the global level of protection in Spain is markedly different to that of most European countries? It is difficult to answer this question without a study that evaluates and checks the accuracy of the NT indicator for Spain as well as for Europe. However, as a first approximation, if we suppose that the downward bias of the NT indicator is inversely proportional to its level, the higher Spanish level would imply a bigger difference in real terms in favour of Spain. In the Italian case, a recent study has confirmed the existence of a moderate profile of protection and an acceptable accuracy of the NT indicator. ${ }^{15}$ The 


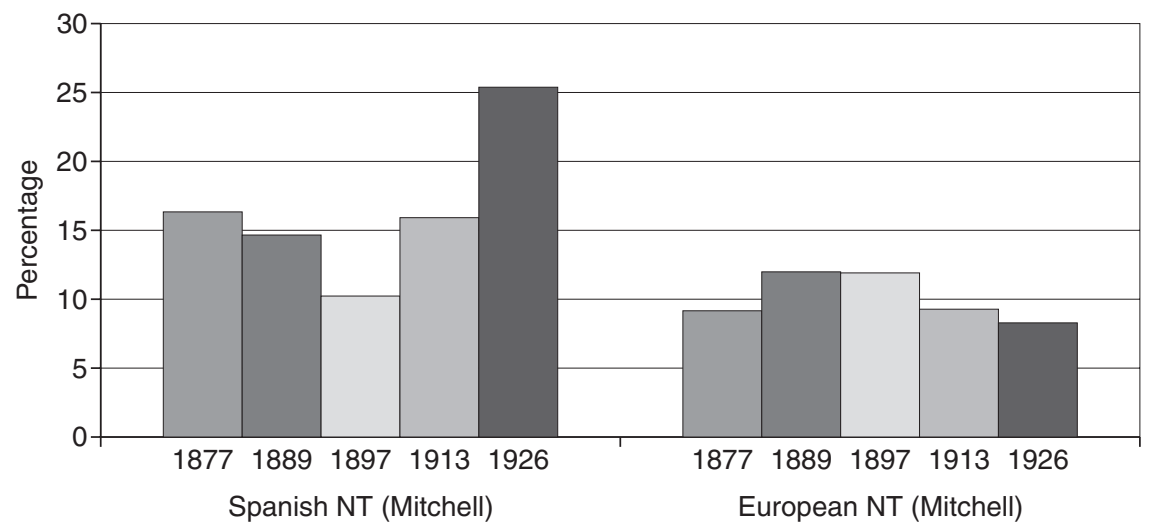

Figure 13.2 Level and profile of nominal protection in Spain and in Europe (sources: Spain, Table I; Europe, arithmetic average of the NT of Germany, Russia, UK, France, Austria-Hungary (Austria in 1926), Italy, Spain, Belgium, the Netherlands, Sweden, Switzerland, Denmark and Portugal (see Federico and Tena, 1998, Appendix Table 4).

intention of the following pages is to offer a rigorous study of the behaviour of the Spanish nominal protection, testing the accuracy of the average tariff index.

\section{How to measure protection}

From the mid-nineteenth century until the Great Depression of the 1930s, quotas and other non-tariff barriers were practically non-existent. Commercial policy was based exclusively on tariffs, and therefore, measuring the protection level of a particular economy is comparatively simple for those years. In principle, a tariff produces the effect of raising the tariffsetting country's internal price above the international price, in an amount equivalent to that of the tariff. ${ }^{16}$ The tariff can be expressed as a percentage of the international price (ad valorem tariff), or, as in Spain and in most continental European countries, as a fixed amount per unit of weight (specific tariff). In the latter case it is necessary, for comparative purposes, to compute it as

$$
T i=A i / P i
$$

where $A i$ is the specific tariff and $P i$ is the international price. ${ }^{17}$

In most empirical work, figures on specific tariffs are taken from tariff laws. This ex-ante measurement produces some mistakes because of the large variety of products imported under special regimes, such as preferential bilateral agreements or exemptions. For this reason, it is better to 
use the ad valorem percentages in ex-post terms, as a percentage of the tariff revenue and imports values for each product:

$$
P N i=\left(Q i^{*} A i\right) /\left(Q i^{*} P i\right)
$$

The main problem is how to aggregate the individual protection of each product in order to estimate the global protection of an economy. In principle, tariffs have to be weighed with the structure of the import demand that would have existed under free-trade conditions. This, unfortunately, is not an observable fact. Although some steps have been done in the right direction recently, economic theory has not yet provided a satisfactory alternative. We thus have to offer three alternative weighting methods:

1 To do without the weightings, i.e. no weightings at all - the simple tariff average across sectors - as suggested by League of Nations (1927) and Liepman (1938):

$$
U N T=\Sigma T_{i} / N
$$

where $T i=A i / P i$ and $N=$ number of products imported or taxed.

2 The actual structure of imports in the given year:

$$
\mathrm{NT}=\Sigma r t_{i}^{*} T_{i}
$$

where $r_{i}$ is the share of the $i$-th good in the total amount of imports ex-post of the introduction of the tariff. By definition, it can be calculated by dividing the total tariff revenue between the total imports.

$$
\mathrm{NT} t=\sum_{i=1}^{n}\left(Q_{i t}^{*} A_{i t}\right) / \sum_{i=1}^{n}\left(Q_{i t}{ }^{*} P_{i t}\right)
$$

3 The composition of trade (the structure of imports) of the country a year before the introduction of the tariff, as McCloskey suggested (1980):

$$
\mathrm{RNT} t=\Sigma r t_{i-1} * T_{i}
$$

where $r t_{i-1}$ is the share of the $i$-th product in total imports ex-ante the tariff introduction. Its calculation would be the following:

$$
\mathrm{RNT} t=\sum_{i=1}^{n}\left(Q i_{t-1} * A i_{t}\right) / \sum_{i=1}^{n}\left(Q i_{t-1} * P i_{t-1}\right)
$$

which is conceptually equivalent to a Laspèyres price index, exactly as NT can be assimilated to a Paasche price index. All these alternatives introduce some type of bias.

The UNT assumes that each imported product has an equal consumption share under free trade, which means that an implausible demand 


\section{2}

structure is assumed. The greater the disaggregation with which it is calculated, the smaller the scale of the bias in relation to a free-trade demand. The magnitude of the bias is (roughly) inversely proportional to the number of products included in the average (Tumlir-Till, 1971), which in turn depends on the lay-out of trade statistics. The NT generally causes a downward bias in the results, given that tariffs reduce the presence of the most protected products in relation to those least protected. In this sense, it can be said that the extent of the bias depends on the elasticity of imports in those groups of products that have a higher share of the demand for imports. ${ }^{18}$

If the elasticity and the quota of the product are significantly high enough, an increase in protection may imply a decrease in the NT indicator. Equally, a country imposing prohibitive tariffs on all products except one (and keeping it with a customs-free access) may appear less protectionist than a country imposing a uniform 5 per cent tariff on all its imports.

Lastly, RNT is possibly the most attractive of all the alternatives offered, if only it were possible to find a (not-too-distant) year with a closer free-trade import structure. In the Spanish case, finding a free-trade and a not-toodistant year must be, as of necessity, considered a very approximate task.

Therefore, it can be concluded that there is no clear and manageable way for measuring a country's protection. The indicator that measures the 'true protection' of an economy cannot be estimated. Therefore, given that there is no ideal solution as yet, the best way forward is to reach a compromise (as occurs in all problems concerning index numbers): given the bias introduced by each indicator, the goal must be to try to see if there is a reciprocal consistency in the joint interpretation of all the indicators.

The proposed indexes also offer the possibility of measuring the degree of incidence of tariffs, prices and changes in the demand structure on changes in the level of protection from one period to the next. Historiography ascribes tariffs a prominent role in most commercial policy changes, but this hypothesis has not been tested. The level of protection can also vary even if tariffs remain constant, either through changes in the composition of trade (as a result of the same commercial policy or other reasons), or, with specific tariffs, due to changes in the general price level or the relative prices of the different product groups that compose it.

Therefore, changes in the NT indicator from one period to another can be expressed as follows:

$$
\left[\mathrm{NT}_{t}-\mathrm{NT}_{t-1}\right]=\left[\mathrm{NT}_{t}-\mathrm{RNP}_{t}\right]+\left[\mathrm{RNP}_{t}-\mathrm{RNT}_{t}\right]+\left[\mathrm{RNT}_{t}-\mathrm{NT}_{t-1}\right]
$$

where NT is defined as in (13.4b), RNT as in (13.6) and RNP as:

$$
\operatorname{RNP} t=\sum_{i=1}^{n}\left(Q i_{t-1} * A i_{t}\right) / \sum_{i=1}^{n}\left(Q i_{t-1} * P i_{t}\right)
$$


Each component of the right-hand side of the equation measures, ceteris paribus, changes in the aggregate protection. The first square brackets (the quantity effect) measure the effect of changes in the composition of imports on the variation of the NT indicator between two consecutive periods (maintaining prices and tariffs constant). The second square brackets - the price effect - measure the influence of prices on variations of NT (maintaining quantities and tariffs constant). Lastly, the third square brackets - the tariff effect - measure the influence of tariff changes on variations of NT (maintaining quantities and prices constant, or, in other words, maintaining the same structure of imports as in the initial period), that is, an approximation to the originally forecasted effect of the trade policy. ${ }^{19}$

\section{Levels, changes and the singularity of protection during the Restauración period}

The years chosen to make this estimation for the Spanish case are 1877, 1889, 1897, 1913 and 1926. They have been selected on two counts. First, in order to minimise the number of years with the condition of being situated before and after the tariff laws of 1882, 1891, 1906 and 1922. Second, so as to work with data from years where the overvaluation and undervaluation of the figures of Spanish statistics would bias as little as possible the estimation of the level of nominal protection. ${ }^{20}$

From official trade statistics in the chosen years, a detailed correspondence between the Spanish tariff classification of products and the second revision of the Standard International Trade Classification of the United Nations (SITC) has been carried out for levels of four and five digits. ${ }^{21}$ The (Spanish) annual volumes of trade before 1933 present two different denominations or categories: 'general trade' (comercio general) and 'special trade'(comercio especial). The first includes all imports for domestic consumption (direct or through free ports). The second also includes products for domestic consumption, but only for those categories with customs-free access or through a special tariff regime. In principle, the sum of these two categories adjusts itself very well to the modern definition of 'special trade', and this is the initial sample that has been used. ${ }^{22}$

Some products have been left out, either due to technical reasons (the type of units in which they were expressed or a lack of correspondence with SITC numbers, for example), or due to economic reasons (for example, gold items and products imported for monopolistic consumption by the state). As a result, a sample has been obtained which includes between 80 per cent and 95 per cent of the total amount of imported products registered by trade statistics as total imports, and almost every import product dedicated to consumption (with the exclusion of the aforementioned group of products due to technical reasons).

The results of this study are represented in a matrix with 750 rows, 


\section{4}

corresponding to the same number of SITC four-digit groups. Along with the SITC number and the product name, the following information is displayed for each of the five years: the number of the tariff classification, the value and quantity imported, the tariff revenue obtained for each product and the value of the specific tariff that legally corresponds for each year. ${ }^{23}$ The prices for each SITC $(P i j)$ have been computed dividing their value by their quantity $(Q i j)$. Likewise, with the tariff revenue and the imported quantity, it has been possible to calculate the tariffs really applied to each SITC number $(A i j)$.

The SITC numbers previously mentioned have been grouped in accordance with the GATT $(1985 / 6)$ classification. This has been done to aid understanding and to offer a clearer economic interpretation of the estimated protection levels for the different indicators. In this way, it is possible to carry out a more rigorous study, using well-defined categories with economic sense, grouping the products of the SITC classification into the following categories: (1) primary products, (2) semi-manufactured goods and (3) industrial manufactures (as well as their subsequent subdivisions). The disaggregated results according to the GATT classification of the estimations of the NT, UNT and RNT indicators are offered in Table 13.A1 of the Appendix.

The global levels of protection of these three indicators are summarised in Table 13.2. The first aspect that needs to be pointed out is the coincidence between the expected biases for each indicator and the results obtained in the estimation of the different indicators. The UNT indicator (tariff level without weightings) shows the highest relative values for the given years, as usually occurs with this type of indicator. ${ }^{24}$ The NT indicator (representing the weightings of the value of present imports, $e x-$ post) has the lowest values. The RNT indicator (that weights the tariff with the amounts of the year before its introduction, ex-ante) displays mostly intermediate values. Broadly speaking, independently from the differences in the level, the three indicators offer a similar description of the evolution and the changes of nominal protection of the Spanish economy.

Table 13.2 clearly shows that the average profile of the three indicators

Table 13.2 Total levels of nominal protection in Spain according to different indicators

\begin{tabular}{lllllll}
\hline & $N T(1)$ & $U N T(2)$ & $R N T(3)$ & $\operatorname{PROM}(4)$ & $N T / U N T(5)$ & $N T / R N T(6)$ \\
\hline 1877 & 12.7 & 17.7 & n.a. & 15.2 & 0.72 & n.a. \\
1889 & 11.0 & 16.7 & 12.0 & 13.2 & 0.66 & 0.91 \\
1897 & 14.6 & 26.3 & 17.8 & 19.6 & 0.55 & 0.82 \\
1913 & 14.9 & 25.2 & 18.4 & 19.5 & 0.59 & 0.81 \\
1926 & 20.1 & 34.3 & 33.8 & 29.4 & 0.59 & 0.60 \\
\hline
\end{tabular}

Source: Appendix 13.1. 
confirms some features but contradicts others shown in Figure 13.1. The result for 1877 confirms the impression that when the Restauracion period began, the level of protection was already significant. ${ }^{25}$ It also confirms the low level of the year 1889, which highlights the moderate character of the General tariff law of 1882, modification of July 1883. and duty reductions produced by the eventual extension of the trade agreements during the 1880s.

The largest contradiction between the new indicators and those of Figure 13.1 can be seen for the year 1897. The NT for that year shows a moderate (but considerable) increase in relation with 1877 and 1889 levels of protection. Additionally, the rest of the indicators, and particularly the UNT, show that the NT indicator was particularly undervalued for that year. This gives coherence to the abrupt but temporary contraction that can be observed in Figure 13.1, which is the consequence of a decrease in imports of a significant group of products and their gradual replacement by other less protected products. The following years maintain a similar trend, although the NT is slightly less undervalued, meaning that protection in 1913 is maintained and a significant increase can only be observed for 1926 .

Table 13.2 suggests that, although the protectionist tendency between 1877 and 1926 was clearly increasing, the changes in the level of protection came about in a cyclical fashion, with periods of increase and periods of moderation. For the years chosen in this study, a period of moderation (1877-89) and a period of relative stability (1897-1913) can be perceived. Between both periods comes the 1891 tariff, which gave rise to a significant change in the level of protection. Something similar occurs with the 1922 tariff, which raised the level of protection between 1913 and 1926 in a similar way. In this sense it is worth keeping in mind that 1897 would be low, as a year representative of the given period, whilst 1926 is, on the contrary, a high year if we consider the annual series of the NT indicator (see Figure 13.1).

This study confirms the existence of a biased NT indicator, both regarding the level as well as the evolution of protection in Spain in the years 1877 through to 1926 . In this sense, it may be useful to compare the UNT indicator of protection (indicator without weightings) of Spain with that of another country, like Italy, for which we also have a similar estimation for those same years (see Figure 13.3). The new profile of this figure does not substantially change the comments about the singularity of the evolution of Spanish protection seen in Figure 13.2. However, it does provide some interesting additional information.

The profile of the Italian NT is similar to that of the European NT, unlike the Spanish case. The Spanish NT is higher than the Italian NT for every year, except for 1889, when Spanish protection was at its lowest and Italian at its highest level. The Spanish NT has a much higher starting point in 1877, and although it has a more cyclical profile, it has a growing 


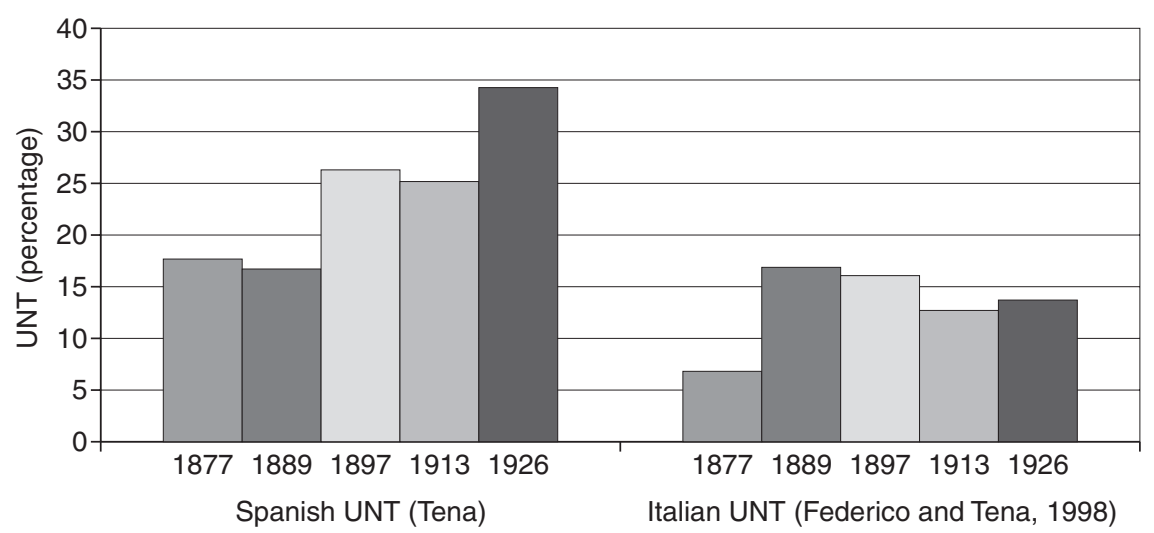

Figure 13.3 UNT indicator (Unweighted Nominal Protection levels) in Spain and Italy 1877-1926 (source: Spain, Appendix 13.1. Italy, see Federico and Tena (1998, Table A1, p. 93).

tendency until 1926. In Spain, years of slight decrease (1889 and 1913) are followed by strong increases (1897 and 1922). On the contrary, Italy, starting at a low level, undergoes a change of level in 1889 followed by some years of moderation (even during the interwar years - until 1926).

Although the comparative study with the Italian case deserves, and will soon crystallise in, a monographic work, it is worth remembering that the Italian NT (as can be expected from a moderate level of protection), in contrast to the Spanish one (with a high level of protection), does not seem to be affected by a significant downward bias in comparison to the UNT and RNT indicators. ${ }^{26}$ This reaffirms the statement that the observed bias in the NT indicator from 1897 onwards is not irrelevant, but is instead a consequence of the inability of the NT indicator to capture the important increase in protection produced from the 1890s onwards.

\section{The nature and the scope of protection in Spain}

As shown in the first section, historiography has been intensely discussing the agricultural or industrial nature of Spanish tariff policy. A first and necessary condition to see if there was a tariff strategy favouring industry would consist in being able to demonstrate that this sector was more protected than the primary sector. ${ }^{27}$

Table 13.3 clearly shows that, in relative terms, protection apparently possessed an industrial profile from the beginning of the Restauracion in the second half of the 1870s. The strong industrial character of 1877 is particularly relevant, as well as the fact that this profile decreases or increases accompanying reductions or expansions in the aggregate protection. In this way, coinciding with the reduction in the aggregate level of protection in 
Table 13.3 Relative levels of industrial and non-industrial nominal protection in Spain*

\begin{tabular}{|c|c|c|c|c|c|c|c|c|}
\hline & $N T$ & $U N T$ & $R N T$ & PROM & $N T$ & $U N T$ & $R N T$ & PROM \\
\hline & \multicolumn{4}{|c|}{ Industrial/non-industrial } & \multicolumn{4}{|c|}{$\begin{array}{l}\text { Industrial/non-industrial (excluding } \\
\text { colonies) }\end{array}$} \\
\hline 1877 & 135 & 125 & n.a. & 129 & 179 & 133 & n.a. & 156 \\
\hline 1889 & 123 & 104 & 70 & 99 & 116 & 106 & 62 & 95 \\
\hline 1897 & 95 & 131 & 133 & 120 & 87 & 136 & 117 & 113 \\
\hline 1913 & 91 & 79 & 34 & 68 & 118 & 93 & 49 & 87 \\
\hline 1926 & 112 & 114 & 116 & 114 & 154 & 130 & 139 & 141 \\
\hline
\end{tabular}

Source: Industrial, manufactures plus semi-manufactures; Non-industrial, primary products. See Appendix, Table 1. Colonial products eliminated from the listings of the sources of Table 13.5.

the years 1889 and 1913, a loss of sharpness in the industrial profile of protection can be observed. This sharpness recovers in the moments of greatest increase of aggregate protection, as in the years 1897 and 1926.

For a better understanding of the factors that determine the global level of protection and its changes, it is necessary to take a detailed look at these main influencing factors. Table 13.A1 of the Appendix shows the results obtained for NT, UNT, RNT and the arithmetic average of these indicators (X). These have been classified using the GATT's classification. The profile that the arithmetic average of the indicators (X) shows will now be analysed along with the more conventional result offered by the weighted indicator of nominal protection (NT). In this sense, the extent to which the NT indicator tends to reduce the importance of those products with higher tariffs will be captured by the difference between the NT and the other indicators. Table 13.A2 of the Appendix explains the changes in the level of the NT indicator between two periods from the perspective of the main variables that have an influence on it: import demand, price and tariff changes. Consequently, the sectorial results of this table will be used to explain the influence of the tariff on changes in the import demand. Table 13.A2 of the Appendix corroborates the extent to which the difference between NT and X (the average of the three indicators) can be held responsible for the capacity of the tariff to impede the entry to those products or groups of products where a heavier tariff was levied. ${ }^{28}$

\section{Primary products}

The NT indicator for primary products (which represent nearly 50 per cent of total imports during this period) reveals an increase in protection only slightly higher to that of the NT indicator for total imports. That is, a moderate protection in 1877 and 1889, a notable increase from 1897 
onwards, that is maintained stable in 1913 and followed by a moderate increase in 1926 (see Table 13.A1 of the Appendix). In contrast to total imports, the largest differences between protection indices would be 1913 and not 1897. The average of the indicators in the group of primary products shows a more moderate increment between 1889 and 1897 (29 per cent) than in the latter and 1913 (33 per cent). The increase in the protection of the primary products was even more moderate between 1913 and 1926 (27 per cent).

The main culprit of this profile is the most important component, foodstuffs, which represent from 20 per cent to 30 per cent of the total imports during the period. This group represents agricultural foodstuffs, that is, agricultural products not used as primary products by the industrial sector. The NT indicator shows a relatively high protection for foodstuffs in 1877 (16.8 per cent) and a substantial decrease for 1889 (12.8 per cent). Later on, 1897 shows an important increase (18.6 per cent) and 1913 a smaller one (20.6 per cent), before reaching the 1926 level of 28.1 per cent. The profile that shows the protection of foodstuffs is radically modified if, instead of the NT, the other indicators are used (just as happens for primary products). If the average of the three indicators is used, the protection of foodstuffs in 1897 (18.9 per cent), although slightly superior to that of 1889 (15.4 per cent), remains similar to that of 1877 (17.8 per cent). In contrast, the average in 1913 (34.2 per cent) entails an 80 per cent increase from the 1897 level. This level is maintained and consolidated in 1926 (37 per cent). This result suggests an undervaluation of the conventional NT indicator for agrarian products and highlights the importance of carrying out a more detailed and rigorous analysis in order to explain it.

The reasons that explain the imperceptible change in the foodstuffs group of the NT indicator for the years 1897 and 1913 can be partly clarified by Table 13.A2 of the Appendix. In this table, it can be seen that foodstuffs suffered a tariff increase of 22 per cent, and that the shift in the imported quantity ( -19.7 per cent) is mainly responsible for the NT indicator in these two years, displaying a variation of only 2 per cent. That is, the NT indicator of 1913 undervalues the highest tariffs by weighing them with the lower import levels, a problem which the other indicators avoid. This can be more closely observed if we pay attention to the relationship between the protection increase and the restriction on imports of significant foodstuffs in 1913, for example wheat flour, canned foodstuffs, milk, eggs, fish, lard, wine, liquor, and particularly foodstuffs such as chocolate, honey, glucose, sweets and those foodstuffs considered 'colonial' by the statistics (sugar, coffee, cocoa and spices). ${ }^{29}$

The nominal protection of wheat deserves special attention, since, given that it represented around 20 per cent of the total agricultural production in the first third of the twentieth century, it has monopolised the literature's views regarding the changes in agricultural protection during 
the period of study, and especially between 1891 and $1913 .^{30}$ The tariff regime for wheat and its flours was fluctuated greatly between 1892 and 1913. Therefore, our choice of annual data for measuring protection may bias the relative protection of the sector. The data from GHER (1980) shows that, if we look at the average customs duties for wheat for the periods in which the 1891 and 1906 tariffs were in force, the tariffs on wheat were greater from 1906 to 1913 than in the preceding period. ${ }^{31}$ Therefore, although the nominal individual protection for the years of this study has decreased from 43.7 per cent to 36.4 per cent, these results need to be qualified if we take into account the average changes in wheat protection during the period 1906-13.

The fact that the arithmetic average of the indicators presents an increase in the protection of foodstuffs between the years 1897 and 1913, in spite of the behaviour of the NT indicator, and at the same time that other indicators like the evolution of the protection of wheat confirm this result, backs the unorthodox hypothesis that the 1906 tariff favoured agricultural interests a lot more than the preceding tariffs. That is, the 1906 tariff reinforced agricultural protection, in contrast to the 1891 tariff, which raised it only slightly from its 1880 s level. This merely brought back the high protection levels already present in the 1870s. Such an increase in the tariffs of foodstuffs was doubtlessly conditioned by the strong increase suffered by the group of so-called 'colonial' products, apparently for 'fiscal' (revenue-seeking) reasons, from the 1899 Fernández Villaverde reform onwards. What has just been observed is that there was also a tariff increase in other agricultural products and that, as a consequence, imports contracted, an effect that the NT indicator does not capture. The controversy lies partly in the apparent 'fiscal nature' of most parts of the agricultural protection that has just been analysed. The protectionist and non-fiscal nature of the 1906 and 1911 tariffs will be further analysed in the next section.

Primary products (such as cork, leather, wool, cotton, and so on) and minerals offer, as expected, a moderate protectionist profile in all of these years. Fuels experience an important increase in protection from 1877 (9.3 per cent) to 1889 (44.9 per cent), a protection that rises again in 1897 (50.6 per cent) and that falls again in 1913 to 33 per cent before moving up to 45 per cent in 1926 (see Table 13.A1 of the Appendix). Coal and coke minerals saw their protection double between 1889 (5 per cent for both) and 1897 (11.4 per cent and 9.7 per cent, respectively). This protection increased again slightly in 1913 (13.5 per cent and 11.4 per cent) and in 1926 (14.7 per cent and 12.5 per cent), but the main items responsible for the high levels of 1889 and 1897 were crude and rectified mineral oils, rectified natural oils and vaseline, which, in 1889, 1897 and 1913 offer indicators that are, in many cases, above the 100 per cent mark in nominal protection, decreasing only in 1926 (33.6 per cent). The fiscal motivation behind these tariff increases in mineral and natural oils and its 
higher or lower protective effect are also a discussion topic in the next section. Non-ferrous metals obtain their lowest average protection level in 1889 (10.9 per cent), an important increase in 1897 (19 per cent), a slight reduction in 1913 and a return to a level of around 25 per cent in 1926.

\section{Semi-manufactures}

Within semi-manufactures, there are two groups of products with an important economic significance: the iron and steel industry and a large section of the chemical industry. The average indicator for the semimanufactures group had its lowest level in 1889 (10.7 per cent). Later on, a first important increase of nearly 50 per cent can be observed in 1897 (15.3 per cent). For 1913, the level is roughly maintained (14.5 per cent), followed by a strong increase of nearly 100 per cent in 1926 (30.9 per cent). The NT indices in 1897 and 1926 are undervalued in relation with the other indices and reduce the increment of protection showed by the average of the indicators.

Among its components, the category for iron and steel shows the highest average level of protection (and the most relevant increase as well). In 1877 and 1889, beginning from average levels of 20 per cent and 21.6 per cent, a first increase of over 50 per cent can be observed for 1897 (33.5 per cent). In 1913, the protection of iron and steel slightly decreases (27.1 per cent), a tendency which is broken with an increase of over 100 per cent in the result for 1926 (54.8 per cent). In this case, the NT indicator for iron and steel presents a higher profile than the average of the indicators in the years 1889 and 1913, and a lower profile than this average for 1897 and 1926. In the explanation of the increases of the NT indicator between 1889 and 1897, Table 13.A2 of the Appendix highlights again the contraction of the imported quantities $(-4.2$ per cent). This means that the NT indicator (as in previous occasions) tends to have a downward bias in the protection increases in iron and steel, as a consequence of the tariff laws of 1891 and particularly the law of September $1896 .^{32}$

Chemical products had a much more moderate protection, especially before 1926. The average of the indicators displays a moderate profile, starting at 9.5 per cent in 1877 , decreasing to 7.6 per cent in 1889 , increasing then to 9.6 per cent in 1897 and 11.5 per cent in 1913. Table 13.A2 of the Appendix captures a strong contractive effect of imports between 1913 and 1926, and a somewhat less important one between 1897 and 1913 . Likewise, the average of the indicators (11.5 per cent and 28 per cent) moves away from the conventional NT indicator $(6.7$ per cent and 10 per cent) in the respective years. This demonstrates that there was a strong contraction of imported quantities of heavily protected chemical products in 1926 as well as in 1913 (although to a lesser extent). 


\section{Finished manufactured goods}

Manufactures do not have such a stable profile as semi-manufactures between 1877 and 1913, although they end up in a similar level in 1926. They begin with a significantly higher level in 1877 (20 per cent), go through a strong decrease and a strong increase (14.8 per cent and 25.8 per cent in 1889 and 1897, respectively), and, in contrast with the stability displayed by semi-manufactures, in 1913 industrial manufactures show a significant reduction of the tariff average (15.8 per cent). While semi-manufactures have their highest tariff protection in 1926 (31 per cent), manufactures display a 32 per cent protection, only slightly higher than the 1897 level (25.8 per cent).

The most significant difference between the NT indicator and the rest of the indicators occurs precisely in 1897 (once again, the year that the average has the highest protection increase of the period). Table 13.A2 of the Appendix sheds light on the important contraction of the demand for imports that joins the significant protection increase between the years 1889 and 1897. Thus, both the contraction of the demand and the differential of NT with the average of the three alternative indicators point out the strong contraction in imports, as a consequence of a significant increase in industrial protection from 1889 to 1897 . On the contrary, from 1897 to 1913, Table 13.A2 of the Appendix shows a significant tariff decrease along with an increase in the price of manufactures, reinforcing a general decrease in the nominal protection levels of manufactures for 1913. As highlighted in Table 13.4, there seems to be little doubt that industrial products achieved less (relative and absolute) protection with the 1906 tariff than they achieved with the 1891 and 1926 tariffs, independently from the chosen indicator.

Among the industrial manufactures, group 3.1, 'capital goods', has the peculiarity of beginning with a lower protection (13.5 per cent in 1877) than the rest of manufactures, but nevertheless ending with a similar level (31.4 per cent in 1926). Between these two years, the level diminishes in 1889 (9.3 per cent), increases in 1897 (16.3 per cent), and is reduced again slightly in 1913 (13.9 per cent). Capital goods only have a strong increase in protection after the First World War. The category 'other capital goods' (including pieces and tools of iron, electrical material, steam engines and measuring machines) and the category 'specific industrial machinery' are the most important components of the group of imported capital goods and play the leading role in causing a certain contraction in the demand in 1913, thus maintaining a similar profile to their aggregate. ${ }^{33}$

Group 3.1, 'consumption goods', displays a different evolution to capital goods, starting off at a much higher level (21.9 per cent in 1877) and reaching a similar level (33 per cent in 1926). In the middle of the period, protection is reduced slightly (16.6 per cent in 1889) and then 
grows again (nearly doubling to 30.1 per cent in 1897). Table 13. A2 of the Appendix explains the cause of this strong increment of industrial consumer protection between 1889 and 1897, which is mainly due to a strong tariff increase. In 1897 the differential of the NT indicator with the rest of indicators is quite impressive and very is well explained in Appendix 132 through the significant demand contraction $(-8.3$ per cent). This crowding-out effect on the demand in 1897 can be clearly observed in the case of textiles, one of its principal components. With a tariff increase of 16.4 per cent and a demand contraction of 8.4 per cent, textiles are, along with 'other consumer goods', the most affected by the undervaluation of the NT indicator for the year 1897. The demand contraction seems generalised between 1889 and 1897, with textiles dropping from 13.2 per cent to 7.6 per cent of total Spanish imports. The average of the indicators shows how textiles, starting with a high level of protection (22.9 per cent in 1877, similarly to their aggregate), moderate this level in 1889 (17.3 per cent), reach their maximum in 1897 (32.9 per cent), later drop back down in 1913 (19.3 per cent) to finish off in 1926 with a similar, though slightly smaller, result than in 1897 (30.7 per cent). The 'clothing industry' shares with 'fabrics and threads' a high starting point in 1877 (22.6 per cent), but, as in the case of steel, chemistry and capital goods, reaches its maximum level at the end of the period, in 1926 (40.9 per cent).

To sum up: nominal protection levels in Spain at the end of the 1870s were relatively high, either compared with subsequent national levels or with other countries. This high starting point can be specially attributed to the prominent role of the protection of consumption manufactures before the Restauración. The decade of the 1880s brings about a decrease in protection due to the combined effects of the 1882 tariff, the extension of preferential agreements and the 1883 law. Later on, keeping in mind the high starting point of the 1870 s, it can be argued that nominal protection in Spain has it most important break-off after the 1891 tariff law was set. The magnitude of this tariff increase depends on the type of indicator used. Nevertheless, in relative terms, there is no doubt that the 1891 tariff represented a significant protection increase and that this increase was lead by the industrial manufactures. The 1906 tariff maintains the level of protection, in global terms; protection only increasing again significantly in 1926.

The stabilisation of protection in 1906 is the result of two opposite tendencies; on the one hand, the significant moderation in the protection of industrial manufactures. On the other, the equally important increase in the protection of agricultural products. The 1922 tariff maintains the protection obtained by the agricultural products and recovers the protection lost by industrial manufactures with the 1906 tariff. Thus, in relative terms, the 1891 and the 1922 tariffs gave the industry a higher nominal protection whilst, on the contrary, the 1906 tariff gave it to agricultural 
products (particularly foodstuffs). The design of the industrial protection implemented by the 1891 and 1922 tariff laws had some important differences: whilst the first one mainly protected traditional industries such as textiles and iron, the second was targeted particularly towards those manufacturing sectors that produce finished goods (clothing and other consumption manufactures) and to the new sectors (chemistry, capital goods and machinery).

The importance of the 'quantity, price and tariff effects' on the changes in nominal protection have been analysed from the data of Table 13.A2 of the Appendix. The price increase played a buffering role only in the period 1913-22, and this affected all sectors except capital goods. In contrast, in the period 1897-1913, the price effect worked in favour of the protection increase in manufactures and semi-manufactures. The tariff increases were the main causes of the upward tendency of protection in all the periods and in most sectors, with the exception of the 1877-89 period in which nominal protection was moderate. The other counter-vailing effect during 1897-1913 came from semi-manufactured imports in addition to the role played by other types of manufactures. In this period, an important decrease in tariffs occurred in both sectors (more markedly in consumption goods, machinery, and iron and steel), counteracted by the prominence of tariffs in the primary sector, or, more precisely, foodstuffs. The 'quantity effect' is negative for all periods and thus tends to moderate the final increase in the NT indicator. This negative effect reflects, on the one hand, the changes in preferences and in the prices of the products. On the other, it also reflects the effect produced by the tariff, shifting demand towards less-protected products. That is, it serves as an indicator of the accuracy, and extends undervaluation problems of, the NT indicator for certain sectors.

The greatest differences among alternative indicators have been found in the years where significant tariff increases have been accompanied with import contractions. This is particularly obvious for manufactures (particularly in consumption manufactures) in 1897, for primary products (especially in foodstuffs) in 1913, and for semi-manufactures (especially for chemical products) in 1926. In all these cases, the rest of the indicators corroborate an undervaluation of the NT indicator as a consequence of the import crowding-out effect from high to low dutiable imports. Therefore, as expected, the conventional NT indicator biases the results, in most cases moderating the increases of nominal protection regarding their theoretical projected values. In this sense, the availability of other indicators allows us to offer alternative and more reliable interpretations to those that have been regularly presented by the historiographic literature. 


\section{The fiscal and agricultural components of the 1906 tariff}

The literature agrees in underlining how, due to the loss of Cuba the group of 'colonial imports' (i.e. colonial foodstuffs) concentrated the interests of the reformers in view of acquiring new sources of revenue, as the tariff reform introduced by Fernández Villaverde in 1899 shows. $^{34}$ What follows is an analysis of the weight (and therefore, of the effects) of the so-called 'fiscal tariffs' in the changes of the composition of protection between the 1891 and the 1906 tariff laws.

The previous section highlighted the significant protection increase in favour of the agricultural sector in comparison with the industrial manufactures in 1913 (both in relative and absolute terms). First, therefore, it is necessary to assess to what extent this occurs as a consequence of tariff increments for 'colonial products'. Second, the complementarities between the fiscal reasons (which tend to increase tariffs in some products as a source of income) and the protectionist effects on the economy are to be discussed.

Table 13.4 summarises the strong protective increase that the so-called colonial products suffered between 1897 and 1913, as well as how their low elasticity of demand allowed an important improvement of the tariff revenue obtained by the group. Both the revenue and the tariff rate (measured by the NT) were multiplied by a factor of (nearly) ten, which means that the level of the imports of the group remained practically constant. The revenue of dutiable colonial products represented nearly onethird of the total revenue increase in $1913 .^{35}$

The previous section allowed us to check that the use of other indicators apart from the NT highlighted the existence of a strong swing in the protectionist policy between the Cánovas and Salvador tariffs, turning from manufactures to agricultural foodstuffs. Two small tests will now be carried out to evaluate the role of the supposed 'fiscal' intentions, to see their importance on the changes in the protection that occurred between 1897 and 1913. To do this, a simple hypothetical scenario will be

Table 13.4 Changes in protection and tariff revenue from 'colonial products'

\begin{tabular}{|c|c|c|c|c|}
\hline & $\begin{array}{l}\text { 'Colonial' } \\
\text { NT }(\%)\end{array}$ & $\begin{array}{l}\text { Total } \\
N T(\%)\end{array}$ & $\begin{array}{l}\text { Colonial products tariff } \\
\text { revenue (millions ptas) }\end{array}$ & $\begin{array}{l}\text { Total tariff revenue } \\
\text { (millions ptas) }\end{array}$ \\
\hline 1897 & 7.4 & 14.6 & 3.0 & 105.4 \\
\hline 1913 & 67.9 & 14.9 & 30.3 & 189.6 \\
\hline
\end{tabular}

Source: Estadisticas del Comercio Exterior.

Notes

Colonial group composed in 1897 by: foreign sugar, glucose, liquid caramel, colonial sugar, foreign cocoa, colonial cocoa, ground cocoa, foreign coffee, colonial coffee, ground coffee, Ceylan cinnamon, other cinnamons, cloves, nutmegs with and without, pepper, tea, vanilla. 
developed with the intention of testing what would have happened to the relative protection between the main sectors concerned if tariffs on this group of products (characterised as 'fiscal' by the literature) had been maintained equal between 1897 and 1913 - the contrafactual which cannot be applied to the foodstuffs sector.

The results presented in Table 13.5 clearly show that the so-called colonial products played an important role for explaining the abrupt change from a tariff structure visibly favourable to industrial products to one that strongly favoured agricultural products in the Spanish tariff policy. Section (a) shows what really happened (including colonial products) and therefore offers the same results already discussed in the previous section. Section (b) explains what would have happened in 1913 if the tariffs on colonial products had been maintained as in 1897 (assuming a constant demand as well). Section (c) simulates what would have happened with the relative protection indicators if colonial products had been absent on both years. The last two sections of this chapter reduce the (net) average level of protection in 1913, offering for foodstuffs a similar level of protection as in 1897.

If we assume that colonial products are mainly 'fiscal products', without protective effects, and that they should therefore be excluded from the calculation of the protection, the conclusions are as follows. First, it can be observed that the group of colonial products increases the total level of protection by three percentage points in 1913, whilst it would reduce it slightly in 1897. Second, the exclusion or the maintenance of tariff rates on colonial products allows us to observe that the (important) group of non-colonial foodstuffs at least maintained its level of protection between these two periods. If we add to this the significant loss of protection of the manufacturing sector between these years, there is no doubt that the 1906 tariff improved the relative position of the agricultural sector (in comparison with the manufacturing sector). The most significant fact that this test proves is that, whether we take the extreme assumption of excluding colonial products or not, the decrease in the protection level of manufactures appears to be the most relevant factor when it comes to explaining the relative improvement of the protection of the agricultural sector between 1897 and 1913 .

Although the literature has focused on the colonial products, the characterisation of the so-called revenue-generating products (on which tariffs are levied with the aim of increasing revenue and not for protecting any products) is a wider matter. The problem lies in the fact that any product of general consumption with a high tariff and a low and elastic demand may be considered a fiscal product (as occurred with wheat in 1906). ${ }^{36}$ In addition, both groups of products have direct or indirect effects on welfare. The inclusion or non-inclusion of exotic products in the total tariff average is part of a recent debate. ${ }^{37}$ The existence of some domestically produced substitutes of colonial products allows us to suggest that some exotic imported products are more fiscal than others. This is quite 


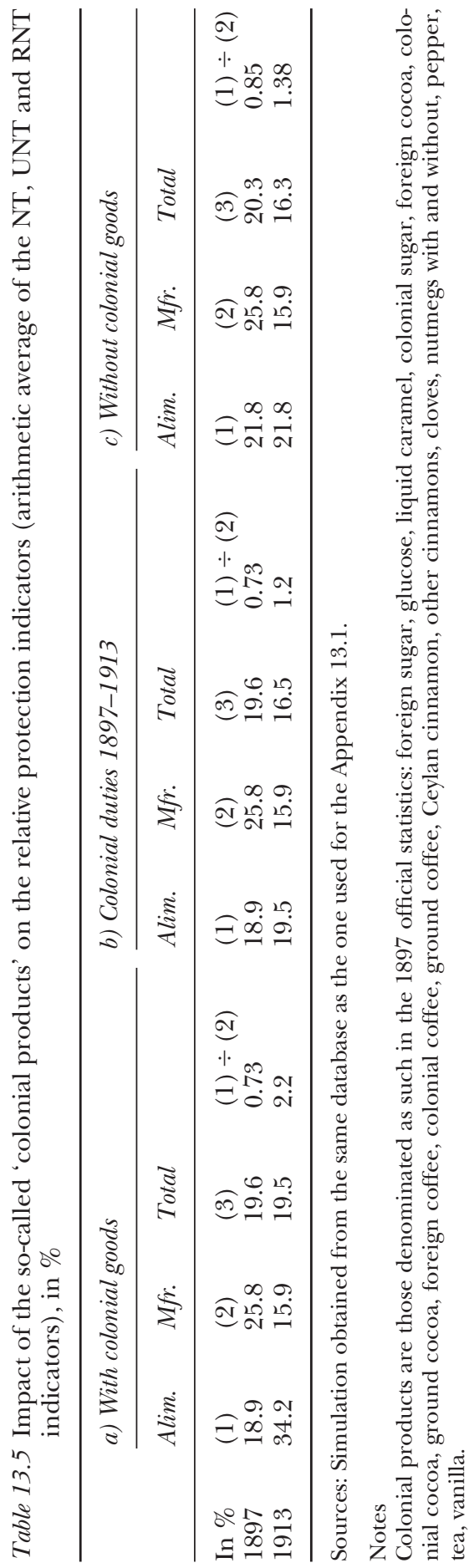


Table 13.6 Impact of the exclusion of a group of 'fiscal products' on the relative protection indicators (arithmetic average of the NT, UNT and RNT indicators)

\begin{tabular}{llllllllll}
\hline & \multicolumn{3}{c}{ a) Fiscal goods included } & & & \multicolumn{3}{c}{ b) Fiscal goods excluded } \\
\cline { 2 - 3 } & Food & Mfr. & Total & & & Food & Mfr. & Total & \\
\hline & $(1)$ & $(2)$ & $(3)$ & $(1) \div(2)$ & & $(1)$ & $(2)$ & $(3)$ & $(1) \div(2)$ \\
1897 & 18.9 & 25.8 & 19.6 & 0.73 & & 21.1 & 25.8 & 19.1 & 0.82 \\
1913 & 34.2 & 15.9 & 19.5 & 2.2 & & 30.7 & 15.9 & 17.5 & 1.9 \\
\hline
\end{tabular}

Source: Simulation based on the same database used in Table 13.3.

an arbitrary decision, but is based on an intuitive economic criterion, rather than on an administrative one. ${ }^{38}$

This last exercise confirms, on general terms, the reflections that arose from the exclusion of colonial products in Table 13.6. With the excluded fiscal products, some agricultural products with high tariffs but without domestic production are maintained. Obviously, this implies that agricultural protection in 1913 was even more important than in Table 13.5. Consequently, Table 13.6 confirms that, between 1897 and 1913, an increase in the nominal agricultural protection existed not only for the group of agricultural consumption products, but also for the selected group of imported agricultural products (without domestic production). Hence, this second test supports the hypothesis of the existence of a change in favour of agriculture in relation to the previous period, in absolute terms and in relation to industry.

\section{Conclusions}

The evidence presented in the previous sections partly contradicts some of the firmly held opinions of the recent literature over the profile and evolution of tariff protection in Spain during the Restauración period. This study is the first to offer a global vision of the evolution of nominal protection using a new group of alternative indicators, both at an aggregate and inter-sectorial level. The new indices show that:

1 The conventional tariff average, weighted by imports, produces a downward bias on Spain's general nominal protection profile during the Restauración period.

2 This bias particularly affects manufactures, as may be reasonably expected, because of their higher demand elasticity.

3 The downward bias is bigger for the periods after the main tariff laws that increased the protection of manufactures, as shown by the results for 1897 and 1926, years which respectively follow the 1891 and 1922 tariff reforms by Cánovas del Castillo and Cambó. ${ }^{39}$ 
4 The tariff law of 1906 moderates the protection of manufactures and increases that of foodstuffs. The former comes about because of the price increase of manufactures, combined with the more moderate tariffs on these. The latter, because of the increment of agricultural tariffs, combined with strong increases of tariffs on exotic products (for fiscal reasons) during the turn of the century.

It may be advanced that a future study will present indicators of effective protection whose results on relative sectorial protection are very similar to those presented here. ${ }^{40}$ Estimations have been made only for a few years, but a projection of the estimated biases over the whole period allows the following reasonable hypotheses to be made.

Although protection after 1875 follows a cyclical upward profile, not every cycle is equal. The most marked one comes after a period of a certain protectionist moderation in the 1880s, with the arrival of the Cánovas tariff of 1891. The 1906 tariff seems to maintain protection, which then continues its upward tendency from the 1920s onwards with the 1922 tariff, although this second cycle has a smoother profile than that observed for the 1890s.

Broadly speaking, it can be said that protection during the whole period of the Restauración has a markedly industrial bias. This can be traced back to its beginning in 1877. The moderation or accentuation of this industrial bias seems to be connected to the decrease or increase of the general level of aggregate protection: industry clearly wins with those tariffs that raise protection, whilst agriculture does it with those that relax it. Although protection during the Restauración had an industrial nature, the Cánovas tariff of 1891 had a much higher industrial bias than the Salvador tariff of 1906, contrary to what most recent studies maintain.

These facts, which have been here contrasted, raise doubts on certain widespread hypotheses in the Spanish historiography. The continuity of the industrial nature highlighted in this study clashes head-on with the interpretation of the 'forceful' or 'fortuitous' nature of the protectionist turn of 1891 which has been very popular recently amongst Spanish economic historians. ${ }^{41}$ This conclusion does not contradict the importance of the efforts of the Spanish Administration in defence of the exporter's interests, nor with the fact that the failure of negotiations with France played a role in reinforcing the positions of the protectionist industrial sectors. The negotiation of the trade agreement with France doubtlessly influenced the design of the 1891 tariff, but other forces determined its final configuration by stressing its industrial nature and maintaining it for such a long period of time. ${ }^{42}$

The facts show that, while the Salvador tariff of 1906 readjusted itself and slightly moderated industrial protection, agricultural products gained a certain prominence. This came about through an increase in the number and the level of protected products, as well as from the significant 
increase in the protection of the so-called colonial products. This confirms that, in both cases, increases in the protection of primary products came about because of the growing state pressure to raise more revenue after the Villaverde reform of 1899. That the fiscal pressure contributed to increasing agricultural tariffs does not mean that it was a primary factor for determining the nature of Spanish protectionism at the beginning of the twentieth century. Proof of this is given by the Cambó tariff of 1922 , where the generalised tariff increase stands out in all sectors and in the renewed prominence of the industrial tariff.

Therefore, there was certain continuity in the protectionist policy of the Restauración before and after the 1891 Cánovas tariff, and, contrary to what has been generally believed until recently, the evidence points towards the strengthening of the idea that Spanish protection had, to a large extent, an industrial bias from the beginning of the given period. This opens up the discussion of the greater or smaller degree of continuity of the protective level of the Spanish economy between the Restauracion and the Sexenio Liberal (1868-74) thus raising the question of whether the international turnaround from Base Quinta to the Figuerola tariff and its repeal in 1875 materialised in actual fact.

Consequently, the traditional hypothesis suggested by Vicens Vives seems strengthened; namely, that the 1891 Cánovas tariff reinforced the interests of the traditional industrial sectors of textiles and steel (the former in 1891 and the latter particularly after 1896), and that these sectors led the coalition with the agricultural representatives. ${ }^{43}$ There is no doubt that many unintentional factors, such as trade relations, fiscal needs or the economic climate, influence the decision-making process of devising tariff structures, and that all these factors contribute to weaken or strengthen the various conflicting interest groups. The political mechanism that gave rise to this result, through pressure from the main interest groups or from the lack of it, is without any doubt one of the most interesting debates that this research opens up. 


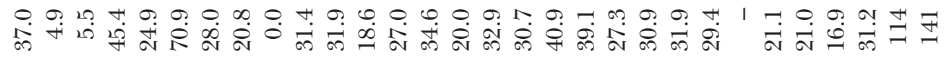

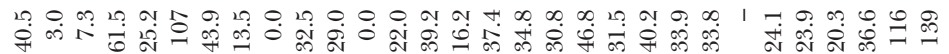

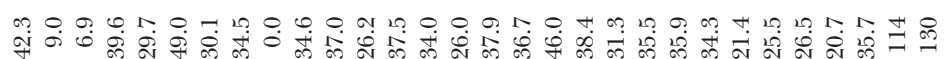

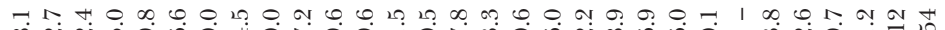

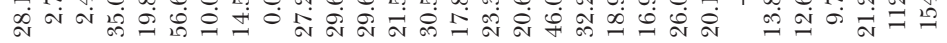

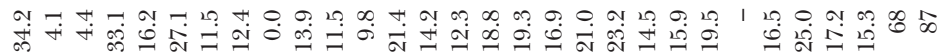

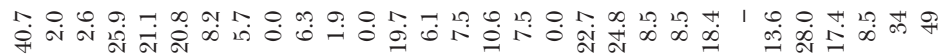

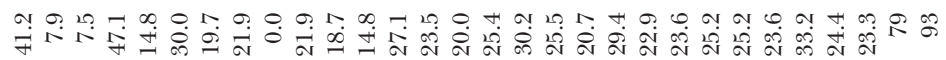

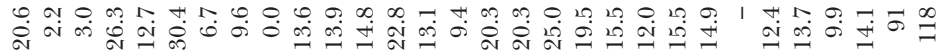
की

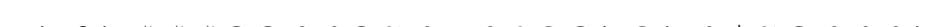

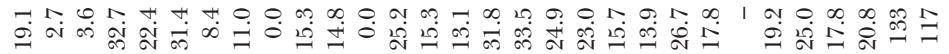

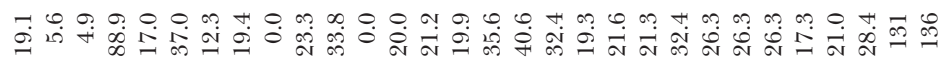
ம. + 근 过 ơ

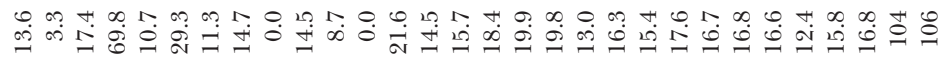

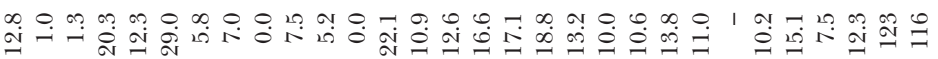

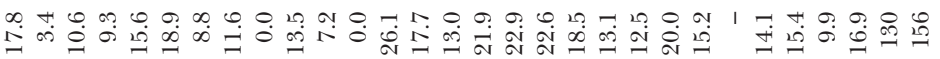
$\begin{array}{lllllllllllllllllllllllllllllll}1 & 1 & 1 & 1 & 1 & 1 & 1 & 1 & 1 & 1 & 1 & 1 & 1 & 1 & 1 & 1 & 1 & 1 & 1 & 1 & 1 & 1 & 1 & 1 & 1 & 1 & 1 & 1 & 1 & 1\end{array}$

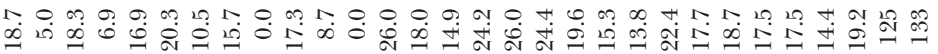

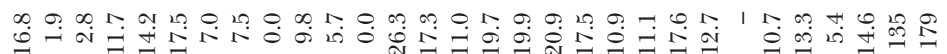

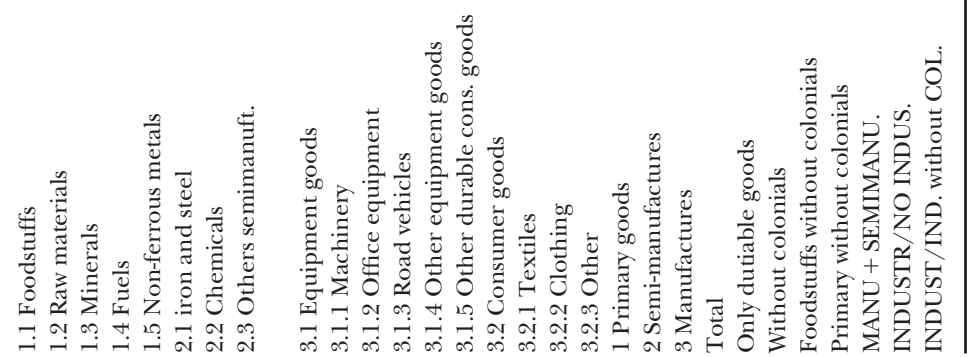




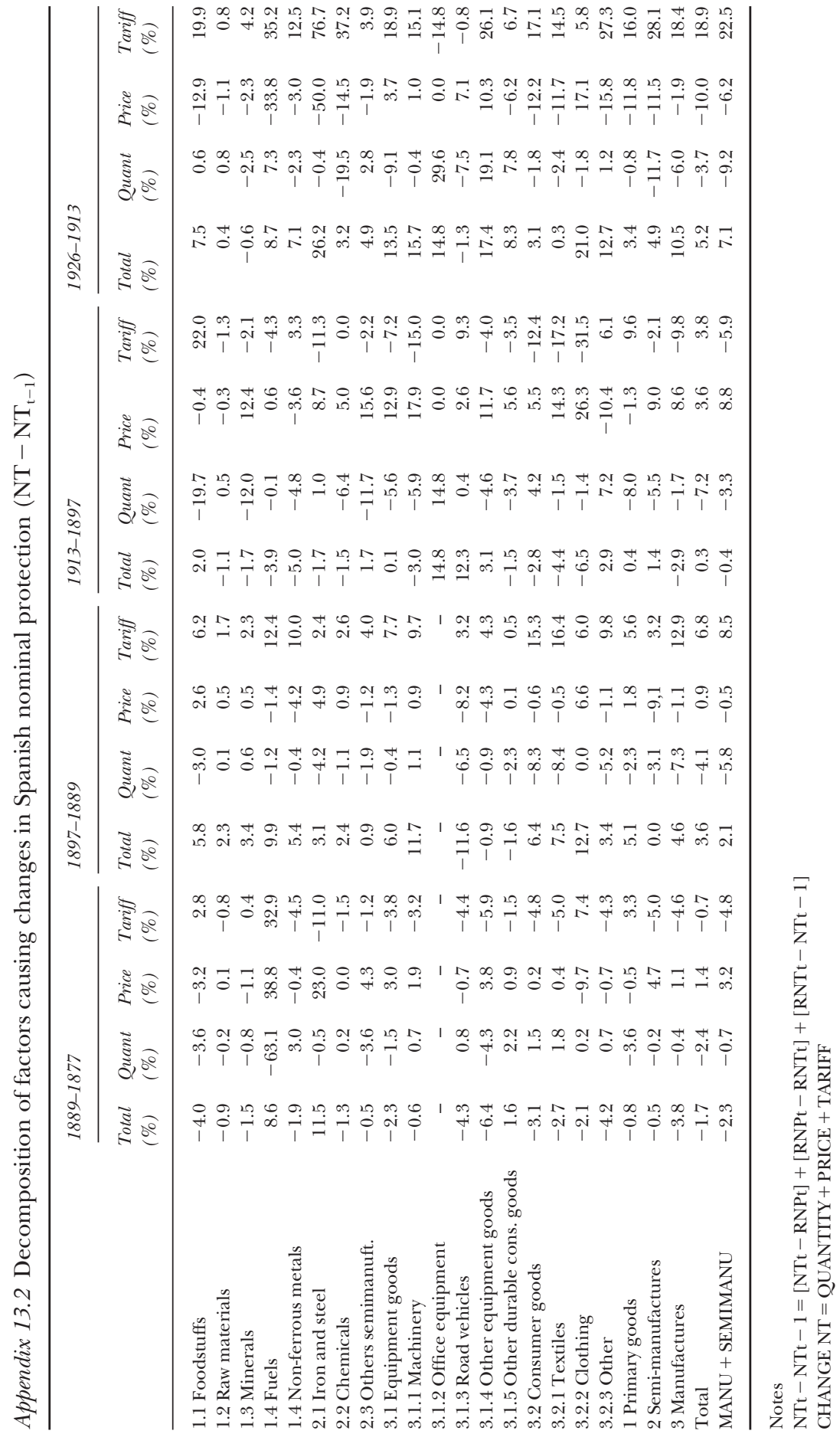




\section{Notes}

1 Parts of this chapter have been presented in different versions at various seminars: at the International University Menéndez y Pelayo, the Fifth Congress of the Association of Economic History, the Eleventh International Economic History Association Congress and at the universities of Valencia and Carlos III of Madrid. I am very grateful for the comment and critique of, amongst others, Concha Beltrán, Giovanni Federico, Pedro Fraile, Agustín Llona, Elena Martínez, Jordi Palafox, Leandro Prados de la Escosura, Pablo Sánchez León and Daniel Tirado, as well as for the useful comments of an anonymous referee. I cannot leave out my most sincere thanks to Laura Cervero, Raimundo Fernández Cuesta and Cristina Cambeiro for their collaboration in the preparation of the database. This project has been financed with a scholarship of the Spanish Ministry of Education CGYCIT: PB 94/073. This is a revised version (February 2005) of the article published in Spanish by Revista de Historia Económica 3 (1999), pp. 579-621. Translation financed by SEJ2004-05894 MEC. Translator: Alejandro Díaz Blanco.

2 As Raymond Carr points out, "the demand for protectionism was only one aspect of the economic pessimism that followed the end of the boom of the Restauración' (Carr, 1990: 381, translated from the Spanish edition). This pessimism is shared by the literature in arguing against alternatives to protectionism.

3 'It was inconceivable that politicians would risk the political and social consequences of sacrificing the Castilian agriculture and the Basque industry' (Carr, 1990: 381, translated from the Spanish edition).

4 Perhaps Flores de Lemus' protectionist position was one of the most conscientious of the costs implied. He highlighted many times that industrial protection was not for free and was paid by the agricultural exporters. His preoccupation for the rhetoric position of 'integral protectionism' has been pointed out many times, given that this implied excessive protectionist measures that damaged the agricultural exports without increasing the effective protection of the industry. In essence, however, he shared the pessimist position that the industry would disappear without protection, and thus favoured such measures. 'So abolish that agricultural export industry and all that stuff and the industrial constitution of Biscayans and Catalans will collapse. But destroy the Basque Country and Catalonia and you shall see what happens to Spanish agriculture...', only to continue saying 'With the construction of this combination of industry and export-oriented agriculture, each of the farmers that pay the protection will naturally have less than if that protection did not exist. But, altogether, they will have more than if the industry did not exist. And altogether with the Nation and Fatherland' (Flores de Lemus, 1928: 42).

5 Vicens Vives tends to present a somewhat positive image of the return to protectionism, portraying its reinforcement as inevitable. Regarding the 1891 tariff, he states that: 'The development of the iron and steel industry and the best moments of the textile industry came about under this protectionist regime ... the loss of the colonies forced Spain to defend itself, and it should not be considered odd that on March 3rd 1906, a clearly protectionist tariff was approved in Spain' (Vicens Vives, 1990: 645, translated from Spanish). Following this line, Josep Fontana also maintains a firm position regarding the inevitability of the protection: 'Perhaps the main problem was not the protection itself, but instead its reinforcement, when it would have been more positive to gradually reduce it' (Maluquer, 1987: 71, translated from Spanish). Later on he confirms the impossibility of reducing the tariff rate with the 1906 tariff: 'The trajectory followed by the Spanish economy in the years 1898-1921 and 
the economic policy that implemented it responded to almost inevitable constraints. There was probably no alternative.' Nevertheless, he ended up reckoning that 'the costs of the nationalist option were probably excessively high' (ibid.: 99).

6 See Tortella (1994), Prados (1982, 1988), Carreras (1984), Fraile (1991), Tena (1992a, 1995).

7 See the studies of Costas (1988), Serrano Sanz (1989) and Sabaté (1996).

8 The project began with the Spanish case study (see Prados and Tena, 1994) and it will hopefully conclude with a summary of all the research in Tena (1999). The Italian case study began at a later stage, but has already given rise to some publications (see Federico and Tena, 1998).

9 The first version of this measurement can be seen in Prados and Tena (1994). For an alternative annual indicator, see Tirado (1994). A critique of the latter can be found in Tena and Tirado (1996).

10 See the studies of Costas (1988), Serrano Sanz (1987, 1989), Tirado (1994) and Sabaté (1996).

11 Demand is normally closely correlated with GDP, but not always.

12 The price index of English exports to Spain, constructed by Prados de la Escosura, rises from 100 in 1850 to 115 in 1864 (Prados, 1988, Table 5-A2: 257). See also el Arancel (1960: 21).

13 The Base Quinta is section number 5 of the regulation plan of the 1869 Figuerola Tariff law. It compelled increasing reductions of tariffs after 1875, enforcing that the maximum tariff on every item would not be more than 15 per cent (ad valorem level) in 1881. It was never implemented because of the Restauración of King Alfonso XII six months before the July 1875 deadline and it was repealed.

14 In principle, customs income from budgetary sources is consolidated but includes export rights, as well as other charges and taxes which are not strictly customs-based. This is reflected in a higher level.

15 Federico and Tena (1998).

16 In principle, the difference between both prices may be less than the total amount of the tariff (so-called watered protection). However, this case does not usually create empirical problems for estimating protection, since these types of goods are not imported due to their higher price in comparison with domestic production.

17 Anderson (1995) and Feenstra (1995) have argued in favour of estimating protection on the base of domestic prices inclusive of tariffs, i.e. $T^{*} i=A i /(P i+A i)$. The difference is small when tariffs are not too high. Nevertheless, leaving aside the traditional definition would imply not being able to compare the results of the estimation with those of most other authors, both for the Spanish case and for other countries.

18 For the bias to be relevant, the fact that the product represents a significant share of total imports is a necessary but not sufficient condition. This is because, if elasticity is low enough, a significant tariff increase may not significantly affect the imported quantity.

19 A similar system, though applied to continuous time-series, has been recently used by Crucini (1994) and Irwin (1998). However, their approach is methodologically less ambitious, since it only considers the price and tariff effects, whilst our main interest is to capture the effect of import shifts.

20 For the years under consideration, the estimated aggregate bias is 8.5 per cent for $1877,4.7$ per cent for $1889,0.8$ per cent for $1897,-10.5$ per cent for 1913 and -7.7 per cent for 1926 . A relatively moderate bias has also been estimated for both primary and manufactured products: in 1877, 8.4 per cent for primary products and 17.7 per cent for manufactures; in 1889, 6.5 per 
cent and 9.4 per cent respectively; in $1897,5.6$ per cent and -0.6 per cent; in $1913,-11.0$ per cent and -4.5 per cent; and, in $1926,-7.7$ per cent and -8.5 per cent. The origin of the biases in the valuations of the products may be attributed to the suspicion that protectionist groups raised the valuations of manufactured goods with the objective of obtaining an ad valorem nominal protection more moderate than the real protection. This overvaluation has only been detected for the years preceding 1896. Concerning manufactures, for the years of this study, only 1877 seems relevant, since the bias for 1889 is small, being negative in other years. The fact that the global bias for manufactures was negative does not however exclude the fact that, within the group of manufactured products, some especially influential pressure groups may have attained overvaluations that were greater than average. A study of the revaluation of manufactures, or especially of those where the risks of a bias are greater, can be justified on the following counts: 1) the difficulty in obtaining international prices homogenous to those of our statistics for a wide variety of manufactured products (reasons stated by all Spanish authors that have worked on this topic); 2) if the biases expected in the historiographic literature are the product of pressure groups, these can only be upward biases, and, in that case, the results of this study would offer an estimation of the nominal protection in accordance with the interest of these pressure groups, that is, more moderate than the real bias. Departing from the supposition that there are good reasons to believe that the biases in the valuations do not have a homogenous tendency and that it is necessary and possible to individually re-valuate each product, an alternative way can be chosen (see Tirado, 1994). A critique of this alternative attempt can be found in Tena and Tirado (1996).

21 The correspondence has been introduced into the database for a level of five digits, with the intention of obtaining a reliable correspondence for the aggregation of three digits. This task was carried out with the systematic use of the United Nations dictionary (1985), which, departing from the name and characteristics of a product, allows a match with a five-digit number from the SITC classification, second revision, for each product included in the Volumenes Anuales del Comercio Exterior (Annual Volumes of [Spanish] Trade) for the five years chosen.

22 Temporary trade (comercio temporal) and returned merchandises (mercaderías devueltas) have been excluded when they are identifiable in the statistics, as occurs for the years 1889, 1897 and 1913. For the year 1926, series of 'general' and 'special' trade seem to already exclude these two concepts with greater rigour.

23 For 1877, products included in the statistics were not corresponded with the tariff classification number, as was subsequently done. In the year 1926, the statistics do not display tariff revenue for each product, so tariff revenues have been estimated from the second column of specific tariffs published in 1925, that is, those available on 1926 for their application (Consejo de Economía Nacional, 1925), which include all the tariffs lowered after the end of the negotiation of trade agreements (carried out between 1921 and 1924).

24 See League of Nations (1927), Tumlir and Till (1971).

25 Compare as well the low level obtained for these same indicators in the Italian case for that same year, 1877 (NT: 7.3 per cent; UNT: 6.3 per cent). Statistical Appendix, Federico and Tena (1998).

26 See Federico and Tena (1998, figure 1: 79), and Chapter 6 in this volume.

27 Although it is generally assumed that the relationship between the increase of the sectorial product and its level of protection have a linear relation, this need not always be the case (Anderson, 1994). 
28 The disaggregated information of all the products included in the estimation, along with the denomination of their ad valorem protection and their importance (arranged in accordance to their SITC within the GATT classification), is available in paper format on request. For any other queries, please contact the author.

29 The nominal protection of wheat flour changed from 31.4 per cent to 41.7 per cent between 1897 and 1913, causing a reduction from 3.57 per cent to 0 per cent of total imports. Meats and canned foodstuffs increased their protection from 17.7 per cent to 33.1 per cent in those same years, thus reducing their percentage over total imports from 0.4 per cent to 0.08 per cent. Cane and brown sugar saw their nominal protection increase from 0.44 per cent to 110 per cent, whilst their weight over total imports shrank from 2.02 per cent to 0.01 per cent. Water, and wine and liquor, saw their percentages change, respectively, from 18.2 per cent to 32.9 per cent and from 0.37 per cent to 0.2 per cent. See Appendix 13.2 for the disaggregation of the results of Table 13.3 (given their extension, they are not presented here, but are available to any reader that requests them).

30 Simpson (1996) estimates that wheat represents, on average, approximately 20 per cent of agricultural production for some years of the period 1890-1932. The fourth chapter of the GHER (1980) book probably remains the best quantitative study available of the evolution of agricultural tariff and non-tariff protection until the First World War.

31 The arithmetic average of the tariffs on wheat for the period 1892-1905 was 6.7 Pesetas per hectolitre, and for the 1897 tariff it was 8.19. For the period 1906-13, the average was 7.39, and for the 1913 tariff it was 6.93 (averages calculated from GHER, 1980, Table 14: 96).

32 From the General Railway Law of 1855 until the tariff law of September 1896, most of the railway equipment enjoyed a special tariff system, with reduced duties in comparison with the other categories of iron and steel. In 1897, although most of the railway equipment was maintained within the category of 'special trade', the privileges of this group were reduced and they suffered a considerable tariff increase (for example, in 1896 the bars and the rails covered by 'special trade' had an ad valorem protection of 13.8 per cent, whilst in 1897 it had risen to 28.8 per cent; linking metallic parts rose from 12 per cent to 53 per cent). Due to the changes introduced by the 1896 law, the year 1897 cannot be considered a representative year regarding what occurred with railway equipment between 1892 and 1896. But, in contrast, the following ten years until 1906 can be considered as such. The changes in tariffs introduced in September 1896 in relation to the 1891 and previous tariffs can be seen in Aran Pérez (1988: 8). Discounts and franchises for railway equipment were included within 'general trade' in the year 1877. In 1889 and 1897, these privileges began to be registered under an entry called 'special trade', and non-privileged railway equipment became incorporated with the rest of the 'general trade'.

33 A study of the levels of protection and imports of electric machinery and materials between 1890 and 1935 can be seen in Tena (1988).

34 See Sabaté (1996) and Comin (1993).

35 Sabaté (1996) quantifies the contribution of the increase in revenue from colonial goods between $1895-9$ and $1900-4$ in 7 per cent of the total ordinary revenue of the state. In this case, the contribution to total revenue is 32 per cent, although the period considered here is different, between 1897 (two years before the Villaverde reform) and 1913 (a year in which the 10 pesetas per kilo surcharge applied by the law of 24 December 1912 on colonial products, excluding sugar, influenced the results heavily). 
36 Traditionally, some scholars believe that it is necessary to exclude the so-called revenue-generating products from the estimates of nominal protection, since their introduction is mainly due to fiscal rather than protectionist reasons. That the legislator declares a fiscal intention when imposing a tariff does not mean that the tariff has no protectionist consequences. Some of the revenuegenerating products were domestically produced or had close direct substitutes. In other cases (that is, when products were not domestically produced and had no close substitutes) the consequences of a tariff only affected consumer welfare (directly) and the allocation of resources (indirectly). The former, through decreasing their income, and the latter, by incentivating the production of direct substitutes (for example, a high tariff on coffee, cocoa or cinnamon can favour the production of chicory or varieties of Mediterranean origin) or of their inputs. Therefore, it is not possible to justify the exclusion of any group of products only due to fiscal reasons. In any case, this exclusion has to be individual and economically justified. As Serrano Sanz (1987: 115-16) explains, in the Spanish case not even the official literature gives a doctrinal explanation:

Since there was no doctrinal definition of what was meant to be understood by revenue-generating products, the outline of the group fades progressively and the number of products included in it keeps on augmenting. On the one hand, some goods of which there is no domestic production but an increasing trade are aggregated, for example petroleum or some chemical products. On the other, some domestically produced goods also provide increasing revenue, such as wheat. The truth is that, when the following tariff reform comes under discussion in 1906, seventy entries are identified as revenue-generating, whilst they were 22 in 1869 (translated from Spanish).

37 Very recently, Nye (1991) has argued that the so-called revenue-generating tariffs on wine and liquor need to be included to estimate British protection in the years 1800-75, in order to capture the protective effects of substitutes on the general consumption of beer (see also his recent controversy on this matter with Douglas Irving (March 1993)).

38 In the Spanish case, there are very clear examples of colonial foodstuffs that have direct substitutes, as is the case of beet and cane sugar. Where price increases due to revenue-generating tariffs on colonial foodstuffs such as cinnamon, pepper and clove may have had protective effects on nationally produced spices such as saffron, cumin, oregano or ground pepper. Something similar could be said of coffee, cocoa or tea, which, as with wine and beer in the English case, may have had substitutes for general consumption (chicory, for example). Any choice could seem arbitrary, and in this case we have introduced many possible options including the more economically intuitive option of excluding a significant group of products without domestic production or close substitutes. See the text for details.

39 Antonio Cánovas del Castillo (1828-97) the principal architect of the restoration of the Bourbon dynasty and author of the 1876 constitution, was several times prime minister between 1874 and his assassination in 1897.

40 See Tena (2001).

41 See Sabaté (1996), Nadal-Sudria (1993), Comín (1993), Pan Montojo (1994) and Tirado (1996a).

42 Many other European tariff laws in this period were designed in the clamour of a commercial war with France and, in spite of starting from negotiating budgets similar to the Spanish one, it is possible to observe both a different nature and a different profile. A wide range of (international) literature on 
this subject highlights that liberalisation and protectionist processes in the nineteenth and twentieth centuries were accompanied by complex bilateral and multilateral negotiations. In every case, the objective of negotiations between governments is to reduce the damage caused by the increase of barriers to the national products exported to foreign markets.

43 Period in Spanish history running from 1868 to 1874.

44 According to Vicens Vives, 1987:

The 1886 crisis gave the opportunity to the Catalan protectionists to rally with the Basque metallurgic workers and the Castilian cereal-growers. That is how the battle for the tariffs in 1891 was won, and the bases for the protectionist articulation of the Spanish economy were established. The loss of the colonies in 1898 made matters worse and prepared for the adoption of the 1906 tariffs.

Raymond Carr (1990) is even more explicit: 'Protectionists that had failed with the French treaty of 1882 succeeded in 1892 when the treaty with Germany was rejected by the Senate. With the National League of Producers, Catalonia had finally managed to create, after insisting for forty years, a "national" organisation in favour of protection that included the interests of the Basque steel and the Castilian wheat' (translated from the Spanish edition). The apparent contradiction of a mainly agricultural country where industry played the leading role in the demand for protection is resolved in 'olsonian' terms in Fraile (1991). 


\title{
14 The role of open economy forces in Portugal and the Balkans, 1870-1913 ${ }^{1}$
}

\author{
Pedro Lains ${ }^{2}$
}

If one were to draw a circle on a map of Europe, with its centre in the North Sea off the English Coast and with a radius of some 800 miles, the area dividing the European continent would approximate the boundary between the relatively prosperous industrial economies of the North and the West and the relatively undeveloped and predominantly agrarian economies of the South and East.

(Moore, 1945: 17)

\section{Introduction}

In the interwar years there was a clear perception that the southern European economies were by then less developed and less industrialized than the economies of the northern periphery, and few authors would disagree that such a gap already existed in 1913. This description is largely correct. Yet, the literature is less clear in what concerns relative income levels half a century earlier. In fact, some authors have argued that, by 1870 , southern Europe had levels of income per capita similar to those in Scandinavia. This chapter questions such belief.

The fact that the Scandinavian countries caught up with the first industrializers, in the period from the mid-nineteenth century to 1913, whereas the southern peripheral countries lagged behind, has led to the conclusion that the latter group of countries failed during that period. ${ }^{3}$ Yet, recent estimates of levels of income per capita in Europe show that the southern periphery, in particular, Portugal and the Balkan countries, was less developed than previously thought, by 1870 , if not at an earlier date. ${ }^{4}$ This implies that we can no longer assume prima facie that the conditions for growth in southern Europe, at the earlier stages of the industrialization process, were similar to those of the northern peripheral countries. In other words, the presumption that the factors which are held responsible for the performance of the Scandinavian countries should also be present in the South is no longer the best device to guide our research into the causes of backwardness of those that remained behind in Europe.

The list of possible causes of backwardness is of course extensive. ${ }^{5}$ In this chapter, we discuss how the poor European countries related to the 
first industrializers. We ask whether the impact of the 'open economic forces' was similar, to the extent that it explains the common levels of slow economic development within the poor periphery of Europe. O'Rourke and Williamson argue that "mass migration and international capital flows together served to explain a third to a half of the spectacular Scandinavian catch-up on Britain', during the period from 1870 to 1913. It follows from that conclusion that the weakness of 'open economy forces', in particular, low emigration and low levels of capital imports, explains an 'important part of Iberian failure' (the explanatory force of differences in tariff levels is reduced in their model). ${ }^{6}$ The Balkan economies lay outside O'Rourke and Williamson's analysis and the fact that the analysis is extended here to the whole poor European periphery helps in improving our understanding of European backwardness.

The chapter proceeds as follows. The next section discusses the available data on income per capita levels in Europe and provides an alternative and more accurate data set. The new data show a clearly distinct group of poor non-converging countries, including Portugal, Greece, Serbia, Bulgaria and Romania. The rest of the chapter deals with the causes of backwardness of this group of countries. The third section analyses the effects of differences in the degree of openness to trade of the same group of countries, towards industrialized Europe. The fourth section deals with the role of capital imports and financial probity, and discusses the role of emigrant remittances and other sources of foreign exchange revenue. The fifth section sets down our main conclusions regarding the causes of backwardness in the poor southern European periphery.

\section{The ranking of per capita income levels in Europe and its uses}

The position given to a country in the ranking of income per capita levels, at the beginning of a certain period, influences the interpretation of economic performance in the following years. According to Gerschenkron, the departing degree of backwardness in nineteenth-century European nations helped to define the conditions for industrialization. In his own words: 'depending on a given country's degree of backwardness on the eve of its industrialization, the course and character of the latter tended to vary in a number of important aspects'. Backward countries could catch up to the levels of per capita income and labour productivity of the forerunners, by substituting the absence of certain 'preconditions' for institutions that fostered economic growth, such as investment banks and public expenditure in social overhead capital and in the industrial sector. ${ }^{7}$ Yet the same author argues that countries should not be too backward in order to be able to converge, and that they had to reach a minimum level of capability in order to be able to enter the club of the successful 
industrializers. Similarly, Simon Kuznets has shown that the first countries to industrialize in Europe 'were already in advance of the rest of the world when modern industrialization began'. Consequently, countries had to reach a 'minimum adequacy level' or a minimum level of product per worker in order to belong to the club of convergence. ${ }^{8}$

The conclusions above were further developed by the literature on convergence of income levels. Abramovitz, for example, has shown that the countries which, in 1870, had levels of income per capita below a minimum threshold, did not converge to the levels of the more advanced countries. According to the same author, the convergence of backward countries' income per capita with those of the leaders requires 'institutional and technical preparedness' to allow for the introduction and adaptation of their forerunners' higher production methods. ${ }^{9}$ On the same lines, Williamson concludes, 'initial conditions in 1870 explain most of the convergence in the late-nineteenth-century environment of globalization'. ${ }^{10}$

Thus, the accurate ranking of countries according to income levels appears as one basic instrument to proceed in our discussion on the causes of southern European economic backwardness.

The most influential attempt at ranking European income levels is, again, the essay by Gerschenkron on nineteenth-century industrialization. ${ }^{11}$ Gerschenkron divided Europe into three groups of countries, namely 'advanced', 'moderately backward' and 'extremely backward', according to a qualitative evaluation of relative economic development levels. His definition of the degree of backwardness depended on his judgement regarding 'the levels of output, the degree of technological process achieved, the skill of the population, the degree of its literacy, the standards of honesty and the time horizon of entrepreneurs'. ${ }^{12}$ Gerschenkron's insights proved to be correct in most cases. Yet the further we go towards the periphery of Europe, the less accurate is the picture provided by him. For example, by assuming that the rate of industrial growth is inversely correlated to the degree of backwardness, the author concludes that Sweden, with a higher industrial growth rate in the 1880s and 1890s, was by then more backward than Germany, Italy and Russia. Consequently, Sweden is considered a 'very backward' country, and is grouped together with Hungary and Bulgaria. ${ }^{13}$ A more precise definition of the degree of backwardness is clearly needed.

Despite the shortcomings in available statistical evidence, it is better to measure the degree of backwardness by comparing levels of GDP per capita. Paul Bairoch provides an extensive data set for income levels in Europe for the nineteenth and twentieth centuries, although with many important flaws. ${ }^{14}$ Such estimates also show similarities in income levels within the geographical periphery of Europe. Although no longer ranked as backward as Italy and Bulgaria, Sweden and the neighbouring Scandinavian countries appear as having similar levels of income per capita as Portugal or Spain in 1860. 
Bairoch's data has led to a conceptual framework that decisively affected explanations of backwardness in southern Europe. In fact, based on Bairoch's description of comparative growth in Europe, Sandberg has defined Sweden as an 'impoverished sophisticate', as the levels of literacy and the development of its financial system were higher than those of the other countries with which Sweden was ranked in 1860 . These distinctive elements appear as major causes of growth for nineteenth-century Sweden. ${ }^{15}$ Based on a similar conception of levels of European development, Sidney Pollard also concluded that the Scandinavian and the Iberian peninsulas 'started from a similar position in the mid-nineteenth century: a great imperial past, but a poverty-stricken, largely agricultural present, rich local resources exploited by foreign capital for foreign markets, dependence on the advanced economies, extreme climate, and poor transport facilities'. From then on, according to the same author, their historical experience diverged because of the influence of differences in the 'mental and political climate', namely in terms of levels of education, forms of religion and forms of government. ${ }^{16}$

More recently, David Landes uses Bairoch's estimates to group the Scandinavian countries in the same income league as the Iberian and Balkan countries, in both 1830 and 1860. From that ranking, Landes concludes for 'the significance of institutional and cultural impediments to development [that] shows well in the contrasting experience of Europe's periphery'. The Scandinavian countries had an 'impressive performance', despite being 'desperately poor in the eighteenth century'. Their difference was the fact that they were 'intellectually and politically rich' ${ }^{17}$

Bairoch's data on income per capita levels has been revised for two main reasons. First, it has important inconsistencies in what concerns relative levels of income per capita and relative levels of labour productivity in agriculture and industry, which he has also estimated. For example, in 1860, Portugal's agricultural and industrial labour productivity are, respectively, 23 and 13 per cent of the British level, which are not compatible with the correspondent estimate of a gap of income per capita of 50 per cent. ${ }^{18}$ Similar problems occur in Bairoch's estimates for Italy, Spain and Greece, but not for Bulgaria, Romania and Serbia. Second, Bairoch's estimates of income growth for Portugal for the period from 1860 to 1913 are not confirmed by new data based on direct evaluation of output, as they undervalue income growth. That explains why these countries appear in Bairoch's tables with higher levels of income per capita in $1860 .{ }^{19}$

Good and Ma provide another sets of indirect estimates for levels of income per capita in the European periphery. ${ }^{20}$ Their estimates are based on Crafts' model, which predicts GDP levels by means of a linear regression where the independent variables are the number of letters posted, the proportion of active population in agriculture, coal consumption and mortality rates. ${ }^{21}$ The regression is estimated for the countries for which there are data, which are mainly industrialized countries, and then the 
regressors are used for the remaining backward countries. Thus, the model assumes that structural relationships in the less-industrialized countries are similar to those of the industrialized countries and stable over time. ${ }^{22}$ This may not be the case for the use of coal, for example, which depends on the availability of natural coal resources or on the capacity to import coal. In the case of Portugal, Crafts' GDP per capita estimate for 1910 is too high as it implies a negative growth rate between 1910-50, which is incompatible with the available data on this period. ${ }^{23}$

Another set of indirect income per capita estimates, by Prados, is based on a model which defines a structural relationship between the price level of each country and nominal GDP per capita and other independent variables, including trade ratio, population, area and net capital inflow. ${ }^{24}$ Once more, the model is estimated for countries for which there are data and extrapolated to the other countries, which are mainly on the periphery, but the data set does not include most of the Balkan countries. ${ }^{25}$

Angus Maddison's extensive collection of income per capita data provides the best basis for comparing income levels in Europe, but his data sets can still be improved on. ${ }^{26}$ Maddison's estimates for historical national income levels are also based on backward extrapolations of income levels for 1950 and thus depend on estimates for income growth for 1913-50 and 1870-1913, which have been revised for some countries. In Table 14.1, GDP per capita levels for 1913 are from Maddison for those countries for which he uses national output indices for backward extrapolation from national account figures starting in 1950. That is not the case for the Balkan states, and thus we took relative levels of income estimated by Colin Clark and Corrado Gini (see Appendix Table 14.A1). ${ }^{27}$

Data for 1870 in Table 14.1 is also based on backward extrapolations. Growth indices for 1870-1913, for nine of the eighteen countries shown in the table, are from Maddison, ${ }^{28}$ and new indices are available for Austria and Hungary, Greece, Spain, Portugal and Sweden. ${ }^{29}$ Income growth for Romania, Bulgaria and Serbia, during 1870-1913, is based on Bairoch's data, as his estimates, derived from wage trends, are consistent. These are lower-bound estimates and they enhances the GDP per capita level in 1870, which makes our estimates biased against the conclusion that the southern European countries were poorer than the Scandinavians in that year. ${ }^{30}$

The new data indicate a north-south divide in European income levels (see Figure 14.1). In fact, in 1870, Bulgaria had the highest income level in the south-eastern periphery at 1,270 US dollars (at 1990 prices) and Serbia, Greece, Portugal and Romania had lower levels of income per capita. Hungary was also in this league and yet, according to Schultz's data, Hungary converged to the levels of the higher-income countries (as did Finland). ${ }^{31}$ In the northern periphery, Norway and Denmark were relatively better of at the beginning of the period and they converged with 
Table 14.1 GDP per capita levels and growth rates, 1870-1913 (1990 international' dollars; annual trend growth rates, per cent)

\begin{tabular}{lrrr}
\hline & \multicolumn{2}{c}{ Levels } & \multirow{2}{*}{ Growth rates 1870-1913 } \\
\cline { 2 - 3 } & 1870 & 1913 & \\
\hline Belgium & 2,779 & 4,220 & 1.00 \\
France & 2,017 & 3,485 & 1.28 \\
Germany & 1,875 & 3,648 & 1.56 \\
Netherlands & 2,874 & 4,049 & 0.80 \\
United Kingdom & 3,249 & 4,921 & 0.97 \\
Denmark & 1,952 & 3,912 & 1.63 \\
Finland & 1,151 & 2,111 & 1.42 \\
Norway & 1,603 & 2,501 & 1.04 \\
Sweden & 1,456 & 3,096 & 1.77 \\
Austria & 1,638 & 2,599 & 1.08 \\
Italy & 1,595 & 2,564 & 1.11 \\
Spain & 1,439 & 2,255 & 1.05 \\
Bulgaria & 1,270 & 1,521 & 0.42 \\
Greece & 996 & 1,255 & 0.54 \\
Hungary & 888 & 1,574 & 1.34 \\
Portugal & 926 & 1,244 & 0.69 \\
Romania & 861 & 1,378 & 1.10 \\
Serbia & 934 & 1,152 & 0.49 \\
\hline
\end{tabular}

Notes and sources: GDP for 1913 is from Maddison (2001: 185-6), except for Greece, Romania and Serbia, which is based in the ratio to UK level from Clark (1951) and for Bulgaria which is the same ratio from Gini (1962) and (1959) (see Appendix 14.1 table and text). Data for 1870 is based on backward extrapolations beginning in 1913. Growth rates are from Maddison (2001), except for Austria and Hungary: Schulze (2000); Greece: Kostelenos (1995); Portugal: Lains (1998); Spain: Prados (1995); Sweden: Schon, unpublished. For Bulgaria, Romania and Serbia, growth rates are from Bairoch (1976b).

the level of income in the core countries. All the other countries in northern Europe converged to the United Kingdom's income level. ${ }^{32}$

The data in Table 14.1 are of course not definitive, but it seems to indicate that Portugal and the Balkans were a distinct group of countries within Europe. As such, we cannot expect them to have, in the period after 1870, those institutions that are believed to have had an important role in the economic development of the richer Scandinavian countries.

Despite the fact that Portugal and the Balkan countries pertain to distinct regions of Europe, the pattern of institutional development, as well as of some basic structural features of their economies, present striking similarities. Such similarities are patent in the development of constitutional monarchies, with regular elections and parliamentary-based governments. In Portugal, institutional development was disrupted in the aftermath of the French Wars and it took several decades before the new constitutional monarchy was firmly established. It was only from the late 1860 s onwards that the basic elements of a modern state were enforced. ${ }^{33}$ 


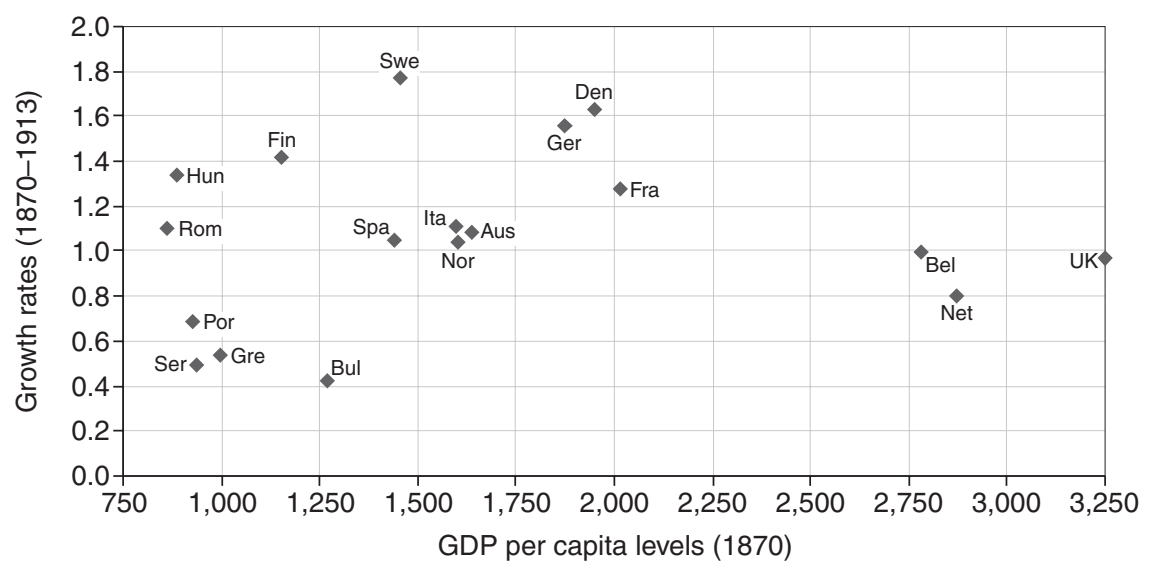

Figure 14.1 GDP per capita levels (1870) and growth rates (1870-1913) (sources: see Table 14.1).

Notwithstanding Ottoman rule, Bulgaria and Romania went through a modernization process during the nineteenth century. When autonomy or independence from the Porte came, in 1878, the development of national institutions that were by then common to western European countries followed immediately. Ottoman rule in the Balkans is stigmatized in the literature, probably as much as was the case with the Ancien Régime in Iberian or French historiography. However, recent writings present the Ottoman regime from a different perspective, according to which the Porte's rule in the Balkan area is no longer seen as totalitarian or 'colonial'. ${ }^{34}$ Palairet goes as far as arguing that the Ottoman rule was highly favourable to institutional development, which, he contends, even slowed down after independence was attained, mainly due to the departure of the political and military Turkish elite. ${ }^{35}$

The Balkan states could be singled out from the rest of Europe, because of the more frequent wars and because of changes in boundaries and the forced migration of populations within the area and to the Ottoman Empire. But the Balkan states were definitely not a world apart in nineteenth-century Europe and the pace and timing of their institutional development approaches that of Portugal.

\section{Foreign trade, commercial policy and the economy}

Despite the similarities in the levels of economic and institutional development, the five poor European countries studied in this chapter show important differences in terms of the degree of openness to foreign trade and in the level of capital imports. As we show below, such differences should be attributed mainly to different economic and financial policies. 
This section deals with the role of foreign trade and the next section deals with the discussion of the role of capital imports.

Portugal's commercial relations were predominantly made with the fastest-growing economies of Western Europe, whereas the Balkan countries were set until late in the nineteenth century within an Empire, which was not particularly dynamic. Yet, after independence, foreign trade from the Balkans gained momentum. Germany and the Austro-Hungarian Empire played a predominant role in that increase, as well as Britain and Russia, in the case of Greek foreign trade. ${ }^{36}$ Romanian, Bulgarian and Serbian wheat, Bulgarian and Serbian livestock, Greek currants and Romanian oil were exchanged for British, German or Austrian manufactured goods, following the classical European trade pattern between areas with different levels of industrialization. ${ }^{37}$ The drive for protectionist policies by Austro-Hungary after the 1870s hindered Balkan exports to the area and eventually led to tariff wars, such as those with Romania, from 1886 to 1891 , and with Serbia, from 1906 to 1911. Yet, the Balkan countries managed to redirect part of their exports to Belgium and other northern European markets. ${ }^{38}$

Altogether, central European markets for foodstuffs and raw materials were probably less favourable than the markets in the West, particularly in free-trade Britain. As Portuguese exports went mainly directed to this country, that may have given her an advantage, but only for a limited period. In fact, from the mid-1880s onwards, as a consequence of the increasing competition from agricultural exports from other parts of the world, Portuguese exports to Britain declined. This change in world markets for agricultural produce led to the increase of exports from Portugal towards the central European countries. However, Portuguese exports had to face higher tariffs and difficult trade agreements. As the country was not in a strategic area for either Germany or Austria, in contrast to what happened with the Balkans, the negotiations of commercial treaties were harder. As a result, Portugal hardly managed to gain the most favoured nation status in central Europe. ${ }^{39}$

With regard to trade policy, the treaties signed between the Porte, Britain and other western powers, between 1838 and 1841, which opened up Ottoman trade routes to foreign nations, imposed limits on tariffs. ${ }^{40}$ In 1878, the treaty of Berlin forced the new Balkan states to keep their tariffs low, at 8 per cent ad valorem. Greece was not under this obligation but also embraced the relatively free-trade policies of the area. Free trade in southeastern Europe contrasted with the highly protectionist policy that had been followed in Portugal since the early nineteenth century. Table 14.2 shows that contrast. In 1870, Romania and Greece had low average tariff rates, whereas Portugal's average tariff level, at 27 per cent, was one of the highest in Europe. ${ }^{41}$

Free-trade policies were to change in the Balkans, after 1870, but that took a long time. In fact, Greece increased its tariffs in 1880, but only 
Table 14.2 Average tariff levels (per cent of import values)

\begin{tabular}{lrrrrr}
\hline & 1870 & 1880 & 1890 & 1900 & 1910 \\
\hline United Kingdom & 6.7 & 4.9 & 4.7 & 5.4 & 4.9 \\
Denmark & 11.9 & 11.9 & 10.5 & 8.1 & 5.3 \\
Finland & - & - & 10.3 & 11.1 & 12.8 \\
Norway & 11.6 & 11.1 & 10.6 & 11.0 & 12.4 \\
Sweden & 11.3 & 10.8 & 10.8 & 11.1 & 9.0 \\
Italy & 8.5 & 11.3 & 16.9 & 12.3 & 8.0 \\
Spain & 12.9 & 20.1 & 16.4 & 14.9 & 15.4 \\
Bulgaria & - & 8.0 & 8.0 & 15.0 & 20.0 \\
Greece & 12.0 & 16.0 & - & - & 27.0 \\
Portugal & 27.0 & 29.5 & 33.3 & 27.2 & 23.6 \\
Romania & 7.8 & 5.7 & 6.5 & 7.7 & 13.4 \\
Serbia & - & 8.0 & 8.0 & 15.0 & 20.0 \\
\hline
\end{tabular}

Sources: Computed from Mitchell (1992, tables E1 and G6), except for: Bulgaria and Serbia, for which I took rates from the international agreements, according to Lampe (1975: 38) and Damjanov (1979: 11). For Greece: Dertilis (1993: 258-9; and Iliopoulus (1973: 40). And for Portugal (in 1870): Lains (1986: 485).

Note

Three-year averages of tariff over import values.

slightly, and it was only in 1894 that Bulgaria was formally allowed by international agreements to increase its maximum tariff rates from 8 to 10 per cent of import values. In 1897, both Bulgaria and Serbia were allowed to increase their rates to a maximum of 25 per cent. ${ }^{42}$ Romania increased its tariffs in 1886. Tariff levels imposed by the international agreements were not necessarily fully applied, and the rates shown in Table 14.2 are only indicative of the evolution of trade policy. As such, in 1897, according to customs revenue statistics, Bulgaria's tariff rate was 17.5 per cent, which is slightly above the rate for 1900 shown in the same table. After 1904, there were further general increases in the Balkan tariffs, which placed the area in tune with European levels of protection. ${ }^{43}$ Despite the increase in average tariffs, the Balkan countries still had lower tariffs than Portugal for many important products. Portugal had the highest rates on cotton and iron of all the countries, particularly in printed cottons, lace and sewing needles. Tariff protection was equally spread, although tariffs on foodstuffs tended to be slightly higher. ${ }^{44}$

The higher degree of openness of Bulgaria and Romania was also reflected in the fact that exports from the area performed better than in Portugal, which is visible in export ratios. According to different estimates, in 1911, Romania exported between 25 and 38 per cent of its GNP and Bulgaria between 20 and 27 per cent. These export ratios are close to those observed in Scandinavia, in the same period. In fact, Sweden had an export ratio of 22 per cent, whereas Denmark's was higher, at 30 per cent. Portugal had an export ratio of 13 per cent, which was below that of land- 
locked Serbia, which was 15-19 per cent. These latter shares were only slightly higher than their equivalent for Spain and Italy. ${ }^{45}$

Trade policies had an important impact on the structure of the industrial sectors, this can be observed by comparing Portugal and Romania, the two countries for which there is better data on the sector. ${ }^{46}$ Although the proportion of industrial output in Romania was close to that of Portugal, the pattern of industrial growth in the two countries was different. From 1870 on, industry expanded faster in Romania than in Portugal and, particularly, Romania had a higher expansion of heavy industrial sectors, which were practically non-existent in Portugal until the 1920s. ${ }^{47}$ In 1910 , the Romanian oil sector accounted for as much as 23 per cent of the output from the secondary sector (industry and mining) and the flour and sugar industries accounted for 19 per cent. A significant part of the output of these sectors was exported. In contrast, the highly protected Portuguese textile industry accounted for 43 per cent of industrial output. These shares were not in accordance with the country's revealed comparative advantages. In fact, by 1910, only 27 per cent of industrial exports from Portugal were composed of textiles, which were mostly sold to the protected colonial markets. The share of textiles in Romania's industrial output was only 15 per cent. ${ }^{48}$

The major distinctive characteristic of Portugal versus the Balkan states (Greece excepted) was that the latter embraced free-trade policies. Such policies contributed to the promotion, to a great extent, of export activities in the agricultural sector and, in the documented case of Romania, in industry as well. Portugal remained highly protectionist throughout the period and agricultural exports dwindled, particularly after 1880, whereas the industrial sector did not develop according to the revealed comparative advantages of the country. Notwithstanding the fact that these countries had important differences in the degree of openness to trade with foreign nations, neither of them showed a tendency to grow at a faster pace than the richer European countries, in order to converge to their levels of income per capita. ${ }^{49}$

\section{Foreign capital, financial probity and infrastructures}

The importance of capital imports for the economies of Portugal and the Balkans can be gauged first by the analysis of the growth and structure of public debt. The raising of foreign loans in order to finance the government deficit or to invest in social overhead capital came at an earlier stage in Portugal than it did in the Balkan countries. Following an earlier foreign loan during the civil war of 1832-4 and a period of financial distress, the Portuguese government raised the first loan of a new era, in 1856, to be invested in the first railway line. The Romanian principalities raised their first foreign loan in 1856, and Serbia in $1876 .{ }^{50}$ After having defaulted, in 1843, Greece remained out of foreign capital markets for a 
Table 14.3 Long-term foreign loans to governments (million French francs)

\begin{tabular}{|c|c|c|c|c|c|}
\hline & \multicolumn{2}{|l|}{ Capital } & \multicolumn{2}{|c|}{ Interest rates } & \multirow[t]{2}{*}{$\%$ par } \\
\hline & Nominal & Effective & Nominal & Effective & \\
\hline \multicolumn{6}{|l|}{ To 1889} \\
\hline Bulgaria (from 1888) & 77 & 71 & 6.0 & 6.5 & 93.0 \\
\hline Greece (from 1879) & 691 & 514 & 4.8 & 6.1 & 74.4 \\
\hline Portugal (from 1852) & 1,613 & 1,129 & 5.0 & 7.0 & 70.0 \\
\hline Romania (from 1864) & 723 & 519 & 5.6 & 7.8 & 71.8 \\
\hline Serbia (from 1876) & 64 & 46.6 & 3.8 & 5.2 & 73.4 \\
\hline \multicolumn{6}{|l|}{$1890-1900$} \\
\hline Bulgaria & 150 & 131 & 5.8 & 6.6 & 87.5 \\
\hline Greece & 203 & - & - & - & - \\
\hline Portugal & 0 & 0 & 3.0 & 6.0 & 50.0 \\
\hline Romania & 1,009 & 779 & 4.4 & 5.7 & 77.2 \\
\hline Serbia & 368 & 258 & 4.0 & 5.7 & 70.2 \\
\hline \multicolumn{6}{|l|}{$1900-11$} \\
\hline Bulgaria & 522 & 464 & 4.7 & 5.5 & 88.9 \\
\hline Greece & 55 & 44 & 4.0 & 5.0 & 79.9 \\
\hline Portugal & 0 & 0 & 3.1 & 6.0 & 51.6 \\
\hline Romania & 952 & 880 & 4.9 & 5.3 & 92.5 \\
\hline Serbia & 555 & 476 & 4.8 & 5.6 & 85.8 \\
\hline
\end{tabular}

Notes and sources: For the Balkan countries: Lampe and Jackson (1982: 233); see also Lazaretou (1995: 33) (for 1890-1900). For Portugal: Valério (1988); nominal interest rates computed from Mata (1993: 242); data for Portugal is for 1852-90.

long period. It was only in 1879 that the Greek government managed to raise another loan abroad. Finally, Bulgaria raised its first loan abroad in 1888. ${ }^{51}$ Capital imports in Romania were mainly German, while in Bulgaria, Greece, Serbia and Portugal they were mainly French and British. Due to its earlier start, Portugal led the group of poor countries in terms of foreign loans to governments, and Romania and Greece followed. Table 14.3 shows that, in 1890, Portugal, with a total debt of 1,129 million French Francs, Romania with 519 m FF, and Greece with 514 m FF, led the league of foreign investment in government bonds.

After 1890, the above picture changed considerably. After having partially defaulted on payments on its foreign debt, in 1892, the Portuguese government was unable to borrow abroad. In 1902, an agreement with foreign bondholders was signed and yet the purchase of bonds by foreign nationals did not resume. ${ }^{52}$ Between 1892 and 1902, Bulgaria had almost no access to European loans but, after 1902, the Bulgarian government managed to resume borrowing abroad, giving the tobacco excise revenue as a guarantee. It should be mentioned that an increasing part of the loans to the Bulgarian government was spent on the military. ${ }^{53}$ The bottom part of Table 14.3, concerning the decade from 1910, clearly marks the contrast between Portugal and Greece vis-à-vis Romania, Serbia 
Table 14.4 National debt, 1913/14

\begin{tabular}{lcccc}
\hline & Total $(m F F)$ & Foreign/total $(\%)$ & \multicolumn{2}{c}{ Total per capita $(F F)$} \\
\cline { 3 - 5 } & & & Nominal & Effective \\
\hline United Kingdom & 17,257 & 0 & 402 & - \\
Denmark & 498 & 75.3 & 166 & - \\
Finland & 164 & 100 & 50 & - \\
Norway & 493 & 93.8 & 200 & - \\
Sweden $(1)$ & 955 & 82.3 & 171 & - \\
Italy & 15,661 & 0 & 423 & - \\
Spain & 9,347 & 10.7 & 459 & - \\
Bulgaria & 986 & 87.5 & 204 & 181 \\
Greece & 1,345 & 74.8 & 224 & 179 \\
Portugal & 3,265 & 31.4 & 544 & 281 \\
Romania & 1,714 & 89.5 & 106 & 98 \\
Serbia & 888 & 13.9 & 195 & 167 \\
\hline
\end{tabular}

Source: Woytinsky (1926: table 269).

Notes

1914 borders; Swedish domestic bonds include foreign bonds repurchased by Swedish residents. Portugal's population in the source was corrected (i.e. 60,000 instead of 6,000). Converted from dollars at US $\$ 1=5.133 \mathrm{FF}$.

and Bulgaria in terms of access to foreign capital markets. Moreover, the effective interest rate paid by the Portuguese governments on foreign loans was among the highest throughout the period considered.

Table 14.4 shows that, in 1913/14, Portugal had the highest per capita national debt, at 281 French francs, but only 31 per cent of it was foreign. This contrasts markedly with Bulgaria and Romania, where foreign nationals held 90 per cent of the debt. Not surprisingly, at the turn of the century, Romania was described as the 'Belgium of south-eastern Europe'. ${ }^{54}$ In fact, such high levels of foreign investment in public debt are common to the northern European early-comers, including the Scandinavian countries, for which data is shown in the same table. ${ }^{55}$

Differences in the levels of borrowing from abroad are clearly associated with different financial conditions in each country. Table 14.5 shows that the governments in Bulgaria and Romania ran surpluses for most of the last quarter of the nineteenth century, whereas Greece and Portugal ran considerable deficits. Moreover, in these two latter countries, a higher proportion of government revenues was used to service their public debt. In fact, as shown in Table 14.6, in 1911, debt service accounted for 42 per cent of government revenue in both Greece and Portugal. As a consequence, the Romanian and Bulgarian currencies were also more stable from the 1890s onwards, whereas Portugal abandoned the gold standard in $1891 .^{56}$

Railways were the single most important destination of foreign capital, both through government and private loans. ${ }^{57}$ In Bulgaria, for example, 
Table 14.5 Government revenue (per cent of expenditure)

\begin{tabular}{lrrrlrrr}
\hline & $1880 / 4$ & $1885 / 9$ & $1890 / 4$ & $1895 / 9$ & $1900 / 4$ & $1905 / 9$ & $1910 / 12$ \\
\hline Bulgaria & 102.9 & 109.4 & 99.7 & 91.6 & 95.0 & 101.2 & 96.7 \\
Greece & 93.5 & 95.8 & 97.5 & 67.8 & 116.7 & 101.6 & 126.4 \\
Romania & 99.0 & 101.7 & 103.7 & 96.1 & 105.3 & 114.4 & 117.0 \\
Serbia & 86.0 & 78.5 & 92.3 & 86.7 & 92.2 & 98.1 & 105.1 \\
Portugal & 79.3 & 79.5 & 81.5 & 93.2 & 94.9 & 97.8 & 99.3 \\
\hline
\end{tabular}

Sources: Lampe and Jackson (1982: tables 7.2 and 7.8); and Mata (1993: table 36), for Portugal.

Table 14.6 Structure of government expenditure, 1911 (per cent of total)

\begin{tabular}{lllllll}
\hline & Debt service & Military & Infrastructures & Education & Economy & Other \\
\hline Bulgaria & 21.4 & 21.4 & 23.8 & 11.9 & 4.8 & 16.7 \\
Greece & 41.8 & 16.4 & - & 3.0 & - & 38.8 \\
Portugal & 42.0 & 23.0 & - & 5.0 & 8.0 & 22.0 \\
Romania & 17.3 & 16.0 & 17.3 & 9.3 & 1.3 & 38.8 \\
Serbia & 27.8 & 23.3 & 11.6 & 7.0 & 2.3 & 27.9 \\
\hline
\end{tabular}

Sources: Lampe and Jackson (1982: table 7.9; and Mata (1993: table 10), for Portugal (data for 1911/12).

21 per cent of the total capital borrowed abroad was invested in railway and port construction, whereas in Serbia the proportion was about 30 per cent. ${ }^{58}$ Railway construction began earlier in Portugal compared to southeastern Europe, because, as previously mentioned, the country managed to raise earlier railway loans abroad. In 1870, Portugal's railway density was 80 kilometres per million of hectares or 164 kilometres per million inhabitants, considerably above Romania, the only Balkan country where railway building was already on the way by then. The extension of the Portuguese railway network was comparable to that of Norway and Italy in terms of number of kilometres per inhabitant. ${ }^{59}$ The construction of railways was related to each country's position in the international financial markets. Railway construction slowed down in Portugal, in the aftermath of the 1891-2 financial crisis, which led to the abandonment of the gold standard and to the reduction of interest payments on its debt. From 1880 onwards, the Balkan countries caught up with Portugal and, by 1910, only Serbia had a smaller railway network than Portugal. ${ }^{60}$

It should be noted, however, that the building of railways also depended on political and strategic factors, particularly in the Balkans. In 1878, Bulgaria and Serbia took over the obligation that had been imposed on Turkey to build the parts of the railway from Vienna to Constantinople and Thessaloniki that passed through their territories, as Austria was inter- 
ested in having its networks connected through the area to the East. ${ }^{61}$ The link was completed in 1888. In 1895, the Bucharest line reached the Black Sea. The completion of these connections possibly explains why railway construction also slowed down after 1890 in this part of Europe.

In the Balkan countries, foreign capital was also invested to a great extent in industrial concerns, and that is also in marked contrast with what happened in Portugal. In Romania, in 1914, 82 per cent of industrial joint-stock capital was foreign. In the oil, gas and sugar industries the proportion of foreign capital was close to 95 per cent. Domestic capital was predominant only in the paper and pulp industries (54 per cent) and foodstuffs (69 per cent). The proportion of Romanian bank assets owned by foreign residents was 15 per cent. In Greece, 50 per cent of the capital invested in the industrial and banking sectors was foreign. In Serbia in 1910, 36 per cent of total capital (fixed and working) in industry was foreign, as was 9 per cent of bank assets. Serbia's mining sector was exclusively foreign-owned. Finally, the share of foreign investment in Bulgaria was probably lower. In the industries with state protection, 23 per cent of the capital was foreign and 12 per cent of bank assets were also foreign. ${ }^{62}$ There is no comparable data for Portugal. However, according to Mata, between 1851 and 1891, total foreign investment, including public and private investment, accounted for only 13 per cent of total investment in the country. ${ }^{63}$

The analysis of open economy forces in the area that concerns us here should also include the analysis of the effects of emigrant remittances, and of other sources of foreign exchange. Emigrant remittances were an important source of external financing in Portugal, in contrast to Bulgaria, Romania and Serbia. ${ }^{64}$ Portugal was also a recipient of considerable foreign exchange earnings from her colonial exports, particularly after the early 1890 s when they became more important then emigrant remittances. ${ }^{65}$ On the other hand, Greece was a large exporter of shipping services. Such alternative sources of foreign revenue somehow substituted for capital imports, particularly after the turn of the century. ${ }^{66}$ Therefore, we may conclude that Portugal and Greece, on the one hand, and the other three Balkan countries, on the other, responded to external influences in different ways. This qualification only stresses further the general conclusion regarding the presumably low importance of financial probity and capital imports in explaining differences in economic behaviour. ${ }^{67}$ In fact, balanced budgets may have promoted capital imports, when necessary, but they could be substituted for remittances and other sources of foreign exchange earnings, when possible.

\section{Conclusions}

The new data on European relative income per capita levels show that Portugal and the Balkan countries were the less-developed economies on 


\section{Pedro Lains}

the European continent, already by 1870. Such low levels of economic development implies that the departing position of these southern European countries was less favourable then that of the Scandinavian countries, at the time when industrialization and international economic integration gained momentum in Europe. The boundary which, according to Moore, divided the "prosperous industrial economies of the North and the West and the relatively undeveloped and predominantly agrarian economies of the South and East', was already there in $1870 .{ }^{68}$ Consequently, the lessons that have been learned from the Scandinavian countries no longer apply to the poor southern peripheral countries.

To explore further lessons that may help in explaining economic backwardness, we need to look at relevant structural factors within the group of poor countries. Despite many important differences, Portugal, Greece and the remaining Balkan states had some important common structural characteristics, including the timing and the speed of the development of political institutions. The institutionalization of constitutional monarchies and parliamentary governments came earlier in Portugal, but only by a few decades. Turkish rule in the Balkans was not the rule of the 'dark ages', particularly after the end of the Napoleonic wars. The constitutional regimes that sprouted after 1878 were by no means perfect, but also that was not the case in Portugal.

Portugal, Greece and the remaining Balkan states showed important differences regarding their participation in world markets. The diversity of experiences in the southern European periphery is related to the degree of openness to foreign trade and capital. In fact, import tariffs were lower in Bulgaria, Romania and Serbia, whereas the level of capital imports was higher there than in Greece and Portugal. A larger participation of foreign capital can be associated with balanced budgets, lower interest rates on government bonds and higher levels of currency stability. Yet, notwithstanding important differences in the ways these countries related to the rest of the world, there were no significant differences in the performance of their economies, as none converged to the levels of income per capita of the first industrializers.

As Gerschenkron and many economic historians that followed have extensively shown, there was no single path to economic growth during the nineteenth century. ${ }^{69}$ By paying attention to a wider diversity of country experiences, including those of the more backward regions at the two ends of the Continent, we have to conclude that the path to economic backwardness was also not unique. The number of experiences of the more backward areas of Europe is probably as large as that of the more advanced countries. Consequently, economic historians should take into account that backwardness can be associated with many different factors and that it may go along with both protectionist and free-trade policies, with both unbalanced budgets and financial probity.

Economic backwardness in southern Europe was too large to be over- 
come in the four decades of industrialization and agricultural growth from 1870 to the First World War. ${ }^{70}$ Economic growth elsewhere in Europe has been associated, perhaps too hastily, to policy devices, such as low tariffs or financial discipline. Yet, there is the strong possibility that the true causes of 'success' lay in the period before industrialization gained momentum. 


\section{Pedro Lains}

\section{Appendix 14.1}

14.A1 Real national income and real national wealth per capita (1914 borders, except when noted)

\begin{tabular}{|c|c|c|c|c|c|}
\hline & \multicolumn{3}{|c|}{$\begin{array}{l}\text { Clark's Real National Income } \\
\text { (1925/34 'international units') }\end{array}$} & \multicolumn{2}{|c|}{$\begin{array}{l}\text { Gini's Real Private } \\
\text { Income (1913 current } \\
\text { French francs) }\end{array}$} \\
\hline & $\begin{array}{l}R N I \\
\text { (million) }\end{array}$ & $\begin{array}{l}\text { Population } \\
(000)\end{array}$ & $\begin{array}{l}R N I \\
\text { per capita }\end{array}$ & $\begin{array}{l}\text { Income } \\
\text { (million) }\end{array}$ & $\begin{array}{l}\text { Income } \\
\text { per capita }\end{array}$ \\
\hline Austria-Hungary & - & - & - & 3,055 & 530 \\
\hline Austria ${ }^{c}$ & 7,060 & 26,150 & 270 & - & $629^{g}$ \\
\hline Hungary & 3,348 & 24,072 & 139 & - & $423^{g}$ \\
\hline Belgium & 2,236 & 7,605 & 294 & 7,200 & $945^{i}$ \\
\hline Bulgaria & - & - & - & $2,150^{i}$ & $380^{i}$ \\
\hline Denmark $^{a}$ & 987 & 2,833 & 348 & $5,400^{i}$ & $830^{i}$ \\
\hline Finland & 570 & 3,027 & 188 & - & - \\
\hline France & 10,901 & 39,770 & 274 & 7,650 & 943 \\
\hline Germany & 21,070 & 66,978 & 315 & 6,161 & 757 \\
\hline Greece $^{a}$ & 530 & 4,800 & 110 & - & - \\
\hline Italy & 5,380 & 35,192 & 153 & 3,125 & $544^{i}$ \\
\hline Netherlands & 2,114 & 6,164 & 343 & 7,100 & $920^{i}$ \\
\hline Norway & 582 & 2,447 & 238 & - & - \\
\hline Portugal & 790 & 6,001 & 132 & 3,082 & $438^{i}$ \\
\hline Romania $^{f}$ & 880 & 7,300 & 121 & - & $315^{h}$ \\
\hline Russia & 18,110 & 138,270 & 131 & 2,146 & $322^{i}$ \\
\hline Serbia $^{e}$ & 480 & 4,750 & 101 & $1,850^{i}$ & $340^{i}$ \\
\hline Spain $^{d}$ & 5,707 & 20,330 & 281 & 3,800 & 530 \\
\hline Sweden $^{b}$ & 1,776 & 5,639 & 315 & $3,750^{i}$ & $630^{i}$ \\
\hline UK & 19,700 & 45,649 & 432 & 8,029 & 1,228 \\
\hline
\end{tabular}

Sources: 1951: 63, 80-113, 155-9, 191. Gini, 1959, 1962; Vandellos 1925: 151-86 (for Spain and Portugal); and von Fellner, Die Verteilung (for Austria-Hungary). Population data is from Maddison, 1990: 111, except for Austria, Greece, Serbia, Romania and Russia, which is from Clark, 1951.

\section{Notes}

Data for 1913 except for France (1911), Italy and Portugal (1914), and Austria and Hungary (1911-13). Clark's estimates include farm consumption.

a Post-1919 borders.

b $\mathrm{RNI}=$ real income in 1913 prices $\times$ price deflator for $1913-29 \times$ adjustment for farm consumption $($ col. 5/4) $\times$ exchange rate $\mathrm{Kr} /$ Int.Unit $(3,179 \times 1.995 \times 1.129 \times 0.246=1,776)$.

c The 1919 borders Austrian Republic RNI per capita is: 1,980 m Int.Unit/6.767 m pop $=293$.

d RNI = National income in pesetas at 1929 prices $\times$ adjustment for farm consumption $\times$ exchange rate Ptas/Int.Unit.

e Includes Montenegro. Yugoslavia's RNI per capita is: 1,520 m Int.Units/1.28 m pop = 119 Int.Units.

f Greater Romania's RNI per capita is: 1,760 m Int.Units/15 m pop $=117$ Int.Units.

g Estimated directly from F. von Fellner, 'Die Verteilung des Volksvermögens und Volkseinkommens der Länder der Ungarischen Heiligen Krone zwischen dem heutigen Ungarn und den Successions Staaten', Metron, III (1923), pp. 227-307, which is Gini's original source.

$\mathrm{h}$ Only estimate for national wealth is given. It was assumed that the ratio private/national wealth was the same as Bulgaria's (12-18\%).

i Mean value. 


\section{Notes}

1 Originally published in the Scandinavian Economic History Review, 50, 1 (2002). Earlier versions of this chapter were presented at a seminar at Lund University and as a lecture (lição de agregação) at Universidade Nova de Lisboa. I would like to thank the participants for their comments. Thanks are also due to Nick Crafts, James Foreman-Peck, Riitta Hjerppe, Rui Ramos, Lennart Schon, Jeffrey Williamson and an anonymous referee. The usual caveat applies.

2 Instituto de Ciências Sociais, Universidade de Lisboa.

3 See Bairoch (1998: 248-53). Under the designation of 'the Balkans', we include Bulgaria, Greece, Romania and Serbia.

4 See Foreman-Peck and Lains, 2000; Reis, 2002; Williamson, 2002. See also Allen, 2000: 1-25;

5 See Reis, 1993: chapter 1; Molinas and Prados, 1989: 385-402; Tortella, 1994: $1-21$.

6 O'Rourke and Williamson, 1997: 153-90. See also Foreman-Peck and Lains, 2002.

7 Gershenkron, 1962: chapter 1.

8 Kuznets, 1958: 25. See also Deane, 1965; Landes, 1969; Crafts, 1983: 387-401; Senghaas, 1985; Bairoch, 1991.

9 Abramovitz, 1986: 385-406. See also Baumol, 1986: 1072-85; Barro and Sala-iMartin, 1995.

10 Williamson, 1996: 277-306.

11 Sylla and Toniolo, 1992.

12 Gerschenkron, 1962.

13 Gerschenkron, 1962.

14 Bairoch, 1976b: 273-340, 1981, 1991.

15 Sandberg, 1979: 225-41; 1982: 675-97. See also Fisher and Thurman, 1989: 621-34.

16 Pollard, 1982: 250. Other interpretations based on Bairoch are, for example, Berend and Ránki, 1982; and Reis, 1993: chapters 1 and 6.

17 Landes, 1998: 248-9

18 See Lains, 1999: table 2.6.

19 See Lains, 1999: chapter 2. See also, as a further example of problems with Bairoch's data set, R. Hjerppe, The Finnish Economy, 1860-1985. Helsinki: Bank of Finland, 1988.

20 Good and Ma, 1999: 103-37, table 2; Prados, 2000: 1-41. See also Good, 1994: 869-91; 1996: table 4.1; Schulze, 2000: 311-40; and Pamuk, 2001.

21 Crafts, 1984: 438-58.

22 Good and Ma, 1992: 106-7.

23 See Crafts, 1983: 28-9; Batista et al., 1997. See also Pammer, 1997: 448-55.

24 Prados, 2000.

25 The reliability of these indirect estimates cannot be assessed. But the fact is that the estimates by Good and Ma, for the Balkans, and by Prados, for Greece, show that, in 1870, these countries, together with Portugal, had levels of income per capita below Denmark and Sweden.

26 Maddison, 1990, 1995, 2001.

27 See Clark, 1951; Gini, 1959, 1962. For most countries in the European periphery, Maddison uses proxies derived from Colin Clark's income estimates and a rough estimate for Greece.

28 Maddison, 1995.

29 See Schulze, 2000 (for Austria and Hungary); Kostelenos, 1995; Prados, 1993; Lains, 1998 (for Portugal). I would like to thank Lennart Schon for providing his unpublished Swedish GDP series for 1850-1914. 
30 For wage trends, see Berov, 1979: 91-115; 1985: 22-38; 1987: 65-83; 1996. On growth trends in the Balkans see also Lampe, 1983: 1, 187-96; and Palairet, 1979: 719-40; 1983: 1, 163-85; 1988, 1997.

31 See Schulze, 2000.

32 This description of relative income levels in 1870 is in agreement with that of O'Rourke and Williamson (1997) and Good and Ma (1992).

33 Lains, 1998.

34 See, for example, Janos, 1989: 325-58; and Todorova, 1997.

35 Palairet, 1997.

36 Basch, 1944: 11-13. See also Berend and Ránki, 1974: 36; Jackson and Lampe, 1983: 4, 385-415, table 3.4; Turnock, 1986: 12; Gluskov, 1976: 26-50.

37 Pollard, 1981: 164-84

38 Preshlenova, 1993: 38-64; 1994. See also Evans, 1924.

39 Lains, 1998; chapter 3.

40 Pamuk, 1987.

41 See Lains, 1987: 481-503.

42 Pasvolsky, 1930: 27.

43 Preshlenova, 1993: 48-9. See also Lampe, 1975: 23-52.

44 Woytinsky and Woytinsky, 1955; and Lains, 1987.

45 Lampe and Jackson, 1982: 164 (for the Balkans); Lains, 1998: 74 (for Scandinavia, Portugal, Spain and Italy). See also Petmezas, 2000: 321-37.

46 See though Popoff, 1920.

47 Portugal's industrial growth throughout 1870-1913 was about 2.5 per cent per year. See Lains, 1998: chapter 2. Estimates for Romania are probably less accurate, as there is some doubt regarding the evolution of price. From the mid1860s to 1912-13, the Romanian industrial sector expanded at 4.0 per cent per year or, at current prices, or 3.8 per cent in real terms (if we assume no inflation between 1860 and 1900 and 1 per cent inflation from 1900 to 1912). See Jackson, 1986: 1, 59-111 and 1986: 2, 231-57. See also Damjanov, 1979: 3-30.

48 Lains, 1998: chapter 2.

49 See O'Rourke, 2000: 456-83.

50 Diouritch, 1919: 3, 293-334.

51 See Lazaretou, 1995: 28-50; Petrakis and Panorios, 1992: 1, 31-46. Greece had also raised her first foreign loan in the 1830s.

52 Mata and Valério, 1991: 421-32.

53 Lampe, 1975: 36; and H. Feis, 1930: 283-4.

54 Miller, 1923: 470.

55 O'Rourke and Williamson, 1997: 173-4.

56 In fact, Romania was on a metallic standard from 1881, and Bulgaria and Serbia from 1897; whereas Greece suspended convertibility from 1877 to 1910; and Portugal abandoned the gold standard, in 1891. See Lampe and Jackson, 1982: 205-20; and Foreman-Peck and Lains, 2002: 91-2.

57 R. Tilly, German banks and foreign investment in central and eastern Europe before 1939, in Economic Transformations in East and Central Europe, Ed. D. F. Good. London: Routledge 1994; Pasvolsky, Bulgaria's economic position, p. 37; Damjanov, Sur le développement.

58 Lampe, 1975: 37-8.

59 Railway data are from Mitchell, 1992, tables A1 and F1; and Diouritch, 1919: 298 for Serbia, and Lampe, 1986: 55.

60 In the Balkans, railways had a lower utilization rate in comparison with northern Europe, particularly on those lines that were predominantly used in the export trade. But that was also the case with Portugal. See Stoianovich, 1994: 106; and Alegria, 1988: 769-803.

61 Preshlenova, 1993: 62. 
62 Damjanov, 1979; 1980: 60-73; Lampe, 1972: 146; 1975: 56-85; and 1975: 74.

63 Mata, 1995. This author gives a share of foreign capital in total investment for 1891-1914 between 33 and 50 per cent, but this is based on the official balance of trade data. That data is misleading, though, due to the undervaluation of exports. See Lains, 1998: 138-40; and 1988: 1, 235-63. If we consider the revised balance of trade values and use Mata's computation method, foreign investment in Portugal would be virtually reduced to zero in the period after 1891.

64 Emigration from Greece was also high. Greece and the rest of the Balkans had large movements of population within the area, displaced by wars and forced migrations. See Palairet, 1997.

65 Lains, 1988.

66 The role of emigration in nineteenth-century Portuguese economic growth was more important in terms of a balance-of-payments constraint model of growth, than in terms of the Hecksher-Ohlin trade model. O'Rourke and Williamson (1997) show how the absence of 'mass emigration' accounted only for a small part of Portugal's rate of divergence.

67 See also Foreman-Peck and Lains, 2002.

68 Moore, 1945: 17.

69 Sylla and Toniolo, 1992.

70 O'Brien, 1986: 2, 291-333. 


\title{
15 A model of later-nineteenth- century European economic development $^{1}$
}

\author{
James Foreman-Peck ${ }^{2}$
}

By the later nineteenth century, European economies were clearly embarked on a period of sustained economic development. National outputs per head all rose, albeit at different rates and from different levels. Distinctive languages, cultures and institutions favoured clear national identities. On the other hand, freedom of movement of people, ideas and goods across national frontiers, coupled with radically improved transport and communications facilities encouraged a convergence of national economies. The gold standard and the most favoured nation clause, together with the railway, the steamship and the telegraph, provided a framework for rapid diffusion of the ideas that the nineteenth century offered for economic development. Since European national economies therefore shared a similar pattern of change and economic growth, it should be possible to model their nineteenth-century development. In this present attempt to do so, the central questions are why some European countries were richer than others between 1860 and 1910, and why some increased their prosperity faster in the period. A satisfactory model would answer these questions. In particular the model should show what characteristics contributed to income gaps, such as that between the economies of Spain and Britain. Even if existing estimates of real national product per head are only approximately correct, the variations to be explained are substantial; in 1860 the wealthiest country was more than three-times richer than the poorest in the sample analysed here, and in 1910 the gap had widened to four times. ${ }^{3}$

The first section of this chapter gives a selective four-part summary of the literature which the proposed model of European economic development is intended to illuminate. The second section identifies the most fundamental terms of an economic historical explanation for development and goes on to classify the possible endogenous variable set. The third section then specifies the model and describes the data on which it is tested and from which the parameters are estimated. The results and their implications are reported in the fourth section. 


\section{The historical background}

Comparative European economic history that explains, as well as describes, events and outcomes requires some theory. One event may follow or be associated with another but a causal connection cannot be inferred without some prior, necessary, link between them. Otherwise the association may merely be a matter of chance. Even when the historian is armed with theoretical reasons for connections, magnitudes and relative contributions cannot usually be inferred. That requires quantification of variables and of relationships between them. The cumulative efforts of researchers now permit tentative steps in this direction and, in taking them, the testing of previous conjectures and hypotheses.

One of the earliest supposed explanations for European economic development in the nineteenth century was, in fact, description (not necessarily accurate); the 'leader and follower' scheme. In this account Britain experienced the first industrial revolution, which boosted her productivity in manufacturing and income above those in the rest of Europe, and then, with varying alacrity, other European economies adopted similar technology and work organisation. The pace at which they did so determined the lag in real income behind Britain. Keywords in this representation, associated in particular with Rostow (1960), Landes (1969), Pollard (1981) and Gerschenkron (1962), are 'discontinuity', 'diffusion' and 'backwardness' (O'Brien, 1986). ${ }^{4}$ Explanations for income differences should then turn on the determinants of the speed of adoption, but that was not usually discussed in any detail. Since it was widely assumed that the new technology could only be adopted if more capital was available, growth models of the $1950 \mathrm{~s}$ and $1960 \mathrm{~s}$ encouraged and reflected this approach to economic development by assigning a central place to capital accumulation, savings ratios and 'traverses' between longrun equilibrium growth paths.

What undermined these conceptions was the quantification of European economic development that was proceeding simultaneously. Subsequent empirical research has proved 'discontinuities', 'take-offs' or 'great spurts' to be mythical in national European economic development. Higher shares of production goods in the output of more backward countries, larger plant scale, greater roles for investment banks and diminished contributions from agriculture, have been shown to be equally chimerical (Milward and Saul, 1973, 1977; Sylla and Toniolo, 1991). The big leap in capital accumulation was actually necessitated not by manufacturing but by infrastructure, in particular by railways, which in Britain accounted for a far higher proportion of the capital stock than manufacturing until the interwar years (Feinstein and Pollard, 1988).

During the later 1970s, the 'alternative roads' school began to erode the 'leaders and followers' approach. The numbers suggested that Britain was different and that other paths to development could and were taken. 
The French did not lag behind British economy as far as had previously been thought and managed to avoid some of the problems of urbanisation for industrial development (O'Brien and Keyder, 1978). Britain's great emphasis on coal was unusual throughout the period (Crafts, 1984). Though coal was a determinant of the possibilities for later-nineteenthcentury economic growth, human capital could be a substitute input. It allowed rapid development, especially in Scandinavia, based upon advanced industrial sectors that Britain tended to neglect, even without indigenous coal deposits (Sandberg, 1982; Cameron, 1985)..$^{5}$ Most ambitious among those who have plotted alternative patterns of development for the years 1850 to 1914 are Morris and Adelman (1988). In addition to European countries, their sample includes Japan, four 'very poor' countries, two Latin American economies and four countries of recent European settlement. With the help of thirty-five criteria for each country and principal components analysis, they find five development paths; two industrial, two agricultural and one 'balanced'. But the selection of indicators is somewhat restricted and arbitrary.

A third group of writers largely rejected formal quantitative methods imported from economics and, in common with traditional economic history, emphasised the role of institutions, while being willing at least to consider the relevance of economic concepts to long-term European economic development. These writers were typically not specifically concerned with Europe. Chandler (1990) addressed British and German business development in relation to the United States; Elbaum and Lazonick (1986) restricted themselves among European countries to Britain; North (1981) adopted a very abstract approach for a historian, and Europe was only one element in Olson's (1982) great scheme. Jones (1981, 1988) did focus on Europe, albeit in a comparative perspective. Political institutions are identified as the key to economic development with remarkable unanimity by authors of recent general economic histories that include Europe in their coverage. Rosenberg and Birdzell's (1986) short answer to the question of why the West became rich is 'by experiment, diversity and autonomy', in particular 'autonomy of the economic sphere from the political'. Jones (1988), maintaining that accumulation of wealth, both individually and collectively, is a strong and universal human propensity, answers that government did not get in the way too much in the West, either through wars and invasions or through regulation and taxation, thanks to a fairly wide dispersion of political power. Cameron (1989) takes a similar tack, agreeing on the primacy of the state in creating favourable conditions. He asserts that states controlled by mercantile interests were those that pursued the most appropriate policies.

Kennedy (1987) contended that the peculiarities of the London capital market distorted British economic development. All these 'new institutionalist' authors offer plausible accounts, but the demonstrations of their 
propositions are not rigorous. Thus, from an industry-by-industry analysis, Chandler maintains that Britain's failure to develop large integrated firms with professional managerial hierarchies from 1880, unlike the USA and, to a lesser extent, Germany, explained British inability to hold her economic lead. Adopting a similar approach to Chandler's, that hypothesis can be tested by considering whether all US world-class firms were organised in professional managerial hierarchies. Ford until the 1930s is a counter-example. Before 1914, Ford foremen were able to hire and fire, and until the 1920s the company was run as a family business following the founders' precepts, rather than those based on rational professional analysis (Wilkins and Hill, 1964; Meyer, 1981). Yet, for much of the first quarter of the century, Ford dominated the world motor industry primarily because of the ability to gain economies of scale and learning, by supplying the US farm market.

Managerial hierarchies in which Britain and most of the rest of Europe were deficient, were not essential for success. Inertia in the face of a changing economic environment plausibly explains a part of the interwar decline of Britain's cotton industry, and more generally may well be a factor preventing the optimum adjustment of market institutions (as Lazonick has consistently maintained). But that does not tell us how much of differential real income levels in Europe should be attributed to this influence.

Olson's no-less plausible theory of distributional coalitions suffers from the same drawbacks. Within national economies, these coalitions become stronger and more pervasive with the passage of time and in the absence of shocks. They redistribute income towards themselves, and in so doing, slow economic development. Much of nineteenth-century European history does not easily square with Olson's account. The formation of the Zollverein in 1834 may have been a salutary economic shock for Germany, but the unification of Italy does not appear to have worked a similar miracle. France regularly experienced political upheavals while Britain's constitutional change was a comparatively tranquil affair. Spain, with fiftyeight governments and eighty-three ministers of public finance between 1868 and 1915 (Platt, 1984: 107), was racked by war and unstable governments, which may have been a cause of lack of development, but at this point indirect tests of Olson's scheme come close to the tautological; the shocks to Spain were obviously not benign. What is needed is some estimation of the pervasiveness and effects of Olson's 'sclerotic institutions'. Pencavel's (1977) estimate of the effects of British unionisation of the coal industry on productivity in the first decade of the twentieth century is supported by a plausible model that fits the data, but the example shows one of the roles of quantification; despite such institutional sclerosis, British income and productivity was generally higher than elsewhere in Europe. Olson's scheme may well have considerable explanatory power without addressing the reasons for differences between European countries and, over time, in incomes per head. 
A variation on the 'new institutionalism' theme is 'path dependence' or 'non-ergodic growth'; a (unique) event, policy or institution (or random shock) in one period changes the state of an economy permanently in the following period. Then, growth is largely determined by events and institutions in previous periods. If this is so, it might seem that no general explanation of economic growth is possible. But still, generalisations may be appropriate for particular regions and epochs. In practice the concept can degenerate to one of the most primitive, though plausible, types of historical explanation, 'post hoc ergo propter hoc'. In the absence of theory, causal ordering is inferred from temporal order. Temporal order does, of course, contain information about causal ordering because (at least ignoring expectations) the arrow of time only flies in one direction. ${ }^{6}$ A possible example of path dependence is the traditional interpretation of nineteenth-century French economic development, which suggests the strong adverse influence of the redistribution of land during the French Revolution (e.g. Caron, 1979: 37). The more egalitarian income distribution and electorally significant numbers in agriculture supposedly encouraged savings patterns and state policies less conducive to industrial growth in France than in Britain. How much can be attributed to these (economically) contingent conditions can be judged from Lévy-Leboyer and Bourguignon's (1990) econometric model. The answer seems to be 'not much'; agriculture was apparently more dynamic than industry, contributing three-quarters of the French economy's growth between 1825 and 1859 (Lévy-Leboyer and Bourguignon, 1990: 226). In this instance, quantification hints at a rather different path dependence from conventional accounts.

Harking back to the earlier literature on European development, recent empirical economic analyses of growth experience for developed countries have been stimulated by a new wave of modelling initiated by Baumol's (1986) attempt to show that there had been a general tendency to convergence since 1870 among GNPs per head of industrial countries. Baumol's thesis was that the US productivity slow down of the 1980s was part of the natural order. An earlier phase of modelling for the post-1945 period had similarly tried to explain British loss of pre-eminence by an inability to take advantage of the productivity gains from reallocating resources from agriculture to industry, because the redistribution had already taken place. This sectoral distinction is at the heart of Arthur Lewis' model of economic development with unlimited supplies of labour. That model formed the basis of many subsequent analyses of economic growth in poorer countries, and Kindleberger (1964) has argued that it is a means of understanding Western European development over a longer period. Only Lévy-Leboyer and Bourguignon's (1990) dual-economy model has taken up the suggestion for the nineteenth century.

Most of these recent models explain the rate of economic growth or the level of income by mean of international cross-section regression or 
sometimes panels. DeLong (1988) showed that extending Baumol's sample beyond the data available in Maddison (1982), in particular including economies such as Argentine and Chile, high income countries in the nineteenth century with poor twentieth-century development records, called into question any tendency for convergence. He also resurrected Weber's thesis by offering a regression in which whether a country was predominantly Protestant determined whether or not it joined the high-income club.

Dowrick (1992) and Dowrick and Gemmel (1991) extended this work for the post-1960 period with more explicit and detailed modelling. Dowrick shows an aggregate production function with 'catch-up' terms explains a significant proportion of inter-country variation in growth rates. He suggests the ability of countries to take advantage of backwardness depended on infrastructure and on population growth. Those countries not showing signs of convergence experienced high population growth and therefore high ratios of young dependants to the total workforce. Dowrick and Gemmell disaggregated into industry and agricultural sectors, finding substantial intersectoral differences in technical progress and disequilibrium in factor markets. Barro (1991) found growth rates in a sample of ninety-eight countries between 1960 and 1985 positively related to 1960 school enrolment rates (a proxy for human capital) and negatively related to the initial level of 1960 real GDP per head, as convergence requires. Barro and Sala-i-Martin (1992) estimated convergence explicitly derived from a neoclassical growth model.

The likelihood is that, among the more fundamental conditions that made 'catching up' a possibility after 1960, and after 1945, was the 'Bretton Woods' regime of fairly liberal trade and monetary relations. This was conducive to the diffusion of techniques, just as was the gold standard period before 1914. In Europe, openness to other European trading partners and to the rest of the world by 1914 had in many cases reached levels comparable to those after 1960. National price changes were not widely dispersed, especially bearing in mind the limitations and comparability of the available index numbers, and intra-European labour flows were substantial; there were more Italian and Belgian workers in France in 1911 than in 1982, if official statistics are to be believed. The similarity between the conditions under liberal gold standard regime and those of the Bretton Woods system and later modifications presents a prima facie case therefore that similar methods of analysis to those employed for the post-1960 years may be appropriate for Europe between 1860 and 1914.

\section{The key variables in European development}

However a good deal of empirical economics is concerned with testing models 'received' from theory and these are not necessarily ideally 


\section{James Foreman-Peck}

adapted for historical explanation. The factors and parameters of the neoclassical production function themselves need explaining; the level of human and physical capital, the fertility of the soil, and perhaps also the size of the labour force, and the adoption of technology. Reference must then be made back to what determines factor supplies and the determinants of the production parameters. The first stage of modelling then is to identify the relevant variables. Figure 15.1 is a classification of the most general causes of economic growth into exogenous and endogenous sets. Technology is at least predetermined, for what can be achieved in a given period is largely dependent upon earlier progress in related technologies. Even such an apparently low-technology development as the safety bicycle of the 1880s depended upon prior metallurgical development in light but strong tubing and for chain links, in (wheel) bearings, in rubber and in pneumatic tyres. ${ }^{7}$ Technology is however embodied in capital, which is certainly an endogenous variable, and to some extent can be advanced by research and development expenditure. Moreover it is extremely difficult to represent in an abstract summary fashion other than through the production function. Assuming rapid diffusion of technical knowledge among European economies, we can treat the most abstract notion of technology as a common element across countries, and embodied in capital with the passage of time. Possibly a difference from American technology was that the European variety, if one existed, was less naturalresource-intensive, was directed to smaller markets and was more skillintensive and so capital-saving (Nelson and Wright, 1992). But here we are only concerned with intra-European technology differences.

Natural resources in the form of coal deposits are (now) a frequently

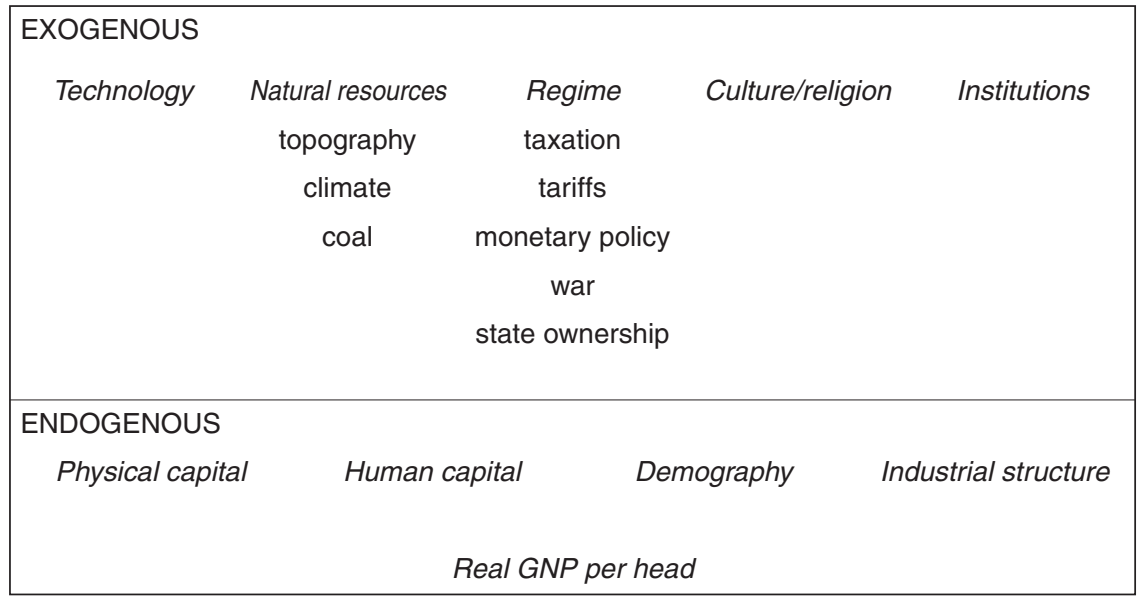

Figure 15.1 Key variables in nineteenth-century European economic development. 
advanced explanation for the pattern of European development in the nineteenth century, determining the availability of power and heat for transport and industrial processes (e.g. Cameron, 1985). Abundant coal allowed precocious development. Trade may or may not have compensated for differential coal endowments. Even within countries, location was a vital influence upon coal prices. Just before the opening of the period of study, in the England of 1843, the coal price in the dearest counties was five times that of the cheapest (Crafts, 1985: 68). Jevons (1906) contended that the price advantage of British coal in the 1860s had been lost to Pennsylvania and matched by Germany by the end of the century. His data show France paying one-third more than her more abundantly coal-endowed European competitors.

If deposits were not exploited, then they could not have contributed to economic growth and therefore production per head of population seems a better indicator of coal resource abundance than deposits. Known deposits are likely to depend upon the intensity of search, which in turn will depend on demand. Although production depends upon infrastructure development, coal output differences between countries are not solely determined by infrastructure but also by geology and trade.

Climate, in particular rainfall at different times of the year and temperature, may be expected to have influenced agricultural productivity, as would soil types. Where rainfall is concentrated in a small number of days, as in Southern Europe, when torrential rain is followed by drought, moisture evaporates in a few hours. By contrast, in Northern Europe, more rainfall over more days with lower temperatures maintains soil moisture, so alfafa, ryegrass and clover grow thick and rich (Azzi, 1956). Cows, sheep and draught animals therefore flourish. Hence, climate is a determinant of the animals-to-land ratio that Slicher van Bath (1963: 282-99) and O'Brien and Keyder (1978) have emphasised as underlying high crop yields. Soil quality is not merely a natural resource; it can be depleted or accumulated by agricultural investment. Hot, dry summers impose a cost in the form of investment in irrigation. On the other hand, higher temperatures alone may allow a greater cash yield per acre. Irrigation and drainage, crop mixes and fertilisers can substitute for nature's deficiencies, but not at zero cost. Countries with more favourable climates would still possess an agricultural productivity advantage. ${ }^{8}$

Most abstract among the more obvious pre-determining variables are culture and religion. Max Weber's thesis that the rational spirit of Protestantism encouraged capitalism found some support from DeLong's 'Protestantism' regression, but a more systematic index would be desirable. There is some French evidence that the nineteenth-century development of religious practices may have influenced the acquisition of reading skills (Caron, 1979: 45). Much later, Protestants in France achieved far higher proportions of top managerial and professional jobs than their minority representation in the French population warranted (Yoshimuri, 
1985). That is consistent with the hypotheses discussed here, but in the absence of more general developments in comparative quantitative religious or cultural history, the presumed consequences of these factors must be employed as potential 'ultimate' - or exogenous - explanations instead. ${ }^{9}$

Quantification of political regimes is easier in some respects than religion and culture. The taxation they impose (both levels and forms), their propensity to wage war, and their monetary arrangements can be statistically summarised and compared across economies. However, aside from tariffs, the different delegations of taxation below central government in practice means that readily available data are likely to measure the degree of federalism as much as the weight of taxation. A genuine measure of democracy in principle is also possible, though requiring considerable work. Much more problematic is the quantification of differences in institutions across Europe, necessitating a great deal of ingenuity in identifying their salient characteristics. That completes the list of noneconomic variables that are exogenous to the model of economic development to be estimated in this chapter.

First among the obvious endogeneous variables is physical capital; higher-income economies create, or have had created for them, more capital. In the later nineteenth century, apart from land and buildings, that meant primarily railways, which for Britain accounted for more capital than the entire manufacturing industry (Feinstein and Pollard, 1988). Capital also embodied new techniques, or rather gross investment in any period did. The second form of produced factor of production is human capital, the education, training, skills and traits embodied in the workforce. The most readily available internationally comparable measure for this period is literacy, as indicated by the bridegroom or bride's ability to sign the marriage register (or by literacy among conscripts or the general population as revealed in census reports).

The structure of industry is yet another endogenous variable, determined by the growth process; with rising incomes, the pattern of demand changes and, as part of the supply response, resources flow to new places of work and activity. These may vary in their productivity potential and so in their contribution to economic development.

\section{Model structure and European characteristics}

Whether there was a common development process across countries and over time can be tested by the significance of the $a_{i}$ parameters for the model in Figure 15.2. A typology aims to predict (but not explain) the characteristic mix $\Sigma_{i} a_{i} X_{i}$ from given values of $Y$ (Chenery and Syrquin, 1975; Crafts, 1984; Molinas and Prados, 1989) while a model predicts or explains $Y i$ from values of $X$. By contrast with a typology, if a causal pattern is identified then it will support counterfactuals; the values of the 


\section{Real GNP per head \\ $Y_{i}$}

Country 1 at beginning of decade 1

$Y_{1}$
pan-European explanatory variables

$X_{i j}$

national peculiarities, policies, events, institutions and measurement errors

Country 2 at decade 1 or Country 1 at decade

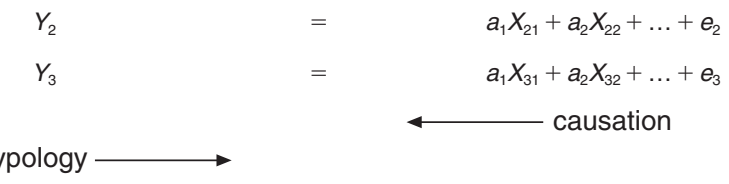

Figure 15.2 A scheme for explaining late nineteenth-century European development.

parameters will not change when the explanatory variables change, either in history or in a thought experiment.

Gerschenkron's notion of substitutes for alleged preconditions of development draws attention to the variety of different values of $X_{i j}$ that are compatible with a given value of $Y$. In this framework, sufficient conditions are easier to model than necessary. ${ }^{10}$ Backwardness or 'catching up' as a positive influence on the potential for raising income can be represented by a term $\left(Y / Y^{*}\right)$ where $Y^{*}$ is the GNP per head of the leader country. But then what is to be explained, $Y$, is also part of the explanation.

The relationships in Figure 15.2 may be either structural or reduced form equations. The reduced form is a summary of a number of explanatory influences, the total impact of the exogenous variables upon the endogenous variable set. It is not the explanation itself, which includes the mutual interaction of endogenous variables as well in the structural equations. What the historian observes or creates is a set of data from which an explanation is constructed. In principle, both structural and reduced form relationships can be fitted to the data to represent the explanations formally. But, although there may be a unique reduced form equation that fits the data best, there will also be a number of alternative structural relations that could be encompassed by that reduced form; a variety of explanations may be consistent with the same body of evidence. Supposing a reduced form indicates that coal availability influenced European nineteenth-century GDP, we may still want to know the channels by which it did so, whether directly through manufacturing consumer goods or indirectly through lowering the costs of capital goods and transport. These last channels would be represented by structural equations. Whether structural parameters can be inferred from the reduced form is 


\section{James Foreman-Peck}

the identification problem. If we are only interested in 'retrodiction', forecasting what would have happened had the exogenous values been different, without explaining, then we need pay no attention to the structural relations and their identification, unless to seek confirmation that the reduced form is correct.

The non-systematic component of the model is represented by random terms, $e_{i}$ (Figure 15.2). In his discussion of why England experienced an industrial revolution before France, Crafts (1977) maintained the values of the relevant $X_{i}$ were similar in the two countries and therefore the explanation was to be sought in the $e_{i}$. If history could be replicated a hundred or a thousand times then, on half of these occasions, France would have been first. The problem in that instance is that we have only one observation. Errors in the measurement of GNP per head are also included in the $e_{i}$.

These disturbance terms are crucial to the estimation of the structure and parameters of the model. Estimated relations are probabilistic; they yield a most probable value and a range of likely values. Desirable properties of parameter estimates are that they should be unbiased relative to the true parameter value, that they should have as low as possible variance around the true value, and that, as the sample size increases, the sampling variance should become smaller and converge on the true value (consistency). These conditions are satisfied by the ordinary least squares (OLS) estimation formula when the error term of the estimated relationship is independent of the explanatory variables. Conceptually the explanatory variables are held constant, while the variable to be explained changes with the value of the random error. When there is simultaneous causation between variables, the observed error term in a single equation is not independent. By implication, a definition of exogeneity of a variable is whether it is uncorrelated with the disturbance term in the equation. If measurement errors are greater at lower income levels, the standard errors of the parameter estimates here will also be biased. ${ }^{11}$

Consistent estimation of the parameters of equations in which endogenous variables are part of the explanation can be achieved by instrumental variables or two-stage least squares. The exogenous variables of the model are used to estimate values of the right-hand-side endogenous variables purged of their error terms, and in the second stage of estimation these new values are entered as independent variables in the structural equation regression. This method may yield different results depending on the variables assumed exogenous in the model, but it does allow the estimation of equations that are over-identified (where more than one set of estimates of structural parameters may be inferred from the reduced form equations).

The basic structure of nineteenth-century European economic development adopted is a production function and three factor supply and demand equations. The aggregate production function explains output 
(GNP) per head of the economy. Data limitations require the assumption that the labour force participation rates do not differ significantly between countries or over the years 1860-1910. Variations in the quality of the labour input, as measured by illiteracy, also are a potentially important contributor to output.

The production function may be thought of as disaggregated between 'traditional' ( $a$ agriculture) and 'modern' ( $m$ urban or manufacturing) outputs. In Figure 15.3 (from Williamson, 1991) a fixed quantity of labour is divided between the demands of the two sectors. When equal wages are paid in each sector then labour is distributed between sectors so as to maximise productivity. The more common position may have been where marginal productivity in the more advanced sector was higher than in agriculture, at $w_{m}$ and $w_{a}$ respectively. An increase in demand for the products of the advanced sector in this model shifts that sector's demand for labour upwards (to $\mathrm{DM}_{2}$ ), but only reallocates labour between the sectors if the marginal productivity gap is not allowed to widen. So long as there is such a gap, labour shifts out of agriculture raise the efficiency of the aggregate production function. Whether agriculture actually had a lower labour productivity on average in Europe may then be tested and the consequences of reallocating labour between sectors may be estimated by including a sectoral distribution of the labour force term in the production function. If the terms of trade shifted against the traditional sector because of cheaper agricultural imports for instance, then the demand for agricultural labour falls, DA shifts leftwards. With the same wage gap,

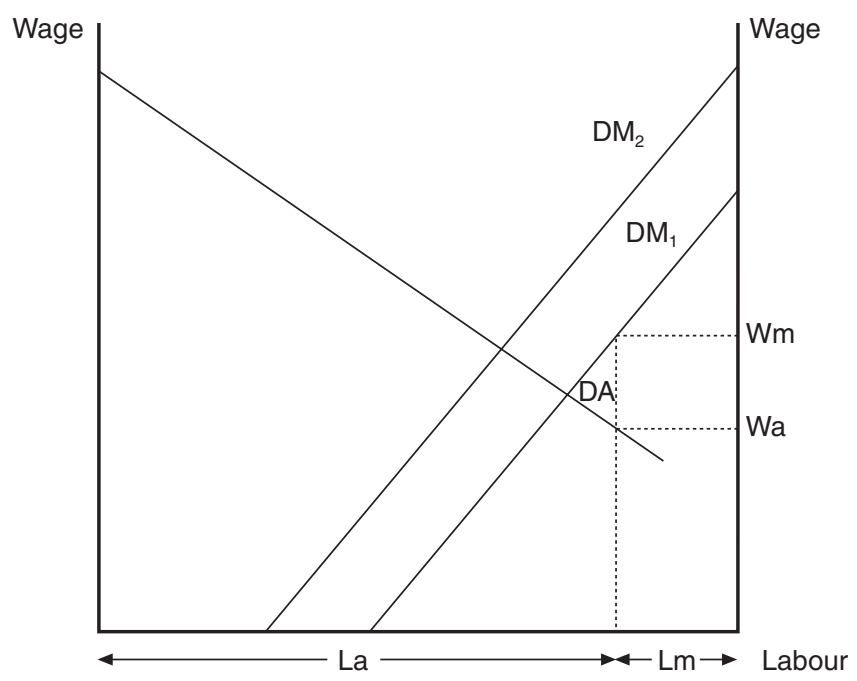

Figure 15.3 Agricultural productivity and the distribution of the labour force. 
output rises as employment in the sector with the higher marginal productivity expands.

Agricultural productivity is likely to have been affected by climate and the proportion of the workforce in agriculture depends upon productivity, for that determines how much can be supplied to the non-agricultural sectors. ${ }^{12}$ The proportion of the workforce in agriculture depends on both the demand for non-agricultural, as well as agricultural, output. Thus, general capital supply, infrastructure and policy variables such as tariffs will influence the ratio.

Railways, modelled in the second structural equation, made the greatest demands upon capital and integrated national markets (O'Brien, 1982). The determinants of national railway sizes can be divided into supply- and demand-side influences. The demand is mainly derived from the production function. Britain was rather exceptional in the proportion of passenger traffic carried on her railways. Large countries had reason to take more advantage of railways, other things being equal, than small. Distances between population centres and natural resource locations were inevitably shorter in small countries and therefore less capital was needed in railways to join them up to create a given productivity level. Railway length is therefore controlled for area in the present model. For two countries with the same-sized railway system, the one with the higher population density would be better served, for willingness to pay for average haul or trip length would be lower; the same number of people can be reached in a smaller area.

The area of a country is also pertinent to foreign trade, for with a given degree of specialisation, division of labour and therefore productivity, a larger country would have less foreign trade. Controlling for country size, openness to foreign trade is a good index of productivity and income per head, but it does not indicate what is responsible for the income per head and therefore adds nothing to the explanation. Railways, by contrast, were the means by which the market was widened and productivity boosted.

Interest rates, as a measure of capital scarcity, presuppose welldeveloped capital markets, which did not exist outside a few Western European economies. Instead there was the international market based in London where national government bonds traded at interest rates which tended to rise with distance eastwards. This spatial pattern depended in part on country risk, on the likelihood of exchange rate depreciation and government default, both of which could be diminished in the eyes of the market by a credible commitment to the gold standard. Guaranteeing national currency convertibility into gold markedly increased the availability of capital from abroad and reduced the cost (Gregory, 1979). ${ }^{13}$

State policy may have influenced the level of literacy by tax-financed schooling, but it is the results of (lagged) literacy or illiteracy that we observe in this specification. Equally, policy may determine the agricultural labour productivity differential or the flow of labour into the 
modern sector, but that will not be identified, nor will the contribution of the state to the spread of railway networks. Tariff protection, the share of the railways owned by the state and general taxation per head might all exercise independent influences on development.

To estimate the model, real output per head data (in 1970 US\$) on up to eighteen European countries at decadal intervals from 1860 and 1910 were assembled. Some of the output per head estimates are at least as controversial as any models that might be used to explain them. While Prados (1992) concludes that, in 1913, Spanish national income per head was far below Italian, Lains' (1998) survey judged that they were very similar. There is as yet no consensus on Portugal's growth experience between 1860 and 1910 (Lains and Reis, 1991). The figures employed here for Greece were taken from Dertilis (1993) (see Foreman-Peck, 1995b, Appendix: 467) and for Romania and Bulgaria in 1913 (as an approximation to 1910) from Gini as transmitted by Lains (1998). For the Kingdom of Austria we use Clark's estimates in Lains (1998: Table A1). New data for Sweden (Krantz, 1988) raises that country in the league markedly, while series for Spain (Prados, 1992) and Portugal (Lains, 1989) lower the output ranking of those two economies. Italian GNP per head was taken from Prados (1992a) and Maddison (1992). Otherwise data is from Maddison (1989) T1.3 and (1982) (the Netherlands, Finland, Switzerland) and those collected in Crafts (1983). ${ }^{14}$ Inevitably there are substantial margins of error in these estimates.

Literacy data are from Flora (1973) with linear interpolations. One difficulty is to find the correct conversion ratio between the three indices, conscript illiteracy, bride and bridegroom illiteracy and general illiteracy as recorded in population censures. Cipolla (1965) however is clear that one exists. There is also a matter of definitions. In nineteenth-century Finland, for instance, the ability to read, although not the ability to write, was widespread (Myllantaus, 1990). Ideally a distinction would be drawn between male and female illiteracy and a range of lags tested (Nuñez, 1990). None the less, the general pattern is clear. Germany and Scandinavia were highly literate. The Netherlands were more literate than Belgium. Britain, by 1870 , was only a little less literate than the Netherlands, and more so than France. Spain was in a worse position than Italy in 1880. In the 1890 s well over 60 per cent of Russian recruits were illiterate, whereas in Italy the figure was under 40 per cent. Literacy is an unambitious indicator of human capital, but it is at least an appropriate direct index, unlike numbers of students or school teachers, whose productivity may vary with time and place.

The proportion of the male labour force occupied in agriculture, forestry and fishing shows the relative strengths of the opposing forces of population pressure and industrialisation (as well as the idiosyncracies of census classifications). Spain's agricultural labour force proportion rose between 1860 and 1877 before falling to Italian levels in 1910. Thanks to 
international specialisation, high-income Denmark's proportion reached a maximum of 50.5 per cent in 1896 compared with low-income Portugal at 65 per cent in 1890. Britain's agricultural workers were only 9 per cent of the total by 1910 .

Denmark, like the Netherlands, was a precocious railway builder between 1860 and 1910, overtaking Spain in the ranking, although by far the densest network at both dates was to be found in Belgium. Coal output per head shows Britain as an outlier, with more than double the 1910 value of her nearest rivals, Germany and Belgium. But low-income Spain mined more than richer Sweden or Italy, and Austria-Hungary more than France. Trade allowed coal consumption per head in Italy by 1910, at 0.29 metric tons, almost to match Spain's consumption of 0.32 metric tons. Ownership of railways, by far the largest use of capital, varied markedly across Europe by 1890 . In Germany almost all were state owned, in France almost all were private. Spanish railways were operated entirely by companies, but about 40 per cent of Italian railways were state operated.

Tariff protection was particularly high in the lowest-income countries, Portugal and Russia. The effects of tariff protection in Portugal from 1890 might be captured by the slower transfer of labour from agriculture consequent upon the tariff influence upon the domestic intersectoral term of trade.

Finally, the willingness to convert the national currency into gold at a fixed rate on demand was a monetary policy option that European governments embraced in larger numbers as the nineteenth century progressed. They clearly believed the gold standard brought economic advantages.

Within countries, climate may vary quite markedly, as between Marseilles and Paris, but generally there are few possible historical observation points - usually national capitals - to choose from (data from Smithsonian Institute, 1927). The variation over the year, or between, say, January and July, is likely to be less sensitive to the location in the country at which it is measured, however, and it is this monthly difference, rather than the annual average, that is likely to matter.

\section{Model estimation and implications}

A good explanation should fit the facts better than other accounts, but should do so parsimoniously and in a manner consistent with knowledge of the way the European economies worked. ${ }^{15}$ The modelling strategy was therefore to adopt the most general specification of an equation (inclusion of as many variables as possible consistent with explanations and theories already advanced) and then test which variables were statistically significant, which zero restrictions could not be rejected. Unfortunately a truly general model would be enormous in view of the range of possible explanatory variables in economic development and the variety of ways in which they might be related. 
The most general representation adopted in this experiment takes the policy variables (tariffs and gold standard membership), illiteracy as an index of human capital, population, and the natural resource variables (temperature, precipitation and coal production - but not consumption) as exogenous. Constant elasticity functional forms are assumed, except in the equation for the proportion of the labour force in agriculture, which is semi-logarithmic.

Four structural relations are estimated; a production function, labour share in agriculture, the determinants of railway size, and an equation for coal consumption. With two or three variables the production function relation explains around 75-80 per cent of the variation in income per head among European countries for which estimates are available between 1860 and 1910 (not reported). Although that leaves a considerable proportion to be explained by measurement error and individual countries' institutions or policies, it is quite satisfactory compared with the fit of empirical models of more recent economic performance. Illiteracy lagged a decade is intended to capture human capital effects. Railways exercised no direct effect on output, once endogeneity was allowed for. The proportion of the male labour force in agriculture measures the impact of the dual economy, which is rather strong. A fall in the agricultural proportion of the workforce from, say, 60 per cent to 50 per cent raises output per head by $[\exp (2.13 \times 0.1)=] 23.7$ per cent.

The direct effect of coal consumption on production is significant when it is (inappropriately) assumed exogenous in estimating the function. But the impact is very small (the elasticity is 0.014 ), and the coefficient is not significantly different from zero at the 95 per cent level of probability when the variable is assumed to be endogenous.

Turning to the factor equations, larger railway networks reduce the proportion of the workforce in agriculture, probably both integrating markets and proxying the growth of industrial capital (not reported). Tariff protection does the opposite, encouraging inefficiency in resource allocation. Wide variations in temperature during the agricultural year, lower soil moisture and impose burdens on agriculture that keeps productivity low, thus raising the workforce proportion employed.

Abundance of coal both creates a need for railways and industrial capital while, at the same time, providing the raw materials necessary for their cheap supply. Membership of the gold standard guaranteed cheap finance and low illiteracy ensured the necessary human capital essential to the capital goods industries.

Coal consumption per head rose slightly more than proportionately with GNP per head because of the prevailing technology. The coefficient of coal production, at 0.195 , indicates that international trade was important in compensating for the lack of coal endowments (equation not reported). A difference in coal production per head between countries of 50 per cent was associated with only a 10 per cent difference in 


\section{James Foreman-Peck}

consumption, other things being equal. Transport from the coal producing areas must have raised coal prices in the consuming areas without coal but, judging by the consumption effect, not apparently by a great deal.

As a check on the possibility of spurious regression the stability of each equation is tested by removing the richest country from the sample. Conventional time-series and cross-section problems are less likely to confound equations estimated on this panel data set.

In order to explain income differences between countries and assess counterfactual possibilities, the system must be solved to yield equations in which only predetermined variables explain the endogenous variables. The relation between the structural and the reduced form equations, where $y$ and $\mathbf{z}$ are respectively the vectors of endogenous and predetermined variables, $\mathbf{B}$ and $\Gamma$, respectively, the coefficient matrices of endogenous and predetermined variables, and $\mathbf{u}$ and $\mathbf{v}$ are error term vectors, may be represented in matrix notation as follows;

$$
\begin{aligned}
& \mathbf{B y}+\Gamma z=\mathbf{u} \ldots(15.1) \text { the structural system, } \\
& \mathbf{y}=-\mathbf{B}^{-1} \Gamma z+\mathbf{v} \ldots(15.2) \text { the reduced forms. }
\end{aligned}
$$

The principle focus of this chapter is on only one row of (15.2), that explaining national output per head, but as (15.1) and (15.2) make apparent, in general that may depend upon all other equations and variables in the system. The structure of model is shown in Figure 15.4. Though it is not particularly original, it has the advantage of being systematically related to the available facts.

Errors in the measurement of the explanatory variables may require the parameter values be interpreted with some caution since they may be biased. Subject to that proviso, we can examine the properties of the model by simulating it, to show for example how a poorly performing

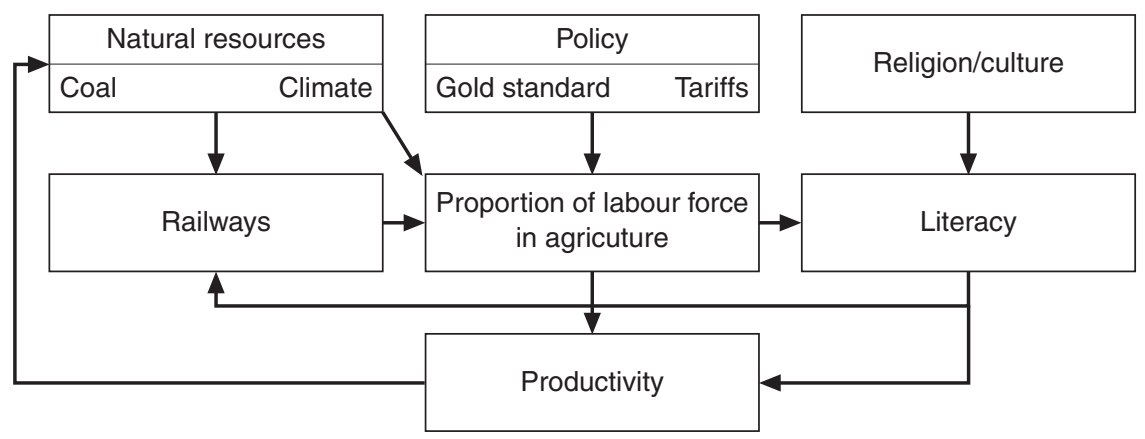

Figure 15.4 The model's structure. 
nineteenth-century European economy, such as Spain, would have developed by 1910 if it had adopted one by one, the policies of the leader economy, Britain, the human capital and the natural resources (Table 15.1). There are two alternative paths, one is to use the reduced form implied by the structural equations, the other is to retrodict with a reduced form estimated directly. The two approaches offer some check on the appropriateness of the model. Although the theoretically correct specification is to explain output per worker, both in the aggregate production function and in the reduced form equation, the loss of degrees of freedom and the diffculties of identifying and standardising workers implied that GNP per head of population was in practice a preferable variable.

The reduced form for GNP per worker implied by the structural equations in logs is:

$$
\begin{aligned}
& \text { Gnp } / \text { pop }=-0.106 \text { illit }-0.212 \text { Tariff }+0.008 \text { Gold }-0.577 \\
& \text { Tempdif }+0.010 \text { Coalprd }-0.045 \text { Area }+0.015 \text { Pop. }
\end{aligned}
$$

Directly estimated reduced forms are;

$$
\begin{aligned}
& \text { Gnp/pop }=-0.121 \text { illit }-0.173 \text { Tariff }+0.007 \text { Gold }-0.384 \\
& \text { Tempdif }+0.022 \text { Coalprd } *+0.013 \text { area } *-0.012 * \text { Pop } \\
& \mathrm{n}=67, \mathrm{R}^{2}=0.77, \mathrm{LM}=1.78
\end{aligned}
$$

Structural break $\mathrm{F}$ test for exclusion of the UK; $\mathrm{F}=2.32 ., \mathrm{F}_{0.01}^{\mathrm{c}}=3.15$;

$$
\begin{aligned}
& \text { Gnp/pop }=-0.121 \text { illit }-0.176 \text { Tariff }+0.007 \text { Gold }-0.215 \\
& \text { Tempdif }+0.016 \text { Coalprd }-0.025 \text { Area* }+0.010^{*} \text { Pop }+0.018 \text { UK } \\
& \mathrm{n}=67, \mathrm{R}^{2}=0.834, \mathrm{LM}=1.84 . \\
& \text { Gnp/pop }=-0.099 \text { illit }-0.150 \text { Tariff }+0.007 \text { Gold }-0.253 \\
& \text { Tempdif }+0.064 \text { July rain }+0.010 \text { Coalprd } *-0.028 \text { Area* }+0.019 * \\
& \text { Pop }+0.017 \text { UK } \\
& \mathrm{n}=56, \mathrm{R}^{2}=0.85, \mathrm{LM}=1.42 . \\
& * \text { indicates not significant at the } 5 \text { per cent level. }
\end{aligned}
$$

The reduced form illiteracy elasticity of output per head or worker is around 0.1 . The coefficient on the metallic standard of 0.007-0.008 implies little gain in output from adhering to the standard (but the apparent gain is large if a binary measure instead of a duration-related specification is adopted). The soil moisture proxy, temperature variation, elasticity is large, between 0.21 and 0.58 , and the upper end of the range is favoured when the July rainfall measure supplements temperature difference. The coal production elasticity is invariably small, around $0.01-0.02$, in contradiction to those accounts that regard the presence or absence of coal deposits as 
central to nineteenth-century economic development. The UK dummy captures the historical legacy that contributed to the low proportion of labour in the agricultural sector by the beginning of the period.

There are two reasons why the model does not fit the data exactly, and therefore why the model does not predict precisely the output per head of later-nineteenth-century Spain or Britain; errors in the measurement of output and unique national policies or characteristics. However a comparison can be made independently of these unique influences by calculating the sequential contributions of the exogenous variables as proportions of the measured Spanish-UK output differential (Table 15.1). Since country characteristics may be positive or negative, even if Spain adopted UK values for all exogenous variables in the model the differential would not be exactly explained; it may be over- or under-determined, depending on the net impact of the two country-specific factors.

The five variables explain more than half of the measured difference in output per head of population in 1880. The remainder of the Spanish-UK differential is left to be explained by differences in institutions, policies and other characteristics not captured by this model, as well as by measurement errors. The two approaches, structural and reduced form, indicate that nineteenth-century liberal economic policies, represented by low tariffs (but not by a more persistant commitment to the gold standard) would have raised output by head per head by one-fifth. Natural resources, as measured in the present model, were important in 1880. Coal and weather gave Britain a $40-45$ per cent advantage over Spain. The cultural inheritance as captured by literacy rates mattered much less in

Table 15.1 Proportionate increase in Spanish GNP per head in 1880 and 1910 if Spain achieved UK values of exogenous variables (\%)

\begin{tabular}{|c|c|c|c|c|}
\hline & \multicolumn{2}{|l|}{1880} & \multicolumn{2}{|l|}{1910} \\
\hline & $\begin{array}{l}\text { Direct } \\
\text { reduced form }\end{array}$ & $\begin{array}{l}\text { From } \\
\text { structural } \\
\text { model }\end{array}$ & $\begin{array}{l}\text { Direct } \\
\text { reduced form }\end{array}$ & $\begin{array}{l}\text { From } \\
\text { structural } \\
\text { model }\end{array}$ \\
\hline Illiteracy & 9.4 & 8.8 & 24.7 & 22.9 \\
\hline Tariffs & 20.5 & 22.5 & 20.4 & 22.3 \\
\hline Gold Standard & 0.6 & 0.5 & 1.0 & 0.7 \\
\hline $\begin{array}{l}\text { Soil moisture } \\
\text { (temperature variation } \\
\text { and July rainfall) }\end{array}$ & 40.7 & 36.5 & 50.0 & 46.6 \\
\hline Coal production & 4.5 & 3.3 & 3.7 & 2.7 \\
\hline
\end{tabular}

Notes

Calculated by exponentiating the difference between values of logged variables for UK and Spain multiplied by regression coefficients. The impact of the gold standard depends critically upon whether duration on the standard matters (and persists), assumed here, or on whether there was once and for all impact. In the second case the effect becomes comparable to the tariff. 
1880. Perhaps Spain would have gained an extra 10 per cent of output per head with British levels of literacy. Further investigation with longer lags and literacy disaggregated between males and females (Nunez, 1990) may change this result however.

By 1910, liberal economic policies still dominated the sources of the output gap. The contribution of the literacy gap had more than doubled and the climatic handicap had also increased. The proportionate impact of tariff policies on the income gap remained unchanged between the two dates at around a substantial 20 per cent.

\section{Conclusion}

The results of the preceding section suggest that there is a causal pattern to nineteenth-century European economic development. An advantage of the present approach is that the model is both simple and sufficiently general to encompass many earlier explanations. With so many countries and so many possible relevant variables, the direct processing limitations of the mind require support from formal methods to sort the specifications that fit historical experience from those that do not. Simplicity, rather than exhaustive descriptive accuracy, is essential to address the range of economic data generated by nineteenth-century Europe. At the same time, the model offers a partial account of why there were leader and follower economies and the sources of catching up and falling behind, rather than merely describing the pattern. By identifying the relative contribution of variables to output per head, the model allows a distinction between equally attractive alternative, and inferior, roads to development. At the same time the approach can cast light on a variety of apparently competing explanations; those based on politics, on institutions, on coal and on literacy. Certain policies (particularly low tariffs) are clearly associated with stronger economic performance, and may even be more pervasive. That does not preclude a contribution from literacy. Despite the pervasiveness of coal as a source of energy and heat, possession of coal deposits do not seem to have mattered a great deal for economic development. Judging by the proportion of output per head not accounted for by the model, national institutions and other (non-tariff and gold standard) policies retain a large role in explanations of nineteenth-century development. Other, higher-level, models may subsume the present attempt. So, in a more general structure, economic policies may be endogenous; tariffs or membership of the gold standard may be explained by lagged economic or current political variables for instance. At the limit, the more general model might depend only on past unique events and it becomes akin to path-dependent or non-ergodic growth models.

Because of the probabilistic parameter estimation, the conclusions do not require the national output measures be free from errors, nor is the 
model proposed here anything more than a beginning. That the units of observations are not internally homogenous does not invalidate the exercise. All that is required is that differences between national economies be greater than those within, a condition that is suggested by the long-term consequences of national policies, institutions and culture, which have shaped nationally distinctive European economic styles. Undoubtedly more precise indicators of both dependent and independent variables are necessary; regional indicators could greatly improve the data set. There is a danger that some important variables, such as general taxation per head, are excluded from the model because their measures are too imperfect rather than because they lack explanatory power. But to ignore what is currently available is to fail to recognise the provisional nature of all scientific results.

To summarise the qualitative conclusions, the proximate determinants of output per head differences between European countries and over the years 1860 and 1910 were the proportion of the labour force working in agriculture, the literacy rate, the density of the railway network (which may be a proxy for all physical capital or merely capture the indirect as well as the direct effect of railways); that is, the stock of physical and human capital and the structure of economic activity. Railways and physical capital were influenced by whether a country was on the gold standard or not and by national coal endowment. The proportion of the workforce in agriculture, reflecting agricultural productivity, depended upon tariff protection and the variability of temperature over the year. So, in the present model, the ultimate determinants of European nations' output per head were climate, tariff protection, very marginally the gold standard, coal and literacy, together with other country-specific factors and perhaps variables not considered in this analysis. The background conditions of the model and the counterfactuals it supports are the state of technology, society and institutional environment of later-nineteenthcentury Europe, and therefore the applicability of the structure and conclusions to other places and times remains an open question.

\section{Notes}

1 This is a slightly different version of 'A model of later-19th-century European economic development', published in Revista de Historia Económica, XIII, 3 (1995), pp. 441-71.

2 Then at St Antony's College Oxford, now Cardiff University Business School, Colum Drive, Cardiff CF10 3EU. Earlier versions of this chapter were given as a lecture at the Instituto Mori, Mexico City, July 1992 and at the European Historical Economics conference on 'Long term economic growth in the European periphery', at Pazo de Marinan July 1993, the Social Science History Association meeting at Baltimore 1993, and seminars at Reading, Oxford and Exeter.

3 Lains' (1998) examination of the reliability of GDP estimates for 1913 shows a similar range of variation in that year. The widening gap is probably a 
consequence of the increasing range of countries in the sample. In the early years of the period, few estimates for the low-income economies were available. Thus, although the gap has persisted for many earlier decades, it was only in 1906 that Prokopovitch began a vigorous debate on Russian economic development with his claim that English income per head was four-and-half-times Russia's (Studenski, 1958: 145-6). Gregory's (1982) figures suggest Russian real national income per head grew by 60 per cent $1860-1910$, but stagnated for the first thirty years. The British growth figure was very similar. So the Russian-UK gap had probably been greater in the 1870s.

4 Gerschenkron's representation focused on industrial production, whereas Rostow referred to GDP.

5 On the other hand, subsequent revision of Swedish national income estimates has cast doubt on the extent to which Sweden was poor in the nineteenth century (Krantz ,1988), and thus calls into question the role of her substantial human capital in causing high economic growth.

6 An observation on which the econometrics of Granger causality places great weight.

7 The limitations of the 'Ordinary' or 'Penny-farthing' show just how necessary these advances were - the tendency of front wheel bearings to seize at speed, throwing the rider over the handlebars, and the athletic prowess necessary even to get into the saddle.

8 I am grateful to Francesco Galassi for discussion and correspondence on these points.

9 That culture and religion were closely intertwined is shown by the two early European novels of the seventeenth century, Cervantes' Don Quixote, and Bunyan's Pilgrims Progress. Bunyan's protestant-influenced novel is closely based on the Bible and, as the title suggests, is an allegory of personal development (in twentieth-century language), whereas Cervantes' story is gently ironic fun. Personal Bible reading was integral to Protestantism, and that must have encouraged literacy, as Sandberg (1982) suggests, whereas in forms of worship influenced by Roman Catholicism, the Bible was listened to collectively, not read by individuals.

10 Even such a simple model can be used to expose the weakness of Weber's (1961: 258-60) demonstration of the causes of the rise of capitalism. His argument has the form: $X 1 \ldots X 4$ are all associated with $Y$ in the West, but we can find cases where $X 1 \ldots X 3$ are not associated with $Y$ elsewhere. Therefore $X 4$ must be the cause. It was not population growth $(X 1)$, because population grew in China without having that effect, it was not the inflow of precious metal from the New World (X2) because a comparable inflow to India from the Roman Empire did not cause Indian capitalism, it was not the geography of European rivers (X3) and the inland sea of the Mediterranean because capitalism did not emerge under the Greek and Roman Empires. Instead it was the rational spirit which gave rise to the rational enterprise, accounting, technology and law. But we might imagine that if, say, $X 1$ and $X 2$, or even $X 5$, took a number of different values (they were not merely binary), then $Y$ might have been different in the rest of the world also, and that the association between $Y$ and $X 4$ was merely a matter of chance or even reverse causation.

11 And so tests for heteroscedasticity are necessary.

12 Direct measures of agricultural productivity are no less uncertain than GDP estimates. O'Brien and Prados (1992) estimate Spain's agricultural labour productivity falls between 68.1 per cent and 106.7 per cent of Italy's.

13 Adherence to the silver standard in the early part of the period may have been helpful for countries concerned to attract French capital. 
14 Other countries included in the eighteen country data set not mentioned explicitly in the paragraph are Belgium, Denmark, France, (post-unification) Germany, Russia, Norway and the United Kingdom. The conversion between different bases uses the United Kingdom's output as the 'numeraire'. As Lains (1998) points out, this conversion may be a source of error if the United Kingdom estimate is incorrect. Crafts' output figures are for GNP, whereas Maddison's are for GDP. British GDP exceeded GNP. Yet the GDP per head implied by Maddison's (1982) TA3 and the output and population series suggest a slightly higher figure for 1910 than Crafts' $\$ 1,320$ $(\$ 68,082 \times 0.922) / 44.916=\$ 1,397$. In both cases the entire United Kingdom is the unit of observation, including Ireland.

15 David Hendry's econometric method suggests the procedure here (e.g. Gilbert, 1986). 


\section{References}

Abramovitz, Moses (1986) "Catching up, forging ahead, and falling behind", Journal of Economic History, 46, 2, 385-406.

Alegria, F. (1988) "Análise geográfica do transporte de mercadorias nos caminhos de ferro portugueses no século XIX”, Análise Social, 24, 769-803.

Allen, Robert C. (2000) "Economic structure and agricultural productivity in Europe, 1300-1800", European Review of Economic History, IV, 1, 1-25.

Anderson, James E. (1994) "The theory of protection", in D. Greenaway and L. A. Winters (eds) Surveys in International Trade, Oxford, Basil Blackwell, pp. 107-38.

Anderson, James E. (1995) "Tariff index theory", Review of International Economics, $3,2,156-73$.

Anderson, James E. (1998) "Trade restrictiveness benchmarks", Economic Journal, 108, July, 1111-25.

Anderson, James E. and Neary, J. Peter (1992) "Trade reform with quotas, partial rent retention, and tariffs", Econometrica, 60, 1, 57-76.

Anderson, James E. and Neary, J. Peter (1994a) "Measuring the restrictiveness of trade policy", World Bank Economic Review, 8, 2, 151-69.

Anderson, James E. and Neary, J. Peter (1994b) "The trade restrictiveness of the multi-fibre arrangement”, World Bank Economic Review, 8, 2, 171-89.

Anderson, James E. and Neary, J. Peter (1996) "A new approach to evaluating trade policy", Review of Economic Studies, 63, 107-25.

Andrade, Anselmo de (1902) Portugal Económico (Manuel Gomes, editor), Lisbon.

Anonymous (1879) O Futuro dos Trabalhadores e da Indústria em Portugal sob a Influência das Pautas das Alfândegas, Porto.

Arana Perez, I. (1988) "El empresariado siderometalúrgico vasco y la Ley de septiembre de 1896", Actas del II $^{\circ}$ Congreso Mundial Vasco, San Sebastian, vol. V.

ARANCEL (1960) "El arancel en la economía española", Información Comercial Española, 322 (June).

Ark, Bart van (1993) International Comparisons of Output and Productivity, Groningue, Groningen Growth and Development Centre, Monograph Series No. 1.

Azzi, G. (1956) Agricultural Ecology, London, Constable.

Baack, B. D. and Ray, E. J. (1983) "The political economy of tariff policy: a case study of the United States", Explorations in Economic History, 20, 73-93.

Bairoch, Paul (1972) "Free trade and european economic development in the 19th century", European Economic Review, 3, 3, 211-45. 
Bairoch, Paul (1976a) Commerce extérieur et développement économique de l'Europe au XIXe siècle, Paris, The Hague, Mouton.

Bairoch, Paul (1976b) "Europe's gross national products 1800-1975", Journal of European Economic History, 5, 273-340.

Bairoch, Paul (1981) "The main trends in national economic disparities since the Industrial Revolution”, in P. Bairoch and M. Lévy-Leboyer (eds) Disparities in Economic Development Since the Industrial Revolution, London, Macmillan.

Bairoch, Paul (1989) "European trade policy, 1815-1914", in Peter Mathias and Sidney Pollard (eds) The Cambridge Economic History of Europe, VIII, Cambridge, Cambridge University Press, pp. 1-160.

Bairoch, Paul (1991) "How and not why? Economic inequalities between 1800 and 1913: some background figures", in Jean Batou (ed.) Between Development and Underdevelopment. The Precocious Attempts at Industrialization in the Periphery, 1800-1870, Geneva, Droz.

Bairoch, Paul (1996) Economics and World History: Myths and Paradoxes, Brighton, Harvester Wheatsheaf.

Bairoch, Pierre (1970) "Commerce extérieur et développement économique: quelques enseignements de l'expérience libre-échangiste de la France au XIXe siècle", Revue Economique, v21, 1, 1-33.

Balassa, B. (1971) "Effective protection in developing countries", in J. N. Bhagwati, R. W. Jones, R. A. Mundell and J. Vanek (eds) Trade, Balance of Payments and Growth. Papers in Honour of C. P. Kindleberger, Amsterdam, North-Holland.

Balassa, Bela (1964) "The purchasing power parity doctrine: a reappraisal”, Journal of Political Economy, 72, 584-96.

Balassa, Bela (1965) "Tariff protection in industrial countries: an evaluation", Journal of Political Economy, 73 573-94.

Baldwin, Robert E. (1969) "The case against infant industry protection", Journal of Political Economy, 77, 295-305.

Bardini, Carlo Albert Carreras and Lains, Pedro (1995) "The national accounts for Italy, Spain and Portugal”, Scandinavian Economic History Review, 43, 1, 115-46.

Barro, R. (1991) "Economic growth in a cross-section of countries", Quarterly Journal of Economics, 106, 407-43.

Barro, R. and Sala-i-Martin, X. (1992) "Convergence", Journal of Political Economy, 100, 223-51.

Barro, R. and Sala-i-Martin, X. (1995) Economic growth, New York, McGraw-Hill.

Basch, A. (1944) The Danube Basin and the German Economic Sphere, London, Kegan Paul, Trench \& Trubner.

Bastiat, Frédéric (1854) Ce qu'on voit et ce qu'on ne voit pas, Paris, Romillat.

Batista, D. et al. (1997) "New estimates for Portugal's GDP 1910-1958”, História Económica, 7.

Baumol, W. J. (1986) "Productivity growth, convergence, and welfare: what the long-run data show", American Economic Review, 76, 5, 1072-85.

Baumont, Maurice, Lacour-Gayet, Jacques and Naudin, Paul (1952) Le commerce depuis le milieu du XIXe siècle, Paris, LGDJ.

Beenstock, M. and Warburton, P. (1983) "Long-term trends in economic openness in the United Kingdom and the United States", Oxford Economic Papers, 35, 132-5.

Benaerts, Pierre (1933) Les origines de la grande industrie allemande, Paris, Turot.

Berend, I. T. and Ránki, G. (1982) The European Periphery and Industrialization, 1780-1914, Cambridge, Cambridge University Press. 
Berend, I. T. and Ránki, G. (1974) Economic Development in East-central Europe in the Nineteenth and Twentieth Centuries, New York, Columbia University Press.

Berov, L. (1979) "Wages in the Balkan lands during the period of manufacturing capitalism and the industrial revolution", Bulgarian Historical Review, 4, 91-115.

Berov, L. (1985) "The effect of the west European economy on the market conditions in the Balkan countries in the nineteenth and the early twentieth centuries”, Etudes Balkaniques, 1, 22-38.

Berov, L. (1987) "Trends in the level and structure of the incomes of the working people in the Balkan countries in the eighteenth and nineteenth centuries up to 1912", Bulgarian Historical Review, 4, 65-83.

Berov, L. (1996) "The industrial revolution and the countries of south-eastern Europe in the nineteenth and early twentieth centuries", in M. Teich and R. Porter (eds) The industrial Revolution in National Context, Cambridge, Cambridge University Press.

Board of Trade (1904) British and Foreign Trade and Industrial Conditions, London, HMSO.

Böhme, Helmut (1967) Deutschlands Weg zur Großmacht, Cologne, Kiepenheuer \& Witsch.

Bondi, Gerhard (1958) Deutschlands Aussenhandel 1815-1870, Berlin, Akademie Verlag.

Bonifacio, M. Fátima (1984) “1834-1842: a Inglaterra perante a evolução política portuguesa (hipóteses para a revisão de versões correntes)", Análise Social, 20, $467-88$.

BPP (1905) "The comparative incidence of foreign and colonial import tariffs of the principal classes of manufactures exported from the United Kingdom”, British Parliamentary Papers, 94, 354.

Broadberry, Stephen (1997) The Productivity Race. British Manufacturing in International Perspective 1850-1990, Cambridge, Cambridge University Press.

Broadberry, Stephen (2003) "Human capital and productivity performance: Britain, the United States and Germany, 1870-1990", in Paul A. David and Mark Thomas (eds) The Economic Future in Historical Perspective, Oxford, Oxford University Press, pp. 103-33.

Broadberry, Stephen and Fremdling, Rainer (1990) "Comparative productivity in British and German industry 1907-1937”, Oxford Bulletin of Economics and Statistics, 52, 4, 403-22.

Broadberry, Stephen N. (1998) "How did the United States and Germany overtake Britain? A Sectoral analysis of comparative productivity levels, 1870-1990", Journal of Economic History, 58, 2, 375-407.

Brown, Lucy (1958) The Board of Trade and the Free Trade Movement 1830-42, Oxford, Clarendon Press.

Burhop, Carsten and Wolff, Guntram B. (2005) "A compromise estimate of German NNP 1815-1913 and its implications for growth and business cycles", Journal of Economic History, 55 (forthcoming).

Cameron, Gavin, Proudman, James and Redding, Stephen (1999) "Openness and its association with productivity growth in UK manufacturing industry", Bank of England Working Paper Series no. 104.

Cameron, Rondo E. (1985) "A new view of European industrialisation”, Economic History Review, 38, 1-23. 


\section{References}

Cameron, Rondo E. (1989) A Concise Economic History of the World, New York and London, Oxford University Press.

Campos, Ezequiel de (1913) A Conservação da Riqueza Nacional, Porto.

Capie, Forrest (1983) "Tariff protection and economic performance in the 19th century", in J. Black and L. A. Winters (eds) Policy and Performance in International Trade, London, Macmillan, pp. 1-24.

Capie, Forrest (1994) Tariffs and Growth. Some Illustrations from the World Economy, Manchester, Manchester University Press.

Caron, François (1979) An Economic History of Modern France, London, Macmillan.

Carr, Raymond (1990) España 1808-1975, Barcelona, Ariel.

Carreras, Albert (1984) "La producción industrial española 1842-1981: la construcción de un índice anual”, Revista de Historia Económica, 2, 1, 127-57.

Casaca, P. Martins (1987) "Sete falsas hipóteses sobre a campanha do trigo", in António Costa Pinto et al. (eds) O Estado Novo: Das Origens ao Fim da Autarcia, 1926-1959, vol. 1, Lisbon, Fragmentos.

Cassing, J., McKeown, T. J. and Ochs, J. (1986) "The political economy of the economic cycle”, American Political Science Review, 80/3, September, 843-62.

Chandler, Alfred (1990) Scale and Scope: the Dynamics of Industrial Capitalism, Cambridge, MA, Belknap Press of Harvard University.

Chenery, H. B. and Syrquin, M. (1975) Patterns of Development 1950-1970, London, Oxford University Press.

Cipolla, Carlo M. (1965) Literacy and Development in the West, Harmondsworth, Middlesex, Penguin.

Clapham, John (1936) The Economic Development of France and Germany, 1815-1914, 4th edn, Cambridge, Cambridge University Press.

Clark, C. (1951) The Conditions of Economic Progress, London, MacMillan.

Clemens, Michael A. and Williamson, Jeffrey G. (2001) "A tariff-growth paradox? Protection's impact the world round 1875-1997”, NBER Working Paper, No. 8459 .

Collins, W. J. and Williamson, J. G. (1999) "Capital goods prices, global capital markets and accumulation 1870-1950", NBER Historical Paper, No. 116 (February).

Collins, W. J., O'Rourke, K. H. and Williamson, J. G. (1997) "Were trade and factor mobility substitutes in history?”, NBER Historical Paper, No. 6059 (June).

Comin, F. (1985) Fuentes Cuantitativas para el estudio del sector público en España 1801-1980, Madrid, IEF.

Comin, F. (1987) "La economía española en el período de entreguerras (1919-1935) - el siglo XX”, in J. Nadal, A. Carreras and C. Sudriá (eds) La economía española en perspectiva histórica, Barcelona, Ariel, pp. 105-49.

Comin. F. (1993) "Política fiscal y proteccionismo en España, La economía política del proteccionismo", Fifth Congress of the Economic History Association, San Sebastián, 29 September to 1 October.

Committee on Trade and Industry (1925) Survey of Overseas Markets, London, HMSO.

Consejo de Economia Nacional (1925) Aranceles de aduanas para la Península e Islas Baleares y repertorio para su aplicación, Madrid.

Conselho-Geral das Alfândegas (1879) Relatório dos Trabalhos Desempenhados nos Anos de 1876 e 1877, Lisbon, Imprensa Nacional.

Corden, W. Max (1966) "The structure of a tariff system and the effective protective rate", Journal of Political Economy, 74, 221-37. 
Corden, W. Max (1971) The Theory of Protection, Oxford, Clarendon.

Cortés Conde, Roberto (1993) "The growth of the Argentine Republic, c.1870-1914", in Leslie Bethell (ed.) Argentina since Independence, New York, Cambridge University Press, pp. 25-83.

Costas, A. (1988) Apogeo del liberalismo en "La Gloriosa". La reforma económica del Sexenio liberal (1868-1874), Madrid, Siglo XXI de España.

Crafts, N. F. R. (1977) "Industrial revolution in England and France: some thoughts or the question, 'Why was England First?’”, Economic History Review, 30, 429-41.

Crafts, N. F. R. (1983) "Gross national product in Europe, 1870-1910: some new estimates", Explorations in Economic History, 20, 387-401.

Crafts, N. F. R. (1984) "Patterns of development in nineteenth-century Europe", Oxford Economic Papers, 36, 438-58.

Crafts, N. F. R. (1985) British Economic Growth During the Industrial Revolution, Oxford, Clarendon Press.

Crucini, M. J. (1994) "Sources of variation in real tariff rates: the United States 1900-1940”, American Economic Review, 84, 3, June, 732-43.

Dakhlia, Sami and Nye, John V. C. (2004) "Tax Britannica: nineteenth-century tariffs and British national income”, Public Choice, December, 121, 309-33.

Damjanov, S. (1979) "Sur le développement industriel du sud-est européen a la fin du XIXe et au début du XXe siècles”. Études Balkaniques, 4, 3-30.

Damjanov, S. (1980) "Sur l'importance des investissements nationaux et étrangers dans l'industrie du sud-est européen (fin du XIXe - début du XXe siècles)", Études Balkaniques, 5, 60-73.

Daunton, Martin (2001a) Trusting Leviathan: the politics of taxation in Britain, 1799-1914, Cambridge, Cambridge University Press.

Daunton, Martin (2001b) "The politics of British Taxation from the Glorious Revolution to the Great War", Paper presented at the conference on "The Formation and Efficiency of Fiscal States in Europe and Asia 1500-1914", Madrid 21-23 June 2001.

David, Paul A. (1970) "Learning by doing and tariff protection: a reconsideration of the case of the ante-bellum United States cotton textile industry", Journal of Economic History, 30/3, 521-601.

Dawson, William H. (1904) Protection in Germany, London, P. S. King.

Deane, P. (1965) The First Industrial Revolution, Cambridge, Cambridge University Press.

Deardorff, Alan V. (1984) "Testing theories and predicting trade flows", in R. W. Jones and P. B. Kenen (eds) Handbook of International Economics, Amsterdam, Elsevier Science Publishers, vol. I, pp. 467-517.

Dedinger, Béatrice (1992) Le commerce extérieur de l'Allemagne, 1871-1939. L'incidence respective des facteurs politiques et économiques, Paris, PhD, Institut d'Etudes Politiques.

DeLong, Bradford (1988) "Productivity growth, convergence and welfare: comment", American Economic Review, 79, 1138-59.

DeLong, Bradford and Summers, Lawrence H. (1991) "Equipment investment and economic growth", Quarterly Journal of Economics, 106/2, 445-502.

Dertilis, G. (1993) Atelesforoi i telesforoi? Taxes and Political Power in Modern Greece, Athens, Alexandreia Press.

Dijol, Marcel (1910) Le tarif douanier de 1892 et la situation économique de la France, Montpellier, Firmin et Montane. 
Diouritch, G. (1919) "A survey of the development of the Serbian (southern Slav) nation: an economic and statistical study", Journal of the Royal Statistical Society, 82, 3, 293-334.

Dohan, M. R. (1991) "Foreign trade", in R. W. Davies (ed.) From Tsarism to the New Economic Policy, Ithaca NY, Cornell University Press, pp. 212-34.

Dollar, David (1992) "Outward oriented developing economies really do grow rapidly. Evidence from 95 LDCs, 1976-85”, Economic Development and Cultural Change, 40, 523-44.

Dormois, Jean-Pierre (1997) L'économie française face à la concurrence britannique avant 1914, Paris, L'Harmattan.

Dormois, Jean-Pierre (2004) "Episodes in catching up. Anglo-French productivity differentials in industry in 1930", European Economic History Review, 8, 1-37.

Dormois, Jean-Pierre (2006) La Défense du travail national. Les effets du protectionnisme sur l'industrie en Europe (1870-1914), Paris, PUPS.

Dormois, Jean-Pierre and Dintenfass, Michael (eds) (1998) The British Industrial Decline, London, Routledge.

Dowrick, S. (1992) "Technological catch up and diverging incomes: patterns of economic growth 1960-1988”, Economic Journal, 102, 600-10.

Dowrick, S. and Gemmel, N. (1991) "Industrialisation, catching up and economic growth: a comparative study across the world's capitalist economies", Economic Journal, 101, 263-75.

Dumke, Rolf (1994) German Economic Unification in the 19th Century: the Political Economy of the Zollverein, Munich, Universität der Bundeswehr.

Dunham, Arthur L. (1930) The Anglo-French Treaty of Commerce of 1860 and the Progress of the Industrial Revolution in France, Ann Arbor, University of Michigan Press.

Easterlin, Richard A. (1971) "A note on the evidence of history", in C. A. Anderson and M. J. Bowman (eds) Education and Economic Development, London, Frank Cass, pp. 422-9.

Edwards, Sebastian (1992) "Trade orientation, distortions and growth in developing countries", Journal of Development Economics, 39, 1, 31-57.

Edwards, Sebastian (1993) "Openness, trade liberalisation, and growth in developing countries”, Journal of Economic Literature, 31, 3, 1358-93.

Edwards, Sebastian (1998) "Openness, productivity and growth: what do we really know?” Economic Journal, 108, 383-98.

Elbaum, Bernard and Lazonick, William (eds) (1986) The Decline of the British Economy, Oxford, Clarendon Press.

Estevadeordal, Antoni (1993) "Historical essays on comparative advantage", $\mathrm{PhD}$ thesis, Cambridge, MA, Department of Economics, Harvard University.

Estevadeordal, Antoni (1997) "Measuring protection in the early twentieth century", European Review of Economic History, 1, 89-125.

Evans, I. L. (1924) The Agrarian Revolution in Romania, Cambridge, Cambridge University Press.

Federico, Giovanni and O'Rourke, Kevin (2000) "Much ado about nothing? Italian trade policy in the 19th century", in J. G. Williamson and S. Pamuk (eds) The Mediterranean Response to Globalization before 1950, London, Routledge, pp. 269-96.

Federico, Giovanni and Tena, Antonio (1998) "Was Italy a protectionist country?", European Review of Economic History, 2, 73-97. 
Federico, Giovanni and Tena, Antonio (1999) "Did Italy foster Italian industrialization? Evidence from effective protection rates 1870-1930", Research in Economic History, 19, 111-38.

Feenstra, R. C. (1995) "Estimating the effects of trade policy", in G. Grossman and K. Rogoff (eds) Handbook of International Economics, 3, Amsterdam, Elsevier North-Holland, pp. 1553-92.

Feinstein, Charles H. (1972) National Income, Expenditure, and Output in the United Kingdom, 1855-1965, Cambridge, Cambridge University Press.

Feinstein, Charles H. and Pollard, S. (eds) (1988) Studies in Capital Formation in the United Kingdom 1750-1920, Oxford, Clarendon Press.

Feis, H. (1930) Europe, the World's Banker, 1870-1914, New Haven, CO: Yale University Press.

Fellner, Friedrich (1916) "Das Vokkseinkommen Österreichs und Ungarns", Statistische Monatschrift Neue Folge, vol. 21, pp. 485-625.

Fenoaltea, Stefano (1988) "International resource flows and construction movements in the Atlantic economy: the Kuznets cycle in Italy", Journal of Economic History, 48, 605-37.

Fenoaltea, Stefano (1992) "Il valore aggiunto dell'industria", in Giorgio Rey (ed.) I conti economici dell'Italia, vol. II, Rome-Bari, Laterza, pp. 105-90.

Fenoaltea, Stefano (2005) "The growth of the Italian economy 1861-1913: preliminary second-generation estimates", European Review of Economic History, 9, 3, 273-312.

Fenoaltea, Stefano and Bardini, Carlo (2000) "Il valore aggiunto dell'industria per gli anni 1891, 1938 e 1951”, in Giorgio Rey (ed.) I conti economici dell'Italia, vol. III, Rome-Bari, Laterza, pp. 112-228.

Fisher, D. and Thurman, W. N. (1989) "Sweden's financial sophistication in the nineteenth century", Journal of Economic History, 49, 621-34.

Fitzpatrick, G. L. and Modlin, M. J. (1986) Direct-Line Distances, International Edition, Metuchen, The Scarecrow Press.

Flora, Peter (1973) "Historical processes of social mobilization: urbanisation and literacy: 1850-1965”, in S. N. Eisenstadt and S. Rokken (eds) Building States and Nations: Model and Data Resources, vol. 1, Beverly Hills, Sage.

Flores de Lemus, A. (1928) Diario de Sesiones, 20 de enero de 1928: "Sobre la politica arancelaria española: un debate en la Asamblea Nacional de la Dictadura", reproduced in Hacienda Pública Española, 42-3 (1976).

Fohlen, Claude (1956) L'industrie textile sous le Second Empire, Paris, Armand Colin.

Foreman-Peck, James (ed.) (1991) New Perspectives on the Late Victorian Economy, Cambridge, Cambridge University Press.

Foreman-Peck, James (1995a) A History of the World Economy. International Economic Relations, Brighton, Wheatsheaf (second édition).

Foreman-Peck, James (1995b) "A model of later nineteenth century European economic development”, Revista de Historia Economica, 13/3, 441-71.

Foreman-Peck, James and Lains, Pedro (2000) "European economic development; the core and the southern periphery 1870-1910", in S. Pamuk and J. G. Williamson (eds) The Mediterranean Response to Globalization, London, Routledge.

Fraile, Pedro (1991) Industrialización y Grupos de Presión. La economía política de la protección en España 1900-1950, Madrid, Alianza.

Fraile, Pedro (1992) "Los mercados del Centro y las Economias Atrasadas de 
Europa 1900-1930", in L. Prados de la Escosura and V. Zamagni (eds) El Desarrollo Económico en la Europa del Sur: España y Italia en Perspectiva Historica, Madrid, Alianza Universidad, pp. 253-68.

Frank, A. G. (1959) "Industrial capital stocks and energy consumption", Economic Journal, 69, 170-4.

Fuà, Giorgio (1981) Lo sviluppo economico in Italia, vol. 1, Lavoro e reddito, Milan, Angeli.

Gallarotti, G. M. (1985) “Towards a business-cycle model of tariffs", International Organization, 39/1, 155-87.

Gammelgård, S. (1985) Billeder af Dansk Macro-Økonomi 1818-1980, Hæfte III, Tabeller, Copenhagen, Gyldendal.

Gardner, G. W. and Kimbrough, K. P. (1992) "Tax regimes, tariff revenues and government spending”, Economica, 59, 233, February, 75-92.

Gerschenkron, Alexander (1943) Bread and Democracy in Germany, Berkeley, University of California Press.

Gerschenkron, Alexander (1962) Economic Backwardness in Historical Perspective, Cambridge, MA, Harvard University Press.

Gide, Charles and Rist, Charles (1944) Histoire des doctrines économiques depuis les physiocrates jusqu'à nos jours, Paris, Sirey (sixth edition).

Gilbert, C. L. (1986) "Professor Hendry's methodology”, Oxford Bulletin of Economics and Statistics, 48, 213-28.

Gilbert, Milton and Kravis, Irwin (1954) A Comparison of National Products and the Purchasing Power of Currencies: United States, United Kingdom, France, Germany, Italy, Paris, OECD.

Giles, J. A. and Williams, C. L. (2000) "Export-led growth: a survey of the empirical literature and some non causality results", Journal of International Trade and Economic Development, 9,3 and 4.

Gini, C. (1959) Ricchezza e reddito, Turin, Unione Editrice Torinese.

Gini, C. (1962) L'Ammontare e la composizione della richezza delle nazione, Turin, Unione Editrice Torinese.

Gluskov, H. S. (1976) Britain's trade relations with the Bulgarian lands during the period after the Crimean War until Bulgaria's liberation from Ottoman rule (1856-1877), Bulgarian Historical Review, 26-50.

Golob, Eugene (1944) The Méline Tariff: French Agriculture and Nationalist Economic Policy, New York, Columbia University Press.

Good, D. F. (1994) "The economic lag of central and eastern Europe: income estimates for the Habsburg successor states, 1870-1910”, Journal of Economic History, 54, 869-91.

Good, D. F. (1996) "Economic growth in Europe's third world: central and eastern Europe, 1870-1989", in D. H. Aldcroft and R. E. Catterall (eds) Rich Nations-Poor Nations: the Long-run Perspective. Cheltenham: Edward Elgar.

Good, D. F. and Ma, T. (1999) "The economic growth of central and eastern Europe in comparative perspective, 1870-1989”, European Review of Economic History, 3, 2, 103-37.

Gourevitch, P. A. (1977) "International trade, domestic coalitions and liberty: comparative responses to the crisis of 1873-1896", Journal of Interdisciplinary History, 17, 281-313.

Grassman, S. (1980) "Long-term trends in openness of national economies", Oxford Economic Papers, 32, 123-33. 
Greenaway, D. (1982) "The foreign trade sector as a source of government revenue", in Peter Mander (ed.) Case Studies in Public Sector Economics, London, Heinemann Educational Books.

Gregory, Paul R. (1979) "The Russian balance of payments, the gold standard and monetary policy”, Journal of Economic History, 39, 379-99.

Gregory, Paul R. (1982) Russian National Income 1885-1913, Cambridge, Cambridge University Press.

Gregory, Paul R. (1994) Before Command: an Economic History of Russia from Emancipation to the First Five-year Plan, Princeton, Princeton University Press.

Grossman, G .M. and Helpman, E. (1991) Innovation and Growth in the Global Economy, Cambridge, MA, MIT Press.

Grunzel, Josef (1916) Economic Protectionism, Oxford, Clarendon Press.

Grupo de Estudios de Historia Rural [GEHR] (1980) Los precios del trigo y la cebada en España, 1891-1907, Madrid, Banco de España.

Hahn, Hans-Werner (1984) Geschichte des Deutschen Zollvereins, Göttingen, Vandenhoeck und Ruprecht.

Haig, Bryan (2001) "New estimates of Australian GDP 1861-1948/9", Australian Economic History Review, 41, 1, 1-34.

Hall, Robert E. and Jones, Charles I. (1999) "Why do some countries produce so much more output per worker than others?", Quarterly Journal of Economics, 114, $1,83-116$.

Harrison, A. (1996) "Openness and growth: a time series, cross-country analysis for developing countries", Journal of Development Economics, 48/2, 419-47.

Hatton, Timothy J. and Williamson, Jeff G. (1991) "Wage gaps between farms and the city: Michigan in the 1890s", Explorations in Economic History, 28/4, 381-408.

Hau, Michel (1994) Histoire économique de l'Allemagne, XIXe-XXe siècles, Paris, Economica.

Hauser, Henri (1919) Les méthodes allemandes d'expansion économique, Paris, Colin (second edition).

Head, K. (1994) "Infant industry protection in the steel rail industry", Journal of International Economics, 37/3-4, 141-65.

Henderson, William O. (1975) The Rise of German Industrial Power: 1834-1914, London, Temple Smith.

Hilsheimer, Jürgen (1973) Interessengruppen und Zollpolitik in Frankreich: die Auseinandersetzungen um die Aufstellung des Zolltarifs von 1892, University of Heidelberg, Phil. Dissertation.

Hoffmann, Wilhelm G., with the collaboration of Franz Grumbach and Helmut Hesse (1965) Das Wachstum der deutschen Wirtschaft seit der Mitte des Neunzehnten Jahrhunderts, Berlin, Springer.

Hohls, Rüdiger and Kaelble, Hartmut (1989) Die Regionale Erwerbstruktur im deutschen Reich und der BRD, St Katharinen, Scripta Mercaturae Verlag.

Holtfrerich, Carl-Ludwig (1983) "The growth of net domestic product in Germany, 1850-1913”, in Rainer Fremdling and Patrick O'Brien (eds) Productivity in the Economies of Europe, Stuttgart, Klett-Cotta, pp. 124-32.

Howe, A. (1997) Free Trade and Liberal England 1846-1946, Oxford, Clarendon Press.

Iliopoulus, P. I. (1973) The Evolution of Greek's External Trade, 1830-1972 (in Greek), Athens. 
Imlah, Albert (1958) Economic Elements in the Pax Britannica, New York, Russell \& Russell.

Irwin, Douglas A. (1993) "Free trade and protection in nineteenth-century Britain and France revisited: a comment on Nye", Journal of Economic History, 51, 1, 146-52.

Irwin, Douglas A. (1998) "Changes in U.S. tariffs: the role of import prices and commercial policies", American Economic Review, 88/4, 1015-26.

Irwin, Douglas A. (2001) "Tariffs and growth in late nineteenth century America", World Economy, 24, 1, 15-30.

Irwin, Douglas A. (2002) "Interpreting the tariff-growth correlation of the late 19th century", American Economic Review, 92, 2, May, 165-9.

Irwin, Douglas A. and Marko, T. (2002) "Does trade raise income? Evidence from the twentieth century", Journal of International Economics, 58, 1, October, 1-18.

Jackson, M. R. (1986) "Industrial output in Romania and its historical regions, 1880 to 1930", Journal of European Economic History, 15, 1, 59-111.

Jackson, M. R. and Lampe, J. R. (1983) "The evidence of industrial growth in south-eastern Europe before the Second World War", East European Quarterly, 16, $4,385-415$.

Janos, A. C. (1989) "The politics of backwardness in continental Europe, 1780-1945", World Politics, 43, 325-58.

Jevons, W. S. (1906) The Coal Question, London, Macmillan.

Jiménez Blanco, J. I. (1986) "La remolacha y los problemas de la industria azucarera en España, 1800-1914", in Garrabou, Barciela and Jiménez (eds) Historia agraria de la España contemporánea, vol. 3, El fin de la agricultura tradicional (1900-1960), Barcelona, pp. 280-316.

Johansen, H. C. (1985) Dansk Økonomisk Statistik 1814-1980, Danmarks Historie, Bind 9, Copenhagen, Gyldendal.

Johansson, Ö. (1967) The Gross Domestic Product of Sweden and its Composition 1861-1955, Stockholm.

Johnson, Harry G. (1969) "The theory of effective protection and preference", Economica, 36, 119-38.

Jones, C. I. (1994) "Economic growth and the relative price of capital", Journal of Monetary Economics, 34/3, 359-82.

Jones, Eric L. (1981) The European Miracle: Environments Economics and Geopolitics in the History of Europe and Asia, Cambridge, Cambridge University Press.

Jones, Eric L. (1988) Growth Recurring: Economic Change in World History, Oxford, Clarendon Press.

Justino, David (1988-9) A Formação do Espaço Económico Nacional: Portugal, 1810-1913, Lisbon, Vega, 2 vols.

Kemp, Tom (1976) "Tariff policy and French economic growth", Revue Internationale d'Histoire de la Banque, 12, 141-55.

Kennedy, W. P. (1987) Industrial Structure, Capital Markets and the Origins of British Economic Decline, Cambridge, Cambridge University Press.

Kindleberger, Charles P. (1951) "Group behavior and international trade", Journal of Political Economy, 59/1, 30-46.

Kindleberger, Charles P. (1961) "Foreign trade in the 19th century: lessons from Britain and France", Economic History Review, 15, 289-305.

Kindleberger, Charles P. (1964) Europe's Post-War Growth: the Role of Labour Supply, Oxford: Oxford University Press. 
Kindleberger, Charles P. (1975) "Germany's overtaking of England, 1806-1914", Weltwirtschaftliches Archiv, 111, 2, 3, 253-81, 477-504.

Kitson, Michael and Solomou, Solomon (1990) Protectionism and Economic Revival: the British Interwar Economy, Cambridge, Cambridge University Press.

Klug, Aaron (2001) "Why Chamberlain failed and Bismarck succeeded: the political economy of trade tariffs in British and German elections", European Review of Economic History, 5, 2, 219-50.

Kostelenos, G. C. (1995) Money and Output in Modern Greece, 1858-1938, Athens, Centre of Planning and Economic Research.

Krantz, Olle (1988) "New estimates of Swedish historical GDP since the beginning of the nineteenth century", Review of Income and Wealth, 34, 215-42.

Krantz, Olle and Nilsson, C. A. (1975) Swedish National Product, 1861-1970: New Aspects on Methods and Measurement, Lund.

Krause, W. and Puffert D. J. (2000) "Chemicals, strategy and tariffs: tariff policy and the soda industry in imperial Germany", European Review of Economic History, 4, 3, 285-310.

Krueger, Anne O. (1997) "Trade policy and economic development: how we learn" American Economic Review, 87, 1-22.

Krugman, Paul (1987) "Is free trade passé ?", Journal of Economic Perspectives, 1, 2, 131-44.

Krugman, Paul (1990) Rethinking International Trade, Cambridge, MA. MIT Press.

Krugman, Paul (1995) "Growing world trade: causes and consequences", Brookings Papers on Economic Activity, 1, 327-77.

Kuznets, Simon (1958) "Underdeveloped countries and the pre-industrial phase in the advanced countries", in A. N. Agarwala and S. P. Singh (eds) The Economics of Underdevelopment, London, Oxford University Press.

Kuznets, Simon (1961) Capital in the American Economy: its Formation and Financing, Princeton, Princeton University Press.

Lains, P. (1986) "Exportações portuguesas, 1850-1913: a tese da dependência revisitada”, Análise Social, 22, 381-419.

Lains, P. (1987) "O proteccionismo em Portugal, 1842-1913: um caso mal sucedido de industrialização 'concorrencial' ”, Análise Social, 23, 481-503.

Lains, P. (1988) “An account of the Portuguese African empire, 1885-1975", Revista de Historia Económica, 16, 1, 235-63.

Lains, P. (1990) “A evolução da agricultura e da indústria em Portugal, 1850-1913: interpretação quantitativa”, História Económica, 1.

Lains, Pedro (1986) "O proteccionismo em Portugal 1836-1913: Um caso mal sucedido de industrialiçao concorrencial”, Analise Social, 22, 381-419.

Lains, Pedro (1989) "Modern economic growth in nineteenth-century Portugal", European University Institute, mimeo.

Lains, Pedro (1998) L'économie portugaise au XIXe siècle, Paris, L'Harmattan.

Lains, Pedro and Reis, Jaime (1991) "Portuguese economic growth 1833-1985: some doubts", Journal of European Economic History, 20, 441-53.

Lambi, Ivo Nikolai (1963) Free Trade and Protection in Germany 1868-1879, Wiesbaden, Steiner.

Lampe, J. R. (1972) “Serbia”, in R. Cameron (ed.) Banking and Economic Development, New York: Oxford University Press.

Lampe, J. R. (1975) "Finance and pre-1914 industrial stirrings in Bulgaria and Serbia", Southeastern Europe, 2, 23-52. 
Lampe, J. R. (1975) "Varieties of unsuccessful industrialization: the Balkan states before 1914", Journal of Economic History, 35, 56-85.

Lampe, J. R. (1983) "Debating the Balkan potential for pre-1914 development", Journal of European Economic History, 12, 1, 187-96.

Lampe, J. R. (1986) The Bulgarian Economy in the Twentieth Century, London, Croom Helm.

Lampe, J. R. and Jackson, M. R. (1982) Balkan Economic History, 1550-1950: from Imperial Borderlands to Developing Nations, Bloomington, IN, Indiana University Press.

Landes, David S. (1969) The Unbound Prometheus: Technological Change and Industrial Development in Western Europe from 1750 to the Present, Cambridge, Cambridge University Press.

Landes, David S. (1998) The Wealth and Poverty of Nations, London, Little Brown.

Laursen, Keld (1998) "Revealed comparative advantage and the alternatives as measures of international specialisation”, DRUID Working Paper, 98-30, December.

Lazaretou, S. (1995) "Government spending, monetary policies, and exchange rate regimes switches: the drachma in the gold standard period", Explorations in Economic History, 20, 28-50.

League of Nations (1927) Tariff Level Indices, Geneva.

Leamer, Edward E. (1974) "Nominal tariff averages with estimated weights", Southern Economic Journal, 41, 1, 34-46.

Leamer, Edward E. (1984) Sources of International Comparative Advantage, Cambridge, MA, MIT Press.

Leamer, Edward E. (1988) "Measures of openness", in Robert E. Baldwin (ed.) Trade Policy Issues and Empirical Analysis, Chicago, University of Chicago Press.

Lebovics, Herman (1988) The Alliance of Wheat and Iron under the Third Republic, Baton Rouge, LA, Louisiana State University Press.

Lee, J. W. (1993) "International trade, distortions and long-run economic growth", IMF Staff Papers, 40/2, June, 299-328.

Lee, J. W. (1995) "Capital good imports and long-run growth", Journal of Development Economics, 48, 1, 299-328.

Lee, J. W. (1998) “Capital good imports and long-run growth", Journal of Development Economics, 48/1, 91-110.

Leontieff, W. W. (1953) "Domestic production and foreign trade: the American capital position re-examined", Proceedings of the American Philosophical Society, 97, 332-49.

Levi, Margaret (1988) Of Rule and Revenue, Berkeley, University of California Press.

Lévy-Leboyer, Maurice and Bourguignon, François (1990) The French Economy in the Nineteenth Century: an. Essay in Econometric Analysis, Cambridge: Cambridge University Press.

Lewis, William A. (1957) "International competition in manufactures", American Economic Review, 47, 2, May, 578-87.

Lewis, William A. (1978) Growth and Fluctuations, 1870-1913, London, Allen and Unwin.

Lewis, William A. (1981) "The rate of growth of world trade, 1830-1973", in Sven Grassman and Erik Lundberg (eds) The World Economic Order. Past and Prospects, London, Macmillan. 
Liepmann, Heinrich (1938) Tariff Levels and the Economic Unity of Europe, London, Allen \& Unwin.

List, Friedrich (1856) National System of Political Economy, Philadelphia (first edn, 1841).

Lotz, Walther (1892) Die Ideen der deutschen Handelspolitik von 1860 bis 1891, Leipzig, Duncker und Humblot.

Lotz, Walther (1904) "The effect of protection on some German industries", Economic Journal, 14, 56, 514-26.

Loveday, Alexander (1928) "The measurement of tariff levels", Journal of the Royal Statistical Society, 112, 487-529.

Maddison, A. (1990) "Measuring European growth: the core and the periphery", in D. Aerts and N. Valério (ed.) Growth and Stagnation in the Mediterranean World, Leuven, Leuven University Press.

Maddison, Angus (1962) "Growth and fluctuations in the world economy, 1870-1960”, Banca Nazionale del Lavoro Quarterly Review, 61, June, 127-95.

Maddison, Angus (1982) Phases of Capitalist Development, Oxford and London, Oxford University Press.

Maddison, Angus (1991) Dynamic Forces in Capitalist Development: a Long-run Comparative View, Oxford, Oxford University Press.

Maddison, Angus (1992): "El crecimiento económico italiano 1861-1989 una revision”, in L. Prados de la Escosura and V. Zamagni (eds) El desarrollo económico en la Europa del Sur: Espana y Italia en Perspectiva Historica, Madrid, Alianza Universidad.

Maddison, Angus (1994) "Explaining the economic performance of nations", in W. J. Baumol, R. R. Nelson and E. N. Wolff (eds) Convergence of Productivity: Cross-National Studies and Empirical Evidence, New York, Oxford University Press, pp. 20-61.

Maddison, Angus (1995) Monitoring the World Economy 1820-1992, Paris, OECD.

Maddison, Angus (2001) The World Economy: a Millennium Perspective, Paris, OECD.

Maizels, Alfred (1963) Industrial Growth and World Trade, Cambridge, Cambridge University Press, NIESR vol. XXI.

Mankiw, N. G., Romer, D. and Weil, D. N. (1993) "A contribution to the empirics of economic growth", Quarterly Journal of Economics, 108, 407-37.

Marczewski, Jean (1965) "Le produit physique de l'économie française de 1789 à 1913", Cahiers de l'Institut de Science Economique Appliquée Series: AF No. 4, $7-154$.

Martin, M. (1982) Azúcar y Decolonización. Origen y desenlace de una crisis agraria en la Vega de Granada. El "ingenio de San Juan 1882-1904", Granada, Universidad de Granada.

Martin-Acena, P. (1993) "Spain during the classical gold standard years, 1880-1914", in Michael D. Bordo and Forrest Capie (eds) Monetary Regimes in Transition, Cambridge, Cambridge University Press.

Mata, E. (1993) "As finanças públicas portuguesas da Regeneração à primeira guerra mundial”, História Económica, 4.

Mata, E. (1995) "Foreign investments in the Portuguese economy from the middle of the nineteenth century until the First World War", Proceedings of the XV Congress of the Portuguese Economic and Social History Association, Évora.

Mata, E. and Valério, N. (1991) "Foreign public debt and economic growth in Portugal”, 1830-1985, Estudos de Economia, 11, 421-32. 


\section{References}

McCloskey, Donald N. (1980) "Magnanimous Albion: free trade and British national income, 1841-1881", Explorations in Economic History, 17, 3, 303-20.

McCloskey, Donald N. and Zecher, J. Richard (1984) "The success of purchasing parity: historical evidence and its implications for macroeconomics", in Michael Bordo and Anna Schwartz (eds) A Retrospective on the Classical Gold Standard, Chicago, Chicago University Press, pp. 121-50.

McCloskey, Donald N. and Zecher, J. Richard (1985) "How the gold standard worked, 1880-1913", in Barry Eichengreen (ed.) The Gold Standard in Theory and History, London, Methuen, pp. 63-80.

McDiarmid, O. J. (1946) Commercial Policy in the Canadian Economy, Cambridge, MA, Harvard University Press.

Messerlin, Patrick (1983) "Bureaucracies and the political economy of protection", Washington, DC, World Bank Staff Working Paper, No. 568.

Messerlin, Patrick (1985a) "Croissance et politiques commerciales: quelques interrogations sur le cas français (1830-1914)", in Croissance, Echange et monnaie en économie internationale, Paris, Economica, pp. 329-48.

Messerlin, Patrick (1985b) "Les politiques commerciales et leurs effets en longue période", in Lassudrie-Duchêne, Bernard and Reiffers, Jean-Louis (eds) Le protectionnisme, Paris, Economica, pp. 71-89.

Meyer, John R. (1965) “An input-output approach to evaluating British industrial production in the late 19th century", in A. H. Conrad and J. R. Meyer (eds) Studies in Econometric History, Chicago, Aldine, pp. 183-225.

Meyer, S. (1981) The Five Dollar Day, New York, New York State University Press.

Miller, W. (1923) The Balkans: Romania, Bulgaria, Serbia, and Montenegro, New York.

Milward, Alan S. and Saul, S. B. (1973) The Economic Development of Continental Europe 1780-1870, London, Allen and Unwin.

Milward, Alan S. and Saul, S. B. (1977) The Development of the Economies of Continental Europe 1850-1914, London, Allen and Unwin.

Mises, Ludwig von (1956) The Anticapitalist Mentality, New York, Van Nostrand.

Mitchell, Brian R. (1988) British Historical Statistics, Cambridge, Cambridge University Press.

Mitchell, Brian R. (1992) International Historical Statistics: Europe 1750-1988, London, Macmillan.

Mitchell, Brian R. (1993) International Historical Statistics: The Americas 1750-1988, London, Macmillan.

Mitchell, Brian R. (1995) International Historical Statistics: Africa, Asia and Oceania 1750-1988, London, Macmillan.

Mokyr, Joel (ed.) (1993) The Economics of the Industrial Revolution, Boulder, CO, Westview Press.

Molinas, C. and Prados de la Escosura, L. (1989) "Was Spain different? Spanish historical backwardness revisited", Explorations in Economic History, 26, 385-402.

Mónica, M. Filomena (1986) Artesãos e Operários: Indústria, Capitalismo e Classe Operária em Portugal, 1870-1934, Lisbon, Instituto de Ciências Sociais.

Moore, W. E. (1945) Economic Demography of Eastern and Southern Europe, Geneva, League of Nations.

Morris, Cynthia Taft and Adelman, Irma (1988) Comparative Patterns of Economic Development 1850-1914, Baltimore, John Hopkins University Press.

Morris, Cynthia Taft and Adelman, Irma (1989) "Nineteenth century development experience and lessons for today", World Development, 17, 9, 1417-32. 
Mulhall, M. G. (1881) Balance Sheet of the World for Ten Years, London.

Mulhall, M. G. (1896) Industries and Wealth of Nations, London, Longmans \& Green.

Mulhall, M. G. (1899) Dictionary of Statistics, London, Routledge (fourth edition).

Myllantaus, T. (1990) "Education in the making of modern Finland", in G. Tortella (ed.) Education and Economic Development Since the Industrial Revolution, Valencia, Generalitat Valenciana.

Nadal, J. (1975) El fracaso de la Revolución Industrial, Barcelona, Ariel.

Nadal, J. and Sudrià, C. (1993) "La controversia en torno al atraso económico español en la segunda mitad del siglo XIX (1860-1913)", Revista de Historia Industrial, 3, 199-227.

Nelson, R. R. and Wright, G. (1992) “American technological leadership”, Journal of Economic Literature, 30, 1931-64.

North, Douglass C. (1981) Structure and Change in Economic History, New York and London Norton.

Nuñez, C. E. (1990) "Literacy and economic growth in Spain", in G. Tortella (ed.) Education and Economic Development Since the Industrial Revolution, Valencia, Generalitat Valenciana.

Nye, John V. (1991) "The myth of free-trade Britain and fortress France: tariffs and trade in the nineteenth century", Journal of Economic History, 51, 1, 23-46.

O'Brien, Patrick (1995) "The productivity of the labour employed by European industries", in I. Zilli (ed.) Fra spazio e tempo, Saggi in onore di Luigi de Rosa, vol. III, pp. 284-300.

O'Brien, Patrick and Prados de la Escosura, Leandro (1992) "Agricultural productivity and Europe industrialisation 1890-1980”, Economic History Review, 45, 514-36.

O'Brien, Patrick K. (ed.) (1982) Railways and the Economic Development of Europe 1830-1914, London, Macmillan.

O'Brien, Patrick K. (1986) "Do we have a typology for the study of European industrialization in the nineteenth century?", Journal of European Economic History, 15, 291-333.

O'Brien, Patrick K. (2002) “The Pax Britannica and American hegemony: present antecedents or just another history?", in P. K. O'Brien and A. Cleese (eds) Two Hegemonies: Britain 1846-1914 and the United States 1941-2001, Aldershot, Ashgate.

O'Brien, Patrick K. and Keyder, Caglar (1978) Economic Growth in Britain and France 1780-1914: Two Paths to the Twentieth Century, London, Allen and Unwin.

O'Rourke, Kevin (2000) "Tariffs and growth in the late nineteenth century", Economic Journal, 110, 456-83.

O'Rourke, Kevin H. (1997) “The European grain invasion 1870-1913", Journal of Economic History, 57/4, 775-801.

O'Rourke, Kevin H. and Williamson, Jeff G. (1997) "Around the European periphery 1870-1913: globalization, schooling and growth", European Review of Economic History, 1, 2, 153-90.

O'Rourke, Kevin H. and Williamson, Jeff G. (1999) Globalization and History: the Evolution of a 19th Century Atlantic Economy, Cambridge, MA, MIT Press.

O'Rourke, Kevin H., Taylor, Alex M. and Williamson, Jeff G. (1996) "Factor price convergence in the late nineteenth century", International Economic Review, 37/3, 499-530. 
Olson, Mancur (1982) The Rise and Decline of Nations: Economic Growth, Stagflation and Social Rigidities, New Haven, Yale University Press.

Palafox, J. (1991) Atraso económico y democracia. La Segunda República y la economía española, 1892-1936, Barcelona, Critica.

Palairet, M. (1979) "Fiscal pressure and peasant impoverishment in Serbia before World War I", Journal of Economic History, 39, 719-40.

Palairet, M. (1983) "Land, labour, and industrial progress in Bulgaria and Serbia before 1914", Journal of European Economic History, 12, 1, 163-85.

Palairet, M. (1988) "Farm productivity under Ottoman rule and self-government in Bulgaria $c .1860-90$, in S. J. Kirschbaum (ed.) East European History, Columbus, $\mathrm{OH}$, Slavica Publishers.

Palairet, M. (1997) The Balkan Economies, c.1800-1914, Cambridge, Cambridge University Press.

Pammer, M. (1997) "Proxy data and income estimates: the economic lag of central and eastern Europe", Journal of Economic History, 57, 448-55.

Pamuk, S. (1987) The Ottoman Empire and European Capitalism, 1820-1913, Cambridge, Cambridge University Press.

Pamuk, S. (2001) "Economic growth in southeastern Europe and the Middle East since 1880", Proceedings of the IV Conference of the Historical Economics Society, Oxford.

Pan Montojo, J. (1994) "El vino y la política comercial en la Restauración”, Agricultura y Sociedad, 72, 167-203.

Pareto, Vilfredo (1984) "L'avenir de l'Europe", in Mythes et idéologies, 2nd edn, Geneva, Droz, 325.

Pasvolsky, L. (1930) Bulgaria's Economic Position, Washington, DC, Brookings Institution.

Pencavel, J. H. (1977) "The efficiency and distributional effects of trade union Britain”, British Journal of Industrial Relations, 15, 137-56.

Pereira, M. Halpern (1978) “'Decadência' ou subdesenvolvimento: uma reinterpretação das suas origens no caso português”, Análise Social, 14, 7-20.

Pereira, M. Halpern (1983) Livre-Câmbio e Desenvolvimento Económico, Lisbon, Sá da Costa Editora.

Petmezas, S. (2000) "Export-dependent agriculture, revenue crisis and agrarian productivity involution: the Greek case (1860s-1930s)", Histoire et Mesure, 15, 321-37.

Petrakis, P. E. and Panorios, H. (1992) "Economic fluctuations in Greece, 1844-1913", Journal of European Economic History, 21, 1, 31-46.

Pinto, J. R. Vaz (1938) A Agricultura no Concelho de Vidigueira: Subsídios para o Seu Estudo Económico e Social, Lisbon, relatório final de curso, Instituto Superior de Agronomia.

Platt, D. C. M. (1972) Latin America and British Trade 1806-1914, London, Black.

Platt, D. C. M. (1984) Foreign Finance in Continental Europe and the USA 1815-1870. Quantities, Origins, Functions and Distribution, London, George Allen \& Unwin.

Pollard, Sidney (1981) Peaceful Conquest: the Industrialisation of Europe 1760-1970, Oxford, Oxford University Press.

Popoff, K. G. (1920) La Bulgarie Économique, 1879-1911, Sofia, Imprimerie de la Cour.

Prados de la Escosura, L. (1993) "Spain's Gross Domestic Product, 1850-1990: a new series", Working Paper D-93002, Madrid, Ministerio de Economia y Hacienda. 
Prados de la Escosura, L. (2000) "International comparisons of real product, 1820-1990: an alternative data set", Explorations in Economic History, 37, $1-41$.

Prados de la Escosura, Leandro (1982) Comercio exterior y crecimiento económico en España 1826-1913: tendencias a largo plazo, Madrid, Banco de España.

Prados de la Escosura, Leandro (1986) "Una serie anual del comercio exterior español (1821-1913)”, Revista de Historia Económica, 1, 103-50.

Prados de la Escosura, Leandro (1988) De imperio a Nación. Crecimiento y atraso económico en España (1780-1930), Madrid, Alianza.

Prados de la Escosura, Leandro (1992) "Crecimiento, atraso y convergencia en Espana y Italia: introducción”, in L. Prados de la Escosura and V Zamagni (eds) El desarrollo económico en la Europa del Sur: España e Italia en Perspectiva Histórica, Madrid, Alianza Universidad.

Prados de la Escosura, Leandro (1995) "Spain's Gross Domestic Product, 1850-1993: quantitative conjectures", Working Paper 95-05, Economics Series 01.

Prados, L. and Tena, A. (1994) "Protectionism in Spain, 1869-1930", Eleventh International Economic Congress, Milan, 12-17 September.

Preshlenova, R. (1993) "Modernization in south-eastern Europe in the perspective of trade with Austria-Hungary before World War I", Études Balkaniques, 38-64.

Preshlenova, R. (1994) "Austro-Hungarian trade and the economic development of southeastern Europe before World War I", in D. F. Good (ed.) Economic Transformations in East and Central Europe, London, Routledge.

Proudman, James and Redding, Stephen (eds) (1998) Openness and Growth, London, Bank of England.

Reis, Jaime (1979) “A 'Lei da Fome': as origens do proteccionismo cerealífero, 1889-1914”, Análise Social, 15, 745-93.

Reis, Jaime (1984) "O atraso económico português em perspectiva histórica, 1860-1913”, Análise Social, 20, 7-28.

Reis, Jaime (1986) “A produção industrial portuguesa, 1870-1914: primeira estimativa de um índice”, Análise Social, 22, 903-28.

Reis, Jaime (1993) O Atraso Económico Português em Perspectiva Histórica, 1850-1930, Lisbon, Imprensa Nacional.

Reis, Jaime (2002) "How poor was the European periphery before 1850? The Mediterranean vs. Scandinavia”, in S. Pamuk and J. G. Williamson (eds) The Mediterranean Response to Globalization, London, Routledge.

Repaci, R. (1962) La finanza Pubblica, Roma, Ed. Universitaria.

Reynolds, Lloyd G. (1985) Economic Growth in the Third World 1850-1980, New Haven, Yale University Press.

Ritschl, Albrecht and Spœerer, Mark (1997) "Das Bruttosozialprodukt in Deutschland nach den amtlichen Volkseinkommens- und Sozialproduktstatistiken 1901-1995”, Jahrbuch für Wirtschaftsgeschichte, 9, 27-54.

Rivera-Batiz, L. A. and Romer, Paul (1991) “Economic integration and endogenous growth”, Quarterly Journal of Economics, 106, 2, 531-55.

Robinet de Cléry, Adrien (1935) La politique douanière de l'Allemagne depuis l'avènement de Caprivi jusqu'à nos jours, Paris, Rivière.

Rodríguez, F. and Rodrik, Dani (1999) "Trade policy and economic growth: a skeptic's guide to cross-national evidence”, NBER Working Paper, No. 7081 (April). 
Romer, C. D. (1989) "The prewar business cycle reconsidered: new estimates of Gross National Product 1868-1908”, Journal of Political Economy, 97/1, 1-37.

Romer, Paul (1994) "New goods, old theory, and the welfare costs of trade restrictions", Journal of Development Economics, 43, 1, 5-38.

Rosenberg, Nathan and Birdzell, L. E. (1986) How the West Grew Rich: the Economic Transformation of the Industrial World, New York, Basic Books.

Rossi, Nicolà, Sorgato, A. and Toniolo, Gianni (1993) "I conti economici italiani: una ricostruzione statistica 1890-1990", Rivista di Storia Economica, 10/1, $1-47$.

Rostow, Walt W. (1960) The Stages of Economic Growth: a Non-Communist Manifesto, Cambridge, Cambridge University Press.

Rousseaux, Paul (1938) Les mouvements de fond de l'économie anglaise, Louvain, Edition Universelle.

Sabaté (1994) "Tipo de cambio y protección en la economía española de principios de siglo", Revista de Economía Aplicada, 1, 1, 67-87.

Sabaté (1996) El proteccionismo legitimado. Política arancelaria española a comienzos de siglo, Zaragoza: Civitas.

Sachs, Jeffrey D. and Warner, A. (1995) "Economic reform and the process of global integration", Brookings Papers on Economic Activity, No. 1, 1-118.

Sandberg, Lars (1979) "The case of the impoverished sophisticate: human capital and Swedish economic growth before World War I", Journal of Economic History, $39,225-41$.

Sandberg, Lars (1982) "Ignorance, poverty and economic backwardness in the early stages of European industrialization: variations on Alexander Gerschenkron's Grand Theme", Journal of European Economic History, 11, 675-97.

Santos, R. Esteves dos (1974) Os Tabacos: Sua Influência na Vida da Nação, Lisbon, Seara Nova.

Saul, S. B. (1982) "The economic development of small nations: the experience of north west Europe in the nineteenth century", in C. P. Kindleberger and Guido di Tella (eds) Economics in the Long View, vol. 2, New York, New York University Press.

Saxonhouse, G. R. (1986) "What's wrong with Japanese trade structure", Pacific Economic Papers, 137, 1-36.

Scheidl, L. F. and Roque, J. L. (1985) A Industrialização no Século XIX: O Caso Alemão, Porto, Paisagem Editora.

Schlote, Werner (1952) British Overseas Trade from 1700 to the 1930s, Oxford, Oxford University Press.

Schon, L. (n.d.) "Economic growth and productivity in a European perspective since 1870" (unpublished).

Schulze, M.-S. (2000) "Patterns of growth and stagnation in the late nineteenth century Habsburg economy", European Review of Economic History, 4, 311-40.

Senghaas, D. (1985) The European Experience. A Historical Critique of Development Theory, Leamington Spa, Berg.

Serrano Sanz, J. M. (1987) El viraje proteccionista en la Restauración: la politica comercial española 1875-1895, Madrid Siglo XXI.

Serrano Sanz, J. M. (1989) "El proteccionismo y el desarrollo económico en la Restauración. Reflexiones para un debate”, Revista de Historia Económica, 7, 1.

Serrano Sanz, J. M. (1991) "La renta de aduanas en España (1849-1935)", Hacienda Pública Española, 1, 107-19. 
Sideri, Sandro (1978) Comércio e Poder. Colonialismo Informal nas Relações Anglo-Portuguesas, Lisbon, Edições Cosmos.

Simpson, J. (1996) Spanish Agriculture: the Long Siesta 1765-1965, Cambridge, Cambridge University Press.

Simpson, J. (1997) “Did tariffs stifle Spanish agriculture before 1936?”, European Review of Economic History, 1, 1, April, 65-87.

Siriwardana, A. M. (1991) "The impact of tariff protection in the colony of Victoria in the late nineteenth century: a general equilibrium analysis", Australian Economic History Review, 31, 2, 45-65.

Slicher van Bath, B. H. (1963) The Agrarian History of Western Europe AD 500-1850, London, Edward Arnold.

Smith, Michael S. (1980) Tariff Reform in France 1860-1900, Ithaca, Cornell University Press.

Smithsonian Institute (1927) World Weather Records, Washington, DC, Miscellaneous Collection.

Solberg, Carl E. (1987) The Prairie and the Pampas: Agrarian Policy in Canada and Argentina, 1880-1930, Stanford, Stanford University Press.

Solomou, Solomos and Catao, Luis (2000) "Effective exchange rates 1879-1913", European Review of Economic History, 4, 3, 361-81.

Sombart, Werner (1903) Die deutsche Volkswirtschaft im neunzehnten Jahrhundert, Berlin, Georg Bondi.

Stoianovich, T. (1994) Balkan Worlds: the First and Last Europe, New York.

Stokey, N. I. (1991) "Human capital, product quality and growth", Quarterly Journal of Economics, 106/2, 587-616.

Studenski, Paul (1958) The Income of Nations: Theory Measurement and Analysis Past and Present, New York, New York University Press.

Sylla, Richard and Toniolo, Gianni (eds) (1991) Patterns of European Industrialization in the Nineteenth Century, London, Routledge.

Taylor, Alex M. (1994) “Three phases of Argentine economic growth", NBER Historical Paper, No. 60 (October).

Taylor, Alex M. (1996) "Sources of convergence in the late nineteenth century", NBER Working Paper, No. 5806 (October).

Taylor, Alex M. (1998) "On the costs of inward-looking development: price distortions, growth and divergence in Latin America”, Journal of Economic History, 58/1, $1-28$.

Tena, Antonio (1988) "Importación, niveles de protección y producción de material eléctrico en España 1890-1935”, Revista de Historia Económica, 2, 341-71.

Tena, Antonio (1989) "Comercio exterior", in A. Carreras (ed.) Estadísticas Históricas de España siglos XIX-XX, Madrid, Fundación Banco Exterior.

Tena, Antonio (1991) "Protección y competitividad en España e Italia, 1890-1960", in Prados, Leandro and Zamagni, Vera (eds) El desarrollo económico en la Europa del Sur: España e Italia en perspectiva histórica, Madrid, Alianza.

Tena, Antonio (1992) "Las estadísticas históricas del comercio internacional: fiabilidad y comparabilidad”, Banco de España, Estudios de Historia Económica, 24.

Tena, Antonio (1995) “The Spanish foreign sector 1885-1985”, in Pablo MartinAceña and James Simpson (eds) The Economic Development of Spain since 1870, Aldershot, Edward Elgar. 
Tena, Antonio (2001) "Por qué fue España un país con alta protección industrial? Evidencias desde la protección efectiva 1870-1930”, Economic History and Institutions Working Papers, UC3M, 01-72 (04).

Tena, Antonio and Tirado, Daniel (1996) "Protección arancelaria en la Restauración. Un debate Antonio Tena-Daniel Tirado", Revista de Economía Aplicada, 4. 11, 135-50.

Thomas, Mark (1991) "An input-output approach to the British economy, 1890-1914”, DPhil, University of Oxford.

Thornton, J. and Molyneux, P. (1997) "Tariff endogeneity: evidence from 19th century Europe", Economics Letters, 56, 3, 345-50.

Tipton, Frank B. (1999) "Tales of Hoffmann: output and labor productivity in German industry, 1850-1937”, First German Cliometrics Conference, Toronto.

Tirado, Daniel (1994) "La protección arancelaria en la Restauración: nuevos indicadores”, Revista de Economía Aplicada, 6, 2, 183-203.

Tirado, Daniel (1996) "La Protección arancelaria en la Restauración: impactos de corto y largo plazo. España, 1870-1913”, PhD thesis, Departament d'Historia i Institucions Económiques, Universitat de Barcelona, March.

Todorova, M. (1997) Imagining the Balkans, Oxford: Oxford University Press.

Toniolo, Gianni (1977) "Effective protection and industrial growth: the case of Italian engineering”, Journal of European Economic History, 6, 659-73.

Tortella, Gabriel (1985) in García Delgado (ed.) La España de la Restauración: política, economía, legislación y cultura, Madrid, Siglo XXI.

Tortella Gabriel (1994a) "Patterns of economic retardation and recovery in southwestern Europe in the nineteenth and twentieth centuries", Economic History Review, 47, 1, 1-21.

Toutain, Jean-Claude (1987) "Le produit intérieur brut de la France de 1789 à 1982”, Economies et Sociétés AF Series, vol. 15.

Tumlir, J. and Till, L. (1971) "Tariff averaging in international comparisons", in H. G. Grubel and H .G. Johnson (eds) Effective Tariff Protection, Geneva, GATT, pp. $147-60$.

Turnock, D. (1986) The Romanian Economy in the Twentieth Century, London.

U.S. Department of Commerce (1975) Historical Statistics of the United States: Colonial Times to 1970, Washington, DC, US Printing Office.

United Nations (1985) "Indices de los productos de la Clasificación Uniforme del Comercio Internacional”, Informes Estadísticos, M series, no. 38, Rev, Vol. I, pp. 1-559, Vol. II, pp. 1-495.

Urquardt, M. C. (1986) "New estimates of Gross National Product, Canada, 1870-1926: some implications for Canadian Development”, in Stanley L. Engerman and Robert E. Gallman (eds) Long-term Factors in American Economic Growth, Chicago, University of Chicago Press, pp. 9-94.

Urquardt, M. C. (1993) Gross National Product, Canada 1870-1926: the Derivation of the Estimates, Kingston, McGill-Queens University Press.

Valério, Nuno (1988) “A dívida pública externa de Portugal, 1890-1950”, Estudos de Economia, 9, 21-32.

Vamvadikis, A. (2002) "How robust is the growth openness connection? Historical evidence", Journal of Economic Growth, 7, 1, 57-80.

Vamvakidis, A. (1997) "How robust is the growth-openness connection? Historical evidence", mimeo, Harvard University. 
Vanplew, W. (ed.) (1987) Australian Historical Statistics, Broadway NSW, Fairfax, Syme and Weldon.

Verdier, Daniel (1994) Democracy and International Trade: Britain, France, and the United States, Princeton, Princeton University Press.

Verley, Patrick (1988) "Exportations et croissance économique", Annales E.S.C., 48, $1,73-110$.

Vicens Vives, J. (1987) Manual de Historia Económica de España, Barcelona, Vicens Vives.

Viner, Jacob (1902) Dumping: A Study, Chicago, Chicago University Press.

Vitali, Ornello (1992) "Gli impieghi del reddito nell'anno 1911", in Guido Rey (ed.) I conti economici dell'Italia, Bari, Laterza.

Wagenführ, Rolf (1933) Die Jndustriewirtschaft. Konjunkturtendenzen der deutschen und internationalen Jndustrieproduktion 1860 bis 1932, Viertelsjahrhefte zur Konjunkturforschung, Sonderheft 31, Berlin.

Webb, Stephen B. (1977) "Tariff protection for the iron industry, cotton textiles and agriculture in Germany, 1879-1914", Jahrbücher für Nationalökonomie und Statistik, 192, 3-4, 336-57.

Webb, Stephen B. (1978) The Economic Effects of Tariff Protection in Imperial Germany, 1879 to 1914, Chicago, PhD Dissertation.

Webb, Stephen B. (1980) "Tariffs, cartels, technology, and growth in the German steel industry, 1879 to 1914", Journal of Economic History, 40, 2, 309-29.

Weber, M. (1961) General Economic History, New York, Scribner's.

Weiller, Jean (1969) "Echanges extérieurs et politique commerciale de la France depuis 1870”, Economies Ẽ Sociétés, III, 10, 1777-93.

Weiller, Jean (1971) "Long-run tendencies in foreign trade: with a statistical study of the French foreign trade structure", Journal of Economic History, 31, 4, 804-21.

White, H. (1980) "A heteroskedasticity-consistent covariance matrix estimator and a direct test for heteroskedasticity", Econometrica, 48, 817-38.

Wilkins, M. and Hill, F. F. (1964) American Business Abroad: Ford on Six Continents, Detroit, Wayne State University Press.

Williams, Ernst E. (1897) "Made in Germany", London, W. Heinemann (fifth edition).

Williamson, Jeff G. (1991) "Did English factor markets fail during the Industrial Revolution?”, in N. F. R. Crafts, N. H. Dimsdale and S. Engerman (eds) Quantitative Economics History, Oxford, Clarendon Press.

Williamson, Jeffrey and Bordo, Michael (eds) (2002) Globalization in Historical Perspective, Cambridge, MA, Harvard University Press.

Williamson, Jeffrey and O'Rourke, Kevin (1999) Globalization and History: the Evolution of a Nineteenth Century Atlantic Economy, Cambridge, MA, MIT Press.

Williamson, Jeffrey G. (1974) "Watersheds and turning points: conjectures on the long-term impact of Civil War financing”, Journal of Economic History, 34, 636-61.

Williamson, Jeffrey G. (1990) Coping with City Growth During the British Industrial Revolution, Cambridge, Cambridge University Press.

Williamson, Jeffrey G. (1996) "Globalization, convergence, and history", Journal of Economic History, 56, 277-306.

Williamson, Jeffrey G. (2002) "Real wages and relative factor prices around the 
Mediterranean, 1500-1940", in S. Pamuk and J. G. Williamson (eds) The Mediterranean Response to Globalization, London, Routledge.

Woytinski, Wladimir and Woytinski, Emma (1955) World Commerce and Governments: Trends and Outlook, New York, Twentieth Century Fund.

Woytinsky, Wladimir S. (1926) Die Welt in Zahlen, vol. 4, Berlin.

Yoshimuri, M. (1988) "Catholicism and anti-business bias: the case of France", International University of Japan Bulletin, 5, 107-31.

Young, A. (1991) "Learning by doing and the dynamic effects of international trade", Quarterly Journal of Economics, 106/2, 369-405. 


\section{Index}

References to notes are indicated by $\mathrm{n}$, to figures by $\mathrm{f}$ and to tables by $\mathrm{t}$.

Abramovitz, Moses 300

Adelman, Irma 156

aggregation methods $91-3$

agriculture: change in share of GDP

$145,145 \mathrm{t}$; effect on of grain

imported from the New World and

Russia 124-5; shift in labour

resources 144-6; tariffs 160-1, 168

Alentejo, Portugal 256

America see United States

Anderson, James E. 54-8

Andrade, Anselmo de 253-4

Anglo-French Treaty of Commerce (1860): and Britain 38; effect of across Europe 124; and France 13, 26, 28n7, 104

Are, G. 196

Argentina: effect of foreign investment 153-4; import duties 157, 158-9n7; openness 158; tariff protection 86-7, $158 \mathrm{n} 5$

Australia 86-7, 125, 155

Austria 86

average nominal rate of protection in Germany 232t

average tariffs: biased measure of protection 198; cross-country evidence 127-30; France 16, 59t, 108f; Great Britain 16, 58-60, Italy 110t; Portugal 244f; Spain 111t

Bairoch, Paul: data on income levels in Europe 300-1; on effect of free trade 125-6; on protection boosting growth 1-2, 142, 158n2, 163, 219-20; trade policy in Europe 13-14

Baldwin, R.E. 90
Balkan countries: capital imports 307-11, 308t; compared to Portugal 307; government revenue $310 \mathrm{t}(1)$; investment in industry 303-4, 311; railway construction 309-10; structure of government expenditure $310 \mathrm{t}$ (2); tariffs 305-6; trade with other European markets 305

Bourguignon, François 14, 15t, 18

Bremen 224

Britain see Great Britain

Broadberry, Stephen 144

Brown, Lucy 21-2

Brussels Classification 88

Bulgaria 308

business cycle, relationship with tariff rates $137-42$

Cambó Tariff 268

Cambridge Economic History of Europe, The 13-14

Cameron, Rondo 28-9n7

Canada 86-7, 125, 154-5, 157-8

Cánovas Tariff 268

Capie, Forrest 126

capital imports, Balkan countries 307-11; Portugal 307-11

capital, physical, and economic development 326

Carr, Raymond 297n44

census dates $176 \mathrm{t}$

cereal production, Portugal 255-6; see also wheat

CGE see Computable General Equilibrium models chemical imports, Spain 280

Clapham, Sir John H. 232 
classic index number problems 111-14

Clemens, Michael A. 152

climate and economic development 325,332

coal industry 324-5, 332, 333-4

Cobden, Richard 40

Cobden-Chevalier Treaty (1860) see Anglo-French Treaty of Commerce (1860)

Collins, William J. 143

colonial products: Spain 284t, 285-7, 293n35

Commerce extérieur et développement économique 2

commodities: classification 88-91; disaggregated tariff rates $168 \mathrm{f}$

Commodity Composition of Trade: Selected Industrial countries, 1900-1954, The 90

competitiveness, impact on of tariff rates 167

Computable General Equilibrium models (CGE) (Italy) 200-1, 203, 207-8

consumer products, luxury 99-100

convergence model, unconditional $133,134 \mathrm{t}$

Corbino, E. 210-11

Corn Laws 14, 20, 103-4

Cortés Conde, Roberto 154

cotton industry, Portugal 249, 252, 253t

cross-country evidence, tariffs 127-30

currencies, European 178t

data collection methods and sources 93-6, 116-17, 125-7, 147-50, 171-5

Daunton, Martin 119n12

Dawson, W. H. 232

demand elasticity 101

depression (economic), effect on tariff rates 137-42

despoilment 162

Dumke, Rolf 225

Dunham, Arthur L. 28n7

East India Company 23

economic development: agricultural productivity and the labour force 327f; and climate 325, 332; effect of protection 123-47, 195-7; Great Britain 336-7; historical background 318-23; Italy 193, 195-7; modelling 323-38, 334f; Portugal 303; scheme for explaining 329f; Spain 265-6; variables in 323-6 economic growth and tariffs: alternative specifications 141t; core and peripheral countries 154t; core countries 153t; correlation 152-8; different countries and periods 138t; difficulties with measuring 53-4; in Germany 219-40; introduction 5-8; performance measured against rate $165 f(1)$; relationship between 130-46, 195-7, 219-21; specific tariff variable $140 \mathrm{t}$

economic growth: France 142;

Germany 226-7; and openness rate 165f(2); Spain 265-6

Economic Protectionism 70

economic structure, Portugal 255-60

elasticity of demand 101

Ellena Committee (Italy) 194

employment, France 184

endowments within Heckscher-Ohlin model 76-7

energy consumption, variable within Heckscher-Ohlin model 76, 98n10

Estevadeordal, Antoni 130

Europe: comparative labour productivity 176 ; currencies 178 t; economic development 319-38; GDP per capita levels and growth rates 303t, 304f; national debt 309t; national income and wealth per capita 314t; per capita income levels 299-304; protection rates 104f; southern countries development 298-9; tariffs 40t, 131t, 306t exchange rate, official 177-8 export led growth 154-5 exports, Germany 224f, 225-30

factor accumulation models 135, 136t, $139 \mathrm{t}$

Federico, Giovanni 8

Fenoaltea, Stefano 175, 197

Finland 86

fiscal products: impact on tariff rates 106-10, 107f; as percentage of French imports 103

fiscal revenues, impact of 107-10

fiscal tariffs 102, 157, 212

Fontana, Josep 292n5

food imports, Spain 278-9

foreign investment, Argentina 153-4

Foreman-Peck, James S. 126-7, 146

Forty Years of Foreign Trade 90-1

France 86; average custom rates 14-15; 
average tariff rates $16,16 \mathrm{t}, 59 \mathrm{t}, 108 \mathrm{f}$; and British tariffs on wine 24-6, 31n33, 47-9; compared with Britain 13-28, 58-60, 101-6; using the TRI 60-3; compared with Germany 221, $221 \mathrm{t}, 222 \mathrm{t}$; duties paid and tariff rates 34t; duty-free imports 17; effect of free trade on growth 142; impact of fiscal revenues on overall tariff rate 107; imports 18t; imports as a share in GDP 47f; industrial output 172-3, 173t; industrial protectionism 181-2; influence of protection on employment 184, 184f; labour productivity 178-9, 188t; major imports 33t; protection rates $187 \mathrm{t}$, $189 \mathrm{t}$; tariff rates $19,19 \mathrm{t}, 20,21 \mathrm{t}$, 58-60; trade war with Italy 195; use of tariff rates to measure openness disputed 36-42; wheat imports 20, 21t free trade: effect on countries growth 1-2, 27-8; effect on income in Italy $207 \mathrm{t}$

free-trade movement 21-2

Gandolfo, Giancarlo 46

Gatt (1985/6) classification 274

General Railway Law (1855), Spain $295 n 32$

Germany, 86, 123-4; 1879 tariff 230-1, 233; changes in imports and exports 227-30, 229t; compared with France 221, 222; compared with US 221t, 222; difficulty of collecting trade statistics 224; effect of export trade on growth 226-7; foreign trade 225-30; growth rates of foreign trade $227 \mathrm{t}$; impact of fiscal revenues on overall tariff rate 107-8; impact of tariffs 184-5; indices of exports and imports 224f; labour productivity 173-4, 178-9, 188t; marketing methods 223; nominal protection rate 231-2; politics and trade policy 232-3; protection levels by sector 234-9; protection rates 187t, 232t; Prussian tariff of 1818 232; Punch cartoon 223f; role of protection in expansion 240; share of world trade 221-7; structure of export and import trade 226t; tariff policy 230-2; tariff rates, $108 \mathrm{f}$

Gerschenkron, A. 196-7, 299-300, 327

Giles, Judith A. 163
Goessel 30n18

Good, David F. 301

grain, imported from the New World and Russia 124-5

Great Britain: average custom rates 14-15, 15t; average tariff rates 16 , 16t, 58-60; compared with France 13-28, 58-60, 101-6; using the TRI 60-3; compared with Germany 221, 221t, 222-3; impact of fiscal revenues on overall tariff rate 106; import duties levied in 1902 41t; imports, as a share in GDP 47f; imports as tariff duties and rates $35 \mathrm{t}, 157$; industrial protectionism 181-2; labour productivity 174-5, 178-9; modelling economic development 336-7; tariffs 18t, 20, 24-6, 102; trade relations with Portugal 31n29; trade restriction index 64t; use of tariff rates to measure openness disputed 36-42; wine imports 24-6, 31n33, 47-9, 102

Gregory, Paul R 158

Growth and Stagnation in the European Economy 90

growth and tariffs: alternative specifications $141 \mathrm{t}$; core and peripheral countries 154t; core countries 153t; correlation 152-8; different countries and periods 138t; difficulties with measuring 53-4; in Germany 219-40; introduction 5-8; performance measured against rate $165 f(1)$; relationship between 130-46, 195-7, 219-21; specific tariff variable $140 \mathrm{t}$

economic growth: France 142; Germany 226-7; and openness rate 165f(2); Spain 265-6

Grunzel, J. 70

Hamberg 224

Heckscher-Ohlin model 53, 67-8, 72-9, 85t, 118n3

Heckscher-Ohlin-Vanek model 77t, $97 \mathrm{n} 7$

Hegemonic stability, theory of $28 \mathrm{n} 5$

Hilgerdt, F. 88-9

historical background, economic development 318-23

historical trade data 88-91

History of British Commerce 32n43

Hoffman, Walter G. 173-4

Hong Kong 57t 
Imlagh, Albert 14

imports: comparison between Britain and France 27, 33t; Germany 224f, 225-30; of New World and Russian grain 124-5; Spain 277-80

income levels, Europe 299-304; Italy 207-8

index-number problem, classic: Britain and France 16; Spanish and Italian tariffs 110-13; and tariffs in nineteenth century 100, 129-30; TRI devised to solve 62

indices of openness 67-8

industrial development: impact of tariff barriers 162-7, 219-21; in Portugal and the Balkans 303-4

Industrial Growth and World Trade 90, 91

industrial output, France 172-3

industrial production, comparative indices $172 \mathrm{f}$

industrial protection 292n4; France 181-2; Great Britain 181-2

industrial tariffs: compared to agricultural 168; overall nominal rates $169 \mathrm{t}$

Industrialization and Foreign Trade 88-9 industries, infant 123-4, 125, 143-4, 146-7

industry: aggregate indices of labour productivity 179; effect on of protection in Italy 196-7; labour productivity indices 188t; protection biased towards 146; real effective protection rates $187 \mathrm{t}$; and tariff protection 160-89

infant industries 123-4, 125, 143-4, 146-7

iron imports, Spain 280

Irwin, Douglas A. 45, 46, 48, 58-62, $101,102,103,106,163-4$

Italian Socialist Party 211

Italy: average tariff rates 110t; causes of protection 208-12; classic index number problems 111-14; conflicting estimates of industrial value $175 \mathrm{t}$; effect of free trade on income 207-8; effect of protection on economic development 193, 195-7; effects of politics on trade policy 212; fiscal motive for protection 212; impact of fiscal revenues on overall tariff rate 108-10; labour productivity 174-5, 178-9, 183f, 188t, 190t; major components of the "Return to protection" 114t; protection on selected products 205t; protection rates $187 \mathrm{t}, 198 \mathrm{f}, 199 \mathrm{t}(1), 199 \mathrm{t}(2)$, 204t, 276f; sectoral change under free trade 202t; short-term variability of protection 206-7; trade policy 194-7; trade war with France 195; weighted and unweighted tariff averages $111 \mathrm{t}$

Keyder, Caglar 19

Klug, Adam 8

Kuznets, Simon 300

labour and economic development 329-30, 331-2

labour market, effect on protection 144-5

labour productivity 164-7, 171-6; aggregate indices $179 \mathrm{t}$; comparative across Europe 176; France 178-9, 188t; Germany 173-4, 178-9, 188t; Great Britain 174-5, 178-9; indices by industry 188 t; Italy 174-5, 178-9, 183f, 188t, 190t; nominal and effective protection rates, Italy 190t; and protection 179-86

labour, endowment in Heckscher-Ohlin model 76

land, endowment within Heckscher-Ohlin model 76

land abundance 156-7

Landes, David 301

Leamer, Edward 72, 75, 87, 118n3

learning-by-doing 144

Lemus, Flores de 292n4

Leontief, Wassily 75, 97n6

Levi, Leone 32n43

Lévy-Leboyer, Maurice 14, 15, 18

Liepmann, H. 70, 130, 169

liquor tariffs 24, 102, 105-6; see also wine

literacy and economic development 331

Loveday, A. 70

Low, David 161, $161 \mathrm{f}$

Luzzatti, Luigi 211

Ma, Tongshu 301

Maddison, Angus 125, 302

Made in Germany 222-3

Maizels, A. 90, 91

manufactures, Spain 280-2 
marketing methods, Germany 223

McCloskey, Donald 17-18, 18t

Méline, Jules 161

Méline tariff 104

Methuen Treaty 48

Mexico 155-6

Mises, Ludwig von 219

Morris, Cynthia Taft 156

Napoleon III 14, 28n7, 30n23

Neary, J. Peter 54-8

New World, grain imported from 124-5

nineteenth century 123, 152-7;

measures of openness 67-8; relationship between tariffs and growth 13-28, 123-47, 195-7; tariff policies $124-5$

Norway 86

Nye, John V. 36, 58-60, 61-3, 101, 103, 106

O'Brien, Patrick 19

official exchange rates $177-8$

openness: indices of $67-8,83 \mathrm{t}$; rate and growth performance $165 f(2)$; tariff rates as measurement of 36-42

O'Rourke, Kevin H. 106, 115-16, 152, 193, 299

Oldham, Great Britain 30n18

Paasche index 111-13

Pareto, Vilfredo 185-6

Pegorari, P. 211

per capita income levels, Europe 299-304

Pescosolido, G. 196

Piedmont, Italy 194

Platt, D. C. M. 158-9n7

politics: and economic development 326 ; effect on trade policy in Italy 212

Pollard, Sidney 301

Portugal: Alentejo region 256; average duties 243-5, 246-7; average tariffs and import prices 244f; breakdown of budget receipts 248t; capital imports 307-11; cereal protection 255-6; compared to Romania 307; cotton industry 249, 252, 253t; customs policy 242-3; development of protectionism 243-7, 249-55; duty on main imported consumer goods 249t; economic development 303; effect of protection on industry
256-60; on structure of the economy, 255-60; excise duties 250t; fiscal aspect of duties 248-9; growth indices 255t, 257t; import and excise duties by product class $251 \mathrm{t}$; main tariff laws 261-2; median added value duties 245t; protectionism and comparative advantages 258t; railway construction 310 ; relations with other countries $31 \mathrm{n} 29,305$; relationship between protection and pressure groups 252-5

Prados, Leandro 302

pressure groups, Portugal 252-5

productivity 164-7, 171-7; see also labour productivity

protection rates: effective $169-70,187 \mathrm{t}$, 189t, 203-6, 204t; France 189t; industrial tariffs 169t; Italy 190t; nominal 198f, 199t(1), 199t(2), 231t; relative effective $205 \mathrm{t}$

protection: biased towards industry 146; causes of 208-12; and economic growth 123-47, 219-21; in Europe 2-3, 104t, 130; index of 146; influence on employment in France 184f; as inevitable 292n5; Italian historians viewpoint 196-7; and the Italian population 201; in Italy 193-213; and the labour market 144-6; and labour productivity 179-86; level of in Europe identical per industry 170 ; measuring intensity for industry 168-71; on semi-finished goods 170; Spain 276-84

protection, measurement of: alternative measures $84 \mathrm{t}$; alternative methods 69t; difficulties of 53-4; need for 67-8; sectoral in 1913 83t; trade restrictiveness index (TRI) 54-8; to compare Britain and France 60-3; use of tariffs debated 46-50; using trade-weighted average tariffs 99-100

Prussia, tariffs 232

PSI see Italian Socialist Party

Punch cartoon 223

purchasing power parity (PPP) exchange rates $177-8,178 \mathrm{t}$

railways: and economic development 330, 332; Balkan countries 309-10; Portugal 310

RCA indices 227-30, 237-8 
recession, effect on tariff rates 137-42 regression results $181 \mathrm{t}, 182 \mathrm{t}, 185 \mathrm{t}$

Reichgründung 225

religion and economic development 325-6

research issues $146-7$

revenue tariffs see fiscal tariffs

Ricardo's model 162, 166

Romania 307, 309

Rossi, A. 210

Russia 124-5, 155, 158

Salazar, Oliveira 256

Salvador Tariff 268

Sapelli, G. 196

Scandinavia 301

Sereni, E. 210

Smith, Adam 2, 4

smuggling $31 n 36$

Solberg, Carl E. 158n5, 159n7

Spain 86; 1849 tariff 267; 1906 tariff

284-7; average tariff rates $110 \mathrm{t}$; changes in revenue from colonial products 284t; chemical imports 280; classic index number problems 111-14; classification of products 273; colonial products 285-7, 295n35; development of protection 267-70, 282-3; General Railway Law (1855) 295n32; GNP per head 336t; impact of fiscal revenues on overall tariff rate 108-10; impact of protection on growth 265-6; import of finished manufactured goods 281-2; import of foodstuffs 278-9; indexes of nominal protection 269t; industrial bias of protection 288-9; iron and steel imports 280; levels of nominal protection $274 \mathrm{t}$; major components of the "Return to protection" $114 \mathrm{t}$; measuring protection 267-73; modelling economic development 336-7; nature and scope of protection 276-84; nominal protection 270f, 276f, 277t, 291t, 296n36; nominal protection of wheat 278-9; primary import products $277-80$; protection and openness of imports 268f; relative protection indicators $287 \mathrm{t}$; semi-manufactures 280; tariff average alternative measures 290t; weighted and unweighted tariff averages $111 \mathrm{t}$
Standard International Trade Classification (SITC) 87, 88, 89t, 91-2, 273-4

Statistisches Reichsamt 224

steel imports, Spain 280

sugar 26, 28n 12

Svennilson, I. 90

Sweden 86, 301

tariff growth paradox 1-2, 164

Tariff Level Indices 70

Tariff Levels and the Economic Unity 130

Tariff Levels and the Economic Unity of Europe 70

tariff rates: in Britain and France 14-26, 29n11, 101-6; disaggregated by commodity 168t; selected commodities 1912-13, 71t; and trade in capital goods 143; use of to measure openness disputed 36-42, 115-16

Tariffs and Growth 53-4

tariffs and growth: alternative specifications 141t; core and peripheral countries $154 \mathrm{t}$; core countries 153t; correlation 152-8; different countries and periods 138 t; difficulties with measuring 53-4; in Germany 219-40; introduction 5-8; performance measured against rate $165 f(1)$; relationship between 130-46, 195-7, 219-21; specific tariff variable $140 \mathrm{t}$

tariffs: agricultural 168; alternatives to 158n4; averages 61t, 62t, 99-100, 128t; Balkan countries 305-6; Britain 20, 24-6, 102; distortions produced by 46 ; effect on drinking tastes 31n35; European (1875-1913), 131t; fiscal 102, 156-7; fiscal and protective 101, 104; free-traders attitude to 21-2; impact on industry 162-7, 219-21; and Italian labour productivity 183f; in Italy 194-5; and labour productivity 179-86; and land abundant countries 156-7; levels across countries and time 129t; limited use as measurement of protection 68-70; observable effects 185; reform 20, 25-6, 37; and smuggling $3 \ln 36$; and structural transformation 145t; textile, comparative between nations $32 \mathrm{n} 43$; on wine and liquor 24-6, 102, $105 f(1), 105 f(2)$ 
taxation: cost of collection/as instrument of protectionism 2-4

Tina, A. 193

textile prices 19

textiles: comparison between France and Britain 27, 32n44; import of 16-17; spinning costs in Goessel and Oldham 30n18

TIR see trade intensity ratio tobacco 26

Tomfool, Goanna 170, 197

Total Nominal Protection 117-18 trade intensity ratio $72,73,74,80,81 \mathrm{t}$, $82 ; 60-3$; used to measure openness 70

trade policy: effect on distribution of income in Italy 207-8; relationship with economic growth 123-47, 195-7, 219-21

trade policy: Italy 194-7; structural change 202-7

Trade Restrictiveness Index (TRI): changes in Colombia 58t; as measurement of protection 54-8, 64-5, 199; trustworthiness 57-8; used to compare Britain and France 60-3

trade wars 195

Tyszynski, H. 89-90

unification, Italy 194, 210

United States 119n10, 123-4, 125,
142-3; compared with Germany 221t, 222, 222t; imports of Hong Kong goods $57 \mathrm{t}$; nominal rate of protection 231, $231 \mathrm{f}$

Vamvakidis, Athanasios 123, 126, 141

variables: economic development 323-6; used in regressions 133t

Verdier, D. 209, 210

Villaverde, Fernández 279, 284

Vives, Vicens 292n5, 297n44

Weiller, Jean 163

wheat: effect of duty on in Italy 197; imports, France 20, 21t; production, Spain 295n32

Williams, Cara L. 163

Williams, E. E. 222-3

Williamson, Jeffrey G. 142-3, 152, 299

wine tariffs 24-6, 31n33, 47-9, 102, $105-6$

World Trade in Manufactured Commodities, 1899-1950 89-90

World Trade in Manufactures Since 1900 90

world trade, German share of 221-7

Yates, P. L. 90-1

Zamagni, V. 196

Zollverein, Centralbureau of the 223-5, 227, 232-3 

eBooks - at www.eBookstore.tandf.co.uk

\section{A library at your fingertips!}

eBooks are electronic versions of printed books. You can store them on your PC/laptop or browse them online.

They have advantages for anyone needing rapid access to a wide variety of published, copyright information.

eBooks can help your research by enabling you to bookmark chapters, annotate text and use instant searches to find specific words or phrases. Several eBook files would fit on even a small laptop or PDA.

NEW: Save money by eSubscribing: cheap, online access to any eBook for as long as you need it.

\section{Annual subscription packages}

We now offer special low-cost bulk subscriptions to packages of eBooks in certain subject areas. These are available to libraries or to individuals.

For more information please contact webmaster.ebooks@tandf.co.uk

We're continually developing the eBook concept, so keep up to date by visiting the website. 




